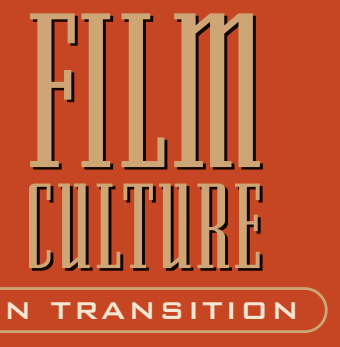

\title{
THE RED YEARS OF
}

\section{cahiers du}

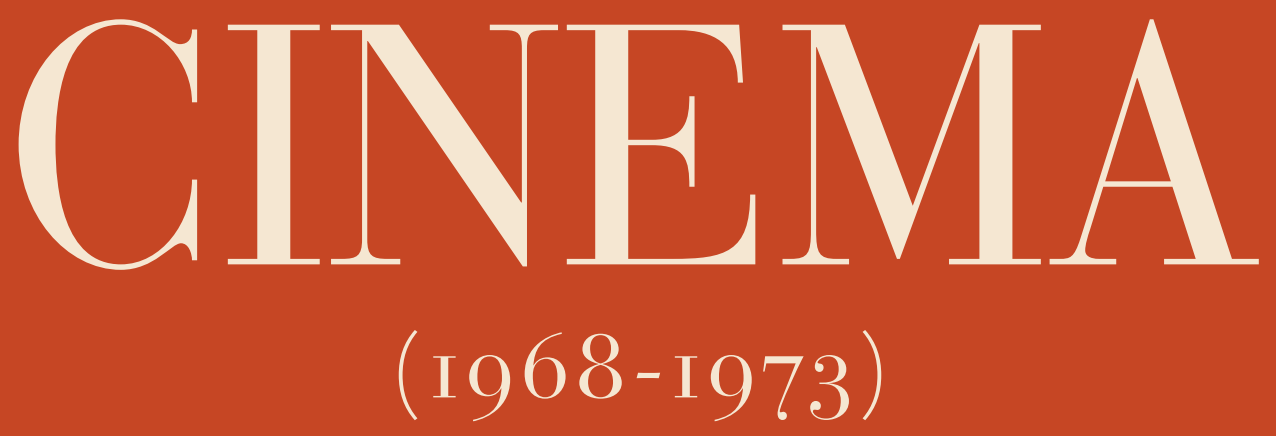

VOLUME I

Ideology and

Politics

DANIEL FAIRFAX 
The Red Years of Cahiers du Cinéma (1968-1973) 



\section{The Red Years of Cahiers du Cinéma (1968-1973)}

Volume I: Ideology and Politics

Daniel Fairfax 
The publication of this book is made possible by a grant from the Forschungszentrum historische Geisteswissenschaften at the Goethe-Universität Frankfurt.

Cover design: Kok Korpershoek

Lay-out: Crius Group, Hulshout

$\begin{array}{ll}\text { ISBN } & 9789463728508 \text { (Vol. I) } \\ \text { ISBN } & 9789463728607 \text { (Vol. II) } \\ \text { ISBN } & 978946372101 \text { (set) } \\ \text { e-ISBN } & 9789048543908 \text { (Vol. I) } \\ \text { e-ISBN } & 9789048543915 \text { (Vol. II) } \\ \text { DOI } & 10.5117 / 9789463728508 \\ \text { NUR } & 674 \mid 757\end{array}$

\section{(c) $(1)(8)$}

Creative Commons License CC BY NC ND

(http://creativecommons.org/licenses/by-nc-nd/3.o)

๑ D. Fairfax / Amsterdam University Press B.V., Amsterdam 2021

Some rights reserved. Without limiting the rights under copyright reserved above, any part of this book may be reproduced, stored in or introduced into a retrieval system, or transmitted, in any form or by any means (electronic, mechanical, photocopying, recording or otherwise). 


\section{Table of Contents}

\section{Volume I: Ideology and Politics}

Acknowledgements

A Note on Translations

Introduction

\section{Part I Theories of Ideology}

1. “Cinéma/Idéologie/Critique”: An Epistemological Break?

2. Jean-Louis Comolli and Jean Narboni: Crossed Lives

3. Décalages: "Young Mr. Lincoln de John Ford"

4. "La Vicariance du Pouvoir" and the Battle of Othon

5. “Technique et Idéologie" by Jean-Louis Comolli

6. Afterlives of the Apparatus

\section{Part II Engagements with Politics}

7. The Radicalization of Cahiers: 1963-1969

8. Cahiers du cinéma and the Rapprochement with the PCF: 1969-1971

9. Cahiers du cinéma's Turn to Maoism: 1971-1973

10. Cahiers du cinéma and Jean-Luc Godard 
12. Bernard Eisenschitz: Cinema, Communism and History

\section{Volume II: Aesthetics and Ontology}

\section{Part III Questions of Aesthetics}

14. Encounters with Structuralism

15. Beyond Structuralism: Film Form and Écriture

16. Re-reading Classical Cinema

17. The Defense and Critique of Cinematic Modernism

18. Encountering the World Through Cinema

19. The Film Aesthetics of Jacques Aumont

20. Two Ciné-fils: Pascal Kané and Serge Daney

\section{Part IV Encounters with Ontology}

21. The Bazinian Legacy $\quad 637$

22. Jean-Pierre Oudart and Suture $\quad 665$

23. Realism and Psychoanalysis in Pierre Baudry 695

24. Partial Vision: The Theory and Filmmaking of Pascal Bonitzer $\quad 717$

25. The Brain is the Screen: Cahiers du cinéma and Gilles Deleuze $\quad 749$

26. Film Ontology in the Age of "New" Media 775 
Conclusion

Index of Names Cited 



\section{Acknowledgements}

My first acknowledgements must go to the Cahiers critics themselves, who challenged me with their writings but also, without exception, welcomed my requests to speak with them about their personal histories. JeanLouis Comolli, in particular, responded with unbounded generosity to my unsolicited email asking to translate Cinéma contre spectacle and has been a true friend since then. Jean Narboni, Jacques Aumont, Bernard Eisenschitz, Sylvie Pierre, Pascal Kané, Pascal Bonitzer and Serge Toubiana were equally ready to share their thoughts and stories on tape, as were other figures from this period such as Michel Delahaye (who has sadly since passed away), Jean Douchet, Jacques Bontemps, Serge Toubiana, Alain Bergala and Serge Le Péron. My only regret is that the deaths of Serge Daney and Pierre Baudry, and the tragic, mysterious fate of JeanPierre Oudart, prevented me from being able to talk with them. Likewise, Pascal Kané's recent passing away is a tragic loss, and I will treasure the moments shared with him, both when conducting interviews and in more informal settings.

This project has gone through many guises, but the most important shepherd throughout all the stages of its development was without a doubt Dudley Andrew, whose assistance in guiding the present book to its completion has been inestimable. He has been a generous and sagacious mentor, and his research on André Bazin was an inspiration for my own study of a later generation of Cahiers critics, so I have cherished the privilege of having such close input from him on my work. During my time at Yale University, Francesco Casetti, John Mackay, Charlie Musser, Aaron Gerow, Brigitte Peucker, Katie Trumpener, Carol Jacobs and Ron Gregg all made treasured contributions to my development as a scholar, teacher and a person. Many formative friendships were also forged in New Haven; I can't not mention those with Joshua Sperling, Luca Peretti, Michael Cramer, Jeremi Szaniawski, Patrick Reagan, Masha Shpoleberg, Grant Wiedenfeld, Moira Weigel, Ksenia Sidorenko, Jensen Suther, Mal Ahern, Jordan Brower, Annie Berke and Joshua Alvizu.

Since moving to the Goethe Universität in Frankfurt am Main I have been blessed to share a department with Vinzenz Hediger, after years of collaboration with him on the "Film Theory in Media History" book series. His dynamism and energy in so many domains are a credit to the field of film studies, while Rembert Hüser, Nikolaus Müller-Stahl, Laliv Melamed, Philipp Dominik Keidl, Sonia Campanini, Bettina Schulte-Strathaus and 
Josefine Hetterich have made Theater, Film and Media Studies a lively and engaging department in which to work.

Further afield I would also like to thank Philip Rosen, Tom Conley, Jane Gaines, Trond Lundemo, Warren Buckland, André Habib, Antoine de Baecque, François Dosse, Hervé Joubert-Laurencin, Dana Polan, D.N. Rodowick, Laleen Jayamanne, Seung-hoon Jeong, Sam di Iorio, Paul Macovaz, Elif Sendur, Chrisa Blümlinger, Volker Pantenburg, Pierre Eugène and Marco Grosoli for their friendly help and guidance at various stages in this project and other associated ventures. Chuck Kleinhans and Philip Watts were also immensely helpful, and I along with so many other people will miss their interventions into the field. Perhaps the biggest recent loss for us all, however, has been that of Thomas Elsaesser. I was lucky enough to have him as a mentor and a friend over the last ten years, and I feel immensely privileged that this book will appear in his "Film Cultures in Transition" series, but it is inevitably shrouded in sadness with his death before its publication.

To my fellow current and former editors at Senses of Cinema, Rolando Caputo, Adrian Danks, Dan Edwards, Alex Heller-Nicholas, Mark Freeman, David Heslin, César Albarrán Tomas, Bradley Dixon and Fiona Villela, I want to thank you for providing Australia (and the world) with an outlet that, in its own modest way, continues the Cahiers mission of fostering original critical thinking on the cinema.

I can't express enough gratitude to Mum and Dad for everything they have given me, as well as to my wife Michelle for her love, support and inspiration, and finally Alex, who makes every day special. 


\section{A Note on Translations}

The translation history of Cahiers texts is a complex matter, with competing versions of the texts available and a range of strategies adopted to render the vocabulary used by the journal into the English language. For the purposes of this book, I have made reference to the original French texts when it comes to documents written by the ten Cahiers critics under study. Often, existing English translations have been consulted, and where this is the case, I have indicated these documents as secondary references, but the quality of these translations is particularly variable. When possible, I have utilized them in my own renderings of the Cahiers writings into English, but this principle has been secondary to considerations of accuracy and consistency. In the case of "Technique et idéologie," "Cinéma/idéologie/ critique," and Cinéma contre spectacle, I have used my own translations as published in the volume Cinema against Spectacle: Technique and Ideology Revisited. In other cases, I have freely modified existing translations when necessary, either to more faithfully render the meaning and flavor of the original text or to eliminate terminological variations between translations. Responsibility for the translation of quoted Cahiers material appearing in this book therefore falls entirely on my shoulders. In the case of non-Cahiers texts, standard translations have been used where these exist, with occasional modifications when this is necessary. In certain cases, the original French is included inside the quoted passage within square brackets when this information is judged to be of use. 



\title{
Introduction
}

\begin{abstract}
In this introduction to The Red Years of Cahiers du Cinéma, I define the scope of the ensuing study of the French film journal in the years 1968-1973 and the legacy this period had for the later work of the film critics involved in it. Whereas even its own former writers have referred to this interlude as the "non-legendary" years of Cahiers du cinéma, I argue that, under the editorship of Jean-Louis Comolli and Jean Narboni, the Marxist orientation it adopted, in combining Louis Althusser's theories of ideology with a critical tradition rooted in the ideas of André Bazin, led to the journal producing an unprecedented outpouring of film theory that continues to have profound lessons for us today. Finally, I argue that an additional point of interest of this era in Cahiers du cinéma's history is the model the critics developed of collective intellectual labor.
\end{abstract}

Keywords: Cahiers du cinéma, film criticism, apparatus theory, Marxism, Louis Althusser, André Bazin

\section{The "Non-Legendary" Years of Cahiers du cinéma}

At the end of Roberto Rossellini's 1950 film Francesco, giullare di Dio, St. Francis of Assisi gathers his band of disciples together and announces that the time has come for them to separate. Each member of the commune spins around until their heads are dizzy and they collapse to the ground. Departing in the direction they were facing at the moment they fell, the disciples set off on their different paths, tearfully leaving their comrades behind forever.

This scene comes from a filmmaker lionized by the French film journal Cahiers du cinéma. It may also serve as an appropriate metaphor for the group of critics who wrote for the journal in the years 1968-1973. These were the "red years" of Cahiers du cinéma, its années rouges, a time when the journal occupied a vanguard position in theory, art and politics. Editors-in-chief

Fairfax, D., The Red Years of Cahiers du Cinéma (1968-1973). Volume I: Ideology and Politics. Amsterdam: Amsterdam University Press, 2021 DOI 10.5117/9789463728508_INTRO 
Jean-Louis Comolli and Jean Narboni were joined in this period by eight other critics who actively collaborated with the journal. Jacques Aumont, Sylvie Pierre, Serge Daney and Bernard Eisenschitz had already been involved with Cahiers prior to 1968, while Pascal Kané, Pascal Bonitzer, Jean-Pierre Oudart and Pierre Baudry joined soon afterwards. For a half-decade, all ten of these individuals participated fully in the life of the journal and in the process formed a tight-knit, hermetic collective. Following the anti-hierarchical ethos of the period, Cahiers became a truly communal undertaking - both organizationally, in the logistical administration of its day-to-day tasks, and intellectually, in its group development of a critical theory of the cinema founded on Marxism. But the editorial team also suffered from other symptomatic traits of the era's far-left political culture: the demand for totalizing commitment from its members, an approach to theory that threatened to slip into dogmatism, and a sectarian attitude to rival groupings. When it became clear by the early 1970 s that this project had exhausted itself, collapsing under the weight of its political and theoretical contradictions, each critic took their own path. Some stayed with the journal in the following years but participated in it in a more dispersed, less theoretically unified manner. Others left—whether willingly or by force. The activities these critics have pursued since their time at Cahiers have varied widely and include academic scholarship, teaching, historical research, journalism, publishing and screenwriting. Many of them, such as Comolli, Bonitzer and Kané, have even turned to filmmaking, stepping behind the camera for works of both documentary and fiction. All have remained closely involved with cinema throughout their lives. From the standpoint of 2020, their time with Cahiers now appears as an intense initiation process to a lifelong preoccupation with the cinema that has now endured for more than half a century.

Founded by André Bazin and Jacques Doniol-Valcroze in 1951, Cahiers had by the late 1960 already become, by most accounts, the most prestigious film journal in France if not the world. Most notably, Cahiers counted among its alumni some of the major filmmakers of the nouvelle vague. François Truffaut, Jean-Luc Godard, Éric Rohmer, Jacques Rivette and Claude Chabrol all served cinematic "apprenticeships" as critics for Cahiers before their turn to filmmaking in the late 1950s and early 196os shook world cinema to its core. Comolli, Narboni and their fellow critics represented the generation after: after the battle to overturn the old cinema had been won, after the luminaries of the new wave had left the journal, after the "golden age" of French cinephilia in the 1950 s had dissipated and, perhaps most crucially, after the political certainties of post-war France had been shattered. Indeed, 
the key turning point in the journal's evolution was incited by a political event. The uprising of May 1968, in which students barricaded the streets of Paris, 10 million workers went on strike, and de Gaulle's regime teetered on the brink of being overthrown, had as revolutionary an effect on Cahiers as it did on the nation as a whole. Having been a primarily cinephilic and politically eclectic organ in the 1950 on and early 1960 s, the journal had already turned markedly towards the left as the 196os progressed. But the events of May, and the period of far-left militant activity in France they ushered in, radicalized and emboldened the critics now writing for Cahiers. By October 1969, the watershed editorial penned by Comolli and Narboni, "Cinéma/idéologie/critique," clearly signaled that the journal had officially adopted Marxism-Leninism as its presiding political and philosophical standpoint. The years that followed were tumultuous for Cahiers. As it moved towards a hardline Maoist outlook, Cahiers underwent major shifts in its understanding of cinema and politics, but a historical materialist approach to film theory would remain its guiding framework until 1973, when the foundering of the project for a "Front culturel révolutionnaire" led to the journal's abandonment of militant Marxism. Their exposure to political engagement left the Cahiers critics bruised, even traumatized, by the experience. Many of them now look back on the journal's Marxist period with a mixture of nostalgia and regret, bitterness and exhilaration. Daney even referred to this phase in the history of the journal as the "non-legendary" period of Cahiers, a sobriquet repeated several years later by Bonitzer. ${ }^{1}$ Today, few of the former Cahiers critics remain wedded to a Marxist-Leninist outlook, but none enacted the spectacular conversion to neo-conservative politics carried out by many former far-left intellectuals and militants in the 1970s and 1980s. To varying degrees of radicalism, all the Cahiers critics have continued to broadly identify with the left politically. In diverse ways, they have continued to use criticism, film theory and filmmaking to interrogate and combat the status quo in both the cinema and the political sphere.

While they may not have found global fame to the degree attained by Truffaut, Godard and company, the critics contributing to Cahiers in the late 1960 and early 1970 s have nonetheless played a crucial role in shaping our understanding of the cinema. Many of their writings have become

1 Serge Daney, L'Exercice a été profitable, Monsieur (Paris: P.O.L., 1993), p. 297; and Pascal Bonitzer, interviewed by Stéphane Bouquet, Emmanuel Burdeau and François Ramone, "Nos années non-légendaires: Entretien avec Pascal Bonitzer," in Emmanuel Burdeau (ed.), Cinéma 68 (Paris: Cahiers du cinéma, 2008 [1998]), pp. 143-156. 
landmark texts of film theory. "Cinéma/idéologie/critique," Comolli's six-part series "Technique et idéologie," Jean-Pierre Oudart's article "La Suture" and the collective analysis "Young Mr. Lincoln de John Ford"-all of which were translated into English and widely disseminated in the 1970s-have been of crucial importance for the field. All four texts are exemplars of the critical project adopted during this time: to elaborate a conceptual system for understanding the cinema that would utilize the advances in critical theory being made in Paris at the time, whether in historical materialism (with the work of Louis Althusser and his followers), psychoanalysis (Jacques Lacan) or literary theory (Roland Barthes, Jacques Derrida, Julia Kristeva). Thanks in part to the efforts of the UK journal Screen, the set of ideas developed by the Cahiers editorial team in these texts became one of the chief foundation stones of film studies in the UK and North America, which was not truly established as a scholarly discipline until what Dudley Andrew has called "the Prague Spring of academia" in the 1970 s. ${ }^{2}$ Cahiers became inexorably linked with the dominant theoretical tendency of that era, which has gone by a variety of appellations. "Apparatus theory," "political modernism," "Screen theory" or simply "1970s theory" are now all used, relatively interchangeably, to refer to the mode of thinking about the cinema inspired by the work of Cahiers and its contemporaries. "1970s theory," however, suffered a backlash against it in the ensuing decades. Many of its key claims were repudiated in hostile fashion, and it was supplanted by a variety of other schools of thought, including cognitivist, neo-formalist, cultural studies-oriented or Deleuzean approaches to the cinema. Even those who remained sympathetic to the theoretical lineage of Cahiers and Screen felt constrained to acknowledge that it had entered into a period of crisis and was now to be looked back on with a mixture of "pride and embarrassment." 3

Those clamorous debates may have since died down, but the result has been to leave the canonical Cahiers texts in a state of relative silence. Obligatory reading in film studies departments they may still be, but only as documents of their time, remaining in a frozen state, without much prospect, it would seem, for re-evaluation, productive re-reading or new research. Moreover, the four texts mentioned above have tended to monopolize

2 Dudley Andrew, “The 'Three Ages' of Cinema Studies and the Age to Come," PMLA vol. 115 no. 3 (May 2000), pp. 341-351, here p. 341.

3 This was the memorable phrase used by Rodowick in his influential overview of this theoretical tradition. D.N. Rodowick, The Crisis of Political Modernism, $2^{\text {nd }}$ ed. (Berkeley: University of California Press, 1994), p. vii. 
scholarly interest in the Cahiers of the post-1968 period. As Nick Browne wrote in 1990, "in regard to the formation of the film studies canon, the work of Cahiers of this period is available primarily through the translation of just four articles, variously anthologized."4 Despite more translations having become available since that time, Browne's judgement remains valid today. The prominent texts of this period have tended to stand in for and occlude the far vaster and more diverse, but still fundamentally unified, corpus of writings produced by Cahiers in the period 1968-1973. As Comolli has stated: "A lot of what appeared in this period could constitute the fragments of a single text. There is a coherence, there are explicit or implicit references, quotations. These texts cross paths again and again; in a certain manner, they are one 'text' in its essential plurality." In addition to this "text," which will form the core object of study in the present book, there is the larger and more heterogeneous collection of articles, books, interviews and films produced by the Cahiers writers before, during and after this period. These works relate to the post-1968 Cahiers project in different ways. In all cases, however, they contribute to a global understanding of the individuals involved in this moment of film theory: their life, their work and their ideas.

\section{Cahiers Under the Microscope}

Existing literature on the Cahiers of the années rouges between 1968 and 1973 has, until now, largely taken two forms. Many writers have inscribed this work within the broader development of film studies, placing it between an earlier model of "classical film theory" — as epitomized by figures such as Bazin, Siegfried Kracauer, Béla Balázs, Jean Mitry, Sergei Eisenstein and Rudolf Arnheim - and the "political modernism" of Screen writers such as Stephen Heath, Laura Mulvey, Peter Wollen and Colin MacCabe. Broadly speaking, the work of D.N. Rodowick (The Crisis of Political Modernism), Sylvia Harvey (May'68 and Film Culture), Dudley Andrew (The Major Film Theories and Concepts in Film Theory) and Francesco Casetti (Teorie del cinema,

4 Nick Browne, "Introduction: The Politics of Representation: Cahiers du Cinéma 1969-1972," in idem. (ed.), Cahiers du Cinéma vol. III: 1969-1972 The Politics of Representation (London: Routledge, 1990), pp. 1-20, here p. 6.

5 Jean-Louis Comolli, interviewed by Daniel Fairfax, "Yes, we were utopians; in a way, I still am...': An Interview with Jean-Louis Comolli (Part 1)," Senses of Cinema no. 62 (April 2012), sensesofcinema.com/2012/feature-articles/yes-we-were-utopians-in-a-way-i-still-am-aninterview-with-jean-louis-comolli-part-1/ (accessed January 1, 2021). 
1945-1990) has discussed the Cahiers critics in these terms. ${ }^{6}$ Alternatively, the Cahiers of the 1968-1973 period has been treated within the context of the journal's own history. Here, Antoine de Baecque's two-volume Les Cahiers du cinéma: Histoire d'une revue is the principal work of reference and offers a wealth of information about the journal drawn from the access he had to its internal archives. The overarching narrative his study presents, however, is contestable. Painting the Marxist-Leninist period of Cahiers in a largely negative light, de Baecque depicts the evolution of the journal as a story of fall and redemption: having abandoned its Bazinian principles for political dogmatism at the dawn of the 1970s, it gradually recovers its lost state of grace, its "openness" to the cinema, by the onset of the 1980 s. ${ }^{7}$ His account has met with objections from those involved with Cahiers: Bérénice Reynaud, a critic for the journal in the 1980 s, has stated that "the book does not avoid a 'teleological' view of history, reading it a posteriori from the perspective of the more open-minded, more commercial, less political framework of the late 1980 s" and that it "fails to provide a materialist reading of this quintessentially materialist phase of Cahiers' history." ${ }^{8}$ Comolli himself has opined that "Antoine de Baecque's book leaves me unconvinced, as, I fear, it is guided by certain partisan considerations," and he concludes from this that "the history of this period, the history of Cahiers, remains to be written." More recently, Emilie Bickerton's more concise, English-language study $A$ Short History of Cahiers du cinéma has offered an alternative account, arguing that the "red years" represented a continuation of the modernist project initiated by Cahiers in the 1950s, which would lapse with the journal's turn towards the commercial mainstream in the $1980 \mathrm{os}$. This position is closer to my own view, but Bickerton's volume possesses other flaws. Strewn with factual inaccuracies, as reviews of the book have noted, its brevity prevents

6 See Rodowick, The Crisis of Political Modernism; Sylvia Harvey, May '68 and Film Culture (London: BFI, 1980); Dudley Andrew, The Major Film Theories (Oxford: Oxford University Press, 1976), pp. 236-241; Dudley Andrew, Concepts in Film Theory (Oxford: Oxford University Press, 1984), pp. 120-124; and Francesco Casetti, Teorie del cinema 1945-1995 (Milan: Bompiani, 1993), pp. 199-223.

7 Antoine de Baecque, Les Cahiers du cinéma: histoire d'une revue vol. II: Cinéma, tours détours 1959-1981 (Paris: Cahiers du cinéma, 1991). This standpoint is particularly evident in the conclusion of his study, pp. 345-349.

8 Bérénice Reynaud, "Introduction: Cahiers du Cinéma 1973-1978," in David Wilson (ed.), Cahiers du Cinéma vol. IV: 1973-1978 History, Ideology, Cultural Struggle (London: Routledge, 2000), pp. 1-44, here p. 8.

9 Jean-Louis Comolli, Cinéma contre spectacle (Lagrasse: Verdier, 2009), p. 18. Translated as Cinema against Spectacle: Technique and Ideology Revisited, trans. and ed. Daniel Fairfax (Amsterdam: Amsterdam University Press, 2015), p. $5^{8 .}$ 
a deeper engagement with the journal's history - a grand total of 13 pages are dedicated to Cahiers' politically radicalized period. ${ }^{10}$ Finally, the BFI's four-volume project to publish key Cahiers texts in English translation presents its own historical overview of the journal, one bolstered by the informative introductions opening each installment of the series. In this vein, the texts by Browne (covering the years 1969-1972) and Reynaud (1973-1978) are of particular utility.

These two approaches, however, suffer from a common drawback: essentially, they both leave the Cahiers critics behind once their collaboration with the journal finishes. Despite the importance of Daney's journalism for Libération in the 1980s, Aumont's role in the development of academic film studies in France, Bonitzer's and Kané's screenwriting and directing, Eisenschitz's work as a film archivist and historian, Comolli's and Baudry's theory and practice of documentary film, Narboni's role in film publishing, or Pierre's position as editor of Trafic, these activities are rarely mentioned in discussions of the Marxist period at Cahiers. In the following two volumes, therefore, I aim to do what no scholar has attempted heretofore. Not only does the focus of my study lie squarely on the period in which Cahiers openly avowed a Marxist outlook, it also places this phase of the journal's historical development within an alternative context: the life and work of the ten critics involved with it during this time. The Red Years of Cahiers $d u$ Cinéma (1968-1973) will draw the links between the critics' time at Cahiers and their later activity. It will discern the ways in which the ideas developed at the journal shaped their subsequent output as well as the ways in which these writings and films can retrospectively shed light on the film theory developed in the post-1968 period. There are, of course, major differences, ruptures and discontinuities within the textual field demarcated by this project, but there are also significant continuities, through-lines and distinguishing features present across this array of writings, and it will be the task of this book to elucidate them.

If such a project has been carried out anywhere before, then it is - sketchily, episodically - in the work of the Cahiers critics themselves. For all of them, their time at Cahiers, when they were still in their twenties and early thirties, was a formative experience that was fundamental for how they

10 Emilie Bickerton, A Short History of Cahiers du Cinéma (London: Verso, 2009). See especially pp. 71-84. For a review of Bickerton's book providing a corrective to some of the book's infelicities, see Bill Krohn, "A Review of A Short History of Cahiers du Cinéma," Kino Slang, October 12, 2011, http://kinoslang.blogspot.com/2011/10/review-of-short-history-of-cahiers-du_12.html (accessed January 1, 2021). 
understood the cinema. Prone to introspection, many of the Cahiers critics have reflected at length on their involvement with the journal, giving voice to their thoughts and reminiscences in interviews and other texts. The apogee of this process came in 2011 with the film $A$ voir absolument (si possible): Dix années aux Cahiers du cinéma 1963-1973. Produced for cable television and directed by Comolli and Narboni, the documentary featured interviews conducted by the two Cahiers editors with their former colleagues. Pierre, Aumont, Eisenschitz, Kané and Bonitzer all participated in $A$ voir absolument (si possible), and it now stands as a precious document attesting to how this period of the journal's history is seen by its participants from the standpoint of the twenty-first century.

To a far greater degree than the secondary literature, the chief research material for the present study is primary in nature: namely, those issues of Cahiers du cinéma dating from the period under examination as well as the broader body of work produced by the ten critics in question, a corpus which runs to thousands of pages in total. Archival holdings in France have also been accessed: most notably those of Jacques Rivette and Henri Langlois at the Espace Chercheurs de la Cinémathèque française in Paris, and the archives of Éric Rohmer and Louis Althusser in the Institut mémoires de l'édition contemporaine in Caen. One significant archival resource, however, has remained inaccessible: that of Cahiers itself, presently off-limits to researchers for legal reasons. This collection would undoubtedly be of inestimable value in gaining a fuller understanding of the history of Cahiers, and its present unavailability is therefore deeply regrettable. Of particular value is the "Journal de travail" maintained by the editorial board in the years 1970-1974, which affords an inside look into the day-to-day operation of the journal during this period. At present, however, only a small portion of this document can be gleaned from those passages of it that are cited or reproduced in de Baecque's history. We can only hope that this material will become available for future scholars.

An alternative resource is available, however, and I have made ample use of it: namely, oral testimonies provided by the critics themselves. In the course of my research, and particularly during a year spent in France in 2013-2014, I conducted interviews with all of this book's subjects who are still alive and of sound mind. Discussions with Jean-Louis Comolli, Jean Narboni, Jacques Aumont, Pascal Bonitzer, Pascal Kané, Sylvie Pierre and Bernard Eisenschitz were all recorded and transcribed, and excerpts from this material are frequently deployed throughout the two volumes of this book. An interview with Serge Toubiana, who joined Cahiers in 1972 and subsequently played a major role in the journal, is similarly important, while 
I also spoke with a number of Cahiers critics active during other periods, including Jean Douchet, Jacques Bontemps, Michel Delahaye, Alain Bergala and Serge Le Péron. Sadly, it was impossible to speak to Serge Daney, Pierre Baudry and Jean-Pierre Oudart. Daney passed away in 1992, and Baudry in 2005. Oudart's status is a mystery: the prevailing hypothesis among his former colleagues is that he was interned in a mental institution in the 1980 s, and his present situation —or even whether he is alive or dead-is unknown. The testimonies that were collated from these interviews form a precious complement to the textual resources consulted for this book, fleshing them out with the personal point of view of those responsible for the texts under analysis, providing precious biographical details, and giving insight into not only the critics' retrospective account of their time with Cahiers but also their thoughts on the present state of the cinema and the world. Aside from Daney, Baudry and Oudart, all these critics are still actively thinking about, writing on and, in some cases, making films. More than four decades after the end of the journal's foray into Marxist-Leninist politics, giving an overview of the Cahiers critics' activity in the cinema is still, therefore, a work in progress. The années rouges are ongoing. Hence, the best future for the present book I can hope for is that it will quickly become outdated by virtue of the continued output of its subjects.

\section{What is Althussero-Bazinism?}

A presiding hypothesis about the work of the Cahiers critics guides this book: that their theoretical understanding of the cinema represented a combination of the structuralist Marxism of Althusser's philosophy and the "ontological realism" of Bazin's film theory. The importance of Althusser to Cahiers in the late 196os and early 1970s is indisputable. In programmatic texts such as "Cinéma/idéologie/critique" and "Technique et idéologie," the influence of his ideas was explicitly asserted and their application to the study of cinema practiced. Of course, Althusser was not alone among contemporary theorists relevant to Cahiers during this period. Lacan, Barthes, Kristeva, Derrida, Michel Foucault, Christian Metz, Alain Badiou and Pierre Macherey were also, in various ways, decisive points of reference for the journal. The significance to Cahiers of other, older tendencies in Marxist aesthetic theory and practice can also be discerned: whether in the German tradition of Bertolt Brecht and Walter Benjamin, the French surrealism of Georges Bataille and Maurice Blanchot, or the montage praxis of 1920 Soviet filmmakers such as Eisenstein and Dziga Vertov. But Althusser nonetheless 
remains the fundamental maitre à penser for Cahiers during its militant phase, both due to his political influence, as he sought to detach Marxism from the doctrinaire stranglehold of the French Communist Party (PCF), and due to the comprehensive nature of his theory of ideology, which was able to embrace not just the cinema but art and culture more broadly, as well as philosophical questions concerning the nature of reality, subjectivity and human society. Althusser's ideas, therefore, formed an entry point - and a conceptual framework-for the Cahiers critics to approach those of his contemporaries in French critical theory.

That Cahiers, even at the height of its Marxist-Leninist period, remained fundamentally indebted to Bazin in its theoretical outlook on the cinema is, by contrast, a much more contested stance to take. Since Screen introduced the writings of the post-1968 Cahiers to English-speaking readers in 1971, it has almost become an article of faith in the historiography of cinema studies that the work of Comolli, Narboni and their colleagues represented an anti-Bazinian tendency in film theory. This relationship has often been depicted in almost OEdipal terms as the violent rejection of the journal's spiritual "father" by the younger generation at Cahiers. Andrew has even cast it as a Shakespearian drama, likening the Marxist shift of the journal to Brutus turning on Caesar. ${ }^{11}$ Certainly, evidence for this outlook can be found on the pages of Cahiers during its politically radical period, when Bazin was frequently referred to in disparaging terms as an "idealist," and articles such as "Lécran du fantasme" by Daney and Bonitzer offered a withering critique of his film theory. But these epithets mask the deeper affinity between Bazin's film theory and the core notions underpinning the post-1968 Cahiers' understanding of the cinema. As Daney recognized, a "Cahiers axiom" governs the work of the journal from its foundation under Bazin through to its Marxist and, subsequently, post-gauchiste phases: "that the cinema has a fundamental relationship with the real, and that the real is not what is represented-and that's final. ${ }^{12}$ Indeed, it is only a simplistic understanding of Bazin that would align his theory with a superficial "surface realism." Thankfully, due primarily to the scholarship of Dudley Andrew and Hervé Joubert-Laurencin, we now understand that Bazin's notion of the "ontological realism" of the cinematic image is subtler and more philosophically complex than this - and quite distinct from the question of a mimetic analogy with a model subjected to a process of filmic

11 Dudley Andrew, "Foreword," in André Bazin, What is Cinema? vol. II, trans. and ed. Hugh Gray (Berkeley: University of California Press, 2004), pp. xi-xxvi, here p. xx.

12 Daney, L'Exercice a été profitable, Monsieur, p. 301. 
recording. ${ }^{13}$ To a large degree, it refers instead to the nature of the filmmaking process itself. The "ontological" realism of the cinema is primarily a question of formal technique rather than the fidelity of the content-or, to use the semiological terminology that found favor during Cahiers' Marxist phase, it is concerned with the signifier rather than the signified. While Bazin's own belief system may well have retained a measure of metaphysical idealism, Joubert-Laurencin has forcefully argued that there is a fundamentally materialist logic to his conception of the cinema, and it is this latent quality, I maintain, that can provide for the existence of a theoretical continuity between Bazin and the later generation of Cahiers writers. ${ }^{14}$

Moreover, Bazin's writings were frequently given an intriguingly favorable mention by Cahiers in the years after 1968. The "Cinéma/idéologie/critique" editorial, for instance, presents them as a necessary first step on the path towards a historical materialist theory of the cinema, whose contradictions were capable of being dialectically superseded. ${ }^{15}$ In his review of Othon by Straub/Huillet - a directorial duo whose materialist application of Bazin's ideas we can now recognize-Narboni declares that "almost nothing" separates "idealism, in one of its most coherent manifestations, from materialism," and his article relies in equal measure on Bazin and Derrida for its theoretical armature. ${ }^{16}$ In "Technique et idéologie," Comolli frequently polemicized against Bazin but is invariably more positive towards his ideas than he is towards those of other film theorists, such as Mitry, Georges Sadoul, Gérard Leblanc and Jean-Patrick Lebel, even if on a political and philosophical level Comolli's thinking would seem much closer to the latter figures. To explain this contradiction, the critic had recourse to Lenin's quote, pertaining to Hegel, that "intelligent idealism is more intelligent than stupid materialism." ${ }^{\prime 17}$ Today, indeed, Comolli recognizes that his

13 See Dudley Andrew and Hervé Joubert-Laurencin (eds.), Opening Bazin (Oxford: Oxford University Press, 2011).

14 This is the governing argument of his recent monograph. See Hervé Joubert-Laurencin, Le Sommeil paradoxal (Paris: Éditions de l'œil, 2014).

15 See Jean-Louis Comolli and Jean Narboni, "Cinéma/idéologie/critique," Cahiers du cinéma no. 216 (October 1969), pp. 11-15, here p. 15. Translated as "Cinema/Ideology/Criticism," trans. Daniel Fairfax, in Comolli, Cinema against Spectacle, pp. 251-259, here p. 259.

16 Jean Narboni, "La vicariance du pouvoir," Cahiers du cinéma no. 224 (October 1970), pp. 43-47, here p. 45. Translated as "Vicarious Power," trans. Leigh Hafrey, in Browne (ed.), Cahiers du cinéma vol. III, pp. 150-162, here p. 156.

17 The Lenin quote actually reads "Intelligent idealism is closer to intelligent materialism than stupid materialism" and derives from a 1915 marginal note written with respect to Hegel's Geschichte der Philosophie. See V.I. Lenin, Philosophical Notebooks, in The Collected Works of V.I. Lenin vol. XXXVIII (Moscow: Progress Publishers, 1976), p. 274. For Comolli's citation of Lenin, 
relationship with Bazin is "an affinity which comes from an opposition" and that "in trying to critique Bazin I ended up very close to him." ${ }^{18}$ Narboni, for his part, has suggested that Marx's relationship with Hegel—in which the "rational kernel" of the idealist philosopher's dialectic needed to be stripped of its "mystical shell" - may be the most profitable analogy for understanding the influence Bazin exercised on him and his cohort: "It's like Hegel and Marx, that's it. We tried to stand him on his feet, but it was not to destroy him."'19 Even "L'écran du fantasme," which was dedicated to analyzing the symptomatic contradictions of Bazin's ideas on the cinema, was, in the end, an "amorous polemic," a form of homage to the journal's founder by means of critique. ${ }^{20}$

Following the model of Lacan's "Kant avec Sade," which argues for a necessary but closeted complementarity between philosophically opposed figures, we can thus posit the existence in Cahiers' Marxist period of a film theory that would have at its core a kind of "Althusser avec Bazin.".21 This "Althussero-Bazinism" represents a distinctive understanding of the relationship between cinema and the real, one which generates the theoretical originality of Cahiers' brand of Marxist film theory. Whereas Bazin emphasizes the "ontological realism" of the cinema, Althusser argues, in texts such as "Idéologie et appareils idéologiques d'État," that our understanding of reality is structured by ideology_indeed that the very concept of reality is an ideological construction. Many of Cahiers' contemporary rivals and later epigones utilized Althusser's ideas to argue that the nature of the cinematic apparatus was fundamentally grounded in the ideology of bourgeois metaphysics, since it was based on the illusion of an analogy between the cinematic image and our perception of the world. In this strand of film theory, we can place Marcelin Pleynet and Jean-Louis Baudry of Tel Quel, Gérard Leblanc and Jean-Paul Fargier of Cinéthique, and many of the writers

see Jean-Louis Comolli, "Technique et idéologie: Caméra, perspective, profondeur de champ [2]," Cahiers du cinéma no. 230 (July 1971), pp. 51-57, here p. 52. Translated as "Technique and Ideology: Camera, Perspective, Depth of Field," trans. Daniel Fairfax, in Comolli, Cinema against Spectacle, pp. 182-193, here p. 184.

18 Comolli, "Yes, we were utopians (Part 1)."

19 Interview with Jean Narboni, April 2, 2014.

20 Interview with Jean Narboni, March 18, 2014.

21 See Jacques Lacan, "Kant avec Sade," in idem., Écrits vol. II (Paris: Seuil, 1966), pp. 765-792. Translated as "Kant with Sade," in idem., Écrits, trans. and ed. Bruce Fink (New York: W.W. Norton, 2006), pp. 645-668. Here Lacan observes that "Philosophy in the Bedroom came eight years after the Critique of Practical Reason. If, after showing that the former is consistent with the latter, I can demonstrate that the former completes the latter, I shall be able to claim that it yields the truth of the Critique." Ibid., pp. 765-766 [p. 646]. 
for Screen in the 1970s. This position is also, erroneously, often ascribed to the post-1968 Cahiers critics, lumped in with the other proponents of "apparatus theory." But their theoretical outlook was substantially different, and this divergence was at the root of their vitriolic polemics with Baudry, Pleynet and the Cinéthique editors. For the Cahiers of the Comolli/Narboni era, the cinema was not a mere tool of ideological obfuscation, serving to mask the true nature of the real. Rather, it was a privileged instrument for understanding the ideologically structured nature of reality itself. Its "realism" came from the insight it could afford into what Althusser called the dominant "system of representation" and the ideological configuration of the society that underpinned this system.

This position is made clear in "Cinéma/idéologie/critique," where Comolli and Narboni argue:

It is known that the cinema "reproduces" reality "totally naturally," because cameras and film stock are made in view of this very goal (and within the ideology that imposes this goal). But it is clear that this reality-susceptible to being reproduced faithfully, reflected by instruments and techniques which otherwise form a part of it—is entirely ideological. [...] It is not the world in its "concrete reality" which is "seized" by (or, rather, impregnates) a non-interventionist instrument, but rather the vague, unformulated, untheorized, unthought world of the dominant ideology.

And, later: "The cinema is burdened from the very beginning, from the very first meter of film processed, by the inevitability of reproducing things not as they are in their concrete reality, but as they are when refracted through ideology." The refraction of reality through ideology is indeed "present at all stages of film production," but it also occurs at the pre-cinematic stage, in our very perception and understanding of reality itself. The task of the cinema, therefore, is to "question the system of representation" and to do so by "question[ing] itself as cinema, in order to provoke a discrepancy or a rupture with its ideological function. ${ }^{22}$ The films that were thus of most interest to Cahiers were those capable of interrogating, subverting or "deconstructing" this system, either consciously, in the case of political modernist filmmakers such as Godard, Straub/ Huillet and Robert Kramer, or symptomatically, in the case of the great auteurs of the classical cinema such as Ford, Josef von Sternberg or D.W.

22 For this quote and those that precede it, see Comolli/Narboni, "Cinéma/idéologie/critique," pp. 12-13 [p. 254]. 
Griffith. This is the essence of "Althusser avec Bazin," and this program would substantively inform the theoretical and critical work carried out by the Cahiers writers in the years following the publication of "Cinéma/ idéologie/critique."

This is not to pretend, however, that the attempted integration of two theoretical frameworks from very different, even incompatible, philosophical traditions was free of contradictions and paradoxes—quite the opposite, in fact. The encounter between Althusserian Marxism and Bazinian film theory produced a convulsive dialectic in the journal. It constituted a theoretical mirror of the notorious political vacillations undertaken by the Cahiers editors in the tumultuous era of the late 1960 s and early 1970s, as the journal swung first towards a rapprochement with the PCF in 1969-1970, then Maoism in 1971-1972, and finally an anti-dogmatic "post-gauchisme" after 1973. But this dialectic also allowed Cahiers to avoid, for the most part, the sterility and latent cinephobia of other variants of "apparatus theory." Far from being content to denounce the "illusionistic" or "idealist" nature of the cinematic dispositif, the Cahiers writers ascribed greater importance to the task of understanding the mechanisms behind this illusion and how these processes could shed light on contemporary social reality. This outlook, I contend, gives the journal an unrivalled pertinence for today. In spite of all the changes in politics, culture and cinema since the 196os, the "Althussero-Bazinism" developed by the Cahiers critics laid the groundwork for the conceptual suppleness and fertility of their diverse ways of grappling with cinema in the following decades, which together form a valuable corpus for reflecting on audiovisual media in the contemporary era.

\section{Ideology and Politics, Aesthetics and Ontology}

How, then, can we take stock of the prodigious output yielded by these ten critics in the period between the 196os and the 2020s? What structure should a study concerning itself with this corpus take? Given the sprawling, web-like nature of this body of work, in which texts connect to each other in multiple ways, several structural approaches suggest themselves. The first would be a strictly chronological history of this generation of Cahiers writers: stretching from the biographical origins of each of the ten critics (all were born in the late 1930s-mid-1940s), through their time at Cahiers, and on to their later activity after the fault line of 1973. But there are several problems with this procedure. Firstly, it would substantially replicate the format of the historical overviews of Cahiers already undertaken by de Baecque 
and Bickerton. Secondly, and more importantly, it would nullify one of the most important aspects of this body of work: the fact that resonances can be detected across different time periods, that the same filmmakers find their œuvres discussed from one decade to the next, that the fundamental ideas guiding the work of the Cahiers critics have continued throughout a historical period that straddles the twentieth and twenty-first centuries, and that these critics have repeatedly interrogated their own past, returning to their earlier ideas and experiences in order to affirm, disown or critique them. Alternatively, the present book could be divided along individual lines: treating the life and work of each critic one by one. The problem here is that, in the case of many texts, written in pairs or larger groups, it is difficult to ascribe authorship to a single figure. More than this, it was the group that was of supreme importance during the years 1968-1973. The whole proved to be greater than the sum of its parts, as the journal strove to implement a non-hierarchical, anti-individualist theoretical practice, replacing the "I" of the critic with the "we" of collective intellectual activity. Adopting a biographical delineation would thus negate this core element in the work of the Cahiers team and would require abstract demarcations of authorial responsibility where, in reality, none should apply.

Instead, I have chosen to adopt a thematic structure. Each of the two volumes of this study contains two sections, which are in turn divided into several chapters. These sections cover the overarching subject areas that account for the film theory developed by the Cahiers critics. Part I, "Theories of Ideology," also functions as an introduction to the core theoretical ideas of the journal during its Marxist phase. Here, in order to elucidate my hypothesis that Cahiers represented an "Althussero-Bazinian" approach to film theory, I provide detailed discussions of three of the most well-known texts produced during this era: "Cinéma/idéologie/ critique" by Comolli/Narboni, "Technique et idéologie" by Comolli, and "Young Mr. Lincoln de John Ford," a historically rare instance of a truly collective text. These will be complemented by "La vicariance du pouvoir," Narboni's review of Othon, not as prominent in the field but of no less importance for the establishment of the Cahiers "line" at the dawn of the 1970s. All four texts provided the fundamentals of Cahiers' position with respect to ideology, film analysis and the "cinematic apparatus," and all four texts intervened into the roiling debates of the era between Cahiers and other journals such as Cinéthique, Positif, La Nouvelle Critique and Tel Quel. Chapters focusing on each of these texts will be contextualized by two further chapters: one on the early life and film criticism of Comolli and Narboni, who were both raised in the pied-noir community of Algeria 
and joined Cahiers after moving to Paris in the early 196os, and one on the "afterlives" of apparatus theory in anglophone film studies, with the reception the major Cahiers texts found in English-language journals such as Screen, Wide Angle and Jump Cut, and the continuation of these debates within academia. While this last aspect is often the prism through which Cahiers under Comolli/Narboni's editorship is viewed, these debates will not be a major point of reference after this point in the present study. Instead, my focus will be trained on the broader work of the Cahiers critics themselves, beyond the landmark texts that have gained renown in the field.

Part II, "Engagements with Politics" looks at the relationship the Cahiers critics have had with the realm of the political and in particular the journal's insertion into the far-left milieu in France in the years after the May 1968 revolt. Structured for the most part in chronological order, it will also serve the purpose of providing a historical overview of Cahiers during this time. The journal's efforts at political engagement undoubtedly represent the most tumultuous aspect of its existence during this period as it delved into the arcane debates and pedantic shibboleths of militant left culture in France. The chapters in Part II will follow the evolution of Cahiers from the eclectic leftism of the mid-196os through the journal's participation in the événements of May, its somewhat counter-intuitive attempt at a rapprochement with the PCF in the period 1969-1971, its precipitous conversion to Maoism and strident "anti-revisionism" in 1972-1973 (which led, under the influence of the Marxist-Leninist activist Philippe Pakradouni, to the abortive project of the "Front culturel révolutionnaire") and, finally, to its long period of "post-gauchiste" politics, stretching from 1973 until Daney's resignation as editor-in-chief in 1981, at which point the last remaining vestiges of the journal's Marxist period were finally liquidated. These chapters focus not only on the political activity of the Cahiers critics but also on their wide-ranging analyses of politically committed cinema: whether historical, with the Soviet montage tradition and Renoir's Popular Front films, or contemporary, with the formally innovative work of Godard and Kramer, and, in a negative sense, the aesthetically conservative narrative cinema of Costa-Gavras and Marin Karmitz, derided as fictions de gauche (leftwing fictions). While Comolli and Narboni claimed, in "Cinéma/idéologie/ critique," that "every film is political," the criteria they established for judging the political nature of films rested primarily on formal properties and represented a spirited defense of avant-garde aesthetics over any attempt to reach a broader audience through conformity to commercial stylistic and narrative norms. A discussion of these issues will be rounded out with 
chapters on the later work of Eisenschitz and Comolli, the two former Cahiers editors who most vocally continue to adhere to a broadly Marxist outlook.

In contrast to the volatility of Cahiers' political engagement, its taste in cinema-its vaunted goût-has remained remarkably stable. Even if the Marxist-Leninist years saw a rarefaction in the ranks of filmmakers $C$ ahiers defended, its critics remained stubbornly loyal to a modernist aesthetic embodied by directors such as Straub/Huillet and Godard. Their cinephilic intuitions were striking in their reliability: if numerous important directors were, for a variety of reasons, neglected, the merits of others-such as Kramer, Philippe Garrel and Carmelo Bene-were detected with unerring precocity, and the cases of an undeserving filmmaker finding favor with Cahiers were rare. Part III, therefore, addresses "Questions of Aesthetics" and is divided into three main segments. The first two chapters look at the relationship between the Cahiers writers and structuralist trends in literary theory: initially the semiology of Christian Metz, Pier Paolo Pasolini and the Barthes of the early 196os, and then the more deconstructionist approach of Derrida, Kristeva and Barthes' later work. Although they often deployed Sausurrean vocabulary, the Cahiers critics never unconditionally adopted a linguistic or semiological model for understanding the cinema. Instead, film was conceived of as a form of écriture, a mode of writing capable of undoing and subverting processes of signification and representation. Such an understanding of the cinema inevitably invokes questions specific to aspects of film form, such as montage, space, framing, and the film-still (photogramme). Debated at length on the pages of Cahiers, they will also be treated here. The second section of Part III, meanwhile, focuses on those films defended by Cahiers that had less immediate political implications than their counterparts discussed in Part II. These include Hollywood films such as Morocco, Sylvia Scarlett and Intolerance, subjected to "symptomatic" readings following the template used for Young Mr. Lincoln, works of European and North American modernists such as Luis Buñuel, Jerry Lewis, Garrel, Federico Fellini and Luchino Visconti, and radical cinema from regions beyond the core of Western Europe and North America, such as Eastern Europe (with filmmakers including Miklós Jancsó, Věra Chytilová, Jerzy Skolimowski), Latin America (Fernando Solanas, Glauber Rocha) and Japan (Yoshishige Yoshida, Masahiro Shinoda, Nagisa Oshima). A final section will look at the legacy of these writings for the later treatment of aesthetic questions by erstwhile Cahiers writers: the focus here will be on Aumont's scholarship during his time in the French university system, and Daney and Kanés preoccupation with the heritage of cinephilia in their journalistic writings and films respectively. 
Part IV, "Encounters with Ontology," will turn to the contentious topic of the cinema's relationship with the real. Here the key tutelary figures are Bazin and Lacan. An initial chapter will examine the legacy of Bazin's ideas for the later generation of Cahiers writers in texts such as "Lécran du fantasme", as well as their ongoing dialogue with Rohmer, a director who, perhaps more than any other, was fundamentally shaped by Bazin's film theory and whose films seemed to stimulate the Cahiers critics as much as his political views enraged them. Subsequent chapters focus on the psychoanalysis-inspired ideas of Oudart (notable above all for relating the Lacanian notion of the "suture" to the study of cinema), Baudry (whose brief time at Cahiers was marked by a clutch of profound articles such as "Sur le réalisme" and "Figuratif, matériel, excrémentiel") and Bonitzer, one of the most prolific and theoretically promiscuous of the Cahiers critics, whose writings developed notions such as the hors-champ (off-screen space), anamorphosis and décadrage (disframing), which were then continued in his film work of the 1990s to the 2010s. A subsequent chapter will scrutinize the relationship between the Cahiers critics - especially Narboni, Bonitzer and Daney_and Deleuze's philosophy of the cinematic image, in which I will show the significant conceptual debt that Deleuze's Cinéma diptych owes to the film journal.

Part IV will end by focusing on a relatively unheralded aspect of the theoretical work carried out by the Cahiers critics, but one which is perhaps the most crucial for the present day. Throughout their time as critics, theorists and filmmakers, the Cahiers writers have dedicated themselves not only to an understanding of the cinema but also to a critical analysis of other forms of visual media. During the journal's Marxist period, this concern was most evident in the collective text on the political talk show $\grave{A}$ armes égales. It came into greater prominence later in the 1970s, when the journal fell under Daney's editorship and a concerted effort to understand the contemporary social functioning of the photographic, cinematic and televisual image was undertaken. This project was continued by Daney during his time at Libération in the 1980 s and early 1990s. Under the influence of Jean Baudrillard and Paul Virilio, major political events (the collapse of communism in Eastern Europe, the Gulf War) were theorized through the prism of their media coverage, the all-encompassing nature of which Daney dubbed the "visual." Since the beginning of the twenty-first century, Aumont and Comolli have also turned their eyes to the relationship between cinema and "new" media. Often these discussions are less systematic and more tentative than their film-centric counterparts, but they are no less a crucial part of the theoretical legacy of Cahiers. 


\section{Cahiers and the Collective Intellectual}

A final word must be said on a more subterranean legacy of the post-1968 Cahiers, one that exists alongside its contribution to film aesthetics and which will be sporadically discussed over the course of this book: namely, its existence as a collective of critics. Although officially, Comolli and Narboni were the editors-in-chief between 1968 and 1972, this status was progressively dissolved, and a more organizationally horizontal group formation arose in its place. With the turn to Maoism, the editorial board officially became a collective body, with no distinctions in rank and a radically egalitarian structure. Daney gives an example of the uncompromising spirit of this ideal: "Didn't we decide, one day, at Cahiers, to pay ourselves according to the principles of the Da Zhai model factory - that is, 'according to merit'? I can even remember granting myself a monthly wage of 900 francs." ${ }^{23}$ More than at any other time in its history, Cahiers functioned as a collaborative entity, internally consolidated, and operating in an autarkic fashion - with the members of the team willfully, if unwittingly, tending to cut themselves off from the rest of the world. This, of course, had its negative side: the history of the journal during this period is strewn with violent quarrels, shifting allegiances, rancorous departures, trials and purges such as can only be produced by so tightly enmeshed a group. Between 1968 and 1974, Michel Delahaye, Eisenschitz and Baudry were all subject to forced exclusion, while Jean-André Fieschi, Sylvie Pierre, Aumont and Pakradouni left voluntarily, but on acrimonious terms. Even today, such disputes have left open wounds on the psyches of their participants, who have retained their share of bitterness, resentment and paranoia about the events of the past. This is a trait held in common with many of those who were involved in the French far left in the years of militant activity following May'68, a time when the stakes of political engagement were particularly acute and sectarianism was rife. It was also mirrored in parallel developments in other journals Cahiers was close to, such as Cinéthique and Tel Quel, as well as Screen on the other side of the Channel.

By the same token, Cahiers' group dynamic had a tremendously positive, even utopian aspect to it. The journal's editorial team was not only institutionally collectivist, it also adopted a communal approach to the production of film theory itself. Numerous texts during this period are ascribed to collective entities (whether "Cahiers du cinéma," "La Rédaction," or noms de guerre such as the "Groupe Lou Sin d'intervention idéologique"). It is true that the cooperative nature of the composition of these texts varied and the 
motivation for this practice can be questioned. Reynaud has argued that the "near impossibility within the tenets of Maoism of saying 'I,' of writing a text in the first person" resulted in "the convenient ploy of writing texts collectively, in order to be able to say 'we."'24 But this was not just a rhetorical device. In certain privileged cases, such as "Young Mr. Lincoln de John Ford," the retrospective consensus among the Cahiers writers is that the texts were produced in a truly collaborative fashion in a writing process where no single figure was dominant but all worked in harmony with each other. Such experiences represented a practical overturning of individualized notions of intellectual labor that has remarkably few parallels in the history of Western ideas, and they had a lasting effect on those involved. Comolli, for instance, discusses the journal's group dynamic in the following terms: "What tied us together was the emergence of a mode of thinking, which arose collectively, because there was collective work, even if it was not very well organized. I profoundly believe in the collectivization of ideas. It was the most important experience of my life. It definitively marked me. Posing questions communally is something which has enormously affected me, and my way of life."25

In $\grave{A}$ voir absolument (si possible), Aumont considers the journal to have been an "avant-garde group" in the vein of the surrealists or the situationists, and he has since expanded on this remark, noting that Cahiers "had the structure of an avant-garde group, and the internal functioning of an avantgarde group," while cautioning that "the avant-garde was in our imaginations. This is why we were so elitist, so little inclined to go out to the banlieue to evangelize the people. We didn't give a stuff about the people, because we were avant-garde." Such criticism notwithstanding, he grants that "there is something respectable in all these groups: the fact of forming a group to do something that surpasses each of the individuals. There is an unselfish quality to this that I find interesting." In the day-to-day life of the Cahiers critic, as Aumont describes it, "we not only saw each other at the Cahiers office, but we went to the cinema together, we often ate together, we paid each other visits, there were parallel endeavors taking place." ${ }^{26}$ Aumont has also noted that the group conversations in the Cahiers office were a "formative" experience for him, even if he was not the most voluble of participants. Indeed, this oral tradition of film criticism - by its very nature more ephemeral and less easy to document-is perhaps just as important as the written texts produced by Cahiers in the theoretical edification of its critics. 
In this regard, it is important to emphasize the position of a figure whose role in the Cahiers of the post-1968 period can otherwise easily be overlooked. If we search for a conduit between the theoretical tradition of Cahiers in the Bazin era and the journal's gauchiste incarnation more than a decade later, then it may well be embodied by Jacques Rivette more than any other individual. While Bazin himself belonged to the center-left, many of the younger critics who took inspiration from him in the 1950s-including Truffaut, Godard and Chabrol, as well as the macmahoniens - adhered to a right-wing, even quasi-fascist political outlook, which flourished under Rohmer's editorship in the early 196os. More left-wing figures did populate the review during the 1950s and early 196os-Pierre Kast, Jean Domarchi and Bernard Dort among them-but they tended to have an anarcho-dandyish approach to politics and were less concerned with the field of theoretical questions opened up by Bazin's thinking. The exception was Rivette. One of the journal's "Young Turks," Rivette both identified squarely with the far left and integrated Bazin's major ideas into his film criticism while also being receptive towards other strands of contemporary critical theory. Between 1963 and 1965, he was editor-in-chief of Cahiers and served as a significant mentor to Comolli and Narboni in their first years at the journal as well as opening Cahiers up to the structuralist ideas that would play a prominent role in its subsequent theoretical evolution. Short but decisive texts from the early 196os such as "Revoir Verdoux" and "De l'abjection" had a talismanic status among the younger generation of critics, who later came to doggedly defend his films, especially when, as in the case of La Religieuse, they fell afoul of the state's censorship regime. In 1968, Rivette effectuated a low-key but pivotal return to Cahiers which lasted until 1970. During this time, he accompanied his fellow critics to screenings, participated and guided group discussions in the Cahiers office, and occasionally penned his own texts for the journal. Rivette's presence in Cahiers was a spectral one, and his appearances in this study are intermittent. But in many ways - their taste in films, their theoretical proclivities, their political evolution - the younger critics during the journal's Marxist phase were decisively shaped by his influence.

\section{Works Cited}

Dudley Andrew, The Major Film Theories (Oxford: Oxford University Press, 1976).

-, Concepts in Film Theory (Oxford: Oxford University Press, 1984).

- , "The 'Three Ages' of Cinema Studies and the Age to Come," PMLA vol. 115 no. 3 (2000), pp. 341-351. 
—, "Foreword," in André Bazin, What is Cinema? vol II, trans. and ed. Hugh Gray (Berkeley: University of California Press, 2004), pp. xi-xxvi.

— and Hervé Joubert-Laurencin (eds.), Opening Bazin (Oxford: Oxford University Press, 2011).

Antoine de Baecque, Les Cahiers du cinéma: histoire d'une revue vol. II: Cinéma, tours détours 1959-1981 (Paris: Cahiers du cinéma, 1991).

Emilie Bickerton, A Short History of Cahiers du Cinéma (London: Verso, 2009).

Pascal Bonitzer, interviewed by Stéphane Bouquet, Emmanuel Burdeau and François

Ramone, "Nos années non-légendaires: Entretien avec Pascal Bonitzer," in Emmanuel Burdeau (ed.), Cinéma 68 (Paris: Cahiers du cinéma, 2008 [1998]).

Nick Browne, "Introduction: The Politics of Representation: Cahiers du Cinéma 1969-1972," in idem. (ed.), Cahiers du Cinéma vol. III: 1969-1972 The Politics of Representation (London: Routledge, 1990), pp. 1-20. Hereafter CDC III.

Francesco Casetti, Teorie del cinema 1945-1995 (Milan: Bompiani, 1993).

Jean-Louis Comolli, “Technique et idéologie: Caméra, perspective, profondeur de champ [2]," Cahiers du cinéma no. 230 (July 1971), pp. 51-57. Translated as "Technique and Ideology: Camera, Perspective, Depth of Field," trans. Daniel Fairfax, in Jean-Louis Comolli, Cinema against Spectacle, Technique and Ideology Revisited (Amsterdam: Amsterdam University Press, 2015), pp. 182-193.

- Cinéma contre spectacle (Lagrasse: Verdier, 2009). Translated as Cinema against Spectacle: Technique and Ideology Revisited, trans. and ed. Daniel Fairfax (Amsterdam: Amsterdam University Press, 2015).

—, interviewed by Daniel Fairfax, "'Yes, we were utopians; in a way, I still am...': An Interview with Jean-Louis Comolli (Part 1)," Senses of Cinema no. 62 (April 2012), sensesofcinema.com/2012/feature-articles/yes-we-were-utopiansin-a-way-i-still-am-an-interview-with-jean-louis-comolli-part-1/ (accessed January 1, 2021).

— and Jean Narboni, "Cinéma/idéologie/critique," Cahiers du cinéma no. 216 (October 1969), pp. 11-15. Translated as "Cinema/Ideology/Criticism," trans. Daniel Fairfax, in Jean-Louis Comolli, Cinema against Spectacle (Amsterdam: Amsterdam University Press, 2015), pp. 251-259.

Serge Daney, L'Exercice a été profitable, Monsieur (Paris: P.O.L., 1993).

Sylvia Harvey, May '68 and Film Culture (London: BFI, 1980).

Hervé Joubert-Laurencin, Le Sommeil paradoxal (Paris: Éditions de l'œil, 2014). Bill Krohn, "A Review of A Short History of Cahiers du Cinéma," Kino Slang, October 12, 2011, http://kinoslang.blogspot.com/2011/10/review-of-short-history-ofcahiers-du_12.html (accessed January 1, 2021).

Jacques Lacan, “Kant avec Sade," in idem., Écrits vol. II (Paris: Seuil, 1966), pp. 765-792. Translated as "Kant with Sade," in idem., Écrits, trans. and ed. Bruce Fink (New York: W.W. Norton, 2006), pp. 645-668. 
V.I. Lenin, Philosophical Notebooks, in The Collected Works of V.I. Lenin vol. XXXVIII (Moscow: Progress Publishers, 1976).

Jean Narboni, "La vicariance du pouvoir," Cahiers du cinéma no. 224 (October 1970), pp. 43-47. Translated as "Vicarious Power," trans. Leigh Hafrey, in CDC III, pp. 150-162.

Bérénice Reynaud, “Introduction: Cahiers du Cinéma 1973-1978," in David Wilson (ed.), Cahiers du Cinéma vol. IV: 1973-1978 History, Ideology, Cultural Struggle (London: Routledge, 2000), pp 1-44.

D.N. Rodowick, The Crisis of Political Modernism, $2^{\text {nd }}$ ed. (Berkeley: University of California Press, 1994).

—, Elegy for Theory (Cambridge, MA.: Harvard University Press, 2014). 



\section{Part I}

\section{Theories of Ideology}

Fairfax, D., The Red Years of Cahiers du Cinéma (1968-1973). Volume I: Ideology and Politics. Amsterdam: Amsterdam University Press, 2021

DOI 10.5117/9789463728508_PARTO1 

Comolli and Narboni's October 1969 manifesto-editorial "Cinéma/idéologie/ critique" marked one of the most significant turning points in the history of Cahiers. From its birth in 1951 until this watershed issue (no. 216), the journal had always been, officially at least, a politically neutral organ - even if, at times (during the Algerian crisis, most pointedly), its façade of apoliticism was hard to defend. As of Comolli/Narboni's concise yet momentous text, Cahiers would now be placed under a revolutionary Marxist political outlook, with historical materialism as its theoretical bedrock. More spectacularly, the editorial so incensed its proprietor Daniel Filipacchi that Cahiers was shut down for four months - between November 1969 and March 1970 - until a dispute over the journal's ownership was resolved. Furthermore, "Cinéma/ idéologie/critique" laid the groundwork for the future texts written by the Cahiers critics during its Marxist phase. It also represented one of the first contributions to what would come to be known as "apparatus theory," which was developed in France through debates between Cahiers, Cinéthique, Tel Quel and La Nouvelle Critique and carried into the English-speaking domain by Screen and other politicized film journals in the UK and North America. Nonetheless, the notion of a clear rupture occurring with the appearance of "Cinéma/idéologie/critique" needs to be mitigated. Prior to its publication, the political vacillations masked behind Cahiers' notional ecumenism were often sharp and acrimonious, particularly in the early 196os when Comolli and Narboni were both starting out as critics. By the mid-196os, however, it was abundantly clear that the journal under Rivette's stewardship had been re-directed to an increasingly overt left-wing orientation, a tendency that found favor with the younger cohort of critics (and readers) and escalated with the events of May '68. These political peripeteia, both within the journal and among French society more broadly, will be further discussed in Part II.

Here, by contrast, I will focus on the field of reflection concerning the ideological nature of the cinema that opened up in France in the late 196os. It should be recalled that, far from being a relatively unified, homogeneous theoretical undertaking, as it often tends to be presented today, "apparatus theory" is an umbrella term that unites figures who engaged in long and often venomous debates with each other. To some degree, of course, this dissension can be ascribed to the taste for polemic prevalent among French film critics and the far left at the time. But this should not conceal the fact that trenchant points of difference are discernible within the barbed vitriol, and this is undeniably true in the debates conducted between Cahiers and its rival journals. Here, the key point of contention concerns the very nature of the relationship between cinema and ideology — with the latter term understood in its Althusserian Marxist sense-and, more specifically, the extent to 
which the cinema is an innately "ideological" apparatus. Notably, between the time of the October 1969 editorial and Comolli's later, equally pivotal text "Technique et idéologie" (published between May 1971 and October 1972), Cahiers' editorial team unequivocally rejected the notion that the cinema by its very nature reproduces bourgeois ideology, a proposition put forth by Tel Quel's Marcelin Pleynet, vocally supported by Cinéthique, and which finds echoes in later texts in Screen. Instead, their standpoint adheres more closely to Althusserian precepts: it is not the cinematic image that provides an ideological falsification of an otherwise undistorted reality. Rather, our very understanding of "the real" is structured by prevailing ideologies, which themselves, far from being static and monolithic, are multiple, contradictory and subject to transformation. Here, the cinema — and consequently the act of film analysis - can play a privileged role in gaining knowledge about the ideological nature of reality itself.

This hypothesis was exhaustively interrogated by the prolonged work of psychoanalytic film theory carried out in Cahiers during its Marxist period, a dynamic that will be discussed more thoroughly in Part IV. Intriguingly, such a standpoint brings the Cahiers of the post-1968 era in proximity to the thinking of Bazin-a trait recognized, and mocked, by the journal's adversaries. For Bazin, the cinema is a privileged instrument for perceptually and conceptually gaining access to the reality of the world. The Cahiers of "Cinéma/idéologie/critique" assents to this viewpoint, as long as it is disburdened of Bazin's supposed "idealism," and is instead combined with an Althusserian understanding of the suffusion of this same reality by ideology. I thus begin this study with a close reading of the October 1969 editorial, one that situates the article within multiple contexts: Althusserian texts on the general question of ideology, and the relationship between ideology and art more specifically (these include works not only by the philosopher himself but also acolytes of his such as Badiou and Macherey); the potential liaison between such a reading and a Bazinian account of cinematic practice; and contemporaneous debates about the cinematic apparatus with Tel Quel and Cinéthique, which notably earned a 10,000-word direct reply from Cahiers in its following issue (November 1969). From this point, I will take a step back and look at Comolli and Narboni's prior cinephilic and critical practice, which for both of them stretches back to their youth in French-occupied Algeria before they migrated to Paris in the early 1960 s and began writing for Cahiers. This output, written between 1962 and 1969, is a rich offering in the critical appreciation of cinema at one of its key historical turning points: the demise of the classical Hollywood system and the rise of nouveaux cinémas on a 
global level. Foreshadowing Comolli and Narboni's later critical practice, these articles offer an additional angle from which "Cinéma/idéologie/ critique" can be understood.

A pair of key interpretative texts from 1970, implicitly illustrating critical categories established in the 1969 editorial, form the central two chapters in this part of my study. The first is one of the most prominent textual readings in the history of film theory: the collective analysis "Young Mr. Lincoln de John Ford." Comolli and Narboni played a key role in the composition of this 1970 text, whose methodology derives chiefly from Althusser's Lire le Capital, Barthes' $S / Z$ (published the same year) and some concepts from Freud and Lacan, but they were joined in this communal endeavor by their team of younger collaborators. Its influence on film interpretation has been so widespread as to have almost rendered the original text banal, its novelty invisible. Nonetheless, I insist that a new reading of this supremely canonical text-one that places it in the context of the long and tumultuous history of Ford reception in Cahiers - is a profitable endeavor. As a pendant to the Hollywood classicism of Ford, meanwhile, Narboni's treatment of Straub/ Huillet's Othon (1969) in "La vicariance du pouvoir" provides a template for the modernist poetics defended by Cahiers in terms of subject matter, theoretical reference points and even the critic's own writing style. In the legendary "Battle of Othon" that pitched Cahiers and the PCF-aligned Nouvelle Critique against Positif and virtually the entire critical establishment, Narboni calls upon figures as diverse as Derrida, Lautréamont and Bazin to make his case in support of the film. Indeed, if a materialist reading of Bazin's film theory can be authorized, its practical application may find no better exemplar than the work of Straub/Huillet, whose œuvre, along with that of Godard, was granted unstinting support by the journal.

A somewhat later text, stretched out over more than a year's worth of issues and intervening into an increasingly divisive political environment, can be seen as the summation of Cahiers' theoretical attempts to grapple head-on with the question of ideology and the cinematic apparatus. Comolli's six-part "Technique et idéologie" is arguably the most prolonged, intensive theoretical engagement carried out under the auspices of Cahiers du cinéma during this time; it, too, has earned a certain canonical respectability. In arguing for the economic and ideological determination of the birth and early history of the cinema, following the model of plural historical temporalities sketched out by Althusser and Kristeva, Comolli also dealt a blow against what he called the "technicist ideology" apparent in the texts of Jean-Patrick Lebel and Jean Mitry. In many ways, the ambition surpassed the man: taxed with other commitments, Comolli left the series unfinished. 
Its central ideas, however, would impregnate his later film theory, discussed in greater detail elsewhere in this book.

A final chapter will look at the "afterlives of the apparatus" - namely, the various ways in which the ideas developed and fostered on the pages of Cahiers, invariably in debate with other French critical traditions, disseminated into other, primarily academic approaches to the cinema. This overview will focus on the seminal status that "Cinéma/idéologie/critique" and "Young Mister Lincoln de Jean Ford" had for a generation of anglophone scholars: from the excitement the texts generated on the pages of Screen, Wide Angle and Jump Cut to the positivist and formalist critiques offered by David Bordwell, Noël Carroll and Richard Allen in the 1980s, whose denunciations were so efficacious that even sympathizers with the tradition of "political modernism" such as Rodowick had to admit to the historical exhaustion of its productive potential. ${ }^{1}$ As a counterpoint to this elegiac position, dominant within the discipline since the 1980s, André Gaudreault has recently attested that the interrogation of film history in "Technique et idéologie" was an important precursor to the "new film history" movement beginning in the 1980s - just one example of the Cahiers writers exerting influence in diverse, and sometimes unexpected, quarters. ${ }^{2}$ As I will demonstrate in the following chapters, a more lasting, positive legacy for the strain of film theory developed by the journal in the post-1968 period can be found not simply by re-reading the well-thumbed Cahiers texts but also through an exploration of the multifarious theoretical and practical body of work these writers produced since that time.

There is nonetheless an irony in this part of my study: whereas I generally maintain the decisive importance of the group as a whole in Cahiers over any of its individual writers, here the focus lies squarely on two figures: Comolli and Narboni. This is not without justification: slightly older than their co-conspirators, the pair of critics joined Cahiers significantly earlier, in the early 196os, and their collaboration stretches back to their youth in Algeria. Although the preeminence of their role within the journal would gradually give way to a more genuine collectivity, for a time (the time, precisely, of "Cinéma/idéologie/critique" and the initial turn to Marxism), Comolli and Narboni were effectively "first among equals" at Cahiers. It is for this reason that, in the next few chapters, the Comolli/Narboni couple largely stands in for the Cahiers group.

1 Rodowick, The Crisis of Political Modernism.

2 See André Gaudreault, Film and Attraction: From Kinematography to Cinema, trans. Timothy Barnard (Urbana: University of Illinois Press, 2011), pp. 11-16. 


\section{Works Cited}

André Gaudreault, Film and Attraction: From Kinematography to Cinema, trans. Timothy Barnard (Urbana: University of Illinois Press, 2011).

D.N. Rodowick, The Crisis of Political Modernism, $2^{\text {nd }}$ ed. (Berkeley: University of California Press, 1994). 



\title{
1. “Cinéma/Idéologie/Critique": An Epistemological Break?
}

\begin{abstract}
This chapter focuses on Jean-Louis Comolli and Jean Narboni's groundbreaking 1969 text "Cinéma/idéologie/critique." With its famous "seven categories" dividing films along political and formal criteria, this editorial established the critical line for the journal in the ensuing period and advocated a Marxist practice of film criticism that emphasized the political value of cinematic form, rather than the overt message of a film's content. Part of an ongoing polemic with the rival left-wing film journal Cinéthique, "Cinéma/idéologie/critique" also represented an opportunity for Comolli/Narboni to argue, in an Althusserian vein, that the cinema was an ideologically determined entity but that specific films were capable of creating gaps in or ruptures with the prevailing bourgeois ideology.
\end{abstract}

Keywords: Cahiers du cinéma, Jean-Louis Comolli, Jean Narboni, Cinéthique, Tel Quel, Louis Althusser

\section{Genesis of a Manifesto}

While "Cinéma/idéologie/critique" was undeniably a breakthrough moment for Cahiers, Marxism came gradually to the journal. Between the beginning of Jacques Rivette's tenure as editor in 1963 and the publication of "Cinéma/idéologie/critique" six years later, there is no single moment of transformation but an incremental, progressive evolution, precipitated by external events and differing in its temporal unfolding depending on the individual writers' own personal developments. This process will be charted more closely in Part II, with its focus on Cahiers' various engagements with politics. As important as it was for emboldening and further radicalizing the Cahiers team, even the uprising of May 1968 was not a decisive turning point. Narboni, in fact, specifically rejects what he sees as the "widespread

Fairfax, D., The Red Years of Cahiers du Cinéma (1968-1973). Volume I: Ideology and Politics. Amsterdam: Amsterdam University Press, 2021 DOI 10.5117/9789463728508_CHO1 
belief out there according to which Cahiers was politicized after May '68. This is absolutely false. The Cahiers folks were absolutely not political virgins beforehand. Firstly, Comolli and I were born in Algeria, so we knew a little something about the history of politics and war."

"Cinéma/idéologie/critique," then, is the culmination of a process of political evolution whose origins stretch back to the beginning of the 1960 s, if not earlier. In the terms of materialist dialectics, it represented the point at which the quantitative leftwards evolution of the journal was transformed into a qualitative political "leap." If the text is a moment of rupture, then this is for two major reasons: firstly, it makes Marxism the overt political and theoretical "line" of the journal; secondly, it opts for a particular variant of historical materialism, namely, one heavily influenced by Althusser's thinking, which was even in late 1969 a relatively fresh point of reference for the journal. The need to establish such a "line" espousing a specific strain of Marxist theory as a programmatic imperative can at least in part be explained by two major contexts influencing the editors' conduct at the time: the contemporary political environment, and Cahiers' own history. In the first case, May 1968 heightened the perceived need amongst the French far left for clarity on political principles and theoretical fundamentals. The downside of this concern was a persistent, internecine sectarianism and often bilious political culture, even (or especially) between tendencies that were close to each other - and Cahiers, to say the least, was not immune to this narcissism of small differences. The journal's own cultural tradition was equally imbued with a spirit of fierce polemic and the steadfast desire to establish an internal consensus, although here it was generally the choice of films more than political considerations that constituted the crucial point of demarcation. One of the journal's co-founders, Jacques Doniol-Valcroze, describes this disposition in eloquent fashion in a text that constitutes the first "history" of Cahiers, a retrospective account of its early years for the journal's $100^{\text {th }}$ issue in October 1959. Here Doniol-Valcroze notes that, whereas the initial conception for Cahiers was for a more inclusive publication, open to a broad range of approaches to the cinema, Truffaut's philippic "Une certaine tendance du cinéma français" perceptibly changed the nature of the journal in a lasting fashion:

The publication of this article marks the real point of departure for what today, rightly or wrongly, Cahiers du cinéma represents. A threshold was crossed, a course of action was opened with which we were all in solidarity, 
this was something that brought us together. From now on, we knew that we were for Renoir, Rossellini, Hitchcock, Cocteau, Bresson... and against $\mathrm{X}, \mathrm{Y}$ and $\mathrm{Z}$. From now on, there was a doctrine. ${ }^{2}$

Indeed, this doctrinal orientation, this need for a critical "line," is one of the most important of the red threads that unites the Cahiers of the $1950 \mathrm{~s}$ with the journal's later, more politicized guises.

A more pressing motivation for "Cinéma/idéologie/critique" came with the emergence of Cinéthique, whose first issue was published in January 1969. The journal, founded by filmmaker Marcel Hanoun, was soon placed under the editorial control of the neophyte critics Gérard Leblanc and Jean-Paul Fargier. Cinéthique was from the beginning an unabashedly gauchiste publication but was initially colored by a certain left-wing eclecticism - it did not adopt the rigid Marxism-Leninism it was later associated with until issue no. 5, which, dating from September-October 1969, was simultaneous with Cahiers' own transformation. Cinéthique nonetheless found ways, in its first four issues, to assail Cahiers from the left. The inaugural issue featured an interview with Godard, who had already converted to Maoism by this point and had severed ties with Cahiers in the process. ${ }^{3}$ Seeing one of the journal's most brilliant alumni speaking to an upstart rival publication was unquestionably a considerable embarrassment for the Cahiers team, one compounded by the harsh words Godard had for his critical alma mater. More pertinent to the theoretical orientation of Cahiers and its position within the "constellation" of French cultural politics was an interview in Cinéthique no. 3 (published in April 1969) with Tel Quel's Marcelin Pleynet and Jean Thibaudeau, titled "Économie, idéologique, formel...". Edited by Philippe Sollers, Tel Quel had been assiduously courted for several years by the Cahiers editors, who had invited writers associated with the literary journal to publish with the film magazine on several occasions. ${ }^{4}$ Comolli and Narboni, however, had also committed a faux pas by giving vocal support to the first issue of Change - a literary journal edited by former Tel Quel editor Jean-Pierre Faye, who was attacked mercilessly by his former comrades — and this may have

2 Jacques Doniol-Valcroze, "L'Histoire des Cahiers," Cahiers du cinéma no. 100 (October 1959), pp. 62-68, here p. 68 .

3 See Jean-Luc Godard, in J.-P.C. and G.L., "Un cinéaste comme les autres," Cinéthique no. 1 (c. January 1969), pp. 8-12.

4 As early as December 1966, Tel Quel editors Philippe Sollers, Jean Thibaudeau and Jean Pierre Faye provided responses to questionnaires for a special issue on "Film et roman: problèmes du récit," and shortly afterwards, Sollers, Faye and Marcelin Pleynet contributed to a dossier on Jean-Daniel Pollet's film Méditerranée for the February 1967 issue of Cahiers. 
contributed to the decision by Pleynet and Thibaudeau to give their backing to Cinéthique. Like Godard, the Tel Quel editors did not refrain from barbed comments aimed at Cahiers, with Pleynet announcing:

Look at what has happened to Cahiers du cinéma, which objectively speaking has never ceased to, as they say, "peddle the merchandise," and which will end up disappearing without ever having been a film journal — or by only ever having been a film journal, as in just another one. It seems to me that, for a group that wants to establish a journal today, there are not a few lessons to be drawn from reading through Cahiers. ${ }^{5}$

Beyond the snide remarks made by Pleynet, "Économie, idéologique, formel..." can also be considered the urtext of apparatus theory in film studies. In a key passage earlier in the interview, Pleynet holds forth on his understanding of the ideological determination of the very mechanism of the cinema:

Have you noticed that all the discourses that can be held on a film, or on the cinema (and large quantities of them have been held), start off from the a priori non-signifying existence of an apparatus producing images, which can then be used indifferently for this or that purpose, on the right or on the left? Does it not seem to you that before interrogating themselves on their "militant function," filmmakers ought to interrogate themselves on the ideology produced by the apparatus (the camera) that determines the cinema? The cinematic apparatus is a properly ideological apparatus, it is an apparatus which diffuses bourgeois ideology, even before diffusing anything else. Even before producing a film, the technical construction of the camera produces bourgeois ideology. ${ }^{6}$

The literary critic then proceeds to discuss the role of quattrocento perspective in the cinema, as well as the contemporaneity of Nièpce's invention of photography with Hegel's "closure" of the history of art. Pleynet's remarks had an incendiary effect, and their reverberations in other texts and projects would irrevocably change the contours of film theory. For Cahiers, they were

5 Marcelin Pleynet and Jean Thibaudeau, interviewed by Gérard Leblanc, "Économique, idéologique, formel...," Cinéthique no. 3 (April 1969), pp. 7-14, here pp. 13-14. Translated as, "Economic - ideological - formal," trans. Elias Noujaim, in Harvey, May '68 and Film Culture, pp. 149-164, here p. 162 .

6 Ibid., p. 10 [p. 155]. 
of seminal importance, but it is important to recall that Cahiers never truly adhered to the propositions laid out by Pleynet. His notions provided grist for an intense period of theoretical investigation and invention lasting throughout Cahiers' Marxist period (and, for some critics, well beyond this point), but this primarily took the form of a stringent critique of his propositions.

Similarly, while the Cinéthique editors often portrayed the "red turn" (virage rouge) of Cahiers as an act of suivisme, opportunistically following the impetus already established by the younger journal, this idea should also be tempered.7 Positif was only too happy to parrot such arguments in order to mock their rival journal, and some historians have also credited this viewpoint. ${ }^{8}$ But, for several years before the founding of Cinéthique, the Cahiers editors were already moving to these positions under their own logic, and other factors are just as decisive in their political transformation: the events of May; exposure to the theories of Althusser, Barthes, Lacan and Derrida; and the development of politically radical film practice on a global level in the 196os, to name a few. Nonetheless, the existence of Cinéthique undeniably hardened the resolve within Cahiers to openly avow its Marxism, and it exacerbated the culture of virulent polemic (both internally and externally) that would dominate the journal. Comolli, indeed, readily admits to the irritation caused at Cahiers by Cinéthique's far-left posture, saying: "We were attacked by the ultra-leftists. They were to the left of us and they considered us to be rather right-wing, which truly annoyed us. [...] At the same time we did not take refuge on the right. Quite the opposite, we went on the attack." 9

This, then, is the context in which "Cinéma/idéologie/critique" came into existence. As for the actual writing of the text, Jean Narboni gives an illuminating account of this process: "One day, with Jean-Louis, we decided to write a manifesto. And so we wrote this text which said [...] that it's not enough for there to be a good progressive content, it's not enough for there to be pretty formal work, there needs to be real writing [écriture], a work on form, a configuration of meaning. ${ }^{{ }^{10}}$ Intriguingly, the first person the article was shown to was Jacques Rivette, who played an instrumental role in having the article accepted by a supervisory conseil de rédaction that

7 For the "virage rouge" comment, see "Cinéthique," "Du bon usage de la valeur d'échange (Les Cahiers du cinéma et le marxisme-léninisme), Cinéthique no. 6 (January-February 1970), pp. 1-12, here p. 1.

8 See Louis Seguin, "Le cinéma dans la politique," Positif no. 113 (February 1970), pp. 3-10; and George Lellis, Bertolt Brecht, Cahiers du Cinéma and Contemporary Film Theory (Ann Arbor: UMI Research Press, 1982), p. 75.

9 Comolli, "Yes, we were utopians (Part 1)."

10 Interview with Jean Narboni, March 18, 2014. 
still included Doniol-Valcroze, Filipacchi, Truffaut and the critic-turnedfilmmaker Pierre Kast: "The first person to have read it in the office was Rivette. Rivette was very in favor of it. I don't know what he thought of it later, but Rivette supported us. Rivette was respected and at this moment he said, 'Yes, I am entirely in agreement."'11

\section{Althusser avec Bazin: Ideology and Reality}

"Cinéma/idéologie/critique" is, even in its opening lines, presented as "a theorization of the criticism being practiced by us," an attempt to systematically give a "global definition of the position we are in, and the direction we are taking." ${ }^{12}$ While the text evidently has the air of a manifesto, Comolli/ Narboni immediately set themselves a modest goal: the aim of their editorial is not, they maintain, that of tracing out "a 'program' for ourselves to proclaim, nor of clutching at 'revolutionary' declarations and projects." Instead, it is to attempt "a reflection, not on what we 'want' (would like) to do, but on what we do and what we can do."13 This prudence ushers in a defensive maneuver, namely, the justification of Cahiers' status inside the "economic system of capitalist publishing" - the fact that it was still owned by the Filipacchi media group. Sensitive to Cinéthique's persistent vaunting of its independent ownership structure ${ }^{14}$ Comolli/Narboni caution against "the utopia of a 'parallelism' whose first—paradoxical—effect is to constitute, alongside the system from which it claims to escape, an illusory externality, a 'neo-system,' under the illusion that it is able to cancel out that which it is content to reject (idealist purism)." ${ }^{15}$

The Cahiers editors likewise claim that all films made in a country such as France are inserted into the capitalist economic system and thus ineluctably act within the dominant ideological formation of the modern bourgeoisie. ${ }^{16}$ They refuse the viability of Godard's declared wish to work

11 Ibid.

12 Comolli/Narboni, "Cinéma/idéologie/critique," p. 11 [p. 251].

13 Ibid.

14 In a notice on the inside cover of issue no. 4 of Cinéthique, its editors trumpeted the fact that "the work that we have undertaken is in complete rupture with the official circuits of distribution" and insisted on the viability of establishing a "parallel circuit of distribution."

15 Comolli/Narboni, "Cinéma/idéologie/critique," p. 11 [p. 252].

16 When speaking of "capitalist ideology," Comolli/Narboni take care, in a footnote, to explain that they are not referring to an "abstract essence" but a phenomenon that is "historically and socially determined, multiple according to place and time, and variable throughout history." 
outside "the system," averring that this "will not prevent him from having to work in another system which is only ever a reflection of the initial one."17 At the very limit, they note, all filmmakers have to use film stock, which means engaging with the Kodak monopoly of that particular industrial product. A truly "underground" cinema, working entirely outside of the structures of capitalism, is inconceivable without a broader social revolution. This standpoint does not, however, lead Comolli/Narboni to a position of economic determinism or one of cynical fatalism, a smug reassurance that revolutionary film practice is impossible or only credible in a distant future political conjuncture. Instead, the Cahiers editors insist that, while all films are "encompassed" within the "vast field" of the dominant ideology, the key factor in determining their political value from a Marxist standpoint is their reaction to this situation, which can markedly differ from filmmaker to filmmaker.

This leads Comolli/Narboni to one of their central statements and one of the lines for which their editorial is most remembered: "every film is political. ${ }^{m 8}$ If this lapidary statement has something of an immutable validity to it, it was also made in reference to a very contemporary phenomenon in 1969. With the popular success of $Z$, France witnessed a wave of films taking politics as their subject matter, to the extent that, as Cahiers often wryly noted, even the listings guide Pariscope saw fit to devise the genre "film politique." For the Cahiers critics, not only were these films-which the journal later dubbed "fictions de gauche" —in no way sufficient for a politically radical cinema, but politics itself was a much vaster terrain than the common tropes of elections, protests or strikes that were the material for these films. If "every film is political," this is because politics permeates into all parts of human society. The phrase itself, however, was not original to Comolli/Narboni. Not only had Pleynet opened his Cinéthique interview by saying "all films are political," on the pages of Cahiers itself, Rivette had also recently expressed the same sentiment when interviewed by his younger colleagues in $1968 .{ }^{19}$

Ibid., p. 15 [p. 253] This preemptively rebuts later criticisms of this text—and "apparatus theory" more generally_for adopting an essentialist, ahistorical understanding of ideology.

17 Ibid., p. 12 [p. 253].

18 Ibid.

19 See Pleynet/Thibaudeau, “Économie, idéologique, formel...," p. 7; and Jacques Rivette, interviewed by Jacques Aumont, Jean-Louis Comolli, Jean Narboni and Sylvie Pierre, "Le temps déborde: Entretien avec Jacques Rivette," Cahiers du cinéma no. 204 (September 1968), pp. 6-21, here p. 20. Translated as "Time Overflowing," trans. Amy Gateff, in Jonathan Rosenbaum (ed.), Rivette: Texts and Interviews (London: BFI, 1977), pp. 9-38, here p. 36. 
In relating cinema to the domain of the ideological, Comolli/Narboni were entering into one of the thorniest questions of Marxist theory: the status of ideology. While this term was of major importance in the writings of Marx and Engels, the founders of Marxism did not dedicate a major text to elucidating the concept, and most of the key passages relating to the notion derive from Marx's early period, in particular his posthumously published Die deutsche Ideologie. In this lacerating assault on Hegelian philosophy, Marx proclaimed that:

We do not set out from what men say, imagine, conceive, nor from men as narrated, thought of, imagined, conceived, in order to arrive at men in the flesh. We set out from real, active men, and on the basis of their real life-process we demonstrate the development of the ideological reflexes and echoes of this life-process. The phantoms formed in the human brain are also, necessarily, sublimates of their material life-process, which is empirically verifiable and bound to material premises. ${ }^{20}$

In a passage that has had obvious attraction to film theorists, Marx would, a little earlier in the same work, memorably compare the function of ideology to the workings of a camera obscura, musing: "If in all ideology men and their circumstances appear upside-down as in a camera obscura, this phenomenon arises just as much from their historical life-process as the inversion of objects on the retina does from their physical life-process." ${ }^{21}$ In later writings, Marx devised another well-known metaphor in order to discuss ideology's relationship with the economy, this time a spatial one: here, the economic base (or substructure) stands at the foundations of the ideological superstructure. Despite only appearing fitfully in Marx's own writings, these comparisons-presenting ideology as the reflex, echo, phantom or sublimate of reality, resulting in an "inversion" of historical life-processes or as an "upper level" of a strictly demarcated pyramid of social practices - were transformed into a catechistic dogma by the dominant Stalinist current within the communist movement.

20 Karl Marx, The German Ideology, in The Collected Works of Marx and Engels vol. V (New York: International Publishers, 1975), p. 36 .

21 Ibid. Reading this analogy with the camera obscura a little too literally, Cinéthique drew a heated rebuke by Cahiers in the second part of "Cinéma/idéologie/critique" for implying that Marx was speaking of the cinema avant la lettre. See Jean-Louis Comolli and Jean Narboni, "Cinéma/idéologie/ critique (II): D'une critique à son point critique," Cahiers du cinéma no. 217 (November 1969), pp. 7-13, here p. 9. Translated as "Cinema/Ideology/Criticism (II): On Criticism at Its Critical Point," trans. Daniel Fairfax, in Comolli, Cinema against Spectacle, pp. 261-280, here p. 269. 
Reacting against this orthodoxy and drawing on the ideas of the Italian communist theorist Antonio Gramsci, Althusser's work of the 1960 s revolutionized the Marxist concept of ideology. His insistence on returning to and closely reading the work of Marx would even lead him to make the claim that "The German Ideology does offer us [...] an explicit theory of ideology, but... it is not Marxist," instead dubbing it a positivist and historicist thesis akin to the pre-Freudian understanding of dreams. ${ }^{22}$ Althusser's own views on the matter were in a state of flux at the time that Comolli/Narboni's editorial was written, and his most well-known text concerning ideology— "Ideologie et Appareils idéologiques d'état"—did not appear until after "Cinéma/Idéologie/Critique," in June 1970. ${ }^{23}$ Already in Pour Marx, however, the French philosopher would seek to replace the base/superstructure "topography" of orthodox Marxism's account of ideology with a relationship of "overdetermination," drawing principally from Freud's analysis of the dream-work in Die Traumdeutung. ${ }^{24}$ In the last article included in Pour Marx, "Marxisme et humanisme," Althusser proceeds to define ideology as "a system (with its own logic and rigor) of representations (images, myths, ideas or concepts, depending on the case) endowed with a historical existence and role within a given society." It is thus to be distinguished from science on the basis that, while both can be considered "systems of representation," in ideology "the practico-social function is more important than the theoretical function (function as knowledge)." Importantly, ideology is considered to be "an organic part of

22 Louis Althusser, "Idéologie et Appareils idéologiques d'état (Notes pour une recherche)," La Pensée no. 151 (June 1970), pp. 3-38, here p. 22. Translated as "Ideology and Ideological State Apparatuses: Notes towards an Investigation," in idem., Lenin and Philosophy and Other Texts, trans. Ben Brewster (New York: Monthly Review Press, 1971), pp. 85-132, here p. 107.

23 Draft copies of Althusser's text circulated in militant circles before its publication in $L a$ Pensée, including to Jean-Pierre Gorin, who used it as the basis for the Groupe Dziga Vertov film Luttes en Italie. As Fargier recalls: "In a café one day, Gorin showed his hand. Shielding them as if had four aces in poker, he showed us the crumpled-up pages, underlined in red, black and green, of an unpublished text by Althusser, which would later appear under the famous title 'Ideological State Apparatuses.' We had the right to read the text, in the cafe, but not to take it with us." Jean-Paul Fargier, "Ici et là-bas: Entretien avec Jean-Pierre Gorin," Cahiers du cinéma no. 388 (October 1986), pp. 37-40, 42, here p. 37. Comolli confirms, however, that Cahiers' first exposure to Althusser's text came with its June 1970 publication and recalls that it was immediately discussed at length in the Cahiers office. Jean-Louis Comolli, private communication, September 5,2013 .

24 See Louis Althusser, "Contradiction et surdétermination," in idem., Pour Marx (Paris: Maspero, 1965), pp. 85-128. Translated as "Contradiction and Overdetermination," in idem., For Marx, trans. Ben Brewster (London: Verso, 2005 [1969]), pp. 87-128. See also Sigmund Freud, The Interpretation of Dreams, trans. James Strachey (New York: Basic Books, 1955 [1900]). 
every social totality." It is not an unfortunate by-product of class-divided societies but an ineradicable aspect of our social existence. Human societies, in Althusser's view, "secrete ideology as the very element and atmosphere indispensable to their historical respiration and life." Even a future classless society, free of social contradictions, could not be disembarrassed of ideology: "historical materialism cannot conceive that even a communist society could ever do without ideology, be it ethics, art or 'world outlook."'25 This is not, however, a politically pessimistic perspective belittling Marx's projection of a communist society as an unfounded utopia. Instead, Althusser sees a possibility for transforming the role that ideology can play: "In a class society ideology is the relay whereby, and the element in which, the relation between men and their conditions of existence is settled to the profit of the ruling class. In a classless society ideology is the relay whereby, and the element in which, the relation between men and their conditions of existence is lived to the profit of all men. ${ }^{26}$ From this foundation, Althusser argues that ideology chiefly concerns the "lived relation between men and their world," as distinct from the "real relations" existing between the two (which, by contrast, are the subject of scientific inquiry, i.e. Marxist theory). In Althusser's words: "In ideology, men do indeed express, not the relation between them and their conditions of existence, but the way they live the relation between them and their conditions of existence: this presupposes both a real relation and an 'imaginary,' 'lived' relation." Finally, he specifies that, as a "system of representations," ideology can take the guise of images and occasionally concepts but that it is primarily as structures that ideologies impose themselves on individuals, in a process that is external to conscious awareness: such representations are "perceived-accepted-suffered cultural objects and they act functionally on men via a process that escapes them."27

At an important stage in "Cinéma/idéologie/critique," the last two passages quoted above are also cited by Comolli/Narboni, who defend their claim that "every film is political" by arguing that each film is "determined by the given ideology which produces it (or in which it is produced, which amounts to the same thing)." Compared to other cultural products, the cinema's ideological determination is particularly forceful, for two main reasons. Firstly, significant sums of capital are required for a film to be

25 This and the preceding quotes are from Louis Althusser, "Marxisme et humanisme," in idem., Pour Marx, pp. 225-250, here pp. 238-239. Translated as "Marxism and Humanism," in idem., For Marx, pp. 219-248, here pp. 231-232.

26 Ibid., pp. 242-243 [pp. 235-236].

27 Ibid., p. 240 [p. 233]. 
produced, even one on a modest budget - and this is before questions of distribution and marketing enter the equation. Secondly, and of greater theoretical importance, the technical equipment required to make a film is itself manufactured on an industrial basis by major corporations with ideological goals in mind: specifically, the "totally natural" reproduction of visual reality. It is at this point, however, that Comolli/Narboni's argument departs from Pleynet's claims and is instead closer to Althusser's thinking. Even if reality could be "reproduced faithfully" by film equipment, this reality is itself "entirely ideological" in nature. For the Cahiers critics, "it is not the world in its 'concrete reality' which is 'seized' by (or, rather, impregnates) a non-interventionist instrument, but rather the vague, unformulated, untheorized, unthought world of the dominant ideology." It is for this reason that Comolli/Narboni argue that "the cinema is burdened from the very beginning, from the very first meter of film processed, by the inevitability of reproducing things not as they are in their concrete reality, but as they are when refracted through ideology." 28

This, then, is Althusser avec Bazin: the world presents itself to the camera's "eye," but this world is already permeated with and structured by ideology. Ideology is not a mask that hides the real existence of things; rather, it is the way we experience the real existence of things, and this goes for "direct" human perception just as much it applies to the images created by the mechanical tool of the cinema. It is for this reason that Comolli/Narboni are actually rather favorably disposed towards Bazin in this text, belying their reputation as CEdipal usurpers of the Bazinian legacy. They do, indeed, declare the "theory of "transparency" to be "eminently reactionary"-but here they have in mind not Bazin (who rarely made reference to "transparent mise en scène") but rather the classical Hollywood system and its most dogged defenders in French film criticism, the macmahoniens, who were indisputably on the political right. As for Bazin, his theories constituted, in the Cahiers critics' eyes, a necessary stage of film theory-consisting of "returning more closely to film in the materiality of its elements, in its signifying structures, its formal organization" - that needed to be dialectically transcended. Although they do not hesitate to pronounce that Bazin's approach suffered from the "major defect" of "phenomenological positivism," they believe that the contradictions in his texts are easily pinpointed and fixed, and suggest that the path he had taken in film theory was continued by "the model of structural linguistics" (here they evidently mean Metz). 
For the "elaboration and application of a critical theory of the cinema [...] with direct reference to the method of dialectical materialism," however, Comolli/Narboni propose the research and experimentation carried out by the Soviet filmmakers of the 1920 (particularly Eisenstein) as the primary historical precedent worthy of interest. ${ }^{29}$ Indeed, the years 1969-1971 will be marked by an intense theoretical interest in the heritage of the Soviet montage tradition, which will be discussed at length in Chapter 8 .

\section{Form and Content in the Cinema: The Seven Categories}

If Comolli/Narboni assert that it is in the nature of "the system" to turn the cinema into an instrument of ideology, they nonetheless do not proceed to a cynical or fatalistic stance towards aesthetic possibilities in filmmaking. Instead they argue that the "most important task of cinema" at present is precisely "to question the system of representation itself: to question itself as cinema, in order to provoke a discrepancy [décalage] or a rupture with its ideological function.. ${ }^{30}$ Already, the language here is interesting: what is demanded is not a sweeping rejection of the prevailing ideology (which would be impossible in any case) but the need for questioning such ideologies, for creating discrepancies or ruptures with them. On the basis of this demand, the Cahiers editors establish their now legendary seven categories of cinema. Despite the fact that the wide familiarity of these categories within film studies is such that they can be recited by heart in "Introduction to Film" classes the world over, it is worth detailing this classification schema.

The first category comprises the vast majority of films and consists of those productions that "everywhere bathe in ideology, express it, carry it forward without any gaps or distortions." ${ }^{31}$ In accepting without reserve the governing "system of representation," these films are marked by an ironclad "conformity" (adéquation) between social demand and the ideological "response" they generate. They are the "unconscious instruments of ideology," and their status within the cinematic mainstream can be determined, even more than by their box office takings, by the "innocent absence at every stage

\footnotetext{
29 Ibid., pp. 14-15 [p. 259].

30 Ibid., p. 12 [p. 254]

31 The use of the word "bathe" recalls the manner in which Althusser speaks of ideology, particularly in his text "Lettre sur la connaissance de l'art (Réponse à André Daspre)," La Nouvelle Critique no. 175 (April 1966), pp. 136-141. Translated as “A Letter on Art in Reply to André Daspre," in idem., Lenin and Philosophy and Other Essays, pp. 151-155.
} 
of their production of even the slightest questioning of the representative nature of the cinema." Comolli/Narboni see little critical interest in these films. At best, Marxist film criticism should account for the success of popular "hits" by investigating "the conformity (at all levels) between the products of ideology and the ideological system." ${ }^{22}$

The following two categories differ from the first in that they enact a "double action" on the "ideological insertion" of cinema, operating on both the level of content (the signified) and filmic form (the signifier), thereby contributing to a "critical de-construction of the system of representation." ${ }^{33}$ But they differ as to the manner in which this break with the dominant ideology is carried out. In category (b) films, it is a directly political action, expressly willed by the filmmaker. Comolli and Narboni include films such as Nicht versöhnt by Straub/Huillet, The Edge by Robert Kramer and Terra em transe by Glauber Rocha in this class. ${ }^{34}$ In category (c) films, by contrast, this double action occurs "against the grain" (à rebours): neither the subject matter of the film nor the express intentions of the filmmaker are explicitly political, but they become so through the critical work performed on them. A more nebulous but potentially much more critically fertile category than category (b), this grouping includes Méditerranée by Pollet/Sollers, Persona by Ingmar Bergman and The Bellboy by Jerry Lewis. Although it is not spelled out as such, it appears that the key dividing line between these two categories is, essentially, whether the director openly identifies as a Marxist or not: if not, Marxist criticism must carry out a counter-reading of the film on the basis of its formal structures to find value in it (which Cahiers did, as we shall see, with both Lewis and Bergman). ${ }^{35}$ Implicitly, too, an "against the grain" reading of a film places the critic in a position of eminence in determining its signification, a hermeneutic strategy that puts the Cahiers of the Comolli/Narboni era in the critical lineage of the politique des auteurs espoused by the journal as early as the 1950s.

Together, these two categories constitute, for Comolli/Narboni, "the essence of the cinema and make up the essence of the journal." The fourth category, by contrast, consists of the increasing number of films which, while

32 The quotes from this paragraph are from Comolli/Narboni, "Cinéma/idéologie/critique," p. 13 [p. 255].

33 Ibid. [p. 256].

34 Although Godard is not expressly mentioned here, his increasingly politicized work is also an obvious exemplar of this tendency.

35 Méditérranée would be a more mixed case: the writer of the film's voice-over, Philippe Sollers, did identify as a Marxist but wrote in a lyrical, poetic register that presented deliberate difficulties in conveying a "message" in the film. For more on the work of Lewis, see Chapter 17. 
supposedly possessing a political content (and often one expressed from a left-wing, or at least left-liberal, point of view), unquestioningly conform to the norms of conventional film language, evidently out of a concern for reaching a mass audience. The paradigmatic example here would appear to be $Z$ by Costa-Gavras, the target of vociferous critique from Cahiers, although Comolli/Narboni prefer to mention Bernard Paul's Le Temps de vivre. These films are generally worthy only of withering condemnation on the pages of Cahiers, since they find themselves "expressing, reinforcing and duplicating exactly what they think they denounce." Of far greater critical interest is category (e): films from classical Hollywood (or the European canon), which enact an "internal dismantling" of the ideological system of representation they ostensibly exemplify, through the generation of "a discrepancy [décalage], a distortion, a rupture between the conditions of its appearance [...] and the end product." Such effects of discrepancy and rupture are primarily produced by "the film's deployment of a certain number of mechanisms of figuration" which allows for the "transformative self-designation of ideology." Cahiers here proposes an "oblique, symptomatic reading" of these works, seizing on the "fault lines" that effectively undermine their intended ideological function, and give the films of John Ford, Carl Theodor Dreyer and Roberto Rossellini as key examples of this tendency. ${ }^{36}$

The final two categories relate to "direct cinema," which is demarcated from the rest of filmmaking for reasons not clearly established (in any case the distinction will not be maintained in the future): a first group whereby the formal qualities of conventional cinema are largely reproduced, due to the filmmakers' emphasis on "transparency," "authenticity," and "lived experience," and a second, more promising cohort of films that "concentrate on the problem of representation in making the filmic material function," the outstanding example of which was the 10 -minute, single-shot 1968 film La Reprise du travail aux usines Wonder. ${ }^{37}$

On the basis of this seven-part classification system, Comolli/Narboni elaborate a fourfold set of guidelines for Cahiers' future critical practice, consisting of the following procedures: firstly, highlighting the total ideological determination of category (a) films; secondly, operating a "double reading" of category (b), (c) and (g) films (on the level of "signifier" and "signified");

36 Ibid., pp. 13-14 [p. 257].

37 Ibid. The Wonder film was frequently held up by Cahiers as a model of militant filmmaking and is treated at greater length in Comolli's text "Le détour par le direct (1)," Cahiers du cinéma no. 209 (February 1969), pp. 48-54. Translated as "The Detour through the Direct," trans. Christopher Williams, idem. (ed.), Realism and the Cinema: A Reader (London: BFI, 1980), pp. 224-244. The film and Comolli's text will be further discussed in Chapter 2. 
thirdly, pointing to the formal weaknesses of category (d) and (f) films; and finally, in the case of category (e) films, locating "the ideological gap produced by the work of the film. ${ }^{38}$ Although they tend to use the language of semiotics, referring to "signifiers" and "signifieds," it is clear that Comolli/ Narboni have recourse, in devising their seven categories, to the form/content dichotomy, one of the oldest problems in the philosophy of aesthetics. In their perspective, form has primacy over content in determining a film's ability to question and resist the dominant ideology. For all this, however, Comolli/ Narboni are not formalists. If category (d) films are denounced for being content-without-form, then we can also ascribe a putative, unmentioned eighth category to the Cahiers editors: form-without-content films, which were also scorned. The experimentation of avant-garde filmmakers or the American underground movement largely left Cahiers cold. Indeed, Comolli/ Narboni specifically critiqued films that consisted of pure formal exercises as operating "on the most superficial level of language" and thereby failing to be truly transgressive, pointing to the "failure" of the lettrists or the Zaum movement in support of their claim. Instead, the films defended by Comolli/ Narboni are those in which-to borrow from Hegel, whose Vorlesungun über die Ästhetik are at the basis of the entire tradition of aesthetic theory from which the Cahiers editors drew-form becomes content. ${ }^{39}$ The form/ content duality should thus be understood not as a mechanical opposition but as a dialectic. For Comolli/Narboni, this dialectic expresses itself in three productive ways: category (b), where it is the express political goal of the filmmaker; category (c), where it is achieved through the formal poetics of modernist filmmakers and the critical analysis made of them by their interpreters; and category (e), where it arises through the internal fissures opened up in otherwise formally classical films by the major auteurist directors, a process that needs to be pinpointed and theoretically elucidated by perceptive critics.

Finally, it is worth subjecting the viability of such a classification system-which divides up the entirety of cinematic production into defined, mutually exclusive groupings - to interrogation. Doing so has drawn accusations of offering a rigidly schematic, if not reductive, approach towards the plural, contradictory field of the cinema. ${ }^{40} \mathrm{~A}$ few things should be remembered here, however. The first is that these seven categories themselves,

38 Comolli/Narboni, "Cinéma/idéologie/critique," p. 14 [p. 258].

39 See G.W.F. Hegel, Vorlesungen über die Ästhetikvol. I-III, in idem., Werke vol. XIII-XV, ed. Eva Moldenhauer and Karl Markus Michel (Frankfurt am Main: Suhrkamp Verlag, 1970).

40 See Andrew, Concepts in Film Theory, p. 120. 
as Rosen recognizes, are centered on "mixed cases and contradictions." ${ }^{11}$ Devising seven categories is a gesture towards complexity in the context of the prevailing Manicheism in the discourse of politically radical film criticism at the time, which tended to sweepingly divide film production into "revolutionary" and "bourgeois" cinema, usually on the basis of the film's content. The second is that these categories were devised chiefly for the purposes of the editorial's line of argument, and - although they clearly programmed much of the later critical work by Cahiers (to take only the most obvious example, Young Mister Lincoln is clearly a "category (e)" film) — they were never referred to as such in subsequent issues of the journal. When discussing films in the wake of "Cinéma/idéologie/critique," the Cahiers critics never aligned it with one of the editorial's categories, nor did the journal entertain debates over how films should be classified - whether, for instance, a particular film corresponded to category (b) or (c). Ironically, this type of scholasticism would be far more prevalent in later academic discussions making use of Comolli/Narboni's text than in anything that appeared in Cahiers itself. ${ }^{42}$

\section{Art and Ideology in the Althusserian Tradition}

In producing a classification system of an art form on the basis of an individual work's response to its own ideological insertion, it appears - at least at first glance - that Comolli/Narboni unequivocally ascribe the cinema, and by extension art more generally, a place within the sphere of the ideological. This, indeed, is forcefully put in the English translation of the text produced for Screen, which claims: “'cinema' and 'art' are branches of ideology." ${ }^{33}$ But this line is a fabrication of the translator, misplacing a wholly different formulation from elsewhere in the original text which speaks, more vaguely, of "the vast field of ideology, one of whose names is 'cinema' or 'art'."44 In

\footnotetext{
41 Philip Rosen, "Preface," in Comolli, Cinema against Spectacle: Technique and Ideology Revisited, pp. 7-16, p. 11.

42 See, for instance, Barbara Klinger, "Cinema/Ideology/Criticism Revisited: The Progressive Text," Screen vol. 25 no. 1 (Jan-Feb 1984), pp. 30-44.

43 See Jean-Luc Comolli and Paul Narboni [sic], "Cinema/Ideology/Criticism," trans. Susan Bennett, Screen vol. 12 no. 1 (Spring 1971), pp. 27-36, here p. 30. This is the most widely available English translation of the text and has been reprinted in numerous other outlets, but it is riddled with inaccuracies which render it fundamentally deficient. I discuss its deficiencies in greater detail in Comolli, Cinema against Spectacle, pp. 247-250.

44 Comolli/Narboni, “Cinéma/idéologie/critique," p. 12 [p. 254].
} 
the end, Comolli/Narboni give no clear guidance on this question in their editorial. In fact, the issue of art's relationship to ideology was a vexatious one for Althusserian Marxism. Althusser had already established a clear distinction between scientific and ideological practice, but this raised an uncomfortable question: did artistic production, which is evidently remote from the former, thus fit unambiguously with the latter? In offhand comments in Pour Marx, Althusser seems to suggest as much. At several points in his text "Sur la dialectique matérialiste," which was reproduced in this volume, he talks of "ideology, whether religious, political, moral, legal or artistic" or of "Marxist investigators working in avant-garde domains such as the theory of ideologies (law, ethics, religion, art, philosophy). ${ }^{25}$ In "Marxisme et humanisme," meanwhile, he categorically refutes the idea that "art could merge with knowledge or become 'everyday life,' etc." and thereby attain a non-ideological status. ${ }^{46}$

This stance, not the result of carefully elaborated reflection from Althusser, evidently left those of his pupils who took an interest in questions of aesthetics dissatisfied. Writing for Cahiers marxistes-léninistes, a young Alain Badiou began his article on "Lautonomie du processus esthétique" by explicitly asserting: "Art is not ideology. It is entirely impossible to explain it by the homologous relation that it would support with the historical real. The aesthetic process decenters the specular relation where ideology perpetuates its closed infinity. The aesthetic effect is indeed imaginary: but this imaginary is not the reflection of the real, since it is the real of this reflection." ${ }^{47}$ Similarly, Pierre Macherey's article "Lénine, critique de Tolstoï"-later included in his instrumental book Théorie de la production littéraire - points to the distinctions between textual production and ideology. For Macherey, “Tolstoy's works cannot [...] be reduced to the ideology which they contain; they are more than that." ${ }^{m 8}$ Instead, the function of the literary work is to "present ideology in a non-ideological form," and Macherey thus concludes that "we can gauge the distance which separates the work of art from true knowledge (a scientific knowledge) but which also

45 Louis Althusser, "Sur la dialectique matérialiste," in idem., Pour Marx, pp. 161-224, here pp. 168, 173. Translated as "On the Materialist Dialectic," in idem., For Marx, pp. 161-218, here pp. 167,172 .

46 Ibid., p. 239 [p. 232].

47 Alain Badiou, "Lautonomie du processus esthétique," Cahiers Marxistes-Léninistes no. 12-13 (July-October 1966), pp. 77-89, here p. 77.

48 Pierre Macherey, "Lénine, critique de Tolstoï," La Pensée no. 121 (June 1965), pp. 78-10o, here p. 86. Translated as "Lenin, Critic of Tolstoy," in idem., A Theory of Literary Production, trans. Geoffrey Wall (London: Routledge, 1978), pp. 117-151, here p. 129. 
unites them in their common distance from ideology. Science does away with ideology, obliterates it; literature challenges ideology by using it."${ }^{\prime 49}$

Responding to these and other notes of concern, Althusser would produce two texts that more deeply explored his thoughts on the specific place of works of art within ideology. In "Lettre sur la connaissance de l'art (Réponse à André Daspre)," Althusser is categorical: "I do not rank real art among the ideologies, although art does have a quite particular and specific relationship with ideology." Art does not substitute for knowledge in the scientific sense, but it does maintain a "specific relationship" with knowledge, one which consists of a form of perceptual sensitivity towards ideology itself: "What art makes us see, and therefore gives to us in the form of 'seeing, 'perceiving' and 'feeling' (which is not the form of knowing), is the ideology from which it is born, in which it bathes, from which it detaches itself as art, and to which it alludes." Althusser is careful to clarify that he is only referring to "authentic art" — and not "works of an average or mediocre level." He specifically mentions Balzac, Tolstoy and Solzhenitzyn as key novelists in this regard, precisely because of their ability to operate "an internal distantiation from the very ideology from which their novels emerged. They make us 'perceive' (but not know) in some sense from the inside, by an internal distance, the very ideology in which they are held.".50 If art works produced a specific mode of knowledge about ideology (from within, as it were), Althusser also emphasizes the need for a scientific theory of the aesthetic, without which our understanding of art is likely to succumb to what he terms "latent humanist ideology." In "Cremonini, Painter of the Abstract," written at roughly the same time as the response to André Daspre, Althusser nonetheless maintains that art has an intimate relation to ideology and suggests that art works therefore have a certain split status between their "cultural" and "aesthetic" aspects: "Every work of art is born of a project both aesthetic and ideological. When it exists as a work of art it produces as a work of art [...] an ideological effect." As a purely aesthetic object, the work of art is, therefore, "no more part of 'culture' than instruments of production (a locomotive) or scientific knowledge are part of 'culture," but by the same token, it can become an "element of the ideological" by being inserted into "the system of relations which constitute the ideological." In fact, an art work, according to Althusser, has a privileged relation with ideology; despite its "internal distance" from the ideological

$5^{0}$ This and the preceding quotes are from Louis Althusser, "Lettre sur la connaissance de l'art," pp. 136-137 [pp. 151-152]. 
domain, it paradoxically "maintains far closer relations with ideology than any other object. ${ }^{51}$

It is this theoretical argument that allows Comolli/Narboni to make what would otherwise be some contradictory claims in their essay: they speak of all films being "encompassed by the dominant ideology," but they also allow for discrepancies, gaps and breaking points within this ideology to arise through the formal-critical work of the artist. Hence, Rodowick's claim, in The Crisis of Political Modernism, that Comolli/Narboni "privileged Althusser's work on epistemology and ideology at the expense of his and Pierre Macherey's writings on art" is unfair on the Cahiers editors..$^{52}$ Not only were Macherey's and Badiou's texts on art and literature cited on multiple occasions on the pages of Cahiers during this time, ${ }^{53}$ but the main argument of "Cinéma/idéologie/critique," emphasizing the potential for a "critical de-construction" of the dominant system of representation, is in line with the writings of the Althusserian theorists on art in this period.

Devising seven categories of film practice was a point of departure from Althusserian theory in one sense, however. While Althusser and his followers highlighted the existence of a strain of bourgeois realist novelists (Balzac, Tolstoy, Dostoyevsky, etc.) whose work, as a form of "authentic art," was elevated from that of average or mediocre works, he does not give us any criteria for being able to make this distinction. What is it that separates Balzac's Père Goriot or Murnau's Sunrise from the second-rate product of a hack writer or workhorse director? We are not to know. In contrast, Comolli/ Narboni do provide such terms of demarcation. These come not strictly in terms of aesthetic quality (although it is not hard to read this is a factor in their text) but in the varying relations between form and content, signifier and signified, ideological effect and critical work. Rather than veering away

$5^{1}$ Louis Althusser, "Cremonini, Painter of the Abstract," in idem., Lenin and Philosophy, pp. 157-166, here pp. 165-166.

52 Rodowick, The Crisis of Political Modernism, pp. 82-83.

53 Both were referenced in the collective text "Young Mr. Lincoln de John Ford," Cahiers du cinéma no. 223 (August-September 1970), pp. 29-44, here p. 30. Translated as "John Ford's Young Mr. Lincoln: A Collective Text by the Editors of Cahiers du Cinéma," trans. Helen Lackner and Diana Matias, Screen vol. 13 no. 3 (Autumn 1972), pp. 5-44, here p. 7. For Macherey, see also Jean-Louis Comolli, "Le détour par le direct (2)," Cahiers du cinéma no. 211 (April 1969), pp. 40-45, here p. 40, 45. Translated as "The Detour through the Direct," trans. Christopher Williams, idem. (ed.), Realism and the Cinema: A Reader (London: BFI, 1980), pp. 224-244, here pp. 235, 242]; and Jean-Louis Comolli, "Dernier acte, encore," Cahiers du cinéma no. 215 (September 1969), pp. 55-58, here p. 57. During the journal's Maoist period in 1972-1973, the Cahiers editors would entertain close relations with Badiou's small Marxist-Leninist group, the Union des communistes français (marxistes-léninistes). 
from their Althusserian models, as Rodowick has suggested, Comolli/Narboni are here, in the specific case of the cinema, making an attempt to fill in a crucial gap in the theory of art that was being developed by Althusser and his followers.

\section{The Debate with Cinéthique}

Issue no. 5 of Cinéthique (dated September-October 1969) appeared virtually simultaneously with the release of the Cahiers number containing "Cinéma/idéologie/critique" (dated October 1969). ${ }^{44}$ As with its rival journal, this number was something of a watershed for Cinéthique: the publication ushered in a new, sober format, and it was now more single-mindedly devoted to writings that, in the eyes of the editors, contributed to developing a Marxist understanding of the cinema. Issue no. 5 was bountiful in this sense: the editorial by Gérard Leblanc ("Direction," pp. 1-8) was followed by "La parenthèse et le détour" by Jean-Paul Fargier (pp. 15-21), Marcelin Pleynet's “Le front 'gauche' de l'art: Eisenstein et les vieux 'jeunes hégéliens"” (pp. 23-32) and Fargier's review of Jean-Pierre Lajournade's Joueur de quilles, "Discours - film (révolution) - mutisme" (pp. 37-40). Of these, the first two texts dealt most closely with the same set of concerns adumbrated by Comolli/Narboni's editorial. In both Cahiers and Cinéthique, repeated reference is made to the writings of Louis Althusser, a discussion of the cinema's determination by bourgeois ideology is held, and alternative modes of filmmaking —involving a "rupture" with dominant forms of ideology and a more "materialist" cinematic practice - are advocated. On multiple occasions, the same films are given similar evaluations: Le Temps de Vivre and $Z$ are denounced, while Méditerranée and Perrault's Le Regne du jour are lauded. The casual reader could be forgiven for thinking that the two journals were in remarkable theoretical and critical confluence with one another. This was not, however, how the editors on either side saw matters. Cahiers was the first to issue a polemical response, with Comolli/Narboni devoting a follow-up editorial in their next issue (November 1969) to a riposte to the texts in Cinéthique no. 5. The newer journal returned fire in their January-February 1970 issue (no. 6). Although this exchange was not without its disagreeable moments, often descending to petty personal attacks (in Cinéthique) or fastidious pedantry (in Cahiers), it is also valuable for allowing

54 The precise release dates of the two issues are uncertain, but it is evident that they were produced without knowledge of each other. 
the participants to delve more deeply into some of the theoretical questions pertaining to ideology and cinema that, by now, had clearly become a central theoretical preoccupation in both corners.

Of greatest theoretical interest in Cinéthique no. 5 is Fargier's "Parenthèse ou détour," subtitled "Essai de définition théorique du rapport cinémapolitique." Here, the Cinéthique editor argued that the cinema had a double ideological function: firstly, to reproduce or reflect existing ideologies, and secondly — and more fundamentally— to produce an ideology specific to itself: the "impression of reality" (which is far more forceful in the cinema than in other forms of representation such as painting). For Fargier, the primary way to avoid the cinema's "natural" inscription into idealist ideology is by means of "theoretical practice" — understood as a historical materialist approach to film criticism — and he thus advocates a "break" [coupure] in filmmaking practice, allowing it to separate its "knowledge function" from its "recognition function." Fargier sees two possibilities for a theoretical practice in the cinema: firstly, a film can reproduce knowledge already produced in the sciences (including historical materialism, but the critic also gives medicine, physics and geography as examples); secondly, and more importantly, a film can produce a specific knowledge about itself by allowing the audience "to see its social and physical materiality." 55 Fargier finds examples of such a "materialist cinema" in the likes of Un film comme les autres by Godard, Octobre à Madrid by Marcel Hanoun, Sollers/Pollet's Méditerranée and Le Joueur de quilles by Jean-Pierre Lajournade. The last title also drew a review from the critic in the same issue, which can be considered an extension of the argument of "Parenthèse ou détour." Fargier sees the film's "mutism" - that is, its negation of intelligible discourse — as marking a rupture in the ideological functioning of the cinema, one which allows it to "speak, by metaphor, of the historical role of the petty-bourgeoisie: to disappear." 56

Cahiers' long, detailed editorial response to Cinéthique was so punctilious as to focus, on two occasions, on typographical errors: a supernumerary accent in one case, and a comma instead of a semi-colon in the other. The text, "D'une critique à son point critique" (presented as a follow-up to "Cinéma/ idéologie/critique") can broadly be divided into two parts, with the second

55 Jean-Paul Fargier, "Parenthèse ou détour: Essai de défınition théorique du rapport cinéma-politique," Cinéthique no. 5 (September-October 1969), pp. 15-21, here p. 20. Translated as "Parenthesis or Indirect Route," Screen vol. 12 no. 3 (Autumn 1972), pp. 131-144, here p. 140. 56 Jean-Paul Fargier, "Mutisme - film (révolution) - discours," Cinéthique no. 5 (SeptemberOctober 1969), pp. 37-40, here p. 37. 
focused on Pleynet's discussion of the Soviet avant-gardes of the 1920s. It is the first part, however, with its attention to the texts of the Cinéthique editors themselves, that is of more considerable interest here. Comolli/Narboni begin their missive by suggesting that while the "program" outlined by Cinéthique of a Marxist approach to film criticism is to be broadly supported, this program is devoid of theoretical substance, and the principles argued for by Cinéthique end up playing the role of "the compensatory affirmation of their necessity-lack." Terms such as rupture, inscription, work, representation and foreclosure are sprinkled throughout the issue, but in Cahiers' view, they are not subject to the necessary theorization that would authorize their usage, and they thus remain at the level of "revolutionary verbiage," with "scientific pseudo-rigor rapidly being substituted for (and masking the absence of) theoretical rigor."57

Particularly problematic for Cahiers is Cinéthique's use of the term "break" [coupure] and Fargier's argument that it is possible for the cinema to transcend its ideological status by producing theoretical knowledge. The paradigm for this argument is clearly Althusser's notion, itself drawn from Bachelard, of an "epistemological break" between the writings of the young Marx, which are still "ideological" in nature, and those of Marx's maturity, when he had established the theory of historical materialism as a practice founded in a scientific approach to the analysis of human societies. ${ }^{8}$ To transplant this notion to the cinema itself, as Fargier does, is in the eyes of the Cahiers editors a dangerous act of theoretical confusion. Neither of the two possibilities for theoretical practice to exist in the cinema as outlined by Fargier are, for Comolli/Narboni, of any validity: the cinema can play a role in the diffusion of scientific knowledge, even of Marxist theory, but this does not change its nature as an "ideological product." In this case, they argue, "far from the film passing from ideology to science, the film enacts a transformation of science into ideology."59 Similarly, acts of cinematic self-reflexiveness (as in Octobre à Madrid) or deliberate "mutism" (LeJoueur de quilles) cannot be equated with the process of producing knowledge about the cinema itself, Fargier's second possibility for theoretical practice in the cinema. As Cahiers notes, Hollywood abounds with films that take the filmmaking process itself as their subject matter, in a manner little different to that of Hanoun, without these films in any way producing

57 Comolli/Narboni, "Cinéma/idéologie/critique (II)," p. 8 [p. 264].

$5^{8}$ See Louis Althusser, "Sur le jeune Marx," in idem., Pour Marx, pp. 45-83. Translated as “On the Young Marx," in idem., For Marx, pp. 49-86.

59 Comolli/Narboni, “Cinéma/idéologie/critique (II)," pp. 8 [p. 266]. 
theoretical knowledge per se. As for Lajournade, his film is nothing but a "monstrous metaphor of its own uselessness and impotence," and the Cahiers critics derisively mock the idea that it could be ushered into the "camp of materialist cinema." ${ }^{\text {" }}$

Comolli/Narboni categorically reject, therefore, the possibility that the cinema could enact a break between ideological and theoretical practice and, provisionally putting to one side the question of the "autonomy of the aesthetic process," squarely position the cinema within the field of ideology:

The cinema is an ideological product, its field of definition and practice is ideology, and not science. To put it simply, at present it is at the service of the dominant (bourgeois, capitalist) ideology, and we hope that in the future it will be in the service of another dominant ideology (a socialist one). But between now and the future, there will not be a transformation in the nature of the cinema. As an ideological instrument, it cannot become a science; instead, there will be a transformation of how it is used and the purposes for which it is used. ${ }^{61}$

It is for this reason that the Cahiers editors, in their original manifesto, preferred to speak of filmmakers "questioning" or "interrogating" ideology, of producing discrepancies or gaps with the dominant systems of representation, rather than proclaiming a comprehensive rupture with the cinema's very functioning as an ideological apparatus. They do not, however, refuse the possibility of a theoretical discourse on the cinema, even one that meets the status of "science" in Althusser's understanding, claiming that it is "not so ridiculous to put into practice a scientific approach to film criticism." ${ }^{62}$ But in this case, too, an epistemological break cannot simply be abruptly declared. Rather, it can only come as the result of a long process of theoretical investigation, critique, self-interrogation and practical testing.

It is tempting to see "Cinéma/idéologie/critique" as a self-proclaimed Althusserian epistemological break with the "ideological" film criticism that marked Cahiers' prior history. Again, the Screen translation of the text suggests that this is how Comolli/Narboni saw themselves, speaking in the text's first paragraph of "scientific film criticism." But this is another invention of the translator: the word the critics actually used was "conséquent" ("rigorous" or "systematic") rather than the far more theoretically charged 
term "scientifique." In fact, Comolli/Narboni were prudent and tentative in their claims and did not follow the practice of grand but flimsy declarations that they censured in Cinéthique. At best, they saw their text not as the arrival of a scientific approach to film criticism but as setting the foundation stones for the future realization of such an approach. Indeed, the entire Cahiers project over the following four years (from late 1969 to 1973) was one where film criticism sought to transcend its own epistemological status. While it would be overblown to refer to this practice as "scientific criticism," it does not seem inappropriate to dub the critical approach following on from the publication of the October 1969 editorial "theoretical criticism," a term that recognizes its complementary role with the "critical theory" (Althusser, Barthes, Lacan, Derrida) that constituted its conceptual basis. On the pages of Cahiers, throughout the early 1970s, criticism strove to become theory.

\section{Works Cited}

Louis Althusser, "Sur le jeune Marx," in idem., Pour Marx (Paris: Maspero, 1965), pp. 45-83. Translated as "Contradiction and Overdetermination," in Louis Althusser, For Marx, trans. Ben Brewster (London: Verso, 2005 [1969]), pp. 49-86.

—, "Contradiction et surdétermination," in idem., Pour Marx (Paris: Maspero, 1965), pp. 85-128. Translated as "Contradiction and Overdetermination," in Louis Althusser, For Marx, trans. Ben Brewster (London: Verso, 2005 [1969]), pp. 87-128. _-, "Sur la dialectique matérialiste," in idem., Pour Marx (Paris: Maspero, 1965), pp. 161-224. Translated as "On the Materialist Dialectic," in For Marx, trans. Ben Brewster (London: Verso, 2005 [1969]), pp. 161-218.

—, "Marxisme et humanisme," in idem., Pour Marx (Paris: Maspero, 1965), pp. 225250. Translated as "Marxism and Humanism," in For Marx, trans. Ben Brewster (London: Verso, 2005 [1969]), pp. 219-248.

—, "Lettre sur la connaissance de l'art (Réponse à André Daspre)," La Nouvelle Critique no. 175 (April 1966), pp. 136-141. Translated as "A Letter on Art in Reply to André Daspre," in idem., Lenin and Philosophy and Other Essays, trans. Ben Brewster (New York: Monthly Review Press, 1971), pp. 151-155.

—, "Cremonini, Painter of the Abstract," in idem., Lenin and Philosophy and Other Essays, trans. Ben Brewster (New York: Monthly Review Press, 1971), pp. 157-166.

—, "Idéologie et les Appareils idéologiques d'état (Notes pour une recherche)," La Pensée no. 151 (June 1970), pp. 3-38. Translated as "Ideology and Ideological State Apparatuses: Notes towards an Investigation," in idem., Lenin and Philosophy and Other Texts, trans. Ben Brewster (New York: Monthly Review Press, 1971), pp. $85^{-132 .}$ 
Alain Badiou, “L'autonomie du processus esthétique," Cahiers Marxistes-Léninistes no. 12-13 (July-October 1966), pp. 77-89.

Cinéthique, "Du bon usage de la valeur d'échange (Les Cahiers du cinéma et le marxisme-léninisme), Cinéthique no. 6 (January-February 1970), pp. 1-12.

Jean-Louis Comolli, "Le détour par le direct," Cahiers du cinéma no. 209 (February 1969), pp. 48-54, and Cahiers du cinéma no. 211 (April 1969), pp. 40-45. Translated as "The Detour through the Direct," trans. Christopher Williams, in idem. (ed.), Realism and the Cinema: A Reader (London: BFI, 1980), pp. 224-244.

—, "Dernier acte, encore," Cahiers du cinéma no. 215 (September 1969), pp. 55-58.

-, Cinéma contre spectacle (Lagrasse: Verdier, 2009). Translated as Cinema against Spectacle: Technique and Ideology Revisited, trans. and ed. Daniel Fairfax (Amsterdam: Amsterdam University Press, 2015).

- Jean Douchet, Jean-André Fieschi, Fereydoun Hoveyda, Jean Narboni and Claude Ollier, "Paralipomènes aux Oiseaux," Cahiers du cinéma, no. 149 (November 1963), pp. 38-44.

— and Jean Narboni, "Cinéma/idéologie/critique," Cahiers du cinéma no. 216 (October 1969), pp. 11-15. Translated as "Cinema/Ideology/Criticism," trans. Daniel Fairfax, in Jean-Louis Comolli, Cinema against Spectacle: Technique and Ideology Revisited (Amsterdam: Amsterdam University Press, 2015), pp. 251-259.

—, "Cinéma/idéologie/critique (II): D’une critique à son point critique," Cahiers du cinéma no. 217 (November 1969), pp. 7-13, here p. 9. Translated as "Cinema/ Ideology/Criticism (II): On Criticism at Its Critical Point," trans. Daniel Fairfax, in Jean-Louis Comolli, Cinema against Spectacle: Technique and Ideology Revisited (Amsterdam: Amsterdam University Press, 2015), pp. 261-280.

Jean-Luc Comolli and Paul Narboni [sic], “Cinema/Ideology/Criticism,” trans. Susan Bennett, Screen vol. 12 no. 1 (Spring 1971), pp. 27-36.

Jacques Doniol-Valcroze, "L'Histoire des Cahiers," Cahiers du cinéma no. 100 (October 1959), pp. 62-68.

Jean-Paul Fargier, "Parenthèse ou détour: Essai de définition théorique du rapport cinéma-politique," Cinéthique no. 5 (September-October 1969), pp. 15-21. Translated as "Parenthesis or Indirect Route," Screen vol. 12 no. 3 (Autumn 1972), pp. 131-144.

—, "Mutisme - film (révolution) - discours," Cinéthique no. 5 (SeptemberOctober 1969), pp. 37-40.

—, "Ici et là-bas: Entretien avec Jean-Pierre Gorin," Cahiers du cinéma no. 388 (October 1986), pp. 37-40, 42.

Sigmund Freud, The Interpretation of Dreams, trans. James Strachey (New York: Basic Books, 1955 [1900]).

André Gaudreault, Film and Attraction: From Kinematography to Cinema, trans. Timothy Barnard (Urbana: University of Illinois Press, 2011). 
Jean-Luc Godard, interviewed by J.-P.C. and G.L., "Un cinéaste comme les autres," Cinéthique no. 1 (c. January 1969), pp. 8-12.

G.W.F. Hegel, Vorlesungen über die Ästhetik vol. I-III, in idem., Werke vol. XIII-XV, eds. Eva Moldenhauer and Karl Markus Michel (Frankfurt am Main: Suhrkamp Verlag, 1970).

Barbara Klinger, “Cinema/Ideology/Criticism Revisited: The Progressive Text,” Screen vol. 25 no. 1 (January-February 1984), pp. 30-44.

Pierre Macherey, "Lénine, critique de Tolstoï," La Pensée no. 121 (June 1965), pp. 78-10o. Translated as "Lenin, Critic of Tolstoy," in idem., A Theory of Literary Production, trans. Geoffrey Wall (London: Routledge, 1978), pp. 117-151.

Karl Marx, The German Ideology, in The Collected Works of Marx and Engels vol. V (New York: International Publishers, 1975).

Marcelin Pleynet and Jean Thibaudeau, interviewed by Gérard Leblanc, "Économique, idéologique, formel..." Cinéthique no. 3 (April 1969), pp. 7-14. Translated as, "Economic - ideological - formal," trans. Elias Noujaim, in Sylvia Harvey, May '68 and Film Culture (London: BFI, 1980), pp. 149-164.

"Les Rédacteurs," “Young Mr. Lincoln de John Ford," Cahiers du cinéma no. 223 (August-September 1970), pp. 29-44. Translated as "John Ford's Young Mr. Lincoln: A Collective Text by the Editors of Cahiers du Cinéma," trans. Helen Lackner and Diana Matias, Screen vol. 13 no. 3 (Autumn 1972), pp. 5-44.

Jacques Rivette, interviewed by Jacques Aumont, Jean-Louis Comolli, Jean Narboni and Sylvie Pierre, "Le temps déborde: Entretien avec Jacques Rivette," Cahiers du cinéma no. 204 (September 1968), pp. 6-21. Translated as "Time Overflowing," trans. Amy Gateff, in Jonathan Rosenbaum (ed.), Rivette: Texts and Interviews (London: BFI, 1977), pp. 9-38.

D.N. Rodowick, The Crisis of Political Modernism, $2^{\text {nd }}$ ed. (Berkeley: University of California Press, 1994),

Philip Rosen, "Preface," in Jean-Louis Comolli, Cinema against Spectacle: Technique and Ideology Revisited, trans. and ed. Daniel Fairfax (Amsterdam: Amsterdam University Press, 2015), pp. 7-16. 


\title{
2. Jean-Louis Comolli and Jean Narboni: Crossed Lives
}

\begin{abstract}
This chapter charts the intersecting biographies of Jean-Louis Comolli and Jean Narboni in the years leading up to their joint editorship of Cahiers du cinéma. Having first encountered each other in Algeria while the country was still under French colonial rule, the two formed a bond over a shared cinephilia that continues to the present day. Upon moving to Paris, they both joined Cahiers and wrote in defence of the last works of the generation of classical Hollywood filmmakers (Alfred Hitchcock and Howard Hawks, most notably) as well as the rising generation of auteurs belonging to the various international nouveaux cinémas. The chapter ends with a discussion of "Le détour par le direct," Comolli's analysis of the use of direct cinema techniques in both documentary and fiction cinema.
\end{abstract}

Keywords: Jean-Louis Comolli, Jean Narboni, Algeria, Cahiers du cinéma, nouveau cinéma, direct cinema

\section{An Algerian Youth}

Since its initial publication, "Cinéma/idéologie/critique" has appeared in numerous film theory anthologies and is still a standard feature of introduction to film syllabuses internationally. The text, indeed, has sealed Comolli and Narboni's names together in the "pantheon" of film theory. This is a fitting outcome: their relationship dates back to well before their collaboration at Cahiers, and the two have remained lifelong friends long after they left the journal. Comolli and Narboni still regularly see each other today, more than 60 years after first making each other's acquaintance. For approximately a decade at Cahiers, meanwhile, they were close collaborators, working on texts together, deciding on the journal's line in tandem, and watching and discussing films on an almost daily basis. This chapter looks at the

Fairfax, D., The Red Years of Cahiers du Cinéma (1968-1973). Volume I: Ideology and Politics. Amsterdam: Amsterdam University Press, 2021 DOI 10.5117/9789463728508_CHO2 
critical articles they wrote for Cahiers in the period 1962-1969 in order to trace something of the backstory to "Cinéma/idéologie/critique": how they came to defend the type of cinema they did for the reasons that they did in that landmark text. Later, in Part II, I will look closely at the political engagements the journal embarked on within this period, but here it is the critical practice developed by the duo over the course of more than half a decade that is of interest.

Perhaps most fascinating about the relationship between Comolli and Narboni is their shared youth: both are originally from Algeria, part of the pied-noir population, and lived there until decamping for Paris in the early $1960 s$, due to a combination of personal and political factors. In the case of both writers, their time in Algeria had a major effect on their outlook on the world, and it was here that they made each other's acquaintance while studying medicine in Algiers. Narboni is the elder of the two critics by nearly four years, having been born to a middle-class Jewish family in Orléansville (now Chlef) on October 24, 1937, although he primarily grew up in Algiers. Comolli, meanwhile, was born on July 30, 1941 in Philippeville (now Skikda), a mostly Arab coastal town in western Algeria. ${ }^{1}$ Both were exposed to the cinema from a young age. Narboni recalls that after the American liberation of French Algeria in 1942, Hollywood films were shown regularly on Algerian screens, well before they could be projected in metropolitan France, and he remembers seeing the work of Capra, Hawks, Tourneur and Ford with his parents during these years. ${ }^{2}$ Comolli, meanwhile, assiduously visited his town's sole ciné-club, administered by a local high school French teacher, from the early 1950s onwards. As a teen he also took to reading Cahiers $d u$ cinéma, purchasing the single copy of the journal that reached Philippeville's maison de la presse, and he also developed a fondness for jazz, which has remained his other great passion alongside cinema: "I collected records, I listened to a lot of music. I discovered the blues, which marked me a lot, I listened to the jazz that was being exported at this moment: Duke Ellington, Charlie Parker, etc."3

\footnotetext{
1 Biographical details for all the Cahiers writers have been drawn from a variety of sources, including interviews with the persons concerned. As far as secondary sources are concerned, of particular value is the one-volume encyclopedia La critique de cinéma en France, ed. Michel Ciment and Jacques Zimmer (Paris: Ramsay, 1997), especially pp. 280 (for Aumont), 291 (for Bonitzer), 312 (for Comolli), 313-314 (for Daney), 323-324 (for Eisenschitz), 370 (for Narboni) and 375 (for Pierre).

2 Interview with Jean Narboni, March 3, 2014.

3 Interview with Jean-Louis Comolli, May 8, 2011. Comolli frequently contributed articles to Jazz Magazine in the 196os and has also written books on the subject matter.
} 
In order to take preparatory classes for entering the medicine faculty, Comolli moved to Algiers in the autumn of 1958 - shortly after De Gaulle had seized power in France and when the situation concerning Algeria's political status had reached a boiling point. It was here that he met Narboni, who was already a few years into his studies, as well as Philippe Carles, later an editor of Jazz Magazine, with whom Comolli wrote FreeJazz/Black Power in $1971 .{ }^{4}$ At the same time, the friendship between Comolli and Narboni was anchored by their frequent attendance at the Algiers ciné-club, which was reputedly the biggest in France at the time (Comolli claims that it had roughly 8000 members), and belonged to the secular left cultural network Peuple et Culture. The Algiers ciné-club was directed by Barthélemy Amengual, a prominent critic in his own right who also moved to Paris upon Algerian independence. Amengual soon tasked the two young cinéphiles with duties convening the screenings, introducing the films or conducting debates afterwards, but the selection of films remained his own. Closely aligned with the Communist Party, Amengual's tastes reflected his political allegiances: the ciné-club's program was dominated by films from Eastern Europe, the Italian neorealist school, and the French poetic realist tradition of Carné and Renoir, while Hollywood films had more difficulty finding favor.

Algeria under French colonial rule was not in a state of strict racial Apartheid, and some Arab-Algerians attended the ciné-club, but its audience was overwhelmingly European and petty-bourgeois in composition. If Amengual's politics came through in his selection of films, they were also manifested in his stubborn insistence on continuing the screenings even in the face of violent conflicts, making the ciné-club a pocket of resistance against the prevailing climate of extremism and civil unrest in the dying days of French rule in Algeria. Narboni remembers that "there were often political incidents the day that there was a ciné-club screening. And often there were people who came into the auditorium, saying 'Yeah, on the streets everybody! Algérie française!' and Amengual would say, 'No, I have my screening.' And often it would happen to be a Soviet film."

While Comolli and Narboni were actively involved in cultural affairs during this period, and while their sentiments were clearly on the left in revulsion at the tactics of the Organisation armée secrète (OAS) and other French Algerian forces, neither of them were politically engaged during their time in Algeria. But the nature of life in a country under such tensions evidently made itself felt on a regular basis, which was recently recounted 
by Comolli in Une terrasse en Algérie, a memoir of his time in Algeria. One particular incident in Philippeville marked Comolli in a more enduring, traumatizing manner. In August 1955, Philippeville was the site of an attack on European residents organized by the Front de libération nationale (FLN) as part of their strategy to trigger a civil war in Algeria, which incited reprisals against the entirety of the Arab population by the French army. Comolli describes his encounter at a young age with this political reality:

Like any other August, I was on the beach, because there was a fishing village close to Philippeville. The fishermen were Arab, but the bosses were from Naples and Sicily, and the village had beautiful beaches. So every day without exception I left home at gam and walked three kilometers to this beach where I spent the whole day swimming. On the evening of this infamous day, I found myself trapped behind a military checkpoint. I immediately understood that something had happened, but I had no idea what it was, because news of the massacre had not reached this beach, which was isolated from the violence. So, because I'm not an Arab, I passed the checkpoint without being arrested and returned to my home town, and there I viewed a scene which overwhelmed me. [...] The riot police held captive a single file of Arab prisoners, all dressed in tattered rags. Some of them were wounded, and this is where my rage against this France dates from, because a French officer asked the Arabs for their papers. Now, these Arabs were probably those who had let off bombs in the city, so they may not have had clean hands, but they gave the officer some vague identity cards and certificates, and, right before my eyes, this officer took their papers and tore them into shreds. This episode was traumatic for me. ${ }^{6}$

Comolli and Narboni both left Algeria voluntarily, shortly before the mass exodus of the pied-noir population in the wake of Algerian independence. Comolli had failed his first-year medicine exams and convinced his father to allow him to enroll in philosophy at the Sorbonne instead, moving to the capital in the rentrée of 1961. Narboni completed his studies in Algiers and moved to Paris shortly afterwards to begin his career. Almost immediately, both young cinephiles gravitated around Langlois' Cinémathèque at the rue d'Ulm. It was here that, after years of reading Cahiers from afar, Comolli and Narboni would come into direct contact with the critics who wrote for the journal.

6 This quote is from the film Jean-Louis Comolli, Filmer pour voir, dir. Ginette Lavigne, 2012. See also Jean-Louis Comolli, Une terrasse en Algérie (Lagrasse: Verdier, 2018), pp. 19-21. 


\section{Critical Beginnings}

In 1961, Comolli had formed a close trio of friends with Jean-André Fieschi, who would also become a long-term writer for Cahiers and later La Nouvelle Critique, and Jean Eustache, who wrote sporadically for Cahiers before becoming one of the most noted filmmakers of the post-nouvelle vague era. All three joined Cahiers through the intermediary of Jean Douchet. At the time, the journal was under the editorship of Éric Rohmer, and Douchet had become something of an unofficial second-in-command at the journal. With the recent elevation of some of its most prominent critics to the status of eminent new wave filmmakers, Douchet saw the need for fresh blood at Cahiers and courted the most assiduous of the cinephiles at the rue d'Ulm to write for the journal. ${ }^{7}$ Comolli published his first article, on Sergeant York by Howard Hawks, in September 1962, barely a year after arriving in Paris, and quickly imposed himself as a regular contributor to the journal. In light of his future activity with Cahiers, overseeing its transformation to an organ of Marxist film theory, the nature of his earliest articles may be a little surprising. The Sergeant York review, "La grandeur du simple," written on the occasion of a retrospective screening of the wartime film, is illustrative. With a clear debt to Rivette's seminal article "Génie de Howard Hawks" (which begins with the resonant declaration: "Evidence is the mark of genius of Hawks" ${ }^{8}$ ), the young Comolli's article argues that the humble simplicity of the character of York (played by Gary Cooper) is an avatar of the straightforward authenticity of Hawks' film style. At the same time, the ambiguity of the director's mise en scène, the ambivalence of his gaze, corresponds to the uncertainty of life itself, as seen through the figure of York. Comolli concludes the article by defining what he sees as the dialectic of Hawks' "grand simplicity": "Man is established, by the purity and the force of Hawks' gaze, such as he may only be in and of himself. This constant presence of the essential confers on the film the grandeur and the simplicity of the immediate revelations of being."

An undercurrent of phenomenological humanism can be detected in the Hawks review, but it is thrust into the open with Comolli's second major

7 Comolli, "Yes, we were utopians (Part 1)."

8 Jacques Rivette, "Génie de Howard Hawks," Cahiers du cinéma no. 23 (May 1953), pp. 16-23, here p. 16. Translated as "The Genius of Howard Hawks," trans. Russell Campbell and Marvin Pister, in Jim Hillier (ed.), Cahiers du cinema, the 195os: Neo-Realism, Hollywood, New Wave (Cambridge, MA: Harvard University Press, 1985), pp. 126-131, here p. 126.

9 Jean-Louis Comolli, "Grandeur du simple (Sergeant York)," Cahiers du cinéma no. 135 (September 1962), pp. 54-58, here p. $5^{8}$. 
article, "Vivre le film." Published in March 1963, this 15-page treatise on the essence of the cinema was an ambitious undertaking for a critical novice not yet 22 years old, but it was also a sign that Comolli had been reflecting on the art form long before writing for Cahiers. In this text, he argues for the enrichment of film criticism through philosophical thought, with Heidegger, Merleau-Ponty, Blanchot and even Hegel constituting the most important reference points in this endeavor. In exploring the relation between "art" and "man," Comolli warns against "the totality and objectivity of a scientific method" which would risk negating the mysterious, miraculous nature of artistic creation. ${ }^{10}$ Instead, the art of cinema, seen as "the search for and expression of a truth of man in the world," must be understood in its relation with the individual spectator, even if this means elevating the importance of the subjective relation (art-work/spectator) over the objective relation (art/ man). ${ }^{11}$ In thus arguing for a "phenomenology of the cinema" - the originality of the seventh art being to "plunge us into life and into ourselves more intensely than the other arts, with a more palpable force"12 —Comolli even provides a personal pantheon of favored films, including Rio Bravo, Viaggio in Italia, Tabu, Vertigo, Johnny Guitar and Der Tiger von Eschnapur, as well as a negative pantheon, which contains Citizen Kane, La Notte, The Seventh Seal and (ironically, given Cahiers' later orientation) Battleship Potemkin. Everything about this text, therefore, seems to separate it from the Comolli of "Technique et idéologie." But there is also an uncanny correspondence between this manifesto and his later texts, which tend to recast the logic of "Vivre le film" - its focus on the relationship between film and spectator-in the more Marxist terms of apparatus theory.

Comolli's next few articles under Rohmer's tenure continued in the vein of "Vivre le film." "La présence et l'absence," reviewing Le Petit Soldat, argues that Godard's film "proves, if there was the need for it, that life is richer than thought, and that cinema is richer than language." "Vanité de l'art" treats the "discordant liberty" of Tourneur's mise en scène in The Flame and the Arrow and Great Day in the Morning. "14 "Lautre ailleurs" finds a "new alchemy" of the human body to be present in Bresson's Le Procès

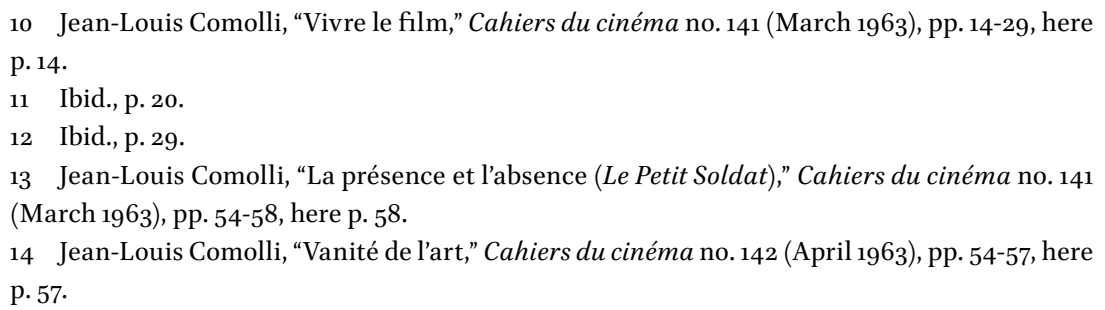


de Jeanne d'Arc. ${ }^{15}$ All three articles attest to a critic growing in confidence, willing to deploy a cluster of artistic and philosophical references, and developing his own writing style and critical outlook. At the same time, Rohmer's standing as editor-in-chief at Cahiers was coming increasingly under threat. In their recent biography of the filmmaker, Antoine de Baecque and Noël Herpe write at great length of the "coup" that deposed Rohmer and replaced him with Jacques Rivette in the summer of $1963 .{ }^{16}$ Concern from certain quarters (Jacques Doniol-Valcroze, Pierre Kast, Michel Delahaye and François Truffaut, in addition to Rivette) at the growing rightwards trajectory of the journal was exacerbated by consternation at the lukewarm support the journal was giving to the nouvelle vague, particularly as the movement came under fire in 1961-1962, and the lack of openness it showed towards modern currents of thinking, all areas in which Rivette promised a sweeping change. Discussions were held with Rohmer about a possible power-sharing arrangement, but the editor was intransigent. The younger crop of critics, including Comolli and Fieschi, were faced with a diabolical choice: support the editors who had given them their start, or side with the current representing modernity and political engagement. Writing from the standpoint of 2009, Comolli relates the position he and his friends found themselves in:

We admired Rohmer and his writing style, as much as Douchet and his critical pertinence. But we also admired the rarer texts written by Rivette, we felt ourselves engaged by the manner in which he thought about the cinema, and the sides he took in the issues of the time. And from my modest position as editorial secretary, I could not avoid seeing how detached the yellow-covered Cahiers were from global movements. ${ }^{17}$

In the end, the "conspirators" made their move: on May 30, a formal letter was addressed to Rohmer informing him of the termination of his role as editor-in-chief at Cahiers, with Rivette taking over as of June 1. Rohmer, however, shifted the responsibility for his departure onto the shoulders of the youngest members of the complot, writing, "March-May 1963: revolution at Cahiers, Jean-Louis Comolli and Jean-André Fieschi push me towards the

15 Jean-Louis Comolli, "L'autre ailleurs (Le Procès de Jeanne d'Arc)," Cahiers du cinéma no. 143 (May 1963), pp. 42-49, here p. 46.

16 See Antoine de Baecque and Noël Herpe, Éric Rohmer (Paris: Stock, 2014), pp. 146-154.

17 Comolli, Cinéma contre spectacle, p. 19 [pp. 58-59]. 
exit." ${ }^{m 8}$ Douchet was equally rueful: "I took it poorly that some of the young critics I brought on stabbed me in the back." ${ }^{\prime 19}$

Under Rivette, Cahiers' openness towards new theoretical tendencies was reflected above all in three interviews carried out with Roland Barthes, Claude Lévi-Strauss and Pierre Boulez in the first months of his stewardship. ${ }^{20}$ But it also entailed opening the journal up to new critical voices - a move partly necessitated by the replenishment of the stock of writers diminished by the departure of Rohmer and Douchet. After moving to Paris in 1962 and finding work in a hospital, Narboni gravitated around the Cahiers group and even made a brief appearance in Rohmer's La carrière de Suzanne (for which Comolli was assistant director), but his entry into the journal did not come until after Rivette's "putsch" — when he made a short contribution to the multi-authored text "Paralipomènes aux Oiseaux" in November $1963 .{ }^{21}$ His first critical texts came early the following year, and his first two reviews exemplify the twin critical tasks that would consume the review in this period. In February 1964, the novice critic was given the chance to review Godard's Le Mépris, and, whilst showering the film with dithyrambic praise, he also provided a structural analysis of the work: founded on the "unrelenting mechanism of a question-and-answer game," the film's dialogues have less to do with "conversation than with incitation and evasion," a structuring principle that gives rise both to the "discrepancy" (décalage) between question and answer (as represented by the frequent interpolations made by the translator) and, figuratively, to the "incessant coming-and-going of the characters, in the pursuit that they conduct without respite, always hard-pressed, out of synch, on the heels of each other."22 The following month, with "Mankiewicz à la troisième personne," Narboni sought to read Joseph L. Mankiewicz's œuvre from the standpoint of literary modernism: far from being marked by elegance, equilibrium and lucidity, his

18 Éric Rohmer, “Chronologie pour les Cahiers du cinéma” (unpublished, 2007). Cited in De Baecque/Herpe, Éric Rohmer, p. $15^{2}$.

19 Jean Douchet, interviewed in Les Inrockuptibles, October 27, 1999. Cited in De Baecque/ Herpe, Éric Rohmer, p. $15^{2}$.

20 For more on these encounters, see Chapter 14.

21 See Jean-Louis Comolli, Jean Douchet, Jean-André Fieschi, Fereydoun Hoveyda, Jean Narboni and Claude Ollier, "Paralipomènes aux Oiseaux," Cahiers du cinéma no. 149 (November 1963), pp. 38-44. When interviewed, Narboni also remembered having an earlier review of Otto Preminger's Where the Sidewalk Ends rejected when Rohmer was still editor, but with the message that he should continue submitting pieces to Cahiers. Interview with Jean Narboni, March 3 , 2014 .

22 Jean Narboni, "Ouvert et fermé (Le Mépris)," Cahiers du cinéma no. 152 (February 1964), pp. 66-69, here p. 68. 
films are striated by "violence and delirium" and subject to the incursion of “obscure forces." For Narboni, the blank neutrality of Mankiewicz's mise en scène has a deep affinity with the writing of F. Scott Fitzgerald: the framing and camera movements of the former "have nothing very remarkable" about them while the literary style of the latter escapes "all narrative artifice, both in process and technique." ${ }^{23}$

These two texts tacitly form the program that governed Cahiers' critical work in the period 1964-1967: firstly, to defend the work of the journal's favored Hollywood auteurs at a moment when the studio system was in crisis, and secondly to support the "new waves" that were flourishing not only in France but also in Italy, Quebec, Eastern Europe, Japan, Brazil and elsewhere. Retrospectively, Narboni speaks of this period as "a historical moment that will never be reproduced" in which multiple "geological layers" coexisted: the last films of the titans of classical Hollywood (Hawks, Walsh, Ford), the latest works of the first generation of modernist filmmakers (Antonioni, Bergman, Buñuel), and finally the debut offerings of the "young cinema," directors in their twenties and thirties who first came to prominence in this decade. ${ }^{24}$

\section{The New "Hitchcocko-Hawksians"}

For all their love of the American cinema, it did not escape the Cahiers critics in the early 1960 s that the studio system was in a state of terminal crisis. One of the most ambitious special issues of Rivette's editorship was precisely devoted to this question. Clocking in at 276 pages, "Situation II du cinéma américain" (December 1963-January 1964) included the round table "Sept hommes à debattre," where Truffaut famously declared: "We used to say that we liked the American cinema but its filmmakers were slaves; what would it be like if they were free men? Well, the moment they become free they make lousy films." ${ }^{25}$ In the same issue, Comolli called for a rethinking

23 Jean Narboni, “Mankiewicz à la troisième personne," Cahiers du cinéma no. 153 (March 1964), pp. 27-31, here p. 30 .

24 Interview with Jean Narboni, March 3, 2014.

25 François Truffaut, in Claude Chabrol, Jacques Doniol-Valcroze, Jean-Luc Godard, Pierre Kast, Luc Moullet, Jacques Rivette and François Truffaut, "Sept hommes à debattre," Cahiers du cinéma no. 150-151 (December 1963-January 1964), pp. 12-23, here p. 20. Translated as "Questions about American Cinema," trans. David Wilson, in Jim Hillier (ed.), Cahiers du Cinéma vol. II: The 196os: New Wave, New Cinema, Reevaluating Hollywood (London: BFI, 1986), pp. 172-180, here p. 176. 
of American cinema in general. If the industrial model had collapsed, there at least remained a small number of filmmakers whose work was of critical interest: "There is no American cinema. At least, not any more. There are only ten, fifteen, twenty filmmakers, artists, with œuvres. Only these men of cinema have made the cinema, and they still do."${ }^{26}$ Later, Comolli issued a guarded defense of Cleopatra, the lavish symbol of the collapse of the studio system, while admitting that the finished film resembled a "nightmare of the creator with his creation." ${ }^{\text {27 }}$ Aside from exceptional cases such as John Ford, the hommes de cinéma defended by Comolli and Narboni were contiguous with the critical taste of the previous generation of Cahiers critics. The generation of Truffaut and Rivette had been dubbed "Hitchcocko-Hawksians" within the journal, so it is fitting that foremost among the directors whose work continued to be championed by Comolli and Narboni were none other than Hitchcock and Hawks. In contrast, however, to the 1950 s critics, who tended to emphasize the classical aspect of these filmmakers, ${ }^{28}$ Comolli and Narboni took an interest in their relationship with aesthetic modernity, a trait that becomes more evident with the onset of Hollywood's post-classical decadence.

The response by Comolli to Man's Favorite Sport is illustrative of this tendency. While the release of Hawks' film prompted Cahiers to run an interview with the director (conducted by Serge Daney and Louis Skorecki) and a review of the film by Michel Delahaye, ${ }^{29}$ Comolli took the opportunity to revisit his stance on Hawks' œuvre, arguing that "from his first steps through to his latest offspring, Hawks has never been either a classic in the classic sense of the term, or the master of 'simplicity,' and even less of the obvious [l'évidence] (something that has been inferred from a misunderstanding of Rivette's idea). His only evidence is that of the lynx: he sees without being seen." ${ }^{30}$ Far from being a "worthy figure with deep humanitarian

26 Jean-Louis Comolli, "L’Amérique à découvert," Cahiers du cinéma no. 150-151 (December 1963-January 1964), pp. 217-224, here p. 217.

27 Jean-Louis Comolli, “Cléopatre, le jeu, l'échec," Cahiers du cinéma no. 153 (March 1964), pp. 32-40, here p. 40 .

28 See, for instance, Claude Chabrol and Éric Rohmer, Hitchcock (Paris: Éditions universitaires, 1957).

29 See Serge Daney, Jean-Louis Noames and James R. Silke, "Entretien avec Howard Hawks," Cahiers du cinéma no. 16o (November 1964), pp. 54-60; and Michel Delahaye, "D'un sport à l'autre (Man's Favorite Sport)," Cahiers du cinéma no. 16o (November 1964), pp. 80-81. "Jean-Louis Noames" was the pseudonym used by Skorecki in the early 1960 s.

30 Jean-Louis Comolli, "H.H., ou l'ironique," Cahiers du cinéma no. 16o (November 1964), pp. 49-52, here p. 49. Translated as "The Ironical Howard Hawks," trans. Norman King, in Hillier (ed.), Cahiers du cinéma vol. II, pp. 181-186, here p. 182. 
concerns," as his devotees often describe him, Hawks is, in Comolli's view, "the most discreet humorist of the century," and in this sense there is no distinction between his comedies and his "serious" films, since both bear the same tacit message: "In the service of the lie, cinema speaks the truth; it lies in the service of truth and can thus serve it better."31 The perpetual play of reversals and false leads required to dissimulate this message means that, for Comolli, Hawks would be "a faux classic if he had not always been a true modern." ${ }^{32}$

With the release of Red Line 7000 in July 1966, Comolli and Narboni had a more difficult task in defending their cherished auteur: the film, focusing on the sport of stock-car racing, was critically reviled and is still one of the most neglected works in Hawks' œuvre. Produced independently with the director's own money, the economy of Red Line zooo betrays itself repeatedly in the film's cheap production values. And yet Comolli, resisting any idea of a decline in Hawks' filmmaking, deems that the director has made a virtue of necessity: the repetition of the same shots standing in for different racetracks augments the "impression of monotony" that prevails throughout Red Line 70oo: "weakness becomes strength, and form. Repetition becomes structure. Monotony turns into vertigo." ${ }^{33}$ The racetracks are a "perpetual mechanism, an empty movement" and thus stand in for the dramaturgical principle of the film as a whole. ${ }^{34}$ It is for this reason that Hawks' modernity, and even his youthfulness, remains intact in this film. Narboni likewise defended the "modernity" of Red Line 7ooo but did so through a discussion of time, speaking of Hawks' "tenacious, obstinate, repetitive temporality, moved forward by accumulation and tautology, rather than straight progression or the sudden take-off," which makes Red Line appear to be "the work of someone ageless." 35 For Narboni, Hawks' cinema can only be accepted or rejected in its entirety, since it constitutes "a vast nervous system, a field of forces or tiered networks." ${ }^{36}$ That both Comolli and Narboni's advocacy of Hawks tended more and more towards abstraction was, however, symptomatic of the increasing difficulties they

$31 \quad$ Ibid., p. 52 [p. 186].

32 Ibid.

33 Jean-Louis Comolli, "Cherchez l'Hawks (Red Line 70oo)," Cahiers du cinéma no. 180 (July 1966), pp. 24-28, here p. 24.

34 Ibid.

35 Jean Narboni, "Contre la montre (Red Line 70oo)," Cahiers du cinéma no. 180 (July 1966), pp. 28-30, here pp. 28, 30. Translated as "Against the Clock," trans. Diana Matias, in Hillier (ed.), Cahiers du Cinéma vol. II, pp. 216-219, here pp. 217-218.

36 Ibid., p. 30. 
had, as the Vietnam War intensified, in defending a filmmaker whose politics were remote from their own. At the same time as the duo praised Red Line 70oo, the high-profile Nouvel Observateur critic Michel Cournot attacked Hawks for espousing a pro-war ideology. ${ }^{37}$ Comolli retorted that Hawks was a "filmmaker of intelligence and subtlety, of irony and non-convention (the total opposite of [Robert] McNamara), ${ }^{38}$ but the contradiction broke out more forcefully the next year. With the release of El Dorado (1967), Comolli, Narboni and Bertrand Tavernier had the opportunity to interview Hawks. Here, the filmmaker confirmed his plans to make a film on the Vietnam War (pending approval from the "War Department") and commented: "It is a totally new war, you know, it's not like anything we've seen before. The Americans are fighting against little people, who are acclimated to their country." ${ }^{39}$ A postscript to the interview gave the Cahiers editors' viewpoint on this project: it represented "a political act, whose politics we condemn." At the same time, however, they acknowledged that "the position taken by H.H. on an event whose urgency solicits those of us who are on the other side of the barricade is itself very Hawksian. ${ }^{30}$ Notwithstanding Hawks' remarks, Comolli gave a cautious defense of El Dorado in the same issue of Cahiers, arguing that it is the director's "refusal of sentimentalism" that allows us "not to despair of Howard Hawks."

The paradoxes of Cahiers' support for the late Hawks were also present, a fortiori, in their continued advocacy of Hitchcock and became manifest with the release of Torn Curtain in 1967. That the "master of suspense" had delivered an overtly anti-communist film, presenting the GDR as a terrorist state and relaying a series of Cold War clichés about life behind the "Iron Curtain," seemed not to perturb a pair of critics who by this point identified squarely with the radical left in France. Emphasizing the film's surreal, dream-like qualities, Narboni asserted that Torn Curtain's "fantastic round-trips and adventurous itineraries" linked it with a less "serious" but no less authentic vein in Hitchcock's œuvre (that of campy spy thrillers like $A$

37 Michel Cournot, “La verticale d'Hanoï," Le Nouvel Observateur, July 6, 1966.

38 Jean-Louis Comolli, “Toujours pour... Hawks!” Cahiers du cinéma no. 181 (August 1966), p. 4. Cournot replied to this text, insisting that "On the evidence Red Line 7000 appears to me to be a monument of idiocy." Michel Cournot, "Et toujours contre!," Cahiers du cinéma no. 181 (August 1966), p. 4.

39 Howard Hawks, interviewed by Jean-Louis Comolli, Jean Narboni and Bertrand Tavernier, "Entretien avec Howard Hawks," Cahiers du cinéma no. 192 (July-August 1967), pp. 14-21, 67-68, here p. 68.

40 Ibid.

41 Jean-Louis Comolli, “L'envers de l'Eden," Cahiers du cinéma no. 192 (July-August 1967), p. 22. 
Lady Vanishes and The Man Who Knew Too Much). The thin, substance-less characters reminded the critic of Giacometti's "thread-like statues," and he avowed that "Torn Curtain affects me through this emaciation, this melting, this loss of substance imposed on characters and on situations. ${ }^{142}$ Comolli similarly highlighted the dream-world in which the film seems to transpire: the journey undertaken by Paul Newman, fleeing the authorities, does not take place in East Germany but in "Hitchcockland," a site "of images, of the dream, and of dream representation, of the projections and of the constitution of phantasms in the setting." Moreover, the inversion of Hitchcock's habitual schema for the spy thriller (this time an American is attempting to reveal the state secrets of an Eastern bloc government) results in a "very Hitchcockian irony and perversion" and a "systematic blurring of significations" which render the political message of the film "rather more ambiguous than a purely political logic would impose."43

\section{Defending the Nouveaux Cinémas}

This insistence on a continued advocacy of the late work of the Hollywood masters, even in the face of subject matter that is politically hostile to the Cahiers critics' own outlook, would prove to be the template for the "symptomatic" analyses of classical Hollywood films during the journal's Marxist period. But it also brought with it the need for a certain contorted critical logic, resting on a taste for paradox, twisted argumentation and counter-reading. When it came to the other component of Comolli/Narboni's critical project of the mid- to late-196os- their defense of the "new cinemas" (nouveaux cinémas, pluralized to acknowledge the international character of the movement) - the contradictions in their critical appraisals are less immediately apparent. Often, the critics were in profound political and generational synchrony with their subjects. Here too, however, occasional "perverse" readings of films were generated in order for consistent support to be given to a director. Nonetheless, the nouveaux cinémas generally gave Comolli and Narboni the opportunity to support and foster a wave of filmmakers to whom they felt closely attuned. Moreover, as Narboni would

42 Jean Narboni, "La machine infernale," Cahiers du cinéma no. 186 (January 1967), p. 35. Translated as "The Infernal Machine," Cahiers du Cinéma in English no. 10 (May 1967), p. 51.

43 Jean-Louis Comolli, “Le rideau soulevé, retombé (Torn Curtain)," Cahiers du cinéma no. 186 (January 1967), pp. 36-39, here pp. 36, 39. Translated as “The Curtain Lifted, Fallen Again," Cahiers du Cinéma in English no. 10 (May 1967), pp. 52-55, here pp. 52, 55. 
write nearly 40 years later, their discovery and promotion of these figures should rightly be seen as one of the most important accomplishments in the history of Cahiers. ${ }^{44}$ The journal, meanwhile, saw its own generational change in this period: in 1965 , Rivette vacated his post as editor-in-chief in order to focus his attention on the production of La Religieuse, leaving the position to Comolli, by that point the most dynamic critical voice at Cahiers. Narboni officially joined him in the role in 1968, but this was a change in title only, as he was already a key editorial presence in Cahiers by the mid-196os. ${ }^{45}$

If Cahiers' support for the French nouvelle vague was unflagging after the "putsch" against Rohmer, the idea that a nouveau cinéma existed outside of France took longer to filter through to the journal's critics. Italy was the first nation where a "young national cinema" was detected, with Narboni and Comolli discussing Prima della rivoluzione by Bertolucci and I Fidanzati by Olmi in July 1964-although here they were already following in the footsteps of André S. Labarthe, who as early as 1962 had noted the existence of a new, post-neorealist generation of filmmakers in the country. ${ }^{46}$ Comolli and Narboni inscribed the work of these directors in the country's neorealist heritage: despite their many differences, both Bertolucci and Olmi exhibit the "refusal of priorities' which André Bazin saw as the essence of neorealism. ${ }^{47}$ But their work also undercut a critical cliché distinguishing the "'positive,' engaged, affirmative" young Italian cinema from the "confusions and uncertainties" of its French equivalent (the work of Godard and Resnais in particular). Rather, the two films, for Comolli/Narboni, exemplify the "dialectic of doubt and affirmation" operative among young Italian filmmakers. ${ }^{48}$

This same dialectic permeated through to emerging filmmakers around the world, as discussion of new auteurs such as Gilles Groulx, Jerzy Skolimowski, Věra Chytilová and Glauber Rocha took an increasingly prominent place on the pages of Cahiers. By 1966, Comolli was so confident in the burgeoning promise of this cinema that he could claim in an editorial:

44 Jean Narboni, "Les futurs antérieurs" in Jean-Louis Comolli, Gérard Leblanc and Jean Narboni, Les années pop: Cinéma et politique: 1956-1970 (Paris: BPI/Centre Pompidou, 2001), pp. 9-20.

45 Interview with Jean Narboni, March 18, 2014. Between November 1965 and September 1968, Jean-Louis Ginibre (an editor at Jazz Magazine, which had the same owner as Cahiers at this time), was credited as a co-editor-in-chief alongside Comolli, but this was a titular function only, and he never wrote for Cahiers or had any role in directing its critical line.

46 André S. Labarthe, "Avant-propos," Cahiers du cinéma no. 131 (May 1962), pp. 1-2. The entire issue that month was dedicated to the theme "Situation du cinéma italien."

47 Jean-Louis Comolli and Jean Narboni, "Retour en Italie," Cahiers du cinéma no. 157 (July 1964), pp. 29-37, p. 36 .

48 Ibid., p. 37 . 
"That there exists, today, a 'new' cinema is something that nobody will contest tomorrow." While the critic recognized that the entire history of the cinema had been marked by fertile periods of formal innovation and is thus an eternal struggle between the forces of "the new" and "the old," he also makes the optimistic historical claim that "the cinema has never before seen arise [...] such an army of conquerors. And never before, at any rate, has the birth of so many filmmakers been granted so much attention." of particular interest for Comolli was the rise of filmmakers from Quebec and Brazil, who found themselves at the forefront of "a combat that is not only of an artistic nature, but which concerns a society, an ethos, a civilization" and thus constituted genuine "cinemas of revolution." 49

The pretext for his editorial was the decision to host a "Semaine des Cahiers" in April 1966: a week-long series of screenings highlighting films from the nouveaux cinémas that had struggled to find regular distribution in France. In May, Narboni gave the historical context to this new crop of filmmakers, arguing for "three ages" of modern cinema in the post-war era: Italian neorealism, the French nouvelle vague and the international nouveau cinéma. If Italian neorealism represented a moment where "the author was effaced to the benefit of the outside world, with its lacunae, its gaps, its discontinuity" and the nouvelle vague represented the "passionate and violent" individual reaction against the cinéma de qualité, then the originality of the nouveau cinéma resides in occupying "the crossroads between these two great movements. ${ }^{\circ 0}$ Correspondingly, Narboni finds the movement's vitality particularly present in the work of three filmmakers Bertolucci, Skolimowski and Bellochio, whose films represent, respectively, the critical, oneiric and parabolic paths towards cinematic autobiography.

Two texts from 1967 also strove to give an account of the nouveau cinéma-now, in a reflection of the radicalized climate pervading both the journal and the country in the months leading up to May 1968, from a perceptibly more political angle. Comolli's “Une morale de la dépense" argued that the key aspect uniting the various nouveaux cinémas, and the quality that gives this global movement a revolutionary status, is "the awareness among the new filmmakers of the need to reevaluate its relationship with society, in its double guise as producer and consumer." ${ }^{51}$ Following on from

49 Jean-Louis Comolli, “Situation du nouveau cinéma, 1," Cahiers du cinéma no. 176 (March 1966), p. 5 .

$5^{0}$ Jean Narboni, "Les trois âges," Cahiers du cinéma no. 178 (May 1966), pp. 58-59.

$5^{1}$ Jean-Louis Comolli, "Une morale de la dépense," Cahiers du cinéma no. 190 (May 1967), pp. 59-6o, here p. 59. Translated as "A Morality of Economics," trans. Diana Matias, in Hillier (ed.), Cahiers du Cinéma vol. II, pp. 290-293, here p. 291. 
the model adopted by Godard, there was also increasing consideration given to the new ways these films could be financed, in which a radically decreased budget would not only allow for the existence of a marginal cinema but also result in a much more intrinsically politicized art form $.5^{2}$ Narboni, for his part, viewed the nouveau cinéma within a broader cinematic movement towards "impertinence" - with the critic playing on the dual meaning of the word, denoting both impudence or effrontery and, on a more strictly linguistic level, the voiding of signification. Films such as Belle de jour, La Chinoise and Nicht versöhnt offered a new relationship between signifier and signified that is much less founded in the analogical relationship between referent and representation, and more focused on exploring new possibilities for cinematic writing. 53

If there was one representative of modernist cinema whose films drew critical attention during this period and whose work was decisive in shaping the critical categories established in "Cinéma/idéologie/critique," it was a figure who was neither young nor particularly new to the cinema. Nonetheless, Ingmar Bergman's films in the late 196os attested to a spirit of formal innovation and social critique that could hardly leave the Cahiers critics indifferent. Comolli, in particular, followed the director's career closely, devoting texts to The Silence, Persona and Hour of the Wolf that played a key role in forming the critic's broader understanding of the cinema. Comolli's long text on the first of these films, "Bergman anonyme" from June 1964, can in retrospect be seen as a turning point in the critic's trajectory, away from the phenomenological humanism of his early texts and towards the "political modernism" of his writings in the second half of the 196os and the 1970s. The Silence, for Comolli, is a new departure for Bergman, in which the thematic obsession that marks the Swede's entire œuvre - the idea of regression-is no longer veiled but openly affirmed. Moreover, the "closed circuit" between spectator and film that Bergman creates with The Silence is such that "the spectator sees himself introduced into the mirror, into the film, in order to become, in turn, a mirror of the spectator. The spectator in the film and the spectator in the cinema repel each other and reflect each other, ceaselessly hurtled back and forth between reality and illusion, between a dynamic vision and a regressive vision." 54

52 Ibid., p. 6 o.

53 Jean Narboni, "Vers l'impertinence," Cahiers du cinéma 196 (December 1967), p. 4. Translated as “Towards Impertinence," trans. Norman King, in Hillier (ed.), Cahiers du Cinéma vol. II, pp. 300-302.

54 Jean-Louis Comolli, "Bergman anonyme (Les Communiants, Le Silence)," Cahiers du cinéma no. 156 (June 1964), pp. 30-39, here p. 36. 
The idea of reflection also dominated Comolli's response to Persona. Discussing the images of a projector's carbon filaments that begin the film, Comolli exclaims: "never was the screen a more faithful mirror. We are in front of it, and what it shows us is in back of us. It and we: transparent phantoms." ${ }^{55}$ Although the film properly speaking starts after these images, the sense of doubt in the spectator aroused by the self-reflexivity of this opening sequence lingers and is reawakened when, halfway through the screening, the filmstrip appears to break up and catch fire, with the rest of the film proceeding as the inversion of Persona's first half. Awestruck in wonder at the modernism of Persona - which is still powerful today, even if its formal devices have become banalized through imitation-Comolli would have recourse to a more elaborate mode of argumentation in defending Shame in 1969. Here he was prompted by Cinéthique's Jean-Paul Fargier, writing for the Tribune socialiste, who censured the film for its "idealist humanism" and overly abstract denunciation of the horrors of war-an aesthetic approach which, in the end, "does nothing to lead people out of the obscurantism in which the cinema plunges them. ${ }^{.56}$ Comolli's affirmation of the film's value from a historical materialist perspective was not helped by Bergman himself, who, when asked about his politics in an interview published in Cahiers, stated, "My personal political position absolutely only concerns myself. As an artist, I am terribly anguished by what is happening right now, but I cannot place myself under any banner."57 Indeed, the critic detects a paradox within Bergman's œuvre: while his films become more radical, his discourse on them has become more paltry, purveying vague ideological notions about "the World" and "Man." If Bergman is to be believed about his own work, then his film does indeed, as Fargier claims, possess a "reactionary message." In Comolli's line of argument, however, "the very fact that Bergman says this outside the film inclines me to think that the film, outside of Bergman, does not say it." ${ }^{n 8}$

It is precisely against Bergman's own interpretation of his work, then, that Comolli defends the film, and in doing so he makes specific reference

55 Jean-Louis Comolli, "Le Fantôme de Personne (Persona)," Cahiers du cinéma no. 188 (March 1967), p. 20. Translated as "The Phantom of Personality," Cahiers du Cinéma in English no. 11 (September 1967), pp. 31-33.

56 Jean-Paul Fargier, "La Honte," Tribune socialiste, cited in toto in Comolli, "Dernier acte, encore," p. 56 .

57 Ingmar Bergman, interviewed by Stig Björkman, Torsten Manns and Jonas Sima, "La mort à chaque aube: Entretien avec Ingmar Bergman," Cahiers du cinéma no. 203 (August 1968), pp. 49-56, here p. 53. The interview was reprinted in French translation (by Kerstin L. Bitsch) from the Swedish film magazine Chaplin.

$5^{8}$ Comolli, "Dernier acte, encore," p. 56. 
to Macherey's concept of "literary production," which rejects a demiurgic, "auteurist" vision of aesthetic creation in favor of a historically and socially contextualized account of the process of "producing" works of art. ${ }^{59}$ For Comolli, the reason for the abstract, historically decontextualized manner of evoking military conflict in Shame is that it should actually be read as a mere echo of the film's principal storyline: the "war" between the husband-and-wife couple played by Liv Ullmann and Max von Sydow. The critic thus advocates a psychoanalytic reading of Bergman's film: "All the war scenes in Shame are filmed like a nightmare, not because the film means to say: war is a nightmare, which is doubtless what Bergman wanted to make it say, but because they are the matter of the couple's nightmare, the oneiric form of their destruction." ${ }^{60}$ It is tempting, as Lellis does, to see this review as "a direct example of Cahiers' being forced on the defensive by a more radical segment of French criticism," ${ }^{61}$ but it is also an example of the critical dexterity the journal could practice during this period, defending a film against the author's own interpretation of it. Readings such as this would contribute to the subtlety and complexity of the categories produced in "Cinéma/idéologie/critique" —Bergman's Persona, it should be recalled, is specifically invoked as an example of a "category (c)" film requiring an "against the grain" critical reading.

\section{"Le détour par le direct"}

The text that would be the most decisive precursor for the October 1969 editorial, however, was Comolli's two-part exploration of "direct" cinema, "Le détour par le direct." Here the Cahiers critic discerns a "certain tendency" in the cinema of the late 1960s: the "formal vanguard" of fiction film and the "direct" tradition of documentary cinema begin to share the same filmmaking techniques. Not only did films such as L'Amour fou by Rivette, Partner by Bertolucci or Silence and Cries by Jancsó adopt shooting practices derived from the documentary aesthetic but, conversely, the "non-fiction" films of Perrault, Eustache or Rouch came to borrow narrative devices from modernist fiction films. For Comolli, it is as if "the traditionally separate and even opposing fields of 'documentary' and 'fictional' films were interpenetrating

59 See Pierre Macherey, Pour une théorie de la production littéraire (Paris: Maspéro, 1966). Translated as $A$ Theory of Literary Production.

60 Comolli, "Dernier acte, encore," p. $5^{8 .}$

61 Lellis, Bertolt Brecht, Cahiers du Cinéma and Contemporary Film Theory, p. 75. 
more and more and intermingling in innumerable ways. It is as if they were engaged in a vast process of exchange, a reciprocal system where reportage and fiction alternate or conjugate within one and the same film." ${ }^{62}$

Since the time of this article, Comolli has maintained a complex relationship with "direct" cinema, one that was no doubt fostered by his own involvement in documentary filmmaking with André S. Labarthe, whose series "Cinéastes de notre temps" he credits with having "put into practice the mutual perversion of documentary and fiction." ${ }^{63}$ The Cahiers critic directed episodes on Pierre Perrault and Miklós Jancsó for the series (both of whom featured prominently in his article) and completed the "direct" documentary Les deux Marseillaises with Labarthe in 1968, which focused on the June 1968 legislative elections, overwhelmingly won by the Gaullists. ${ }^{64}$ Comolli's practical experience in this area did not, however, leave him with any illusions about the virtues of direct cinema. In "Le détour par le direct" he claims that, while "in its raw form direct cinema is present in every scrap of reportage filming, just as the cinema in its raw form is present in any sequence of images," there is a "basic deception" in direct cinema: that it can claim to "transcribe truly the truth of life." For Comolli, the very act of filming a given situation serves irrevocably to transform it, and thus a clear antinomy between the direct cinema and a cinema of "aesthetic manipulation" is impossible to maintain. If the direct method has a drawback, it is, for Comolli, not through any supposed "lack of honesty" towards the filmed material but rather through an "excess of respect" and a "lack of audacity." The very act of filming already constitutes a form of "manipulation" that changes - and even "perverts" - the nature of the event being filmed, but "direct cinema" suffers from a palpable neglect of the very "principle of perversion" that is the foundation of the cinema. ${ }^{65}$

In the documentary cinema, Comolli finds perhaps the most startling example of an effective use of direct filmmaking in the 10-minute short $L a$ Reprise du travail aux usines Wonder, made by Jacques Willemont. The film consists of a single shot, the length of a reel, showing factory workers at the Wonder battery plant returning to work after the end of a (victorious) strike. One woman, however, resists: tears streaming down her face, she is vocally unwilling to return to the daily oppression of factory life after having tasted the emancipatory experience of the strike, despite the encouragement of the

62 Comolli, "Le détour par le direct (1)," p. 48 [p. 225].

63 Comolli, "Le détour par le direct (2)," p. 44 [p. 241].

64 For a more in-depth disussion of Comolli's filmmaking, see Chapter 13.

65 The above quotes are all from Comolli, "Le détour par le direct (1)," p. 48 [pp. 225-226]. 
bosses, union leaders and even her fellow workers. If this short film achieves a fiction effect through documentary means, the reverse operation takes place in films such as Silence and Cries and L'Amour fou, and Comolli provides detailed discussions of the shooting style of both filmmakers. Rivette's film is of particular interest for introducing montage effects between the scenes of theater rehearsals, shot on $16 \mathrm{~mm}$ by a documentary crew headed by Labarthe, and the "real life" footage, shot on $35 \mathrm{~mm}$ with a standard professional crew: here, paradoxically, it is the "artificial situation" of the theater that is given a documentary treatment, while the off-stage scenes become dream-like through their marked coding as "fictional" within the formal system established for the film.

More broadly, Comolli sketches a mini-history of the cinema seen through the prism of the direct method, whose techniques can be traced back to the practice of Vertov and Eisenstein in the Soviet silent cinema. The rise of direct cinema (ushered in by the advent of portable synch sound in the early 1960s) represents, for Comolli, a formal revolution on the same level as the development of sound cinema in the late 1920s. In contrast to the advent of sound, direct cinema imposes itself through a "diffuse operation, a subtle reversal, an insidious change." ${ }^{n 6}$ Its ideological effects are no less powerful, however, and have shaken what Comolli calls the "system of representation" (here meaning conventional narrative cinema) to its core: "In the case of the talkie it was the language of the ruling class and the dominant ideologies which conquered the cinema. With synchronized sound it was the cinema which conquered speech, all speech, the speech of both sides, that of the workers and that of the bosses." ${ }^{\prime 67}$ There is a certain idealism in the excesses of this claim, ascribing opposed class interests to different technologies of sound cinema, and Comolli does not pursue this particular line of thinking, although it does form the germ for his later, more influential text "Technique et idéologie." The later series of articles is also specifically anticipated in Comolli's contestation of Marcelin Pleynet's reproach of the cinema in Cinéthique for being the "natural ideological accomplice" of the existing world of the bourgeoisie by virtue of its "duplicative nature." 68 This is the first time Cahiers addresses the Tel Quel critic's remarks and is evidence of the immediate impact the interview had on the journal. As he will also do in "Technique et idéologie," Comolli flatly repudiates Pleynet; here, interestingly, he turns to Macherey in order to do so, and in particular

68 Comolli, “Le détour par le direct (2)," p. 45. 
the literary theorist's claim that an "image which conforms absolutely to the model merges with it and loses its status as image; it remains such only by virtue of the gap separating it from what it imitates." ${ }^{n 9}$ It is in this innate gap or "discrepancy" (décalage) between image and referent-the discussion inevitably recalls Bazin's invocation of the cinema as an "asymptote" of reality ${ }^{70}$ - that Comolli sees a possibility for the cinema to avoid being the ideological reduplication of the capitalist status quo: not only does the cinema "reproduce" only a small slice of the world as it really exists, it is also "the product of a particular work operating on images as its basic material, but also on meaning, rhythms, devices, etc." In the best manifestations of direct cinema (whether in "documentary" or "fiction" film practice), the filmed event does not pre-exist the film but is instead produced by the very act of filming. It is therefore an act of "trans-formation" rather than "re-presentation," one that deposes "the world as model of the film by depriving the film of any 'model."'71 As in his later, more polemical series of articles, therefore, Comolli here argues for a close relationship between film "technique" and its potential "ideological" repercussions, and "Le détour par le direct" thus stands as the most important theoretical precursor to both "Cinéma/idéologie/critique" and "Technique et idéologie," adumbrating fundamental questions of cinematic representation that would animate Cahiers in the ensuing years.

\section{Works Cited}

Antoine de Baecque and Noël Herpe, Éric Rohmer (Paris: Stock, 2014).

André Bazin, “Une grande œuvre: Umberto D.," in idem., Qu'est-ce que le cinéma? vol. IV: Une esthétique de la réalité: le néo-réalisme (Paris: Éditions du Cerf, 1962), pp. 92-96. Translated as “Umberto D.: A Great Work," in idem., What is Cinema? vol II, trans. and ed. Hugh Gray (Berkeley: University of California Press, 2004), pp. 79-82. Ingmar Bergman, interviewed by Stig Björkman, Torsten Manns and Jonas Sima, "La mort à chaque aube: Entretien avec Ingmar Bergman," Cahiers du cinéma no. 203 (August 1968), pp. 49-56.

69 Macherey, Pour une théorie de la production littéraire, p. 129 [p. 7o]. Cited in Comolli, "Le détour par le direct (2)," p. 45 [p. 242].

70 See André Bazin, "Une grande œuvre: Umberto D.," in idem., Qu'est-ce que le cinéma? vol. IV: Une esthétique de la réalité: le néo-réalisme (Paris: Éditions du Cerf, 1962), pp. 92-96, here p. 96. Translated as "Umberto D.: A Great Work," in idem., What is Cinema? Vol. II, trans. and ed. Hugh Gray, pp. 79-82, here p. 82 .

71 Comolli, "Le détour par le direct (2)," p. 45 [pp. 242-243]. 
Claude Chabrol and Éric Rohmer, Hitchcock (Paris: Éditions universitaires, 1957). Claude Chabrol, Jacques Doniol-Valcroze, Jean-Luc Godard, Pierre Kast, Luc Moullet, Jacques Rivette and François Truffaut, "Sept hommes à debattre," Cahiers $d u$ cinéma no. 150-151 (December 1963-January 1964), pp. 12-23. Translated as "Questions about American Cinema," trans. David Wilson, in Jim Hillier (ed.), Cahiers du Cinéma vol. II: The 196os: New Wave, New Cinema, Reevaluating Hollywood (London: BFI, 1986), pp. 172-180. Hereafter CDC II.

Michel Ciment and Jacques Zimmer (eds.), La critique de cinéma en France (Paris: Ramsay, 1997).

Jean-Louis Comolli, "Grandeur du simple (Sergeant York)," Cahiers du cinéma no. 135 (September 1962), pp. 54-58.

—, "Vivre le film," Cahiers du cinéma no. 141 (March 1963), pp. 14-29.

—, "La présence et l'absence (Le Petit Soldat)," Cahiers du cinéma no. 141 (March 1963), pp. 54-58.

—, "Vanité de l'art," Cahiers du cinéma no. 142 (April 1963), pp. 54-57.

—, "Lautre ailleurs (Le Procès de Jeanne d'Arc)," Cahiers du cinéma no. 143 (May 1963), pp. 42-49.

—, "L'Amérique à découvert," Cahiers du cinéma no. 150-151 (December 1963-January 1964), pp. 217-224.

—, "Cléopatre, le jeu, l'échec," Cahiers du cinéma no. 153 (March 1964), pp. 32-40.

—_, "Bergman anonyme (Les Communiants, Le Silence)," Cahiers du cinéma no. 156 (June 1964), pp. 30-39.

—, "H.H., ou l'ironique," Cahiers du cinéma no. 160 (November 1964), pp. 49-52. Translated as "The Ironical Howard Hawks," trans. Norman King, in CDC II, pp. 181-186.

—, "Situation du nouveau cinéma, 1," Cahiers du cinéma no. 176 (March 1966), p. 5 .

—, "Cherchez l'Hawks (Red Line 7ooo)," Cahiers du cinéma no. 180 (July 1966), pp. 24-28.

—, "Toujours pour... Hawks!" Cahiers du cinéma no. 181 (August 1966), p. 4.

—, "Le rideau soulevé, retombé (Torn Curtain)," Cahiers du cinéma no. 186 (January 1967), pp. 36-39. Translated as “The Curtain Lifted, Fallen Again," Cahiers du Cinéma in English no. 10 (May 1967), pp. 52-55.

—, "Le Fantôme de Personne (Persona)," Cahiers du cinéma no. 188 (March 1967), p. 2o. Translated as "The Phantom of Personality," Cahiers du Cinéma in English no. 11 (September 1967), pp. 31-33.

—, "Une morale de la dépense," Cahiers du cinéma no. 190 (May 1967), pp. 596o. Translated as "A Morality of Economics," trans. Diana Matias, in CDC II, pp. 290-293.

—, "L'envers de l'Eden," Cahiers du cinéma no. 192 (July-August 1967), p. 22. 
—, "Le détour par le direct," Cahiers du cinéma no. 209 (February 1969), pp. 48-54, and Cahiers du cinéma no. 211 (April 1969), pp. 40-45. Translated as "The Detour through the Direct," trans. Christopher Williams, in idem. (ed.), Realism and the Cinema: A Reader (London: BFI, 1980), pp. 224-244.

—, "Dernier acte, encore," Cahiers du cinéma no. 215 (September 1969), pp. 55-58.

-, Cinéma contre spectacle (Lagrasse: Verdier, 2009). Translated as Cinema against Spectacle: Technique and Ideology Revisited, trans. and ed. Daniel Fairfax (Amsterdam: Amsterdam University Press, 2015).

—, interviewed by Daniel Fairfax, "Yes, we were utopians; in a way, I still am...': An Interview with Jean-Louis Comolli (Part 1)," Senses of Cinema no. 62 (April 2012), sensesofcinema.com/2012/feature-articles/yes-we-were-utopians-in-a-way-istill-am-an-interview-with-jean-louis-comolli-part-1/ (accessed January 1, 2021).

—, Une terrasse en Algérie (Lagrasse: Verdier, 2018).

—, Jean Douchet, Jean-André Fieschi, Fereydoun Hoveyda, Jean Narboni and Claude Ollier, "Paralipomènes aux Oiseaux," Cahiers du cinéma, no. 149 (November 1963), pp. 38-44.

—, Gérard Leblanc and Jean Narboni, Les années pop: Cinéma et politique: 1956-1970 (Paris: BPI/Centre Pompidou, 2001).

— and Jean Narboni, "Retour en Italie," Cahiers du cinéma no. 157 (July 1964), pp. 29-37.

Michel Cournot, "La verticale d'Hanoï," Le Nouvel Observateur, July 6, 1966.

Michel Delahaye, "D’un sport à l'autre (Man's Favorite Sport)," Cahiers du cinéma no. 160 (November 1964), pp. 80-81.

Howard Hawks, interviewed by Serge Daney, Jean-Louis Noames and James R. Silke, "Entretien avec Howard Hawks," Cahiers du cinéma no. 160 (November 1964), pp. 54-6o.

- , interviewed by Jean-Louis Comolli, Jean Narboni and Bertrand Tavernier, "Entretien avec Howard Hawks," Cahiers du cinéma no. 192 (July-August 1967), pp. 14-21, 67-68.

André S. Labarthe, "Avant-propos," Cahiers du cinéma no. 131 (May 1962), pp. 1-2.

George Lellis, Bertolt Brecht, Cahiers du Cinéma and Contemporary Film Theory (Ann Arbor, MI: UMI Research Press, 1982).

Pierre Macherey, Pour une théorie de la production littéraire (Paris: Maspéro, 1966). Translated as A Theory of Literary Production, trans. Geoffrey Wall (London: Routledge, 1978).

Jean Narboni, "Ouvert et fermé (Le Mépris)," Cahiers du cinéma no. $15^{2}$ (February 1964), pp. 66-69.

—, "Mankiewicz à la troisième personne," Cahiers du cinéma no. 153 (March 1964), pp. 27-31.

—, "Les trois âges," Cahiers du cinéma no. 178 (May 1966), pp. 58-59. 
—, "Contre la montre (Red Line 70oo)," Cahiers du cinéma no. 180 (July 1966), pp. 2830. Translated as "Against the Clock," trans. Diana Matias, in CDC II, pp. 216-219. —, "La machine infernale," Cahiers du cinéma no. 186 (January 1967), p. 35. Translated as “The Infernal Machine," Cahiers du Cinéma in English no. 10 (May 1967), p. 51.

—, "Vers l'impertinence," Cahiers du cinéma 196 (December 1967), p. 4. Translated as "Towards Impertinence," trans. Norman King, in CDC II, pp. 300-302.

—, "Les futurs antérieurs" in Jean-Louis Comolli, Gérard Leblanc and Jean Narboni, Les années pop: Cinéma et politique: 1956-1970 (Paris: BPI/Centre Pompidou, 2001), pp. 9-20.

Jacques Rivette, “Génie de Howard Hawks," Cahiers du cinéma no. 23 (May 1953), pp. 16-23. Translated as "The Genius of Howard Hawks," trans. Russell Campbell and Marvin Pister, in Jim Hillier (ed.), Cahiers du Cinéma, the 1950s: Neo-Realism, Hollywood, New Wave (Cambridge, MA: Harvard University Press, 1985), pp. 126-131. 


\title{
3. Décalages: "Young Mr. Lincoln de John Ford"
}

\begin{abstract}
This chapter discusses Cahiers du cinéma's collective text "Young Mr. Lincoln de John Ford," a critical re-reading of a canonical film from the classical era of Hollywood cinema, and places it in the context of the journal's long relationship with Ford's œuvre. Highlighting the article's status as a truly communal theoretical undertaking and its indebtedness to the structuralist reading method espoused by Roland Barthes in $S / Z$, this chapter closely scrutinizes the text on Young Mr. Lincoln. While later critics for Screen noted flaws in the political analysis offered by Cahiers, I show that the value of the Cahiers critics' reading lies in their emphasis on the American director's formal language, the play of visibility and invisibility that produces symptomatic discrepancies with the conscious ideological goals of the original project.
\end{abstract}

Keywords: Cahiers du cinéma, John Ford, Young Mr. Lincoln, Roland Barthes, re-reading, classical Hollywood

\section{The Critical Rehabilitation of John Ford by Cahiers du cinéma}

Over the course of the year 1970, it became clear that the categories established in "Cinéma/idéologie/critique" would determine the nature of Cahiers' critical work. While contemporary cinema still remained the principal focus for the journal, its interest in returning to works of the past was signaled early in the year by a text on Jean Renoir's 1936 militant film La vie est à nous in March and the special issue on "Russie années vingt" two months later. These two moments in film history witnessed the conscious engagement of filmmakers in a politically left-wing-even revolutionary - project, and they will hence be discussed in Part II. Treating the critically worthy products of the Hollywood studio system required a

Fairfax, D., The Red Years of Cahiers du Cinéma (1968-1973). Volume I: Ideology and Politics. Amsterdam: Amsterdam University Press, 2021 DOI 10.5117/9789463728508_CHO3 
different critical approach, one that is explicitly foreshadowed by Comolli/ Narboni in their editorial when, referring to category (e) films, they speak of a "discrepancy, a distortion, a rupture" between the initial ideological project and the end product in certain works of the classical era and argue that there are specific "mechanisms of figuration" that enable the reflection of the dominant ideology in such films to be deformed or even shattered. ${ }^{1}$ Evidently, this was a means by which the Cahiers editors could critically recuperate the journal's historical canon of classical auteurs, who were now considered, effectively, to be sites of ideological décalage in a system whose political goals and economic functioning were otherwise antithetical to those of the cinema espoused by Cahiers. ${ }^{2}$

It is noteworthy, however, that the three names mentioned as directors pertinent to this category—Ford, Dreyer and Rossellini—are not widely considered to represent a common aesthetic tendency within the cinema, even if all three are distinctly cahiersiste auteurs. Only Ford belonged to the Hollywood filmmaking system, whereas Dreyer and Rossellini are more associated with European "art" cinema. The three filmmakers are also identified with multiple periods in film history: from the silent era, in the case of Ford and Dreyer, up to the post-war modernist moment. We can thus assume that the trio of names was intended to give category (e) a certain eclectic veneer, avoiding a knee-jerk assimilation with classical Hollywood. And yet it is notable that, in the period following "Cinéma/ idéologie/critique," neither Dreyer nor Rossellini is discussed in any detail by Cahiers: an extensive dossier had been dedicated to the Danish director in December 1968, but his work was not discussed by the journal after this date; Rossellini, meanwhile, despite being one of the key figures de prou for the Cahiers of the 1950s and early 196os, found his work largely ignored by the journal between a review of La prise de pouvoir par Louis XIV by Serge Daney in January 1967 and an article by Narboni on Germania anno zero more than eleven years later. ${ }^{3}$ Classical Hollywood, by contrast, was a constant focus of critical analysis during this time, with re-readings of

1 Comolli/Narboni, “Cinéma/idéologie/critique," p. 13 [p. 257].

2 The term décalage was used by Comoll and Narboni with clear reference to Althusser, who made ample use of it in his discussions of ideology in For Marx and other texts. Ben Brewster has made a sustained case for translating this word as "discrepancy" in English. See Ben Brewster, in Louis Althusser, Politics and History: Montesquieu, Rousseau, Marx, trans. and ed. Ben Brewster (London: Verso, 2007 [1972]), pp. 113-114.

3 Jean Narboni, "Allemagne année zéro," Cahiers du cinéma no. 290-291 (July-August 1978), p. 47. Kané also briefly touched on La Prise du pouvoir in his 1974 article "Cinéma et histoire: L'effet d'étrangeté," Cahiers du cinéma no. 254-255 (December 1974 - January 1975), pp. 77-83. 
films such as Morocco, Sylvia Scarlett and Intolerance appearing in the years $1970-1972 .^{4}$

By far the most well-known example of a critical analysis of a Hollywood film - following the methodology sketched out in the paragraph on category (e) films in "Cinéma/idéologie/critique"-is the enormously influential collective text on John Ford's Young Mr. Lincoln, which appeared in the August-September 1970 issue of Cahiers. The choice of film was at least partly the product of circumstance: Young Mr. Lincoln was, at the time, screening as part of a revival series in Paris, which allowed the Cahiers writers to view it repeatedly in order to hone their close reading of the film. ${ }^{5}$ With its focus on the early life of one of the United States' most revered statesmen, around whom a considerable cult of the individual had been built up in the decades prior to Ford's film, Young Mr. Lincoln also evinced a connection to questions of politics and ideology in the cinema that was more direct and more immediately apparent than is the case in the vast majority of Hollywood films, which are usually characterized by the veiled nature of their political substance. ${ }^{6}$

That it should be a film by John Ford that received the first, and still the most prominent, of the re-readings of classical cinema from the standpoint of Cahiers' new theoretical framework was itself an appropriate gesture. Comolli and Narboni's defense of Ford stretched back to their early years at Cahiers, but it was a position that was at odds not only with critical consensus on Ford in the 196os but also with the journal's own prior attitudes towards the filmmaker. Historically, Ford had not counted among those auteurs favored by Cahiers. Famously, one of the figures most closely associated with the journal in its initial incarnation, Roger Leenhardt, published a polemical piece in L'Écran français whose title, "À bas Ford/Vive Wyler!," neatly encapsulated the critical dichotomy operative in the Cahiers critical

4 These three films, and the dossier on Dreyer, will be discussed further in Chapter 16.

5 The film screened earlier that year as part of the "Hollywood Story" series organized by the Cinémas Associés chain. This program also included Morocco, subject to analysis by Cahiers later in 1970, and a number of other Ford films. Details of this event can be found in a notice publicizing it in Cahiers du cinéma no. 220-221 (May-June 1970), p. 2.

6 For a journal that was engaged, at the time, in a prolonged effort to publish translations of Eisenstein's writings, it is also notable that Young Mr. Lincoln was a film that the Soviet director himself held in high esteem. See Sergei Eisenstein, "Mr. Lincoln by John Ford," in idem., Selected Works vol. III: Writings, 1934-147, trans. William Powell, ed. Richard Taylor (London: IB Tauris, 2010), pp. 174-183. Eisenstein's admiration for Ford's film was known to Cahiers and mentioned by Delahaye in 1966. See Michel Delahaye, “De John Ford à Sean O'Feeney," Cahiers du cinéma no. 183 (October 1966), pp. 55-59, here p. 55. Curiously, however, it was not noted in the 1970 article. 
tradition during the 1950s. Leenhardt contended that, unlike Wyler, Ford's aesthetic was too rooted in the stylistic expressionism of silent cinema to be considered a representative of the modernity the critic demanded of filmmakers. ${ }^{7}$ Bazin, too, was noticeably ambivalent about the director of The Searchers, despite what would seem to be clear affinities between filmmaker and theorist. ${ }^{8}$ In "Lévolution du langage cinématographique," Ford was unfavorably compared to both Wyler and Welles for his reluctance to deploy a deep-focus, long-take aesthetic, ${ }^{9}$ while in "Évolution du western," Bazin viewed late-1940s Ford films such as My Darling Clementine and Fort Apache as constituting an aesthetically dubious "baroque embellishment" of the historically superseded classicism of Stagecoach. ${ }^{10}$

Prior to Comolli and Narboni's interventions, the only significant critical voice in Cahiers to respond positively to the American's work was Louis Marcorelles, a critic who later became chief film reviewer for Le Monde. Marcorelles pronounced Ford the greatest filmmaker alive alongside Jean Renoir in his critical overview "Ford of the Movies" and reviewed The Horse Soldiers (1959) in similarly glowing terms. ${ }^{11}$ Although he contributed articles and interviews for more than a decade between the late 1950s and late 196os, Marcorelles was always a rather marginal figure in Cahiers, with views that were often distinct from its prevailing tastes. Comolli's enthusiastic review of Cheyenne Autumn in the March 1965 issue was therefore a critical gambit. Not only was he challenging Cahiers' generally lukewarm attitude towards the director, but he also stood in opposition to the broader critical consensus on this late entry in Ford's œuvre. Even diehard Fordians, he recognized, saw the film as a "regression," and if left-wing critics gave Cheyenne Autumn's depiction of the American West from the perspective of

7 Roger Leenhardt, “À bas Ford/Vive Wyler!," L'Écran français no. 146, April 13, 1948.

8 Ford's proclivity, for instance, for shooting in natural landscapes such as Monument Valley would seem to be apposite to Bazin's film aesthetics.

9 André Bazin, “L'Évolution du langage cinématographique," in idem., Qu'est-ce que le cinéma? vol. I: Ontologie et langage (Paris: Éditions du Cerf, 1958), pp. 131-148, here p. 143. Translated as "The Evolution of Film Language," in André Bazin, What is Cinema?, trans. and ed. Timothy Barnard (Montreal: Caboose, 2009), pp. 87-107, here p. 100. Jean Narboni has stated that for Leenhardt and Bazin, "the modern cinema was Welles and Wyler. They were right on Welles, but mistaken on Wyler." Interview with Jean Narboni, March 18, 2014.

10 André Bazin, "Évolution du western," in idem., Qu'est-ce que le cinéma? vol III: Cinéma et sociologie (Paris: Éditions du Cerf, 1961), pp. 146-156, here p. 147. Translated as "The Evolution of the Western," in idem., What is Cinema vol. II, trans. and ed. Hugh Gray, pp. 149-157, here p. 150. 11 See Louis Marcorelles, "Ford of the movies," Cahiers du cinéma no. 86 (August 1958), pp. 32-37, here p. 32; and Louis Marcorelles, "Heureux qui comme Ford (Les Cavaliers)," Cahiers du cinéma no. 101 (November 1959), pp. 46-49. 
its Indian inhabitants a certain measure of support, they did so precisely by opposing the film to Ford's pre-existing corpus. Comolli, by contrast, argued that Ford's latest film, the 129th in his career, was not a "sudden realization" brought about by the contrition of the "great destroyer of the Indians"; rather, Ford had, for twenty years already, been "painstakingly dismantling the very myths that he himself had more or less created." ${ }^{22}$ For Comolli, therefore, Ford had been engaged in making "anti-Westerns" well before younger directors like Aldrich and Peckinpah adopted the practice. The critic nonetheless recognized the paradoxes of writing about an auteur whose vast œuvre, made over the course of four decades, represents an implicit challenge to the tenets of the politique des auteurs: "Who is Ford? After ten films, we already begin to talk about an auteur. After thirty, we talk about him a lot. But past a hundred, how can we still talk about what the author is?" Ford's voluminous body of films, which vacillate between confirming and confuting the auteur's recognized stylistic signature, can thus appear to film critics and spectators as both "rich and confused or perfunctory and narrow."13 The importance of Cheyenne Autumn, in Comolli's view, is that it represents the point at which the centrifugal and the centripetal forces of Ford's œuvre fuse with one another: at one and the same time, Ford's penultimate film takes his work in a bold new direction and consciously returns to the central core of the director's thematic preoccupations.

The release of Seven Women in September 1966 saw a renewed focus on the director. Twin reviews of the film by Comolli and Narboni argued, respectively, that the film is "Ford at his most bitter and his most lucid"14 and that it represents "one of those works, at once synthesis and crowning achievement, in which the absolute project of an author is located at the borderline between the excessive and the sublime. Yet all Ford is present, though in a tranquil immoderation." ${ }^{15}$ The following issue continued the focus on Ford: an interview with the director by Cahiers' "Hollywood correspondent" Axel Madsen was followed by articles on the film from Michel Delahaye and Comolli, the latter of which, while focusing on the motif of

12 Jean-Louis Comolli, "Signes de piste (Les Cheyennes)," Cahiers du cinéma no. 164 (March 1965), pp. 75-76, here p. 75. Translated as "Signposts on the Trail," in John Caughie (ed.), Theories of Authorship: A Reader (London: Routledge, 1981), pp. 109-116, here p. 111.

13 Ibid.

14 Jean-Louis Comolli, "Dé-composition (Frontière chinoise)," Cahiers du cinéma no. 182 (September 1966), pp. 16-20, here p. 20.

15 Jean Narboni, "La preuve par huit (Frontière chinoise)," Cahiers du cinéma no. 182 (September 1966), pp. 20-24, here p. 24. Translated as "Casting Out the Eights," in Caughie (ed.), Theories of Authorship, pp. 117-120, here p. 119. 
ballroom dances in Ford's work, also examined Cahiers' own attitudes to Ford. Paradoxically, Comolli here argued that it was the primacy the journal consistently accorded to formal detail that had prevented it from seeing Ford's originality, which is situated at the level of "the entire film, and the assemblage of its sequences, the strength of its portraits" rather than specific approaches to montage or framing. With an uncanny sense of premonition, the critic concludes his short piece by declaring "the study of Ford's work here has just begun." ${ }^{16}$

Serge Daney, whose involvement with Cahiers at this time was fitful, did not write about Ford in the pages of the journal prior to the Young Mr. Lincoln text; nonetheless, his attachment to the director was evinced in an entry written on Ford for the Dictionnaire du cinéma in 1966. Allowing that Ford was "a strangely misrecognized filmmaker," Daney noted that a retrospective of his work at the Cinémathèque française had contributed to a generalized change in mood; combined with the release of Cheyenne Autumn, the critic considered 1964 to be "the year of Ford." Foreshadowing the argument of Young Mr. Lincoln, Daney deems that "it is the fate of the classics, propelled by the excess of their own logic, to evolve towards the extremes of modern art." Moreover, contesting the widespread notion of Ford as a politically reactionary filmmaker, Daney insists that he has always "taken the side of minorities," explaining: "This is the only logic that can take stock of a social and political thought that has been greatly spoken about without its cause being seen, which is of a purely sentimental and poetic nature. Ford will always be on the side of minorities that organize themselves, he is at once a defender of order and a cop-hater."17

If there is one figure, however, who can claim ultimate responsibility for Cahiers' change in position on Ford, then it is Rivette. In spite of the fact that Rivette never wrote a single word in Cahiers on Ford, Narboni explains that the journal's "hyper-Fordian turn came about under Jacques Rivette." The key moment in this transformation took place during Langlois' Ford retrospective: "I remember that after the screening of The Wings of Eagles, we spoke with Rivette about the film in front of the cinémathèque, and we were absolutely awestruck-it's a sublime film. And after that, Cahiers became extremely Fordian." ${ }^{18}$

16 Jean-Louis Comolli, “Ford et les autres," Cahiers du cinéma no. 183 (October 1966), p. 55.

17 Serge Daney, "John Ford," in Dictionnaire du cinéma (Paris: Éditions universitaires, 1966). Repr. in idem., La Maison cinéma et le monde vol. I: Les temps des Cahiers 1962-1981, ed. Patrice Rollet (Paris: P.O.L., 2001), pp. 278-285, here pp. 279-280.

18 Interview with Jean Narboni, March 3, 2014. 


\section{"Young Mr. Lincoln de John Ford": Theoretical Framework and Method}

The groundwork had thus been laid for Ford to be a central figure in Cahiers' project of critically re-reading classical Hollywood from a Marxist point of view. Retrospectives and other revival screenings had familiarized the critics with his prodigious œuvre, and the Cahiers writers had become emboldened enough to treat the director's films with theoretical rigor by their defense of his work in the critical skirmishes over Cheyenne Autumn and Seven Women. Running to nearly twenty double-columned pages, "Young Mr. Lincoln de John Ford" represented the most in-depth critical analysis of a film to appear in Cahiers up to that time. Although divided into 25 sections, the article can more broadly be partitioned into three main subdivisions: the first (sections 1-7) outlines the political context in which the film was made and gives the theoretical and methodological framework through which it is to be analyzed; the second (8-23) offers a close reading of the film that hews closely to the order of its narrative structure; and the third (24-25) summarizes the article's findings before offering a psychoanalytic reading of the film (attributed to Oudart) that centers on the theme of "violence and the law."

From the very start of their analysis, Cahiers define the goal of their text to be that of an active reading (lecture) and re-marking (re-marquage) of Young Mr. Lincoln. As a classical work founded on the twin imperatives of "analogical representation" and "linear narrative," Ford's film calls all the more acutely for such a reading, precisely because it had previously been "limited to a kind of non-reading guaranteed by [its] apparent non-writing." The precise nature of this act of reading is initially defined negatively, with a fourfold explanation of what the analysis of Young Mr. Lincoln is not intended to be: the text will not be a commentary, seen as an "errant and proliferating pseudo-reading, which misses the reality of the inscription"; it will not be a new interpretation, deemed to be the supposedly "absolute knowledge of an exegete blind to the ideological (and historical) determination of his practice and his pretext-object"; it is not to be the "dismemberment of an object conceived as a closed structure"; and, finally, it should not be seen as a "demystification." ${ }^{19}$ This last term, with its roots in Marxist theories of cultural and ideological practice, warrants a deeper exposition. Whereas the three previous inadequate reading methods can be ascribed to idealist, bourgeois critical tendencies, the explicit target in this case is "the most 
extreme positions within Cinéthique," which are criticized for carrying out a "mechanically applied" materialist method and for considering it sufficient to designate the ideological falsehoods or errors expressed in a work in order to bring about its theoretical deconstruction. ${ }^{20}$ Against this moralizing denunciation of a "bad object," Cahiers insist that "an artistic product cannot be linked to its socio-historical context [dehors] according to a linear, expressive, immediate causality" but that it has a "complex, mediated and decentered relation with this context.".21

In arguing against a mechanical "demystification" of an artistic work, the Cahiers critics elucidate the theoretical framework for their own study. Walter Benjamin's notion of the "author as producer" is glossed, with Cahiers contending that his insistence on considering the literary work not as a reflection of the relations of production but as taking place within these relations applies not only to "progressive works" but also to certain "art products which appear to lack any intentional critical dimension concerning capitalist relations of production." ${ }^{22}$ At this point, too, the Cahiers critics stress the importance of Badiou's notion of the "autonomy of the aesthetic process" and Macherey's theses on literary production in his text "Lenin, Critic of Tolstoy" in providing a framework for their critical practice. The latter article, in particular, is something of a tutor-text for Cahiers' study: here Macherey, following on from the articles Lenin dedicated to the Russian novelist in 1908, describes Tolstoy's writings as the distorted, selective reflection of the social contradictions of the historical era depicted by the author (in particular, the state of the Russian peasantry in the late nineteenth century). ${ }^{23}$ Channeling Lenin, Macherey argues that "the text is not directly rooted in historical reality, but only through a complex sequence of mediations" and that "Tolstoy is present at history above all by his absences: the material development of power is obscured for him." ${ }^{24}$ Macherey's discussion

20 Ibid., p. 30 [p. 7]. The most obvious text implied here (and indeed, one of the few texts in which Cinéthique discusses a non-contemporary film) is Gérard Leblanc's denunciation of Citizen Kane in "Welles, Bazin et la RKO (à propos de Citizen Kane)," Cinéthique no. 6 (January-February 1970), pp. 27-32. This article would also be discussed at length by Comolli in "Technique et idéologie." 21 “Young Mr. Lincoln de John Ford," p. 30 [p. 7].

22 Ibid. See also Walter Benjamin, "The Author as Producer," in idem., Reflections, trans. Edmund Jephcott, ed. Peter Demetz (New York: Schocken, 1978), pp. 220-238.

23 For Cahiers, Lenin's writings on Tolstoy represented a rectification of the "simplistic positions" of Trotsky and Plekhanov on the Russian novelists. Indeed, throughout its Marxist period, the journal was consistently dismissive of Trotsky's views on literature and art, a stance no doubt determined by its political allegiances first to the PCF and then to the Maoist movement, both of which were exceedingly hostile to Trotskyism.

24 Pierre Macherey, “Lénine, critique de Tolstoï,” pp. 88, 85 [pp. 132, 128]. 
of the literary work is founded on another act of textual analysis that is also of major importance for the Cahiers writers: namely, the collective project under Althusser's auspices to conduct a "symptomatic" reading of Marx in Lire le Capital. Indeed, the notion developed by Althusser of "structuring absences" - the "inner darkness of exclusion" which allows the reader to take into account a given text's "insights and oversights" (vues et bévues) - is of fundamental importance for Cahiers, both in the Young Mr. Lincoln article and in their critical method more generally. ${ }^{25}$

Although it goes unmentioned in the article, Roland Barthes' scrutiny of Balzac's novella Sarrasine in $S / Z$ is also of major significance for Cahiers: the text was published by Seuil in 1970, the same year as the Young Mr. Lincoln article, and was based on seminars Barthes held at the Collège de France in 1968-1969, which were attended by some of the Cahiers critics. Moreover, the journal was in regular contact with the theorist, attending screenings with him and occasionally publishing his work. ${ }^{26}$ Indeed, Bonitzer now sees $S / Z$ as the decisive text for the Young Mr. Lincoln analysis: "Barthes had made a kind of systematic reading of a Balzac novella called Sarrasine. It was a semiological reading. And we attempted to give a kind of semiological and ideological framework to Young Mr. Lincoln following this model."27 More specifically, Barthes' notion, in $S / Z$, of the "writerly text" (a "galaxy of signifiers" allowing for a plurality of readings) as well as his examination of the interaction and interpenetration of the multiple codes operating within the narrative of Sarrasine is of obvious pertinence to Cahiers' study of Ford's film. The latter text appears to be structured along very similar lines to the "step-by-step" analysis of Barthes' work, even though the theorist had cautioned that this approach is "of necessity a renewal of the entrances to the text, it avoids structuring the text excessively, avoids giving it that supplementary structure which would come from a dissertation and would close it: it splinters [étoiler] the text, instead of assembling [ramasser] it." ${ }^{28}$ Barthes' methodology is eagerly adopted by the Cahiers writers, who, when confronted with moments when their interpretation could otherwise appear strained or contrived, boldly state, "we do not hesitate to force the text,

25 See Louis Althusser, Étienne Balibar, Roger Establet, Pierre Macherey and Jacques Rancière, Lire le Capital (Paris: Maspero, 1965). Translated in abridged form as Reading Capital, trans. Ben Brewster (London: Verso, 2009 [1970]). The "inner darkness of exclusion" quote appears on p. 21 [p. 27].

26 For more on Cahiers' links with Barthes, see Chapters 14 and 15 .

27 Interview with Pascal Bonitzer, April 30, 2014.

28 Roland Barthes, $S / Z$ (Paris: Seuil, 1970), p. 17. Translated as $S / Z$, trans. Richard Miller (New York: Hill and Wang, 1974), p. 13. 
even to re-write it, insofar as the film only constitutes itself as a text by the integration of the reader's knowledge." ${ }^{29}$

It should not be forgotten, however, that, alongside aesthetic theorists working within the Marxist tradition, a crucial influence for Cahiers is Marx himself. The Young Mr. Lincoln article begins with an epigraph drawn from an article by Marx for Die Presse in which the founder of historical materialism wrote, "Lincoln is not the product of popular revolution: the banal game of universal suffrage, ignorant of the great historical tasks to be resolved, has raised him to the summit, him, a plebeian, a self-made man who rose from being a stone breaker to being the Senator for Illinois." ${ }^{\circ}$ Amidst his theoretically penetrating accounts of the economic and ideological contours of the Civil War, Marx implacably defended the North during the conflict ${ }^{31}$ and was not averse to heaping praise on Lincoln himself: the First International sent a telegram congratulating the president on his 1864 electoral victory, and after Lincoln's assassination, Marx declared him to be "one of the rare men who succeed in becoming great, without ceasing to be good. Such indeed, was the modesty of this great and good man, that the world only discovered him a hero after he had fallen a martyr." ${ }^{2}$

The Cahiers writers stress that their analysis is "overdetermined" not only by Marxist theory but also by its "twin discourse," Freudian psychoanalysis. They argue that there are two overarching "structuring lacks" determining the film: a sexual "other scene," and a political "other other scene." Whereas in its subsequent analysis of Morocco, Cahiers places an emphasis on the erotic repression governing Sternberg's film, in the case of Young Mr. Lincoln, politics is judged to be the film's primary determination, with sexuality remaining a secondary concern. The journal thus takes great care to elucidate the political and economic context in which Ford's biopic of

29 “Young Mr. Lincoln de John Ford," p. 44 [p. 37].

$3^{0}$ Karl Marx, "Comments on the North American Events," Die Presse, October 12, 1862. Repr. in The Collected Works of Marx and Engels vol. XIX (London: Lawrence \& Wishart, 2010), p. 248. Cited in "Young Mr. Lincoln de John Ford," p. 29.

31 For more on this matter, see Karl Marx, Dispatches for the New York Tribune: Selected Journalism of KarlMarx, ed.James Ledbetter(London: Penguin, 2007), pp. 261-311. Cahiers' own position, seeing the Republican party as "abolitionist by economic opportunism" and quickly returning to racism and segregationism after the conclusion of the Civil War, is therefore distinct from Marx's own views and neglects the period of Radical Republican rule during the early Reconstruction era. 32 Karl Marx, "Address from the Working Men's International Association to President Johnson" Bee-Hive, May 20, 1865. Repr. in The Collected Works of Marx and Engels vol. XX (London: Lawrence \& Wishart, 2010), pp. 99-101. This text was cited by Ben Brewster in "Notes on the Text 'John Ford's Young Mr. Lincoln' by the Editors of Cahiers du Cinéma," Screen vol. 14 no. 3 (Autumn 1973), pp. 29-43, here p. 40. 
Lincoln was produced. Three pertinent contextual levels are apparent to the critics: the political/economic situation of the United States in the late 1930s; the financial health of the Hollywood industry during this period; and the ideological goals of the film's production company, 2oth Century Fox, which at the time was under the control of studio boss Darryl F. Zanuck, an outspoken Republican. The first level is shaped by a fresh economic downturn beginning in 1937: Cahiers notes that unemployment hovered at around 10 million jobless at this time, and economic activity was $37 \%$ below its 1929 levels. But it was also marked by the reform agenda pursued by Roosevelt's New Deal program and the resistance to it by the Republican party (which represented the interests of monopoly finance capital) as the country headed into the 1940 presidential election. Hollywood in the Depression era, meanwhile, was marked both by a high degree of monopolization and by the increasing control of the film industry by finance capital. The result was firm support from the studios for the Republican party in the upcoming presidential elections, against a third term for Roosevelt. Although Lukàcs is not a reference point for Cahiers at this time, his notion of reified consciousness seems germane to the logic employed here: the studio bosses were militantly pro-Republican because their economic position impelled it. ${ }^{33}$ The Cahiers writers conclude that "all this allows us to assume that in 1938-39, Fox [...] participated in its own way in the Republican offensive by producing a film on the legendary character of Lincoln. Of all the Republican presidents, he is not only the most famous, but on the whole the only one capable of attracting mass support." 34 Seeking, however, to avoid the temptation of what Rosen describes as a vulgar Marxist account of a film's ideological determination, ${ }^{35}$ they temper this assumption, insisting instead that we must not "exaggerate the film's political determinism." Young Mr. Lincoln did not represent a major investment for Fox, and, contrary to other Ford films such as The Grapes of Wrath (1940), there is little evidence of Zanuck having been personally involved in the production..$^{6}$

33 See Georg Lukács, History and Class Consciousness, trans. Rodney Livingstone (London: Merlin Press, 1971). The link with Lukács has already been argued for in Andrew, Concepts in Film Theory, p. 122. The Cahiers writers themselves, however, rarely mentioned the work of the Hungarian Marxist, with the chief exception being Daney/Oudart's article on Visconti's Morte a Venezia. See Chapter 17.

34 “Young Mr. Lincoln de John Ford," p. 31 [p. 11].

35 See Philip Rosen, "Screen and the Marxist Project in Film Criticism," Quarterly Review of Film Studies vol. 2 no. 3 (1977), pp. 273-287, here p. 275.

36 Moreover, although Cahiers only touches on this matter lightly, the Republican party of Lincoln was a very different creature to the party of the 1940 election: little continuity can be found between the anti-slavery movement of the 1850 s and 1860 os and the right-wing, laissez-faire 
Instead, the Cahiers writers prefer to inscribe the film within a broader hagiography of Lincoln constructed throughout Ford's œuvre. Already in 1924, the figure of Lincoln had played an important role in The Iron Horse; his assassination and its aftermath had been depicted in 1936's The Prisoner of Shark Island (a film that pitilessly attacks the post-Lincoln rule of the Radical Republicans), and he was repeatedly invoked as a talisman in Ford's late films, including Sergeant Rutledge (1960), How the West Was Won (1962) and Cheyenne Autumn (1964). Moments of self-citation are sprinkled throughout these films: Lincoln, for instance, requests the playing of the southern anthem "Dixie" in the opening of Shark Island, a song which he had, as Cahiers recalls, "already" played on the Jew's Harp in Young Mr. Lincoln. ${ }^{37}$ The result is a "synthetic personality" who traverses Ford's films as "a sort of universal referent which can be activated in all situations." Young Mr. Lincoln is nonetheless demarcated from the other films by the fact that the figure of Lincoln, having been made the film's protagonist, is here inscribed as a "Ford character," and this shift comes at the cost of "a certain number of distortions and reciprocal coups de force" with respect to the Lincoln character within the film's narrative. ${ }^{38}$

\section{"Young Mr. Lincoln de John Ford": The Becoming-a-Text of the Film}

The Cahiers critics thus define the ideological project of Young Mr. Lincoln as a "reformulation of the historical figure of Lincoln on the level of the mythical and the eternal." They reiterate, however, the complex nature of the network of ideological énoncés in the film, viewing it as a site for the mutual interference of "philosophical assumptions (idealism, theologism), political determinations (republicanism, capitalism), and, in its relative autonomy, the aesthetic process (figures, filmic signifiers, narrative mode) specific to Ford's writing." Paradoxically, giving an account of this intricate

capitalist grouping of the 1930s. To complicate matters even further, the Democrats under Roosevelt consisted of an "unholy alliance" of northern liberals and racist white southerners, who had transformed the former confederate areas into one-party states based on the disenfranchisement of blacks.

37 "Already," that is, in the sense of Lincoln's biography, not the chronological order of the films in question. Lincoln's fondness for "Dixie" was not fictional, but the idea that he played the song as a young man is an anachronism: "Dixie" was not composed until the 1850 , two decades after the time Young Mr. Lincoln was set.

38 “Young Mr. Lincoln de John Ford," p. 32 [p. 13]. 
web of signification requires, in Cahiers' view, a linear account of the film. This is motivated not so much by the strictly chronological narrative of the film itself as it is by methodological necessity: an alternative method, reading each code in the film simultaneously in all the scenes in which it is present, would have the shortcoming of "turning the film into a text which is readable a priori"; a sequential approach, by contrast, has the advantage of "making the reading itself participate in the film's becoming-a-text, and of authorizing such a reading only by what authorizes it in each successive moment of the film." The Cahiers writers nonetheless understand the critical work undertaken to consist of "breaking down [briser] the closures of the individual scenes by setting them in action with each other and in each other." ${ }^{39}$ Sections 8-23 of the text thus give what is virtually a sequenceby-sequence dissection of the film, one which ends up resembling a kind of Marxo-Freudian explication de texte. Three key episodes in the film (and the article) warrant particularly detailed attention here: the electoral speech given by Lincoln at the beginning of the film (9); a central sequence involving, in succession, the murder of Scrub White, the attempted lynching of the Clay brothers, and the ball given by Mary Todd (15-17); and, finally, the long courtroom scene that concludes Young Mr. Lincoln (20-23).

The scene of Lincoln's election stump speech is, in spite of its brevity, decisive in establishing the "future anterior" tense in which Young Mr. Lincoln plays out, in which the "present" of the film's diegesis_Lincoln's youth - is read from the "future" of the viewer's assumed familiarity with his later political life. For Cahiers, this narrative temporality produces a "retroactive action of the spectator's knowledge of the myth on the chronicle of events" depicted in the film..$^{40}$ In the opening scene, Henry Fonda's Lincoln is shown in shirtsleeves and suspenders, addressing a small crowd of rural residents from a wooden porch. Although Lincoln would gain celebrity for his 1858 series of three-hour senatorial debates with Stephen Douglas (also a character in the film), his oration here is brief and opens with the laconic line: "You all know me, I'm plain Abe Lincoln." The Cahiers critics recognize

39 For all the quotes in this paragraph, see ibid. [p. 13-14].

40 Ibid, p. 33 [p. 15]. Lacan's notion of the "future anterior," based on Freud's concept of Nachträglichkeit, was defined by the French psychoanalyst as follows: "What is realized in my history is not the past definite of what was, since it is no more, or even the present perfect of what has been in what I am, but the future anterior of what I shall have been for what I am in the process of becoming." Jacques Lacan, "Fonction et champ de la parole et du langage en psychanalyse," in idem., Écrits vol. I (Paris: Seuil, 1966), pp. 237-322, here p. 30o. Translated as "The Function and Field of Speech and Language in Psychoanalysis," in idem., Écrits, pp. 197-268, here p. 247 . 
that this statement "addresses not only the spectators in the film, who are anyway absent from the screen [champ], but also, through a suture, the spectator of the film, who is brought into the filmic space."41

Lincoln's political platform is equally succinct: favoring the introduction of protectionist tariffs and the establishment of a national bank. Cahiers asserts that the stump speech has a twofold, contradictory function: although Lincoln was running for the Whig party, his platform aligns him, in the eyes of the film's 1939 audience, with the contemporary Republican platform; at the same time, however, his mode of address marks him out as "the opposition and remedy to such 'politics." Moreover, Cahiers notes that the speech is the only moment in the film in which Lincoln is ascribed with a "positive relation" to politics (in the sense that he espouses a concrete set of policies associated with a political party). It is notable, too, that his electoral fate is a question that Ford leaves suspended - his loss at the ballot box is not shown but is to be inferred by the audience from his subsequent turn to the legal profession. From this point on, the character of Lincoln will be anchored in a form of "divine morality" that elevates him above the field of partisan politics. As Cahiers insists, however, this repression of the political is itself a "direct result of political presuppositions," namely, the ideological notion of American capitalism's foundation in a moral, divine order. As a corollary, it also allows the film to efface the question of slavery: a "not-said" that, in line with Althusser's notion of structuring absences, Cahiers sees as having tremendous significance for the film. In expunging Lincoln's signal political stance (or "castrating" him of his historico-political dimension, in Cahiers' psychoanalytically inflected terminology), the film is placed on a "purely ideological plane" and thereby participates in the transformation of the historical figure of Lincoln into a myth, an ahistorical "symbolic value. ${ }^{.42}$

When it comes to the murder scene (15), politics, along with the character of Lincoln himself, is pushed into the background - in fact, it is crucial to the film that this episode is a "new fiction from which Lincoln is absent"

41 Ibid. [p. 16] The Lackner/Matias translation is particularly loose at this point in the text and elides the word "suture" from this passage entirely. For more on the notion of suture, as developed by Jean-Pierre Oudart, see Chapter 22. Conley has observed that Cahiers' reliance on the French version of Lincoln's phrase ("Vous me connaissez tous: je suis tout simplement Abraham Lincoln") led the journal to overlook the subtle wordplay involved in the original dialogue: the film shows the future president declaring himself to the on-screen spectators to be "plain Abe Lincoln" as well as, through a homophonic pun, Henry Fonda avowing to the audience that he is "playin' Abe Lincoln." See Tom Conley, “Comolli Again," paper at 2011 Society of Cinema and Media Studies conference, New Orleans.

42 The quotes in this paragraph are from ibid., pp. 33-34 [pp. 16-19]. 
and that, at this stage, he should possess "no knowledge of it." In giving a description of this scene, Cahiers nonetheless acknowledges that it is, strictly speaking, indescribable: the scene is constructed on the basis of a "lure-system" (système de leurre or système leurrant) that occludes its content. The sequence's mise en scène, its editing structure, what it shows to the viewer and what it conceals, is precisely calibrated in order to substitute the "real" question — "who is the killer?" — with a lure-question: "which of the two brothers is the killer?", thereby excluding the possibility that Cass is the murderer. In fact, Cass' entry into the scene deliberately takes place in a "break" in the spectator's attention and appears to be motivated by the "classic typology" of "dying-in-one's-best-friend's-arms." Ford's cinematic ingenuity, however, allows him to show Cass as the murderer-he is depicted in a close-up, holding the bloodied knife with a look of terror on his face-in a shot which "independently of this drama [...] is classically a shot of the guilty." And yet, as spectators, we are at this point in the narrative unable to effectively read this shot for what it is; we only retrospectively recognize its content once Cass' guilty status is confirmed at the film's end. Cass' guilt had therefore already been shown in the film but was "rendered non-legible" by Ford's cinematic écriture. ${ }^{43}$

The lynch scene that immediately follows (16) is, in many regards, the centerpiece of the film. Cahiers notes that there was a contemporary political resonance to this episode: the 1920 s and 1930 s were marked by a resurgence of lynching and other forms of vigilante justice (attributable to a resurgent Ku Klux Klan), and this phenomenon had already been registered in films of the period such as They Won't Forget by Mervyn LeRoy, Black Legion by Archie Mayo, and, most notably, Fury by Fritz Lang, whose lynch sequence can almost be seen as a model for Ford's own mise en scène. Unmentioned by Cahiers, however, is Ford's broader thematic preoccupation with the frontiers between civilization and barbarism. If, in his other films, this fault line is racially coded (Europeans/Indians in his Westerns, Europeans/Asians in Seven Women), here it is within White America itself that the boundary line is drawn: the $1830 \mathrm{~s}$ Illinois of Young Mr. Lincoln is a mostly rural, sparsely populated frontier-land whose inhabitants, when fueled by alcohol and a lust for vengeance, are quick to abandon the niceties of legal process and give themselves over to mob violence. ${ }^{44}$ It is Lincoln, here, who represents the "figure of the Law" by

43 The quotes in this paragraph are from ibid., pp. 38-39 [pp. 26-27]. Emphasis in the original.

44 The trial scenes, too, are marked by an unstable hegemony of bourgeois law: the courtroom frequently bursts into rapturous laughter or tumultuous chaos, wildly departing from the orthodoxies of juridical process. 
enforcing the prohibition of extra-judicial violence. Ironically, in addition to cajoling the rabble, joking with them, and evoking religious doctrine, he also achieves this through threatening his own violent deeds. The "castrating power" wielded by Lincoln (already signaled in the "empty, icy, terrifying stare" he had given to two squabbling farmers in an earlier scene) has the effect of "exceeding, deviating the ideological discourse" of the film and is here graphically demonstrated by a shot of the mob's makeshift battering ram drooping in flaccid discouragement as the pacified crowd disperses. ${ }^{45}$

The final section of the film is consumed by the courtroom sequence, discussed at length by Cahiers (20-23). The journal sees the trial as a "classical figure of Hollywood cinema" that both represents "the mise en scène of American legalist ideology" and constitutes a "reduced model of the social totality." ${ }^{\prime 6}$ In depicting Lincoln as unwilling to choose between the two brothers accused of the murder of Scrub White, Ford provides an allegory for Lincoln's mythical—and historically contestable—status as a unifier of North and South. ${ }^{47}$ Moreover, in his aggressive, "castrating" crossexamination of Cass, Ford shows Lincoln to have a power of premonition that inscribes him in a relationship not with verifiable knowledge but with a metaphysical Truth rooted in divine law rather than legal code. It is on the second day of the trial, however, that the "miraculous dimension of Lincoln's revelation of the Truth ${ }^{\prime 28}$ comes about after a chance consultation of his almanac leads him to disprove Cass' story of having seen the crime committed in the "moon-bright" night. The almanac had lurked throughout the film as a kind of Chekhovian gun, or, in Cahiers' semiological parlance, a "signifier without a signified"; its importance for his biographical destiny having long gone unheeded by Lincoln. The future president's discovery of this text is presented as a fortuitous event in the film, giving rise to several possible readings: it either demonstrates Lincoln's omnipotence (he magically has access to the right information when it is needed) or his

45 Ibid., p. 37 [p. 24]. In the following scene, this process is inverted: from actively wielding "castrating power," Lincoln's emasculation in this scene sees him submit to his own castration. Referring to Lacan's "La signification du phallus," the Young Mr. Lincoln article thus declares that "Lincoln does not have a phallus, he is the phallus." See ibid., p. 42; and Jacques Lacan, "La signification du phallus," in idem., Écrits vol. II, pp. 685-695. Translated as "The Signification of the Phallus," in idem., Écrits, trans. and ed Bruce Fink, pp. 575-584.

46 Ibid., p. 43 [p. 32].

47 Peter Wollen stresses this point more forcefully than Cahiers in his afterword to the translated version of the Young Mr. Lincoln article in Screen. Peter Wollen, "Afterword," Screen vol. 13 no. 3 (Autumn 1972), pp. 44-47. Such a vision of Lincoln as unifier had a long lineage in Hollywood, beginning at the latest with Griffith's Birth of a Nation.

48 “Young Mr. Lincoln de John Ford," p. 43 [p. 34]. 
impotence, in the sense that he is dependent on the "power of the signifier" and remains in a position of "radical misrecognition" with respect to the book. Alternatively, it can be interpreted as a "pure fictional coup de force implying an imposition of Ford's writing on the figure of Lincoln." The Cahiers writers give greater credence to the latter two readings, which would make manifest "a distortion of the ideological project by the writing of the film." ${ }^{49}$ Moreover, while the hectoring tone with which Lincoln forces a confession out of Cass is the culminating instance of his castrating power, its violent nature also detracts from what would have otherwise been a straightforwardly edifying, hagiographic scene. Indeed, it is at Lincoln's very moment of triumph-in the closing sequence, he is shown walking off-screen before Ford cuts to a shot of the Lincoln Monument in Washington DC - that he becomes, for Cahiers, "an intolerable figure" whose "excessive, monstrous dimension" is highlighted by the "violences of Ford's writing." $5^{\circ}$

\section{"Young Mr. Lincoln de John Ford": Theorizing Collectively}

"Young Mr. Lincoln de John Ford" closes with an exergue titled "La violence et la Loi,"51 which, in contrast to the rest of the article, is attributed to Jean-Pierre Oudart alone. This section (25) resumes the discussion in section 11 on "La Nature, la Loi, la Femme," which focused on Lincoln's encounter with Ann Rutledge. Whereas the rest of the text had mingled the interpretative strategies of Althusser, Barthes and Lacan, Oudart's section is written in a more purely psychoanalytic register and focuses on the position of the Mother in Young Mr. Lincoln. Lincoln's own mother is only represented in the film through an absence: namely, the poem during the opening credits consisting of the questions she would ask her son "if she returned to the Earth." For Oudart, the Mother in Ford's fiction incarnates "the figure of the ideal Law," and when she is also a widow-as is the case with Mrs. Clay, who functions as something of surrogate mother for Lincoln in the film - she plays the role of guardian of "the Law of the dead Father." ${ }^{22}$ Young Mr. Lincoln, however, is distinguished by the fact

49 Ibid., p. 44 [pp. 36-37].

50 Ibid., p. 45 [p. 39].

$5^{1}$ This conclusion was, it would appear, written before the rest of the article. The Cahiers writers declare that it is a text "which will follow our work and which served as a point of departure for it." Ibid., p. 46 [p. 39].

52 Ibid., p. 46 [p. 36]. The implied reference here is to Lacan's notion of the Nom-du-Père, originally articulated in his interrupted 1963 seminar. See Jacques Lacan, Des Noms-du-Père 
that the character of Lincoln "literally takes the place of the Mother, that is, he takes on simultaneously her ideal position and her function (since he assumes responsibility for [Mrs. Clay's] children and promises to feed them well in the new home which the prison becomes)." ${ }^{33}$ This "curious transformation" in the Lincoln figure is only one instance of what Oudart sees as the film's "scriptural perversion," which is brought about by the fact that, "paradoxically, in a film meant to be the Apology of the Word, the last word is always given to the iconic signifier." It is Ford's stubborn will to "always make sense, to not leave any area free to any effect of implicit meaning" that leads him to stylistically undermine and parody the film's ideological project: instead of a straightforward glorification of Lincoln, we find a "properly scriptural projection [mise en relief] [...] of the effects of the repression of violence," which results in a subversion of the "deceptively calm surface of the text." 54

Whereas this conclusion is ascribed to Jean-Pierre Oudart on an individual basis and more closely adheres to that critic's interest in a Lacanian approach to film theory, the rest of the article is unabashedly presented as a "collective text." In this sense, too, "Young Mr. Lincoln de John Ford" is a landmark. Collaborative efforts had, of course, long been practiced at Cahiers, and with the journal's politicization in the years 1968-1970, this tendency had only intensified: Comolli and Narboni, of course, co-wrote their "Cinéma/ idéologie/critique" texts, while the March 1970 overview of Renoir's La vie est à nous was a joint effort by Bonitzer, Comolli, Daney, Narboni and Oudart. But the Young Mr. Lincoln article was the first time that a text was considered as the collective endeavor of the entire editorial committee - a practice that would become increasingly common in Cahiers in the ensuing period. ${ }^{55}$

How could a single text be prepared by up to ten writers working conjointly with one another? We might suspect that the article's composition was not quite as collective as it is purported to be. And yet, while Bonitzer judges Narboni to have been the "dominant mind" in analyzing Young Mr.

(Paris: Seuil, 2005).

53 Ibid., p. 47 [p. 41].

54 Ibid. [pp. 43-44].

55 It is probable that all of the figures under consideration here had at least some involvement in the article's composition. Pierre Baudry had only started contributing to Cahiers at the beginning of 1970, so he may or may not have participated in writing the article. Michel Delahaye was still officially part of the editorial team at the time of "Young Mr. Lincoln de John Ford" and had previously written on Ford for Cahiers, but his theoretical/political perspectives were so remote from the rest of the journal's writers that it is unlikely he played any role in formulating this text, and he was removed from the editorial board of Cahiers a couple of months afterwards. 
Lincoln $5^{6}$ there is widespread consensus among the Cahiers critics that it was a truly communal effort. Narboni himself views the text as "the purest example" of a collective critical undertaking at the journal, even going as far as to say, "at the time Young Mr. Lincoln was written, I think that there was a moment of grace. ${ }^{\prime 57}$ Aumont has expressed a similar sentiment, saying of the text's preparation, "I have very fond memories of it, because this absolutely improbable mode of working was very pleasant, it was very nice. [...] Young Mr. Lincoln was the moment where we were the most united, it was the moment when we all breathed together. ${ }^{n}{ }^{8}$ Comparing the harmony of the group to that of a monastic order, Aumont considers that:

It was really a matter of a singular thought [pensée unique]. I am completely incapable of saying which phrase came from which one of us. We really wrote it together. We were all seated around a table, somebody suggested a phrase, somebody else said, "No, how about this?" And by the end we had no idea who had written the phrase. It was really the only time I have ever experienced that. 59

De Baecque notes that during the writing of the article, it was Comolli who was "at the typewriter, and typed the phrases that the critics proposed and discussed. ${ }^{\prime 60}$ Comolli himself has retrospectively understood the text as a key moment in his lifelong dedication to developing various modes of collective theoretical and artistic creation, which had its origins, in his view, in the broader intellectual culture prevailing at Cahiers:

I am very happy with this work. Moreover, it was a collective effort. It was therefore something which was not practiced but which was desired, both for the very poor reason of doing away with the personal signature, of overcoming the question of the signature, which was terribly naïve, but also because we believed - and I still believe-in the collective intellectual. I still believe in it because ideas are developed in discussion, in the confrontation that comes with collective work. This text was based on putting these ideas into practice, on asking: can we work as a group? We can! And we did it all the time, because Cahiers in this whole period,

56 Interview with Pascal Bonitzer, April 30, 2014.

57 Interview with Jean Narboni, March 18, 2014.

58 Interview with Jacques Aumont, March 11, 2014.

59 Ibid.

60 De Baecque, Histoire d'une revue vol. II, p. 218. 
and even before 1968, was based on people seeing each other every day, seeing the same films and talking about them. There was something like a circulation of reflection, whoever said something knew that they were being listened to. Everything was listened to and forged anew in this collective. ${ }^{61}$

Cahiers' analysis of Young Mr. Lincoln, then, is an exceedingly rare object in the history not only of film criticism but of Western thought more generally. It was a truly communal undertaking, whose composition resembled, if anything, an improvised jazz session. Although there are no recordings of the editorial discussions that formed the basis of the article, something of their tenor can be seen in Eisenschitz's 1969 documentary Les Cahiers face au film: Une partie de campagne. ${ }^{62}$ In this precious audiovisual artifact, Comolli, Narboni, Oudart, Pierre, Aumont, Bonitzer and Daney are seated in the former cinémathèque auditorium in the rue d'Ulm for a group discussion of Jean Renoir's Une partie de campagne. The critics propose their responses to the film, riff on each other's ideas, finish each other's thoughts, and question and critique each other, but all the while a singular train of thinking is apparent. One can imagine that a similar dialogic process was at work in developing "Young Mr. Lincoln de John Ford." And yet, Cahiers found it difficult to reproduce this nearly utopian experience of joint intellectual labor: later articles with group authorship tended to either fall more heavily on the shoulders of one or more individual writers working in a more isolated manner (the reading of Sternberg's Morocco, for instance, which was more conspicuously drawn from an initiative of Oudart's) or were the product of the tumultuous politics of the Maoist period, when the journal was often divided against itself and prone to schisms.

\section{Resonances of "Young Mr. Lincoln de John Ford" in Film Theory}

Cahiers did strive to recreate the formula of its Young Mr. Lincoln analysis in further re-readings of classical Hollywood films such as Morocco, Sylvia Scarlett and Intolerance. The degree to which these articles achieved the same theoretical acuity as their progenitor varied, but the Ford text has had a striking impact on the history of film theory in two other ways. Firstly, having been widely anthologized and critically discussed, it has become

61 Comolli, "Yes, we were utopians, (Part I)."

62 The film is now available as an extra on the 2005 Studio Canal DVD of Une partie de campagne. 
a canonical text in the field of film studies and, beginning in the 1970s, a template for a large number of critical re-readings of classical Hollywood films. Secondly, and more confidentially, it constitutes a stepping stone between the earlier articles on Ford and later texts on the director by the Cahiers critics-a preoccupation with the filmmaker that continues to the present with Sylvie Pierre's 2014 monograph on Seven Women.

The renown of "Young Mr. Lincoln de John Ford" in the English-speaking world originates in its appearance, in a translation by Helen Lacker and Diana Matias, in the Autumn 1972 issue of Screen. Appended to the Cahiers text was an "Afterword" by Peter Wollen, which was the first of a large number of articles appearing in the 1970s that discussed, developed and critiqued Cahiers' analysis of the film. Wollen, who had discussed Ford's œuvre at length in his 1969 monograph Signs and Meaning, focuses on two areas in which he feels the original text requires clarification. The first is the political context of the Civil War, which Wollen sees as "present, but in disguised form, implicit rather than explicit." Lincoln is presented by Ford as "the bringer of unity rather than division," but this is carried out through metaphoric means (the pie-judging, the quarreling farmers, the defense of the Clay brothers). Although his rhetorical jousting in the adversarial arena of the courtroom may seem to run contrary to this position, Wollen stresses that Lincoln "is not presented as a lawyer in the usual sense at all"-importantly, he establishes the truth of the crime "not by the adjudication of the jury [...] but by the confession of the true murderer." ${ }^{n 3}$ This not only emphasizes Lincoln's "gift as a seer," it also champions a vision of natural justice that is at odds with both the mob rule of the lynch scene and the "artificial, elitist mumbo-jumbo of the courts"; hence, the film represents the ideology of "classical petit-bourgeois populism" based on the "independent rural yeomanry of homesteaders." Secondly, Wollen focuses on the figure of Lincoln's Mother. Noting that many of Ford's films are "constructed around the drama of a family threatened with dissolution" and only held together by the efforts of the mother, the English critic nonetheless argues that the character of "Ann Rutledge should be distinguished from Lincoln's mother more than is done in the Cahiers article." ${ }^{64}$

Ben Brewster followed Wollen with an article on Young Mr. Lincoln published in Screen one year later, but his attempt to shoehorn Metz's semiology into the Cahiers text is jarring. Moreover, his twin criticisms of the original article - that its attribution of a "future anterior" structure to the film 
dubiously separates the character of Lincoln from the historical role he played, and that the Cahiers writers "posit a highly specific aim on the part of the producers of the film which is unsubstantiated" - are both already refuted in the Young Mr. Lincoln analysis itself. ${ }^{65}$ Cahiers finds a defense from Brewster's strictures in Henderson's "Critique of Cine-Structuralism," but the latter critic, in expressing his opposition to an ostensible "empiricist" tendency in structuralist film analysis, unjustly rejects one of the positive contributions made by Brewster, who discusses the film in relation to "the ideology of the Hayes-Tilden compromise," which is, in fact, a useful piece of political contextualization that was skirted over by Cahiers. ${ }^{66}$

In the mid-197os, a flurry of texts discussing Young Mr. Lincoln (both the film and the Cahiers article) included pieces by Bill Nichols - who, although writing from a similar theoretical and political perspective as the Cahiers writers, nonetheless denigrates their article as a "flattened analysis" resting on "the incredible weakness and superficiality of their analysis of the film's historical context" - and Richard Abel, who, in a more affirmative appraisal of Cahiers' efforts, discusses the film's paradigmatic features as a complement to the French journal's purported focus on its "syntagmatic" structures, focusing in particular on the stylistic "pairing" of the electoral address with Lincoln's speech calming the lynch mob, among other scenic couplings. ${ }^{67}$ The most sophisticated response to the Cahiers text, however, came from Nick Browne, who both provided a corrective to Brewster by emphasizing the journal's cautions against "exaggerating the film's political determinism" and stressed the role played by Althusser's notion of complex structural causality in their analysis, ${ }^{68}$ while at the same time pinpointing a "stubborn illogicality" in the text: it is based on a "self-validating hermeneutic system" that justifies its interpretation through the very act of translating the film's terms into "an entire psychoanalytic

65 Ben Brewster, "Notes on the Text 'John Ford's Young Mr. Lincoln' by the Editors of Cahiers du Cinéma," p. 38.

66 See ibid., p. 40; and Brian Henderson, "Critique of Cine-Structuralism (II)," Film Quarterly vol. 27 no. 2 (Winter 1973-1974), pp. 37-46, here p. 44. The Hayes-Tilden compromise was an agreement between Democrats and moderate Republicans after the disputed election of 1876 , which put an end to the Reconstruction period and Radical Republican rule. Moderate Republican Hayes became president, but Southern Democrats were given the leeway to establish Jim Crow laws disenfranchising black citizens, which were not overturned until the $1960 \mathrm{~s}$.

67 See Bill Nichols, "Style, Grammar and the Movies," Film Quarterly vol. 28 no. 3 (Spring 1975), pp. 33-49, here p. 42; and Richard Abel, "Paradigmatic Structures in Young Mr. Lincoln," Wide Angle vol. 2 no. 4 (August 1976), pp. 20-26.

68 Nick Browne, "Cahiers du cinéma's Rereading of Hollywood Cinema: An Analysis of Method," Quarterly Review of Film Studies, vol. 3 no. 3 (1978), pp. 405-416, here p. 406. 
meta-language drawn from the Lacanian system (Law, repression, etc.)." ${ }^{69}$ Browne's focus on the Lacanian side of the Young Mr. Lincoln text is, however, indicative of a broader prejudice within anglophone responses to it: these have overwhelmingly treated the article as an unalloyed psychoanalytic reading of Ford's film, mentioning Althusser's influence only cursorily by comparison. More astonishing still, the influence of Barthes on the "Young Mr. Lincoln de John Ford" is largely neglected in these pieces despite the clear parallels with $S / Z$ and his evident importance for Cahiers at the time-an omission that suggests the text was being used as a battering ram to fight theoretical battles within the Anglo-American academy more than it was being examined in its own right. ${ }^{70}$

It is also notable that, in 1978 already (that is, merely eight years after its original publication), Browne spoke of the need to retrospectively "re-read" the Young Mr. Lincoln article, as if it was an object from a long-lost era. Indeed, his discussion is the last article devoted primarily to Cahiers' analysis of the film: from this point on, it is frequently reprinted in anthologies and glossed in film studies textbooks but rarely discussed in any profound manner. The text nonetheless continues to be of crucial importance to the field, albeit in more diffuse, inconspicuous ways than it was during the tempestuous debates of the 1970s. Alongside Metz's study of Adieu Philippine and Bellour's close analysis of the Bodega Bay sequence from The Birds ${ }^{71}$ Cahiers' re-reading of Young Mr. Lincoln inspired numerous analogous efforts, including, most notably, Heath's interpretation of Touch of Evil, and Browne's rhetorical analysis of a central scene from another Ford film, Stagecoach. ${ }^{2}$ It is true, as Dudley Andrew argued, that the Young Mr. Lincoln text may not have constituted a "privileged vantage point" on

69 Ibid., p. 411.

70 The editorial board at Screen was notably divided over the question of the value of psychoanalysis for film theory, with several of its members resigning over the question in 1976. See Ben Brewster, "Editorial," Screen vol. 17 no. 2 (Summer 1976), pp. 5-7, and associated texts published in the same issue. Exceptionally, the importance of $S / Z$ for Cahiers' Young Mr. Lincoln was later recognized by John Ellis in his introduction to Screen Reader: Cinema/Ideology/Politics vol. 1 (London: SEFT, 1977), pp. v-xii, here p. xi.

71 See Christian Metz, Essais sur la signification au cinéma (Paris: Klincksieck, 2013 [1968]), pp. 145-168. Translated as Film Language: A Semiotics of the Cinema, trans. Michael Taylor (Oxford: Oxford University Press, 1974), pp. 149-176; and Raymond Bellour, "Les Oiseaux: analyse d'une séquence," Cahiers du cinéma no. 216 (October 1969), pp. 24-38. Translated as The Birds: Analysis of a Sequence, trans. Ben Brewster, Camera Obscura no. 3-4 (Summer 1979), pp. 105-134.

72 See Stephen Heath, "Film and System: Terms of Analysis," Screen vol. 16 no. 1 (Spring 1975), pp. 7-77, and Screen vol. 16, no. 2 (Summer 1975), pp. 91-113; and Nick Browne, "The Spectator-inthe-Text: The Rhetoric of Stagecoach," Film Quarterly vol. 29 no. 2 (Winter 1975-76), pp. $26-38$. 
Ford's film from which "the conditions under which any interpretation is possible" could be discerned and critically analyzed. ${ }^{73}$ But, in arguing for a critical re-reading of Hollywood films that stressed the décalage between the intended ideological project and what is actually produced by its inscription in the film's writing process, Cahiers nonetheless contributed to a qualitative leap forward in the nature of film interpretation, one whose impact can still be felt today: as recently as 2013, the release of Spielberg's Lincoln prompted Jump Cut to run a dossier on the figure of Lincoln in the cinema, which included a text by Chuck Kleinhans offering a reconsideration of Cahiers' analysis of the Ford film. ${ }^{74}$

We therefore come to the alternative lineage for which the Young Mr. Lincoln article is important: namely, the continued interest, up to the present day, that the Cahiers writers have shown in the œuvre of John Ford. Ford has been one of the major auteurs of choice for the critics involved in formulating the analysis of Young Mr. Lincoln, although none-perhaps through a sense of hermeneutic saturation-have dedicated a subsequent text to his 1939 film. Daney, for instance, returned to Seven Women with his contribution to a Cahiers special issue on Ford, discussing the relationship between theater and cinema in the director's work and comparing depth of field in Ford to that of Wyler. In Daney's view, Ford's deep-focus shots are not "the site of ambiguity" but rather, as with Buñuel, "a curvature of space such that the repressed - and it alone - can return without warning, in sped up fashion."75 Comolli, meanwhile, would turn his eye to The Grapes of Wrath, retrieving concepts earlier developed by Cahiers such as the lure and spectatorial disavowal in order to analyze the "circulation of gazes" governing a scene in the film that shows Mae underselling candy to $\mathrm{Pa}$ Joad, which integrates the spectator into Ford's "narrative dispositive." For Comolli, the mise en scène in this sequence renders the spectator "a bit too much of a spectator to not be implicated as anything but a spectator." ${ }^{76}$

Comolli's article was part of a dossier in the journal Trafic titled "Politique(s) de John Ford," edited by Sylvie Pierre, and she too contributed

73 Andrew, Concepts in Film Theory, p. 129.

74 Chuck Kleinhans, "Young Mr. Lincoln and Ideological Analysis: A Reconsideration (with many asides)," Jump Cut no. 55 (Fall 2013), https://www.ejumpcut.org/archive/jc55.2013/KleinhansCahiersInContext/text. html (accessed January 1, 2021).

75 Serge Daney, "Le Théâtre des entrées," Cahiers du cinéma hors série, "John Ford" (1990), pp. 62-64. The special issue was edited by Patrice Rollet (later an editor for Trafic) and Nicolas Saada. By 1990, none of the critics discussed in this book were still principally associated with Cahiers, but articles by some of them still appeared on an irregular basis.

${ }_{76}$ Jean-Louis Comolli, "Les raisons de la colère," Trafic no. 56 (Winter 2005), pp. 91-98, here p. 98. 
an article detailing the figure of the "good faith hypocrite" in Ford's films, an oxymoron that, for Pierre, is appropriate given the "obscure clarity" of the director's mise en scène. While examples of insincerity can be found with respect to alcoholism, sexuality and sanctimony in Ford's œuvre, Pierre focuses in particular on the analogous hypocrisies of Agatha Andrews in Seven Women and Colonel Thursday in Fort Apache, who "play the same bad role as that of the Pharisee in the New Testament: he who, following the fine definition given by Alain, 'is a man who believes in God, and who believes that God is happy with him." ${ }^{77}$ For Pierre, the beauty of these characters is "the force, the scriptural power, the figural exploit represented by their incarnation on the screen by immense actors: they are the very idea of the monsters that they represent transfigured into cinematic flesh. ${ }^{\prime 7} 8$

Pierre is without doubt the most voluble of Cahiers" "Fordians": her Trafic article was the third that the critic had dedicated to the director, following earlier texts on The Iron Horse and on gender relations across a wide range of Ford's work. ${ }^{79}$ In 2014, meanwhile, she crowned this scrutiny of Ford's œuvre with a monograph on Seven Women. If Cahiers had distanced themselves from an auteurist perspective in the Young Mr. Lincoln text, considering Ford more as a "network of signifiers" (the sum total of his films) than as a source of artistic expression, Pierre seems to revel in auteurism, boldly stating on the first page, "What I like about John Ford is John Ford, the substance of the œuvre rather than the accident of the films." ${ }^{80}$ This view is tempered, however, by political considerations: Ford the individual, Pierre admits, was engaged in right-wing activities towards the end of his life. And yet the critic is adamant that the point of view of Ford's films is not at all reactionary, especially when it comes to his depiction of women, and she insists that "we must not confuse, with John Ford or any artist, the positions of the man with the ethic of his works." ${ }^{81}$ Drawing from a mode of film analysis honed at Cahiers, Pierre crafts a sensitive, insightful discussion of Ford's last film, which attempts to discern a putative "Ford touch" that would be "even subtler and less definable than that of Lubitsch. ${ }^{82}$ Arguing that Ford's cinema is marked by his "profound

79 See Sylvie Pierre, "L'Indien, le chien et le cheval de fer," Vertigo no. 19 (October 1999), pp. 27-31; and Sylvie Pierre, "Les hommes et les femmes chez John Ford," in Jacques Aumont (ed.), $L a$ différence de sexes est-elle visible? (Paris: Cinémathèque française, 2000), pp. 217-240.

80 Sylvie Pierre, Frontière chinoise (Crisnée: Yellow Now, 2014), p. 7.

81 Ibid., p. 9 .

82 Ibid., p. 11. 
respect for human life, even in times of war," ${ }^{183}$ Pierre finds this quality ironically exemplified in the murder-suicide that concludes Seven Women, with Anne Bancroft's Dr. Cartwright choosing to poison herself and the "barbarian" Tunga Khan rather than submit to his desires. Comparing the visual style of this scene to Rembrandt's portraiture, Pierre describes the final seconds of Ford's last film in affecting terms: "The poor, oafish barbarian collapses into the off-screen space to the bottom-right of the frame, and Cartwright, herself savage, tosses her poisoned chalice aside, like a Cossack after drinking. We do not see her fall, but darkness seizes her and it is the end." ${ }^{84}$

Seven Women was a wretched failure with the public and was scorned by the vast majority of reviewers; thanks largely to the efforts of the $1960 \mathrm{~s}$ generation of writers for Cahiers, however, it and many other Ford films have been rescued from critical oblivion in the intervening years, and, at least in France, his work has gained an undisputed place in the cinematic pantheon. Even many critics who were originally lukewarm towards Ford, such as Jean Douchet, are now strident advocates of his cinema. If the Young Mr. Lincoln article has had a seminal impact on the nature of film analysis, then the resuscitation of Ford's critical fortunes from the nadir he had reached in the mid-196os should be considered no less important a legacy of the Cahiers critics' defense of his work.

\section{Works Cited}

Richard Abel, "Paradigmatic Structures in Young Mr. Lincoln," Wide Angle vol. 2 no. 4 (August 1976), pp. 20-26.

Louis Althusser, Politics and History: Montesquieu, Rousseau, Marx, trans. and ed. Ben Brewster (London: Verso, 2007 [1972]).

—, Étienne Balibar, Roger Establet, Pierre Macherey and Jacques Rancière, Lire le Capital (Paris: Maspero, 1965). Translated in abridged form as Reading Capital, trans. Ben Brewster (London: Verso, 2009 [1970]).

Dudley Andrew, Concepts in Film Theory (Oxford: Oxford University Press, 1984). Roland Barthes, $S / Z$ (Paris: Seuil, 1970). Translated as $S / Z$, trans. Richard Miller (New York: Hill and Wang, 1974).

André Bazin, "L'Évolution du langage cinématographique," in idem., Qu'est-ce que le cinéma? vol. I: Ontologie et langage (Paris: Éditions du Cerf, 1958), pp. 131-148. 
Translated as “The Evolution of Film Language," in André Bazin, What is Cinema?, trans. and ed. Timothy Barnard (Montreal: Caboose, 2009), pp. 87-107.

—, "Évolution du western," in idem., Qu'est-ce que le cinéma? vol III: Cinéma et sociologie (Paris: Éditions du Cerf, 1961), pp. 146-156. Translated as "The Evolution of the Western," in idem., What is Cinema? vol. II, trans. and ed. Hugh Gray (Berkeley: University of California Press, 2004), pp. 149-157.

Raymond Bellour, "Les Oiseaux: analyse d'une séquence," Cahiers du cinéma no. 216 (October 1969), pp. 24-38. Translated as The Birds: Analysis of a Sequence, trans. Ben Brewster, Camera Obscura no. 3-4 (Summer 1979), pp. 105-134.

Walter Benjamin, "The Author as Producer," in idem., Reflections, trans. Edmund Jephcott, ed. Peter Demetz (New York: Schocken, 1978), pp. 220-238.

Ben Brewster, "Notes on the Text 'John Ford's Young Mr. Lincoln' by the Editors of Cahiers du Cinéma," Screen vol. 14 no. 3 (Autumn 1973), pp. 29-43.

—, "Editorial," Screen vol. 17 no. 2 (Summer 1976), pp. 5-7.

Nick Browne, "The Spectator-in-the-Text: The Rhetoric of Stagecoach," Film Quarterly vol. 29 no. 2 (Winter 1975-76), pp. 26-38.

-, "Cahiers du cinéma's Rereading of Hollywood Cinema: An Analysis of Method," Quarterly Review of Film Studies, vol. 3 no. 3 (1978), pp. 405-416.

Jean-Louis Comolli, “Signes de piste (Les Cheyennes)," Cahiers du cinéma no. 164 (March 1965), pp. 75-76. Translated as "Signposts on the Trail," in John Caughie (ed.), Theories of Authorship: A Reader (London: Routledge, 1981), pp. 109-116.

—, "Dé-composition (Frontière chinoise)," Cahiers du cinéma no. 182 (September 1966), pp. 16-20.

—, "Ford et les autres," Cahiers du cinéma no. 183 (October 1966), p. 55.

—, "Les raisons de la colère," Trafic no. 56 (Winter 2005), pp. 91-98.

—, interviewed by Daniel Fairfax, "Yes, we were utopians; in a way, I still am...': An Interview with Jean-Louis Comolli (Part 1)," Senses of Cinema no. 62 (April 2012), sensesofcinema.com/2012/feature-articles/yes-we-were-utopians-in-a-way-istill-am-an-interview-with-jean-louis-comolli-part-1/ (accessed January 1, 2021).

— and Jean Narboni, "Cinéma/idéologie/critique," Cahiers du cinéma no. 216 (October 1969), pp. 11-15. Translated as "Cinema/Ideology/Criticism," trans. Daniel Fairfax, in Jean-Louis Comolli, Cinema against Spectacle: Technique and Ideology Revisited (Amsterdam: Amsterdam University Press, 2015), pp. 251-259.

Tom Conley, "Comolli Again," paper at 2011 Society of Cinema and Media Studies conference, New Orleans.

Serge Daney, "John Ford," in Dictionnaire du cinéma (Paris: Éditions universitaires, 1966). Repr. in Serge Daney, La Maison cinéma et le monde, vol. I: Les temps des Cahiers 1962-1981 (Paris: P.O.L., 2001), pp. 278-285.

—, "Le Théâtre des entrées," Cahiers du cinéma hors série, "John Ford" (1990), pp. 62-64. 
Michel Delahaye, "De John Ford à Sean O'Feeney," Cahiers du cinéma no. 183 (October 1966), pp. 55-59.

Sergei Eisenstein, “Mr. Lincoln by John Ford," in idem., Selected Works vol. III: Writings, 1934-147, trans. William Powell, ed. Richard Taylor (London: IB Tauris, 2010), pp. 174-183.

John Ellis (ed.), Screen Reader: Cinema/Ideology/Politics vol. 1 (London: SEFT, 1977).

Stephen Heath, "Film and System: Terms of Analysis," Screen vol. 16 no. 1 (Spring 1975), pp. 7-77, and Screen vol. 16 no. 2 (Summer 1975), pp. 91-113.

Brian Henderson, “Critique of Cine-Structuralism (II)," Film Quarterly vol. 27 no. 2 (Winter 1973-1974), pp. 37-46.

Pascal Kané, “Cinéma et histoire: L’effet d'étrangeté," Cahiers du cinéma no. 254-255 (December 1974-January 1975), pp. 77-83.

Chuck Kleinhans, "Young Mr. Lincoln and Ideological Analysis: A Reconsideration (with many asides)," Jump Cut no. 55 (Fall 2013), https://www.ejumpcut.org/archive/ jc55.2013/KleinhansCahiersInContext/text. html (accessed January 1, 2021).

Jacques Lacan, "Fonction et champ de la parole et du langage en psychanalyse," in idem., Écrits, vol. I (Paris: Seuil, 1966), pp. 237-322. Translated as "The Function and Field of Speech and Language in Psychoanalysis," in idem., Écrits, trans. and ed. Bruce Fink (New York: W.W. Norton, 2006), pp. 197-268.

—, "La signification du phallus," in idem., Écrits, vol. II (Paris: Seuil, 1966), pp. 685695. Translated as "The Signification of the Phallus," in idem., Écrits, trans. and ed Bruce Fink (New York: W.W. Norton, 2006), pp. 575-584.

—, Des Noms-du-Père (Paris: Seuil, 2005).

Gérard Leblanc, "Welles, Bazin et la RKO (à propos de Citizen Kane)," Cinéthique no. 6 (January-February 1970), pp. 27-32.

Roger Leenhardt, “À bas Ford/Vive Wyler!," L'Écran français no. 146, April 13, 1948. Georg Lukács, History and Class Consciousness, trans. Rodney Livingstone (London: Merlin Press, 1971).

Louis Marcorelles, "Ford of the movies," Cahiers du cinéma no. 86 (August 1958), pp. 32-37.

—, "Heureux qui comme Ford (Les Cavaliers)," Cahiers du cinéma no. 101 (November 1959), pp. 46-49.

Karl Marx, "Comments on the North American Events," Die Presse, October 12, 1862. Repr. in The Collected Works of Marx and Engels, vol. XIX (London: Lawrence \& Wishart, 2010), p. 248.

_-, "Address from the Working Men's International Association to President Johnson" Bee-Hive, May 20, 1865. Repr. in The Collected Works of Marx and Engels, vol. $X X$ (London: Lawrence \& Wishart, 2010), pp. 99-101.

—, Dispatches for the New York Tribune: Selected Journalism of Karl Marx, ed. James Ledbetter (London: Penguin, 2007). 
Christian Metz, Essais sur la signification au cinéma (Paris: Klincksieck, 2013 [1968]). Translated as Film Language: A Semiotics of the Cinema, trans. Michael Taylor (Oxford: Oxford University Press, 1974).

Jean Narboni, "La preuve par huit (Frontière chinoise)," Cahiers du cinéma no. 182

(September 1966), pp. 20-24. Translated as "Casting Out the Eights," in John Caughie (ed.), Theories of Authorship: A Reader (London: Routledge, 1981), pp. 117-120.

—, "Allemagne année zéro," Cahiers du cinéma, no. 290-291 (July-August 1978), p. 47. Bill Nichols, "Style, Grammar and the Movies," Film Quarterly vol. 28 no. 3 (Spring 1975), pp. 33-49.

Sylvie Pierre, "L'Indien, le chien et le cheval de fer," Vertigo no. 19 (October 1999), pp. 27-31.

—, "Les hommes et les femmes chez John Ford," in Jacques Aumont (ed.), La différence de sexes est-elle visible? (Paris: Cinémathèque française, 2000), pp. 217-240.

—, "Ford et les Pharisiens," Trafic no. 56 (Winter 2005), pp. 12-25.

-, Frontière chinoise (Crisnée: Yellow Now, 2014).

Philip Rosen, "Screen and the Marxist Project in Film Criticism," Quarterly Review of Film Studies vol. 2 no. 3 (1977), pp. 273-287.

Texte collectif, "Young Mr. Lincoln de John Ford," Cahiers du cinéma no. 223 (AugustSeptember 1970), pp. 29-44. Translated as "John Ford's Young Mr. Lincoln: A Collective Text by the Editors of Cahiers du Cinéma," trans. Helen Lackner and Diana Matias, Screen vol. 13 no. 3 (Autumn 1972), pp. 5-44.

Peter Wollen, “Afterword," Screen vol. 13 no. 3 (Autumn 1972), pp. 44-47. 



\title{
4. "La Vicariance du Pouvoir" and the Battle of Othon
}

\begin{abstract}
This chapter charts the critical battle that coursed between Cahiers du cinéma and Positif at the turn of the 1970s over the film Othon by Jean-Marie Straub and Danièle Huillet. Of particular importance here was Jean Narboni's review of the film, "La vicariance du pouvoir," which defended Straub/Huillet's adaptation of the Corneille play by invoking the deconstructionist method of Jacques Derrida, as well as André Bazin's views on the relationship between theater and cinema. Published a few months after Cahiers' analysis of Young Mr. Lincoln, "La vicariance du pouvoir" can rightly be seen as its pendant, establishing a method for grappling with radical modernist films much as the earlier article did for classical Hollywood films. It likewise marks an early landmark in a lengthy engagement with the work of Straub/Huillet, which continues to the present day.
\end{abstract}

Keywords: Cahiers du cinéma, Jean-Marie Straub \& Danièle Huillet, Othon, Positif, Jean Narboni, Jacques Derrida

\section{Cahiers du cinéma and Straub/Huillet: Early Encounters}

At the precise moment in 1970 that Cahiers devoted itself to devising a Marxist re-reading of Ford's 1939 depiction of Lincoln, it was also grappling with Jean-Marie Straub and Danièle Huillet's latest release, an adaptation of Corneille. ${ }^{1}$ Earlier in the year, Jean-Claude Biette (an actor in the film) had

1 Straub/Huillet's film is officially titled Les yeux ne veulent pas en tout temps se fermer, ou Peut-être qu'un jour Rome se permettra de choisir à son tour, but for the sake of expedience it is usually referred to as Othon. In the 1960 s and much of the 1970s, Huillet's status as a co-director of their films was generally overlooked by critics, including those at Cahiers, who referred to Straub as the sole author of these works. Here I will use the binomial term "Straub/Huillet" when

Fairfax, D., The Red Years of Cahiers du Cinéma (1968-1973). Volume I: Ideology and Politics. Amsterdam: Amsterdam University Press, 2021 DOI 10.5117/9789463728508_CHO4 
written a short piece on the filming of Othon, and in the same issue as the Young Mr. Lincoln article a lengthy interview with Straub/Huillet appeared, conducted by the Italian group Cinemateka. In the following number (dated October 1970), Cahiers published their own interview with the filmmaking couple, accompanied by one of the most important texts of the journal's Marxist phase, Jean Narboni's "La vicariance du pouvoir." Outside of France, Narboni's article on Othon has not resulted in the same lasting impact that the collective text on Ford's film has had; an English translation was not published until 1990. ${ }^{2}$ But for the development of Cahiers' critical "line" in this period, "La vicariance du pouvoir" can be seen as just as important as the Ford analysis. Appearing in successive issues, the articles on Ford and Straub/Huillet function as complements to one another: whereas Young Mr. Lincoln is a reasonably straightforward example of a category (e) film, Othon addresses modes of critical reading discussed in categories (b) and (c) of the classificatory system established in "Cinéma/idéologie/critique."3 Moreover, it is apt that the two filmmakers marshaled for instituting a new critical practice should be Ford and Straub/Huillet: despite working in extremely different filmmaking environments, there are considerable parallels between them, as Tag Gallagher has forcefully argued, and Straub has always avowed his admiration for and debt to Ford. ${ }^{4}$ As with Ford, Straub/Huillet's films have been consistently championed by Cahiers,

referring to the films they made together, and Straub when referring to texts or statements in interviews made by Straub alone. In textual citations, however, I will preserve the original usage, which frequently mentions Straub alone.

2 The title is, however, mistranslated as "Vicarious Power": "vicariance," in both English and French, is a biological term referring to the process of species differentiation due to geographical separation. Its use here by Narboni suggests an affinity with Derrida's notion of "dissemination." The translations of passages from Narboni's text I offer in this volume depart markedly from Hafrey's rendering of his text.

3 See Comolli/Narboni, “Cinéma/idéologie/critique," p. 13 [p. 257]. Straub/Huillet's earlier film Nicht versöhnt was specifically given as an example in category (b). The fact that the filmmakers are conscious Marxists would indicate that Othon would also be applicable here, but many of the film's formal and narrative features seem more pertinent to the "against the grain" reading recommended in category (c). In any case, making this distinction was not a question that concerned Narboni when discussing Straub/Huillet's film.

4 See Tag Gallagher, "Lacrimae rerum materialized," in Astrid Ofner (ed.), Die Früchte des Zorns under Zärtlichkeit: Werkschau Danièle Huillet und Jean-Marie Straub (Vienna: Viennale, 2004), pp. 8-33. Among the many plaudits Straub has given to Ford, there is his early declaration that the director, "after having led the American cinema to its apogee (Two Rode Together, The Searchers and Horse Soldiers) and having precipitated its fall (Liberty Valance, Cheyenne Autumn) has just sublimated it, as we know: Seven Women!" Jean-Marie Straub, "Questions aux cinéastes," Cahiers du cinéma no. 185 (December 1966), pp. 123-124, here p. 124. 
even in the face of derision from other critics, and the journal's advocacy has been a major contribution to the widespread acceptance today of the couple's work.

Unlike Ford, however, Straub/Huillet did not pass through a period of critical purgatory at Cahiers. From their very first short film, MachorkaMuff, their work was positively received by the journal-a response that may have had to do with the couple's contacts with Parisian cinephile circles, including writers for Cahiers, before their exile to Germany in 1958.5 Rivette was the first at Cahiers to write on Straub/Huillet, dedicating a short notice to Machorka-Muff, which he called the "first (little) auteurist film in all of post-war German film production," and reprinting a letter to Straub written in praise of the film by the modernist composer Karlheinz Stockhausen. ${ }^{6}$ Delahaye also discussed Straub/Huillet's debut film, placing them within a "Munich group" of young filmmakers who were reviving German cinema after two decades of post-war malaise. Against the critical consensus in Germany (including Filmkritik, which censured the film for its "sympathetic" depiction of a military general), Delahaye considered Machorka-Muff to be "the most violently anti-militarist film that has ever been made." ${ }^{7}$

Delahaye's provisional appraisal of Nicht versöhnt was confirmed in his subsequent reports on the Oberhausen and Berlin film festivals, and the critic quickly became a forceful advocate for Straub/Huillet on the pages of Cahiers, an important task given the film was threatened with legal action by Heinrich Böll's publishers. ${ }^{8}$ An interview with Straub on the occasion of a screening of Nicht versöhnt at Pesaro in 1966 was particularly legendary, with

5 A well-known photograph, for instance, shows Straub with François Truffaut in 1954. Straub also wrote film criticism during this period, although none of it was published in Cahiers $d u$ cinéma. See Jean-Marie Straub and Danièle Huillet, Écrits, ed. Philippe Lafosse and Cyril Neyrat (Paris: Independencia, 2014).

6 Jacques Rivette, “Cinéma et nouvelle musique," Cahiers du cinéma no. 145 (July 1963), p. 36. The original Stockhausen letter can now be found in Jacques Rivette's archives, deposited at the Bibliothèque du Film (Paris).

7 Michel Delahaye, "Allemagne ciné zéro," Cahiers du cinéma no. 163 (February 1965), pp. 59-67, here pp. 64,67 .

8 Nicht versöhnt was based on the Böll novel Billard um halb zehn, but the author later withdrew permission for his text to be adapted. The film was refused by Oberhausen, giving rise to a petition in support of Straub and other young German filmmakers, but screened out of competition at Berlin as well as at Venice, where it was reviewed by Jean-Claude Biette, who saw affinities with Dreyer and Fritz Lang. See Michel Delahaye, "Oberhausen en trois actes," Cahiers du cinéma no. 164 (March 1965), pp. 59-62; Michel Delahaye, "Berlin entre deux chaises," Cahiers du cinéma no. 171 (October 1965), pp. 11-15; and Jean-Claude Biette, "Nicht versöhnt de Jean-Marie Straub (Allemagne)," Cahiers du cinéma no. 171 (October 1965), p. 49. 
the filmmaker dubbing the vast majority of cinema "pornography" — understood here as the "parody of reality" and counterposed to "cinema in a naked state. ${ }^{\prime 9}$ With the film's Parisian release in 1967 , Narboni took up the baton from his colleague. In his short but insightful review "Les temps retrouvés," Narboni argued that the project of the film was to render history "present to itself" and in particular to posit the possibility of a contemporary resurgence of Germany's past Nazism through the notion of an "eternal return" of the same motifs and themes from 1870 to the present day. ${ }^{10}$ Anticipating the argument that the cinema's "ontological presence" (the reference to Bazin is explicit) could aid Straub/Huillet in this undertaking, Narboni instead argues that it "thwart[s] the political will of the author," and it is Straub/ Huillet's stubborn insistence on operating against the dispositions offered by their own art that prompts the highly lacunary narrative model of the film, defined as "a kind of accumulation of successive moments, a 'suspense' in the chemical sense of the word, a crystalline state identical to that of the filmic matter itself."11

Much of Narboni's review was inspired by comments Straub himself gave to Cahiers. The filmmaker made many appearances in the journal throughout the second half of the 196os, which took the form not only of interviews but also letters and public statements. A fecund, ongoing dialogue between the filmmaking couple and Cahiers was thus established. Narboni's description of Nicht versöhnt as a "lacunary" film, for instance, was drawn from Straub's missive "Frustration de la violence," in which, having stated "I risked making a lacunary film," he quoted the Littré dictionary definition of the term: "Lacunary body, a body composed of agglomerated crystals which produce intervals between themselves." ${ }^{12}$ A similar communiqué on Chronik der Anna Magdalena Bach was published in the September 1967 issue, where Straub defined his intention to make "a film in which we would utilize music, neither as accompaniment, nor as commentary, but as aesthetic material. ${ }^{13}$ In December the same year, Straub even contributed a fiery

9 Jean-Marie Straub, interviewed by Michel Delahaye, “Entretien avec J.-M. Straub," Cahiers du cinéma no. 180 (July 1966), pp. 53-57, here p. 53.

10 Jean Narboni, "Les temps retrouvés," Cahiers du cinéma no. 186 (January 1967), pp. 66-67, here p. 66 .

11 Ibid.

12 Jean-Marie Straub, "Frustration de la violence," Cahiers du cinéma no. 177 (April 1966), p. 64.

13 Jean-Marie Straub, "Sur Chronique d'Anna Magdalena Bach," Cahiers du cinéma no. 193 (September 1967), pp. 56-58, here p. 56. In its April-May 1968 issue, Cahiers published the script of the film, which included transcripts of the film's sparse dialogues, and a list of the musical pieces played. See Jean-Marie Straub, "Chronique d'Anna Magdelena Bach," Cahiers du cinéma no. 200-201 (April-May 1968), pp. 42-52. 
article to the journal's dossier on Dreyer, attesting to the Dane's influence on his own uncompromising approach to film. ${ }^{14}$

Along with Delahaye and Narboni, Jean-Claude Biette (who wrote intermittently for Cahiers while based in Italy in the 1960s) also covered Straub/ Huillet's work, penning articles on Der Bräutigam, die Komödiantin und der Zuhälter and Othon. With Othon, Biette called on his own experiences as an actor in the film in order to discuss Straub's decision "to have Corneille's alexandrines spoken by the greatest possible diversity of accents, perhaps in order to explode the great unity of the classical verse, and in order that the voluntary, systematic frugality of Corneille's vocabulary should be redistributed in the most varied, individualized voices possible." Biette stresses that Straub had nonetheless eradicated every possibility of improvisation, both in terms of performance (the film's actors underwent three months of daily rehearsals) and in terms of staging (the scenes were carefully blocked out, the framing and camera movements meticulously prepared), thereby replacing the "explosive liberty" of Marc'O or Věra Chytilová with the "methodical, microcosmic repetition of a repressive structure." Such an approach allowed, in Biette's view, for "multiple, anonymous traces" buried within each actor to come to light. ${ }^{15}$

\section{“La vicariance du pouvoir": Deconstructing Corneille}

Biette's account of Othon, along with the twin interviews with Straub/ Huillet published by Cahiers, formed the primary contextual material for Narboni's response to the film in "La vicariance du pouvoir." The other decisive framework for this text was the newly prominent theory of Jacques Derrida. In relation to the analytic method of "Young Mr. Lincoln de John Ford," which was influenced by Althusser, Barthes and Lacan, "La vicariance du pouvoir" inflects the theoretical prism towards Derridean deconstruction. In 1970, these interpretative methods were not necessarily seen as being theoretically or politically antagonistic. Rather, they were understood by Cahiers to complement, challenge and develop each other. Indeed, Derrida himself - whose fully-fledged break with the Marxist tradition would not

14 Jean-Marie Straub, "Féroce," Cahiers du cinéma no. 207 (December 1968), p. 35. This text, and Cahiers' broader outlook on Dreyer, will be discussed further in Chapter 16.

15 Jean-Claude Biette, “Othon et Jean-Marie Straub," Cahiers du cinéma no. 218 (March 1970), p. 43. See also Jean-Claude Biette, "Jean-Marie Straub: Le fiancé, la comédienne et la maquereau," Cahiers du cinéma no. 212 (May 1969), pp. 9-10. 
come until later in the 1970s-was perfectly happy to publish his work in an avowedly Marxist-Leninist journal, Tel Quel. And yet contradictions are apparent between the two approaches: whereas in the Young Mr. Lincoln article the Cahiers writers were unabashed in their willingness to "force" the meaning of the film, Narboni, at the outset of his response to Othon, questions the very existence of an "ultimate signified" or a "primary truth" in Straub/Huillet's films and instead, drawing from Derrida's discussion of Rousseau's Confessions in De la grammatologie, argues that there is a "logic of substitution and supplementarity" at work in the Corneille adaptation. ${ }^{16}$ The ensuing text is a demanding, theoretically dense piece which rhetorically mimics the works it discusses: not only was Straub/Huillet's film often accused of illegibility (a charge refuted by Narboni), but Derrida was also notorious for his paratactic, allusive writing style. In this sense, however, Narboni's response to Othon is something of an outlier in his critical corpus: his articles for Cahiers are generally written in a more limpid style, and he admits that the Othon piece is "the only text of mine inspired by Derrida." ${ }^{17}$ While Derrida became a major point of reference for Cahiers in the years 1970-1971, other texts invoking his theories tended to be written by Daney, Bonitzer or Oudart rather than Narboni.

Narboni insists that Othon possesses a radical quality that makes "almost the entirety of what is presently proposed in the name of the cinema" appear to be "in decline and aging." But the radical character of the film exists en creux, by what it is not. Straub/Huillet's project is characterized by what it deprives film criticism of, namely: a subject, as the creative authority of the film (the auteur), a theme (the film's "meaning effects" come from its writing process rather than the expression of a content) and, finally, style-Straub/ Huillet's aesthetic is marked by a distinct lack of ornamentation or symbolism. It is for this reason that what Narboni calls the "sites of obscurantist resistance" within the French critical world rejected the film so brutally, attacking its "imposture, hermeticism, illegibility." Against this attitude, the critic calls for films such as Othon to "penetrate into a field of wider readability. ${ }^{18} \mathrm{He}$ cautions, however, against the idea that Othon could be

16 Narboni, “La vicariance du pouvoir," p. 43 [p. 15o]. See also Jacques Derrida, De la grammatologie (Paris: Minuit 1967), pp. 203-234. Translated as On Grammatology, trans. Gayatri Chakravorty Spivak (Baltimore: Johns Hopkins University Press, 1974), pp. 141-164. Straub himself gained a certain amount of notoriety for his comment that, "I always try to eliminate all intentions — the will to explanation. [...] Stravinsky said: 'I know very well that music is incapable of expressing anything at all." Jean-Marie Straub, “Sur Chronique d'Anna Magdalena Bach," p. 57.

17 Interview with Jean Narboni, March 18, 2014.

18 These quotes are from Narboni, "La vicariance du pouvoir," p. 43 [p. 151]. 
spontaneously received by marginalized or oppressed layers of society-an illusion to which Straub himself sometimes succumbed. ${ }^{19}$ Referring to Bourdieu/Passeron's study of the "sociology of aesthetic perception," which argued that workers relate to artistic products on the basis of an "absent bourgeois culture," Narboni contends that in the present political context, a film such as Othon is primarily apt to penetrate into the "petty-bourgeois intellectual layers wishing to align themselves with Marxist positions" (a category in which both the readers and writers of Cahiers itself are included), at the same time as being unequivocally rejected by those "holders of bourgeois knowledge who are definitively attached to their codes and conditioning."20 It is thus by fracturing its petty-bourgeois audience along ideological lines - forcing it to choose either the camp of the proletariat (a Marxist critical practice) or the camp of the capitalist class ("obscurantist reaction") — that the film, for Narboni, finds its political potency.

In charting Straub/Huillet's desire to make a "film on aphasia" in which the "eloquence" of Corneille's original play is "strangled" and "reduced to silence," Narboni's focus rests on the dispositif established by the filmmakers, in particular their choice to give the play's roles to actors who, for the most part, do not speak French as their native language. Following Biette, Narboni argues against viewing this technique as an instance of "anarchic improvisation" or willed disorder, which in his view, would merely result in exchanging the petty-bourgeois "fantasy of control" for a still more derisory delusion of unhinged chaos. Instead, this strategy works to "sterilize" the film of all "expressivity, emotive nuances, smoothness, oratory, rubato, interiorization and psychology," privileging instead the mass and density of the speech act itself, the rhythm and timbre of the voices of the on-screen figures reciting Corneille's text. Additionally, Straub/ Huillet's method has the effect that the "scene" of the filmic representation is no longer dominated by a "speech [ parole] which commands it"; rather, the utterance (énoncé) is transformed into a "desire of the voice [...] for the énoncé(r). ${ }^{{ }^{21}}$ Here Narboni insists that the work on vocal enunciation

19 Straub had harbored plans to project the film on $16 \mathrm{~mm}$ to factory workers, but this quixotic idea was never realized. See Jean-Marie Straub and Danièle Huillet, interviewed by Joel Rogers, "Jean-Marie Straub and Danièle Huillet Interviewed: Moses and Aaron as an Object of Marxist Reflection," Jump Cut no. 12-13 (December 1976), pp. 61-64.

20 Narboni, "Vicariance du pouvoir," p. 47 [p. 160]. See also Pierre Bourdieu, Jean-Claude Chamboredon and Jean-Claude Passeron, Le Métier du sociologue (Bordas: Mouton, 1968).

21 Narboni's term "énoncé( $r$ ") is an untranslatable pun based on the homophony between the past participle énoncé (utterance), a standard term in Saussurean semiology, and the inifinitive version of the verb (énoncer), "to utter." 
in the film takes the form of "light condensations and displacements" (a conscious allusion to the mechanisms of the dream-work in Freud's Traumdeutung). Citing Derrida's article "La dissemination," the Cahiers critic argues that Othon triggers a "power of inscription no longer merely verbal, but phonic. Polyphonic."22 The film's polyphonic quality stems above all from its wide range of speech registers and vocal cadences, varying from the near-naturalistic performances of some actors to what Richard Roud has called the "gabbling" of others. ${ }^{23}$

In turning to the relationship between cinema and theater in the film, Narboni insists on the possibility of glimpsing a "general materialist writing practice," which is counterposed to what he sees as the historically failed conception of "engaged art" in the Sartrean sense. This writing practice explodes the standard opposition in the "bourgeois ideology of art" between "servile naturalism" and its "banal formalist inversion." While it is of necessity connected with the broader social reality, it should be conceived not as the passive reflection of this reality but as being capable of "producing contradictions and meaning effects" with respect to it. Invoking Derrida's notion of the "the cast-aside-reference, the being aside [la référence écartée, être à l'écart]," Narboni locates examples of this materialist writing in the work of Eisenstein, Mallarmé and Artaud (in cinema, poetry and theater respectively) but considers that its most advanced contemporary formulation is to be found precisely in the films of Straub/Huillet, and in particular in the dialectic generated between the theatrical scene and its cinematic equivalent in Othon. Refusing the idea of a two-stage process by which the Corneille text is first staged for the theater and then "adapted" to the cinema, Narboni argues that "the film, in a single operation, unites the construction of a theatrical scene and its cinematic transformation, it simultaneously effectuates a theatrical set-up and its subversion." ${ }^{24}$ Here, Derrida's notion of the supplement is germane: if the supplement draws on the double meaning of the French word to refer to a process of both addition and substitution,

22 The quotes from this paragraph are from Narboni, "Vicariance du pouvoir," p. 44 [pp. 152-153]. For the Derrida quote, see Jacques Derrida, "La dissemination," Critique no. 261-262 (1969). Translated as "Dissemination," in Jacques Derrida, Dissemination, trans. Barbara Johnson (Chicago: University of Chicago Press, 1981), pp. 287-366, here p. 332.

23 See Richard Roud, Straub (London: Martin Secker \& Warburg, 1971), p. 111. Narboni, however, criticized Roud for "incompetently" defending the film in an earlier article the American wrote on Othon. See Narboni, "La vicariance du pouvoir," p. 47 [p. 161].

24 The quotes in this paragraph are from ibid., p. 45 [pp. 155-156]. For the Derrida quote, see Jacques Derrida, "La double séance" Tel Quel no. 41 (Spring 1970), pp. 3-43, and no. 42 (Summer 1970), pp. 3-45. Translated as “The Double Session," in Jacques Derrida, Dissemination, pp. 173-286, here p. 242. 
then the relationship between theater and cinema in Othon, as Narboni describes it, can indeed be said to be one of supplementarity.

\section{The Logic of the Supplement: Derrida avec Bazin}

It is at this point in the article that Narboni takes what he calls a "historical detour." Having deployed Derrida, Schefer, Mallarmé and Artaud to discuss Straub/Huillet, Narboni now turns to Bazin, and particularly the text "Théâtre et cinéma." For those adhering to the idea that Cahiers under Comolli/Narboni was "anti-Bazinian," the terms in which Narboni speaks of his forebear are surprising. He considers "Théâtre et cinéma" to possess "extreme perspicacity and systematic rigor," judging Bazin to be "well in advance of today's general film criticism," to the extent that many of the reproaches directed at Othon are already "foreseen, inscribed and deconstructed" by the critic, writing years before the film was released. Indeed, we can most fruitfully understand Othon — and Straub/Huillet's œuvre more generally_as a materialist application in filmmaking practice of some of the key precepts of Bazin's theory not only on the adaptation of theatrical works to the cinema but also, more fundamentally, on the implications of the ontological realism of the cinematic image for film technique. In Straub/Huillet's case, this pertains to the filmmakers' predilection for long-takes, filming in natural settings, intransigent insistence on synchronized sound, and the performances they draw from their actors, who are more often than not non-professionals. It was precisely this Bazinian core in the couple's work that attracted the Cahiers critics of the post-1968 period, but Narboni does not argue for a direct, unambiguous relationship between Bazin and the directors of Othon. Rather, in Narboni's view, Straub/ Huillet operate a "displacement" of Bazin's theory, one that "is none other than the essential almost-nothing that separates idealism, in one of its most coherent manifestations, from materialism. ${ }^{25}$

While rejecting the "filmed theater" of the cinema's early years, Bazin also disparages the idea that introducing overt "signs" of cinematic specificity into the filmed adaptation of a play is a commendable formal maneuver. Instead, he advocates the injection of "aesthetic catalysts" in "infinitesimal doses" into the mise en scène of the film in order to "guarantee its truth," giving as examples of this strategy the noise of a windscreen wiper in Les Dames du Bois de Boulogne, the "pellet of real earth" in La Passion de Jeanne 
d'Arc or a branch rustling in the breeze in Die Nibelungen. ${ }^{26}$ A more radical approach, and one for which Bazin evinces still more enthusiasm, is that adopted by filmmakers such as Laurence Olivier (Henry V), Orson Welles (his versions of Macbeth and Othello) and Jean Cocteau (the self-adaptation Les Parents terribles), in which, far from seeking to minimize or mask the theatrical provenance of the films, their theatrical quality is highlighted and accentuated precisely by means of their cinematic mise en scène. In Bazin's view, Cocteau, for instance, "understood that he must not add anything to his décor, that the cinema was not there to multiply it but to intensify it." ${ }^{27}$

For Narboni, the value of Straub/Huillet's adaptation of Corneille lies in the fact that "in the same movement, in a single gesture" they both "interrogate and threaten" Bazin's propositions. ${ }^{28}$ Narboni focuses on (and cites three times) a key phrase plucked from "Théâtre et cinéma," which, he argues, encapsulates Bazin's "classical" ontology, to wit: "The cinema being by essence a dramaturgy of nature, there can be no cinema without the construction of an open space, substituting itself for the universe instead of being included in it." ${ }^{29}$ This notion of the cinema "substituting itself" for the natural universe is, in Narboni's view, threatened by "the logic of supplementarity" elaborated by Jacques Derrida, a logic which, as outlined above, conceives of the supplement as both a process of addition and substitution. In the case of Straub/Huillet, the supplement arises in their act of showing a "representation in the process of its own making [en train de se faire],"30 an operation that allows for the superimposition of the film's "theatrical scene" and its "cinematic scene," with each scene "inscribing" the other, "which at the same time exceeds it and overflows it." Narboni detects examples of "aesthetic catalysts" at work in Othon-focusing in particular on one of the most controversial elements of Straub/Huillet's film: the images and sounds of cars and airplanes in the background of shots purportedly taking place in ancient Rome-but he insists that these do not play the role for which Bazin conceived the notion. If this were the case, they would merely

26 André Bazin, "Théâtre et cinéma," in idem., Qu'est-ce que le cinéma? vol. II: Le Cinéma et les autres arts (Paris: Éditions du Cerf, 1959), pp. 69-118, here p. 104. Translated as "Theatre and Film," in idem., What is Cinema?, trans and ed. Barnard, pp. 161-214, here p. 199.

27 Ibid., p. 83. Cited in Narboni, "La vicariance du pouvoir," p. 46 [p. 157]. The emphasis is Narboni's.

28 Ibid.

29 Bazin, "Théâtre et cinéma," p. 104. Cited in Narboni, "La vicariance du pouvoir," p. 45 [p. 156].

30 Ibid. The phrase is a direct allusion to the subtitle of Godard's La Chinoise (1967): "un film en train de se faire." 
function as "effects of the real" (in Barthes' sense), ${ }^{31}$ which would serve to reinforce the scene's realism (whether in the historical or the ontological sense). Instead, they undo this sense of realism, deconstruct it, and thereby "insert into the closed representation an openness towards its unlimited exteriority, as limited marks worked by the infinity of exteriority (history)." ${ }^{22}$

This superimposition of the two "scenes" of Othon, following Derrida's logic of the supplement, can be perceived above all in the idiosyncratic verbal enunciation found in the film, the pauses, gaps and hesitations that dismember Corneille's verse, rendering it alien by uncoupling its component lexical units and reuniting them along new syntactical and metrical lines. But it also takes place in the relationship between the structure of the play and the film's découpage. Although the film reproduces the dialogue of the play virtually to the letter, Straub nonetheless noted that: "The découpage of the film in 69 shots [...] contradicts the construction of Corneille in a five-act tragedy, and adds itself to it. For the first four acts the blocking is cinematic and the découpage rather theatrical (as in Chronik der Anna Magdalena Bach and the first part of Der Bräutigam), whereas for the fifth act the blocking is theatrical and the découpage more cinematic." ${ }^{33}$ Narboni latches onto this statement in order to posit that there is always, throughout Othon, "one scene in addition to the other, one scene on top of the other," and in this sense, Straub/Huillet's aesthetic method is an uncanny likeness of Corneille's play, in which there is "one role, one postulant too many (Othon and/or Pison) for a place, not yet empty, at the head of the Empire (Galba)."34

Whereas Narboni seeks to deploy Derrida in order to deconstruct the idealist metaphysics that is supposedly at the heart of Bazinian theory, we may ask if this operation does not, in fact, already take place in Bazin himself-and above all, precisely in "Théâtre et cinéma." Indeed, Derrida's efforts, in De la grammatologie, to overturn the hierarchies of such "logocentric" binaries as speech/writing, original/copy and absence/presence are curiously foreshadowed in Bazin's text. The last dichotomy, in particular, comes in for a highly nuanced discussion. Invoking the notion of the photographic image as a "trace" (itself a term with Derridean echos),

31 See Roland Barthes, "L'effet de réel," Communications no. 11 (1968), pp. 84-89. Translated as "The Reality Effect," in idem., The Rustle of Language, trans. Richard Howard (Berkeley: University of California Press, 1989), pp. 141-148. This article, and the use Cahiers made of it, is discussed in greater detail in Chapter 23.

32 Narboni, "La vicariance du pouvoir," p. 46 [p. 158].

33 Jean-Marie Straub and Danièle Huillet, "Entretien," Cahiers du cinéma no. 224 (October 1970),

pp. 40-42, here p. 42. Cited in Narboni, "La vicariance du pouvoir," p. 47 [p. 159].

34 Ibid. 
Bazin refutes the notion that the cinema cannot place the spectator in the physical presence of the actor and argues for the existence of a "possible intermediate between presence and absence," noting that "philosophers and aestheticians" have not yet adequately taken stock of the "subsistence" of presence on the movie-screen. ${ }^{35}$ At the same time, and again prefiguring Derrida's vocabulary, he recognizes the existence of "an indefinable supplement of pleasure that real representation [in the theater] dispenses to me. ${ }^{36}$ When it comes to the relationship between Bazin and Derrida, then, the logic of the supplement works both ways.

Of still more pertinence for the post-1968 Cahiers is Narboni's assertion of the "almost nothing" separating the materialism of Straub/Huillet's filmmaking practice from the "idealism" of Bazin's theory: this is not only a conceptual framework that will persist in Cahiers' critical reception of Straub/Huillet's work throughout the 1970s, it is also a notion that ramifies throughout the journal's critical project during this time. It is particularly striking that, of the contemporary filmmakers defended on the pages of Cahiers during the late 1960s and 1970s, a large number of them-Rivette, Garrel, Jancsó, Rocha, Kramer, Perrault, Duras and, above all, Godard—can in their own ways be considered, like Straub/Huillet, to be "Bazinian materialists," and this proclivity continues in these writers' attitudes to more contemporary directors, with neo-Bazinian directors such as Pedro Costa, Abbas Kiarostami and Jia Zhang-ke tending to find favor in the former Cahiers writers' critical judgements.

\section{The Battle of Othon}

"La vicariance du pouvoir" did not appear in a critical void. Othon was not released in France until January 1971, but festival screenings at Cannes and New York had already earned it a significant amount of derision, if not vituperative condemnation, from critics whose adverse response to the film inspired, to a large degree, Narboni's spirited defense of Straub/Huillet. ${ }^{37}$ The

35 Bazin, "Théâtre et cinéma," pp. 91-92 [p. 185]

36 Ibid., p. 115 [p. 209]. Emphasis added. Barnard's translation gives "supplement of pleasure" as "extra enjoyment," thus annuling the resonance with Derrida.

37 A later review by Gaston Haustrate ("Le cas Straub," Hebdo Témoignage Chrétien, January 28, 1971), in speaking of "the impostor Straub, this disciple/victim of the bedroom Marxism-Leninism and pathological esotericism of Cahiers du cinéma," so infuriated the journal that they printed the piece in full and "refuted" it with a long extract from Barthes' Critique et vérité. See La Rédaction, "Nouvelles de l'idéologie dominante," Cahiers du cinéma no. 228 (March-April 1971), pp. 63-64. 
previous month (September 1970) had seen Positif publish a disdainful review of the film by Michel Ciment, who labeled Othon a "perfectly reactionary exercise" that had transformed Corneille's "reflection on the fine arts of governing and marrying into an abstruse, 9o-minute long recital," and which could only be defended by a "fistful of terrorist cheerleaders in Rome, Paris, Munich, New York and London." ${ }^{38}$ In "La vicariance du pouvoir," Narboni took specific umbrage at this philippic, dubbing it a "sublimated concentration of a decadent, depressed non-reading." 39 The divergent opinions on the film appositely encapsulated the differing critical positions of the two publications. While Cahiers moved from its rightist dalliances towards a Marxist-Leninist political perspective in the 196os, Positif retained the left-surrealism that had characterized its outlook since its founding in 1954-and even took glee in mocking its rival for the precipitous swerves in its political orientation. The competing journals had achieved a certain détente in the years 1967-1968, refraining from overt attacks and promoting each other's "semaines," but the heightened political stakes of the post-May period and Cahiers' increasing concern with Althusserian and Lacanian theory revived Positif's propensity to hurl sarcastic barbs at its counterpart, a practice that was denounced in Cahiers as a form of qualunquismo (populist anti-intellectualism) that evinced "an idea of relations between the journals that was rather close to the Oxford-Cambridge rivalry in British academia. ${ }^{20}$ 1970 saw a sharpening of this debate. In his article "Le cinéma dans la politique," published in February, Louis Seguin delivered a critique of both Cinéthique and Cahiers. Although he is, in the end, more favorable to Cahiers, judging that "their competence easily dismantled the maladroit mechanicism of Cinéthique" to such an extent that "we quickly have a sentiment of malaise before the crushing of the weaker party, so great is the disproportion of forces," Seguin nonetheless adopts a tone of condescending superiority towards both journals, reproving them for their "pink" political coloration, which is overly proximate, in his eyes, to the positions of the Parti communiste français (PCF). Seguin censures Cahiers as "fervent Althusserians" who insist on remaining "with prudence and complexity on a purely theoretical terrain."41 Seguin's article would prove to be a mild rejoinder, however, when compared to his later contribution "Sur une petite bataille d'Othon" (co-authored with

38 Michel Ciment, "Othon ou Les yeux ne veulent pas en tout temps se fermer ou Peut-être qu'un jour Rome se permettra de choisir à son tour, de Jean-Marie Straub (Allemagne-Italie)," Positif no. 119 (September 1970), pp. 29-30.

39 Narboni, "La vicariance du pouvoir," p. 47 [p. 16o].

40 Bernard Eisenschitz, "Le cahier des autres," Cahiers du cinéma no. 211 (April 1969), pp. 58-59.

Louis Seguin, "Le cinéma dans la politique," pp. 5, 7. 
Ciment), an article that appeared in the same December issue as Benayoun's rebarbative diatribe against Cahiers, "Les enfants du paradigme."

Seguin/Ciment's article was specifically intended as a riposte to "La vicariance du pouvoir." Insisting that Cahiers' Marxist theory rests on the "simplistic" notion that "since contemporary film language is a bourgeois language, nothing can be said in the cinema without destroying this language," Ciment/Seguin conclude that this standpoint excludes not only the content of films but also the economic and social conditions in which they are made. ${ }^{42}$ In similar fashion, Narboni's decidedly pragmatic recognition that Othon will primarily find an audience among radicalizing sections of the petty-bourgeois intelligentsia, rather than the workers and peasants to whom Straub had dreamed the film could be shown, is interpreted as a "phantasm of [...] cultural restriction [that] covers over the reality of the political tactics of the P.C.'F.", with the Positif critics deploying the analogy that, “just as for the $\mathrm{P}^{\prime} \mathrm{C}$ ' $\mathrm{F}$. the working class is not ripe for the revolution, so for Cahiers it is not ripe for the cinema." Cut off, in the absence of any alternative practice recommended by Cahiers, from culture (and even from "all real communication"), the working class is thereby abandoned "to televi-

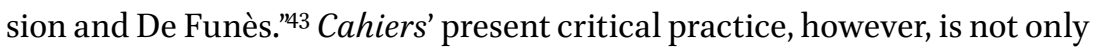
associated with the "revisionist" politics of the PCF. It is also seen to be drawn from the journal's own political heritage. Whether "reactionaries, Gaullists or revisos," its critics have "always manifested the same sovereign contempt for explicitly political cinema," and as a piece of evidence, Positif makes the dubious move of quoting at length from Comolli's 1962 disquisition "Vivre le film," a text from which the Comolli of 1970 would certainly have taken his distance. ${ }^{44}$ In opposition to the "revolutionary snobbism" of Straub and Narboni, the Positif critics speak favorably of the "third cinema" of Solanas and Espinosa, who concretely base their film technique on "the means, the theme and the intended spectators," and Seguin/Ciment also count films as diverse as There Was a Crooked Man, Tell 'em Willie Boy Is Here and Le peuple et ses fusils as positive models of political cinema. ${ }^{45}$

42 Michel Ciment and Louis Seguin, "Sur une petite bataille d'Othon," Positif no. 122 (December 1970), pp. 1-6, here p. 2 .

43 Ibid., p. 3. The quotation-marks around the "C" in the French Communist Party's initials were frequently used by the far left to denote the PCF's purported abandonment of communism, a practice that would be adopted by Cahiers itself when the journal made its Maoist turn. De Funès was a popular French actor known for starring in low-brow comic films in the 1950s-1960s. 44 Ibid., p. 4. "Reviso" was an informal shortening of the word "revisionist" and thus commonly used to refer to the PCF and its allies by those who were to the left of the party.

45 Ibid., pp. 5-6. 
Cahiers predictably considered the dedication of 26 of the 72 pages in Positif's December 1970 issue to polemics against it to be a "calumnious campaign," and in his response, Narboni critiqued Ciment's journal for "obscurantism" and the "imposture" of "refusing, in the field of ideological/ cultural struggle, the relative specificity of this struggle and of the site where it is inscribed." Resisting the idea that the battle over Straub/Huillet was simply the continuation of an age-old quarrel between Cahiers and Positif, he loftily declared that "the good old days are dead. [...] The real debate is today taking place in a field from which Positif, in spite of its attempt to feed off of it, finds itself, due to its regressive practice, excluded." ${ }^{m 6}$ This rebuttal also had the effect, however, of closing off any further debate with Positif over Othon. From this point, the forum for Cahiers to discuss the film was the communist cultural milieu. In part thanks to the filmmakers' own political leanings, Straub/Huillet's Corneille adaptation found a warmer reception among PCF-aligned critics than it did in many other quarters. At the time of the film's release, both L'Humanité and the party's arts weekly Les Lettres françaises (edited by Louis Aragon) published interviews with Straub and dedicated positive, if occasionally condescending, reviews by François Maurin and Marcel Martin respectively. ${ }^{47}$ It was in the cultural monthly La Nouvelle Critique, however, that the film was most favorably looked upon. The shared interest in Straub/Huillet's film was only one of the factors drawing Cahiers and the PCF-journal close to one another during this period, a rapprochement that will be more fully discussed in Part II. JeanAndré Fieschi, a former Cahiers critic who left the journal at the dawn of the May 1968 protests and joined the Communist Party, had become one of the main film critics for La Nouvelle Critique and in November 1970 gave Othon an enthusiastic review, judging it to be a "difficult film, but only insofar as a (formal and moral) gambit is pushed to the extremes of its rigor-demanding an alert attentiveness, whose reward is equal to the effort solicited. ${ }^{38}$ Soon

46 Jean Narboni, “Sur quelques contresens," Cahiers du cinéma no. 226-227 (January-February 1971), pp. 116-118, here pp. 116-117.

47 See Jean-Marie Straub, interviewed by François Maurin, “À propos d'un film controversé: Entretien avec Jean-Marie Straub," L'Humanité, January 1, 1971; Jean-Marie Straub, interviewed by Marcel Martin, “Jean-Marie Straub: Balayez-moi tout ça!,” Les Lettres françaises, January 13 , 1971; François Maurin, "La voie de la facilité," L'Humanité, January 16, 1971; and Marcel Martin, "À titre 'expérimental," Les Lettres françaises, January 13, 1971. Maurin appreciated the approach but judged the end-product to be unconvincing, while Martin asserted that "for want of seeing it as a political film, with Othon we can still take the pleasure of a visual and verbal magic that Straub does not consider to be in contradiction with his didactic aspirations."

48 Jean-André Fieschi, “Jean Marie Straub: Othon," La Nouvelle Critique no. 38 (November 1970), p. 97 . 
afterwards, a round table on Othon was organized by the journal involving Fieschi, Narboni and PCF-affiliated theater specialists Richard Demarcy, Maurice Goldring and Aimé Guedj. The proceedings were not published until April 1971, well after the film's commercially unsuccessful Parisian run. ${ }^{49}$ Here, although the tone of the debate is refreshingly cordial, opinions on the film were nonetheless divided: while Fieschi and Narboni avidly championed Othon, both Guedj and Goldring admitted to being initially irritated during their viewing before adopting a more positive response to the film. Richard Demarcy, meanwhile, expressed more persistent reservations about Straub/ Huillet's method, and the contretemps between him and Fieschi/Narboni would dominate the discussion.

Demarcy argued that Straub, "by privileging the text, willingly cuts himself off from a signifying scenic discourse," and gives the example of a shot in the film of a grotto where communist partisans had stored weapons during World War II (a political context that can only be known with recourse to statements from Straub/Huillet). Comparing the filmmakers unfavorably to Brecht's version of King Lear and Patrice Chéreau's staging of Richard II for the Théâtre de France,,$^{50}$ Demarcy deemed the formal work in Othon to be "uncontrolled, confusing, contradictory and illegible." ${ }^{51}$ Fieschi opposed his Nouvelle Critique colleague: while accepting that Straub/Huillet's system was not "uncriticizable" (and giving credit to the idea that their work is "elitist"), he argued against the notion of an "equivalence of signs between the theatrical expressive system and the cinematic expressive system" and accused Demarcy of equating the "signs" in the film with "symbols." Fieschi insisted that "signification is born, here, from the relations between signs and from the series of signs, not from pure and simple addition." He thus called for a "musical reading" of Othon, in addition to the standard narrative/dramaturgical approaches to reading a film..$^{2}$ Narboni, unsurprisingly, also defended Straub/Huillet, arguing that, in contrast to Chéreau, they position themselves "outside of any attempt to 'express meaning"; instead, their film "produces a new distribution of the play, following a different [signifying] economy," which involves both the

49 Richard Demarcy, Jean-André Fieschi, Maurice Goldring, Aimé Guedj and Jean Narboni "Débat sur Othon," La Nouvelle Critique no. 43 (April 1971), pp. 58-67.

50 Patrice Chéreau's production of the Shakespeare play screened on French television in February 1970. While originally active as a theater and opera director, Chéreau turned to filmmaking in the mid-1970s and is known for works such as La Reine Margot (1994) and Intimacy (2001).

51 Demarcy, in ibid., p. 63.

$5^{2}$ Ibid., pp. 63, 65-66. 
enunciation of Corneille's classical verses and their relationship to the film's shot construction. ${ }^{53}$ To justify his point of view, Narboni made reference to Kristeva's notion of the literary character as a "pure voice" and called for a mode of interpretation that would understand both the filmic subject (the director) and the work itself as "effects of the chain of signification, and governed by this chain, this network." 54 Finally, the Cahiers critic again had recourse to Bazin's ideas on the cinematic adaptation of dramatic works. Bazin, he argued, understood that "only the maintenance (or even the accentuation) of 'theatricality' in a film could lead to productive effects." Similarly, in Othon:

The theatrical scene, the Representation, is never abolished, drowned in an overload of cinematic effects, but maintained — not in its opposite (which would encompass it), but at the same time as its opposite (the cinematic work). Here, once more, there are two texts, which neither cancel each other out nor constrain each other; they are simply, each one in its own turn, legible inside each other. ${ }^{55}$

\section{Straub/Huillet and Cahiers du cinéma: A Long Engagement}

The "battle of Othon" proved to be one of the most memorable polemics in the history of Cahiers. In essence, it is a battle that its critics have not ceased waging. The journal's critical support for Straub/Huillet was enduring, and its writers continue to speak highly of their films to the present day. Alongside Godard's output, they saw Straub/Huillet's work as one of the major sites of a truly political film practice, presenting it in these terms in texts such as "Film/politique (2)" by Comolli (which couterposed Othon to the negative example of Costa-Gavras' L'Aveu) and Bonitzer's “La 'Réalité' de la dénotation." The journal was also willing to publish Straub/Huillet's own writings: in November 1971, Cahiers printed a letter from Straub consisting of a "montage of texts" (his response to a questionnaire from the Italian film magazine Filmcritica, a translation of a passage from Eisenstein, and a bilingual version of a poem by Brecht on theater) in which he advocated a mode of film criticism - one that, as he noted, even Cahiers was not practicing - that would analyze "the means (including TV) of (non-)production 
and (non-)distribution of anesthetizing or toxic (film) products. ${ }^{n 6}$ Shortly afterwards, in 1972, Straub/Huillet's shooting script for Geschichtsunterricht also appeared on the pages of the journal. ${ }^{57}$ It is commonly accepted that, during Cahiers' "hardline" Marxist-Leninist phase, virtually the only filmmakers who still found grace in the journal's eyes were Straub/Huillet and Godard. Indeed, in the aftermath of this period, Bonitzer would dedicate an article to "J.-M.S." (Jean-Marie Straub) and "J.-L.G.," (Jean-Luc Godard) defining them as the "two extremes of cinematic modernity." ${ }^{8} 8$ But the reality is more nuanced than this: other films were defended during the journal's Maoist phase, while the years 1973 and 1974 also saw the journal remain relatively taciturn about Straub/Huillet's work. The release of Moses und Aron in 1975, however, led Cahiers to publish a flurry of texts relating to the film; for the next half-decade at least, Straub/Huillet's work again became central to the journal's critical project as it negotiated new paths for articulating politics and cinema.

This question came to the fore in Serge Daney's article "Un tombeau pour l'œil": written for the July-August 1975 issue, it was, surprisingly, the first text written by a Cahiers critic to be solely dedicated to a Straub/Huillet film since "La vicariance du pouvoir" five years earlier. Daney's piece focuses on Einleitung zu Arnold Schönbergs Begleitmusik zu einer Lichtspielscene, made in tandem with their adaptation of Schönberg's opera, but the critic uses the short film to open up a wide-ranging discussion about the couple's filmmaking method. For Daney, Straub/Huillet's entire œuvre is governed by a "master idea" that is already spelled out in their early film of the same name: not reconciled. This stance constitutes an approach to the cinema that leads Straub/Huillet towards what Daney calls a "refusal of all forces of homogenization" and a "generalized practice of disjunction." Such a practice finds itself instantiated not only in the "filmic heterogeneity" present in Einleitung (the irreconcilable montage between images of historical atrocities and the letters between Schönberg, Kandinsky and Brecht read out on

56 "Lettre de Jean-Marie Straub," Cahiers du cinéma no. 233 (November 1971), pp. 49-52.

57 Jean-Marie Straub and Danièle Huillet, "Leçons d'histoire (d'après Les affaires de Monsieur Jules César de Bertolt Brecht): découpage avant tournage," Cahiers du cinéma no. 241 (SeptemberOctober 1972), pp. 46-66. In the position platform "Quelles sont nos tâches sur le front culturel?: Projet de plate-forme," published in the following issue of Cahiers (no. 242-243, NovemberDecember 1972-January 1973, pp. 5-25), the journal criticized itself for having published the script "without presentation or justification of any sort, precisely due to our incapacity to clearly demarcate our position in relation to this film, and to the 'avant-garde' in general" (p. 6).

58 Pascal Bonitzer, "JJ-M.S. et J.-L.G.," Cahiers du cinéma no. 264 (February 1976), pp. 5-10, here p. 5. See Chapter 10 for more on this text. 
the soundtrack) but also, more importantly, in Straub/Huillet's "staging" of the voice-over readings themselves. The announcers in the film are Günter Straschek and Peter Nestler, and their manner of speech, as Daney observes, betrays the fact they are "not 'speakers,' not even simulacra of speakers." ${ }^{\prime 59}$ We see them reading out the correspondence in the recording studio, surrounded by "recording devices" [appareils], as they make use of their own "enunciation apparatus": their voices. ${ }^{60}$ In counterpoint to these voices is the archival footage shown in the film and in particular a pair of images depicting the corpses of murdered Communards and an American $\mathrm{B}_{5} 2$ conducting bombing raids during the Vietnam War. For Daney, these are "images produced by naked power, the power of repression and genocide," and the film's method consists of excising from such images that power which "would like us no longer to be surprised by them." It is this that makes every shot of the film, in Daney's evocative language, "a gravesite for the eye."61

Daney's article accompanied an interview with the filmmakers, while the following issue of Cahiers was largely devoted to Moses und Aron, with the journal publishing the English critic Gregory Woods' diary of the film shoot, another interview with the filmmakers, a dialogue from the film, and an article praising Straub/Huillet's work by none other than Louis Seguin, who had quit Positif over political differences the previous year. ${ }^{62}$ In 1977 , the release of Fortini/Cani, which completed Straub/Huillet's "Jewish trilogy," garnered similar coverage from Cahiers: the script to the film was again published in the journal, and Narboni, who had resumed writing for Cahiers after a post-1973 hiatus, provided a review. Returning to Straub's definition of Nicht versöhnt as a "lacunary body composed of agglomerated crystals," Narboni judges that Straub/Huillet's new film is composed of "lapidary inscriptions, sites of memory, shards of time immured in stone, landscapes, mountains, monuments, ossuaries. And each shot [...] is itself a stone." As with his treatment of Othon, Narboni again has recourse to Mallarmé-in particular, the poet's line from Un coup de dès n'abolira jamais le hasard

59 Serge Daney, “Un tombeau pour l'œil," Cahiers du cinéma no 258-259 (July-August 1975), pp. 27-35, here p. 29.

60 Ibid., p. 31.

61 Ibid., p. 35 .

62 See Louis Seguin, "La famille, l'histoire, le roman," Cahiers du cinéma no. 260-261 (OctoberNovember 1975), pp. 57-68. An extract of this text is translated as "Family, History, Romance," trans. Annwyl Williams, in Wilson (ed.), Cahiers du Cinéma vol. IV, pp. 132-141. Seguin's “conversion" to Straub/Huillet was an enduring one: in 1991 he published a monograph on their films, Aux distraitement désespérés que nous sommes... (Toulouse: Éditions Ombres, 1991). 
that "nothing will have taken place but the place" - and defines Straub/ Huillet's "topographical" filmmaking method as "a meticulous research of the place. ${ }^{n 3}$ Returning to Othon, the Cahiers critic discloses that Barthes' discussion of "writing aloud" was inspired by a viewing of the Corneille adaptation ${ }^{64}$ but asserts that, in filming the author Franco Fortini reading extracts from his 1967 book, I cani del Sinaï, it is not the "pleasure of the voice's grain" that is emphasized but "the effect on the character of listening to his own reading, of listening to himself speak: an effect of astonishment, stupor, non-recognition, or of adhesion and the already-heard." ${ }^{\prime 65}$

Following on from "Un tombeau pour l'œil," Daney returned to Straub/ Huillet's work with a commentary on Dalla nubia alla resistenza for Cahiers in 1979, in which he introduced the term of the "Straubian shot," defined as "the product, or rather the remains (the remainder), of a triple resistance: that of texts to bodies, places to texts and bodies to places. ${ }^{n 66}$ Reviews for Libération followed of Klassenverhältnisse and Trop tôt, trop tard, in the latter of which the critic perceived that the main "actor" of the film is the landscape and affirmed that the essence of Straub/Huillet's art is their search for the "moral point" from which a given scene demands to be filmed. ${ }^{67}$ Perhaps the most poignant response to their work by a Cahiers critic, however, was Comolli's 2010 retrospective look at Othon for Les Lettres françaises. From the perspective of the twenty-first century, Straub/Huillet's film is far from being dated or formally stale. Rather, it is an enduring perceptual challenge to the "accelerated whirligig of images and sounds" that characterizes the contemporary media landscape. ${ }^{68}$ Straub/Huillet's film is, in Comolli's view,

63 Jean Narboni, "Là," Cahiers du cinéma no. 275 (April 1977), pp. 6-14, here p. 9. The reference to Mallarmé was evidently important for Straub/Huillet: the duo would film a recitation of his Coup de dès poem for the short film Toute révolution est un coup de dès in 1979.

64 Narboni repeats this claim with an anecdotal recollection of taking the theorist to a suburban screening of Othon, driving a bemused Barthes to the auditorium in a Citroën $2 \mathrm{CV}$. See Jean Narboni, La nuit sera noire et blanche: Barthes, La Chambre claire, le cinéma (Paris: Capricci, 2015), pp. 33-34. This quixotic adventure is also firmly lodged in the memories of Jacques Aumont and Pascal Kané, who attested in interviews to Barthes' sense of unease during the excursion.

65 Ibid., pp. 13-14.

66 Serge Daney, "Le plan straubien (De la nuée à la résistance)," Cahiers du cinéma no. 305 (November 1979), pp. 5-7, here p. 5.

67 Serge Daney, "Franz Kafka strauboscopé (Rapports de classe)," Libération, October 3, 1984, repr. in idem., La Maison cinéma et le monde vol. II: Les Années Libé 1981-1985, ed. Patrice Rollet (Paris: P.O.L., 2005), pp. 244-247; and Serge Daney, "Trop tôt, trop tard (Jean-Marie Straub, Danièle Huillet)," Libération, February 20, 1982, repr. in idem., Ciné journal vol. I: 1981-1982 (Paris: Cahiers du cinéma, 1998 [1986]), pp. 125-131, here pp. 127, 130.

68 Jean-Louis Comolli, "Les yeux ne veulent pas en tout temps se fermer," in idem., Corps et cadre: Cinéma, éthique, politique (Lagrasse: Verdier, 2012), pp. 555-557, here p. 555 . 
"a workshop where the vision and the hearing of the spectator is formed," and the former Cahiers editor argues that their political program is expressed less in the subject matter of their films and more in a manner of filming in which the invisible is as important as the visible. Moreover, Comolli sees Straub's controversial comments at Pesaro in 1966 on the pornographic nature of mainstream cinema as being of particular pertinence for today. For Comolli:

All the images that dance around us, are they not prone to being publicity? Misery, indignity, infirmity, combat, beauty, ugliness, horror, nudity, death, nothing, anymore, is safe from the tentacles of the spectacle. Everything has to be seen, everything has to be shown, ad nauseam. No, it doesn't have to, Danièle Huillet and Jean-Marie Straub's cinematograph tells us. Saving the cinema from itself, preserving it from its fatal disposition to the commodity-spectacle, seems to me to be one of the urgent tasks of the present. ${ }^{69}$

\section{Works Cited}

Roland Barthes, "L'effet de réel," Communications no. 11 (1968), pp. 84-89. Translated as "The Reality Effect," in idem., The Rustle of Language, trans. Richard Howard (Berkeley: University of California Press, 1989), pp. 141-148.

André Bazin, "Théâtre et cinéma," in idem., Qu'est-ce que le cinéma? vol. II: Le Cinéma et les autres arts (Paris: Éditions du Cerf, 1959), pp. 69-118. Translated as "Theatre and Film," in idem., What is Cinema?, trans. and ed. Timothy Barnard (Montreal: Caboose, 2009), pp. 161-214.

Jean-Claude Biette, "Nicht versöhnt de Jean-Marie Straub (Allemagne)," Cahiers du cinéma no. 171 (October 1965), p. 49.

—, "Jean-Marie Straub: Le fiancé, la comédienne et la maquereau," Cahiers du cinéma no. 212 (May 1969), pp. 9-10.

—, "Othon et Jean-Marie Straub," Cahiers du cinéma no. 218 (March 1970), p. 43.

Pascal Bonitzer, “J.-M.S. et J.-L.G.," Cahiers du cinéma no. 264 (February 1976), pp. 5-10.

Pierre Bourdieu, Jean-Claude Chamboredon and Jean-Claude Passeron, Le Métier du sociologue (Bordas: Mouton, 1968).

[Cahiers du cinéma], "Quelles sont nos tâches sur le front culturel?: Projet de plateforme," Cahiers du cinéma, no. 242-243 (November-December 1972-January 1973), pp. $5^{-25}$.

69 Ibid., pp. 556-557. 
Michel Ciment, "Othon ou Les yeux ne veulent pas en tout temps se fermer ou Peutêtre qu'un jour Rome se permettra de choisir à son tour, de Jean-Marie Straub (Allemagne-Italie)," Positif no. 119 (September 1970), pp. 29-30.

— and Louis Seguin, "Sur une petite bataille d'Othon," Positif no. 122 (December 1970), pp. 1-6.

Serge Daney, “Un tombeau pour l'œil," Cahiers du cinéma no 258-259 (JulyAugust 1975), pp. 27-35.

—, "Le plan straubien (De la nuée à la résistance)," Cahiers du cinéma no. 305 (November 1979), pp. 5-7.

Michel Delahaye, "Allemagne ciné zéro," Cahiers du cinéma no. 163 (February 1965), pp. 59-67.

—, "Oberhausen en trois actes," Cahiers du cinéma no. 164 (March 1965), pp. 59-62.

—, "Berlin entre deux chaises," Cahiers du cinéma no. 171 (October 1965), pp. 11-15. Richard Demarcy, Jean-André Fieschi, Maurice Goldring, Aimé Guedj and Jean Narboni “Débat sur Othon," La Nouvelle Critique no. 43 (April 1971), pp. 58-67. Jacques Derrida, De la grammatologie (Paris: Minuit 1967). Translated as On Grammatology, trans. Gayatri Chakravorty Spivak (Baltimore: Johns Hopkins University Press, 1974).

—, "La dissemination," Critique no. 261-262 (1969). Translated as "Dissemination," in Jacques Derrida, Dissemination, trans. Barbara Johnson (Chicago: University of Chicago Press, 1981), pp. 287-366.

—, "La double séance" Tel Quel no. 41 (Spring 1970), pp. 3-43, and no. 42 (Summer 1970), pp. 3-45. Translated as "The Double Session," in Jacques Derrida, Dissemination, trans. Barbara Johnson (Chicago: University of Chicago Press, 1981), pp. 173-286.

Bernard Eisenschitz, "Le cahier des autres," Cahiers du cinéma no. 211 (April 1969), pp. $5^{8-59 .}$

Jean-André Fieschi, “Jean Marie Straub: Othon," La Nouvelle Critique no. 38 (November 1970), p. 97.

Tag Gallagher, “Lacrimae rerum materialized," in Astrid Ofner (ed.), Die Früchte des Zorns under Zärtlichkeit: Werkschau Danièle Huillet und Jean-Marie Straub (Vienna: Viennale, 2004), pp. 8-33.

Gaston Haustrate, “Le cas Straub," Hebdo Témoignage Chrétien, January 28, 1971.

Marcel Martin, “À titre 'expérimental,” Les Lettres françaises, January 13, 1971.

François Maurin, “La voie de la facilité," L'Humanité, January 16, 1971.

Jean Narboni, "Les temps retrouvés," Cahiers du cinéma no. 186 (January 1967), pp. 66-67.

—, "La vicariance du pouvoir," Cahiers du cinéma no. 224 (October 1970), pp. 43-47. Translated as "Vicarious Power," trans. Leigh Hafrey, in Nick Browne (ed.), Cahiers 
du Cinéma vol. III: 1969-1972 The Politics of Representation (London: Routledge, 1990), pp. 150-162.

—, "Sur quelques contresens," Cahiers du cinéma no. 226-227 (January-February 1971), pp. 116-118.

—, "Là," Cahiers du cinéma no. 275 (April 1977), pp. 6-14.

_-, La nuit sera noire et blanche: Barthes, La Chambre claire, le cinéma (Paris: Capricci, 2015).

La Rédaction, "Nouvelles de l'idéologie dominante," Cahiers du cinéma, no. 228 (March-April 1971), pp. 63-64.

Jacques Rivette, "Cinéma et nouvelle musique," Cahiers du cinéma no. 145 (July 1963), p. 36 .

Richard Roud, Straub (London: Martin Secker \& Warburg, 1971).

Louis Seguin, "La famille, l'histoire, le roman," Cahiers du cinéma no. 26o-261 (OctoberNovember 1975), pp. 57-68. Partially translated as "Family, History, Romance," trans. Annwyl Williams, in David Wilson (ed.), Cahiers du Cinéma vol. IV:1973-1978 History, Ideology, Cultural Struggle (London: Routledge, 200o), pp. 132-141.

—, Aux distraitement désespérés que nous sommes... (Toulouse: Éditions Ombres, 1991).

Jean-Marie Straub, "Frustration de la violence," Cahiers du cinéma no. 177 (April 1966), p. 64.

—, interviewed by Michel Delahaye, “Entretien avec J.-M. Straub," Cahiers du cinéma no. 180 (July 1966), pp. 53-57.

—, "Questions aux cinéastes," Cahiers du cinéma no. 185 (December 1966), pp. 123-124.

—, "Sur Chronique d'Anna Magdalena Bach," Cahiers du cinéma no. 193 (September 1967), pp. 56-58.

—, "Chronique d'Anna Magdelena Bach," Cahiers du cinéma no. 200-201 (AprilMay 1968), pp. 42-52.

—, "Féroce," Cahiers du cinéma no. 207 (December 1968), p. 35.

—, interviewed by François Maurin, "À propos d'un film controversé: Entretien avec Jean-Marie Straub," L'Humanité, January 1, 1971.

—, interviewed by Marcel Martin, "Jean-Marie Straub: Balayez-moi tout ça!," Les Lettres françaises, January 13, 1971.

—, "Lettre de Jean-Marie Straub," Cahiers du cinéma no. 233 (November 1971), pp. 49-52.

— and Danièle Huillet, "Entretien," Cahiers du cinéma no. 224 (October 1970), pp. 40-42.

—, "Leçons d'histoire (d'après Les affaires de Monsieur Jules César de Bertolt Brecht): découpage avant tournage," Cahiers du cinéma no. 241 (September-October 1972), pp. 46-66. 
— , interviewed by Joel Rogers, "Jean-Marie Straub and Danièle Huillet Interviewed: Moses and Aaron as an Object of Marxist Reflection," Jump Cut no. 12-13 (December 1976), pp. 61-64.

—, Écrits, eds. Philippe Lafosse and Cyril Neyrat (Paris: Independencia, 2014). 


\title{
5. "Technique et Idéologie" by Jean-Louis Comolli
}

\begin{abstract}
This chapter outlines the six-part series of articles by Jean-Louis Comolli, “Technique et idéologie." Perhaps the most theoretically in-depth text produced by Cahiers du cinéma during its Marxist phase, Comolli's series interrogated questions concerning the ideologically determined nature of film technology, thereby intervening into debates between Cahiers, Tel Quel and La Nouvelle Critique. Here, he argued that the invention and subsequent technological evolution of the cinema is motivated by the interplay between economic and ideological factors. While film does rely on technologies grounded in scientific research, this does not grant it the status of an "objective" instrument, and its insertion into the sphere of ideology (for instance, through its use of Renaissance perspective) cannot be denied. From this point he moves onto a historical discussion of various developments in film technique-from depth of field to the close-up and the advent of sound cinema - and advocates a historiographic method based on Althusser's notion of differential historical temporality.
\end{abstract}

Keywords: Cahiers du cinéma, Jean-Louis Comolli, apparatus theory, film history, depth of field, ideology

\section{Debating the Cinematic Apparatus: Comolli, Lebel, Baudry}

If the texts on Young Mr. Lincoln and Othon staked a claim to being "theoretical criticism," film theory in the purer sense of the term was far from neglected in the period following the publication of "Cinéma/idéologie/ critique." Cahiers refrained from an official response to the pair of rebuttals to "D'une critique à son point critique" printed in issue no. 6 of Cinéthique. "Du bon usage de la valeur d'échange" by the Cinéthique editors had asserted that Cahiers fulfilled "an objective necessity: to represent petty-bourgeois

Fairfax, D., The Red Years of Cahiers du Cinéma (1968-1973). Volume I: Ideology and Politics. Amsterdam: Amsterdam University Press, 2021 DOI 10.5117/9789463728508_CHO5 
ideology in the field of the cinema," and "Le point aveugle" by Marcelin Pleynet, which, on a more conciliatory note, wished that "this point, having been recognized and rectified, may permit them, and permit us, to be done with more serious blind spots." ${ }^{2}$ Disregarding these broadsides, Cahiers pursued its project of theoretical reflection on the basis of the program sketched out in the journal's 1969 editorial, with its focus on the ideological determination of the cinematic apparatus, and key texts during the years 1970-1971 included "Travail, lecture, jouissance" by Daney and Oudart, "Leffet de réel" and "Notes pour une théorie de la représentation" by Oudart, and the series of texts beginning with “'Réalité' de la dénotation" by Bonitzer, all of which will be discussed in the second volume. The most concerted theoretical undertaking of this period, however, and the Cahiers article that has arguably had the most resonance in the history of film theory was the six-part series “Technique et idéologie” by Jean-Louis Comolli, published between May 1971 and September-October 1972, and it is this text that will form the focus of the present chapter. ${ }^{3}$

"Technique et idéologie" is a sprawling, dispersed undertaking, which retains noticeable traces of the condition in which it was written. Composed on a month-to-month basis while Comolli was also absorbed by the more mundane tasks of editing the journal, the series appeared at a moment when Cahiers' own political and theoretical perspectives were rapidly changing. When "Technique et idéologie" was initiated, the journal was still in the midst of its brief alignment with the PCF, but by the time the sixth and final installment had been published, Cahiers had come under the grip of "anti-revisionist" Maoism. Despite the political shifting sands, however, the whole series orbits around the central hypothesis governing Comolli's argument: the history of the cinema can be analyzed from a theoretical framework that takes into account the "reciprocal reinforcement" of the ideological and economic demands placed on the medium by the capitalist

1 "Cinéthique," "Du bon usage de la valeur d'échange (les Cahiers du cinéma et le marxismeléninisme)," p. 11.

2 Marcelin Pleynet, "Le point aveugle," Cinéthique no. 6 (January-February 1970), pp. 13-20, here p. 20. The "point" in question was the period above the comma missing from an earlier citation Pleynet made of Cahiers, which had been remarked upon in Comolli/Narboni, "Cinéma/ idéologie/critique (II)," p. 13 [p. 276].

3 The six installments of "Technique et idéologie" appeared as follows: Part I, Cahiers du cinéma no. 229 (May 1971), pp. 4-21; Part II, Cahiers du cinéma no. 230 (July 1971), pp. 51-57; Part III, Cahiers du cinéma no. 231 (August-September 1971), pp. 42-50; Part IV, Cahiers du cinéma no. 233 (November 1971), pp. 39-45; Part V, Cahiers du cinéma no. 234-235 (December 1971-February 1972), pp. 94-100; and Part VI, Cahiers du cinéma no. 241 (September-October 1972), pp. 20-24. For more on the publication history of Comolli's text in French and English, see Comolli, Cinema against Spectacle, pp. 301-303. 
societies in which it was developed. Despite this theoretical through-line, "Technique et idéologie" is a protean, fluid text, a quality that is accentuated by the large number of interlocutors with whom Comolli engages, whether amicably or antagonistically: Jean-Patrick Lebel, Marcelin Pleynet, JeanLouis Baudry, André Bazin, Jean Mitry, Georges Sadoul, Pierre Francastel, Jean Louis Schefer, Julia Kristeva and Louis Althusser all feature in Comolli's text. Of these, the key polemical sparring partners, at least in the first part of "Technique et idéologie," were Baudry and Lebel. Between them, Comolli, Baudry and Lebel can thus stand in as synecdochic representatives of the three major tendencies of French Marxist film theory during this period as it was being developed on the pages of Cahiers du cinéma, Cinéthique (allied, until mid-1971, with Tel Quel) and La Nouvelle Critique.

"Technique et idéologie" is often seen as a rebuttal to Lebel's own series of articles titled "Cinéma et idéologie." Indeed, Comolli opens proceedings with a stinging repudiation of Lebel and a defense of Cahiers' theoretical outlook against the PCF critic's attacks. By the same token, however, it should be noted that a projected article on the subject of "Technique et idéologie" was first openly mentioned in a March 1970 Cahiers advertisement, thereby predating Lebel's series by several months. Moreover, the polemical nature of Lebel's articles did not, initially, preclude collaborations between the two journals, such as the April 1971 round table on Othon discussed in the preceding chapter. In fact, "Technique et idéologie" did not appear until a full year after Lebel's first critique of Cahiers, a delay that suggests political considerations were involved in the decision to proceed with the writing of Comolli's text: it was only when Cahiers was ready to sever ties with the PCF that it could authorize going public with such a forceful repudiation of Lebel's party-sanctioned viewpoint.

The first part of Lebel's series offers a perspective on the ideological function of the cinema and formed the focal point of Comolli's response. After an opening passage that seeks to distinguish the positions of Cinéthique and Cahiers, Lebel nonetheless tends to treat their respective theoretical perspectives in a synthetic manner, critiquing what he terms the "ideological current" for its "mechanistic conception of ideology" and "essentialist conception of the cinema" and arguing that by "confusing the utilization of

4 See Jean-Patrick Lebel "Cinéma et idéologie," La Nouvelle Critique no. 34 (May 1970), pp. 67-72; no. 35 (June 1970), pp. 6o-67; no. 37 (October 1970), pp. 6o-64; and no. 41 (February 1971), pp. 6o-69. These texts were reprinted in expanded form as Jean-Patrick Lebel, Cinéma et idéologie (Paris: Éditions sociales, 1971). Lebel would go on to be a documentary filmmaker in the 1980 s and 1990 s and died in 2012. 
the cinema by the dominant ideology with a 'natural' blemish of the cinema, cause and effect are inverted and the cinema is made into an ideological instrument 'in itself'." Rejecting arguments that the ideological nature of the cinema derives from the film camera's adoption of Renaissance perspective (itself a product of the nascent bourgeoisie), Lebel insists that the camera is a passive recording device that is "not constructed according to an ideology of representation (in the speculative sense of the term), but on [a] scientific basis." ${ }^{\prime 6}$ Lebel is careful, however, not to divorce the cinema as such from ideology: he considers the cinema today to be overwhelmingly used as a "vehicle of ideology" but insists that this is due not to the inherently ideological nature of the cinematic apparatus but to the very dominance of the dominant ideology in contemporary culture. Such hegemony does not, Lebel argues, preclude the camera from being used for scientific purposes, nor does it invalidate a cinematic practice that could seek to produce a revolutionary alternative to bourgeois ideology. It is this latter possibility that is broached in the second part of Lebel's text, focusing more particularly on the question of film form, where the critic schematically opposes the "deconstruction" proposed by Cahiers (and, to a lesser extent, Cinéthique) to a Brechtian approach that would rest, in his opinion, "more on an aesthetics of 'transparency' than on an aesthetics of 'deconstruction."'7 Although signification "only manifests itself through form(s)," Lebel asserts that no form can, in fact, "claim to have a signification in itself," and he warns that the "valorization of esthetico-theoretical particularities" in avant-garde films can lead to the constitution of a "normative aesthetics that risks merely being the expression of formal snobbism."

Lebel's endeavor was clearly supported by the PCF membership and its organizational machinery. ${ }^{9}$ The party's in-house publishing arm Éditions sociales released the series in an expanded format as the monograph Cinéma et idéologie in mid-1971. And yet Eisenschitz - who was aligned with both Cahiers and La Nouvelle Critique at the time and thus something of a neutral party in this debate-now feels that Lebel was "left to his own devices" by the party's intellectuals and that "there were no real theoretical discussions surrounding his book or its positions. [...] With Jean-Patrick, they abandoned

5 Lebel, “Cinéma et idéologie (I)," p. 70.

6 Ibid., p. 72.

7 Lebel, “Cinéma et idéologie (II)," p. 62.

8 Ibid., p. 67 .

9 La Nouvelle Critique, for instance, published a selection of readers' letters on the debate, which were broadly supportive of Lebel and even more hostile towards Cahiers than Lebel had allowed himself to be. See La Nouvelle Critique no. 37 (October 1970), pp. 58-59. 
him to his fate." Moreover, while stressing Lebel's "formidable erudition," Eisenschitz found that his fellow critic did not have a "theoretical fiber" and considered his ideas to be "a little clumsy."10 Indeed, Lebel's recourse to spurious analogies and his reliance on "common sense" arguments, while perhaps ingratiating himself with the Party, made his texts an easy target for figures schooled in Althusserian Marxism.

It is perhaps not surprising, then, that Lebel's effort has remained obscure and little-read and is generally now mainly known as a straw man for Comolli's argument." The opposite can be said of Jean-Louis Baudry's article for Cinéthique, "Cinéma: effets idéologiques produits par l'appareil de base," perhaps the purest distillation of the notion that it is the camera itself that produces an ideological effect, and a polemical target for both Lebel and, as will be seen, Comolli. Although few have unconditionally adhered to its radical conclusions, Baudry's article has, along with its later pendant, "Le dispositif: approches métapsychologiques de l'impression de réalité," become a key text of film theory, despite the fact that Baudry himself was hardly a specialist in the area. ${ }^{12}$ Baudry even seems to directly address Lebel's argument when asking, in his opening paragraph: "Does the technical nature of optical instruments, directly attached to scientific practice serve to conceal, not only their use in ideological products, but also the ideological effects which they may themselves provoke?" Invoking theorists of Renaissance painting, Lacanian psychoanalysis and Husserl's views on Cartesian subjectivity, Baudry argues that "between 'objective reality' and the camera, site of inscription, and between the inscription and the projection are situated operations, a work which has as its result a finished product."'3 Notably, the Tel Quel critic finds the darkened theater and

10 Interview with Bernard Eisenschitz, April 7, 2014.

11 One of the chief exceptions here is James Spellerberg, "Technology and Ideology in the Cinema," Quarterly Review of Film Studies vol. 2 no. 3 (1977), pp. 288-301. On numerous points, in fact, Spellerberg sides with Lebel over Comolli.

12 See Jean-Louis Baudry, "Le dispositif: approches méta-psychologiques de l'impression de réalité," Communications no. 23 (1975), pp. 56-72. Translated as, "The Apparatus: Metapsychological Approaches to the Impression of Reality in Cinema," trans. Jean Andrews and Bertrand Augst, in Philip Rosen (ed.), Narrative, Apparatus, Ideology: A Film Theory Reader (New York: Columbia University Press, 1986), pp. 299-318. Baudry himself was to say of his reputation as a film theorist: "I am not (I was not) a specialist in cinema, no more than I was a professional intellectual. [...] I merely had the possibility of approaching the cinema through pathways that, as I learnt later, had been rarely taken before.” Jean-Louis Baudry, L'Effet cinéma (Paris: Éditions Albatros, 1978), p. 9. 13 Jean-Louis Baudry, "Cinéma: effets idéologiques produits par l'appareil de base," Cinéthique no. 7-8 (c. mid-late 1970), pp. 1-8, here pp. 1-2. Translated as "Ideological Effects of the Basic Cinematographic Apparatus," trans. Alan Williams, in Rosen (ed.), Narrative, Apparatus, Ideology, pp. 286-298, here pp. 286-287. 
the screen framed with black to be "privileged conditions of effectiveness" for the cinematic apparatus to produce the ideologically charged effects of specularization and identification, and he develops a comparison between the condition of the spectator in a movie-theater and that of a child during Lacan's mirror phase (roughly 6-18 months of age). This view leads him to infer that "the 'reality' mimed by the cinema is thus first of all that of an 'ego'" and that the camera comes to stand in for the transcendental subject of Western metaphysics. For this reason, Baudry concludes that the cinema is an "apparatus destined to obtain a precise ideological effect, necessary to the dominant ideology: creating a phantasmatization of the subject." Only films that contain "disturbing cinematic elements" - such as Vertov's Man with a Movie Camera, which, with its intense auto-interrogation of the mechanisms of the cinematic apparatus, effectively theorizes its own status as a film - are able to avoid being absorbed into this innately idealist function of the cinema. ${ }^{14}$

\section{The Ideology of Film Technology}

Baudry's text is thus a mirror-inversion of Lebel's: the former's naïve faith in the scientific nature of the camera is reflected and reversed in the latter's quasi-paranoiac insistence on the idealist essence of the cinematic apparatus itself, which only the most formally advanced films are capable of escaping. In "Technique et idéologie," Comolli refuses both points of view and seeks to carefully negotiate a path between the two theoretical extremes offered by Lebel and Baudry. Comolli's article begins by taking a clear stance against what he calls "technicist ideology." While he acknowledges that, as the "certain effect of a certain amount of pressure" (tacitly referring here to Cahiers' own efforts), the majority of film critics have accepted the notion that "every film is an ideological product" and that the number of films explicitly asserting their political nature had dramatically risen in the period leading up to his article, Comolli nonetheless remarks on the continued existence of a "point of blockage" amongst film commentators. Surprisingly, this blockage comes in the shape of a demand not for the "autonomy of aesthetic processes" but rather for the "autonomy of technical processes." In other words, the representatives of this tendency demand that "film technique be given a place off to one side, sheltered from ideology, outside of history, social procedures and signification processes. Film technique, they tell us, is precisely a neutral 
technique, capable of being used to say anything and everything, not saying anything in and of itself, and only saying what it is made to say (whether by the filmmaker or the technician)." Here it is not difficult to discern Lebel's text as the principal point of reference for Comolli. Indeed, the Cahiers critic not only avows that "Cinéma et idéologie" has the dubious merit of "formulating the implications of this 'discourse-of-the-technicians," he also spends much of the early section of "Technique et idéologie" debunking the key claim made by Lebel: that the technology of the cinema has a "scientific heritage" free of ideological determinations, a heritage that bestows the medium with the "twin virtues" of precision and neutrality. ${ }^{15}$

And yet the opposition between Comolli and Lebel is not as clear-cut as that between Lebel and Cinéthique. Comolli, in fact, states his agreement with Lebel that the cinema does not possess a "natural ideological blemish," although he clarifies that this should not "conceal, behind an inconsistent 'scientific basis,' the fact that it is under the effects of an economic demand - that is, within ideology and as an instrument of ideology - that the cinema is progressively imagined, made and purchased. ${ }^{.6}$ By the same token, Comolli distances himself from the position of Baudry and Pleynet (whose interview in issue no. 3 of Cinéthique is quoted at length). He argues that the Tel Quel writers, while analyzing the ideological nature of the cinematic apparatus, hypostasize the camera as a metonymic substitute for the broader processes of film technique. While Comolli acknowledges that Lebel points out this tendency, he notes that the PCF critic "never shows the reader that he prevents himself from doing the same," since Lebel's argument as to the "objectivity" of the cinema rests largely on the scientific basis of camera technology ${ }^{17}$ Despite targeting the "ideology of the visible linked to Western logocentrism" through their discussions of the role of quattrocento perspective in the ideological make-up of the film apparatus, Pleynet and Baudry succumb to what Comolli sees as a theoretical paradox: "It is by focusing on the domination of the camera (the visible) over the whole of film technique which it is supposed to represent, inform and program (through its function as model), that one intends to denounce the submission of this camera, in its conception and construction, to the dominant ideology of the visible." ${ }^{18}$ 
Against this privileging of what Comolli calls "the visible part of film technique," which reinforces a cleavage that already exists in the technical practice of the cinema, the Cahiers critic advocates concentrating on the "invisible part" of the cinema, defined here as "the black space between the frames, chemistry, developing baths, laboratory work, negative copies, the cuts and 'matches' of the editing process, the soundtrack, the projector, etc." For Comolli, these processes constitute the "unthought, 'unconscious' side" of the cinema, an aspect of film technique that is actively repressed by the emphasis, in film theory and criticism, on the act of shooting with a camera. In making this argument, Comolli echoes the critique of the "real = visible" equation earlier issued by Serge Daney in his article "Sur Salador."19 Comolli thus ends his initial section of "Technique et idéologie" by calling for a discussion of two techniques in film practice that "reside within cinema's hidden, unconscious realm" - namely, color grading and sound mixing. And yet, despite unequivocally stating that "this is what we will attempt," the promised inquiry never really eventuates. Instead, Comolli makes a detour into film history from which his text never returns: his attention, over the course of the rest of his series of articles, falls more on a historical analysis of the economic and ideological determinations of the evolution of film as a "signifying practice," discussing, in sequence, the series of technical advances leading up to the invention of the cinema, the use of deep-focus photography, the role of the close-up, and the advent of sound film, before the series is prematurely cut short.

Before turning to these sections, it is worth examining the question of ideology and the cinema in Comolli's article and its roots in Althusserian theory. In refusing the clear-cut dichotomy presented by the respective stances of Lebel and Baudry, Comolli maintains that a "materialist theory of the cinema" should not see the cinema's "ideological heritage" and its "scientific heritage" as being mutually exclusive of each other but rather as interacting with each other, entering into reciprocal relationships with one another. His line of thinking thus resonates with contemporaneous texts by Althusser such as "Lénine et la philosophie" and "Idéologie et appareils idéologiques d'état" in which the philosopher moves away from his earlier binary opposition between the scientific and ideological domains. ${ }^{20}$ As

19 Ibid. pp. 7-8 [pp. 151-152]. Daney's text appears in Serge Daney and Jean-Pierre Oudart, “Travail, lecture, jouissance," Cahiers du cinéma no. 222 (July 1970), pp. 39-46. Translated as "Work, Reading, Pleasure," trans. Diana Matias, in Browne (ed.), Cahiers du Cinéma vol. III, pp. 115-136. 20 See Louis Althusser, "Lénine et la philosophie" (1968), in idem., Solitude de Machiavel, ed. Yves Sintomer (Paris: P.U.F., 1998), pp. 103-144. Translated as “Lenin and Philosophy," in Louis 
such, Comolli's text can be clarified with recourse to two Althusserian concepts from this period. The first is the philosopher's distinction between ideologies in the specific, historically determinate sense and ideology more generally as that which "human societies secrete [...] as the very element and atmosphere indispensable to their historical respiration and life."21 The second, meanwhile, is Althusser's notion of overdetermination: that is, the idea that any given situation is "complexly-structurally-unevenly determined" by the structural totality. ${ }^{22}$ Inspired by Freud's attempts at unravelling the psychological determinations of the dream-work, Althusser sought to portray the complex, mutually intersecting dialectics at work in any historical process, which can lead, for instance, to the first proletarian revolution taking place in a nation where the relations of production had "matured" to a far lesser degree than other industrialized powers. So too, in Comolli's understanding, does the history of the cinema unfold in a complex relation of structural determination with broader historical/social processes: it neither evolves in an autarkic fashion divorced from the social totality nor is it a direct reflection of these processes or the ideology that underpins them. Reading Comolli in the light of Althusser, then, we can comprehend the cinema as being historically overdetermined by bourgeois ideology (due primarily to the fact that its invention and technical development has largely taken place in modern capitalist societies), but this by no means entails that film is by its very nature an idealist phenomenon unwaveringly diffusing this selfsame ideology.

Utilizing these lessons from Althusser, Comolli's insistence on the imbrication of the economic and ideological aspects of the development of the cinema and their mutual overdetermination may represent his key theoretical breakthrough. The theoretical maneuver allows his study to avoid the twin pitfalls that had beset other Marxist accounts of the evolution of cinema: a mechanistic economic determinism on the one hand, which would understand the cinema purely from the standpoint of the profit motive of the bourgeoisie, and an essentializing of ideology on the other hand, which can be found in Baudry's claim that the very mechanism of the cinema propagates the idealist metaphysics of bourgeois ideology. Instead, it is the confluence of - and at times contradiction between-these two factors that animates the historical development of film technique. 


\section{"Birth = Deferral": The Invention of the Cinema}

The interplay between ideology and economics can perhaps best be seen in the long — and, as Comolli sees it, "deferred" — gestation of the cinema, culminating in its "birth" in the late nineteenth century. If, as film historians agree, the actual invention of the cinema significantly postdated the moment of its technical viability, what is it that explains this "deferral," this chronological discrepancy, this décalage? An initial response is suggested by Bazin in "Le mythe du cinéma total," his review of the Marxist (and PCFaligned) film historian Georges Sadoul's L'Invention du cinéma (1832-1897). Here Bazin asserts, in a passage quoted at length by Comolli, that:

In this instance we need to reverse historical causality, which proceeds from the economic infrastructure to the ideological superstructure, and view fundamental discoveries as fortunate and propitious accidents essentially secondary to the initial conceptions of cinema's inventors. Cinema is an idealist phenomenon; men's idea of it existed fully equipped in their brains, as in Plato's higher world, and the tenacious resistance of matter to the idea is more striking than technology's prompting of the inventor's imagination. ${ }^{23}$

Writing for Cinéthique, Leblanc latches onto this passage-and Bazin's subsequent argument that the key figures involved in the invention of the cinema in the nineteenth century were "obsessive eccentrics, handymen or, at best, clever industrialists" - in order to support his notion that the cinema has a fundamentally "idealist" nature. Bazin, Leblanc contends, "always underlined the idealism that presided over the invention of the camera, the artisanal, non-scientific character of its construction. The camera realized one of man's ancestral dreams: to reproduce reality, to reproduce oneself." ${ }^{24}$ The claim is easily refuted by Lebel, who notes that all technical inventions in the pre-modern era had an "artisanal character," which does not necessarily negate their scientific status. ${ }^{25}$ On this point, Comolli is in agreement with the author of Cinéma et idéologie. He nonetheless insists that the question as to whether the discoveries leading up to the invention of the cinema as

23 André Bazin, "Le mythe du cinéma total," in idem., Qu'est-ce que le cinéma? vol. I, pp. 21-26, here p. 21. Translated as "The Myth of Total Cinema," in idem., What is Cinema?, trans. and ed. Barnard, pp. 13-20, here p. 13. Cited in Comolli, "Technique et idéologie (I)," p. 10 [p. 156].

24 Gérard Leblanc, "Welles, Bazin et la RKO," p. 30.

25 See Lebel, “Cinéma et idéologie (I)," p. 71. 
a technological device were "scientific" or not is one whose importance is secondary to that of the cinema's status as a "signifying practice" producing meaning and ideology. For Comolli, this is precisely the issue that eludes Lebel - a theoretical blind spot evinced by the latter's notoriously maladroit analogy of the cinema with aviation (another realization of an "ancient dream of humanity"). ${ }^{26}$

Comolli notes the problems historians have had in arriving at an original date for this prehistory (which is "lost in the dark night of ancient times and myths") as well as the difficulties they have had in adequately accounting for the "brusque condensation of research and invention" in the second half of the nineteenth century, which resulted in near simultaneous technical developments occurring autonomously in several different industrialized nations. ${ }^{27}$ Rejecting the notion of a providential coincidence in the state of scientific research, Comolli accounts for this phenomenon by turning to "the sphere of ideology" and, more pointedly, highlighting "the rift opened up by photography in the figurative representations of the world, in the fresh questions it provoked [...] on the central role of the human eye, its solar position, its intimate relationship with the world." ${ }^{28}$ The photographic image, in Comolli's view, not only perfects and reinforces the method of perspectiva artificialis developed by Renaissance painting, it also leads to a "crisis of confidence" in the human eye as an organ of vision, fostering a pronounced interest in optical illusions and the decomposition of visual perception - as exemplified by the experiments of Plateau, Marey and Muybridge, who were all notably unconcerned with realizing the "ancient dream" of visually reproducing the world such as we see it. And yet, for these experiments to transcend their status as scientific curiosities and become a socially widespread signifying practice, another aspect would be decisive, one that went beyond the mere technical advances made by Edison and the Lumières. This is the economic factor, the ability to derive financial profit from the invention of the cinematic apparatus. With reference to discussions by Deslandes and the British film historian Brian Coe concerning the importance of the profit motive in the development of the Lumières' cinématographe and Edison's kinetoscope, Comolli argues that this

26 Comolli, “Technique et idéologie (I)," p. 11 [pp. 158-159].

27 Ibid., pp. 11, 12 [pp. 159, 162]. For the pre-history of the cinema, Comolli largely relied on information provided in Jacques Deslandes' Histoire comparée du cinéma and Bessy/Chardans' Dictionnaire du cinéma et de la télévision, some of which is now outdated. See Jacques Deslandes, Histoire comparée du cinéma vol. I (Brussels: Casterman, 1966); and Maurice Bessy and Jean-Louis Chardans, Dictionnaire du cinéma et de la télévision (Paris: Jean-Jacques Pauvert, 1965).

28 Ibid., p. 12 [p. 162]. 
economic impetus is, in fact, the "principal determination in the constitution of film technique." ${ }^{29}$ It is the opening up of a social demand for moving images that leads to the frenetic technical advances of the 189os, with the "simultaneous eruption onto the market of several, practically identical, recording-projecting devices." Thus, Comolli concludes, the cinema "owes its existence to the reciprocal reinforcement of an ideological demand ('to see life as it is') and an economic demand (to make it a source of profits)." In this sense, the cinema is "no different to the majority of technologies, which tend toward the realization of an objective assigned by and constituted in both of these two demands." ${ }^{\circ}$

There are certainly questions left unresolved by Comolli's account of the "deferred" birth of the cinema. Why, for instance, does the social/economic demand for the cinematic apparatus only open up in the 1890 s and not earlier (or later)? What explains the uncanny simultaneity of near-identical inventions, independently developed, in countries as economically and culturally disparate as the US, France, Germany and Russia? On these and other matters, Comolli remains silent, and these gaps in his text evidently call for greater research - much of which has indeed been carried out by film historians in the decades since his articles appeared. There are empirical omissions and inaccuracies in "Technique et idéologie," but these are of secondary consequence when compared to the capital importance of the broader perspective adopted by Comolli, which, in articulating economic and ideological factors, represents a clear advance over both empiricist and vulgar Marxist accounts of film history. All proportions guarded, the significance of his series in the realm of film history can thus be seen as analogous to that of Engels' The Origins of the Family, Private Property and the State in anthropology, a text which, while based on outmoded nineteenth-century conceptions of early human societies, is nonetheless still a valuable epistemological tool for Marxists in the field by virtue of its elucidation of methodological principles that retain a more generalized validity. $3^{1}$

29 Ibid., p. 14 [p. 166]. For the Coe text, see Brian Coe, "William Friese Green and the Origins of Kinematography,” The Photographic Journal (March-April 1962), pp. 92-104, 121-126.

30 Ibid., p. 15 [pp. 168-169].

31 It is for this reason that Joubert-Laurencin's recent claim that Comolli's text has "become anachronistic" should be resisted. See Hervé Joubert-Laurencin, Le Sommeil paradoxal, p. 204. In one particular area, however, Comolli now fully accepts the outdated nature of his text: whereas in 1971 he had spoken about the "persistence of vision" to explain the sensation of movement caused by the rapid succession of still images, he now accepts that this hypothesis is scientifically outmoded. See Comolli, Cinéma contre spectacle, p. 49-50 [pp. 82-83]. 
It is indisputably the stridently anti-teleological outlook that Comolli espouses in his article that has had the greatest impact in film historiography, and this stance will be of crucial importance in his discussion of the contradictory development of depth of field cinematography in the first half-century of the cinema's existence. In a section of his text titled "For a materialist history of the cinema," Comolli not only argues against understanding film history as the autonomous evolution of aesthetic forms divorced from broader historical currents, he also warns against conceiving of its relationship to society in general as "a system of direct causality - one that is overly simplistic, elementary, and, above all, convenient because it confirms the illusion of a homogenous, full, continuous historical temporality." ${ }^{22}$ Here, despite their differences, both Bazin's and Lebel's accounts of the cinema converge and lead to a teleological position that interprets the modification of techniques and styles as a process of increasing perfection, with the cinema in its current state the implied ideal to which all previous innovations had been striving. Against this tendency, Comolli invokes the notion of "differential historical temporality" found in Lire le Capital, a concept which, in Althusser's words, "obliges us to [...] to think in its peculiar articulation, the function of such an element or such a level

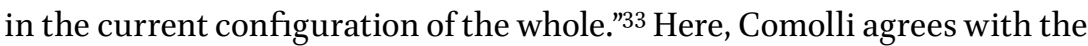
standpoint articulated by Norbert Massa, a writer for the ephemeral film magazine Ciné-forum, who argued that "the constitution of a history of the cinema requires the determination of the historical moment where the filmic text appears in a reduplication designating it as such: this is the first scansion of history, and, for theory, it is the point of no return from history as science to the ideology of history." ${ }^{34}$

Following Massa, Comolli also insists on the centrality of Kristeva's concept of the "signifying practice" in the development of a "materialist history of the cinema." 35 Kristeva devised the term primarily to relieve aesthetic theory of the burden of the "ideology" of artistic creativity, enabling

\footnotetext{
32 Comolli, "Technique et idéologie (II)," p. 55 [p. 189].

33 Althusser et al., Lire le Capital, p. 133 [p. 106]. Cited in Comolli, "Technique et idéologie (II)," p. 57 [p. 193].

34 Cited in ibid., p. 56 [p.192]. Ciné-forum was a roneotyped bulletin published by the organizing committee of a film society in Poitiers. Apart from the favorable attitude Cahiers exhibited towards the magazine, however, little is known about it (or Norbert Massa) today. For more on Ciné-forum, see Pascal Bonitzer, "Ciné-forum," Cahiers du cinéma no. 230 (July 1971), pp. 63-65. 35 See Comolli, "Technique et idéologie (II)," p. 57 [pp. 192-193]; and Julia Kristeva, "Cinéma: pratique analytique, pratique révolutionnaire," Cinéthique no. 9-10 (c. early 1971), pp. 71-79, here p. 74 .
} 
art to instead be understood, precisely, as a practice, as a socio-historical formation. Understanding the cinema as a "signifying practice" will, Comolli hopes, allow future film historians to overcome some of the impasses reached by figures such as Brasillach, Sadoul and Mitry when contending with the development of new film techniques — in particular by distinguishing between the mass of films that, due to their "univocal signification," merely embody the cinema as an ideological apparatus, and those "films of rupture" in which "the work in the signifier modifies the statute of meaning," thereby creating a surplus exceeding the norms of communicative discourse (or, in Comolli's words "the ideology of signification"). ${ }^{36}$ For Kristeva, the concept of signifying practice can lead to a "smashing" of "the conceptual mechanism which produces a historical linearity" and to a reading of "stratified history: with a discontinuous, recursive, dialectical temporality, irreducible to a singular meaning, but made up of types of signifying practices whose plural series remain without origin or endpoint."37 It is on this basis that Comolli urges his readers to understand film technique as "a double scene of practice and signifying." This reasoning also leads him to issue a challenge to disciplinary boundaries that even now, more than four decades later, remains pertinent: for Comolli, "it is no longer possible to keep film history and film theory hermetically sealed from one another." ${ }^{38}$ Instead, we must recognize that theoretical questions in the cinema always imply problems of film history, and vice versa.

\section{"For the first time...": The Close-Up and Depth of Field Cinematography}

Following the model of Althusser's "symptomatic" reading method in Lire le Capital, Comolli finds a symptom of the inadequacies of the linear, teleological histories of the cinema in the frequency with which a "fixed syntagm" is uttered — namely, the phrase, "for the first time...." He writes:

The decisive operation of these "histories" is to evoke and give an overview of the greatest possible number of technical, stylistic and formal

36 Comolli, “Technique et idéologie (III)," p. 44 [pp. 195-196]. Here, Comolli is distinctly following the argument of the earlier text "Cinéma/idéologie/critique."

37 Julia Kristeva, Sémiotiké: Recherches pour une sémanalyse (Paris: Seuil, 1969), p. 13. Cited in Comolli, "Technique et idéologie (III)," p. 44 [p. 196].

$3^{8}$ Ibid. [p. 197]. 
innovations, each one of which is presented (and sought out) as the initiation of a succession of aesthetic developments (the "progress" of a "language") whose finality, endpoint or perfection is the cinema such as it is practiced at the moment when each historian writes its history. ${ }^{39}$

Comolli locates one of the key examples of this tendency in the writings of Jean Mitry. Mitry, he asserts, represents an "a contrario demonstration" of the imperative to combine film history and film theory by dint of the fact that he had "scholastically" divided his study of the cinema into a History and an Aesthetics and Psychology..$^{40} \mathrm{In}$ an argument that is also articulated in Cahiers by Bonitzer's parallel series of articles "La 'Réalité' de la dénotation," Comolli maintains that it is Mitry's contradictory reflection on the "first close-up" in the history of the cinema that betrays the limitations of his theoretical perspective and his conformity to the prevailing "technicist ideology."41 In particular, Comolli points out the telltale notional vagueness of Mitry's phrase "the close-up as we know it" (used with reference to Griffith's 1913 film Judith of Bethulia), deploying it as evidence that the theorist remains beholden to an "empirical understanding of the 'close-up." Comolli argues that "there is no kinship between the close-ups of 1913 and those of 1960 that would guarantee their equivalence, because the pertinent element of the opposition is not the parameter of the size of the shots, but the network of differences of determination between two moments of film practice, differences which, precisely, prohibit the constitution of an ahistorical chain of 'close-ups'."42 More generally, he sees the need for formal devices such as the close-up to be theoretically defined before the question of their first historical appearance can be broached. Such a theoretical definition, moreover, would perforce involve relating the technique in question to the broader signifying practices at work in the film.

In an article for Cahiers de la Cinémathèque, Mitry vigorously defended himself from the criticisms of his work made by Comolli. Averring that the Cahiers critic "incessantly conflates the noun that designates a technical fact and the qualifier that implies a signifying value," Mitry insists that questions of technique are, in fact, secondary to aesthetic considerations in his study

Ibid., p. 45 [p. 197].

40 Ibid., p. 47 [p. 201]. See also Jean Mitry, Histoire du cinéma: Art et industrie (Paris: Éditions universitaires, 1967), 5 vol.; and Jean Mitry, Esthétique et psychologie du cinéma (Paris: Éditions universitaires, 1963), two volumes.

41 For a discussion of the series of articles by Bonitzer beginning with "La 'Réalité' de la dénotation," see Chapter 24.

42 Comolli, “Technique et idéologie (III)," p. 47 [p. 203]. 
and are only addressed to the extent that they are considered "in the context of production, and for what [they] can signify in this production. ${ }^{133} \mathrm{He}$ also disputes the charge of a "teleological" approach to film history, describing his method as follows:

Historians observe present facts just as they observe facts from the past. They then research, discover and analyze the cause and effect chains that constitute and shape the past. But these continuous chains do not entail a linear development unfolding within a determinist, univocal logic, inevitably leading from a lesser to a higher degree of perfection. [...] There is progression but not necessarily "progress." Progress is a value judgement imposed on these historical facts; it is not the facts themselves. ${ }^{44}$

Mitry further develops his response to Cahiers (and other theorists of ideology in the cinema such as the Cinéthique editors) in the book-length study La Sémiologie en question. ${ }^{45}$ It is unfortunate, however, that Mitry fails to address Comolli's remarks on another area of film technique, depth-of-field cinematography. ${ }^{46}$ Here, his younger colleague's critique appears much more difficult to refute. Indeed, a large proportion of "Technique et idéologie" is consumed with discussions of depth of field and more particularly its place in the theories of Bazin and Mitry. The two French film theorists had notable differences with each other: most pointedly, Mitry registered his disapproval of Bazin's "transcendental realism" and refused to countenance the existence of the plan-séquence, preferring to see such takes as a series of spatially contiguous yet distinct "shots." Comolli, however, rebukes both theorists for the shared theoretical problems created by their teleological accounts of film history, considered autonomously both of other signifying practices (especially theater, photography and painting) and of broader social and historical processes. In particular, Comolli highlights a conceptual stumbling block that confronted the two theorists: the provisional abandonment of depth-of-field cinematography in the years after 1925 and its return, in an altered mode of signification, in the films of Renoir and Welles from the late 1930s onwards.

Resting largely on the articles "Lévolution du langage cinématographique" and "William Wyler ou le janseniste de la mise en scène," Comolli's précis

43 Jean Mitry, “De quelques problèmes d'histoire et d'esthétique du cinéma," Cahiers de la Cinémathèque no. 10-11 (1973), pp. 113-141, here pp. 133, 123.

44 Ibid., p. 121.

45 See Jean Mitry, La Sémiologie en question (Paris: Éditions du Cerf, 1987), especially pp. 61-64.

46 In his Cinématographe article, Mitry foreshadows doing so in a follow-up text, but this never materializes. Mitry, “De quelques problèmes," p. 141. 
of Bazin's views on the merits of a film aesthetic based on depth-of-field photography can be summarized in a couple of key points: by more closely approximating the norms of human perception and thereby revealing the "immanent ambiguity of reality" (or, as Comolli frames it, reinforcing the "reality effect" of the cinematic image), the deep-focus style practiced by filmmakers such as Welles and Wyler creates a "surplus realism" (the term is Bazin's but self-consciously has echoes of Marx's "surplus-value") which, as opposed to the Soviet montage style and its implied authoritarianism, more adequately reflects both the cinema's representational vocation and the liberal-democratic ideology of American society. ${ }^{47}$ Although Bazin's last point is at least partly tongue-in-cheek, Comolli nonetheless notes that he requires not a few rhetorical coups de force in order to sustain his argument, including his perverse inclusion of Stroheim in the anti-montage school.

Whereas Bazin sees a relationship of analogy between the cinematic image and everyday perception, Mitry stresses the "mediatized nature" of film and more specifically the spatially and temporally fragmentary, delimited nature of the shot, which stands in stark contrast to the homogeneity and continuity of human vision. On this question, however, his position ends up approximating that of Bazin. For Mitry too, deep focus constitutes a form of "surplus realism," although in his view it makes up for a lack of verisimilitude rather than adding to the cinema's innate analogical power. Or, as Comolli puts it: "With the proviso that depth of field not be turned into an omnivalent principle, capable of being substituted for all other formulations of mise en scène, Mitry declares himself, in this matter, to be 'perfectly in agreement with Bazin."' ${ }^{8}$ More incongruously still, for Comolli, even Cinéthique's Leblanc gives credence to the idea of a "surplus reality" arising from the deep-focus shot, unquestioningly accepting Bazin's notion that "deep focus and the long-take assure the impression of reality."49 Here, however, Leblanc's argument comes not to extol the cinema's realism but to damn its congenitally "illusionist" nature.

For Comolli, by contrast, nothing could be less certain than the notion that the image generated by deep-focus lenses yields a more "lifelike" visual

47 Comolli, "Technique et idéologie (I)," p. 18 [p. 175-176]. See André Bazin, "William Wyler ou le janseniste de la mise en scène," in idem., Qu'est-ce que le cinéma? vol. I, pp. 149-173, here p. 160. Translated as "William Wyler, the Jansenist of Mise en Scène, in idem., What is Cinema?, trans. and ed. Barnard, pp. 45-72, here p. 57 .

48 Comolli, "Technique et idéologie (I)," p. 21 [p. 181]. See also Mitry, Esthétique et psychologie du cinéma vol. II, p. 169 .

49 Leblanc, "Welles, Bazin et la RKO," p. 30. Cited in Comolli, “Technique et Idéologie (I)," p. 21 [p. 181]. 
field than do other cinematic forms; rather, he argues that, in the films of Welles in particular, it "produces a space that is at once composite and composed, fragmentary and discontinuous, and distinctly coded. ${ }^{\circ 0}$ Comolli even proposes that depth of field, "far from manifesting a 'surplus reality,' actually enables the filmmaker to show less of the real, to play around with masking effects and visual tricks, as well as with the division and distortion of space..." ${ }^{11}$ Intriguingly, however, of the three figures with whom he here polemicizes, Comolli ends up most sympathetic to Bazin. Leblanc, who is otherwise politically closest to Comolli, is taken to task for his "hurried" reading of Bazin, which failed to take into account his "place within ideology, the tangle of determinations which acted upon him, and even the insertion and effect of his discourse in the field of cinematic practice.".52 Mitry is critiqued for failing to apprehend the disavowal mechanisms that lead the spectator to accept the "illusion of homogeneity and continuity" created by cinematic signification, despite the fact that filmic space is carved up in a way that is alien to "natural" vision. His "formalism" is thereby considered by Comolli to be the flip side of Bazin's "idealism."53 As for Bazin himself, while Comolli repeatedly insists on his "idealist" worldview, his conceptual system nonetheless has-in comparison to those of Mitry and, a fortiori, Leblanc - the virtue of coherence and possesses a "certain theoretical force" to the extent that reading his work impels us to locate the "indices of contradiction" that end up subverting his own discourse. ${ }^{54}$ Comolli admits that such an approach may provide grist to the mill of figures such as Lebel and Leblanc - both of whom, in spite of their own far-reaching differences, insist on the kinship between Bazin and Cahiers in its Marxist phase and do so in order, as Comolli puts it, "in the name of our 'father' to mark us with the indelible imprint of idealism." 55 But he is unafraid to run this risk, and, in a line that may well serve as an epigram for the post-1968 Cahiers' relationship with the journal's founder, Comolli finds an analogy for his attitude towards Bazin in a quote from Lenin, speaking of Hegel, to the effect that "intelligent idealism is more intelligent than stupid materialism. ${ }^{56}$

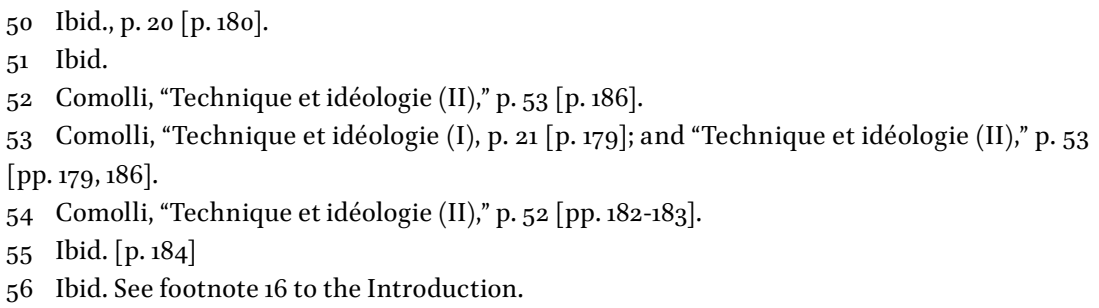


Indeed, retrospectively, Comolli is even more conciliatory towards Bazin. He has recently stated: "I must admit that we were very Bazinian, but Bazin is more complex than people take him for. He wrote things which, if not contradictory, at least tended to be open. Bazin interested me much more as a theorist than as a critic." He does not shy away, however, from acknowledging the paradoxical nature of his relationship with the film theorist. While readily admitting to an affinity with Bazin, Comolli clarifies that: "It is an affinity that comes from an opposition, that is what is interesting. In trying to critique Bazin I ended up very close to him." ${ }^{57}$

\section{“Which Speech?": Depth of Field and the Advent of Sound Cinema}

Such contradictions again come through in Comolli's treatment of the "almost total eclipse" of depth of field in filmmaking practice between 1925 and 1940, which evidently presents a problem for a putative teleological history of the cinema that would understand the medium as irresistibly tending towards a higher degree of "realism" through the increasing prevalence of a deep-focus, long-take aesthetic. If this tendency towards what Bazin called the "asymptote" of reality exists, then how can this hiatus be explained? If depth of field is already present in the films of the Lumière brothers, why should it disappear from screens for a decade-and-a-half? The question, indeed, is not ignored in Bazin's essay on the evolution of film language. He ascribes the adoption of shallow focus to the rise of a montage aesthetic and lucidly insists on the functional difference between "primitive" depth of field and the technique as used by later filmmakers such as Welles, Renoir and Wyler. ${ }^{5}$ Mitry, by contrast, confidently gives an alternative explanation to resolve the enigma: the loss of depth of field can be attributed, he claims, to the adoption of panchromatic film stock in the mid-1920s, which required a different, less powerful lighting system and resulted in the inability to clearly represent deep visual fields. .9

For Comolli, however, the solution proffered by Mitry merely "explains technical changes through other technical changes, without for a moment envisaging that these changes are not 'free,' that they bring into play economic forces and forces of labor." Mitry therefore unwittingly creates

57 These three quotes all come from Comolli, "Yes, we were utopians, (Part I)."

$5^{8}$ André Bazin, "L'Évolution du langage cinématographique," pp. 141-142 [pp. 99-10o]

59 See Mitry, Esthétique et psychologie du cinéma vol. II, p. 41. Cited in Comolli, "Technique et idéologie (IV)," pp. 43-44 [pp. 211-212]. 
an "(interminable) chain of "technical causes." ${ }^{\prime 60}$ Instead, the temporary "effacement" of depth can be accounted for, Comolli argues, through "the displacing of the codes of cinematic verisimilitude from the level of the mere impression of reality to the more complex levels of fictional logic (narrative codes), psychological verisimilitude, and the impression of homogeneity and continuity (the coherent space-time of classical drama). ${ }^{n 1}$ More specifically, panchromatic stock brought about a more fine-grained gradation of color shades and thus represented a gain in the level of "fidelity 'to the colors of nature" (while still remaining monochromatic); with the social spread of consumer photography, Comolli posits, the high-contrast images of early cinema were no longer found to satisfy the prevailing "codes of photographic realism," and, momentarily at least, "in the production of 'reality effects,' depth (perspective) thus lost out in importance to shades, tones and colors." ${ }^{2}$ For Comolli, therefore, it is the shift in the ideological requirements of the codes operative in film that determines, in the final instance, the cinema's momentary "disaffection" for depth of field.

By critiquing Mitry's "technicist" account, Comolli acknowledges that he could appear to be in proximity to Bazin's thesis on depth of field, which also rejects a technical explanation for this stylistic phenomenon. But he insists that Bazin, too, errs in "determin[ing] the demise and rebirth of depth of field by turning it into the 'will' or 'lack of will' of a given filmmaker or technician." ${ }^{63}$ It is here, moreover, that Comolli carries out another shift in his text's focus, precipitated by the observation of a symptomatic absence in Mitry, who discusses the technical reasons for the abandonment of depth of field without mentioning what is indisputably the paramount technical transformation in the cinema in the second half of the 1920s: the advent of sound. Noting that the chain "panchromatic stock/shallow-focus lenses/ sound cinema" functions better as a "technical causality" than Mitry's account, Comolli nonetheless admits that this "better' explanation would only serve to re-mark the coincidence between the arrival of sound cinema and the ejection [mise hors-jeu] of depth of field—and it would not provide us with an underlying reason. ${ }^{64}$ In fact, both phenomena were determined

\footnotetext{
6 Ibid., pp. 44-45 [pp. 218-219].

61 Ibid., p. 43 [p. 216]

62 Ibid., p. 44 [p. 219]

63 Comolli, "Technique et idéologie (V)," p. 96 [pp. 225-226]. The reference is to Bazin's statement, in "L'Évolution du langage cinématographique," that when it came to the rise of depth-of-field photography in the late 1930s, "It was enough to want to do so" ("Il suffisait de vouloir"). See André Bazin, “L’Évolution du langage cinématographique," p. 138 [p. 95].

64 Comolli, “Technique et idéologie (V)," p. 97 [p. 229].
} 
by the intertwining of ideological and economic factors, which also explains the "delay" or "différance" between the technical viability of synchronized sound film (possible, Comolli notes, as early as 1912) and its widespread adoption by Hollywood in the years following $1927 .{ }^{65}$

This adoption of sound swiftly made the silent film image "intolerable" for spectators, but it also led to a "sharp decline" in the formal quality of Hollywood films, which ceded any reference to novelistic or even musical formal models in favor of a dependency on "bourgeois theater" (Broadway in particular). Latching onto a remark made by Benjamin, Comolli notes the historical paradox that the "nationalization" of cinemas brought about by the use of spoken language in place of linguistically interchangeable written intertitles entailed a process of "internationalization" both of the global film industry's economic structures and of film language itself. ${ }^{66}$ Gone were the formal "schools" of the silent era, to be replaced by the "global hegemony" of "Hollywood and its epigones." ${ }^{7} 7$ With a few notable exceptions (Vertov, Eisenstein, Chaplin), the question of which speech would be found in the talking cinema failed to be posed by the film industry; it was simply assumed that "life itself would speak" and that "all that had to be done was to 'capture' this speech in life in order to 'put' it in the film," with the supposed "mimetic nature of the cinema" guaranteeing the success of the maneuver. ${ }^{68}$ In Comolli's account, the Hollywood sound film, by more preponderantly handing the cinema over to the forces of spectacle (especially in the newly minted genre of the musical), played a vital role in ideologically insulating the American populace at a time when the US was facing one of the most serious economic and political crises in its history, the Great Depression. But it also had a transformative effect on the cinema's formal structures: far from "bring[ing] editing back to realism," as Bazin proposed, the advent of sound "utterly liquidated montage as a general principle of cinematic writing" in the cinemas of the capitalist nations, which instead adopted a rigidly codified form of "classical découpage" in order to attain "a certain realism determined by capitalist relations of production and the bourgeois conception of the world." ${ }^{\prime 9}$

It is here that Comolli infers an additional motivation for the rise of sound cinema and, concomitantly, the "invisible" editing of classical découpage

65 Ibid., p. 99 [pp. 232-233]

66 Comolli, "Technique et idéologie (VI)," p. 21 [pp. 238-239]. The Benjamin remark appears in Walter Benjamin, "The Work of Art in the Age of Mechanical Reproduction,", in idem., Illuminations, trans. Harry Zohn, ed. Hannah Arendt (New York: Schocken, 1968), pp. 217-251, here p. 244. 67 Ibid.

68 Ibid., p. 20 [p. 237]

69 Ibid., p. 23 [p. 241]. 
(one which, however stimulating, may not withstand sustained historical scrutiny): an industrial and political rivalry with Soviet montage cinema, which had reached its own apogee in the late 1920s - notably with the popular success in Western Europe and North America of Battleship Potemkin - at the precise moment that Hollywood made its turn to sound. Between an aesthetic based on montage and one based on analytic découpage, Comolli concludes, "there is not a harmonious evolution, an unobtrusive gradation, a transition through improvements and corrections, from a lesser to a greater degree of realism, but a rupture. There is an antagonism between the two systems, the latter is not an advance on, or the conclusion or transcendence of the former, but its refusal and its censorship." ${ }^{70}$ The two different approaches to the articulation of images in the cinema thus stood in for two inimical ideological systems (capitalist and socialist), and although Comolli warns against making a hasty equation between montage/ découpage and materialism/idealism, he insists that it is "not for nothing that Eisenstein and Vertov conceived, practiced and defended montage as responding to the dialectical materialist conception of film writing and the filmic scene." The découpage of the sound era in Hollywood, by contrast, insists on a "continuous, homogenous, oriented space" but does so through the "phantom machinery" of "invisible" editing procedures: the system requires both cuts and their perceptual effacement in order to reproduce and reveal the filmic scene as "an already-there." ${ }^{11}$ After the historical defeat of Soviet montage, due to a combination of Stalinist political repression and the industrial supremacy of Hollywood sound cinema, it is only in the 1960 - and particularly with the experiments made by Godard in films such as Vivre sa vie (1962) and Une femme mariée (1965) — that this system is again interrogated and disrupted and new formal pathways begin to be explored.

Despite the theoretical potency of Comolli's discussion of sound, these passages are by far the least well-known section of "Technique et idéologie" and were only made publicly available in English translation in 2015. Moreover, they were left incomplete by Comolli himself, with a lapidary "à suivre" ("to be continued") capping off the final installment, symptomatically promising a continuation of the text that would never be fulfilled. Indeed, a petering out of the series of articles that went by the name "Technique et idéologie" could already be discerned by this point: after the initial five installments appeared consecutively in almost every issue of Cahiers between no. 229 (May 1971) and no. 234-235 (December 1971-January-February 1972), the 
sixth and final "episode" did not find publication until roughly nine months after the fifth, in issue no. 241 (September-October 1972). By this point, the journal's political orientation had been transformed to a dogmatic variant of Maoism, and its energies were dedicated to forming a "cultural front" with other revolutionary activists in the arts. In this context, a theoretical reflection on technical developments in film history seemed rather out of place, and indeed a programmatic text in the following issue (likely written by Philippe Pakradouni) forcefully critiqued Comolli's series for being a "purely theoretical" reflection that had lost its "power of intervention" and that represented a tendency within the journal to produce "theoretical articles without a concrete base of reference, and without a political and organizational articulation with the struggle. ${ }^{72}$ Comolli himself was, moreover, somewhat marginalized within the journal during this period: never entirely comfortable with the turn to Maoism, he was also preoccupied with other projects at the time. Together with Philippe Carles, Comolli wrote Free Jazz/BlackPower in 1971, a book that articulates the development of free jazz by musicians such as John Coltrane, Ornette Coleman and Cecil Taylor with the political awakening of the black population in the 1950s-196os, as manifested in the civil rights movement and its more radical aftermath. ${ }^{73}$ Comolli also spent the early 1970 s making short films and working on early versions of the script for his debut feature La Cecilia, thus limiting the time he had available for film criticism. "Technique et idéologie" would, in fact, prove to be the last significant text Comolli wrote for Cahiers while still being centrally involved with the journal.

The thread that was dropped with the cessation of the series was picked up again, however, in 2009, when Comolli returned to the themes of "Technique et idéologie" with the publication of Cinéma contre spectacle (which included a reprint of the earlier series in full). In this book, Comolli insists on the continued pertinence of "Technique et idéologie," confessing that the six articles published in 1971-1972 "have not ceased to shape my work" - despite the fact that he had not re-read them since their initial appearance. "Technique et idéologie" represents the "echo of an era" that still haunts him, "because this era is not dead, because I am caught in it like a rat in a trap." Despite the sweeping transformations in cinema and the media in the intervening four decades, Comolli discerns the continued pertinence in

72 “Quelles sont nos tâches sur le front culturel?," p. 6.

73 Philippe Carles and Jean-Louis Comolli, Free Jazz/Black Power (Paris: Éditions Champ Libre, 1971). Translated as Free Jazz/Black Power, trans. Grégory Pierrot (Jackson: University Press of Mississippi, 2015). 
contemporary audiovisual culture of the themes and concepts adumbrated in "Technique et idéologie" and, in an observation that can only be assented to, remarks that the key ideas of this text resonate throughout his more recent theoretical and filmmaking practice. "Re-reading ['Technique et idéologie'] today, I discover," Comolli writes, "certain motifs maintained throughout the technological, economic and mediatic vicissitudes which have affected the place of the cinema in our societies and which, to a certain degree, have drowned it in the bath of the so-called 'audiovisual' flux - a development which could barely be discerned at the beginning of the 1970s."74 Such resonances, and Comolli's more recent practice in general, will be discussed at greater length in the rest of this study.

\section{Works Cited}

Louis Althusser, "Sur la dialectique matérialiste," in idem., Pour Marx (Paris: Maspero, 1965), pp. 161-224. Translated as "On the Materialist Dialectic," in idem., For Marx, trans. Ben Brewster (London: Verso, 2005 [1969]), pp. 161-218.

—, "Marxisme et humanisme," in idem., Pour Marx (Paris: Maspero, 1965), pp. 225250. Translated as "Marxism and Humanism," in idem., For Marx, trans. Ben Brewster (London: Verso, 2005 [1969]), pp. 219-248.

—, "Lénine et la philosophie" (1968), in idem., Solitude de Machiavel, ed. Yves Sintomer (Paris: P.U.F., 1998), pp. 103-144. Translated as "Lenin and Philosophy," in Louis Althusser, Lenin and Philosophy and Other Texts, trans. Ben Brewster (New York: Monthly Review Press, 1971), pp. 11-44.

— , "Idéologie et les Appareils idéologiques d'état (Notes pour une recherche)," La Pensée no. 151 (June 1970), pp. 3-38. Translated as "Ideology and Ideological State Apparatuses: Notes towards an Investigation," in idem., Lenin and Philosophy and Other Texts, trans. Ben Brewster (New York: Monthly Review Press, 1971), pp. 85-132.

—, Étienne Balibar, Roger Establet, Pierre Macherey and Jacques Rancière, Lire le Capital (Paris: Maspero, 1965). Translated in abridged form as Reading Capital, trans. Ben Brewster (London: Verso, 2009 [1970]).

Jean-Louis Baudry, "Cinéma: effets idéologiques produits par l'appareil de base," Cinéthique no. 7-8 (c. mid-late 1970), pp. 1-8. Translated as "Ideological Effects of the Basic Cinematographic Apparatus," trans. Alan Williams, in Philip Rosen (ed.), Narrative, Apparatus, Ideology: A Film Theory Reader (New York: Columbia University Press, 1986), pp. 286-298. 
—, "Le dispositif: approches méta-psychologiques de l'impression de réalité," Communications no. 23 (1975), pp. 56-72. Translated as, "The Apparatus: Metapsychological Approaches to the Impression of Reality in Cinema," trans. Jean Andrews and Bertrand Augst, in Philip Rosen (ed.), Narrative, Apparatus, Ideology: A Film Theory Reader (New York: Columbia University Press, 1986), pp. 299-318.

—, L'Effet cinéma (Paris: Éditions Albatros, 1978).

André Bazin, "Le mythe du cinéma total," in idem., Qu'est-ce que le cinéma? vol. I: Ontologie et langage (Paris: Éditions du Cerf, 1958), pp. 21-26. Translated as "The Myth of Total Cinema," in idem., What is Cinema?, trans. and ed. Timothy Barnard (Montreal: Caboose, 2009), pp. 13-20.

—, "L'Évolution du langage cinématographique," in idem., Qu'est-ce que le cinéma? vol. I: Ontologie et langage (Paris: Éditions du Cerf, 1958), pp. 131-148. Translated as "The Evolution of Film Language," in idem., What is Cinema?, trans. and ed. Timothy Barnard (Montreal: Caboose, 2009), pp. 87-107.

_ , "William Wyler ou le janseniste de la mise en scène," in idem., Qu'est-ce que le cinéma? vol. I: Ontologie et langage (Paris: Éditions du Cerf, 1958), pp. 149-173. Translated as "William Wyler, the Jansenist of Mise en Scène, in idem., What is Cinema?, trans. and ed. Timothy Barnard (Montreal: Caboose, 2009), pp. 45-72.

Walter Benjamin, "The Work of Art in the Age of Mechanical Reproduction,", in idem., Illuminations, trans. Harry Zohn, ed. Hannah Arendt (New York: Schocken, 1968), pp. 217-251.

Maurice Bessy and Jean-Louis Chardans, Dictionnaire du cinéma et de la télévision (Paris: Jean-Jacques Pauvert, 1965).

Pascal Bonitzer, “Ciné-forum," Cahiers du cinéma no. 230, pp. 63-65.

[Cahiers du cinéma], "Quelles sont nos tâches sur le front culturel?: Projet de plateforme," Cahiers du cinéma, no. 242-243 (November-December 1972-January 1973), pp. $5^{-25}$.

Philippe Carles and Jean-Louis Comolli, Free Jazz/Black Power (Paris: Éditions Champ Libre, 1971). Translated as Free Jazz/Black Power, trans. Grégory Pierrot (Jackson: University Press of Mississippi, 2015).

"Cinéthique," "Du bon usage de la valeur d'échange (Les Cahiers du cinéma et le marxisme-léninisme), Cinéthique no. 6 (January-February 1970), pp. 1-12.

Brian Coe, "William Friese Green and the Origins of Kinematography," The Photographic Journal (March-April 1962), pp. 92-104, 121-126.

Jean-Louis Comolli, “Technique et idéologie: Caméra, Perspective, Profondeur de champ," Part I, Cahiers du cinéma no. 229 (May 1971), pp. 4-21; Part II, Cahiers du cinéma no. 230 (July 1971), pp. 51-57; Part III, Cahiers du cinéma no. 231 (AugustSeptember 1971), pp. 42-50; Part IV, Cahiers du cinéma no. 233 (November 1971), pp. 39-45; Part V, Cahiers du cinéma no. 234-235 (December 1971-February 1972), 
pp. 94-100; Part VI, Cahiers du cinéma no. 241 (September-October 1972), pp. 2024. Translated as "Technique and Ideology: Camera, Perspective, Depth of Field," trans. Daniel Fairfax, in Jean-Louis Comolli, Cinema against Spectacle, Technique and Ideology Revisited (Amsterdam: Amsterdam University Press, 2015), pp. 143-244.

-, Cinéma contre spectacle (Lagrasse: Verdier, 2009). Translated as Cinema against Spectacle: Technique and Ideology Revisited, trans. and ed. Daniel Fairfax (Amsterdam: Amsterdam University Press, 2015).

Serge Daney and Jean-Pierre Oudart, "Travail, lecture, jouissance," Cahiers du cinéma no. 222 (July 1970), pp. 39-46. Translated as "Work, Reading, Pleasure," trans. Diana Matias, in Nick Browne (ed.), Cahiers du Cinéma vol. III: 1969-1972 The Politics of Representation (London: Routledge, 1990), pp. 115-136.

Jacques Deslandes, Histoire comparée du cinéma vol. I (Brussels: Casterman, 1966). Hervé Joubert-Laurencin, Le Sommeil paradoxal (Paris: Éditions de l'œil, 2014). Julia Kristeva, Sémiotiké: Recherches pour une sémanalyse (Paris: Seuil, 1969).

_-, "Cinéma: pratique analytique, pratique révolutionnaire," Cinéthique no. 9-10 (c. early 1971), pp. 71-79.

Jean-Patrick Lebel “Cinéma et idéologie," La Nouvelle Critique no. 34 (May 1970), pp. 67-72; no. 35 (June 1970), pp. 6o-67; no. 37 (October 1970), pp. 6o-64; and no. 41 (February 1971), pp. 6o-69. Repr. in expanded form as Jean-Patrick Lebel, Cinéma et idéologie (Paris: Éditions sociales, 1971).

Gérard Leblanc, "Welles, Bazin et la RKO (à propos de Citizen Kane)," Cinéthique no. 6 (January-February 1970), pp. 27-32.

Jean Mitry, Esthétique et psychologie du cinéma (Paris: Éditions universitaires, 1963), two volumes.

—, Histoire du cinéma: Art et industrie (Paris: Éditions universitaires, 1967), five volumes.

— , "De quelques problèmes d'histoire et d'esthétique du cinéma," Cahiers de la Cinémathèque no. 10-11 (1973), pp. 113-141.

—, La Sémiologie en question (Paris: Cerf, 1987).

Marcelin Pleynet, "Le point aveugle," Cinéthique no. 6 (January-February 1970), pp. 13-20.

James Spellerberg, "Technology and Ideology in the Cinema," Quarterly Review of Film Studies vol. 2 no. 3 (1977), pp. 288-301. 


\title{
6. Afterlives of the Apparatus
}

\begin{abstract}
In this chapter, the focus lies on the "afterlives" of Cahiers du cinéma's post1968 period in Anglo-American film studies since the latter's consolidation as an academic discipline in the 1970s. Championed by journals such as Screen, the writings of the Cahiers critics attained a wide purchase in the nascent field, but this often came at the expense of a reductive interpretation, compounded by the limited corpus of available translated texts, and in later decades many of the positions associated with Cahiers increasingly came under attack, while even its defenders admitted to the state of crisis that the "political modernism" it represented had entered. But this chapter also shows the wider influences that Cahiers has had on film scholarship, such as the importance of Comolli for the rise of the "new film history" movement, and it concludes by stressing the necessity for a productive re-reading of the original Cahiers texts.
\end{abstract}

Keywords: Cahiers du cinéma, Screen, political modernism, apparatus theory, feminist film theory, new film history

\section{Cahiers du cinéma and "Screen Theory"}

A discussion of the role played by theories of ideology and the cinematic apparatus in the Cahiers of the post-1968 period would not be complete without examining the effects they have had on film theory and on AngloAmerican academic film studies in particular. These effects, in spite of the period of relative neglect they have suffered since the 1980s, continue to leave their marks on the field up to the present day. This chapter will therefore center on the "afterlives" of the theoretical texts of Cahiers in the English-speaking world, a phenomenon that is every bit as tumultuous as the history of the journal itself.

It was the UK journal Screen that initially played the role of introducing the work of the Cahiers writers to English-speaking readers in the early 1970s,

Fairfax, D., The Red Years of Cahiers du Cinéma (1968-1973). Volume I: Ideology and Politics. Amsterdam: Amsterdam University Press, 2021 DOI 10.5117/9789463728508_CHo6 
and these texts were used as a springboard for a burst of original work that viewed the cinema through the prism of radical aesthetics, psychoanalytic theory and, later, feminist accounts of spectatorship. But the Cahiers writers would find themselves under attack as "1970s theory" was subject to withering critiques in the 1980 s from several angles, including, most notably, the positivist "post-theory" of figures such as Noël Carroll and David Bordwell. This offensive has left Cahiers inhabiting a curious position within the discipline. A limited number of its texts have unmistakably passed into the film studies canon and remain required reading for those entering the field. For the most part, however, they are seen chiefly as genealogical precursors to the efforts of the Screen theorists and other pioneering scholars in the field rather than theoretical contributions in their own right, inscribed into a critical lineage distinct from that of Anglo-American film theory.

Screen had very different origins to Cahiers, beginning life as a pedagogically oriented quarterly under the auspices of the British Film Institute rather than an independent monthly magazine targeted at a broad, non-academic readership. Moreover, once its politically radical phase had dissipated in the 1980 , Screen was transformed into a standard scholarly journal-a function it still plays today but a path that was never taken by its French counterpart. For much of the 1970s, however, Screen adopted a theoretical and political orientation broadly analogous to that of Cahiers in the 1968-1973 period. Discussions of the theoretical evolution of Screen are abundant and can easily be found elsewhere. ${ }^{1}$ Here I will restrict myself to the ramifications of its exposure to the key ideas articulated by Cahiers.

Screen's very transformation, in 1971, to a journal preoccupied with theories of the cinema inspired by Althusserian Marxism and Lacanian psychoanalysis occurred on the basis of contemporaneous developments in French film theory and more particularly the evolution of Cahiers. It is indicative here that the first issue of the "new" Screen (vol. 12 no. 1), under Sam Rohdie's editorship, contained a translation of "Cinéma/idéologie/critique" along with a pair of explicatory articles on the status of contemporary French film criticism. ${ }^{2}$ This acknowledgement of the importance of Cahiers for the English journal was continued in vol. 12 no. 3 with the publication of

1 See, in particular, Rodowick, The Crisis of Political Modernism; and Philip Rosen, "The Concept of Ideology and Contemporary Film Criticism," PhD dissertation, University of Iowa, 1978. For a more personal account of this period, see Colin MacCabe, Tracking the Signifier: Theoretical Essays: Film, Linguistics, Literature (Minneapolis: University of Minnesota Press, 1986).

2 See Jean-Luc Comolli and Paul Narboni [sic], "Cinema/Ideology/Criticism (1)"; Claire Johnston, "Film Journals: Britain and France," Screen vol. 12 no. 1 (Spring 1971), pp. 39-48; and Ben Brewster, "Structuralism in Film Criticism," Screen vol. 12 no. 1 (Spring 1971), pp. 49-58. 
Cinéthique's ripostes to its rival ("Direction" by Gérard Leblanc and "La parenthèse ou le détour" by Jean-Paul Fargier) as well as part II of Cahiers' editorial. English versions of these texts were produced by a BFI-funded translation project closely linked to Screen, which proved crucial to the development of film studies in the anglophone world during this period. ${ }^{3}$ While this endeavor also involved translations of German, Italian and Russian texts relating to twentieth-century radical art, the French articles formed the focal point of the project. This undertaking allowed for key Cahiers texts such as "Young Mr. Lincoln de John Ford" and Oudart's "La Suture" to appear in translated form in Screen during this period, while others (including "Technique et idéologie"), although never officially published by Screen, were translated and distributed through informal channels on the back of the BFI project. ${ }^{4}$

Screen never sought, however, to operate a direct transposition of Cahiers' ideas in a British environment. Rather, it was a theoretically syncretic endeavor, outlining the basis of a political aesthetics of the cinema that drew from both Cahiers and Cinéthique (and tended to stress the similarities between the two journals rather than their differences), as well as Metz, Althusser, the Russian formalists and Brecht. Although many of these influences were shared with the French journal, subtle differences in emphasis and orientation can be discerned: the British quarterly, for instance, placed a much greater emphasis on Brecht's praxis of distantiation (Verfremdung) than Cahiers, for whom the German playwright would only gain prominence in the years 1972-1973. ${ }^{5}$ As with Cahiers, Godard, Straub/Huillet and Oshima were held up as models of contemporary political cinema, while the importance of 1920 S Soviet cinema as a historical case study was underscored. But Screen also entertained a much greater interest in anti-fascist and popular front filmmaking from the 1930s and 1940s, which was of only passing concern for Cahiers, and, betraying its institutional origins in the pedagogical arm of the BFI (an affiliation that was maintained even at the

3 One of the key translators, Diana Matias, was also an editorial assistant for Screen between 1970 and 1972.

4 The first installment of "Technique et idéologie" was eventually formally published in the short-lived American journal Film Reader in 1977. See Jean-Louis Comolli, "Technique and Ideology: Camera, Perspective, Depth of Field," trans. Diana Matias, Film Reader no. 2 (1977), pp. 128-140. Parts III and IV were published, in a modification of Matias' translation by Marcia Butzel and Philip Rosen, in Rosen (ed.), Narrative, Apparatus, Ideology, pp. 421-443. The entirety of "Technique et idéologie" was published in English for the first time, in a new translation, in 2015, as part of Comolli, Cinema against Spectacle, pp. 143-244.

5 Cahiers did exhibit some interest in Brecht in the early 1960 , resulting in a dossier on the dramatist assembled by Bernard Dort in the December 1960 issue. 
height of its "Freudo-Marxist" phase), Screen displayed more interest in the public reception of films, contrasting with Cahiers' blithe indifference to the question of the cinema audience. Moreover, Screen tended towards a more binary antithesis between "classical realism" and "modernism" in the cinema, whereas Cahiers evinced more of a fascination for the internal contradictions of Hollywood filmmaking. Although the "Young Mr. Lincoln" article was republished and discussed at length in Screen, there was a paucity of parallel attempts made under the auspices of the English journal, with Stephen Heath's analysis of Touch of Evil constituting a significant exception.

Differences emerged in other areas: Screen was more dismissive of the work of Bazin, who was viewed as merely representing an "idealist" approach to the cinema, ${ }^{6}$ whereas-as the governing hypothesis of this book maintains - the Cahiers of the post-1968 period continued to be exercised by its founder's ideas. In this sense, then, Screen hewed more closely to Cinéthique than Cahiers, and such an inclination can also be seen in the journals' respective approaches to ideology and cinema. Although the work of Cahiers in this area was repeatedly highlighted by Screen, writers such as Colin MacCabe and Ben Brewster tended to conceive of the cinema as an illusionist apparatus serving primarily to occlude the real nature of social relations. Finally, Screen tended towards an ascetic, even puritanical attitude towards the cinema. In articles including "Visual Pleasure and Narrative Cinema" by Laura Mulvey and "Principles of Realism and Pleasure" by Colin MacCabe, ${ }^{7}$ spectatorial pleasure came largely to be seen as a pernicious instrument of bourgeois cinema; instead, the viewer was urged to "work" to understand a film such as Straub/Huillet's Geschichtsunterricht. ${ }^{8}$ Indeed, the notion of "work" as it appeared in Screen tended to be an overly literal understanding of the word (as productive labor or toil), in contrast to the use made by Cahiers of the term travail, which followed Kristeva in referring more broadly to processes of textual transformation (in like fashion to Freud's concept of the "dream-work"). Spectatorial pleasure, it must be stressed, was never fully rejected by the

6 See, for instance, Christopher Williams, "Bazin on Neo-Realism," Screen vol. 15 no. 1 (Spring 1974), pp. 61-68, and Peter Wollen's more theoretically fertile contribution “'Ontology' and 'Materialism' in Film," Screen vol. 17 no. 1 (Spring 1976), pp. 7-25.

7 Laura Mulvey, "Visual Pleasure and Narrative Cinema," Screen vol. 16 no. 3 (Autumn 1975), pp. 6-18; and Colin MacCabe, "Principles of Realism and Pleasure, Screen vol. 17 no. 3 (Autumn 1976), pp. 7-27.

8 See, for instance, the discussion between Martin Walsh and Colin MacCabe in "The Politics of Separation (on Deux ou trois choses que je sais d'elle and Tout va bien)," Screen vol. 16 no. 4 (Winter 1975), pp. 46-61, here pp. 59-6o. 
Cahiers writers, who were reluctant to purge themselves of their cinephilic backgrounds. Far from understanding a film such as Othon as forestalling the possibility of aesthetic pleasure, the Cahiers critics explicitly took the opposite stance. In an interview with Politique-Hebdo, they declared it to be a "beautiful" and "pleasurable" film:

Let us once again clarify: all this in no way means that we have "elected" this film for its "inaudibility," its "hermeticism," its rebarbative, provocative character. On the contrary, we feel that Othon is a very beautiful film, also capable of arousing pleasure, but a pleasure which, let us be clear, has nothing to do with the narcissistic identification and hedonism which is almost always the rule in cinematic spectacle. ${ }^{9}$

The initial importation of Cahiers' ideas into the English-speaking world, by means of the work carried out primarily by Screen, is thus a transposition marked by a certain number of "translation issues." This applies on a broader level—the appropriation of theoretical concepts in a markedly different political and cultural environment could not take place without certain effects of distortion, assimilation and reduction — but was also, to a certain degree, exacerbated by translation issues in the narrower sense. Not all the writers for Screen - let alone its readers-were conversant in French, and they were thus reliant on the BFI translation project for exposure to original texts written by Cahiers, Cinéthique and others. While these translations were of crucial importance for disseminating the key ideas espoused by the French journals and have since achieved a canonical status through recurrent inclusion in film theory anthologies, they nonetheless tended to have a reductive effect on the reception of Cahiers in the English-speaking world. Through this process, the voluminous, theoretically paroxysmal output of the late 196os and early 1970s was winnowed down to a handful of programmatic texts that were constituted into a more easily digestible "line." Even those articles that were translated were often rendered into English in a hasty fashion by translators who were not always familiar with the theoretical context of the original texts. The most egregious example here is Bennett's rendering of "Cinéma/idéologie/critique," some of whose infelicities have already been discussed above. Rodowick has recently maintained that, "in retrospect, this translation seems tendentious in a way that smooths out the style of the text to make it seem more formal and 
'scientific,"'10 and similar tendencies can be discerned in other translations published by Screen, including those of the prominent texts "Technique et idéologie," "La Suture" and "Young Mr. Lincoln."

\section{Lines of Flight: Radical Politics, Psychoanalysis and Feminist Theory in the $1970 \mathrm{~s}$}

A certain level of distortion thus occurred when the ideas initially developed by Cahiers were imported to the English-speaking world, and these continued to be present during the solidification of what has come to be known as "Screen theory," "1970s theory" or (pejoratively) "Grand Theory" into a recognizable theoretical paradigm. The positive aspect of this phenomenon, however, was the re-thinking of some of the key concepts of "apparatus theory" and their application in new and often strikingly different social and ideological contexts. The "field" of film theory was considerably expanded by this process, which took place not only on the pages of Screen but also in journals such as Afterimage, Wide Angle, Ciné-tracts, Monogram and Jump Cut. Three "lines of flight" produced by the migration of concepts from France to the UK and North America are particularly worth discussing: the encounter of film theory with far-left politics at a time of student and worker radicalization in the English-speaking world, the recasting of psychoanalytic theories of film spectatorship, and the advent of feminist theories of the cinema. While the former two areas entailed re-working aspects of film theory already explored at great length by Cahiers, a feminist approach to the cinema was mostly absent from the French journal's considerations during this period and would only_belatedly_be broached in the second half of the 1970s by later contributors such as Thérèse Giraud, Nathalie Heinich and Danièle Dubroux. Cahiers was not alone in this neglect: if anything, other French film journals were even more masculinist in their outlook. In this case, then, Anglo-American film theory represented a crucially important advance on its French sibling.

While on a broader social level, the scale of political radicalization was an order of magnitude lower in the US and the UK than it was in France, film culture was profoundly affected by the rise of the "new left" in these countries, and this was reflected both in the birth of new, explicitly political film periodicals and the transformation of existing outlets. While publications such as Screen and Wide Angle (a US-based quarterly founded in 
1976), focused more on theoretical and historical questions rather than interventions into the political arena, magazines such as Afterimage in the UK and Ciné-Tracts in Canada were more concretely engaged with contemporary issues and sought to articulate them with the radical filmmaking of the day. ${ }^{11}$ In both publications, the films of the Groupe Dziga Vertov were of primordial importance, with Third Cinema, militant films and the work of the experimental avant-gardes also given attention. For an articulation of the theoretical legacy of Cahiers with far-left politics in the anglophone context, however, the most interesting organ was the American film review Jump Cut, edited by Chuck Kleinhans and Julia Lesage. Familiar with the political milieu in which Cahiers was operating (the two traveled to Avignon for the 1972 symposium organized by the Cahiers editors ${ }^{12}$ ), the Jump Cut editors were nonetheless critical of many aspects of apparatus theory as developed by Cahiers. This ambivalence was shown in Jump Cut's April 1978 issue: here, Kleinhans came to the defense of the French journal when responding to a more unambiguously negative article on Cahiers by William Guynn, who had lacerated the journal by equating its work with "the crude ideology and class-determinism of Socialist Realism." ${ }^{\text {"13 }}$ At the same time, Kleinhans insisted on the need for "a political critique of Cahiers," which, in his view, is "studiously evaded by most of those who profess the importance of recent French film thought and filmmaking." ${ }^{14}$ While this critique is never explicitly produced on the pages of Jump Cut, it can be read en creux in a large number of articles in the journal responding to militant and avant-garde filmmaking throughout the 1970s.

If Jump Cut did not issue a thoroughgoing critique of Cahiers, its editors nonetheless assailed the psychoanalytic approach to cinema developed by Cahiers critics such as Oudart, Bonitzer and Pierre Baudry, as well as, subsequently, by writers associated with Screen. A concern for psychoanalytic theory postdated Screen's Marxist turn. It was not until the Summer 1974 issue of Screen that film was discussed in conjunction with psychoanalysis in any prolonged fashion, following on from cursory remarks made in the previous issue's editorial. In both cases, however, the links forged were

11 Afterimage was established by Simon Field and Peter Sainsbury at the University of Essex and published intermittently between 1970 and 1987. For a brief, first-hand account of its history, see Simon Field (with Peter Sainsbury), "Présentation," in Nicole Brenez and Michael Witt (eds.), Jean-Luc Godard: Documents (Paris: Centre Pompidou, 2006), p. 144.

12 Chuck Kleinhans, private communication, March 22, 2016.

13 William Guynn, "The Political Program of Cahiers du cinéma, 1969-1977," Jump Cut no. 17 (April 1978), pp. 32-35, here p. 32.

14 Chuck Kleinhans, "Twelve Frames per Second," Jump Cut no. 17 (April 1978), p. 36. 
highly idiosyncratic: the Spring 1974 editorial read Barthes' S/Z through a Freudian lens, while texts by MacCabe and Heath sought to do much the same for Brechtian aesthetic practice by drawing on the concept of fetishism..$^{15}$ This perspective was opposed from a feminist standpoint by Lesage in Jump Cut, but her rebukes of the Screen writers in this text are too scattered to constitute a sustained critique. ${ }^{16}$ Reprinted in Screen, her article was vigorously rebutted in a rejoinder authored by Brewster, MacCabe and Heath, who defended their use of psychoanalytic concepts in film theory but insisted that they did so at a remove from "a monolithic 'orthodox Freudianism" that was in any case far less preponderant in the British context than it was in the United States. The three also sought to draw links between Freud and the contemporary theoretical work of Althusser and Barthes. ${ }^{17}$ Although at this point Lacan's recasting of Freud tended to go unmentioned by the Screen writers, the French psychoanalyst's work subsequently gained in prominence, especially with Heath's article "Anata Mo" (a discussion of Lacan's notion of the real in conjunction with Oshima's Death by Hanging) and the published translation of Oudart's "La Suture" with appended notes on the text by Heath. ${ }^{18}$

And yet, in contrast with the situation at Cahiers, psychoanalytic film theory was far from unanimously welcomed by the editors of Screen and was the cause of a rupture in its editorial board: in the Summer 1975 number, the editorial noted opposition within the journal's ranks to the "esoteric" nature of certain articles drawing on Freud and Lacan and expressed concern at their "lack of real engagement with the politico-cultural issues which should form the context of Screen's work." ${ }^{19}$ Later that year, these reservations were expanded upon in a statement signed by Edward Buscombe, Christine Gledhill, Alan Lovell and Christopher Williams, which bemoaned the "lack

15 See Ben Brewster and Colin MacCabe, "Editorial," Screen vol. 15 no. 1 (Spring 1974), pp. 4-10; Colin MacCabe, "Realism and the Cinema: Notes on Some Brechtian Theses," Screen vol. 15 no. 2 (Summer 1974), pp. 7-27; and Stephen Heath, "Lessons from Brecht," Screen vol. 15 no. 2 (Summer 1974), pp. 103-128. The Brecht special issue also included a text by Bernard Eisenschitz, "Who does the World Belong to? The Place of a Film," Screen vol. 15 no. 2 (Summer 1974), pp. 66-73. 16 Julia Lesage, "The Human Subject - You, He or Me? (Or, the Case of the Missing Penis)," Jump Cut no. 4 (November-December 1974), pp. 26-27. Repr. in Screen vol. 16 no. 2 (Summer 1975), pp. $77-83$.

17 Ben Brewster, Stephen Heath and Colin MacCabe, "Comment," Screen vol. 16 no. 2 (Summer 1975), pp. 83-9o, here p. 84 .

18 Stephen Heath, “Anata Mo," Screen vol. 17 no. 4 (Winter 1976-1977), pp. 49-66; Jean-Pierre Oudart, “Cinema and Suture," trans. Kari Hanet, Screen vol. 18 no. 4 (Winter 1977-1978), pp. 24-34; and Stephen Heath, “Notes on Suture," Screen vol. 18 no. 4 (Winter 1977-1978), pp. 48-76.

19 “Editorial," Screen vol. 16 no. 2 (Summer 1975), pp. 4-6, here p. 6. 
of any critical distance from psychoanalysis in Screen" and reproached texts by Heath, MacCabe and others for their supposed conceptual obscurity and inaccessibility. ${ }^{20}$ The tensions within the editorial board on this matter were never adequately resolved and led to the departure of the statement's four signatories in the summer of $1976 .^{21}$

Although Screen's deployment of psychoanalytic concepts had mixed results, one area in which it was undeniably fecund on the theoretical level was in the fusion of psychoanalysis with feminist film theory carried out in Laura Mulvey's landmark article "Visual Pleasure and Narrative Cinema," which first appeared in the Autumn 1975 issue of the journal. Mulvey was not the first to make this conceptual maneuver or to draw on the ideas of Cahiers to do so: Pam Cook and Claire Johnston had earlier evoked Comolli/Narboni's call for an "oblique, symptomatic reading" of the discrepancies and fault lines in auteurist classical cinema to discuss the position of 'woman' as the locus of a dilemma for the patriarchal human order" in Raoul Walsh's œuvre..$^{22}$ But the explosive effect of her article was such that "Visual Pleasure and Narrative Cinema," with its argument that the mechanism of spectatorship in classical narrative cinema is decisively determined by a scopophilic "male gaze," is still considered one of the major texts in the field. While the psychoanalytically inflected articles of Cahiers are an evident precursor to Mulvey's text, particularly in her discussions of Sternberg's Morocco, it is when her attention turns to the role of voyeurism in Vertigo that Mulvey's debt to the journal is most apparent. But here the influence comes from an unexpected source: not any of the Cahiers writers of the Comolli/Narboni era but rather Jean Douchet's 196o text "Hitch et son public," in which the right-leaning, resolutely cinephilic critic analyzes the film as a metaphor for the very functioning of the cinema. ${ }^{23}$ Indeed, while Mulvey concludes by asserting that women "cannot view the decline of the

20 Particular areas of censure centered on the notions of fetishism, the analogy of film spectatorship with the infant's mirror phase (as discussed by Metz in The Imaginary Signifier) and the pedagogically unprofitable assumption that the viewer of mainstream narrative cinema is an innately passive consumer of images. See Edward Buscombe, Christine Gledhill, Alan Lovell and Christopher Williams, "Statement: Psychoanalysis and Film," Screen vol. 16 no. 4 (Winter 1975), pp. 119-130, here p. 119.

21 See Edward Buscombe, Christine Gledhill, Alan Lovell and Christopher Williams, "Why We Have Resigned from the Board of Screen," Screen vol. 17 no. 2 (Summer 1976), pp. 106-109. 22 Pam Cook and Claire Johnston, "The Place of Woman in the Cinema of Raoul Walsh," in Philip Hardy (ed.), Raoul Walsh (London: BFI, 1974), pp. 92-109, here p. 109. The article was the source of a polemic between Alan Lovell, Colin MacCabe and Elizabeth Cowie in "Film Culture," Screen vol. 16 no. 1 (Spring 1975), pp. 128-141.

23 Jean Douchet, "Hitch et son public," Cahiers du cinéma no. 113 (November 1960), pp. 7-15. 
traditional film form with anything much more than sentimental regret," a certain ambivalent attitude towards classical cinema can be detected in her text, one that links it more closely with the Cahiers tradition than may be immediately apparent: while Hollywood films mobilize the male gaze, their best examples (Sternberg, Hitchcock) are also able to operate an internal critical analysis of the scopophilic mechanism at the heart of the cinematic apparatus. ${ }^{24}$

\section{Theoretical Flows and Countercurrents in the 1970s and 1980s}

Mulvey's article instigated a flurry of theoretical reflection in the second half of the 1970 and the 1980 s that combined a feminist outlook (often inspired by French thinkers such as Kristeva, Hélène Cixous and Luce Irigaray) with Freudian/Lacanian approaches to the cinema. Key figures in this tendency included Linda Williams, Teresa de Lauretis and Kaja Silverman, ${ }^{25}$ and it is probably the most striking example of the ideas developed by the Cahiers critics in the post-1968 period serving as the basis of a theoretical undertaking that was quite remote from their own. The "flow," therefore, of ideas from France to the UK and North America was a more complex process than that of a straightforward importation or transplantation into a new context and involved a significant degree of original thinking on the part of the latter figures. It must be reiterated, however, that there were distinct limitations to this transference: not only was it based on a very limited number of the vast corpus of texts produced by Cahiers during this period, there was also little cognizance of the evolution of the French journal in the years after 1973 (a period when many of its earlier positions were subject to extensive criticism), and the journal's more recent articles received meager attention. ${ }^{26}$ Moreover, the theoretical flow was a distinctly monodirectional affair: there is scant evidence of the Cahiers writers being in any way influenced by theoretical developments in Screen or other anglophone journals, which they were only

24 Mulvey, "Visual Pleasure and Narrative Cinema," p. 18. This ambivalence is curiously present in The Riddles of the Sphinx, made by Mulvey and Wollen, in the beginning of which the former can be seen leafing through a copy of the French film magazine Midi-minuit fantastique (which concentrated on série B and horror films).

25 Oudart's notion of the suture was of particular importance for this strand of film theory, and this relationship will thus be further discussed in Chapter 22.

26 One exception was Jean-Louis Comolli's “Un corps en trop" (Cahiers du cinéma no. 278, July 1977, pp. 5-16) which was published in English translation as "Historical Fiction: A Body Too Much," trans. Ben Brewster, Screen vol. 19 no. 2 (Summer 1978), pp. 41-53. 
dimly aware of in the first place. There were two major exceptions to this state of affairs, both of which arose through Cahiers writers taking part in conferences organized by sympathizers in the UK and the US, events which also revealed a significant degree of friction between their French and Anglo-American participants. In 1977, Serge Daney traveled to the Edinburgh Film Festival as an invited guest for a symposium organized by the Screen editors on the topic of "History/Production/Memory." In Daney's account, however, the event was marked by a series of discords and décalages between himself and his British interlocutors. Noting that the theoretical references of the conference participants centered on Althusser, Derrida and Lacan (but a Lacan that was, in Daney's view, "truncated, reduced to a ping-pong game between the imaginary and the symbolic, without the moment of the real"), he observed that the position of Cahiers was repeatedly brought into question: "It was vaguely recognized as having been the first to show a preoccupation with 'cinema-and-history' in its columns, but it was silently reproached for having moved away from an orthodox position [towards] a highly suspect spontaneism." ${ }^{27}$ For his part, Daney felt that the discussions at Edinburgh tended to neglect "the historical conditions in which this debate appeared, in the French far-left and in Cahiers in particular," with a narrow Althusserianism instead leading the symposium's participants to view this moment as "a pure struggle in theory. ${ }^{28}$ In the end, Daney concluded, the one thing that was forgotten during the event, as its title symptomatically revealed, was the cinema itself.

A similarly disharmonious tone marked the following year's conference on "The Cinematic Apparatus," held in Milwaukee and organized by Stephen Heath and Teresa de Lauretis, which was attended by a number of key figures from the nascent field of Anglo-American film studies (Peter Wollen, Mary Ann Doane, Dudley Andrew, Kristin Thompson, Maureen Turim, Laura Mulvey and Bill Nichols among them) as well as Christian Metz and Jean-Louis Comolli. The conference was already a source of controversy, as the editors of Jump Cut had waged a vocal campaign against its "elitist" and "sexist" organizational principles. ${ }^{29}$ Once the conference was underway, significant and sometimes acrimonious differences between Comolli's views and those of many of the other attendees also became apparent: a

27 Serge Daney, “Festival d'Edinbourg: Histoire/Production/Mémoire," Cahiers du cinéma no. 283 (December 1977), pp. 57-6o, here p. 57 .

28 Ibid., pp. 57-58.

29 See B. Ruby Rich, Chuck Kleinhans and Julia Lesage, "Report on a conference not attended: The scalpel beneath the suture," Jump Cut no. 17 (April 1978), pp. 37-38. 
screening of his film La Cecilia in conjunction with the conference met with an unfavorable reception from the attendees, highly critical of its portrayal of women, while his paper "Machines of the Visible" (a series of extracts from "Technique et idéologie" alongside more recently composed passages) was subject to a feminist critique by Jacqueline Rose. ${ }^{30}$ Most rancorous, however, was an exchange between Comolli and the structuralist/ materialist filmmaker and theorist Peter Gidal: Comolli's argument that even abstract, non-figurative films can produce spectatorial fascination and that avant-garde cinema may be less necessary in the 1970s than it was at a time when Hollywood's domination of cinematic form was more absolute met with a virulent response from Gidal, who exclaimed to his French counterpart "you must be blind" before comparing his remarks to "Radek's speech against James Joyce." ${ }^{11}$

If these exchanges marked moments of dissension within the ranks of those who identified with "apparatus theory" during the 1970s, then the following decade would be distinguished by a frontal attack on the entire movement, which would continue until well into the 199os. The offensive began with Noël Carroll's 74-page review for October of Heath's Questions of Cinema. Heath's anthology, completed in January 1980, can in retrospect be seen as a symbolic capstone of "1970s theory" in its Anglo-American guise..$^{32}$ Carroll's riposte, drawing chiefly on a logical positivist methodology, was relentless in its opprobrium and centered around the argument that the Screen contributor's theoretical model suffered at once from the "enfeebling $[. .$.$] hyper-generality" of its overarching concepts of suture and subject-$ positioning and from "sacrific[ing] focus for detail" in its micro-descriptions of the film-viewing situation. ${ }^{33}$ This critique launched a debate with Heath in subsequent issues of October which, while forming one of the most vocal and detailed polemics between the theoretical tendencies these two scholars represented, often descended into petty personal bickering. ${ }^{34}$ The ideas sketched out by Carroll in these articles would form the basis of Mystifying Movies, his 1988 book-length take-down of apparatus theory's fusion of

30 See Jean-Louis Comolli, "Machines of the Visible," in Stephen Heath and Teresa de Lauretis (eds.), The Cinematic Apparatus (London: Macmillan Press, 1980), pp. 121-142; and Jacqueline Rose, "The Cinematic Apparatus: Problems in Current Theory," in Heath/de Lauretis (eds.), The Cinematic Apparatus, pp. 172-186.

31 Heath/de Lauretis (eds.), The Cinematic Apparatus, pp. 170-171.

32 Stephen Heath, Questions of Cinema (Bloomington: Indiana University Press, 1981).

33 Noël Carroll, "Address to the Heathen," October no. 23 (Winter 1982), pp. 89-163, here p. 163.

34 See Stephen Heath, "Le Père Noël," October no. 26 (Autumn 1983), pp. 63-115; Noël Carroll, "A Reply to Heath," October no. 27 (Winter 1983), pp. 81-102. 
psychoanalysis, semiotics and Marxist notions of ideology. ${ }^{35}$ At the same time, and in tandem with Carroll's work, David Bordwell was embarking on a similar undertaking, the arguments of which were most clearly expressed in his 1988 article "Historical Poetics of Cinema." Here, Carroll's positivist philosophical arsenal was joined by a "neoformalist" approach derived from early twentieth-century Slavic poetics. ${ }^{36}$

Both figures tended to view apparatus theory as a monolithic entity that dominated the academic "establishment" in film studies (if not the humanities more broadly), and they referred derisively to their polemical target as "The Theory," "Grand Theory," or, in Bordwell's coinage, "SLAB Theory" (the letters standing for Saussure-Lacan-Althusser-Barthes), a nomenclature that suggests a conceptual homogeneity and claim to universal validity that was never truly present in the original texts. The culmination of Bordwell and Carroll's dismantling of "1970s theory" came in the 1995 edited collection Post-Theory. Here, in addition to continuing their attacks on psychoanalytic and semiotic approaches to the cinema, they espoused the pursuit of "middle-level research" as an alternative practice to "Theory," one that would combine the collection of detailed empirical data with the development of modest, verifiable theoretical claims and which, in their eyes, had found a viable methodological model in the wave of "new" film history that had emerged in the 1980 s. $^{37}$

\section{“Technique et idéologie" and the New Film History Movement}

Bordwell's evocation of research into film history relates to another critique of the theoretical tradition derived from Cahiers that was issued from various quarters in the 1980s: that its discussion of the role of ideology in the cinema was largely ahistorical, essentializing "bourgeois ideology" and presenting it as an amorphous, eternal entity divorced from historical context. Here, the value of Comolli's "Technique et idéologie," in particular, came into question. Dudley Andrew, for instance, argued in Concepts in Film Theory that, "for all their concern to document the ideological underpinnings of the lens and its perspectival image," the Cahiers critics—and Comolli

35 Noël Carroll, Mystifying Movies (New York: Columbia University, 1988).

36 David Bordwell, "Historical Poetics of Cinema," Georgia State Literary Studies no. 3 (1989), pp. 369-398.

37 David Bordwell, "Film Studies and Grand Theory," in David Bordwell and Noël Carroll (eds.), Post-Theory: Reconstructing Film Studies (Madison: University of Wisconsin Press, 1995), pp. 3-36, here p. 27 . 
more particularly_ - "can be indicted for their own brand of idealism since they have essentially reified technology for all time." Andrew unfavorably compared their work with that of those American scholars who had "tried to show the complex interplay of historical context in the invention and use of new technology."38 This argument was echoed by Bordwell, who, while accepting the value of Comolli's "emphasis upon the lag between technological possibility and extended use" and his "non-teleological model of change," criticized "Technique et idéologie" as "sweepingly reductive." For Bordwell, Comolli made "the concept of 'ideology' do too much work," assuming "that 'bourgeois ideology' rests in place for three centuries, from Caravaggio to Citizen Kane." In this context, he also reiterates Sartre's critique of 'lazy' Marxists who replace 'real, perfectly defined groups' by vague collectivities such as 'bourgeois ideology."'39

This criticism is a curious one to make in light of the consistent emphasis placed by Comolli on the importance of charting the historical metamorphoses of the ideologies embedded in the cinema, his insistence on refusing an autonomous approach to film history and stressing the political and economic factors at work in the evolution of film form and technique, and his explicit concern with historiographic methods (and more particularly his adoption of the Althusserian model of "differential historical temporalities"). The success of his approach, and the validity of his findings, is certainly open to question. Indeed, given the enormous strides forward in our understanding of the early history of the cinema, it would be a tremendous surprise if Comolli's text were not empirically outdated in certain respects. But the notion that in "Technique et idéologie" Comolli sweepingly ignored the broader historical context of transformations occurring in film technology and eternalized the "ideological apparatus" of the cinema is one that does not withstand scrutiny. ${ }^{40}$

It is also not an argument made by any of the representatives of the "new film history" movement itself, who, in the wake of the 1978 FIAF congress at Brighton, sought to revisit and re-evaluate the accounts of early cinema provided by preceding generations of film historians (such as Ramsaye, Jacobs, Sadoul and Mitry) and who were often quite amenable to Comolli's vision of

38 Dudley Andrew, Concepts in Film Theory (Oxford: Oxford University Press, 1984), p. 16.

39 David Bordwell, Janet Staiger and Kristin Thompson, The Classical Hollywood Cinema: Film Style and Mode of Production to 1960 (New York: Columbia University Press, 1985), pp. 247, 249-250.

40 The translation history of Comolli's text is partly a factor in this distortion. The historical element in his discussion becomes more preponderant in the later parts of "Technique et idéologie," which long remained publicly inaccessible in English. 
film history. Robert Sklar has outlined the sharp fault line that dominated historical study of the cinema during this period, dividing the field between adherents of an Althusserian Marxist approach to the understanding of ideology and social change and those who remained within more traditional methods of historical research, with mutual hostility reigning between the two sides. ${ }^{41}$ And yet the main proponents of what has come to be known as the "post-Brighton" school of film history-Tom Gunning, Charles Musser and André Gaudreault, most notably_-all evince a significant debt to Comolli's text. The anti-teleological thrust of Gunning's notion of the "cinema of attractions," which opposed a conception of the early period of the cinema as the primitive form of a later state of perfection attained by the medium, finds a notable forerunner in Comolli's polemics against the "teleological" presentations of film history provided by Bazin, Mitry and others. ${ }^{42}$ In a similar vein, Musser has invoked Comolli when warning of the ideological pitfalls that can be encountered in the search for "first times" in accounts of the evolution of film techniques, although he also cautions against an approach that would veer too far in the other direction and "seek to forsake starting points entirely [or] offer the possibility of so many starting points that the notion of a beginning is not only diffused but ultimately avoided." ${ }^{43}$

It is Gaudreault, however, who has most unabashedly asserted the importance of "Technique et idéologie" for the new generation of film historians. In his recent text, Film and Attraction, the Quebecois scholar forcefully argues for the influence of the Cahiers critic. He insists that "Comolli's articles were one of the rare studies to give a thrashing to 'official history' at such an early date and in such a systematic and forceful manner" and that they formed "a user's manual for the scholars who were soon about to express an interest in the early days of cinema. ${ }^{144}$ Gaudreault even goes so far as to call the movement "post-Comolli criticism," avowing that its members "borrowed, consciously or not, from Comolli's shaking up of official history."45

41 Robert Sklar, "Oh! Althusser!: Historiography and the Rise of Cinema Studies," in Robert Sklar and Charles Musser (eds.), Resisting Images: Essays on Cinema and History (Philadelphia: Temple University Press, 1990), pp. 12-36.

42 Gunning has written amply on the "cinema of attractions," but the concept was first adumbrated in his "The Cinema of Attractions: Early Film, Its Spectator and the Avant-Garde," Wide Angle vol. 8 no. 3-4 (Fall 1986), pp. 63-70.

43 Charles Musser, The Emergence of Cinema: The American Screen to 1907 (New York: Scribner, 1990), p. 15 .

44 André Gaudreault, Film and Attraction: From Kinematography to Cinema, pp. 11, 16.

45 Ibid., pp. 12, 16. This esteem for the groundbreaking character of Comolli's work was no doubt a major motivation for Gaudreault to co-organize the "Impact of Technological Innovations on the Historiography and Theory of Cinema" conference in 2011, which brought together many of 
The repercussions of Comolli's text for the new film historians was, like the influence of Cahiers on Screen in the 1970s, largely a one-way affair: there has been little sign of Comolli theoretically engaging or personally collaborating with the major figures in this area of research. For a direct, individual link between the Cahiers of the post-1968 period and "post-Brighton" film historiography, we must therefore turn to another of the journal's alumni: Jacques Aumont. Aumont's position as a founding figure of film studies as an academic discipline in France, contemporaneous with its development in the English-speaking world, and his broader, decades-long project to theorize film aesthetics (discussed further in Chapter 19), have inevitably entailed a deep preoccupation with the early history of the cinema. Moreover, his ties with English-language academia were deepened with his editorship of the bilingual journal Iris in the 1980s, which published the work of French and North American scholars in equal measure. In this vein, a couple of projects stand out from among his large corpus of writings and activities. In August 1985, Aumont co-organized with André Gaudreault and Michel Marie a symposium at Cerisy on the topic "L'Histoire du cinéma: nouvelles approches." One of the first conferences - in France or anywhere - to specifically present the work of the "new film historians," the colloque's proceedings, including contributions by Gunning, Rick Altman, Paolo Cherchi Usai and Mitry, were published in book form in $1989 .{ }^{46}$ In addition, Aumont can also be credited with contributing to the revival of scholarly interest in the work of D.W. Griffith, the reconsideration of whose œuvre would-thanks also to the work of Gunning ${ }^{47}$ — become a major aspect of research into the early history of the cinema. In Aumont's contribution to Bellour's landmark edited collection Le Cinéma américain, "Griffith, le cadre, la figure," he argues that shot construction in Griffith's Biograph era works functions along strikingly different principles than later conventional film practice. In these films dating from 1908-1912, Griffith "does nothing to hide the white threads which sew the frames together: on the contrary, he makes much of them, flaunts them, puts a great deal of emphasis on them, marks them with a whole signifying apparatus"; as such, the pioneer of American cinema, for

the "original combatants" of the "technique and ideology" debates—including Comolli, Leblanc and Lebel—-to return to the issues raised 40 years earlier. See Daniel Fairfax, "Conference Report: The Impact of Technological Innovations on the Historiography and Theory of Cinema," Cinema Journal vol. 52 no. 1 (Fall 2012), pp. 127-131.

46 Jacques Aumont, André Gaudreault and Michel Marie (eds.), L'Histoire du cinéma: Nouvelles approches (Paris: Publications de la Sorbonne, 1989).

47 See Tom Gunning, D.W. Griffith \& The Origins of American Narrative Film (Chicago: University of Illinois Press, 1994). 
Aumont, remains resolutely outside the codes of continuity editing that would become the dominant practice in the classical Hollywood system. ${ }^{48}$

\section{The Legacy of Cahiers du cinéma and "Apparatus Theory" Today}

Bordwell and Carroll's attacks on "Grand Theory" left their opponents reeling and were accompanied by parallel undertakings such as Richard Allen's Projecting Illusion, which used a Wittgensteinien approach to challenge Althusserian and Lacanian ideas on the functioning of the cinematic apparatus. ${ }^{49}$ While contributors to Screen and other figures in the anglophone academy were the main targets of these strictures, it was inevitable that the Cahiers writers, and in particular their psychoanalytically oriented texts, should find themselves in the crosshairs. By the 1980s and 1990s, indeed, few could be found to champion this tendency. Many of the earlier proponents of "apparatus theory" had abandoned it as a conceptual paradigm, often embarking on turns to cultural studies or Deleuzian/Foucauldian approaches to film theory. Even defenders of its legacy, such as D.N. Rodowick, had to accept that "political modernism" had entered a "crisis" and sought to draw out the contradictions and shortcomings of the original theories, while hoping to salvage a kernel of theoretical validity from amidst the conceptual wreckage.

Rodowick's was not the first retrospective account of this theoretical tradition. As precursors to The Crisis of Political Modernism we can count, with a focus on the French context, Sylvia Harvey's superb account of the political climate in which Cahiers and Cinéthique developed their theoretical perspectives (May '68 and Film Culture) and George Lellis' more prosaic overview of the relationship between Brechtian artistic practices and the critical work of Cahiers (Bertolt Brecht, Cahiers du Cinéma and Contemporary Film Theory), while Dana Polan also provides a broad summary of this tendency in film theory, albeit with less focus on Cahiers, in his study The Political Language of Film and the Avant-Garde..$^{50}$ But Rodowick was the

48 Jacques Aumont, "Griffith, le cadre, la figure," in Raymond Bellour (ed.), Le Cinéma américain vol. I(Paris: Flammarion, 1980), pp. 51-67, here pp. 59-6o. Translated as "Griffith: The Frame, the Figure," in Early Cinema: Space, Frame, Narrative, ed. Thomas Elsaesser (London: BFI Publishing, 1990), pp. 348-359, here p. 353.

49 Richard Allen, Projecting Illusion: Film Spectatorship and the Impression of Reality (Cambridge: Cambridge University Press, 1995).

50 See Sylvia Harvey, May'68 and Film Culture; George Lellis, Bertolt Brecht, Cahiers du Cinéma and Contemporary Film Theory; and Dana Polan, The Political Language of Film and the AvantGarde (Ann Arbor: UMI Research Press, 1985). 
first to categorically state what had elsewhere, by the late 1980 , become a generalized sentiment in the field: that the tendency of "political modernism," "apparatus theory," "Screen theory" or "1970s theory" was in a state of crisis. In the preface to the second edition of his monograph, Rodowick memorably stated that "the 1970s, or what I call the era of political modernism, is often treated with an equal mixture of pride and embarrassment"; moreover, from the perspective of 1994, he argued that the "formalism and extravagant political claims" of this period appear "a bit passé." ${ }^{11}$ Nonetheless, he points to the contradictory attitude towards this foundational moment in the field, noting that "film studies today tends retroactively both to pose and to deny its historical continuities with the 1970s," and he asserts that "the era of political modernism is still with us in many ways." $5^{2}$ The acuity of Rodowick's study is indisputable, and the scope of his framework is also impressive, taking in the gamut of the theoretical, political and formal concerns that were at the core of political modernism, a term that, although not coined by Rodowick, his book has served to popularize. 53 However, The Crisis of Political Modernism often has a tendency to elide the role of Cahiers and Cinéthique in acting as a conduit between the "French theory" of Tel Quel, Derrida, Lacan and Althusser and its introduction into Anglo-American film studies. Oudart, for instance, is curiously absent from Rodowick's discussion of suture, which passes directly from Jacques-Alain Miller to Stephen Heath, despite the fact that Heath is explicitly indebted to the Cahiers critic. ${ }^{54}$ Moreover, when Cahiers is discussed, Rodowick almost exclusively turns to the "Cinéma/idéologie/critique" editorial, leaving the vast corpus of other writings in the journal largely untouched.

Ironically, at the same time that Rodowick was writing, the number of articles from Cahiers' post-1968 period available in English rapidly expanded with the 1990 publication of the third volume of the BFI's selection of Cahiers articles, focusing on the years 1969-1972. In his introduction to the volume, Nick Browne lucidly defends the Cahiers project of this period and expands the terrain on which the journal's theory should be judged to cover lesser known texts such as Oudart's "Jeux de mots, jeux de maitre," Oudart, Narboni and Comolli's "Lectures de Jancsó: hier et aujord'hui” and Daney and Oudart's "Le Nom-de-l'Auteur (à propos de la 'place' de Mort à Venise)." ${ }^{55}$ This effort vol. 23 no. 1 (May-June 1982), pp. 45-59.

54 Ibid., pp. 193-197.

55

Ibid., pp. vii-viii.

Rodowick, The Crisis of Political Modernism, p. vii.

The term first appeared in Sylvia Harvey, "Whose Brecht? Memories for the Eighties," Screen

55 See Browne, "Introduction: The Politics of Representation." 
was followed a decade later with the fourth and final volume in the series covering the period 1973-1978. While these anthologies have been invaluable in providing greater access for English readers to previously unavailable material, the ensuing decades have seen few efforts to resuscitate this work for a contemporary context. One of the rare exceptions has been Martin Jay's endeavor, in Downcast Eyes, to situate the post-1968 Cahiers within a broader critique of "ocularcentric" thought in French critical theory, with Daney's "Sur Salador" and Comolli's "Machines of the Visible" both discussed at length in this framework. ${ }^{6}$

The key Cahiers texts, such as "Cinéma/idéologie/critique," "Technique et idéologie" and "Young Mr. Lincoln de John Ford," have, of course, retained their canonical status within the discipline and still feature frequently in course syllabi and film theory anthologies. But they largely remain in a frozen state, read as documents of their time rather than being subject to productive re-readings or new lines of research. Indeed, when Rodowick returns to discussing Cahiers' critical legacy, he even more definitively associates them with the past tense of a remote historical era: if in 1988 he invoked the "crisis" of political modernism, he now speaks of an "elegy" for theory itself. ${ }^{57}$ Against such a mournful outlook consigning this work to a distant, outmoded past, I contend not only that a rigorous yet creative exegesis of the original Cahiers texts can hold valuable lessons for the field of film studies in the contemporary era but also that the most profitable avenue for this enterprise is to turn to the vast corpus of writing and filmmaking produced by the Cahiers critics themselves, whether during their time at the journal or in other outlets and media in the four decades since the landmark articles of the 1969-1972 period that have been discussed so far. It is this task that will occupy the following parts of this book.

\section{Works Cited}

Richard Allen, Projecting Illusion: Film Spectatorship and the Impression of Reality (Cambridge: Cambridge University Press, 1995).

Dudley Andrew, Concepts in Film Theory (Oxford: Oxford University Press, 1984). Jacques Aumont, "Griffith, le cadre, la figure," in Raymond Bellour (ed.), Le Cinéma américain vol. I (Paris: Flammarion, 1980), pp. 51-67. Translated as "Griffith:

56 Martin Jay, Downcast Eyes: The Denigration of Vision in Twentieth-Century French Thought (Berkeley: University of California Press, 1995), pp. 464-492.

57 See Rodowick, Elegy for Theory. 
The Frame, the Figure," in Early Cinema: Space, Frame, Narrative, ed. Thomas Elsaesser (London: BFI Publishing, 1990), pp. 348-359.

—, André Gaudreault and Michel Marie (eds.), L'Histoire du cinéma: Nouvelles approches (Paris: Publications de la Sorbonne, 1989).

David Bordwell, "Historical Poetics of Cinema," Georgia State Literary Studies no. 3 (1989), pp. 369-398.

—, "Film Studies and Grand Theory," in David Bordwell and Noël Carroll (eds.), Post-Theory: Reconstructing Film Studies (Madison: University of Wisconsin Press, 1995), pp. 3-36.

- Janet Staiger and Kristin Thompson, The Classical Hollywood Cinema: Film Style and Mode of Production to 1960 (New York: Columbia University Press, 1985).

Ben Brewster, "Structuralism in Film Criticism," Screen vol. 12 no. 1 (Spring 1971), pp. 49-58.

—, and Colin MacCabe, "Editorial," Screen vol. 15 no. 1 (Spring 1974), pp. 4-10.

—, Stephen Heath and Colin MacCabe, "Comment," Screen vol. 16 no. 2 (Summer 1975), pp. 83-9o.

Nick Browne, "Introduction: The Politics of Representation: Cahiers du Cinéma 1969-1972," in idem. (ed.), Cahiers du Cinéma vol. III: 1969-1972 The Politics of Representation (London: Routledge, 1990), pp. 1-20.

Edward Buscombe, Christine Gledhill, Alan Lovell and Christopher Williams, "Statement: Psychoanalysis and Film," Screen vol. 16 no. 4 (Winter 1975), pp. 119-130.

—, "Why We Have Resigned from the Board of Screen," Screen vol. 17 no. 2 (Summer 1976), pp. 106-109.

Noël Carroll, "Address to the Heathen," October no. 23 (Winter 1982), pp. 89-163.

—, "A Reply to Heath," October no. 27 (Winter 1983), pp. 81-102.

—, Mystifying Movies (New York: Columbia University, 1988).

Jean-Louis Comolli, "Technique and Ideology: Camera, Perspective, Depth of Field," trans. Diana Matias, Film Reader no. 2 (1977), pp. 128-140.

—, "Un corps en trop," Cahiers du cinéma, no. 278, July 1977, pp. 5-16. Translated as "Historical Fiction: A Body Too Much," trans. Ben Brewster, Screen vol. 19 no. 2 (Summer 1978), pp. 41-53.

—, "Machines of the Visible," in Stephen Heath and Teresa de Lauretis (eds.), The Cinematic Apparatus (London: Macmillan Press, 1980), pp. 121-142.

Jean-Luc Comolli and Paul Narboni [sic], "Cinema/Ideology/Criticism," trans. Susan Bennett, Screen vol. 12 no. 1 (Spring 1971), pp. 27-36.

Pam Cook and Claire Johnston, "The Place of Woman in the Cinema of Raoul Walsh," in Philip Hardy (ed.), Raoul Walsh (London: BFI, 1974), pp. 92-109.

Serge Daney, "Festival d'Edinbourg: Histoire/Production/Mémoire," Cahiers du cinéma no. 283 (December 1977), pp. 57-60.

Jean Douchet, "Hitch et son public," Cahiers du cinéma no. 113 (November 1960), pp. 7-15. 
Bernard Eisenschitz, "Who does the World Belong to? The Place of a Film," Screen vol. 15 no. 2 (Summer 1974), pp. 66-73.

Daniel Fairfax, "Conference Report: The Impact of Technological Innovations on the Historiography and Theory of Cinema," Cinema Journal vol. $5^{2}$ no. 1 (Fall 2012), pp. 127-131.

Simon Field (with Peter Sainsbury), "Présentation," in Nicole Brenez and Michael Witt (eds.),Jean-Luc Godard:Documents (Paris: Centre Pompidou, 2006), p. 144. André Gaudreault, Film and Attraction: From Kinematography to Cinema, trans. Timothy Barnard (Urbana: University of Illinois Press, 2011).

Tom Gunning, "The Cinema of Attractions: Early Film, Its Spectator and the AvantGarde," Wide Angle vol. 8 no. 3-4 (Fall 1986), pp. 63-70.

—, D.W. Griffith \& The Origins of American Narrative Film (Chicago: University of Illinois Press, 1994).

William Guynn, "The Political Program of Cahiers du cinéma, 1969-1977," Jump Cut no. 17 (April 1978), pp. 32-35.

Sylvia Harvey, May '68 and Film Culture (London: BFI, 1980).

—, "Whose Brecht? Memories for the Eighties," Screen vol. 23 no. 1 (May/June 1982), pp. $45-59$.

Stephen Heath, "Lessons from Brecht," Screen vol. 15 no. 2 (Summer 1974), pp. 103-128.

—, "Anata Mo," Screen vol. 17 no. 4 (Winter 1976-1977), pp. 49-66.

—, "Notes on Suture," Screen vol. 18 no. 4 (Winter 1977-1978), pp. 48-76.

—, Questions of Cinema (Bloomington: Indian University Press, 1981).

—, "Le Père Noël," October no. 26 (Autumn 1983), pp. 63-115.

Martin Jay, Downcast Eyes: The Denigration of Vision in Twentieth-Century French Thought (Berkeley: University of California Press, 1995).

Claire Johnston, "Film Journals: Britain and France," Screen vol. 12 no. 1 (Spring 1971), pp. 39-48.

Chuck Kleinhans, “Twelve Frames per Second," Jump Cut no. 17 (April 1978), p. 36. George Lellis, Bertolt Brecht, Cahiers du Cinéma and Contemporary Film Theory (Ann Arbor: UMI Research Press, 1982).

Julia Lesage, "The Human Subject - You, He or Me? (Or, the Case of the Missing Penis), Jump Cut no. 4 (November-December 1974), pp. 26-27. Repr. in Screen vol. 16 no. 2 (Summer 1975), pp. 77-83.

Alan Lovell, Colin MacCabe and Elizabeth Cowie in "Film Culture," Screen vol. 16 no. 1 (Spring 1975), pp. 128-141.

Colin MacCabe, "Realism and the Cinema: Notes on Some Brechtian Theses," Screen vol. 15 no. 2 (Summer 1974), pp. 7-27.

-, "The Politics of Separation (on Deux ou trois choses que je sais d'elle and Tout va bien)," Screen vol. 16 no. 4 (Winter 1975), pp. 46-61.

—, "Principles of Realism and Pleasure, Screen vol. 17 no. 3 (Autumn 1976), pp. 7-27. 
—, Tracking the Signifier: Theoretical Essays: Film, Linguistics, Literature (Minneapolis: University of Minnesota Press, 1986).

Laura Mulvey, "Visual Pleasure and Narrative Cinema," Screen vol. 16 no. 3 (Autumn 1975), pp. 6-18.

Charles Musser, The Emergence of Cinema: The American Screen to 1907 (New York: Scribner, 1990).

Jean-Pierre Oudart, "Cinema and Suture," trans. Kari Hanet, Screen vol. 18 no. 4 (Winter 1977-1978), pp. 24-34.

Dana Polan, The Political Language of Film and the Avant-Garde (Ann Arbor: UMI Research Press, 1985).

La Rédaction, "Réponses à Politique Hebdo," Cahiers du cinéma no. 229 (MayJune 1971), pp. 61-64.

B. Ruby Rich, Chuck Kleinhans and Julia Lesage, "Report on a conference not attended: The scalpel beneath the suture," Jump Cut no. 17 (April 1978), pp. 37-38.

D.N. Rodowick, The Crisis of Political Modernism, $2^{\text {nd }}$ ed. (Berkeley: University of California Press, 1994),

—, Elegy for Theory (Cambridge, MA: Harvard University Press, 2014).

Jacqueline Rose, "The Cinematic Apparatus: Problems in Current Theory," in Stephen Heath and Teresa de Lauretis (eds.), The Cinematic Apparatus (London: Macmillan Press, 1980), pp. 172-186.

Philip Rosen, "The Concept of Ideology and Contemporary Film Criticism," PhD dissertation, University of Iowa, 1978.

[Screen], "Editorial," Screen vol. 16 no. 2 (Summer 1975), pp. 4-6.

Robert Sklar, "Oh! Althusser!: Historiography and the Rise of Cinema Studies," in Robert Sklar and Charles Musser (eds.), Resisting Images: Essays on Cinema and History (Philadelphia: Temple University Press, 1990), pp. 12-36.

Christopher Williams, "Bazin on Neo-Realism," Screen vol. 15 no. 1 (Spring 1974), pp. 61-68.

Peter Wollen, “'Ontology' and 'Materialism' in Film," Screen vol. 17 no. 1 (Spring 1976), pp. 7-25. 


\section{Part II}

\section{Engagements with Politics}

Fairfax, D., The Red Years of Cahiers du Cinéma (1968-1973). Volume I: Ideology and Politics. Amsterdam: Amsterdam University Press, 2021

DOI 10.5117/9789463728508_PART02 

"Every film is political," trumpeted Comolli/Narboni in "Cinéma/idéologie/ critique," at the precise moment, in late 1969, that Cahiers' political outlook came to be unabashedly informed by revolutionary Marxism. ${ }^{1}$ Politics was absolutely central to the Cahiers project of the late 196os and 197os. Everything during this period - and not least the cinema-was to be read through the lens of the militant left-wing politics to which the journal's editors were committed. But the tenor of Cahiers' political approach to film writing in the post-1968 period also owed a debt to the journal's critical heritage. Indeed, the very phrase used by the editors in "Cinema/Ideology/Criticism" was a conscious echo of Rivette, who had, a year earlier, in September 1968, boldly affirmed that "all films are political," proceeding to explain: "what is most important politically is the attitude that the filmmaker takes with regard to all the aesthetic criteria-or rather, so-called aesthetic criteria-which govern art in general and cinematic expression, in triple inverted commas, in particular." Furthermore, the core of Cahiers' approach to political questions in the cinema can be traced back further, to the legendary equation between morality and the tracking shot made conjointly by Moullet and Godard, as well as Rivette's text “De l'abjection."In this brief but seminal review of Gillo Pontecorvo's Kapò (1960), the critic dissects a shot where Emmanuelle Riva commits suicide by throwing herself on the electric fence of a concentration camp, pronouncing the edict that "the man who decides, at this moment, to make a forward tracking-shot to re-frame the corpse from a high-angled view, taking care to precisely inscribe the hand raised at an angle to the final framing, deserves only the most profound contempt."' It is here that Rivette establishes the idea, fundamental for Cahiers, that filmmaking consists both of "showing certain things" and "at the same time, and by the same operation, showing them a certain way; these two acts being rigorously indissociable."4 In line with Rivette's exhortations, Cahiers' project consisted, as Browne has noted, of "a

1 Comolli/Narboni, "Cinéma/idéologie/critique," p. 12 [p. 253]. Symptomatic of the journal's political and theoretical tergiversations in this era, the proclamation would soon be subject to critique by Cahiers itself, with Aumont stating, in late 1971, "This was Cahiers' formulation two years ago, but we have since reassessed it in order to refine and clarify it—for in that form it practically presented nothing but dangers." Jacques Aumont, "Lettres," Cahiers du cinéma no. 234-235 (December 1971-January-February 1972), pp. 101-102, here p. 101.

2 Rivette, "Le temps déborde: entretien avec Jacques Rivette," Cahiers du cinéma no. 204 (September 1968), p. 20 [p. 36].

3 See Jacques Rivette, "De l'abjection," Cahiers du cinéma no. 120 (June 1961), pp. 54-55, here p. 54 .

4 Ibid., p. 55 . 
politics, not a poetics, of representation. ${ }^{5}$ Comolli has likewise argued that the journal's "central problem" was the politics of form, and more specifically the question of "how to articulate a reflection on film form with political questions. In my opinion there is a very strong link between the political scope of a film and its form. The form does not have to absolutely be in the avant-garde, but the film must intervene in a cultural field, an ideological field, and this intervention must have political meaning." 6

Whereas Part I centered on the development of theories of the ideological nature of the "cinematic apparatus" during Cahiers' Marxist period, here the focus will be on the journal's encounters with politics sensu stricto. A specific concern for interventions into the political arena chiefly took two forms in the period of its engagement with the far left. Firstly, and notwithstanding the notion that all films are political by nature, there was the critical discussion of films with explicitly political subject matter, which were to be judged, following the precepts of "Cinéma/idéologie/critique," primarily on a formal basis, on the level of their "signifiers" rather than their signified. Secondly, there was, throughout this period, interaction in various guises with the far-left movements and organizations that were simultaneously energized by the spirit of revolt flowing out of the May protests and paralyzed by paranoia, doctrinaire rigidity and internecine sectarian quarreling during the post-1968 period, tendencies from which Cahiers itself was not immune.

Cahiers' phase of political radicalization, therefore, also marked one of the periods where the journal's internal critical evolution was most visibly articulated with broader historical events. For the most part, however, this nexus was marked by a chronic temporal displacement: the journal's own political turns were - slightly but crucially-out of synch with the broader shifts in the political climate of France. The rapprochement Cahiers enacted with the PCF in 1969-1971, for instance, came at a moment when the party was most politically discredited among the far left, having aided in dampening the utopian spirits of the May'68 revolt, while the subsequent turn to Maoism in 1972-1973 took place after the "pro-Chinese" movement in France had already reached its apogee and entered a stage of terminal decline. As Daney recognized, the history of the journal during this time is that of a décalage (a discrepancy or lag), ${ }^{7}$ and it is this missed encounter

5 Nick Browne, "Introduction," p. 2.

6 Comolli, "Yes, we were utopians (Part 1)."

7 Serge Daney, interviewed by Bill Krohn, "Les Cahiers du cinéma 1968-1977: Entretien avec Serge Daney par Bill Krohn," in Daney, La Maison cinéma et le monde vol. I, pp. 17-31, here p. 21. 
with Politics with a capital " $P$ " that accounts for the tragi-comic nature of this period in the journal's history, which led to the near-collapse of Cahiers after the failure of the "Front culturel" policy of 1973. Bonitzer admits that "Between 1971 and 1973, Cahiers almost fell into the abyss of a definitive hors-champ," ${ }^{8}$ while Daney, mindful perhaps of Marx's apothegm that history happens "first as tragedy, then as farce," recalls having nurtured the project of writing a comedy about the political extravagances of the journal's Maoist period but ended up renouncing the project. "In any case," he surmised, "who would have laughed about these excesses?"9

Owing to Cahiers' contorted relationship with the currents of history during the 1960s and 1970s, Part II will assume a chiefly chronological structure, and for this reason it also serves as a surrogate for a more detailed history of the journal during this time. As Kané has noted in conversation with Comolli and Narboni, what is most striking about this period is "the extraordinary mobility of the political positions" successively taken by the journal; when Comolli responded by noting that this was a more general phenomenon that was not specific to Cahiers, Kané retorted that "the difference is the speed" with which Cahiers switched its political allegiances. ${ }^{10}$ In the late 1960 s and early 1970s, the journal was in a constant state of flux: renouncing claims it had made in previous issues, peremptorily modifying theoretical stances it had peremptorily taken in the first place, launching disputes with other journals (notably Tel Quel, La Nouvelle Critique and Cinéthique) and then reconciling with them, and purging its ranks of those members of the team unable to keep up with the latest political turn. Nonetheless, it is possible to discern four distinct phases in Cahiers' political engagement, which conform to four of the chapters in this section.

The first period consists of the progressive process of radicalization that took place between 1963 (when Rivette took over as editor-in-chief from Rohmer) and the 1969 editorial. Throughout this time, Cahiers did without an official political line and remained steadfastly independent of partisan politics. While, under Rivette and then Comolli/Narboni, it came to be identified with the left and with an ardent opposition to Gaullist rule, it remained ideologically eclectic. The prevailing sentiment around the editorial team nonetheless perceptibly shifted from a soft-left, Mitterrandist

Translated as T.L. French [Bill Krohn], "Les Cahiers du Cinéma 1968-1977: Interview with Serge Daney," The Thousand Eyes no. 2 (1977), pp. 18-32, here p. 21.

8 Pascal Bonitzer, La Vision partielle (Paris: Capricci, 2015), p. 10.

9 Daney, L'Exercice a été profitable, monsieur, p. 298.

10 À voir absolument (si possible): Dix années aux Cahiers, dir. Jean-Louis Comolli and Jean Narboni, 2011. 
outlook in the mid-196os to the more radically anti-capitalist mood of the end of the decade. ${ }^{11}$ This evolution was shaped not only by broader historical forces, in particular the radicalization of the student and cultural milieux in the late 196os, but also by Cahiers' own encounters with filmmakers undergoing the same trajectories (among them Godard, Garrel and Pasolini) and the forms of political activity its editors embarked on: battles against censorship (of La Religieuse, notably), state repression (the dismissal of Langlois from the Cinémathèque française) and the commercial imperatives of its proprietor, media tycoon Daniel Filipacchi, which ended in Cahiers winning its economic independence after a four-month ownership dispute.

With the Filipacchi contretemps resolved in early 1970, the next 18 months were marked by an attempted rapprochement with the PCF, judged to be the only viable political force worth orienting towards, even after the disreputable role it had played during the May protests. This period coincides with what is undeniably the journal's most theoretically fertile moment, marked notably by critical work on Renoir's La vie est à nous, 1920 S Soviet cinema (particularly Eisenstein's films and theory), Robert Kramer's Ice and, in a negative light, fictions de gauche such as Costa-Gavras' $Z$. The Cahiers editors have stressed that this strategy was principally an attempt to relate to the party's intellectual layers, and specifically the cultural organ La Nouvelle Critique, rather than its considerably more doctrinaire political leadership. However, increasing dissatisfaction with the PCF, combined with the pull of Tel Quel, led to a violent rupture in late 1971, as Cahiers came under the sway of a "Marxist-Leninist," Maoist orientation for the next two years. With its political intolerance, alienation from cinematic concerns and jargon-laden texts (which, the consensus has it, "have not aged well ${ }^{12}$ ), this era is widely viewed as an unmitigated disaster, not least by the Cahiers editors themselves. For Bonitzer it was "a sinister era," while for Narboni it represented an "arid, dogmatic and closed-off period" —and these two critics were among the chief proponents of the turn to Maoism. ${ }^{13}$ Although it may have few defenders, I will not, in this chapter, be content

11 Following the 1965 presidential election, which pitted socialist candidate François Mitterand against the incumbent de Gaulle, Fieschi noted that, "We all voted Mitterrand, albeit without any particular joy." Jean-André Fieschi, "Le cahier des lecteurs," Cahiers du cinéma no. 174 (January 1966), pp. 5-6, here p. 6.

12 The phrase is Daney's. See Serge Daney, La Rampe (Paris: Cahiers du cinéma, 1983), p. 49.

13 Interview with Pascal Bonitzer, April 30, 2014; and Jean Narboni, "Du côté des noms," in François Dosse and Jean-Michel Frodon (eds.), Gilles Deleuze et les images (Paris: Cahiers du cinéma, 2008), pp. 21-30, here p. 24. The duo was nicknamed "Narbonitzer" within Cahiers, such was their shared zeal during the Maoist turn. Interview with Jacques Aumont, March 11, 2014. 
with a condescending denunciation of the shortcomings of the journal's Maoist period. Rather, I will seek out a political understanding of why this path should have been taken, and the reasons for the impasse it led to. It should be recalled that French Maoism was a significant and vibrant, albeit short-lived, political movement in the early 1970s, around which gravitated some of the most charismatic figures in the student left, as well as a large number of intellectuals, including Jean-Paul Sartre, Roland Barthes, Michel Foucault, Jean-Luc Godard, Julia Kristeva and Philippe Sollers. It is as a part of this broader phenomenon that Cahiers' turn must be understood.

While the first year of Cahiers' Maoist period was marked by a continuation of their theoretical outpouring, the second year consisted chiefly of preparations for the "Front culturel révolutionnaire." When the launch of this project at Avignon in the summer of 1973 resulted in a dispiriting debacle, the Cahiers editorial team evaporated. Comolli, Narboni and Aumont all departed, and it was left to Daney and Serge Toubiana to form the nucleus of a new team, a pairing which would last until Daney's resignation in 1981. This whole period can be seen as a "post-gauchiste" phase in the history of Cahiers. Abandoning Maoism, the journal's critics nonetheless continued to identify with the far left, but they did so with an increasing pessimism as to the concrete prospects of revolutionary social change. But this era was also marked by a return to film criticism, and insightful writing on the cinema was published - by Daney, Bonitzer, Kané and Oudart, as well as newer critics such as Serge Le Péron, Thérèse Giraud and Alain Bergala.

These four chronologically sequenced chapters will be interspersed with three further chapters, serving as excurses from the political history of the journal. The first (Chapter 10) will look at the long relationship that Cahiers entertained with Jean-Luc Godard, which reached a high point with the long studies devoted to the Groupe Dziga Vertov films in 1972, a time when, along with Straub/Huillet, Godard was virtually the only filmmaker defended by the journal. The other two chapters will look at the legacy of Cahiers' political engagement in the subsequent work of a pair of former editors: Eisenschitz, who as a card-carrying PCF member continued to write for La Nouvelle Critique after his expulsion from Cahiers in 1972 while furthering his activities as a film historian, and Comolli, whose theory and filmmaking up to the present day continue to be impregnated by a strident political radicalism. They are the only two members of the Cahiers team who continue to broadly identify as Marxists; tellingly, perhaps, neither was fully implicated in the excesses of the Maoist turn. Those who were have a perceptibly more traumatized response to their political past. But it is notable that all the Cahiers editors remained avowedly on the left after 
the demise of the post-1968 militant period. None embarked on the kind of spectacular conversions to neo-conservatism staged by contemporaries of theirs such as Alain Finkielkraut, André Glucksmann or Jean-Claude Milner. Daney was perhaps the most scathing about Cahiers' tumultuous engagement with politics, to the point of confessing: "I even hoped that it would create nothing. Can you imagine if our general line had succeeded. It was horrifying!"14 But even he came to be unrepentant about this period: "I no longer have any desire to apologize because once, fifteen years ago, we were lacking in the good manners of bourgeois arrivisme. For the first time, I would actually prefer to plead for the defense." ${ }^{m 5}$

\section{Works Cited}

Pascal Bonitzer, La Vision partielle (Paris: Capricci, 2015).

Nick Browne, "Introduction: The Politics of Representation: Cahiers du Cinéma 1969-1972," in idem. (ed.), Cahiers du Cinéma vol. III: 1969-1972 The Politics of Representation (London: Routledge, 1990), pp. 1-20.

Jean-Louis Comolli, interviewed by Daniel Fairfax, "Yes, we were utopians; in a way, I still am...': An Interview with Jean-Louis Comolli (Part 1)," Senses of Cinema no. 62 (April 2012), sensesofcinema.com/2012/feature-articles/yes-wewere-utopians-in-a-way-i-still-am-an-interview-with-jean-louis-comolli-part-1/ (accessed January 1, 2021).

— and Jean Narboni, "Cinéma/idéologie/critique," Cahiers du cinéma no. 216 (October 1969), pp. 11-15. Translated as "Cinema/Ideology/Criticism," trans. Daniel Fairfax, in Jean-Louis Comolli, Cinema against Spectacle: Technique and Ideology Revisited (Amsterdam: Amsterdam University Press, 2015), pp. 251-259.

Serge Daney, interviewed by Bill Krohn, "Les Cahiers du cinéma 1968-1977: Entretien avec Serge Daney par Bill Krohn," in Daney, La Maison cinéma et le monde vol. I: Les temps des Cahiers 1962-1981 (Paris: P.O.L., 2001), pp. 17-31. Translated as T.L. French [Bill Krohn], "Les Cahiers du Cinéma 1968-1977: Interview with Serge Daney," The Thousand Eyes no. 2 (1977), pp. 18-32.

Serge Daney, La Rampe (Paris: Cahiers du cinéma, 1983

—, L'Exercice a été profitable, Monsieur (Paris: P.O.L., 1993).

—, Persévérance (Paris: P.O.L., 1993), p. 143. Translated as Postcards from the Cinema, trans. Paul Douglas Grant (Oxford: Berg, 2007).

14 Serge Daney, Persévérance (Paris: P.O.L., 1993), p. 143. Translated as Postcards from the Cinema, trans. Paul Douglas Grant (Oxford: Berg, 2007), p. 119.

15 Daney, L'Exercice a été profitable, monsieur, p. 300. 
Jean-André Fieschi, “Le cahier des lecteurs," Cahiers du cinéma no. 174 (January 1966), pp. 5-6.

Jean Narboni, "Du côté des noms," in François Dosse and Jean-Michel Frodon (eds.), Gilles Deleuze et les images (Paris: Cahiers du cinéma, 2008), pp. 21-30

Jacques Rivette, "De l'abjection," Cahiers du cinéma no. 120 (June 1961), pp. 54-55. —, interviewed by Jacques Aumont, Jean-Louis Comolli, Jean Narboni and Sylvie Pierre, "Le temps déborde: Entretien avec Jacques Rivette," Cahiers du cinéma no. 204 (September 1968), pp. 6-21. Translated as "Time Overflowing," trans. Amy Gateff, in Jonathan Rosenbaum (ed.) Rivette: Texts and Interviews (London: BFI, 1977), pp. 9-38. 



\title{
7. The Radicalization of Cahiers: 1963-1969
}

\begin{abstract}
This chapter gives an account of the political radicalization of Cahiers du cinéma between the years 1963 (when Éric Rohmer was ousted as editor-in-chief and replaced by Jacques Rivette) and 1969 (when "Cinéma/ Idéologie/Critique" was published). Whereas in the 1950s, Cahiers had been studiously eclectic in its political leanings, under Rohmer it veered towards the far right. Rivette's editorship saw a corrective to this course, a tendency that was escalated when Comolli succeeded him in 1965. The left-wing orientation in the second half of the 196os witnessed Cahiers' participation in a number of key battles: from the censorship of La Réligieuse to the sacking of Henri Langlois as head of the cinémathèque and the national upheaval of May'68, which affected the cinema as much as it did the rest of French daily life. At the same time, a younger crop of critics - including Serge Daney, Bernard Eisenschitz, Sylvie Pierre and Jacques Aumont - gravitated towards Cahiers during these years.
\end{abstract}

Keywords: Cahiers du cinéma, May '68, Cinémathèque française, Étatsgénéraux du cinéma, militant filmmaking

\section{From Rohmer to Comolli: Political Transformations in the 196os}

Cahiers has never been an apolitical publication. Even if it avoided any official declarations on political matters, such questions nonetheless left an imprint on the journal throughout the 1950s, a time marked by the Cold War, decolonization and political unrest in France. Conceived by its founders Bazin and Doniol-Valcroze as a broad church, Cahiers nonetheless shifted perceptibly to the right after the former's death in 1958. Rohmer's stewardship in the late 1950 s and early 1960 s saw the ascendancy of the macmahonien group within the journal. Named after the $8^{\text {th }}$ arrondissement

Fairfax, D., The Red Years of Cahiers du Cinéma (1968-1973). Volume I: Ideology and Politics. Amsterdam: Amsterdam University Press, 2021 DOI 10.5117/9789463728508_CHO7 
movie theater programmed by Pierre Rissient, the macmahoniens promoted a cinema of "transparent mise en scène" — as embodied in the work of the "four aces" of Walsh, Lang, Losey and Preminger — — while also associating with right-wing groupings, including neo-fascist organizations and Algérie française supporters. Such political allegiances occasionally surfaced in articles for Cahiers, including, notoriously, Michel Mourlet's "Apologie de la violence," in which the "Boileau of the macmahoniens" argued that "mise en scène in its truest essence tends [...] towards what certain people call 'fascism."'3 Proclamations such as this scandalized the leftist wing of Cahiers at the time - a faction that included Rivette, Doniol-Valcroze and Pierre Kast - and would eventually bring about the putsch against Rohmer. It should be remembered, however, that in spite of his conservative views, le grand Momo, as he was affectionately known, was even-handed enough to promote the writing of figures from across the political spectrum. Rohmer's tenure, for instance, saw a special issue on Bertolt Brecht put together by Bernard Dort as well as several articles by the PCF-aligned critic Georges Sadoul on Soviet cinema.

But this was not enough to prevent Rohmer from being ousted as editor-ofchief in the summer of 1963. The move was presented to Cahiers' readership as a purely administrative measure: an editorial notice in the July 1963 issue, the first under the new regime, insisted that "it is only a matter of a modification in the structure and internal organization of our team" and that "Cahiers du cinéma is changing neither its line nor its orientation." A rider to the effect that "in addition to its original role as an organ of culture and information, it must once again become an instrument of combat" does point, however, to the pronounced shift in orientation the journal would subsequently undertake. ${ }^{4}$ The macmahoniens were no longer published, while other figures who sympathized with Rohmer (such as Jean Douchet and Barbet Schroeder) also left. The new orientation was most readily visible

1 Comolli has recently made the point that the "transparent" mise en scène advocated by the macmahoniens was "not overly characteristic of the style of these filmmakers, with the exception of some of Walsh's films." Comolli, Cinéma contre spectacle, p. 22 [p. 61]. Aside from Walsh, too, the "four aces" are associated with a left-liberal, anti-fascist political orientation totally at odds with the inclinations of the Rissient circle.

2 According to de Baecque, this was Mourlet's nickname within French cinephile circles, in reference to the seventeenth-century literary critic Nicolas Boileau-Despréaux. De Baecque, Histoire d'une revue vol II, p. 63.

3 Michel Mourlet, “Apologie de la violence," Cahiers du cinéma no. 107 (May 1960), pp. 24-27. For Mourlet's writings on the cinema, see Michel Mourlet, Sur un art ignoré: La mise en scène comme langage (Paris: Ramsay, 2008).

4 “Éditorial," Cahiers du cinéma no. 145 (July 1963), p. 1. 
in the series of interviews Rivette arranged with high-profile representatives of "cultural modernism": Roland Barthes, Claude Lévi-Strauss and Pierre Boulez. Although these encounters had mixed results, they provided the impetus to align Cahiers with contemporary trends in art and theory and move it away from the conservative classicism of Rohmer. ${ }^{5}$ Young critics gravitating around the review at this time included not only Narboni, Comolli and Jean-André Fieschi (dubbed the "gang of Corsicans" due to their last names, although only Fieschi was actually from the island) but also Jacques Bontemps, Jean Eustache, André Téchiné, Jean-Claude Biette, Louis Skorecki (writing as Jean-Louis Noames) and Paul Vecchiali. They were all sympathetic to the left and to the new generation of filmmakers and followed Rivette's signal to develop a much more political approach to their writing. The journal, therefore, increasingly did come to resemble the "instrument of combat" promised in 1963.

The other prominent transformation during this period came with the change of owner: in June 1964, Daniel Filipacchi, owner of the press conglomerate Union des Éditions Modernes, became majority shareholder in Cahiers' parent company, the Éditions de l'Étoile, and the journal's offices moved from the Champs-Elysées to 5, rue Clément-Marot. ${ }^{6}$ Most spectacularly, the yellow-covered format of its first 14 years was abandoned for a larger, glossier, more modern layout. Doniol-Valcroze sought to soothe readers concerned about the ramifications of these changes with an editorial promising that "a change of address is not a change of doctrine" and insisting that despite the radical change in the "chassis," the "engine preserves the same principles." Indeed, the Cahiers team, with Comolli replacing Rivette as editor-in-chief the following year, would fiercely guard their editorial independence. This stance would color many of the disputes engaged in by the journal, which frequently placed Cahiers in conflict with its own proprietor.

Chief among these was the battle around Jacques Rivette's La Religieuse. In April 1966, the film became a rallying point for Cahiers when, with the backing of André Malraux, then the minister of culture under de Gaulle, its release was refused by the state censorship board. La Religieuse was not the first nouvelle vague film to be censored (Le Petit Soldat had been shelved in 1961), but the decision incensed the Cahiers editors, and the

5 These interviews will be discussed more deeply in Chapter 14.

6 De Baecque, Histoire d'une revue vol II, p. 96.

7 Jacques Doniol-Valcroze, "La ligne générale," Cahiers du cinéma no. 160 (November 1964), p. 7. In Doniol-Valcroze's metaphor, the "engine" contained "Ginibre-Rivette as the twin-bodied carburator, Comolli as the suspension, Delahaye as the exhaust pipe, Fieschi as the tires, Narboni as the brake discs, Bontemps as the radiator, Moullet as the sparkplug, etc." 
journal immediately mobilized in defense of Rivette's film. While Rivette himself remained relatively quiet during the campaign, the younger writers were joined by Godard and others in their vocal attacks on the Gaullist state. A vitriolic letter Godard wrote to the "minister of Kultur" was published in Le Nouvel Observateur on April 6 (and re-published in Cahiers). The filmmaker excoriated Malraux for having "cheerfully accepted the banning of a work which nevertheless taught you the exact meaning of two inseparable ideas: generosity and resistance," adding: "I see now that it was simply cowardice. ${ }^{8}$ In tandem with this text, Godard also took it upon himself to write the editorial for the April 1966 issue of Cahiers, which, if anything, was of even greater violence, accusing the Gaullist state of censoring Rivette's film out of political opportunism and claiming that the regime's "true, totalitarian face" had been revealed. ${ }^{9}$ This editorial itself caused a subsidiary mini-scandal: Filipacchi, incensed at the naked ferocity of Godard's language, refused to distribute the issue containing the text, even after it had come back from the printers. At a tremendous cost to his company, the original print run was pulped and a new issue was printed, identical to the former version save for a much less vituperative notice penned by the editors themselves. ${ }^{10}$ Over the next several months, meanwhile, La Religieuse would become a rallying cry for Cahiers against the repression wielded by a sclerotic Gaullist state, and the wave of solidarity with Rivette eventually succeeded in overturning the ban, with the film finding a release in September 1967 .

For the young Cahiers critics, this battle was something of a political dépucélage. But it also exemplified the politicized nature of showing films in a country groaning under rigid governmental and industrial censorship. Whereas Cahiers traditionally responded to films released on commercial runs in Parisian theaters, the journal was increasingly becoming interested in radical works encountered in international festivals that were unable to find distribution in France. At the same time as supporting parallel

8 See Jean-Luc Godard, “Lettre au Ministre de 'Kultur," Le Nouvel Observateur, April 6, 1966. Translated as "Letter to the Minister of 'Kultur," in idem., Godard on Godard, trans. and ed. Tom Milne (New York: Da Capo Press, 1972), pp. 237-238, here p. 238. The letter was also published in Cahiers du cinéma no. 177 (April 1966), pp. 8-9.

9 Jean-Luc Godard (unsigned), "La guerre est commencée," Cahiers du cinéma no. 177 (April 1966), unpublished version.

10 The scandal and Godard's editorial are retrospectively discussed by the Cahiers editors in À voir absolument (si possible). The editorial was left unfinished and completed by Comolli. It now exists in a few "souvenir editions" kept by the editors themselves. Acknowledgements go to Jacques Bontemps for providing a copy of the original version of the issue withdrawn from publication. 
efforts such as the Hyères festival, the journal took the initiative to launch a "Semaine des Cahiers" in Paris. In April 1966, two theaters (the Napoleon and the Saint-Paul) were hired for a week to screen seven unreleased films from the "new cinemas," including Prima della rivoluzione by Bertolucci, Nicht versöhnt by Straub/Huillet and Rysopsis by Skolimowski. Close to 10,000 tickets were sold, exceeding even the most optimistic forecasts. Reporting on the event, a jubilant Comolli noted an "intimate satisfaction at having made things 'move,' at having confronted readers and friends with our own passions. ${ }^{\text {"11 }}$ What Narboni would later call an "intra-cinematic militancy"12 continued with follow-up events in October 1967 and October 1968 and foreshadowed a prolonged practice of public outreach by the journal throughout its politicized period. Beginning with the tumultuous events of 1968 , this activity was increasingly combined with "extra-cinematic" political activity.

\section{Four Fledgling Critics: Daney, Eisenschitz, Pierre and Aumont}

It was during this time that members of the future team, beyond the more established duo of Comolli and Narboni, entered the ranks of Cahiers. Four of them-Serge Daney, Bernard Eisenschitz, Sylvie Pierre and Jacques Aumont - began to contribute articles between 1963 and 1967 . The pathways that led them to the journal, however, differed markedly. As opposed to the solid team that formed after 1968, the group of writers contributing to the journal in the mid-196os was more diffuse, more dispersed, with collaborators contributing from Italy, the US, and even Japan. As Daney explains: "There was no editorial committee, and all the important decisions were made by one or two people. There were a lot of freelancers that might or might not be accepted from time to time, without feeling themselves to be part of a global point of view."13

Daney himself, however, felt destined to write for the journal, confessing that "the idea of working for another magazine simply never crossed my mind." ${ }^{14}$ In his writings and interviews, including the testimonial dialogue with Toubiana published in book form as Persévérance, Daney is voluble about his early years. His first encounter with Cahiers came in 1959 when he

11 Jean-Louis Comolli, “Une semaine comme une autre," Cahiers du cinéma no. 178 (May 1966), p. 66.

12 Interview with Jean Narboni, March 18, 2014.

13 Daney, "Les Cahiers du cinéma 1968-1977: Entretien avec Serge Daney," p. 18 [p. 19].

14 Daney, La Rampe, p. 11. 
purchased issue no. 99 (which featured a dossier on Fritz Lang), and within five years, at the age of 20 , he began contributing to the journal. ${ }^{15}$ Born on June 4, 1944, Daney was raised by a single mother in the $11^{\text {th }}$ arrondissement, where he would live his entire life. Together, the two assiduously attended the neighborhood cinema located across the street from their apartment, the Cyrano-Roquette. Daney would later find out that his Jewish father, a bit-part actor by the name of Pierre Smolensky, had perished in the camps. ${ }^{16}$ This link between his parents and the cinema would lead Daney to later term himself a "ciné-fils," a concept whose autobiographical core will be further explored in Chapter 20. Schooled at the Lycée Voltaire, where he found a mentor in the film scholar Henri Agel, Daney formed a close bond with Louis Skorecki, beginning a collaboration which would last until their years together at Liberration in the $1980{ }^{17}{ }^{17}$ The two young cinephiles founded the ephemeral journal Visages du cinéma in 1962, declaring in the inaugural editorial "What we propose here is not so much an informative magazine, but rather an approach, a constant interrogation of those who make the true cinema. ${ }^{18}$ Despite only lasting two issues, Visages du cinéma is now a precious document of the duo's cinematic predilections. The first number, dedicated to Hawks, featured articles by Daney on Scarface and Rio Bravo, and by Skorecki on Hatari, as well as a piece by Agel on "The Modernity of Howard Hawks," who presumably wrote for the magazine at Daney's urging. The second, dated March 1963, turned its focus to the films of Preminger. ${ }^{19}$ This "gerontophilic" inclination, as Daney termed it, ${ }^{20}$ prompted him to travel with Skorecki to Los Angeles in 1964 and interview the old masters of classical Hollywood, who tended to treat the pair as "two oddballs, two amateurs, the fat one and the skinny one, at once petrified in admiration and determined not to be disappointed." ${ }^{21}$ All the same, the resulting interviews, with Sirk, Lewis, Hawks, McCarey, Sternberg and Fuller, were gratefully snapped up by Cahiers and served to "pay for their entry ticket" into the journal. ${ }^{22}$ Reviews of films including Family Jewels, Chimes at Midnight, La Prise de pouvoir par Louis XIV and Hurry Sundown

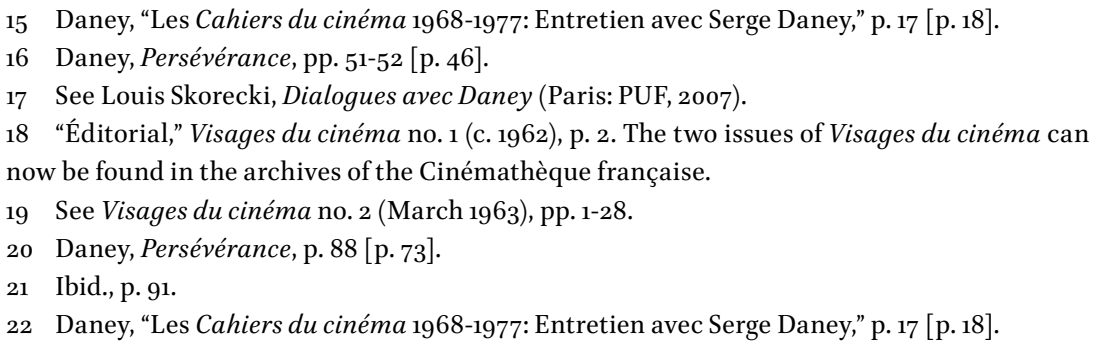
now be found in the archives of the Cinémathèque française.

19 See Visages du cinéma no. 2 (March 1963), pp. 1-28. 
followed, ${ }^{23}$ but Daney's independent streak and taste for international travel meant that he did not become a fully integrated member of the editorial team until around 1969-1970.

Eisenschitz shared with Daney a grisly autobiographical trait: his father, a half-Jewish Resistance fighter, was arrested and killed in the camps during World War II. In fact, Eisenschitz himself was born in a deportation facility in Calais on July $3,1944 .{ }^{24}$ His mother's side of the family consisted of Austrian Jewish intellectuals, and his maternal grandfather was the prominent painter Willy Eisenschitz. Educated at the elite Lycée Henri IV, where he was taught by the critic Jean-Louis Bory, Eisenschitz began attending the Cinémathèque in 1959, but his cinephilia departed markedly from the Cahiers canon, as he took an initial interest in the Hollywood B-movies screening at the Nickel Odéon cinema, as well as the Italian pulp cinema of the $1960{ }^{25}$ In contrast with Daney's predestined fidelity to Cahiers, Eisenschitz was something of a critical polygamist, contributing to a number of magazines before settling with Comolli/Narboni's journal in 1968. A specialist in the art of compiling comprehensive filmographies (thus showing early signs of his skills as a film historian), Eisenschitz helped with dossiers on Billy Wilder in 1962 and the special issue on American cinema in 1963 but would not write his first article for Cahiers until November 1966, with a report on the shoot of Losey's Accident. ${ }^{26}$ In the meantime he collaborated on issues of L'Avant-scène cinéma and the right-leaning Présence du cinéma (which was edited by Mourlet after he left Cahiers) and wrote intermittently for Midi-minuit fantastique, where he discussed the work of Bava, Cottafavi and Petri, among others. ${ }^{27}$ Eisenschitz is even one of the few

23 See Serge Daney, "Un rien sur fond de musique douce (Family Jewels)," Cahiers du cinéma no. 175 (February 1966), pp. 36-37; "Welles au pouvoir (Falstaff)," Cahiers du cinéma no. 181 (August 1966), pp. 26-28; "Le pouvoir en miettes (La Prise du pouvoir par Louis XIV)," Cahiers du cinéma no. 186 (January 1967), pp. 64-65; and "La dé-faite (Hurry Sundown)," Cahiers du cinéma no. 196 (December 1967), pp. 63-64.

24 For more on Eisenschitz' family background, including his links with Willy Eisenschitz, see Eisenschitz Bernard, dir. Georges Ulmann, 2013.

25 Bernard Eisenschitz, interviewed by Fernando Ganzo, "A French Roman. A Story about the Influence of Soviet Avant-Garde on Cahiers du Cinéma and the Later Rediscovery of Nicholas Ray: An Interview with Bernard Eisenschitz," Cinema Comparat/ive Cinema no. 2 (Spring 2013), pp. 18-28, here p. 19 .

26 Bernard Eisenschitz, “Joseph Losey sur 'Accident,"” Cahiers du cinéma no. 184 (November 1966), pp. 12-13. According to Eisenschitz, he also conducted an extensive interview with Cy Endfield which was rejected by the editorial team and never returned. Interview with Bernard Eisenschitz, April 1, 2014.

27 Eisenschitz's contributions to Midi-minuit fantastique were: "Les trois derniers films de Mario Bava," Midi-minuit fantastique no. 8 (January 1964), pp. 62-63; "Lettre d'Italie," Midi-minuit 
writers to have published with both Positif and Cahiers, covering the 1967 Pesaro film festival as well as conducting interviews with Roger Corman and Abraham Polonsky for the former journal. ${ }^{28}$ This brief affiliation would not prevent him from lacerating Positif in an April 1969 notice, deriding its "outrageous self-satisfaction, with a taste for the pompous platitude, and its corollary, contempt for the outside world." ${ }^{29}$ Eisenschitz's articles for Cahiers, even once he became an established member of the editorial committee, were mostly restricted to short critical notices, but his true value to the group came with the meticulous preparatory work carried out for the two dossiers on 1920s Soviet cinema in 1970, for which he traveled to Moscow in 1969. His talents as a historian, moreover, were in evidence in the long-form texts he wrote in the late 196os, a body of work that includes special issues of L'Anthologie du cinéma on Ernst Lubitsch (March 1967) and Douglas Fairbanks (December 1969), ${ }^{30}$ and a 1967 monograph dedicated to Humphrey Bogart, which comprised a biographical overview penned by Eisenschitz, testimonies from those who worked with "Bogie," and a detailed filmography. With their concern for factual precision and historiographical rigor, all three works can be seen as methodological precursors to the later studies Eisenschitz composed on figures such as Fritz Lang and Nicholas Ray, and this approach is already consciously defended in the introduction to Bogart:

Hence our meticulous and obsessive interest for figures, dates and titlesequences, which is so often mocked; one should not point out their uselessness, since the filmography (to only take one example) represents, for anyone who looks at it honestly, a renewal of the perspective on Bogart admitted until now, in that it re-establishes the true value of the role played by Warner Bros and its conceptions of film production in the career and life of the actor in question..$^{31}$

fantastique no. 9 (July 1964), pp. 40-42; "Entretien avec Edgar G. Ulmer" (with Jean-Claude Romer), Midi-minuit fantastique no. 13 (November 1965), pp. 1-14; “Cannes 65," Midi-minuit fantastique no. 13 (November 1965), pp. 37-50; and "Lettre d'Italie," Midi-minuit fantastique no. 13 (November 1965), pp. 55-58.

28 See Bernard Eisenschitz, Bertrand Tavernier and Chris Wicking, "Corman parle," Positif no. 59 (March 1964), pp. 15-28; Bernard Eisenschitz, "Abraham Polonsky par lui même," Positif no. 84 (May 1967), pp. 7-18; and Bernard Eisenschitz, Bernard Cohn and T. Perez-Turrent, "Pesaro 1967," Positif no. 88 (October 1967), pp. 20-26.

29 Bernard Eisenschitz, "Le cahier des autres," pp. 58-59.

30 See Bernard Eisenschitz, "Lubitsch," L'Anthologie du cinéma no. 23 (March 1967); and Bernard Eisenschitz, "Fairbanks," L'Anthologie du cinéma no. 59 (December 1969).

${ }^{1}$ Bernard Eisenschitz, Bogart (Paris: Losfeld, 1967), p. 10. 
The accession of Sylvie Pierre and Jacques Aumont to the Cahiers team was far more straightforward than that of Eisenschitz or Daney. Moreover, their passages were inextricably linked, as the two were married between 1965 and 1971, after first meeting in $1962 .{ }^{32}$ Having moved in the same friendship circles as the Cahiers writers for several years, they both began publishing articles in 1967 and quickly became central figures in the editorial team. Pierre was the first to feature in the journal. Raised in a middle-class family (an engineer father, a schoolteacher mother) in the same neighborhood as Serge Daney, Pierre was also born within a month of him, on July 22, 1944, although the two only became properly acquainted with Daney's return to France in 1970. Her early experiences of the cinema were mainly of the "Saturday night movie" variety, although a screening of Paisà at the age of 12-13 remains a vivid memory.33 Taking preparatory classes for the École normale supérieure, she paid for her studies by writing for the Filipacchiowned teen-oriented magazine Mademoiselle âge tendre. It was in their common offices that she met the Cahiers editors and began frequenting the Cinémathèque with them from 1964 onwards. At their encouragement, Pierre submitted an article on Jancsó's The Round-Up, for which she recalls having made "a tremendous effort - I would have been humiliated if they had refused my first text."34

The review was published in February 1967. Pierre thus became the first woman to penetrate a hitherto purely masculine grouping. ${ }^{35}$ She is often self-deprecating about her status as the first female writer for Cahiers, saying "I was a very pretty girl, and since they were very macho, very seductive, very dandyish, seeing a smart, pretty girl write for them was amusing. They forgave me for being an intellectual because I was cute." ${ }^{36}$ More seriously, however, she has also claimed that she was "subtly patronized" by her male colleagues. ${ }^{37}$ Certainly, Pierre rarely pursued an explicitly feminist agenda on the pages of the journal- this would have to wait until the 1970s, with the contributions of writers such as Thérèse Giraud, Dominique Villain, Danièle Dubroux and Nathalie Heinich. The

32 Interview with Sylvie Pierre, March 7, 2014.

33 See Sylvie Pierre, "À mes parents," Trafic no. 17 (Winter 1996), pp. 77-87.

34 Interview with Sylvie Pierre, March 7, 2014.

35 Sylvie Pierre, "L’ordre et l'ordinateur (Les Sans-espoir)," Cahiers du cinéma no. 187 (February 1967), pp. 66-68.

36 Ibid.

37 Sylvie Pierre, interviewed by Bill Krohn, "Interview with Sylvie Pierre," Senses of Cinema no. 23 (December 2002), sensesofcinema.com/2002/feature-articles/pierre/ (accessed January 1, 2021). 
upside of this treatment, however, was that Pierre subjected herself to a grueling critical apprenticeship in order to catch up with the accrued cinephilic knowledge of her Cahiers colleagues. On top of writing texts on Eustache, Guerra and Rouch, as well as an in-depth piece on the "considerable talent" of G.W. Pabst, she also assumed responsibility for the journal's photothèque after the tragic drowning of Jean-Pierre Biesse in July $1967 \cdot 3^{38}$ From that point on, she would play a central role in Cahiers' editorial work.

Joining his then wife as a Cahiers contributor, Aumont published his first batch of articles in the October 1967 issue. Pride of place here was his review of La Religieuse (an inordinate honor for a critical debutant) in which he poetically claimed that "the cinema — art—is, therefore, not that which lays mysteries bear, but that which poses them in the density of their obscurity. It is what lets us see the night."39 Born into an aristocratic Lyonnais family on February 25, 1942, Aumont completed his studies at the École polytechnique (an institution known for educating France's business elites) and upon graduating in 1965 obtained a position as an engineer at the ORTF, the French public television station, which he held until going full-time with Cahiers in $1970 .{ }^{40}$ Soon, however, he found himself more interested in attending the thrice-daily Cinémathèque screenings with Pierre and the Cahiers editors. Aumont's cinematic tastes underwent a notable metamorphosis in this time: "I did not read Cahiers before meeting [the journal's editors]. I read Positif. I adored John Huston... I switched camps because I was easily influenced, and because speaking with Narboni was spellbinding. His arguments were both very rational and totally seductive, nobody could resist him."41 Like Pierre, Aumont also assumed a significant administrative role in the journal: "Because I had gone to the Polytechnique," he acerbically explained, "they thought I could count up to twelve without making a mistake. So, in 1970, I was confided with the administration of the Éditions de l'Étoile, the

38 See Sylvie Pierre, "Une œuvre de salut public (Le Père Noël a les yeux bleus)," Cahiers du cinéma no. 188 (March 1967), p. 59; "Poétique et politique (Oz fusis)," Cahiers du cinéma no. 190 (May 1967), p. 66; "Le regard brûlant du conteur (La chasse au lion à l'arc)," Cahiers du cinéma no. 192 (July-August 1967), pp. 65-66; and "Le considérable talent de G.W. Pabst," Cahiers du cinéma no. 193 (September 1967), pp. 42-47. A tribute to Biesse was published in Cahiers $d u$ cinéma no. 193 (September 1967), p. 5 .

39 Jacques Aumont, "Voir la nuit (La Religieuse)," Cahiers du cinéma 194 (October 1967), pp. 64-65. 40 Aumont was also briefly a member of the Jeunesse communiste (the youth wing of the PCF) in 1963 but was never involved in the organization in a serious way. See Interview with Jacques Aumont, March 11, 2014.

41 Jacques Aumont, interviewed by Patrice Blouin and Jean-Marc Lalanne, "Le gai savoir," Les Inrockuptibles, April 27, 2005, pp. 36-38, here p. 37. 
publisher of Cahiers. ${ }^{\text {,2 }}$ With texts on Godard, Skolimowski, Satyajit Ray and Jancsó, among others, Aumont published prolifically during his first years at Cahiers, and his writing already attests to the conceptual logic and trenchant intelligence of his more mature works of film theory. Nonetheless, only a handful of his texts from this period-notably, "Le caractère inépuisable du murmure" from September 1968 and "Le concept de montage" from April 1969 - offered a prolonged reflection on the cinema of the sort that he would later produce, and today he tends to downplay the importance of his experience in the journal for his subsequent career. In the end, more than his individually authored texts, it is Aumont's contribution to the journal's collective endeavors - the texts on Young Mr. Lincoln, New Babylon, Morocco and Ice, and, above all, the mammoth Eisenstein translation project-that constitute the most crucial aspect of his involvement with Cahiers.

\section{On the Barricades: Cahiers in 1968}

In the late 196os, it was customary for Cahiers to include an epigram from a literary or cultural figure at the top of its contents page, inside the front cover. In March 1968, Lenin received the honor, with the journal reproducing his statement from a 1919 lecture at the Sverdlov University that "We must consign the state-machine to the scrap-heap." 43 The quote was an augury of the fact that 1968 for Cahiers - as with the rest of France and a significant part of the world - would be a year of revolt. The year began with the sacking of Henri Langlois from the Cinémathèque in February, leading to a dogged and ultimately victorious protest movement against state interference in the archival institution, climaxed with the uprising of May, and continued with a spirit of radical struggle that permeated the journal. Although Cahiers' process of politicization predates the social explosion of 1968, the editors' central involvement in these seismic events transformed the nature of the journal, paving the way for their own existential dispute with Filipacchi the following year.

Langlois' dismissal as head of the Cinémathèque française on February 9, 1968 was foreseeable: despite having overseen the organization since founding

42 Jacques Aumont, interviewed by Nicole Vulser, “Jacques Aumont, le cinéma né sous X," Le Monde, September 29, 2003.

43 Cahiers du cinéma no. 198 (March 1968), p. 3. For the original source, see V.I. Lenin, "The State: A Lecture Delivered at the Sverdlov University, July 11, 1919," The Collected Works of V.I. Lenin vol. XXIX (Moscow: Progress Publishers, 1976), pp. 470-488. 
it in the 1930s, his idiosyncratic managerial style met with resistance from the technocratic functionaries of a sclerotic state apparatus, galled by the significant public subsidies handed out for its film preservation activities. It nonetheless came as a shock when, at a meeting of the Cinémathèque's administrative board, its government-appointed chairman Pierre Moinot proposed that Langlois, his three-year contract having expired, be replaced by Pierre Barbin, thus placing the Cinémathèque under the direct control of the state film body, the Centre National du Cinéma (CNC). With the government-aligned members forming a 16-8 majority on the board, the pro-Langlois minority walked out of the meeting and the motion was carried. ${ }^{44}$ That the dismissal was a "remote-controlled maneuver, resembling a putsch in every way" was made clear, in the eyes of Cahiers at least, by the fact that, the same afternoon, Barbin moved into Langlois' offices, evicting its employees (including Mary Meerson and Marie Epstein) and changing the locks on its doors. ${ }^{45}$ The next day, the Cahiers bureau became an unofficial headquarters for the movement to reinstate Langlois, and the journal's editors began the process of contacting filmmakers to withdraw authorization for their films to be shown at the Cinémathèque, in solidarity with its ousted supremo. Combined with a rolling picket of the Trocadéro auditorium, this effectively stopped screenings from taking place. The "Children of the Cinémathèque" disseminated leaflets declaring that "the Cinémathèque will never open without Henri Langlois." ${ }^{26} \mathrm{~A}$ demonstration on February 14 of 3000 "friends of Langlois" calling for the resignation of Barbin was violently attacked by the police. The scenes of bruised and bloodied filmmakers (Godard had his trademark dark glasses smashed during a scuffle) have led many to see the Langlois movement as a prologue to May '68, a claim made by Cahiers itself as early as June that year. ${ }^{47} \mathrm{On}$ the Friday, an incendiary press conference featuring Godard, Rivette, Chabrol, Renoir, Rouch, Kast, Astruc, Carné and others was held, in which Rivette praised Langlois' Cinémathèque as being "not like a museum but like a permanent action, a permanent revolution, [...] a permanent discovery of what is justly

44 Issue no. 199 of Cahiers includes a precious timeline of the "Affaire Langlois" which, while evidently partisan in its pro-Langlois sympathies and violent condemnation of the state, nonetheless allows us to establish a precise chronology of the events surrounding the dismissal. See Jean-Louis Comolli, “L'Affaire Langlois: 1. Historique et bilan,” Cahiers du cinéma no. 199 (March 1968), pp. 32-33.

45 Ibid.

46 "Declaration des Enfants de la Cinémathèque française," in the Fonds Comité de Défense de la Cinémathèque française, Espace chercheurs de la Cinémathèque française, dossier CDCF9-B1. 47 "Le retour de Langlois," Cahiers du cinéma no. 202 (June-July 1968), p. 68. 
the permanence of the cinema." ${ }^{m 8}$ The same day, a "Comité de Défense de la Cinémathèque française" was formed, with Alain Resnais elected as its president. As with the storm over La Religieuse, Malraux was a prominent target, with Godard stating, "as if by chance it is always the same André Malraux who eliminates those who speak a certain language and have a certain independence."${ }^{\prime 49}$ By February 23, hundreds of filmmakers and other cultural figures had signed the petition in support of Langlois, and even Jack Valenti, president of the Motion Picture Association of America, had given his backing to the "dragon of the Cinémathèque." $5^{0}$ The state's position became increasingly untenable - de Gaulle himself was heard to grumble "Who is this Henri Langlois?" ${ }^{1}$ On behalf of the regime, Barbin engaged in a counter-propaganda campaign, which was denounced by Comolli in the newspaper Combat..$^{2}$ Eventually, on April 22 (75 days after his dismissal) the government ceded to the pressure and allowed Langlois to return to his former position. Cahiers, which featured Langlois on the front cover of its $200^{\text {th }}$ issue, trumpeted the victory as one where, "for the first time, perhaps, the cinema in its entirety, from cinephiles to filmmakers, [is] victorious (and not in the Pyrrhic sense, as is usually the case) against those who-agents of the state or not, perfidious or not-more or less engage in opposing it and weakening it." Its editors argued for "consider[ing] the battle of the Cinémathèque as the first of those, all of those, that are in the offing, and that must be won if the French cinema is able to conquer-after so many years of adolescence, crisis and oversight - its true status, a status warranted by its maturity and its liberty, the former real, the latter, alas, still virtual." ${ }^{\prime 3}$ The victory came at a price, however, as all state subsidies for the archive were henceforth removed. As the third and final issue of the L'Affaire Langlois bulletin put it, the Cinémathèque now found itself "free but poor." 54

48 "L'Affaire Langlois: 2. Conférence de presse," Cahiers du cinéma no. 199 (March 1968), pp. 34-44, here p. 37.

49 Ibid., p. 43.

$5^{0}$ See Laurent Mannoni, Histoire de la Cinémathèque française (Paris: Gallimard, 2006), p. 390. Mannoni discusses the Langlois dismissal more generally on pp. 361-404.

$5^{1}$ See Colin MacCabe, Godard: A Portrait of the Artist at Seventy (New York: Farrar, Straus and Giroux, 2003), p. 202.

$5^{2}$ This material is reprinted in a "Brochure Barbin" disseminated by the Langlois Defense Committee. See Fonds Comité de Défense de la Cinématheque française, Espace chercheurs de la Cinémathèque française, $\mathrm{CDCF}_{13}-\mathrm{B}_{13}$. The riposte was originally published in the March 1 , 1968 issue of Combat.

53 “Éditorial," Cahiers du cinéma 200-201 (April-May 1968), p. 5.

54 L'Affaire Langlois no. 3 (May 18, 1968). Fonds Comité de Défense de la Cinémathèque française, dossier $\mathrm{CDCF}_{9}-\mathrm{B} 1$ 
The role of the Cinémathèque protests as a precursor to May'68 has often been overstated, and they rarely feature prominently in non-cinema-centric histories of the uprising. As Kast cautioned: "If it is impossible to cry 'Viva Castro' without crying 'Viva Langlois,' one can perfectly well shout 'Viva Langlois' without thinking 'Viva Castro.'"55 The timing of the two revolts is nonetheless uncanny. Within two weeks of Langlois' reinstatement, rolling student occupations at the Université de Nanterre on the western perimeter of Paris had spread to the Latin Quarter, culminating in the "night of the barricades" on May 10. A mass demonstration of up to 1 million protestors marched from République to Denfert-Rochereau on May 13, and by May 24, 10 million workers were on strike across France, bringing the country to a standstill and threatening to topple the government. This is not the place to delve deeply into the events of May '68, which have given rise to a vast literature in the five decades since they shook Europe. ${ }^{6}$ It should nonetheless be noted that the Cahiers editors were eager and active participants in the revolt. Comolli, who collaborated on a photo-essay of the events on the occasion of the $5^{0^{\text {th }}}$ anniversary of May, has confirmed that the members of the équipe were on the barricades at the Sorbonne and elsewhere in the Latin Quarter, ${ }^{57}$ while Narboni has stated: "In May we were entirely in the movement, from start to finish. There was no hesitation." ${ }^{8}$ As with the rest of the country, work at the journal essentially ceased for the month. Daney, still not entirely integrated into the editorial team, experienced the revolt "differently to the Cahiers folks (who were, I felt, rather reformist or 'reviso' as we used to say); in a radical, destabilizing, almost hippy-like manner."59 Instead of joining his fellow film critics, he spent the events with a "gang of anarcho-dandies" linked to Philippe Garrel. Participating in the occupation of the Odéon theater, he recalls being particularly influenced by Debord's Société du spectacle at the time, a treatise that, with its near totalizing

55 Pierre Kast, "A Farewell to the Movies," Cahiers du cinéma no. 200-201 (April-May 1968), pp. 13-18, here p. 18 .

$5^{6}$ For the wave of militant filmmaking produced during and after the events, see Sébastien Layerle, Caméras en lutte en Mai 68: "Par ailleurs le cinéma est une arme..."(Paris: Nouveau Monde, 2008); and Paul Grant, Cinéma Militant: Political Filmmaking \& May 1968 (New York: Wallflower Press, 2016). Grant makes the argument that this strand of cinema was an implicit, practical riposte to the theoretical excesses of "apparatus theory" as developed by Tel Quel and Cahiers. 57 Comolli, "Yes, we were utopians (Part 1)." See also Jean-Louis Comolli and Jacques Kebadian, Les fantômes de Mai 68 (Crisnée: Yellow Now, 2018).

$5^{8}$ Interview with Jean Narboni, March 18, 2014.

59 See Daney, Persévérance, pp. 97-99 [pp. 80-82]. Here, Daney noted the irony of his participation in the occupation of the Odéon theater, when he had always felt that the theater as an art form was not "home" but a "place of unease." 
denunciation of the culture industry, was distinct from Cahiers' political/ theoretical framework. ${ }^{60}$ Delahaye, meanwhile, found himself on the south coast during the uprising, covering Cannes for Cahiers, and reported on the cancelation of the festival after vivid protests led by Godard and Truffaut had succeeded in interrupting the May 18 gala screening of Carlos Saura's Peppermint Frappé. ${ }^{61}$

The key activity for Cahiers during this volatile period, however, was its participation in the États-généraux du cinéma (EGC), a series of mass meetings attracting approximately 1500 members of the French film industry to the École Louis Lumière (a filmmaking school) on the Rue Vaugirard. The États-généraux - the name was a deliberate nod to France's revolutionary heritage - continued the militant, all-embracing spirit of the pro-Langlois movement and promptly declared the abolition of the CNC. ${ }^{62}$ Due to the general strike, no filmmaking or projection took place on French soil, with the exception of militant films linked directly to the protest movement. Interrogating the organizational principles of the French film industry was evidently in the air-Cahiers had only just published their dossier "Vers un livre blanc du cinéma français," which consisted of a questionnaire about the functioning of the CNC filled out by 28 French filmmakers, from Philippe Garrel to Jacques Tati. ${ }^{63}$ As such, most of the EGC's energies were spent in drawing up plans for the revolutionary reconstruction of the economic and cultural basis of the cinema. Nineteen projects in all were developed, of which four gained significant support. The project most closely

60 See Guy Debord, La Société du spectacle (Paris: Buchet/Chastel, 1967). Translated as The Society of the Spectacle, trans. Donald Nicholson-Smith (New York: Zone Books, 1995). In his later writings, Comolli nonetheless evinces a profound debt to Debord.

61 Michel Delahaye, "Fin d'un festival: Cannes," Cahiers du cinéma no. 203 (August 1968), pp. 26-27. The 1968 Cannes festival is discussed at greater length by Peter Cowie in Revolution!: The Explosion of World Cinema in the Sixties (New York: Faber and Faber, 2004), pp. 199-205. While Cahiers eagerly supported the cancelation of Cannes, it did not support a blanket boycott of all festivals and later in the year published a detailed position paper defending its participation at Venice, which, while undeniably a "bourgeois festival," proposed an "audacious," highly politicized program (including Straub, Kluge, Bertolucci, Pasolini and Sembene) judged to be useful in "the struggle for a renewal of the cinema." La Rédaction, "Venise malgré tout," Cahiers du cinéma no. 206 (November 1968), pp. 23-24. The editors did, however, urge a boycott of Venice in 1971, after the festival's organization had been taken over by right-wing forces. See "Venise," Cahiers du cinéma no. 232 (October 1971), pp. 57-58.

62 For an overview of the États-généraux written dans le chaud, see "Les états-généraux du cinéma," Cahiers du cinéma no. 203 (August 1968), pp. 23-46. The events are also discussed by Sylvia Harvey, May'68 and Film Culture, pp. 17-27.

63 "Vers un livre blanc du cinéma français," Cahiers du cinéma no. 200-201 (April-May 1968), pp. 73-93. 
associated with Cahiers - no. 16, dubbed "La Ligne générale (Lancien et le nouveau)" - advocated the abolition of censorship bodies, a public sector of production and distribution freed of the profit motive and run on the principle of "autonomy and autogestion," and an end to the institutional division between cinema and television, with the EGC becoming the chief organizational body for the general direction of all audiovisual activities. Projects 13 (backed by technicians aligned with the Confédération générale du travail [CGT], France's communist-dominated confederation of trade unions) and 19 (endorsed by Michel Cournot, Claude Lelouch, Marcel Carné and others) offered variations on the same fundamental conception, and the second General Assembly saw a proposal synthesizing the three projects drawn up. This program nonetheless met with the dogged opposition of the supporters of project 4 (who included Marin Karmitz and Claude Chabrol), the most utopian of the proposals, which called for free entry to all screenings, and was seen by Cahiers' as "both a warhorse for the 'hardest' faction," and a "Trojan horse" that felled, one by one, all the other platforms. ${ }^{64}$. When no consensus could be reached, the third General Assembly on June 5 settled on a vague final motion elaborating the broad principles on which the new cinema was to be organized. As May became June, however, and De Gaulle re-established his grip on the nation with the calling of legislative elections for the end of the month, the revolutionary spirit of the EGC faded, and none of the plans elaborated at its meetings were realized. The CNC was soon restored, and commercial film production continued virtually unchanged from the way it functioned before May.

\section{From May '68 to “Cinéma/Idéologie/Critique”: Becoming a Marxist Film Journal}

For Cahiers, by contrast, the events of May had a lasting, transformative effect, which led to Comolli/Narboni's open avowal of the Marxist orientation of the journal in October 1969. The texts of this transitional period attest to the buoyant mood felt among the Cahiers writers at the time. Not only were they faced with a cinema in effervescence, but the critics themselves were politically optimistic, confident that May 1968 was merely a dress rehearsal for the revolution to come. This insurrectionary atmosphere not only contaminated their dialogues with filmmakers and their critical writings, which became more and more exigent in their radicalism, it also 
led the editors to question the nature of Cahiers itself. Not yet seeking a political alignment with the PCF, the editors prized their sense of independence, but this increasingly ran counter to the journal's membership of the Filipacchi stable. In affirming their autonomy from Cahiers' owner, the editors saw fit both to modify the format of the journal and to heighten the political radicalism of its content. These changes were first made public in August 1968, when an editorial alerted readers to the "disappearance of the Council of Ten and the reduction of the number of critical notes in the 'List of Films Released in Exclusivity in Paris'," as well as further prospective changes to other sections linked with current events in film, which in the view of the editors "corresponded less and less to what constitutes presentday cinema for us." ${ }^{\prime 6}$ With political censorship and the commercial film market wielding deleterious effects, it was in fact the cinematic mainstream that had become "marginal" for Cahiers. The response to these steps was mixed-one reader proclaimed that "you are drowning in your aberrant communism"66 _ but two months later a new section appeared_-À voir absolument (si possible)"-listing new films recommended by Cahiers regardless of their release status. ${ }^{67}$

Of greater importance than these formal changes was the politicization of film criticism within the review in the years 1968 and 1969. As Comolli and Narboni acknowledged in October 1969, "fragmentarily, our position could already be read in recent texts (articles, editorials, debates, responses to readers' letters), but in a vague and accidental manner." ${ }^{28}$ To a large degree, this came about through encounters with filmmakers who had themselves radicalized in their views. Indeed, this period is particularly rich in interviews with politically engaged and formally experimental directors-including Rivette, Garrel, Borowczyk, Jancsó, Makaveyev, Polonsky, Perrault, Bene and Rocha-who outlined their thoughts on the relationship between art and revolutionary activism. Rivette, for instance, declared to his younger colleagues that "a revolutionary cinema can only be a 'differential'

65 "Éditorial," Cahiers du cinéma no. 203 (August 1968), p. 5. The "Council of Ten" was a grid of ratings (from zero to four stars) by ten Paris-based critics enlisted by Cahiers. It was later revived and continues to be published to this day.

66 See Jacques Aumont, "Le cahier des lecteurs," Cahiers du cinéma no. 205 (October 1968), p. 10. A few months later, Narboni defended the changes and noted the support of other readers for Cahiers' transformation. See Jean Narboni, "Le cahier des lecteurs," Cahiers du cinéma no. 208 (January 1969), p. 5 .

67 The rubric lasted little more than a year, appearing for the final time in March 1970, the journal's first post-Filipacchi issue.

68 Comolli/Narboni, “Cinéma/idéologie/critique," p. 11 [p. 251]. 
cinema, which challenges the rest of the cinema," while "films that content themselves with taking the revolution as a subject actually subordinate themselves to bourgeois ideas of content, message and expression. ${ }^{n 9}$ Rivette mentioned Terra em transe as a favorable model for revolutionary film, and Rocha himself was interviewed for the July/August 1969 issue, where he put forth the view that "political film should not be accompanied by too much systematization" and indicated his preference for "polemical films, where everything is mobile," proceeding to express his fear that "systematization would break the creative élan, especially if this creation is initially chaotic or spontaneist. ${ }^{70}$

While there was a great deal of interest within the journal in the political documentaries of international filmmakers such as Fernando Solanas ( $L a$ Hora de los Hornos) and Emile de Antonio (In the Year of the Pig), militant filmmaking in France mostly left the Cahiers critics cold. As the "Cinema/ Ideology/Criticism" editorial had outlined, this mode of film production could be divided into two categories: the vast majority contented themselves with "depict[ing] miners' strikes in the same formal system as Les Grandes Familles" and thus failed to "truly differentiate themselves from non-political cinema. ${ }^{71}$ While an alternative approach would consist of films that "concentrate on the problem of representation in making the filmic material function," few works successfully managed to do this. $L a$ Reprise de travail aux usines Wonder was virtually the only French militant film made during the 1968 protests to find grace in the eyes of the Cahiers editors and was described by Rivette as "the only interesting film on the May 'events,' [...] because it is a terrifying and painful film." ${ }^{72}$ The Cahiers writers did not entirely refrain from critiquing right-wing productions: Comolli called Green Berets "rubbish" and Narboni later described L'Armée des ombres as "the first and finest cinematic example of Gaullist Art, in content and form." ${ }^{73}$ But the chief targets of their criticism in this period

69 Jacques Rivette, “Le temps déborde: Entretien avec Jacques Rivette," p. 19 [p. 33].

70 Glauber Rocha, interviewed by Michel Delahaye, Pierre Kast and Jean Narboni, "Entretien avec Glauber Rocha," Cahiers du cinéma no. 214 (July-August 1969), pp. 23-40, here pp. 26, 29. 71 Comolli/Narboni, “Cinéma/idéologie/critique," p.14 [p. 258]. Comolli has recently spoken of this cinema in the following terms: "We ferociously critiqued militant films at the time, which we did not like at all. By the way, I recently re-watched some of them in the DVD boxset put out by Éditions Montparnasse, and, unfortunately, they are woefully bad. Films such as Oser lutter, oservaincre are calamities, they are very bad films." See Comolli, "Yes, we were utopians (Part 1)."

72 Rivette, "Le temps déborde: Entretien avec Jacques Rivette," p. 20 [p. 35].

73 Jean-Louis Comolli, "Les berets verts," Cahiers du cinéma no. 215 (September 1969), p. 65; and Jean Narboni, “L'Armée des ombres," Cahiers du cinéma no. 216 (October 1969), p. 63. 
were films of the left that did not meet their exacting requirements for a break with the dominant "system of representation." These fictions de gauche, as they would later be called, gained in prominence in this period, as the film industry saw potential profits to be made in films with political themes but conventional narrative structures, and they will be discussed at greater length in Chapter 8.

Within Cahiers' ranks, the politicization of 1968 and 1969 was not without its human toll, as several critics departed from the journal. Jacques Bontemps, who played a key role in the years 1965-1967, ceased writing at the beginning of 1968 in order to concentrate on his philosophy studies at the École normale supérieure, but his departure was amiable. He still retains close ties with Pierre, Comolli and Narboni and has returned to film criticism in recent years with a string of articles for Trafic. ${ }^{74}$ Jean-Claude Biette had moved to Italy, where he occasionally filed reports on the local film scene, but after 1970 he took a hiatus from the journal that lasted until 1977, when he resumed writing criticism in tandem with a blossoming career as a filmmaker. ${ }^{75}$ Jean-André Fieschi's rupture with Cahiers was less benign. Finding himself in disagreement with the journal's "anti-authoritarian" politics during the May events, going so far as to tell Comolli during one of the last marches of May '68, "you are petty-bourgeois, we must participate in the movements, ${ }^{76}$ Fieschi quit the journal and joined the PCF, becoming one of the main film critics for La Nouvelle Critique. During Cahiers' rapprochement with the party, close ties would again be established with Fieschi (he participated in discussions on Othon and Ice), and the critic was to forge an enduring bond with Eisenschitz when the latter joined him at La Nouvelle Critique, but relations soured during Cahiers' Maoist period. Upon Fieschi's death in 2009, Comolli lamented that "of this friend from my first days in Paris I am left with a sense of regret. [...] The reader will understand how much this once close friendship with JAF counted for me. His death left me frightened."77

Still more acrimonious was the rift with Delahaye. A generation older than his colleagues (he was born in 1929) and from an impoverished rural background that contrasted with the bourgeois milieux of most of the other Cahiers writers, Delahaye also distinguished himself by refusing to accede

74 See, for instance, Jacques Bontemps, “Diligence des Straub," Trafic no. 9 (Winter 1994), pp. $76-85$.

75 Biette was particularly close to Daney and would later join him as an editor at Trafic.

76 Comolli, "Yes, were utopians (Part 1)."

77 Comolli, Corps et cadre, pp. 478-479. 
to the Marxism of his fellow critics, retaining an "anarcho-evangelist" attitude, and provoking his colleagues by claiming, "If Narboni is the Engels of Cahiers, I am its Barrès." ${ }^{8}$ The differences between Delahaye and the rest of the journal did not go unnoticed by Cahiers' rivals, with Cinéthique relishing the opportunity to malign the "monument of modernist eclecticism, theoretical inconsistency and hippy senility."79 Delahaye stayed with the journal even after the break with Filipacchi, his part-time salary as editorial secretary being his only source of income at the time, but by October 1970 he was forced out against his will — a brief notice in that issue pointing to his "complete ideological and theoretical discord" with the journal's editorial line. ${ }^{80}$ Right up until his death in 2016, Delahaye remained bitter about the experience and spoke scathingly about the political evolution of Cahiers up to and after his departure. ${ }^{81}$

\section{The Dispute with Filipacchi}

As Cahiers radicalized, a clash with its owner was increasingly seen as inevitable. Relations had never been entirely smooth: while the Cahiers editors acceded to Filipacchi's demands to withdraw Godard's La Religieuse editorial in April 1966, they affirmed their autonomy six months later when Filipacchi accepted a lavish eight-page spread (and full-color front cover) advertising Chappaqua by the self-funded American filmmaker Conrad Rooks, an "experimental" feature remote from Cahiers' own tastes. The editors remained defiant: in the same October 1966 issue, the film was ridiculed in a brief notice incorporated into Cahiers' coverage of that year's Venice festival. Written by Narboni but published anonymously, ${ }^{82}$ the review labeled Chappaqua "the Cleopatra and West Side Story of beatnik cinema" and suggested that its merits could be tested by being screened

78 See De Baecque, Histoire d'une revue vol. II, p. 226. Maurice Barrès was a writer and right-wing nationalist in the late nineteenth and early twentieth centuries.

79 "Du bon usage de la valeur d'échange (les Cahiers du cinéma et le marxisme-léninisme)," p. 4 .

80 La Rédaction, "Informations," Cahiers du cinéma no. 224 (October 1970), p. 57.

81 See Interviews with Michel Delahaye, April 11, 2014 and May 1, 2014. Delahaye's writings for Cahiers are collected in Michel Delahaye, À la fortune du beau (Paris: Capricci, 2010). For more on his life, see Daniel Fairfax, "Farewell Michel Delahaye," Senses of Cinema no. 81 (December 2016), sensesofcinemacom/2016/feature-articles/farewell-michel-delahaye/ (accessed January 1, 2021). 82 Narboni admitted to his authorship of the article when interviewed, and it is of a piece with his writing style at the time. Interview with Jean Narboni, March 18, 2014. 
for the Red Guards. The only (ironic) words of praise in the review were for Conrad Rooks' exorbitant publicity strategy. ${ }^{83}$

Unable to bring their editorial independence into question, Filipacchi bit his tongue at this act of critical recalcitrance. Matters were different when it came to the journal's participation in the Henri Langlois defense campaign. With the journal's Champs-Elysées offices transformed into the movement's headquarters, the Cahiers editors racked up a significant phone bill from the international calls imploring foreign directors to withhold their permission for cinémathèque screenings, and Filipacchi wrote to Truffaut demanding that the Defense Committee reimburse the expenses. ${ }^{84}$ De Baecque reports, too, that 1969 saw a worsening of the journal's financial situation, losing 26,466 francs in the first nine months of the year. ${ }^{85}$ Conversely, the editors were increasingly frustrated at their association with the media tycoon. In "Cinéma/idéologie/critique," Comolli/Narboni dismissed the "utopia of parallelism" and accepted that their journal was inserted into the "economic system of capitalist publishing." ${ }^{\text {" }}$ But having to suffer barbed comments about their subordinate status to the Filipacchi group from Cinéthique and-more galling still-Jean-Luc Godard was difficult for the editors to abide. $^{87}$

Matters came to a head in October 1969. De Baecque gives a detailed account of Filipacchi's experience of reading issue no. 216, presumably drawn from a letter the publisher wrote to the journal's editors. ${ }^{88}$ For the present-day film scholar, the number in question contains a bounty of ground-breaking texts: “Cinéma/idéologie/critique," was accompanied by a translated installment of Eisenstein's Non-indifferent Nature (appearing in French for the first time), Raymond Bellour's analysis of the Bodega Bay sequence from The Birds, and a scintillating interview with Luc Moullet. ${ }^{89}$ Filipacchi, however, was infuriated at the conceptual obtuseness and political stridency of these texts, and his rage climaxed upon reading a review of La Sirène du Mississippi by Oudart, the language of which was particularly

83 [Anon.], “Chappaqua de Conrad Rooks (USA)," Cahiers du cinéma no. 183 (October 1966), pp. 30-31. A notice on p. 33 of this issue advised that "the unsigned review is collective."

84 The exchange can be found in the Fonds Comité de Défense de la Cinémathèque française in the Espace chercheurs de la Cinémathèque française, $\mathrm{CDCF}_{13}-\mathrm{B} 7$.

85 See de Baecque, Histoire d'une revue vol. II, p. 220.

86 Comolli/Narboni, "Cinéma/idéologie/critique," p. 11 [p. 251].

87 See Godard, "Un cinéaste comme les autres.”

88 See de Baecque, Histoire d'une revue vol. II, pp. 220-222.

89 See Luc Moullet, interviewed by Michel Delahaye and Jean Narboni, "Entretien avec Luc Moullet," Cahiers du cinéma no. 208 (January 1969), pp. 40-49, 56-62. 
impenetrable for those unversed in contemporary theory, as attested by passages such as:

Here, the return to the literality of the énoncé is no longer, as in La Voie lactée, the utopian guarantee of a 'true' reading delivered from the clutches of connotation: for the process of reading is reversed, resting on an énoncé whose literality (the return to the letter) is only ever a pause, a halt, an eclipse of meaning, a limit and a scansion of the cinematic text. ${ }^{90}$

Filipacchi called for a meeting with the editors on October 20, but proceedings were mired in a stalemate, and the following day Narboni and Comolli found themselves locked out of their offices, with a tongue-in-cheek press release put out by Filipacchi declaring that "the managers and the majority of shareholders of the monthly Cahiers du cinéma have decided on an indefinite strike" and demanding "the liberalization of the magazine which [...] has, in the hands of the intransigently totalitarian editors, become an obscure, indigestible publication from which all objectivity has been excluded."91 The Cahiers editors publicly responded by affirming their "intention to preserve the total liberty of action and critical spirit" of the journal. ${ }^{92} \mathrm{~A}$ second meeting, presided over by lawyer George Kiejman, sought to resolve the impasse: Filipacchi initially demanded a new, broad-based editorial team, and when the editors refused what they saw as a "committee of patronagesurveillance," ${ }^{\prime 93}$ he offered to sell his shares for the sum of 280,000 francs. The November issue appeared as usual, "in the interests of Cahiers and its readers," ${ }^{\prime 94}$ and showed no signs of a softening in Cahiers' line, but after that, publication was suspended; it would not resume until March 1970.

With this offer from Filipacchi on the table, the journal mobilized in a bid to achieve its financial independence. An op-ed article in Le Monde by Comolli and Narboni defended Cahiers as having always been "a review of opinion and criticism, making choices which, beyond their polemical appearance, proceed from a work of reflection on the cinema" while justifying its more recent turn towards the "new cinemas" outside of Hollywood as well as its concern for "research carried out in domains other than the cinema

90 Jean-Pierre Oudart, "Rêverie bouclée (La Sirène de Mississippi)," Cahiers du cinéma no. 216 (October 1969), pp. 51-52, here p. $5^{1 .}$

91 The press release is cited in full in De Baecque, Histoire d'une revue vol. II, p. 222.

92 [Anon.], "Conflit aux Cahiers du cinéma," Le Monde October 22, 1969.

93 As Comolli and Narboni dubbed his proposed structure. "Éditorial," Cahiers du cinéma no. 228 (March-April 1971), p. 5 .

94 As a notice published by Cahiers put it. See Cahiers du cinéma no. 217 (November 1969), p. 3. 
(Marxism, psychoanalysis and linguistics primarily)." They concluded that: "It does not appear possible to us to keep cinema (or any other aesthetic manifestation) sealed off or sheltered away from history and politics. Although transforming Cahiers into a political tribune has always been out of the question, we are unable to analyze the cinema without analyzing the mechanisms determining it, on both an economic level (production, distribution) and an ideological level (content, forms). ${ }^{\prime 95}$ Friends and sympathizers of the journal were exhorted to contribute capital, with Comolli, Narboni, Sylvie Pierre, Jean Riboud, Claude Berri, Pierre Braunberger, Pierre Cardin and even Costa-Gavras investing in the venture. By January 10, Le Monde reported that "an agreement has been reached between the editors of Cahiers du cinéma and their proprietor, M. Daniel Filipacchi," and the newspaper announced the reappearance of Cahiers under the same editorial team. ${ }^{6}$ Comolli recalls that Filipacchi was in fact "very upstanding about the matter, he did not insist on an exorbitant price." 97 The tycoon himself has a more amused recollection of the sale of Cahiers..$^{8}$

In any case, with the handover settled, Cahiers now found itself, like the Cinémathèque, "free but poor." New offices were found at 39, rue Coquillère, near Les Halles in the $1^{\text {st }}$ arrondissement, considered better value than the Champs-Élysées area where they had previously been housed. An internal document on the "Reorganization and Re-purchasing" of Cahiers, now held in the Fonds Jacques Rivette, gives details on the administrative structure of the newly independent journal and precious insight into its day-to-day functioning. All administrative tasks previously exercised by Filipacchi's staff would now be undertaken by the editors themselves. Comolli and Narboni remained editors-in-chief on a salary of 1500 francs a month each, with Narboni responsible for subscriptions, stock and diffusion and Comolli overseeing publicity and promotion. Delahaye and Pierre remained on staff with a part-time salary of $65^{\circ}$ francs each, as the former was tasked with preparing the "Semaines des Cahiers" (until his sacking in October), and the

95 Jean-Louis Comolli and Jean Narboni, "Qu'est-ce que les Cahiers du cinéma?," Le Monde, November 2-3, 1969, p. 17.

96 [Anon.], "M. Daniel Filipacchi se retire des Cahiers du cinéma," Le Monde, January 10, 1970.

97 Comolli, "Yes, we were utopians (Part 1)."

98 In his 2012 memoir, Filipacchi speaks of the rupture with Cahiers in the following terms: "I had bought Cahiers to save it from collapse, at the request of Henri Langlois, but also because they defended the American cinema, notably thanks to François Truffaut. But soon Godard, Doniol-Valcroze and Truffaut abandoned Cahiers to make films, and a team of leftist madmen who had taken possession of the place became hysterical. The readers, already not very numerous, evaporated before my eyes. I lost the willpower." Daniel Filipacchi, Ceci n'est pas une autobiographie (Paris: Bernard Fixot, 2012), pp. 345-346. 
latter continued to administer the photothèque; they were joined by Aumont, who was given the position of editorial secretary at $105^{0}$ francs a month. In addition, freelance writers (pigistes) were paid at a rate of 30 centimes a line, with the total monthly ceiling established at 2500 francs (below the 400o-franc level under Filipacchi). A comité de rédaction comprising Rivette, Truffaut, Kast and Doniol-Valcroze was maintained as a supervisory body and was accompanied by a conseil de rédaction consisting of the most active contributors to the journal, which would hold weekly meetings where "all writers will participate, and all problems can be discussed."99

When the first issue of the financially autonomous Cahiers was released in March, an editorial notice exhorted readers to reinforce their support of the journal by taking out subscriptions (a doubling in the number of subscribers, from 4500 to 9000 , was set as a target). It also insisted on the continued pertinence of the theoretical position established in the two installments of "Cinéma/idéologie/critique," one that was essentially rooted in Marxist aesthetics. The editors saw three key tasks for the journal: in addition to the work of "information and critical reflection" and the "circulation and diffusion of unknown and little-known films," they articulated the need for the elaboration of a critical theory that would be "founded on the Marxist science of historical materialism, and the principles of dialectical materialism. ${ }^{100}$ Rejecting the idea of a contradiction between the first task (information/criticism) and the third (theory), the editors tacitly took aim at their rivals Positif and Cinéthique: "abandoning to the formalist right (cf. no. 216) the eclectic exploitation of works regardless of whether they are subversive or not, we will also leave to the theologians of the "break" [coupure] the concern for fetishizing the handful of films that claim to have carried this out."101 In the early stages of this project, at least, the response from the journal's readership was broadly positive: the "Réponses aux lecteurs" column in July 1970 featured readers who, in the

99 “Cahiers du cinéma: Réorganisation et rachat," Fond Jacques Rivette, Espace chercheurs de la Cinémathèque française, dossier RIVETTE89-B21. A French franc in 1970 was worth roughly the same as a euro today (by way of comparison, the cover price of Cahiers was 6 francs then, and $€_{5.90}$ in 2020), although certain living expenses such as rent and eating out were considerably more affordable in 1970. Eisenschitz has spoken of the standard of living enjoyed by the Cahiers team at the time: "When he was with Newsreel, Robert Kramer said that nobody had any money but at the same time you didn't have any problems. It was the same: we went to restaurants, we never found ourselves in situations that were so difficult that we had to economize on restaurants, on movies (where we usually paid for tickets)." Interview with Bernard Eisenschitz, April 7, 2014. 100 "Éditorial," Cahiers du cinéma no. 218 (March 1970), pp. 3-4, here p. 4. 101 Ibid. 
words of one letter, declared themselves favorable to Cahiers' "pertinent, and even correct, interpretation and demarcation of the ideological vectors that confront each other in this field."102 In the March-April 1971 issue, the first anniversary of the journal's independence was toasted with the news that a moderate growth in readership had taken place. Subscriptions had risen from 4375 to 4540 , while off-the-shelf sales increased from 4766 to 5021 , to combine for a total circulation of nearly 10,000 copies. ${ }^{103}$ Certainly this was well short of the ambitious target set a year earlier, but the fact that Cahiers could be run on autonomous lines without losing readership was an achievement in and of itself and represented an important level of stability that could be built upon. As the journal's political line hardened between 1971 and 1973, however, its readership consequently suffered a dramatic collapse.

\section{Works Cited}

[Anon.], "Chappaqua de Conrad Rooks (USA)," Cahiers du cinéma no. 183 (October 1966), pp. 30-31.

—, "Conflit aux Cahiers du cinéma," Le Monde October 22, 1969.

—, "M. Daniel Filipacchi se retire des Cahiers du cinéma," Le Monde, January 10, 1970. Jacques Aumont, "Voir la nuit (La Religieuse)," Cahiers du cinéma 194 (October 1967), pp. $64-65$.

—, "Le Cahier des lecteurs," Cahiers du cinéma no. 205 (October 1968), p. 10.

—, "Lettres," Cahiers du cinéma no. 234-235 (December 1971-January-February 1972), pp. 101-102.

—, interviewed by Nicole Vulser, "Jacques Aumont, le cinéma né sous X," Le Monde, September 29, 2003.

—, interviewed by Patrice Blouin and Jean-Marc Lalanne, "Le gai savoir," Les Inrockuptibles, April 27, 2005, pp. 36-38.

Antoine de Baecque, Les Cahiers du cinéma: histoire d'une revue vol. II: Cinéma, tours détours 1959-1981 (Paris: Cahiers du cinéma, 1991).

102 Pierre Baudry, "Réponses aux lecteurs," Cahiers du cinéma no. 222 (July 1970), pp. 53-54, here p. 53 .

103 "Éditorial," Cahiers du cinéma no. 228 p. 5. The editors took no small pleasure in proving wrong those who "doubted that we could, by our own means, by taking over the running of the journal ourselves, and without any 'commercial' concessions, continue to put it out under normal conditions." Indeed, ten issues had been published in the twelve months up to the editorial, each with substantially more text than the average issue in the Filipacchi years. 
Pierre Baudry, "Réponses aux lecteurs," Cahiers du cinéma no. 222 (July 1970), pp. 53-54.

Jacques Bontemps, "Diligence des Straub," Trafic no. 9 (Winter 1994), pp. 76-85. [Cahiers du cinéma], "Éditorial," Cahiers du cinéma no. 145 (July 1963), p. 1.

—, "L'Affaire Langlois: 2. Conférence de presse," Cahiers du cinéma no. 199 (March 1968), pp. 34-44.

—, "Éditorial," Cahiers du cinéma 200-201 (April-May 1968), p. 5.

—, "Vers un livre blanc du cinéma français," Cahiers du cinéma no. 200-201 (AprilMay 1968), pp. 73-93.

—, "Le retour de Langlois," Cahiers du cinéma no. 202 (June-July 1968), p. 68.

—, "Éditorial," Cahiers du cinéma no. 203 (August 1968), p. 5.

—_, "Les états-généraux du cinéma," Cahiers du cinéma no. 203 (August 1968), pp. 23-46.

—, "Éditorial," Cahiers du cinéma no. 218 (March 1970), pp. 3-4.

—, "Informations," Cahiers du cinéma no. 224 (October 1970), p. 57.

—, "Éditorial," Cahiers du cinéma no. 228 (March-April 1971), p. 5.

[Cinéthique], "Du bon usage de la valeur d'échange (Les Cahiers du cinéma et le marxisme-léninisme), Cinéthique no. 6 (January-February 1970), pp. 1-12.

Jean-Louis Comolli, "Une semaine comme une autre," Cahiers du cinéma no. 178 (May 1966), p. 66.

—, "L'Affaire Langlois: 1. Historique et bilan," Cahiers du cinéma no. 199 (March 1968), pp. 32-33.

—, "Les berets verts," Cahiers du cinéma no. 215 (September 1969), p. 65.

-, Cinéma contre spectacle (Lagrasse: Verdier, 2009). Translated as Cinema against Spectacle: Technique and Ideology Revisited, trans. and ed. Daniel Fairfax (Amsterdam: Amsterdam University Press, 2015).

—, interviewed by Daniel Fairfax, "'Yes, we were utopians; in a way, I still am...: An Interview with Jean-Louis Comolli (Part 1)," Senses of Cinema no. 62 (April 2012), sensesofcinema.com/2012/feature-articles/yes-we-were-utopians-in-a-way-istill-am-an-interview-with-jean-louis-comolli-part-1/ (accessed January 1, 2021).

-, Corps et cadre: Cinéma, éthique, politique (Lagrasse: Verdier, 2012).

— and Jacques Kebadian, Les fantômes de Mai 68 (Crisnée: Yellow Now, 2018).

— and Jean Narboni, "Cinéma/idéologie/critique," Cahiers du cinéma no. 216 (October 1969), pp. 11-15. Translated as "Cinema/Ideology/Criticism," trans. Daniel Fairfax, in Jean-Louis Comolli, Cinema against Spectacle: Technique and Ideology Revisited (Amsterdam: Amsterdam University Press, 2015), pp. 251-259.

— and Jean Narboni, “Qu'est-ce que les Cahiers du cinéma?," Le Monde, November 2-3, 1969, p. 17 .

Peter Cowie, Revolution!: The Explosion of World Cinema in the Sixties (New York: Faber and Faber, 2004). 
Serge Daney, "Un rien sur fond de musique douce (Family Jewels)," Cahiers du cinéma no. 175 (February 1966), pp. 36-37.

—, "Welles au pouvoir (Falstaff)," Cahiers du cinéma no. 181 (August 1966), pp. 26-28.

—, "Le pouvoir en miettes (La Prise du pouvoir par Louis XIV)," Cahiers du cinéma no. 186 (January 1967), pp. 64-65.

—, "La dé-faite (Hurry Sundown)," Cahiers du cinéma no. 196 (December 1967), pp. 63-64.

—, interviewed by Bill Krohn, "Les Cahiers du cinéma 1968-1977: Entretien avec Serge Daney par Bill Krohn," in Daney, La Maison cinéma et le monde vol. I: Les temps des Cahiers 1962-1981 (Paris: P.O.L., 2001, pp. 17-31. Translated as T.L. French [Bill Krohn], "Les Cahiers du Cinéma 1968-1977: Interview with Serge Daney," The Thousand Eyes no. 2 (1977), pp. 18-32.

—, La Rampe (Paris: Cahiers du cinéma, 1983).

—, Persévérance (Paris: P.O.L., 1993). Translated as Postcards from the Cinema, trans. Paul Douglas Grant (Oxford: Berg, 2007).

Guy Debord, La Société du spectacle (Paris: Buchet/Chastel, 1967). Translated as The Society of the Spectacle, trans. Donald Nicholson-Smith (New York: Zone Books, 1995).

Michel Delahaye, "Fin d'un festival: Cannes," Cahiers du cinéma no. 203 (August 1968), pp. 26-27.

—, À la fortune du beau (Paris: Capricci, 2010).

Jacques Doniol-Valcroze, "La ligne générale," Cahiers du cinéma no. 160 (November 1964), p. 7 .

Bernard Eisenschitz, "Les trois derniers films de Mario Bava," Midi-minuitfantastique no. 8 (January 1964), pp. 62-63.

—, "Lettre d'Italie," Midi-minuit fantastique no. 9 (July 1964), pp. 40-42.

—, "Entretien avec Edgar G. Ulmer" (with Jean-Claude Romer), Midi-minuit fantastique no. 13 (November 1965), pp. 1-14.

—, "Cannes 65," Midi-minuit fantastique no. 13 (November 1965), pp. 37-50.

_ , "Lettre d'Italie," Midi-minuit fantastique no. 13 (November 1965), pp. 55-58.

—, "Joseph Losey sur 'Accident,"” Cahiers du cinéma no. 184 (November 1966), pp. 12-13.

—, Bogart (Paris: Losfeld, 1967).

—, "Lubitsch," L’Anthologie du cinéma no. 23 (March 1967).

—, "Abraham Polonsky par lui même," Positif no. 84 (May 1967), pp. 7-18.

_ , "Fairbanks," L’Anthologie du cinéma no. 59 (December 1969).

- interviewed by Fernando Ganzo, "A French Roman. A Story about the Influence of Soviet Avant-Garde on Cahiers du Cinéma and the Later Rediscovery of Nicholas Ray: An Interview with Bernard Eisenschitz," Cinema Comparat/ive Cinema no. 2 (Spring 2013), pp. 18-28. 
—, Bertrand Tavernier and Chris Wicking, "Corman parle," Positif no. 59 (March 1964), pp. 15-28.

—, Bernard Cohn and T. Perez-Turrent, "Pesaro 1967," Positif no. 88 (October 1967), pp. 20-26.

Daniel Fairfax, "Farewell Michel Delahaye," Senses of Cinema no. 81 (December 2016), sensesofcinemacom/2016/feature-articles/farewell-michel-delahaye/ (accessed January 1, 2021).

Daniel Filipacchi, Ceci n'est pas une autobiographie (Paris: Bernard Fixot, 2012).

Jean-Luc Godard, “Lettre au Ministre de 'Kultur," Le Nouvel Observateur, April 6, 1966. Repr. in Cahiers du cinéma no. 177 (April 1966), pp. 8-9. Translated as "Letter to the Minister of 'Kultur," in idem., Godard on Godard, trans. and ed. Tom Milne (New York: Da Capo Press, 1972), pp. 237-238.

- (unsigned), "La guerre est commencée," Cahiers du cinéma no. 177 (April 1966), unpublished version.

—, interviewed by J.-P.C. and G.L., "Un cinéaste comme les autres," Cinéthique no. 1 (c. January 1969), pp. 8-12.

Paul Grant, Cinéma Militant: Political Filmmaking \& May 1968 (New York: Wallflower Press, 2016).

Sylvia Harvey, May '68 and Film Culture (London: BFI, 1980).

Pierre Kast, "A Farewell to the Movies," Cahiers du cinéma no. 200-201 (AprilMay 1968), pp. 13-18.

Sébastien Layerle, Caméras en lutte en Mai 68: “Par ailleurs le cinéma est une arme...” (Paris: Nouveau Monde, 2008).

V.I. Lenin, “The State: A Lecture Delivered at the Sverdlov University, July 11, 1919," The Collected Works of V.I. Lenin vol. XXIX (Moscow: Progress Publishers, 1976), pp. 470-488.

Colin MacCabe, Godard: A Portrait of the Artist at Seventy (New York: Farrar, Straus and Giroux, 2003).

Laurent Mannoni, Histoire de la Cinémathèque française (Paris: Gallimard, 2006). Luc Moullet, interviewed by Michel Delahaye and Jean Narboni, "Entretien avec Luc Moullet," Cahiers du cinéma no. 208 (January 1969), pp. 40-49, 56-62.

Michel Mourlet, “Apologie de la violence," Cahiers du cinéma no. 107 (May 1960), pp. 24-27.

-, Sur un art ignoré: La mise en scène comme langage (Paris: Ramsay, 2008).

Jean Narboni, "Le Cahier des lecteurs," Cahiers du cinéma no. 208 (January 1969), p. 5.

—, "L'Armée des ombres," Cahiers du cinéma no. 216 (October 1969), p. 63.

Jean-Pierre Oudart, "Rêverie bouclée," Cahiers du cinéma no. 216 (October 1969), pp. $5^{1-52}$.

Sylvie Pierre, "L'ordre et l'ordinateur (Les Sans-espoir)," Cahiers du cinéma no. 187 (February 1967), pp. 66-68. 
—, "Une œuvre de salut public (Le Père Noël a les yeux bleus)," Cahiers du cinéma no. 188 (March 1967), p. 59.

—, "Poétique et politique (Oz fusis)," Cahiers du cinéma no. 190 (May 1967), p. 66.

—, "Le regard brûlant du conteur (La chasse au lion à l'arc)," Cahiers du cinéma no. 192 (July-August 1967), pp. 65-66.

—, "Le considérable talent de G.W. Pabst," Cahiers du cinéma no. 193 (September 1967), pp. 42-47.

—, interviewed by Bill Krohn, "Interview with Sylvie Pierre," Senses of Cinema no. 23 (December 2002), sensesofcinema.com/2002/feature-articles/pierre/ (accessed January 1, 2021).

La Rédaction, "Venise malgré tout," Cahiers du cinéma no. 206 (November 1968), pp. 23-24.

—, interviewed by Jacques Aumont, Jean-Louis Comolli, Jean Narboni and Sylvie Pierre, "Le temps déborde: Entretien avec Jacques Rivette," Cahiers du cinéma no. 204 (September 1968), pp. 6-21. Translated as "Time Overflowing," trans. Amy Gateff, in Jonathan Rosenbaum (ed.), Rivette: Texts and Interviews (London: BFI, 1977), pp. 9-38.

Glauber Rocha, interviewed by Michel Delahaye, Pierre Kast and Jean Narboni, "Entretien avec Glauber Rocha," Cahiers du cinéma no. 214 (July-August 1969), pp. 23-40.

Louis Skorecki, Dialogues avec Daney (Paris: PUF, 2007).

[Visages du cinéma], "Éditorial," Visages du cinéma no. 1 (c. 1962), p. 2. 



\title{
8. Cahiers du cinéma and the Rapprochement with the PCF: 1969-1971
}

\begin{abstract}
Soon after the publication of "Cinéma/idéologie/critique," Cahiers $d u$ cinéma embarked on a concerted rapprochement with intellectuals aligned with the Parti communiste français, which would last until mid-1971. The timing was strange: in the eyes of much of the far left, the PCF had been thoroughly discredited by the role it played during the May'68 protests. Looming large over the Cahiers critics, however, was the influence of Louis Althusser (who also advocated working within the nation's only mass working-class party), and they found the critics writing for the party's cultural journal La Nouvelle Critique to be promising interlocutors. This strategic orientation led to groundbreaking critical work on Soviet cinema, Jean Renoir's La vie est à nous, Robert Kramer's Ice and the fiction de gauche, while at the same time Pascal Kané, Jean-Pierre Oudart, Pascal Bonitzer and Pierre Baudry joined the fold at Cahiers. Soon, however, the contradictions of the journal's attempted dialogue with the PCF would emerge.
\end{abstract}

Keywords: Cahiers du cinéma, Parti communiste français, Soviet cinema, La vie est à nous, Robert Kramer, fiction de gauche

\section{Cultural Politics and the PCF}

No sooner had the Cahiers editors established their autonomy from the Filipacchi group than they sought out a new institutional partnership, this one in the political sphere. The first issue of the independent Cahiers coincided with the beginning of a concerted attempt at a rapprochement between the journal and the PCF, by far the largest party on the French

Fairfax, D., The Red Years of Cahiers du Cinéma (1968-1973). Volume I: Ideology and Politics. Amsterdam: Amsterdam University Press, 2021 DOI 10.5117/9789463728508_CHo8 
left at the time and the organizational umbrella for much of the country's industrial working class. This status notwithstanding, the journal's attraction to the party seems anomalous: not only had the Cahiers critical tradition contrasted itself with communist film criticism since Bazin's 1950 article for Esprit on "Le cinéma soviétique et le mythe de Staline" but the party also had a distinctly more negative attitude towards the May'68 uprising than the Cahiers editors. ${ }^{1}$ Denouncing the student protestors as petty-bourgeois provocateurs and participating eagerly in the Grenelle agreements that ended the strike wave, the party leadership essentially saw the revolt as a distraction from its favored electoral route to power. ${ }^{2}$ In the eyes of many on the far left, then, May '68 conclusively served to politically discredit the PCF. As the editors themselves would later emphasize, however, a sense of disorientation and political reflux after de Gaulle had quashed the protests (the June legislative elections had given a large parliamentary majority to the right) led the journal to view the communist party as "the only force with a coherent strategy vis-à-vis the bourgeoisie," and its cultural policy contrasted favorably with what they saw as the "mechanistic anti-theoretical stance" of much of the era's gauchiste movement. ${ }^{3}$

When asked more recently about the choice to align with the PCF, both Comolli and Narboni have stressed the role of Althusser's chosen political strategy of transforming the party into a genuinely revolutionary organization. Asked about the reasons for the PCF alignment, Narboni answered with one word: "Althusser." Comolli, meanwhile, expanded on this: "Even while we criticized Althusser's logic, we had integrated it into our thinking. [...] His thesis was: 'Do not believe that the PCF has actually turned its back on the revolution. If we join the party, if we carry out entryism, we can push it towards more openness.' This was his logic: reform the party."4 Although the Cahiers editors had little personal contact with Althusser, they moved in the same circles as students of his who had been involved with

1 André Bazin, “Le cinéma soviétique et le mythe de Staline," Esprit no. 170 (August 1950), pp. 210-235. Translated as "The Stalin Myth in Soviet Cinema," trans. Georgia Gurrieri, Film Criticism vol. 3 no. 1 (Fall 1978), pp. 17-26.

2 For more on the effects of the May '68 protests on the PCF, see Jeannine Verdès-Leroux, Le Reveil des somnambules: Le Parti communiste, les intellectuels et la culture, 1956-1985 (Paris: Fayard, 1987); and Danielle Tartakowsky, Une histoire du P.C.F. (Paris: Presses universitaires de France, 1982), pp. 89-101.

3 La Rédaction, "Politique et lutte idéologique de classes, Intervention 1," Cahiers du cinéma no. 234-235 (December 1971-January-February 1972), pp. 5-12, here p. 6. Translated as "Politics and Ideological Class Struggle," trans. Alan Williams, in Browne, Cahiers du Cinéma vol. III, pp. 334-341, here p. 335 .

4 Comolli, "Yes we were utopians (Part 1)." 
the pre-1968 proto-Maoist grouping the Union des jeunesses communistes marxistes-léninistes (UJCM-L) such as Pierre Macherey, Alain Badiou and Jacques Rancière, and Comolli affirms the prolonged influence of Althusser on Cahiers' political engagement: "We were Althusserians. Let's say that among the different currents which took shape in the course of May '68, we felt close to the Althusserians. Why? Because they were theorists. Later, we would still remain within this line-we did not end up orienting ourselves towards the Gauche prolétarienne, the 'Mao-Spontex' currents. We remained, in the end, neo-Althusserians or post-Althusserians."

Althusser's strategy, although it would end up in failure (the philosopher himself publicly broke with the party after the 1978 legislative elections ${ }^{6}$ ), was not necessarily doomed from the outset. In the late 196os, the PCF was a politically heterogeneous body, ranging from hardline Stalinists to "Eurocommunist" reformists, as well as those seeking to shift the party in a more left-wing direction, and the relative strength of these factions was in a perpetual state of flux. In the cultural arena, a period of openness had been initiated following the landmark Argenteuil central committee meeting of March 1966, in which party intellectuals and "fellow travelers" were given greater leeway to pursue reflection on cultural matters independently of the party's political leadership. While this shift could be interpreted in a cynical vein, as a method to circumvent the attraction of more radical groups to the cultural left in the political climate of the late 196os, concrete measures were nonetheless undertaken in line with the Argenteuil resolutions.

The most important of these was the re-founding of the party's main cultural journal, the bi-monthly La Nouvelle Critique, in 1967, along politically and culturally heterodox lines, with a newer generation of critics including Émile Breton, Albert Cervoni and Jacques de Bonis taking over responsibility for the publication. A fault line had thus opened up within the party on questions of art and culture, with La Nouvelle Critique, La Pensée and Louis Aragon's literary review Les Lettres françaises more favorable towards the artistic avant-gardes, ${ }^{7}$ while the party's major newspapers such as L'Humanité pursued a more conservative line in cultural matters. Alongside

5 Ibid.

6 See Louis Althusser, Ce qui ne peut pas durer dans le Parti communiste (Paris: Maspero, 1978). This text was originally published as a series of articles in Le Monde, April 24-27, 1978.

7 Les Lettres françaises was relatively conservative during the Stalin era but became more receptive to the avant-garde in the 1960 s. After Aragon vocally condemned the invasion of Czechoslovakia, Eastern European governments canceled their subscriptions to the journal, and it ceased publication in 1972. This would not stop Tel Quel, notably, from attacking Aragon during its Maoist phase. 
Althusser, then, La Nouvelle Critique was the most important influence on Cahiers' turn towards the PCF. Narboni notes the close alignment in aesthetic opinions the Cahiers editors had with the PCF journal's editors, which contrasted with their dissatisfaction regarding the less sophisticated cinematic tastes of Maoist and Trotskyist groups:

There was a moment when, bizarrely, it was not the gauchistes, but the PCF members, the people from La Nouvelle Critique, who were the only people with whom we could speak about the cinema that we like. We could not hold a discussion on Othon in La Cause du peuple or Rouge, but we could do so in La Nouvelle Critique. When we presented Straub or Godard at universities with leftists and anarchists we were booed. These people were politically radical, but cinematically they were extremely conservative. $^{8}$

The presence of Fieschi on the editorial committee of La Nouvelle Critique fostered collaboration between the two journals and gave rise not only to the joint round table on Othon but also to valuable work on Ice by Robert Kramer, Soviet silent cinema and Renoir's Popular Front films. Within La Nouvelle Critique, however, there were theoretical and political tensions at play, and even when relations were warmest, Cahiers' work was generally discussed by the PCF journal with a tone of mitigated benevolence. ${ }^{9}$ In the end, these tensions, combined with the difficulty of politically reconciling with Georges Marchais' stewardship of the party, under whom denunciations of the far left became ever more vitriolic, ${ }^{10}$ would see Cahiers become increasingly alienated from the PCF over the course of 1971.

The final interlocutor determining Cahiers editors' stance towards the PCF was Tel Quel. Like Cahiers, the literary journal equivocated in its attitudes towards the party, an ambivalence that was reflected in a division

8 Interview with Jean Narboni, March 18, 2014. La Cause du peuple was a Maoist newspaper associated with the Gauche prolétarienne, while Rouge was the official newspaper of the Ligue communiste révolutionnaire, a Trotskyist organization.

9 Claude Prévost, for instance, while broadly defending Cahiers, wrote that the journal "risks sliding into 'theoreticism': the link between 'theory' and the 'works' to critique or make often appears as a mechanistic, cause-and-effect link, which is neither dialectical nor, consequently, Leninist." Claude Prévost, "Dans le numéro de novembre des Cahiers du cinéma," La Nouvelle Critique no. 30 (January 1970), p. 65.

10 Marchais became de facto leader of the PCF in 1970 when its aging General Secretary Waldeck Rochet succumbed to illness. He was officially elevated to the position in 1972, where he remained until 1994. His slightly buffoonish personal style and conservative leadership made him a figure of mockery for the far left. 
within its editorial board. Jean Thibaudeau (a PCF member) and Marcelin Pleynet advocated fraternal relations with the party, while Philippe Sollers and Julia Kristeva leaned towards the gauchiste movement. The latter two were decisive in Tel Quel's violent rejection of the PCF in mid-1971 and its adoption of a Maoist orientation that would heavily influence Cahiers' own trajectory. Between 1967 and 1970, however, Tel Quel was open to collaboration with La Nouvelle Critique, earning a high-profile presence in several issues of the communist periodical and thereby exposing its wider readership to contemporary developments in literary theory. ${ }^{11}$ The Cahiers editors frequented meetings of Tel Quel's "Groupe d'études théoriques," and its influence on the film journal's thinking became overpowering. After an initial period of skepticism towards Cahiers from the part of Sollers and Pleynet, ${ }^{12}$ relations between the two journals became so close that, by December 1970, they saw fit to issue a joint communiqué attacking Positif. ${ }^{13}$

Cahiers' rapprochement with the PCF, while short-lived and never adequately theorized as a coherent political strategy, ${ }^{14}$ was a genuine attempt to engage in dialogue with those intellectual layers attempting to think through questions relating to the cinema from a Marxist standpoint, who were judged at the time to be mostly gravitating around the party. Although this perspective led to ironic remarks from other journals about "Narboni and Marchais, hand in hand,"15 and was ultimately abandoned as unworkable, it nevertheless coincided with one of the most theoretically fertile periods in the history of Cahiers. Indeed, from the standpoint of film theory, 1970, the high point of Cahiers' rapprochement with the PCF, can also be seen as something of an annus mirabilis for the journal.

11 See, in particular, La Nouvelle Critique no. 19 (December 1968), which published proceedings from a conference held by Tel Quel on "Linguistics and Literature," with interventions from Jean-Louis Baudry, Kristeva, Sollers and Pleynet.

12 See, in particular, Pleynet/Thibaudeau, "Économique, idéologique, formel...."

13 See Jean-Louis Comolli, Jean-Paul Fargier, Gérard Leblanc, Jean Narboni, Marcelin Pleynet and Philippe Sollers, "Cinéma, littérature, politique," Cahiers du cinéma no. 226-227 (JanuaryFebruary 1971), p. 115. Translated as "Cinema, Literature, Politics," trans. Alan Williams, in Browne (ed.), Cahiers du Cinéma vol. III, pp. 287-29o. The communiqué was dated December 21, 1970 .

14 A letter from Dominique Païni in the March-April 1971 issue requested an in-depth explanation from the Cahiers editors of their political alignment, but this was never produced, and the allegiance to the PCF was abandoned several months later. Dominique Païni, "Une lettre," Cahiers du cinéma no. 228 (March-April 1971), p. 64. A sustained critique of this position was nonetheless produced at the inception of Cahiers' Maoist period.

15 Ibid., p. 64. Païni points to a text written by Jean Delmas in Jeune Cinéma no. $5^{2}$ (February 1970). 


\section{Expanding the Critical Ranks: Kané, Bonitzer, Baudry and Oudart}

At the same time that Cahiers allied itself with the institutional muscle of the PCF's cultural apparatus, its editors sought to expand the ranks of its writing team. Some figures who gravitated towards the journal at this time-Geneviève Reinach, Sebastien Roulet, Robert Alburni, Dominique Noguez and Eduardo de Gregorio among them-only wrote briefly for Cahiers. Others, most notably Pascal Kané, Pascal Bonitzer, Pierre Baudry and Jean-Pierre Oudart, became fully integrated into its editorial team, immersing themselves in the "adventure" of Cahiers during its politically radicalized period, up to the fiasco of the Front culturel and beyond. Of the four, Kané was the first to contribute to Cahiers, making his bow with a review of Polanski's Cul-de-sac in February 1967. Born on January 21, 1946 into a Jewish family of Polish origin, ${ }^{16}$ Kané felt an obvious affinity for the work of Polanski, and when he became, after Eisenschitz, one of the first of his generation of Cahiers writers to publish a book-length work in 1970, it was natural that the monograph would be devoted to the Polish filmmaker. ${ }^{17}$ Raised in the $9^{\text {th }}$ arrondissement, he took an interest in the cinema at the age of 14 and began reading Cahiers and attending the Cinémathèque in 1963, his last year of high school. ${ }^{18}$ Studying law and economics at university, he wrote his mémoire on the economics of the film industry, but this aspect of the cinema was of little lasting interest, and his writings for Cahiers attest above all to a cinephilic approach to film. Kanés integration into Cahiers was not a smooth one: more than two years would elapse between his first published text and his acceptance as a full-fledged member of the editorial team in mid-1969. During this time he intermittently wrote short reviews, while a longer text offering a Sadean reading of Raoul Walsh's œuvre (inspired by a special issue of Tel Quel on Sade) was rejected by Comolli as "not structural enough." ${ }^{.9}$ Later, an article he wrote on the Marx brothers

16 In 2001, Kané made the essayistic documentary La Théorie du fantôme about his family background. See Chapter 20 for more on this film.

17 Pascal Kané, Roman Polanski (Paris: Éditions du Cerf, 1970).

18 The first issue of Cahiers Kané recalls reading was no. 150-151 (December 1963-January 1964), a special on American cinema. He also recalls driving a Citroën ${ }_{2} \mathrm{CV}$ from Barcelona to Paris (and back) to watch the screening of Monsieur Verdoux for the opening of the Cinémathèque française's new venue at the Palais de Chaillot. Interview with Pascal Kané, March 12, 2014. 19 Ibid. The dossier on Sade appeared in Tel Quel no. 28 (Winter 1967). Kané's article centered mainly on the character played by Clark Gable in Band of Angels, but that text is now lost. Kané retrospectively admits that it was "too vague" and "too ambitious" for the debutant critic that he was in late 1967. Interview with Pascal Kané, March 12, 2014. 
for Politique Hebdo was also criticized by the Cahiers editors: contributing to a newspaper of the non-communist left constituted "playing the game of anti-communism" in their eyes, and Kané desisted from writing for that publication..$^{20}$ At the same time, he came to play a more high-profile role at Cahiers, contributing to its major collective texts and writing substantial articles on Chabrol, Allio's Pierre et Paul and Borowczyk's Goto, île d'amour in $1969 .{ }^{21}$ The Goto review read Borowczyk's film through the prism of Barthes' notion of the "effect of the real," and the literary theorist was one of the key theoretical points of reference for Kané, who attended his Collège de France lectures and helped forge a close relationship between Barthes and Cahiers during this time. Kané was less comfortable, however, with the journal's politicization, confessing that "I was hopeless on the political level. It is not at all my Eros. ${ }^{\text {"22 }}$ Indeed, even at the height of Cahiers' Marxism-Leninism, he continued to take an interest in contemporary Hollywood releases. Indicative here is the fact that Kané's review of Hitchcock's Topaz, in which he rejected the commonly held view of the film as a metaphor for Hitchcock's "anti-communist" decision to work in the US, was published in an issue otherwise almost entirely devoted to "Russia in the 1920 s." $^{23}$ Throughout the 1970s, Kané was virtually alone among the Cahiers critics to pursue a critical reading of contemporary Hollywood films.

Like Kané, Bonitzer (born February 1, 1946) read Cahiers for several years before stepping up as a writer for the journal: he vividly recalls discovering issue no. 120 in a family attic, which contained a transcription of the soundtrack to Le Petit Soldat, and became a subscriber from that moment on. ${ }^{24}$ Viewings of The Lady of Shanghai in his local $16^{\text {th }}$ arrondissement cinema in 1959 and $\grave{A}$ bout de souffle in London in 1962 had already awoken his cinephilia, and he also dabbled in painting and fiction writing. But

20 Interview with Pascal Kané, March 12, 2014.

21 See Pascal Kané, "L'organisation du désordre (La Route du Corinthe, Les Biches, Une femme infidèle)," Cahiers du cinéma no. 211 (April 1969), pp. 53-55; "La matière filmique (Goto, île d'amour)," Cahiers du cinéma no. 212 (May 1969), pp. 57-60; and "Le travail et l'usure (Pierre et Paul)," Cahiers du cinéma no. 214 (July-August 1969), p. 60.

22 Interview with Pascal Kané, March 12, 2014.

23 Pascal Kané, “Topaz,” Cahiers du cinéma no. 220-221 (May-June 1970), pp. 127-128.

24 Although it does not feature in Bonitzer's recollections, it is perhaps notable that this issue also contained Rivette's totemic article "De l'abjection." For more on Bonitzer's biographical details, see: Pascal Bonitzer, “Comment j’ai rencontré Jacques Bontemps," in Sarah Bertrand (ed.), Des nouvelles du cinéma: Une première fois vol. II (Paris: Seuil, 2004), pp. 107-115; Pascal Bonitzer, "Mes dates clés," Libération, December 2, 2003; and Emmanuèle Frois, "Pascal Bonitzer, éléments d'un portrait," Le Figaro, December 2, 2003. These details were also confirmed in an interview with Bonitzer (Paris, April 30, 2014). 
Bonitzer's youth was profoundly shaped, above all, by politics. His father was a prominent member of the PCF, and much of the younger Bonitzer's militant activity can be seen in an CEdipal light: enrolled in the philosophy department at Nanterre after failing the entrance exam to the IDHEC (the national film school), he was briefly a member of the Trotskyist youth group Jeunesse communiste révolutionnaire before associating with the anarchist Mouvement de Mars 22, where he made the acquaintance of Daniel CohnBendit and Anne Wiazemsky. Bonitzer joined them on the barricades during the May events, although he recalls being distinctly less excited by the protests than a friend who, teargas in his eyes, confided "Pascal, this is the most beautiful day of my life!"25 It was through these circles that he crossed paths with Cahiers: meeting Delahaye over dinner one evening, Bonitzer confessed his desire to write for the journal, and the older critic, aware of the need for new writers, proposed a review of Sembene's Le Mandat. After some hesitation, Bonitzer took up Delahaye's offer, writing a precocious text published in the February 1969 issue that invoked Brecht and Derrida in arguing that money was the "true subject" of the film, and its "foreign, magic, maleficent element." ${ }^{26}$ More than Delahaye, however, it was the elegant writing style of Jacques Bontemps that most impressed the young Bonitzer, and in a strange turn of events, Bontemps was also friends with Bonitzer's high school teacher, the Heideggerian philosopher Michel Deguy. ${ }^{27}$ Bontemps proved to be a useful model for the younger critic's own development as a writer: throughout his twenty-year association with Cahiers, Bonitzer would always be distinguished by his unparalleled literary flair and a confident, if not always rigorous, deployment of post-structuralist and psychoanalytic theory. Unlike Kané, Bonitzer wasted no time in imposing himself at Cahiers: after writing reviews of Teorema, Ma Nuit chez Maud, Break-Up and The Party in 1969, he played a key role in the collective text on La vie est à nous in March $1970 .{ }^{28}$ It was, however, his discovery of Japanese cinema in 1970, and in particular Death by Hanging by Oshima and Eros + Massacre by Yoshida, that truly saw Bonitzer develop his consummate critical voice.

25 Bonitzer's response was “Ah, the fool." See Bonitzer, “Comment j'ai rencontré Jacques Bontemps," p. 111.

26 Pascal Bonitzer, "Largent-fantôme (Le Mandat)," Cahiers du cinéma no. 209 (February 1969), pp. 57-58, here p. 57 .

27 See Bonitzer, “Comment j'ai rencontré Jacques Bontemps.", pp. 109-110, 114-115.

28 See Pascal Bonitzer, "Le carré (Teorema)," Cahiers du cinéma no. 211 (April 1969), p. 53; "Maud et les phagocytes (Ma Nuit chez Maud)," Cahiers du cinéma no. 214 (July-August 1969), p. 59; "L'homme au ballon (Break-up)," Cahiers du cinéma no. 215 (September 1969), pp. 6o-62; and "Les vases communicants (The Party)," Cahiers du cinéma no. 216 (October 1969), pp. 52-53. 
Jean-Pierre Oudart began writing for Cahiers at roughly the same time as Bonitzer and Kané. Very little, however, is known about his background before that point. No record exists of his date of birth or family background, although de Baecque relays that he worked at the municipal library in Orléans and had read Cahiers attentively since the early 196os. From 1967 onwards, he dispatched hand-written letters to the journal, and after an in-person meeting with the editors, began to publish with Cahiers in January $1969 .{ }^{29}$ In comparison with the rest of the editorial team, Oudart's cinematic culture was slight, but he made up for this with his thorough grounding in Lacanian psychoanalysis..$^{30}$ Pierre recalls that he was initially treated by the rest of the team as a "literary madman" and not taken entirely seriously, with Narboni and Rivette the first to recognize the theoretical import of his writings. ${ }^{31}$ After publishing three critical notices in early 1969 , on Les Contrebandières by Moullet, Freaks by Browning and L'Enfance nue by Pialat, all of which centered around themes of aberration, monstrosity and madness, ${ }^{32}$ Oudart sealed his place in the history of film theory with the two installments of "La Suture" (March and May 1969), an enormously influential article that merits its status as the origin-text of psychoanalytic film theory and which for Oudart initiated an idiosyncratic theoretical concern for the cinema that would endure throughout his association with Cahiers up to 1980.

Baudry was the last critic to join Cahiers before the onset of its Maoist period, contributing his first article, an overview of three Sergio Sollima films, in March 1970.33 He was introduced to the journal by Comolli, who remained friends with Baudry until the latter's death in 2005, ${ }^{34}$ and was quickly given a high level of editorial responsibility. As early as July 1970, Baudry was tasked with the "Réponses aux lecteurs" rubric, clarifying the journal's political positions for inquisitive readers. ${ }^{35}$ Born in Reims on January 28,1948 , he moved to Paris in 1966 to take preparatory classes for the École normale supérieure, where he completed a maîtrise in philosophy with

29 De Baecque, Histoire d'une revue vol. II, pp. 216-217.

30 Aumont joked that before joining the journal, Oudart "had seen twelve films, eleven of which were by Bresson." Interview with Jacques Aumont, March 11, 2014.

31 Interview with Sylvie Pierre, May 26, 2014.

32 See Jean-Pierre Oudart, "L'aberrant dévié (Les Contrebandières)," Cahiers du cinéma no. 208 (January 1969), pp. 59-6o; "Au hasard Pialat (L'Enfance nue)," Cahiers du cinéma no. 210 (March 1969), pp. 55-56; and "Humain, trop humain (Freaks)," Cahiers du cinéma no. 210 (March 1969), pp. 57-58.

33 Pierre Baudry, "Trois films de Sollima," Cahiers du cinéma no. 218 (March 1970), pp. 59-61.

34 Comolli wrote an obituary notice on Baudry for Cahiers upon his death. See Jean-Louis Comolli, "Salut à l'homme de Varan," Cahiers du cinéma no. 600 (April 2005), p. 73.

35 Baudry, "Réponses aux lecteurs." 
a thesis on St. Augustine..$^{6}$ Thanks to his familiarity with psychoanalytic theory, Baudry rounded out the small team of Lacanians within Cahiers, alongside Oudart, Bonitzer, Kané and Daney. His taste in films, however, was decidedly eclectic. With a predilection for spaghetti Westerns and slapstick comedy, Baudry was virtually the only critic at Cahiers to write on genre cinema during this period, while he also contributed in-depth discussions on Alexander Nevsky, Trafic and Intolerance, as well as critical lacerations of Zabriskie Point and Le Chagrin et la Pitié. ${ }^{37}$ The youngest member of the Cahiers editorial team, Baudry's association with the journal was also the briefest, and he was the least prolific of the ten writers under discussion here: only 23 articles appeared in his name before he resigned from the journal in 1973, having found himself unable to conform to the Maoist line of the Front culturel period.

\section{Cahiers, Communism and Jean Renoir: La vie est à nous}

The introduction of these new critics in the years 1969-1970 quickly made itself felt within the journal: in March 1970 already, Bonitzer and Oudart joined with Comolli, Narboni and Daney in composing an analysis of Jean Renoir's La vie est à nous. A collective film made for the communist party's propaganda arm during the anti-fascist Popular Front period in 1936, La vie est à nous represented an ideal opportunity for Cahiers to combine its cinephilic heritage with its new political strategy of liaising with the PCF. Given a re-release in the Studio Gît-le-cœur in November 1969-as part of a retrospective on French cinema from the early sound era titled "29-36" - the film was widely covered in the communist press, with Michel Capdenac of Les Lettres françaises hailing it as "the first example in France of a militant cinema, a 'parallel' cinema." ${ }^{8}$ Renoir, of course, has been one of the key filmmakers for Cahiers throughout its history: as early as issue no. 8 (January 1952), Bazin penned a 20-page article on "Renoir français"; a two-part interview with Rivette and Truffaut appeared in issues no. 34 and 35 (April-May 1954); and the August-September 1954 (no. 38) and Christmas 1957 (no. 78) numbers featured dossiers dedicated to Renoir's œuvre. ${ }^{39}$ The

36 See Francis Marmande, “Pierre Baudry, cinéaste philosophe," Le Monde, February 25, 2005.

37 See Chapter 24 for more on this body of writing.

38 Michel Capdenac, "La vie est à nous de Jean Renoir," Les Lettres françaises, November 12, 1969.

39 See André Bazin, "Renoir français," Cahiers du cinéma no. 8 (January 1952), pp. 9-29; Jean Renoir, interviewed by Jacques Rivette and François Truffaut, "Entretien avec Jean Renoir," Cahiers du cinéma no. 34 (April 1954), pp. 3-22 and Cahiers du cinéma no. 35 (May 1954), pp. 14-30; 
late 196os, meanwhile, saw a renewed interest in Renoir on the part of Comolli/Narboni's Cahiers: new interviews appeared in July 1966 (no. 180), January 1967 (no. 186) and December 1967 (no. 196), while, adventitiously, the script for the unmade film C'est la révolution! was published in the April-May 1968 issue (no. 200-201). ${ }^{40}$ Moreover, Comolli had analyzed $L a$ Marseillaise (a sister work to La vie est à nous, also supported by the PCF and made under the Popular Front) in a 1967 article, where he argued that the film opened up "the possibility for a political cinema to be intelligent, and for an intelligent cinema to take a political stance. ${ }^{41}$ Far from La Marseillaise being a work of ecumenical humanism in tension with the project's stated propagandistic goals, Comolli maintained that "propaganda, here, is propagated and diffused throughout the entire film, inscribed in the very forms it employs." Moreover, the state of harmonious equilibrium that is supposedly Renoir's stylistic hallmark is, in this film, subject to a perpetual process of construction and demolition. It is this "writing operation," therefore, that makes manifest the notions of "difference, alterity and radical separation" governing the film. ${ }^{42}$

An anti-humanist reading of Renoir is also on view in Les Cahiers face au film: Une partie de campagne, a pedagogical film shot by Eisenschitz on November 28, 1969. Here, the Cahiers team argues that the severe, dark and even malicious tone of Renoir's unfinished short film runs counter to the "terribly human, humorous, pantheistic Renoir" that dominates critical understandings of his work. Far from being a naturalist work in the vein of the Maupassant story from which it is adapted (an interpretation bolstered by the mythology around the film crafted by Renoir), the formal structure of Une partie de campagne centers on modernist notions of theatricality, as evinced by the gaze of Sylvia Bataille directly into the camera, twenty years before Bergman would repeat the technique in Summer with Monika. Narboni here concludes that it is "masking effects" (effets de masque) such

"Les soixante ans de Jean Renoir," Cahiers du cinéma no. 38 (August-September 1954), pp. 2-54; and "Jean Renoir," Cahiers du cinéma no. 78 (Christmas, 1954), pp. 2-86.

40 See Jean Renoir, interviewed by Michel Delahaye and Jean-André Fieschi, "Mes prochains films: Entretien avec Jean Renoir," Cahiers du cinéma no. 180 (July 1966), pp. 37-46; André S. Labarthe and Jacques Rivette, "Jean Renoir le patron: propos de Renoir," Cahiers du cinéma no. 186 (January 1967), pp. 23-26; Jean Renoir, interviewed by Michel Delahaye and Jean Narboni, "La Marche de l'idée: entretien avec Jean Renoir," Cahiers du cinéma no. 196 (December 1967), pp. 13-22, 66-68; and Jean Renoir, "C'est la révolution! (Crème de beauté)," Cahiers du cinéma no. 200-201 (April-May 1968), pp. 32-42.

41 Jean-Louis Comolli, "Des migrations exemplaires," Cahiers du cinéma no. 196 (December 1967), pp. $25-26$, here p. 25 .

42 Ibid., p. 26. 
as this that result in the film becoming a "critical operation opposing the laborious, academic French cinema of the 1930s."${ }^{n 3}$

This recurring interest in Renoir's 1930s work provided the basis upon which the Cahiers critics embarked on a political/formal analysis of La vie est à nous, an endeavor that undoubtedly represented the most significant forerunner to the collective text on Young Mr. Lincoln. Unlike Ford's film, however, La vie est à nous was governed by an ideological standpoint close to that held by Cahiers at the time the article was written. Indeed, the text was later criticized in the journal for "rehashing, word for word, in an uncritical manner, the thesis of the film (the theses of the PCF at the time of the Popular Front and, today, their theses on the Popular Front).".44 Moreover, while Young Mr. Lincoln was made for standard commercial release and conformed to the formal and narrative strictures of classical Hollywood, La vie est à nous was conceived from the start as a "militant film," blending documentary and fiction elements, and was primarily intended for screenings at political meetings to convey to audiences the political line of the PCF. For this reason, Cahiers explicitly contrasted Renoir's film with contemporary militant cinema, the vast majority of which was looked upon in a negative light.

Signed by Bonitzer, Comolli, Daney, Narboni and Oudart, "La vie est à nous, film militant" is divided into four sections, which respectively deal with the "situation" of the film, its "function," its "political effectiveness," and finally "problems of militant cinema." As with the Young Mr. Lincoln article, the first part of the text, which in fact takes up nearly half of the entire article, begins by giving a historical overview of the broader political situation in which Renoir's film was made. Europe in the mid-193os was marked, the Cahiers critics note, by economic crisis and violent political struggles, which led to the consolidation of fascist regimes across much of the continent. This fascist wave was met with a tepid response by bourgeois democracies, fearful of giving support to communist forces, and the situation required the Soviet leadership to "provisionally subordinate the struggle against capitalism to the struggle against fascism" by adopting the "popular front"

43 Les Cahiers face au film: Une partie de campagne, dir. Bernard Eisenschitz, 1969.

44 La Rédaction, "Politique et lutte idéologique de classes, Intervention 1," p. 6. They go on to say that it was "symptomatic that this text was practically the only Cahiers article-if recognized 'cultural values' such as Vertov, Eisenstein and Griffith are excepted-that was cited with praise by the party press." Notably, there is no criticism in "La vie est à nous, film militant" of the Comintern's disastrous "Third Period" policy of the early 1930s, which denounced social-democratic parties as "social-fascists" and hamstrung attempts to prevent Hitler's rise to power. 
tactic. ${ }^{45}$ Then PCF general secretary Maurice Thorez and Comintern head Georgi Dimitrov are at this point both quoted approvingly, the latter to the effect that, "At the present time the working masses can no longer choose between bourgeois democracy and the dictatorship of the proletariat; they can choose only between bourgeois democracy and fascism. ${ }^{m 6}$

Following on from the stance taken towards La Marseillaise and Une partie de campagne, Cahiers argues that this historical context is necessary to combat the dominant critical reception of La vie est à nous, the majority of which is "not concerned with the militant nature of the film-except in a nostalgic mode" and instead focuses on "what seemed to justify its interest in the film." ${ }^{\prime 7}$ A piece by Claude Beylie (who organized the retrospective) is quoted as symptomatic of the attempt by "idealist criticism" to locate, within a work directly commissioned for the purposes of political agitation, the "Renoir touch" - namely, the filmmaker's ineffable charm and humor, as well as certain signature formal techniques such as the use of deep-focus. Against this tendency, the Cahiers critics insist on emphasizing the collective nature of the project and its alignment with the political theses of the PCF at the time. They note, for instance, that a report by Maurice Thorez at the party's 1936 congress formed the skeleton for the film's structure and was quoted from at length in the schoolteacher's opening monologue. And yet, while contesting the auteur-focused nature of the dominant critical response to the film, the Cahiers writers themselves become caught in an auteurist aporia from which they struggle to break free: collective filmmaking itself is recognized as one of the red threads in Renoir's œuvre, and the discussion of La vie est à nous is often dominated by its relationship with other Renoir films. Cahiers assert, for instance, that: "Renoir has always had a taste for experimentation. [...] It was natural that at that time he would take propaganda as his material and tackle the problems of militant filmmaking. ${ }^{38}$

The functioning of La vie est à nous as a militant film is subject to a discussion that is at once richer and less problematic than the first section of the article. Here it is the dialectic between the documentary footage (edited with discernible Vertovian influences) and the fiction sequences (which possess similarities to the use of Gestus and typage in Brecht/Dudow's Kuhle

45 Pascal Bonitzer, Jean-Louis Comolli, Serge Daney, Jean Narboni and Jean-Pierre Oudart, "La vie est à nous, film militant," Cahiers du cinéma no. 218 (March 1970), pp. 45-51, here p. 45. Translated as "La vie est à nous: A militant film," trans. Randall Donald, in Browne (ed.), Cahiers du Cinéma vol III, pp. 68-88, here p. 69.

46 Ibid., p. 45 [p. 69].

47 Ibid., p. 46 [pp. 71-72].

48 Ibid., p. 48 [p. 77]. 
Wampe ${ }^{49}$ ) that allows the film to explore "not only what is said and in what way, but to whom it is being told."50 Paradoxically, Cahiers argues, in the France of 1936 it is the fiction sequences that have a greater epistemological credibility, given that "newsreels, documentaries and reportage were the privileged vehicle of the dominant ideology, as television may be today." ${ }^{1}$ The techniques of fiction (not only in the explicitly fictional episodes but also in the staged speeches of the communist leaders that crown the film) are needed in order "to criticize the documentary, produce the political argumentation, and convey the militant message," but to do so the fiction must present itself "as the evolution of the documentary-as the resolution of the contradiction between the documentary's authenticity and its ideological use. ${ }^{\prime 5^{2}}$ The political effectiveness of the third and most dramatically developed fictional episode is thus given a close analysis: in charting the consciousness-raising of an unemployed engineer (René, played by Julien Bertheau) who becomes a party member, the class-determined goal of the episode is clearly to win over middle-class voters to communist positions rather than confirming proletarian/peasant layers in their class convictions (as was the case in the earlier two fiction episodes). In Lacanian terms, René's "sudden, unpremeditated swing" to join the party represents a recognition of the radical lack that defines his petty-bourgeois existence. At a moment of acute personal crisis, "only the Other can intervene-in the form of either death or rescue by the Party," and René's decision to take the latter path leads to "the transformation of the subject (of self-awareness) within the social collective."53

Through its dialectization of fiction and documentary and its awareness of the class nature of its audience, La vie est à nous thus "includes in its own process the question of its addressee," thereby establishing its political/ formal superiority over the vast majority of militant cinema, which tends to ignore this problematic and assume a viewing public consisting of "a motley collection of individuals, by definition incapable of any real action." 54 The

49 Cahiers notes that Kuhle Wampe screened in Paris in October $193^{2}$ and that Karl Koch worked on both films but cannot establish for certain that Renoir had seen Brecht/Dudow's film before making La vie est à nous. A domestic scene in the third episode, showing René with his wife, nonetheless has distinct parallels with the "suicide scene" of Kuhle Wampe. The first episode, meanwhile, with its depiction of a strike in a metallurgy plant, may owe more to Eisenstein's Strike.

50 Ibid., p. 48 [p. 78].

$5^{1}$ Ibid., p. $5^{0}[$ p. 82].

52 Ibid. [pp. 82-83].

53 Ibid., p. $5^{1}$ [p. 86].

54 Ibid., p. $5^{1}$ [p. 87]. 
article concludes with a tantalizing "To be continued, then," but Renoir's films would be of little interest for Cahiers for most of the rest of the 1970s: it was not until 1977-with Comolli's texts "Un corps en trop" and the threepart series "Deux fictions de la haine" (co-authored with historian François Géré) — that Renoir's work would again be discussed by Cahiers. ${ }^{55}$ Comolli and Géré even planned to write a book on La Marseillaise; although this would never materialize, the articles that were published by Cahiers were significant for the development of Comolli's later work in both filmmaking and film theory.

\section{A Historical Precursor: The USSR in the 1920s}

More than Renoir's films, the most important historical precursor for the post-1968 Cahiers was indisputably the Soviet cinema of the 1920s. In the years 1969-1972, this school was the subject of sustained critical and historical work. Translations of Eisenstein's writings were an ever-present feature of Cahiers between February 1969 and January-February 1971, reaching 16 installments in total. On two occasions, special issues relating to Soviet cinema were published: in May-June 1970 ("Russie années 20") and JanuaryFebruary 1971 ("S.M. Eisenstein"). The pertinence of the post-revolutionary Soviet cinema for the critical/theoretical work that Cahiers was carrying out was freely acknowledged: in "Cinéma/idéologie/critique," Comolli and Narboni asserted that "the only possible direction for criticism is, it appears to us, to go back to the theoretical research of the Russian filmmakers of the 1920 (Eisenstein primarily) and to attempt the elaboration and application of a critical theory of the cinema [...] with direct reference to the method of dialectical materialism." ${ }^{6}$ This prolonged preoccupation with the Soviet cinema of the pre-Stalin era had little to do with perceived parallels between the concrete political situation of Russia after 1917 and France after 1968. In the USSR, a mass revolutionary party had overthrown Tsarist rule and established a dictatorship of the proletariat, unleashing a wave of experimentation in the aesthetic sphere, while France was still firmly under bourgeois rule and its radically minded artists had to take an oppositional stance towards the political status quo. Instead, analogies

55 See Jean-Louis Comolli, "Un corps en trop"; Jean-Louis Comolli and François Géré, "Deux fictions de la haine," Cahiers du cinéma no. 286 (March 1978), pp. 30-36, Cahiers du cinéma no. 288 (May 1978), pp. 4-15, and Cahiers du cinéma no. 290-291 (July-August 1978), pp. 91-98. 56 Comolli/Narboni, “Cinéma/idéologie/critique," p. 15 [p. 262]. 
were primarily found with those individual artists and theorists who sought to reconcile the needs of aesthetic production with a political worldview rooted in Marxism.

Broadly speaking, there were two aspects of Cahiers' output on Soviet cinema: historical research (translation, documentation, interviews) and critical exegesis (analysis, interpretation and theoretical discussions). The two-year Eisenstein translation project, publishing French versions of texts such as "The Cinematographic Principle and the Ideogram," "A Dialectic Approach to Film Form" and Non-Indifferent Nature, all of which were drawn from the six-volume Russian edition of his selected writings, ${ }^{57}$ formed the core of the former category, and they were bolstered by translated texts and interviews by filmmakers such as Dziga Vertov, Grigori Kozintsev, Lev Kuleshov and Mikhail Romm, as well as figures writing on the cinema such as Boris Eikhenbaum, Yuri Tynyanov and even Lenin. The major figures involved in this "archeological" work (as Cahiers termed it) were Aumont and Eisenschitz: having learned Russian at the École polytechnique, Aumont oversaw the translation project, while Eisenschitz's trip to Moscow in 1969 enabled him to establish a warm rapport with Soviet archivists, who provided a significant amount of logistical support for the endeavor. Eisenschitz even considers himself to have been, for all intents and purposes, "the editor-in-chief of 'Russie années 20."'58

A notice accompanying the original installment of the Eisenstein translations had already foreshadowed "a series of attempts to interrogate the texts, aiming to place them in their historical (and political/cultural) context and give them contemporary relevance in a cinematic and extra-cinematic theoretical problematic."59 This promise was essentially fulfilled in the meticulously prepared "Russie années 20 " issue. The "stellate and centrifugal structure" of this dossier was all the more necessary, in Cahiers' eyes, to avoid the myth of the "solitary genius" frequently attached to Eisenstein as well as to avoid the theoretical error of "totalization" (that is, comprehending a historical moment on the sole basis of practices linked to the cinema); instead, the journal's editors were at pains to understand the

57 Prior to this project, the only Eisenstein texts available in French were those included in a single, slim volume published in 1958. See Sergei Eisenstein, Réflexions d'un cinéaste, translated into French by Lucia Galinskaia and Jean Cathala (Moscow: Éditions Langues Étrangères, 1958). The two volumes in English translated and edited by Jay Leyda (Film Form and The Film Sense) were, however, widely known in French film circles.

$5^{8}$ Interview with Bernard Eisenschitz, April 1, 2014.

59 “Écrits d'Eisenstein (1)," Cahiers du cinéma no. 209 (February 1969), p. 21. 
cinema as "a signifying practice non-hierarchically articulated with other practices. ${ }^{n 60}$ Furthermore, they were conscious of the historiographical exigencies required in republishing texts dating from up to fifty years earlier. Drawing from the same Althusserian theories of historiography that would later inform Comolli's "Technique et idéologie," the editors rejected a "mechanistic conception of history as linear, as empirically given," in favor of a "stratified history, yet to be constructed, articulated in blocs and series in complex ways." ${ }^{\prime \prime}$

The scholarly rigor and sophisticated historiographical methodology of this ambitious project earned the journal near universal plaudits from both the communist press and French cinephile circles. ${ }^{62}$ Given that the two figures are so often counterposed within film theory, it may be tempting to see the focus on Eisenstein as a repudiation of Bazin's "idealism," but it was rarely presented in such terms on the pages of Cahiers itself. It did, however, provide the basis for a sustained period of theoretical work on the question of montage in the cinema. Aumont recalls that the journal's exposure to Eisenstein's theoretical writings "opened a window for us," ${ }^{63}$ and the filmmaker's diverse influence can be seen in the later work of many of the Cahiers writers, including Aumont himself, Eisenschitz, Bonitzer and Comolli. One figure who was less satisfied with the project was Tel Quel's Marcelin Pleynet, who criticized Cahiers in a Cinéthique article for ambiguities in their presentation of Eisenstein's texts and for skirting over certain ideological infelicities in his writings, in particular his residual Hegelianism. ${ }^{64}$ Partly, this was condemnation by association: Jean-Pierre Faye's journal Change had also published Eisenstein translations, in a less rigorous fashion than Cahiers but with the explicit approbation of the film journal, ${ }^{6}$ and Pleynet interpreted this collaboration as "the submission

6o La Rédaction, “Russies années vingt (1)," Cahiers du cinéma no. 220-221 (May-June 1970), pp. 3-4. Translated as “Editorial: 'Russia in the 2os' (1)," trans. Randall Conrad, in Browne (ed.), Cahiers du cinéma vol. III, pp. 112-114.

61 Ibid., p. 4.

62 The special issue was hailed in La Nouvelle Critique. See Jean-André Fieschi, "Le cinéma soviétique des années 20," La Nouvelle Critique no. 36 (September 1970), p. 61.

63 Interview with Jacques Aumont, March 11, 2014. At the same time, he cautions that while Eisenstein's theories were "very idiosyncratic," the Cahiers writers "did not have the means to see the extent to which it was idiosyncratic, because we knew very little of it."

64 Marcelin Pleynet, "Le front 'gauche' de l'art: Eisenstein et les vieux 'jeunes hégéliens,"” Cinéthique no. 5 (September-October 1969), pp. 23-32, p. 32.

65 Cahiers had warmly welcomed the first issue of Change (appearing in December 1968), which was dedicated to the theme of montage and included extracts of Eisenstein texts. See Jean-Louis Comolli, "Le cahier des autres," Cahiers du cinéma no. 209 (February 1969), p. 4. 
of Cahiers du cinéma to the theories of the Change notebooks [cahiers] ${ }^{n 66}$ - $\mathrm{a}$ capital crime in the internecine world of French literary rivalries. Comolli and Narboni rebutted Pleynet's claims in the second installment of "Cinéma/ idéologie/critique," accusing him of conflating the two journals, which earned an equally strident rejoinder from the Tel Quel editor. ${ }^{67}$ As part of a broader detente between the two journals, however, a reconciliation was effected, and by the time of the special issue on Eisenstein in early 1971, Pleynet agreed to an amicable interview with Cahiers which focused on the relationship between the Bolsheviks and the artistic avant-gardes in post-revolutionary Russia. ${ }^{68}$

The focus on Soviet montage cinema led to a number of articles analyzing the films arising out of this movement, including Oudart on Ivan the Terrible, Baudry on Alexander Nevsky and Bonitzer on Strike, as well as Eisenschitz on the work of Mikhail Romm. ${ }^{69}$ The most detailed exegesis of Soviet cinema, however, pertained to Kozintsev/Trauberg's depiction of the Paris commune in The New Babylon, whose script drew extensively from Marx's post festum overview of its rise and fall in The Civil War in France..$^{70}$ In this two-part text, published in July and October 1971, Cahiers defended the film against the "naïve and dogmatic" criticisms made of it by the Stalin-era writer Nikolai Lebedev and interpreted the film through its "double reference": both to a past revolutionary event (Paris in 1871 ) and to the political situation of Russia in 1929. ${ }^{71}$ But this double ideological determination gives rise, in Cahiers' analysis, to the central contradiction of the film: that between the "inscription of the events in

66 Pleynet, "Le front 'gauche' de l'art," p. 30.

67 See Comolli/Narboni, Cinéma/idéologie/critique (II)"; and Marcelin Pleynet, "Le point aveugle," Cinéthique no. 6 (January-February 1970), pp. 13-20.

68 Marcelin Pleynet, interviewed in Pascal Bonitzer and Jean Narboni, "Sur les avant-gardes révolutionnaires: Entretien avec Marcelin Pleynet," Cahiers du cinéma no. 226-227 (JanuaryFebruary 1971), pp. 6-13.

69 See Jean-Pierre Oudart, "Sur Ivan Le Terrible," Cahiers du cinéma no. 218 (March 1970), pp. 15-23; Pierre Baudry, "Notes sur Alexandre Nevski," Cahiers du cinéma no. 226-227 (JanuaryFebruary 1971), pp. 39-41; Pascal Bonitzer, "Système de La Grève," Cahiers du cinéma no. 226-227 (January-February 1971), pp. 42-45; and Bernard Eisenschitz, "Sur Romm," Cahiers du cinéma no. 219 (April 1970), pp. 19-20.

70 See Karl Marx, The Civil War in France, in The Collected Works of Marx and Engels vol. XXII (London: Lawrence \& Wishart, 2010).

71 Aumont, Bonitzer, Narboni and Oudart were responsible for the first part of the text, while only Narboni and Oudart were credited with the second installment. Jacques Aumont, Pascal Bonitzer, Jean Narboni and Jean-Pierre Oudart, "La métaphore 'commune," Cahiers du cinéma no. 230 (July 1971), pp. 15-21; and Jean Narboni and Jean-Pierre Oudart, "La nouvelle Babylone (La métaphore 'commune,' 2)," Cahiers du cinéma no. 232 (October 1971), pp. 43-51. Both parts were translated as "The New Babylon: The 'Commune' Metaphor," trans. Randall Conrad, in Browne (ed.), Cahiers du Cinéma vol. III, pp. 254-275. 
mythic terms" (as a representation of class struggle in general) and the political utilization of the subject matter in the context of the first five-year-plan, with its breakneck industrialization and collectivization of agriculture, and emphasis on questions of productivity. This contradiction is displaced and transformed by a supplementary third term in The New Babylon, namely the character of Jean, a peasant-soldier who ideologically floats between the bourgeois and proletarian sides of the conflict, thus metonymically standing in for the viewer-a narrative device that enables the film to "interpellate" (in the Althusserian sense) its own spectators. By inscribing the film's signifying economy with overt "designation effects," Kozintsev/Trauberg consciously sought to produce an analogy with the theatrical metaphors sprinkled throughout The Civil War in France. As Cahiers recognizes, Marx's text "systematically inscribes his bourgeois figures in scenic terms, literally re-marking the stage effects of the political discourse of its representatives." ${ }^{2}$ The New Babylon thus acts as a reinscription of Marx's own writing effects. In the second installment of their analysis of the film, however, Narboni/Oudart critique the filmmakers for succumbing to a "mechanistic mode" of transposing Marx's text to the screen, which results in the condensation of "scenic effects" that Marx carefully lodged within The Civil War in France being reduced to mere ornamentation in The New Babylon (the key example being the decadent party sequences). The antagonism between the bourgeoisie (denoted by artifice) and the proletariat (naturalness) that determines the film is concomitantly reduced to a "schematic, dualist flattening out" of class contradictions, and mere causality replaces a dialectical conception of history. ${ }^{73}$ While they commend Kozintsev/Trauberg's attempt to make a political film from a historical materialist standpoint, the Cahiers critics ultimately judge The New Babylon to be a flawed example of Marxist filmmaking.

\section{Against the "fiction de gauche"}

While a historical concern for the political cinema of earlier eras was of major importance for Cahiers in the years 1969-1971, the critics also continued to focus on responding to contemporary cinema. Increasingly, this took the form of vigorously critiquing what the journal would later dub the "fiction de gauche." The term itself only came into use later in the 1970 s. ${ }^{74}$ It nonetheless

72 Aumont et al., "La métaphore 'commune," p. 21 [p. 263].

73 Narboni/Oudart, “La métaphore 'commune,' 2," p. 51 [p. 273].

74 The term was forcefully introduced to Cahiers by Louis Skorecki in “'Cinéma et histoire' à Valence," Cahiers du cinéma no. 268-269 (July-August 1976), pp. 85-88. 
adequately serves to denote the wave of films-including $Z$ and L'Aveu by Costa-Gavras, Le Temps de vivre by Bernard Paul and Camarades by Marin Karmitz - that presented political themes from a broadly left-of-center perspective but did so, in Cahiers' eyes, without "operat[ing] any veritable critique of the ideological system in which they are captured, as they adopt its language and modes of figuration without question." These works, of course, comprised the "Cinéma/idéologie/critique" editorial's category (d), and the negative appraisal of their ideological function led Cahiers to argue for the need to "question the transmission of the political critique desired by these films." 75

Cahiers' offensive against the fiction de gauche began in earnest with Narboni's March 1969 review of $Z$. Costa-Gavras' fictionalization of military rule in Greece initiated a wave of films with political themes and conventional narrative/formal structures. For Narboni, the very fact that $Z$ gained such unanimous approbation was proof of its status as a "singular and massive process of imposture/recuperation," which is impregnated by petty-bourgeois ideology "as much in the operation of the film as in its consumption." Instead of offering a "concrete analysis of a concrete situation," as the Leninist phrase demands, works such as $Z$ merely provide the public with a spectacle centering on a bourgeois individual's crisis of conscience, thereby reconstituting "the mythology at work in any number of American films, according to which a Good Man can always resist the pressures, influence and intrigue of the court-rooms or police stations." Although Costa-Gavras' use of types and caricatures could potentially lead to comparisons with Eisenstein, Narboni strenuously rejects such an analogy, arguing that, in contrast to the Soviet filmmaker's abstraction, Costa-Gavras' film hews closely to "analytic realism" and is hence a work, above all, of mystification..$^{7}$

Narboni's line of argumentation patently rests in the tradition of Rivette's famed excoriation of Kapò and followed Comolli's vituperative response to Un homme et une femme, in which Lelouch's film was condemned for "recuperating, without risk, the expressive ticks of modern cinema, the tattered rags of a modernity whose soul has been cast adrift."77 Narboni's $Z$ review drew an indignant response from some readers, but Comolli

75 Comolli/Narboni, “Cinéma/idéologie/critique," p. 13 [pp. 256-257].

76 Jean Narboni, "Le Pirée pour un homme (Z)," Cahiers du cinéma no. 210 (March 1969), pp. 54-55.

77 Jean-Louis Comolli, "Lelouch, ou la bonne conscience retrouvée (Un homme et une femme), Cahiers du cinéma no. 180 (April 1966), pp. 67-68, here p. 68. 
defended his colleague by insisting on the necessity "of furiously attacking the pseudo-engaged cinema" and accused Costa-Gavras of disingenuously representing the true political nature of fascist regimes..$^{7}$ Over the course of the next year, similar lines of attack would be used against films such as Le Temps de vivre by Bernard Paul, Les Choses de la vie by Claude Sautet and The Liberation of L.B. Jones by William Wyler (the last of which was seen as a "vicarious defense of 'engaged' French commercial cinema"),79 but the critique of such works was most comprehensively developed in two articles that took the lapidary title "Film/politique." The first, by Pascal Bonitzer (in July 1970) focused on the "special question" of militant cinema, but in discussing the " $Z$ effect" present in a number of these films, it addressed many of the same critical issues as Narboni's article. Indeed, in the course of his text, Bonitzer specifically invokes the "Narbonian proposition" that "every shot is present twice" - that is, every film is a metaphor of its own work - which he sees as the point of departure for the political interpretation of cinema. ${ }^{80}$ Resting on Bourdieu/Passeron's notion of the "power of symbolic violence" in contemporary bourgeois ideology, Bonitzer registers the recent, systematic emergence of political discourse in "the films of the dominant cinema," which tends to take the form either of the open apologia of imperialism or, more preponderantly, of the communication of a "soi-disant progressive discourse." ${ }^{81}$ For Bonitzer, the present political balance of forces (namely, the rise of movements of social contestation in the advanced capitalist countries) has led to the "massive, inflationist injection of progressive and revolutionary themes in the film market." Even militant films of the ilk of La Hora de los hornos by Solanas/Getino and Camarades by Marin Karmitz had been affected by this phenomenon. An interview with the latter for Cinéma 7o, in which Karmitz expressed his desire to "touch the maximum number of people" is highlighted by Bonitzer as symptomatic of a "political" cinema that,

78 Jean-Louis Comolli, "Le cahier des lecteurs," Cahiers du cinéma no. 215 (September 1969), pp. 4-9, here p. 6 .

79 See Jean Narboni, "Le temps de vivre," Cahiers du cinéma no. 214 (July-August 1969), p. 63; Pierre Baudry, "Les choses de la vie," Cahiers du cinéma no. 220-221 (May-June 1970), p. 126; and Bernard Eisenschitz and Jean Narboni, "The Liberation of L.B. Jones," Cahiers du cinéma no. 223 (August-September 1970), pp. 62-63.

80 Pascal Bonitzer, "Film/politique," Cahiers du cinéma no. 222 (July 1970), pp. 33-37, here p. 35. The "Narbonian proposition" was uttered at a 1969 round table on "L'Espace," which remained unpublished until 2016. See Chapter 15.

81 Ibid., p. 33. See also Pierre Bourdieu and Jean-Claude Passeron, La Réproduction: Éléments pour une théorie du système d'enseignement (Paris: Minuit, 1970). Translated as Reproduction in Education, Society and Culture, trans. Richard Nice (London: Sage Publications, 1977). 
in wishing to "produce a 'normal,' that is, commercial, fiction," is unable to question the "dominant mode of film viewing" and thus subjects the audience to a "mutilated double lecture" with the "inevitable political effect of separating what the spectator believes to be the 'content' (politics) of the film and what they believe to be the 'form' (aesthetics)." ${ }^{82}$ In contrast, Bonitzer insists that the aesthetic operation of a film is itself political. The critic is more charitable towards La Hora de les hornos, insisting on its status as a film from a Third World nation (Argentina), but he nonetheless censures Solanas/Getino for "oscillat[ing] perpetually between violence and meaning, between 'enthusiasm' without any rational foundation [...] and the channeled analysis of this violence (history, theory)." Bonitzer concludes that the discourse of their film suffers from a "fundamental voluntarism" which results in the "systematic reabsorption of real contradictions into the facticity of conflicts and events." ${ }^{83}$

Three months later, Comolli would pick up the baton from Bonitzer with "Film/politique (2)." At issue was another Costa-Gavras film, L'Aveu (1970), a far soberer affair than $Z$ which focused on the experiences of Czechoslovak communist Artur London (played by Yves Montand) during the Stalinist show trials of the 1950s. Despite this, Comolli assimilates the two films with his claim that they "are not the site of cinematic work, of any signifying practice capable of subverting the aesthetic-cultural norms of the dominant ideology" and opposes Costa-Gavras' work to films such as Othon, Sotto il segno dello Scorpione, Eros + Massacre and Ice. These are "unequivocally political films" because "they (we) are not satisfied with the pure and simple delivery of a 'political message"'; rather, they operate "scriptural work" on their very materiality, which thus becomes a form of political work; by contrast, L'Aveu "contains no productive work at the level of its signifiers and thus [...] never calls into question the conditions production/writing/diffusion/reading of the film." As with $Z$, then, it is the very accessibility of L'Aveu's discourse, the unanimity of its critical reception, that seems to damn it in Comolli's eyes. In line with Althusserian thinking, the critic is certain that the film will "reproduce the modes and through them the themes of the dominant ideology." ${ }^{\prime 4}$ More specifically, Comolli analyzes the "ideology of the visible" which, while absent from London's

\footnotetext{
82 Bonitzer, "Film/politique," pp. 34-35.

83 Ibid., p. 37 .

84 The preceding quotes are from Jean-Louis Comolli, "Film/Politique (2):L'Aveu: 15 propositions," Cahiers du cinéma no. 224 (October 1970), pp. 48-51, here p. 48. Translated as "Film/Politics (2): L'Aveu: 15 Propositions," trans. Nancy Kline Piore, in Browne (ed.), Cahiers du Cinéma vol. III, pp. 163-173, here pp. 163-164.
} 
original memoir, is operative in Costa-Gavras' filming of the torture episodes described therein. These scenes are filmed in such an insistent manner, Comolli argues, that the spectator departs from the "place of the reader" and instead becomes the voyeur of a spectacle who responds to what they see with "repulsion-gratification," thereby impeding the possibility of a political reading. ${ }^{85}$ Comolli is on firm ground in asserting that a change in "signifying system" (from book to film) can have the effect of transforming the political content of the signified; he is less convincing, however, in his attempts to claim that London's rejection of Stalinism morphs into a blanket anti-communism in Costa-Gavras' adaptation, and this line of argumentation seems determined more by Cahiers' pro-PCF sympathies at the time than by a legitimate reading of the film. ${ }^{86}$

Indeed, Narboni would later be highly critical of what he sees as the "dogmatic" and "uselessly violent" attacks made against Costa-Gavras, who "did not deserve them as a person or as a filmmaker." He explains: "I wrote a very harsh article on $Z$, which I regret today. [...] It was not the right way to critique this film. I took it on a terrain which was not where the film itself was situated. [...] To rehash an old terminology, the contradiction with him was not antagonistic." ${ }^{87}$ While Cahiers' hostile stance towards these fictions de gauche is open to criticism, it did enable the journal to develop a more substantial understanding of the "writing operations" of those films that did combine political radicalism with formal experimentation. Moreover, when it came to questions of censorship (which was particularly heavy-handed in de Gaulle's France), the journal unfailingly took a principled position condemning all forms of state repression, a stance that overrode any negative attitudes its writers may have had towards the film in question. Narboni, for instance, had critiqued the "absence of a broader political context" in Battle of Algiers, comparing it unfavorably to Strike and Le Petit Soldat. ${ }^{88}$ Pontecorvo is, by any measure, certainly not a "Cahiers auteur." And yet when the film's 1970 theatrical release was threatened by de facto censorship following threats of violence by the far right, the Cahiers editors leapt to

85 Ibid., p. 50 [p. 168].

86 The question of Stalinist rule in Eastern Europe was a particularly difficult one for the communist movement in the West, particularly after the invasion of Czechoslovakia in 1968. While the PCF formally condemned the invasion, it still maintained fraternal relations with the CPSU. Ironically, the communist press tended to be more favorable towards the "Série Z" films than Cahiers. See Émile Breton and Jean-André Fieschi, “Cinéma: série Z," La Nouvelle Critique no. 49 (January 1972), pp. 74-81.

87 Interview with Jean Narboni, March 18, 2014.

88 Jean Narboni, “La Bataille d'Alger," Cahiers du cinéma no. 183 (October 1966), pp. 25-26. 
its defense, unequivocally asserting that "demanding the release of Battle of Algiers [...] constitutes a prime political gesture." ${ }^{89}$

\section{Cinema and Counter-Culture: Ice by Robert Kramer}

Of the films defended by Cahiers in this period, Robert Kramer's Ice spoke to the journal's editors on the most multifaceted level, addressing not only theoretical questions of politics and film form but also, more intimately, the psychodramas associated with militant activity in small but closely knit groups. Indeed, for Cahiers during a significant part of the late $196 \mathrm{os}$ and 1970s, Kramer's work — despite its utterly marginal position within the broader film industry - stood in for contemporary American cinema as a whole, which suffered from a critical neglect exacerbated by the journal's political opposition to US imperialism. Hollywood cinema, in an interim period between the demise of the classical studio system and the rise of "New Hollywood" auteurs, largely failed to interest Cahiers at this time, and its editors-perhaps due to a residual Bazinian concern for the photographic nature of the medium - were also impervious to the "underground" or experimental cinema coming out of New York, arguing that its techniques of "perceptual jamming" involved "alteration on the most superficial level of language, the immediate creation of a code of the impossible, which is then resolutely rejected, and not transgressive. ${ }^{n 0}$ Famously, the short-lived off-shoot Cahiers du Cinéma in English, edited by Andrew Sarris out of New York, had even been censured in 1967 for publishing a special issue on Warhol without its "parent" publication's permission. ${ }^{91} 1968$ saw Cahiers become more favorable to avant-garde tendencies in the US, with a dossier in its October issue featuring articles on and interviews with "four American filmmakers" -Warhol, Cassavetes, Clarke and Kramer. ${ }^{92}$ Kramer, however, was the only one of the quartet whose œuvre was closely followed by Cahiers in the years to come, and along with Straub and Godard he became one of the central filmmakers - and, indeed, dialogue partners - for the journal in its leftist period.

89 "Éditorial," Cahiers du cinéma no. 222 (July 1970), pp. 4-5, here p. 5.

90 Comolli/Narboni, "Cinéma/idéologie/critique," p. 15 [p. 256].

91 See Jacques Bontemps, "Le cahier des autres," Cahiers du cinéma no. 193 (October 1967), p. 4. Cahiers du Cinéma in English ceased publication soon afterwards.

92 See Cahiers du cinéma no. 205 (October 1968), pp. 20-56. In this dossier, the text "Deux visages de Faces" was of most interest. See Jean-Louis Comolli and Sylvie Pierre, "Deux visages de Faces," Cahiers du cinéma no. 205 (October 1968), pp. 37-38. 
Kramer's work was first discovered by Cahiers at the 1967 Pesaro festival. ${ }^{93}$ In 1968, Narboni described him as "combin[ing] the qualities of the 'classicism' of the great Hollywood cinema and the free-spirited nature of the New York independent filmmakers, at the same time as he testifies to a set of preoccupations [...] which, as Kramer himself declares, owes much to modern European cinema." In an interview with Kramer that focused on his first two films, In the Country and The Edge, a common frame of cinephilic references was firmly established between the filmmaker and the journal, as they discussed the work of Rivette, Straub and Godard. ${ }^{94}$ Later that year, Kramer was interviewed again (by Delahaye) and Eisenschitz reviewed The Edge, noting that "if Kramer's film is the reflection of a part of the New York left that has passed to militant action, it responds to something else, uncertainties, weaknesses, which put the filmmaker [...] out of step [en décalage] with his milieu."95

Cahiers' interest in Kramer fully blossomed with the release of Ice in 1970. Bonitzer discussed the film in "Film/politique" in July that year, holding it up as a positive counter-model to Camarades for offering the possibility of a "free' political reading" that was not "blocked by the ideological glazing of linear writing." ${ }^{\prime 6}$ In December 1970, Cahiers dedicated a significant portion of that month's issue to discussing Ice, with its coverage of the film including a recorded interview with Kramer, a review of the film by Eisenschitz, and an eleven-page round table discussing its political and cinematic ramifications, involving Narboni, Comolli, Bonitzer, Aumont, Pierre and, from La Nouvelle Critique, Fieschi. All these texts centered on the question of the film's political discourse and the means with which such discourse should be read. While Ice is a fiction film depicting a group of far-left urban guerrillas in the midst of a future revolutionary struggle in the US (at a time when the nation is at war with Mexico), Kramer insisted that he sought to "find the means to make fiction films that give the impression of documentary reality" and expressed his hope that "the major lines of reality emerge in the film." 97 Indeed, he had been involved with the Newsreel documentary filmmaking group, which funded Ice but disavowed the

93 See Jean Narboni, “Pesaro An III," Cahiers du cinéma no. 192 (July-August 1967), pp. 24-26.

94 Robert Kramer, interviewed by Jean Narboni, “Entretien avec Robert Kramer," Cahiers du cinéma no. 200-201 (April-May 1968), pp. 114-117, here p. 114.

95 Bernard Eisenschitz, "En marche (The Edge)," Cahiers du cinéma no. 205 (October 1968), pp. 53-54.

96 Bonitzer, “Film/politique," p. 36.

97 Robert Kramer, “Ice de Robert Kramer, 2: Propos de Kramer," Cahiers du cinéma no. 225 (December 1970), p. 16. 
film and refused to distribute it upon completion. Eisenschitz, who also defended Kramer's film in a review for La Nouvelle Critique, argued that Ice was a theorization of the "decentering between the historical real, ideology and the signifying process," a decentering that was "projected into the very structure of the film," and felt that its dialectization of its own political contradictions could provide for "the syntax of a filmic discourse. ${ }^{m 8}$ The round table was more contentious, centering around the question, as Narboni framed it in the discussion's opening statement: "Is a work (a book, a film) reducible to the énoncés contained within it? Can the discourse of a film be boiled down to the discourses held in the film? And, in the negative, what treatment does the artistic process, with its specific laws of functioning and its relative autonomy, subject them to?"99 Fieschi, while declining to simply label Ice an ultra-left film, preferred to read its political theme as a symptom of the political immaturity of the radical left in the US, which unlike France was bereft of a mass working-class party, and criticized its lack of any economic or political analysis of American capitalism. ${ }^{100}$ Warning against "dangerously retrograde" avant-gardist films, Fieschi felt that there was "a greater reflection in Kramer's work on the cinema than on politics" and even conjectured that Cahiers suffered from "a rather suspect dread of 'recuperation,' or, in any case, of a certain misrecognition of the processes of mediation." ${ }^{101}$

The other editors defended Kramer-and themselves-from these charges and emphasized the décalage between the propositions enunciated in the film and the stance taken by the filmmaker towards such perspectives. They argued that, while the actions and views of the characters in Ice can and should be critiqued, this critique is already carried out in the film, primarily through its formal system, its écriture. Comolli, for instance, asserted that "the debate on the political signifieds and the symptomatic character of Ice is not possible if we do not start out by posing the question of the level of

98 Bernard Eisenschitz, "Ice et les USA," Cahiers du cinéma no. 225 (December 1970), pp. 14-15. See also Bernard Eisenschitz, "Ice," La Nouvelle Critique no. 38 (November 1970), pp. 96-97.

99 Jean Narboni, in Jacques Aumont, Pascal Bonitzer, Jean-Louis Comolli, Jean-André Fieschi, Jean Narboni and Sylvie Pierre, "Ice de Robert Kramer 3: Débat," Cahiers du cinéma no. 225 (December 1970), pp. 17-27, here p. 17.

100 In this, Fieschi broadly reflected the response to the film by PCF-aligned critics. L'Humanité's François Maurin pointed to its "voluntarist temptation resulting in political confusion and an absence of political thinking” ("Phantasmes 'révolutionnaires': Ice de Robert Kramer," L'Humanité, October 28, 1970), while Marcel Martin, writing for Les Lettres françaises, called it "demoralizing, demobilizing" but also a "fascinating work" ("Ice de Robert Kramer," Les Lettres françaises, October 28, 1970).

101 Fieschi, in Jacques Aumont et al., “Ice de Robert Kramer 3. Débat," p. 20. 
engagement of the film" and that "the study of the film/politics relationship requires that we not confuse the political discourse(s) in the film with the discourse of the film itself."102 Bonitzer, meanwhile, specified that "the film is formally constructed along two series of contradictory effects-a 'realist' series and a 'fantasy' series" — and outlined the undermining of the film's documentary qualities by a combination of its syntax (the "frustrating discontinuity of the editing") with the "unhinged, floating, oneiric character of certain episodes" and the insertion of quasi-Vertovian sequences that were "absolutely heterogeneous to the narrative." Together, these effects served to "oblige the spectator to weave a reading, to tie the threads together, and to observe the lacunae, blanks and holes in the ideological and scriptural tapestry of Ice."103

Beyond its direct purpose of thrashing out differences of opinion on Kramer's work, the round table on Ice served to highlight certain incompatible contradictions between the Cahiers editors and PCF intellectuals, even those, such as Fieschi, who shared a background with the journal. The end of 1970 and the beginning of 1971 represented the high point of Cahiers' rapprochement with the party but also the moment at which the untenable nature of continued collaboration became more and more apparent to the editors. ${ }^{104}$ In the twelve months after Ice was discussed by Cahiers, the journal's rupture with the PCF would take on a violent, acrimonious form, and it would adopt a Maoist political line broadly shared by Tel Quel, Cinéthique and a number of small but energetic political organizations. Cahiers' interest in Kramer, however, was of greater longevity than its attraction to the PCF or Maoism. The filmmaker spoke, perhaps more than any other, to the critics' own anxieties about the promises and pitfalls of political engagement: Milestones was subject to another round table in 1976 , and films such as Route One USA and Berlin 10/9o also had a profound impact on former Cahiers writers such as Comolli. ${ }^{105}$ Eisenschitz, meanwhile, provided the greatest tribute to Kramer: shortly before the latter's death, he conducted a series of long interviews with the director about his œuvre,

102 Comolli, in ibid., p. 18.

103 Bonitzer, in ibid., pp. 19-20.

104 The alliance was such that Cahiers was even accused of "censoring" remarks made by Kramer in his interview that were hostile to the orthodox communist movement, a charge they vigorously denied. See “À propos d'une' lettre," Cahiers du cinéma no. 230 (July 1971), pp. 6o-62. For the original accusation, see La Rédaction, "Envoi," Positif no. 124 (February 1971), pp. 79-80, here p. 80.

105 See Jean-Louis Comolli, Voir et pouvoir: L'innocence perdue: cinéma, télévision, fiction, documentaire (Lagrasse: Verdier, 2004), pp. 607-615. 
which, published in book form in 2001, constitute a valuable testimony to a filmmaker who, while always operating in the margins of the film industry, was steadfastly defended by Cahiers as a figure of central importance to contemporary cinema. ${ }^{106}$

\section{Works Cited}

Louis Althusser, Ce qui ne peut pas durer dans le Parti communiste (Paris: Maspero, 1978).

Jacques Aumont, Pascal Bonitzer, Jean-Louis Comolli, Jean-André Fieschi, Jean Narboni and Sylvie Pierre, "Ice de Robert Kramer 3. Débat," Cahiers du cinéma no. 225 (December 1970), pp. 17-27.

—, Pascal Bonitzer, Jean Narboni and Jean-Pierre Oudart, "La métaphore 'commune," Cahiers du cinéma no. 230 (July 1971), pp. 15-21. Translated as "The New Babylon: The 'Commune' Metaphor," trans. Randall Conrad, in Nick Browne (ed.), Cahiers du Cinéma vol III: 1969-1972 The Politics of Representation (London: BFI, 1990), pp. 254-263. Hereafter CDC III.

Pierre Baudry, "Trois films de Sollima," Cahiers du cinéma no. 218 (March 1970), pp. $59-61$.

—, "Les choses de la vie," Cahiers du cinéma no. 220-221 (May-June 1970), p. 126.

—, "Réponses aux lecteurs," Cahiers du cinéma no. 222 (July 1970), pp. 53-54.

—, "Notes sur Alexandre Nevski," Cahiers du cinéma no. 226-227 (JanuaryFebruary 1971), pp. 39-41.

André Bazin, "Le cinéma soviétique et le mythe de Staline," Esprit no. 170 (August 1950), pp. 210-235. Translated as "The Stalin Myth in Soviet Cinema," trans. Georgia Gurrieri, Film Criticism vol. 3 no. 1 (Fall 1978), pp. 17-26.

—, "Renoir français," Cahiers du cinéma no. 8 (January 1952), pp. 9-29.

Pascal Bonitzer, "Largent-fantôme (Le Mandat)," Cahiers du cinéma no. 209 (February 1969), pp. $57-58$.

—, "Le carré (Teorema)," Cahiers du cinéma no. 211 (April 1969), p. 53.

—, "Maud et les phagocytes (Ma Nuit chez Maud)," Cahiers du cinéma no. 214 (July-August 1969), p. 59.

—, "L'homme au ballon (Break-up)," Cahiers du cinéma no. 215 (September 1969), pp. 6o-62.

—, "Les vases communicants (The Party)," Cahiers du cinéma no. 216 (October 1969), pp. $5^{2-53}$.

106 See Bernard Eisenschitz (ed.), Points de départ: Entretien avec Robert Kramer (Aix-enProvence: Institut de l'Image, 2001). 
—, "Film/politique," Cahiers du cinéma no. 222 (July 1970), pp. 33-37.

—, "Système de La Grève," Cahiers du cinéma no. 226-227 (January-February 1971), pp. 42-45.

—, "Mes dates clés," Libération, December 2, 2003.

—_, "Comment j'ai rencontré Jacques Bontemps," in Sarah Bertrand (ed.), Des nouvelles du cinéma: Une première fois vol. II (Paris: Seuil, 2004), pp. 107-115.

- Jean-Louis Comolli, Serge Daney, Jean Narboni and Jean-Pierre Oudart, " $L a$ vie est à nous, film militant," Cahiers du cinéma no. 218 (March 1970), pp. 45-51. Translated as "La vie est à nous: A militant film," trans. Randall Donald, in CDC III, pp. 68-88.

Jacques Bontemps, “Le Cahier des autres," Cahiers du cinéma no. 194 (October 1967), p. 4.

Pierre Bourdieu and Jean-Claude Passeron, La Réproduction: Éléments pour une théorie du système d'enseignement (Paris: Minuit, 1970). Translated as Reproduction in Education, Society and Culture, trans. Richard Nice (London: Sage Publications, 1977).

Émile Breton and Jean-André Fieschi, “Cinéma: série Z," La Nouvelle Critique no. 49 (January 1972), pp. 74-81.

[Cahiers du cinéma], "Éditorial," Cahiers du cinéma no. 222 (July 1970), pp. 4-5.

Michel Capdenac, "La vie est à nous de Jean Renoir," Les Lettres françaises, November 12, 1969 .

Jean-Louis Comolli, "Lelouch, ou la bonne conscience retrouvée (Un homme et une femme), Cahiers du cinéma no. 180 (April 1966), pp. 67-68.

—, "Des migrations exemplaires," Cahiers du cinéma no. 196 (December 1967), pp. 25-26.

—, "Le cahier des autres," Cahiers du cinéma no. 209 (February 1969), p. 4.

—, "Le cahier des lecteurs," Cahiers du cinéma no. 215 (September 1969), pp. 4-6.

—, "Film/Politique (2): L'Aveu: 15 propositions," Cahiers du cinéma no. 224 (October 1970), pp. 48-51. Translated as "Film/Politics (2): L'Aveu: 15 Propositions," trans. Nancy Kline Piore, in CDC III, pp. 163-173.

—, "Un corps en trop," Cahiers du cinéma, no. 278, July 1977, pp. 5-16. Translated as "Historical Fiction: A Body Too Much," trans. Ben Brewster, Screen vol. 19 no. 2 (Summer 1978), pp. 41-53.

—, Voir et pouvoir: L'innocence perdue: cinéma, télévision, fiction, documentaire (Lagrasse: Verdier, 2004).

—, "Salut à l'homme de Varan," Cahiers du cinéma no. 600 (April 2005), p. 73.

—, interviewed by Daniel Fairfax, "Yes, we were utopians; in a way, I still am...': An Interview with Jean-Louis Comolli (Part 1)," Senses of Cinema no. 62 (April 2012), sensesofcinema.com/2012/feature-articles/yes-we-were-utopians-in-a-way-istill-am-an-interview-with-jean-louis-comolli-part-1/ (accessed January 1, 2021). 
— and Jean Narboni, "Cinéma/idéologie/critique," Cahiers du cinéma no. 216 (October 1969), pp. 11-15. Translated as "Cinema/Ideology/Criticism," trans. Daniel Fairfax, in Jean-Louis Comolli, Cinema against Spectacle: Technique and Ideology Revisited (Amsterdam: Amsterdam University Press, 2015), pp. 251-259. — and Jean Narboni, "Cinéma/idéologie/critique (II): D’une critique à son point critique," Cahiers du cinéma no. 217 (November 1969), pp. 7-13. Translated as "Cinema/Ideology/Criticism (II): On Criticism at Its Critical Point," trans. Daniel Fairfax, in Jean-Louis Comolli, Cinema against Spectacle: Technique and Ideology Revisited (Amsterdam: Amsterdam University Press, 2015), pp. 261-280.

— and Sylvie Pierre, "Deux visages de Faces," Cahiers du cinéma no. 205 (October 1968), pp. 37-38.

- Jean-Paul Fargier, Gérard Leblanc, Jean Narboni, Marcelin Pleynet and Philippe Sollers, "Cinéma, littérature, politique," Cahiers du cinéma no. 226-227 (JanuaryFebruary 1971), p. 115. Translated as "Cinema, Literature, Politics," trans. Alan Williams, in CDC III, pp. 287-29o.

— and François Géré, "Deux fictions de la haine," Cahiers du cinéma, no. 286 (March 1978), pp. 30-36, Cahiers du cinéma, no. 288 (May 1978), pp. 4-15, and Cahiers du cinéma, no. 290-291 (July-August 1978), pp. 91-98.

Bernard Eisenschitz, "En marche (The Edge)," Cahiers du cinéma no. 205 (October 1968), pp. 53-54.

—, "Sur Romm," Cahiers du cinéma no. 219 (April 1970), pp. 19-20.

—, "Ice," La Nouvelle Critique no. 38 (November 1970), pp. 96-97.

—, "Ice et les USA," Cahiers du cinéma no. 225 (December 1970), pp. 14-15.

- (ed.), Points de départ: Entretien avec Robert Kramer (Aix-en-Provence: Institut de l'Image, 2001).

— and Jean Narboni, “The Liberation of L.B. Jones," Cahiers du cinéma, no. 223 (August-September 1970), pp. 62-63.

Sergei Eisenstein, Réflexions d'un cinéaste, translated into French by Lucia Galinskaia and Jean Cathala (Moscow: Éditions Langues Étrangères, 1958).

Jean-André Fieschi, “Le cinéma soviétique des années 20," La Nouvelle Critique no. 36 (September 1970), p. 61.

Emmanuèle Frois, "Pascal Bonitzer, éléments d'un portrait," Le Figaro, December 2, 2003.

Pascal Kané, "L’organisation du désordre (La Route du Corinthe, Les Biches, Une femme infidèle)," Cahiers du cinéma no. 211 (April 1969), pp. 53-55.

_., "La matière filmique (Goto, île d'amour)," Cahiers du cinéma no. 212 (May 1969), pp. 57-6o.

—, "Le travail et l'usure (Pierre et Paul)," Cahiers du cinéma no. 214 (JulyAugust 1969), p. 60.

—, Roman Polanski (Paris: Éditions du Cerf, 1970). 
—, “Topaz," Cahiers du cinéma no. 220-221 (May-June 1970), pp. 127-128.

Robert Kramer, interviewed by Jean Narboni, "Entretien avec Robert Kramer," Cahiers du cinéma no. 200-201 (April-May 1968), pp. 114-117.

—, "Ice de Robert Kramer, 2: Propos de Kramer," Cahiers du cinéma no. 225 (December 1970), p. 16.

André S. Labarthe and Jacques Rivette, "Jean Renoir le patron: propos de Renoir," Cahiers du cinéma no. 186 (January 1967), pp. 23-26.

Francis Marmande, "Pierre Baudry, cinéaste philosophe," Le Monde, February 25, 2005 .

Marcel Martin, “Ice de Robert Kramer," Les Lettres françaises, October 28, 1970.

François Maurin, "Phantasmes 'révolutionnaires': Ice de Robert Kramer," L'Humanité, October 28, 1970.

Karl Marx, The Civil War in France, in The Collected Works of Marx and Engels vol. XXII (London: Lawrence \& Wishart, 2010).

Jean Narboni, “La Bataille d'Alger," Cahiers du cinéma no. 183 (October 1966), pp. 25-26.

—, "Pesaro An III," Cahiers du cinéma no. 192 (July-August 1967), pp. 24-26.

—, "Le Pirée pour un homme (Z)," Cahiers du cinéma no. 210 (March 1969), pp. 54-55.

—, "Le temps de vivre," Cahiers du cinéma, no. 214 (July-August 1969), p. 63.

- and Jean-Pierre Oudart, "La nouvelle Babylone (La métaphore 'commune,' 2)," Cahiers du cinéma no. 232 (October 1971), pp. 43-51. Translated as "The New Babylon: The 'Commune' Metaphor," trans. Randall Conrad, in CDC III, pp. 263-275. Jean-Pierre Oudart, "L'aberrant dévié (Les Contrebandières)," Cahiers du cinéma no. 208 (January 1969), pp. 59-6o.

—, "Au hasard Pialat (L'Enfance nue)," Cahiers du cinéma no. 210 (March 1969), pp. $55^{-56}$.

—, "Humain, trop humain (Freaks)," Cahiers du cinéma no. 210 (March 1969), pp. 57-58.

—, "Sur Ivan Le Terrible," Cahiers du cinéma no. 218 (March 1970), pp. 15-23.

Dominique Païni, “Une lettre," Cahiers du cinéma no. 228 (March-April 1971), p. 64.

Marcelin Pleynet, "Le front 'gauche' de l'art: Eisenstein et les vieux 'jeunes hégéliens," Cinéthique no. 5 (September-October 1969), pp. 23-32.

_ _, "Le point aveugle," Cinéthique no. 6 (January-February 1970), pp. 13-20.

—, interviewed in Pascal Bonitzer and Jean Narboni, "Sur les avant-gardes révolutionnaires: Entretien avec Marcelin Pleynet," Cahiers du cinéma no. 226-227 (January-February 1971), pp. 6-13.

— and Jean Thibaudeau, interviewed by Gérard Leblanc, "Économique, idéologique, formel..." Cinéthique no. 3 (April 1969), pp. 7-14. Translated as, "Economic ideological - formal," trans. Elias Noujaim, in Harvey, May '68 and Film Culture (London: BFI, 1980), pp. 149-164. 
Claude Prévost, "Dans le numéro de novembre des Cahiers du cinéma," La Nouvelle Critique no. 30 (January 1970), p. 65.

La Rédaction, "Russies années vingt (1)," Cahiers du cinéma no. 220-221 (MayJune 1970), pp. 3-4. Translated as “Editorial: 'Russia in the 20s' (1)," trans. Randall Conrad, in CDC III, pp. 112-114.

—, "À propos d"une' lettre," Cahiers du cinéma no. 230 (July 1971), pp. 6o-62.

—, "Politique et lutte idéologique de classes, Intervention 1," Cahiers du cinéma no. 234-235 (December 1971-January-February 1972), pp. 5-12. Translated as "Politics and Ideological Class Struggle," trans. Alan Williams, in CDC III, pp. 334-341.

—, "Envoi," Positif no. 124 (February 1971), pp. 79-80.

Jean Renoir, interviewed by Jacques Rivette and François Truffaut, "Entretien avec Jean Renoir," Cahiers du cinéma no. 34 (April 1954), pp. 3-22 and Cahiers du cinéma no. 35 (May 1954), pp. 14-30.

—, interviewed by Michel Delahaye and Jean-André Fieschi, "Mes prochains films: Entretien avec Jean Renoir," Cahiers du cinéma no. 180 (July 1966), pp. 37-46.

—, interviewed by Michel Delahaye and Jean Narboni, "La Marche de l'idée: Entretien avec Jean Renoir," Cahiers du cinéma no. 196 (December 1967), pp. 13-22, 66-68.

—, "C'est la révolution! (Crème de beauté)," Cahiers du cinéma no. 200-201 (AprilMay 1968), pp. 32-42.

Louis Skorecki, “'Cinéma et histoire’ à Valence," Cahiers du cinéma no. 268-269 (July-August 1976), pp. 85-88.

Danielle Tartakowsky, Une histoire du P.C.F. (Paris: Presses universitaires de France, 1982).

Jeannine Verdès-Leroux, Le Reveil des somnambules: Le Parti communiste, les intellectuels et la culture, 1956-1985 (Paris: Fayard, 1987). 


\title{
9. Cahiers du cinéma's Turn to Maoism: 1971-1973
}

\begin{abstract}
Over the course of 1971, the limitations of Cahiers du cinéma's alignment with the PCF were keenly felt, and with the encouragement of Cahiers alumnus Jean-Luc Godard and the literary journal Tel Quel, the editors peremptorily switched allegiances to the Maoist movement. Although a curious phenomenon in retrospect, French Maoism was a thriving political force in the years following 1968 , with thousands of students and intellectuals taking inspiration from events in China. The change in line had a convulsive impact on Cahiers: while initially the hyper-politicization it produced coexisted with a continued cultivation of film theory and criticism, by late 1972 the journal's energies were focused on its project for a "Front culturel révolutionnaire." In the end, the lukewarm results of this venture in 1973, combined with the general political climate in France at the time, plunged Cahiers into a near-fatal crisis.
\end{abstract}

Keywords: Cahiers du cinéma, Maoism, Tel Quel, Chinese cultural revolution, Front culturel révolutionnaire

\section{The Alliance with Tel Quel: Breaking with the PCF}

Difficulties in reconciling Cahiers' own theoretical, aesthetic and political perspectives with those of the PCF had already punctuated the year 1970. In August, for instance, Cahiers' presence at the Avignon festival (where films such as La Vie est à nous, Othon, Sotto il segno del scorpione, Moonfleet and Once Upon a Honeymoon were screened and discussed) was reviewed by Nouvelle Critique writer Albert Cervoni for L'Humanité: while broadly positive towards "this team whose research reclaims an ideology that is our own," Cervoni critiqued Cahiers for their "somewhat mystical, mechanistic" variant of Marxism as well as their predilection for an "opacity determined

Fairfax, D., The Red Years of Cahiers du Cinéma (1968-1973). Volume I: Ideology and Politics. Amsterdam: Amsterdam University Press, 2021 DOI 10.5117/9789463728508_CHo9 
by a will to theorize which could have proceeded by other verbal means." The article was amicably but firmly rebuffed by the Cahiers editors, who argued that their work on the role of language in Straub, Godard and the Tavianis constituted a "holistic strategy" indebted to the materialist theories of Tel Quel and Jacques Lacan, which viewed language in the cinema "not as the vehicle of a pre-existing meaning, but as signification produced in the movement of language." At the same time, Jean-Patrick Lebel had begun his "Cinéma et idéologie" series opposing the "ideologist" current of Cahiers and Cinéthique, and while Lebel himself took care to present his articles as fraternal critiques, this did not prevent him from distorting and conflating arguments made on the pages of the two journals. La Nouvelle Critique's readers, meanwhile, did not evince the same care for tactful diplomacy: a reader identified as "A.L." from Ivry, for instance, accused Cahiers of being an "opportunist journal" and "luminously eclectic" in its theoretical interests. ${ }^{3}$

Cahiers protested against these claims in a letter published in $L a$ Nouvelle Critique, but a theoretical response to Lebel met with delays, the political coloring of which was evident by the change in language used to describe his ideas. When Lebel's articles were first rebutted, beginning with the first installment of Comolli's "Technique et idéologie" in May 1971, the refutation was confrontational but still broadly respectful. The same issue, however, saw the Cahiers editors make a cryptic reference to "eclectic social-democrats" in an interview given in Politique-Hebdo, which was later acknowledged to be a coded reference to the PCF. ${ }^{4}$ Indeed the January-February issue had already seen a guarded riposte to Lebel and other PCF critics appear in the joint statement on Positif's ostensible anti-Marxism issued by Cahiers, Tel Quel and Cinéthique. ${ }^{5}$ In September, a notice in Cahiers expressed outright exasperation at the "allusive quotation marks" in a Humanité-Dimanche article by Samuel Lachize praising Lebel and opposing those who "attack his book, from the 'left' (see Cahiers du cinéma) and from the right." By November, Bonitzer upped

\footnotetext{
1 Albert Cervoni, “Avignon, le cinéma et les sandwiches," L'Humanité, August 26, 1970, p. 6.

2 La Rédaction, "Les Cahiers à Avignon," Cahiers du cinéma no. 224 (October 1970), pp. 57-58.

3 A.L., "Un amalgame tendencieux," La Nouvelle Critique no. 37 (October 1970), p. 59.

4 La Rédaction, “Réponses à Politique-Hebdo," Cahiers du cinéma no. 229 (May 1971), pp. 61-64, here p. 61.

5 See "Cinéma, littérature, politique."

6 "Lu dans la presse," Cahiers du cinéma no. 231 (September 1971), p. 53. At this time, too, the internal "Journal de la rédaction" was far less guarded in its reproaches, with the editors writing "We are sick of being the hard tendency of a soft party" and daubing the exercise book with Chinese ideograms. See De Baecque, Histoire d'une revue vol. II, p. 245, 248.
} 
the ante, labeling Lebel's standpoint "anti-Marxist, idealist and reactionary," summing up his position with the watchword used by the Maoist movement to describe the pro-Soviet communist parties: "revisionist." In light of the vitriolic disputes between the PCF and the Maoist groups at the time, which frequently broke out into acts of physical violence, ${ }^{8}$ the ramifications of Bonitzer's vocabulary (repeated in a statement at the Porretta-Terme festival appearing in the same issue) were unmistakable. From this point on, no functional relationship with the PCF or anyone aligned with it would be possible. Later, Bonitzer framed the rupture in the following terms: "At a certain point it became clear that the PCF was using us for reasons of pure political opportunism, that Eisenstein, Artaud, Bataille, etc., did not interest them in the slightest. An old story, that of the failed relations between the artistico-theoretical avant-gardes and the communist party."9

Cahiers' turn towards the Maoist variant of "Marxism-Leninism" was determined, if not explicitly programmed, by the political evolution of $\mathrm{Tel}$ Quel. In addition to the charisma of editor Philippe Sollers, the quarterly was undoubtedly the center of gravity for avant-garde literary theory in France in the 196os. Kristeva, Barthes, Derrida, Todorov and Schefer all regularly published with the journal. After a period of collaboration with the PCF, by $1970 \mathrm{Tel}$ Quel was chafing against the theoretical inertia of the party's intellectuals: its vocal calls for a "revolution of language" and its defense of the avant-gardism of Lautréamont, Mallarmé and Joyce were undoubtedly a mismatch for a party that still retained heavy traces of its Stalinist heritage. Combined with this tension was Sollers' personal sinophilia and fascination for Mao Zedong: in the Winter 1970 issue, he had already translated and published ten of Mao's poems, while the Spring 1971 issue featured a lengthy treatise by Sollers on the Chinese leader's key philosophical text On Contradiction, in which the Frenchman claimed that Mao's thinking represented a "considerable and completely original 'leap forward' in dialectical materialist theory. ${ }^{10}$ Such polemical disputes, the caustic tone of which was often pushed to parodic extremes (a quality

7 Pascal Bonitzer, "Fétichisme de la technique: la notion de plan," Cahiers du cinéma no. 233 (November 1971), pp. 4-10, here p. 7 .

8 A note in Cahiers, for instance, reported on a meeting organized by Tel Quel in the SaintMichel bookshop on December 10, 1971, which was subject to "violent aggression" organized by the Union des Étudiants Communistes. See Jacques Henric, "Une déclaration de J. Henric," Cahiers du cinéma no. 236-237 (March-April 1972), p. 98.

9 Bonitzer, "Nos années non-légendaires," p. 146.

10 Philippe Sollers, "De la contradiction," Tel Quel no. 45 (Spring 1971), pp. 3-23, here p. 3. 
accentuated by the insouciant rapidity with which Tel Quel shifted its targets), were a perennial feature of the literary journal, and in June 1971, the contradictions between Tel Quel and the party burst out into the open: under Sollers' initiative, the "pro-Chinese" faction of the journal's editorial board launched the "Mouvement de juin 1971" in support of the Italian communist journalist Maria-Antonietta Macciocchi's encomium to the cultural revolution, De la Chine. ${ }^{11}$ When the PCF prevented Macciocchi's book from being sold at its annual Fête de l'Humanité in September, Sollers and his fellow editors launched a high-profile media campaign against the act of "anti-democratic repression."12 The resulting position paper of the "Mouvement de Juin 71" - complete with the sloganistic peroration "Down with dogmatism, empiricism, opportunism and revisionism! Long live the true avant-garde! Long live the thought of Mao Zedong!"13 — set the tone for much of Tel Quel's writing from mid-1971 until Mao's death in 1976. Despite the fact that the journal's flirtation with Maoism lasted far longer than that of most other French intellectual currents, its political interventions appeared at least partly to be tongue-in-cheek — as evinced by "dazibaos" daubed on the walls of the journal's office declaring, "Two conceptions of the world, two lines, two paths: Aragon or Mao Zedong? Comrades, you must choose!"'4 Indeed, the jargon-heavy pronunciamentos appearing in Tel Quel at this time had a strange co-existence with avant-garde literary experiments such as Sollers' multi-installment stream-of-consciousness text Paradis, and it is tempting - and not entirey unreasonable — to read them today as an elaborate literary satire of the textual production of the far left.

For Cahiers, continuing to work with both Tel Quel and La Nouvelle Critique had become impossible with the Macciocchi affair, and the journal promptly sided with Sollers' quarterly, although de Baecque notes an initial reluctance to do so on the part of Aumont and Comolli. ${ }^{15}$ Suspicions about Sollers'

11 Maria-Antonietta Macciocchi, De la Chine, translated into French by Louis Bonalumi (Paris: Seuil, 1971). Tel Quel's Maoist turn resulted in the expulsion of PCF member Jean Thibaudeau from Tel Quel's editorial board. Pleynet had also been a firm advocate of a pro-PCF position but fell in behind the new Maoist position and remained with Tel Quel.

12 See “Déclaration sur l'hégémonie idéologique bourgeoisie/révisionnisme," Tel Quel no. 47 (Autumn 1971), pp. 133-141.

13 "Mouvement de juin 1971," “Le dogmatisme à la rescousse du révisionnisme," Tel Quel no. 48-49 (Spring 1972), pp. 175-19o, here p. 190.

14 See Philippe Forest, Histoire de Tel Quel (Paris: Seuil, 1995), p. 385.

15 De Baecque also recounts a lunch attended by Sollers, Comolli, Narboni and Bonitzer on September 29, 1971, just before the Porretta-Terme festival, where the Tel Quel writer incited the Cahiers editors to break with the PCF. See de Baecque, Histoire d'une revue vol. II, p. 244-247. 
motives were nonetheless later aired by Bonitzer, ${ }^{16}$ while Aumont is now unafraid to label the Tel Quel editor an "ambitious Rastignac" and a "total opportunist." ${ }^{17}$ Narboni, by contrast, rejects such characterizations and states "I have always admired in him that he was a good writer and above all an excellent critic. And I also found him likable," while cautioning: "I was never in the Tel Quel orbit, I was never a disciple of the journal. But the relations I had with the journal were always cordial relations. [...] There were influences from Tel Quel on our comportment. But there was never any subordination to them." ${ }^{18}$ In any case, Cahiers' adoption of Maoism was taken far more seriously than that of Tel Quel, and it eventually broke with the literary journal on this basis. ${ }^{19}$ Whereas the Maoist adventure of Cahiers left deep, traumatic scars on its participants, Tel Quel's renunciation of its pro-PRC position was swift and peremptory, its Maoism easily forgotten. Shortly after Mao's death, a brief notice in the Winter 1976 issue proclaimed: "if Tel Quel indeed tried, for a while, to inform public opinion on China, above all to oppose the systematic deformations of the PCF, such is not the case today." ${ }^{20}$

On a political level, Cahiers' ties with Tel Quel were most apparent in the dispute with Positif in early 1971 and, later that year, the two communiqués connected with Cahiers' presence at the Porretta-Terme festival (where, on October 2-10, Cahiers screened Othon, Luttes en Italie, The Ceremony, La vie est à nous, New Babylon and A Sixth of the World). The first, which served as the program's introductory text, clarified the journal's understanding of the cinema/politics duality in the light of Althusser's theory of the "Ideological State Apparatus." Following the philosopher, the Cahiers editors understand the cinema as a "link" in the ISAs, which represent both "a stake and a locus of the class struggle" and are capable of absorbing progressive themes without

16 In 1981, Bonitzer remarked that, "It appears today that all the positions it took [...] were parodic. With hindsight, indeed, it is striking." He also claimed that Cinéthique was essentially a "cover" for Tel Quel and compared Sollers' journal to a "super-massive black hole" in its ability to "rigidify and sterilize everything that did not gravitate in its field." Pascal Bonitzer, "Tel Quel," in "Dictionnaire sans foi ni loi," Cahiers du cinéma no. 325 (June 1981), p. 120.

17 Interview with Jacques Aumont, March 11, 2014.

18 Interview with Jean Narboni, March 18, 2014.

19 See "Critique des positions du 'Mouvement de Juin 71," Cahiers du cinéma no. 245-246 (AprilMay-June 1973), pp. 68-87. Earlier, the "Journal de la rédaction" had documented reservations about being aligned too closely with Tel Quel, with the editors writing, "We don't care if we are considered to be the puppets of Tel Quel-it's up to us to prove that we are something different, and better." Cited in De Baecque, Histoire d'une revue, vol. II, p. 245.

20 “À propos du 'Maoïsme,"' Tel Quel no. 68 (Winter 1976), p. 104. In a further sign of its ideological volte-face, the journal's following issue was titled “Éloge de l'Amérique." 
putting the dominance of bourgeois ideology into question. ${ }^{21}$ And yet formal disruption alone is an insufficient criterion for the "work of ideological subversion and deconstruction required by the historical moment in which we live."22 Rather, in a line of thought that responds to some of the arguments left open in "Cinéma/idéologie/critique," the Cahiers editors seek to dialectize the form/content distinction by asserting that the ideological work of the film can find itself displaced onto its apparently formal machinery. Hence, "what finds itself determined as 'formal," they argue, "is not the external envelope, or the 'expression,' of which the ideological (or political) 'content' would be what is 'expressed,' the intentional kernel. What is presented as 'formal' is thoroughly ideological, and thus has secondary political effects."23 Cahiers cautions, however, that these political effects may not take hold immediately. The ideological struggle, as opposed to the political struggle, is "long-term work" requiring an approach to filmmaking — such as that to be found in the work of Godard, Straub and Oshima - that "interrogates within its own production, in its very texture, the ideological role of the chain of images/sounds, playing with them dialectically."24

The second text, signed by Comolli, Narboni and Bonitzer and read out at Porretta-Terme on October 9, 1971, conclusively signaled the journal's alignment with the French Maoist movement. Here, the Cahiers editors sought to defend their participation in an "event placed under the sign of the dubious, un-worked out notion of 'political cinema," thereby differentiating themselves from the "eclecticism" otherwise prevailing in these discussions. ${ }^{25}$ Positif, Cinéma 71 and Lebel were mercilessly attacked, while Cinéthique was critiqued for its dogmatism but, in a gesture of reconciliation, deemed to be capable of potential collaboration due to its own adherence to MarxismLeninism. The political transformation of Cahiers was made clear in the text's final paragraph, which spoke in faultless Maoist jargon of "the Marxist and Leninist principle, taken up and developed in practice and theory by the Chinese Communist Party (which has been applied to great effect in the Great Cultural Proletarian Revolution) of placing politics in the command post." 6

21 C.d.C., "Cinéma, idéologie, politique (pour Porretta-Terme)," Cahiers du cinéma no. 232 (October 1971), pp. 54-55, here p. 54. Translated as "Cinema, Ideology, Politics (for Porretta Terme)," trans. Alan Williams, in Browne (ed.), Cahiers du Cinéma vol. III, pp. 287-29o, here p. 288.

22 Ibid.

23 Ibid., p. 55 [p. 289].

24 Ibid. [p. 289-290].

25 Pascal Bonitzer, Jean-Louis Comolli and Jean Narboni, "Cinéma/idéologie/politique: Porretta Terme, 2," Cahiers du cinéma no. 233 (November 1971), pp. 46-47, here p. 46.

26 Ibid., p. 47 . 


\section{Maoism in Theory}

The public statement read out at Porretta-Terme thus openly avowed Cahiers' new politics, which governed the journal's activity up to the summer of 1973, a period of nearly two years. Beyond the aforementioned influence of $\mathrm{Tel}$ Quel within the sphere of French literary culture, the attraction of Maoism was determined by two political phenomena. The first, of course, was the Cultural Revolution in China, which took place between 1966 and 1976. Widely viewed today as an unmitigated catastrophe, the GRCPC (as it came to be known on the pages of Cahiers) was in fact a complex phenomenon whose legacy remains open to dispute. At the behest of Mao, students and workers rose up to overthrow what the Chinese leader claimed was an ossified bureaucratic caste intent on the restoration of capitalism. The early stages of the cultural revolution, in particular, saw an outpouring of emancipatory energy and experimentation in social organization on a mass scale (such as the establishment of a workers' commune in Shanghai). But the cultural revolution also gave rise to widespread social disorder and political repression. Educational and health standards took a backwards step during this period, and, while a concrete number is difficult to establish, the toll of those imprisoned, tortured and killed during the time of the cultural revolution probably numbers in the hundreds of thousands. ${ }^{27}$

In valorizing the notion of revolutionary social upheaval, Maoism nonetheless represented an attractive alternative to the sclerosis of Soviet communism for the international left. In the case of France, the Maoist movement at its height collected several thousand activists - mostly young, highly educated and from bourgeois backgrounds - into a large number of often ephemeral groupuscules, which coalesced around two main tendencies. The first, represented chiefly by the Parti communiste français marxiste-léniniste (PCFM-L), was a split from the PCF and developed a more dogmatic, Stalinized variant of Maoism. The latter tendency, by contrast, grew out of the remnants of the Union des jeunesses communistes marxistesléninistes, a circle of Parisian students grouped around Althusser which had dissolved in 1968, and gave rise to more youthful organizations such as the

27 The first account in the West of the human cost of the cultural revolution was Simon Leys, Les Habits neufdu président: Chronique de la "révolution culturelle" (Paris: Édtions Champ Libre, 1971). Translated as The Chairman's New Clothes: Mao and the Cultural Revolution, trans. Carol Appleyard and Patrick Goode (New York: St. Martin's Press, 1977). The veracity of Leys' account was vigorously denied by Western Maoists at the time. Ironically, the subsequent economic development of China under Deng Xiaoping and his successors has seemingly verified Mao's stance that the party itself had been infiltrated by "capitalist roaders." 
Prolétaire ligne rouge, Badiou's "theoreticist" Union des communistes de France marxistes-léninistes (UCFM-L) and two "Mao-Spontex" (spontaneist) groupings, the anarchist-leaning Vive la révolution! (which evaporated in 1971) and, most prominently, the Gauche prolétarienne (GP). When the GP was banned by the Gaullist state in May 1970, selling its newspaper $L a$ Cause du peuple became a badge of honor for left-leaning intellectuals such as Sartre, Lanzmann, Godard and Truffaut. ${ }^{28}$ The Mao-Spontex current reached a zenith of activity in the period between 1970 and 1972, but in spite of its high media profile and the efforts of militants to "implant" themselves in factories, French Maoism had virtually no presence among the country's industrial working class. ${ }^{29}$

Cahiers, however, was substantially alienated from both of these political contexts. As far as Mao's China was concerned, the journal, like many other Maoist sympathizers in France, remained largely ignorant of the concrete political situation in the country, partly out of willful blindness. Comolli notes that he and his colleagues had a purely "textual knowledge" of the cultural revolution: fascinated by Mao's writings (particularly On Contradiction), they relied on copies of Pékin-Information bought at the Maspero bookshop for information on China.$^{30}$ Both Comolli and Narboni have pointed to the pertinence of Jean-Claude Milner's recent work L'Arrogance $d u$ présent for its account of the "completely distant vision we had of China." ${ }^{11}$ Moreover, Cahiers' relationship with the existing Maoist groups in France was generally lukewarm, primarily because of their regressive views on the cinema. As Narboni stated, "The number of gauchiste groupuscules which

28 A broader history of the Maoist movement in France and its relationship with French intellectuals can be found in Christophe Bourseiller, Les Maoïstes: La folle histoire des gardes rouges français (Paris: Plon, 1996). See also Kristin Ross, May '68 and its Afterlives (Chicago: University of Chicago Press, 2002); Richard Wolin, Wind from the East: French Intellectuals, the Cultural Revolution, and the Legacy of the 196os (Princeton: Princeton University Press, 2010); and François Hourmant, Les Années Mao en France: Avant, pendant et après Mai 68 (Paris: Odile Jacob, 2018).

29 For the most famous first-hand account of this strategy of implantation, see Robert Linhart, L'Établi (Paris: Minuit, 1978). Translated as The Assembly Line, trans. Margaret Crosland (Amherst: University of Massachusetts Press, 1981).

30 Comolli, "Yes, we were utopians (Part 1)." For Mao's text, see Mao Zedong. "On Contradiction" (1937), in idem., Mao: On Practice and Contradiction, ed. Slavoj Žižek (London: Verso, 2007), pp. 67-102.

31 Interview with Jean Narboni, March 18, 2014. See Jean-Claude Milner, L'Arrogance du présent: Regards sur une décennie 1965-1975 (Paris: Bernard Grasset, 2009). Daney confesses that he felt the desire to apologize for his adherence to Maoism (which he would later view as a form of "fascism pure and simple") when he first traveled to China in the 1980 s. See Daney, Persévérance, p. 146 [p. 121]. 
tried to have a relationship with Cahiers was large, and it was incessant. It was we who did not want to [foster links] because we found that their position on the cinema was very far from our own." ${ }^{32}$ It was only during the "Front culturel" period (late 1972-1973), that Cahiers nourished ties with political organizations-especially Badiou's UCFM-L. Instead of orienting towards actually existing groups, the Maoist Cahiers invariably invoked the phantom of a mass revolutionary party, which was understood to exist only in absentia and which needed to be constructed by the extant Marxist-Leninist forces in opposition to the "revisionism" of the PCF.33

Cahiers' political and theoretical rupture with the PCF and its adoption of an "anti-revisionist" line was consecrated in the issue following the Porretta-Terme statement in a long text titled "Politique et lutte idéologique de classes." This piece affirmed that the accusation of "revisionism" against Lebel's take on film theory extended well beyond the individual in question and took aim at the cultural politics of the PCF as a whole, of which Cinéma et idéologie was merely "a symptom and a reflection" and which itself was an expression of the party's political revisionism. Much of "Politique et lutte idéologique de classes" was devoted to a critique of the PCF's political line-judged to be founded on an "economistic" outlook (prioritizing campaigns for higher wages to the exclusion of other political/ideological struggles) — but the journal was also willing to issue a bracing autocritique of its prior perspectives. Due to an "overestimation of theoretical practice" flowing from the "dominance of Althusser's positions," Cahiers had, in this account, been led to "think that the progressive elements of the Party could win out in an internal struggle - despite our fundamental disagreement with the Party's cultural positions (eclectic, liberal, reactionary) and despite our reservations (which never appeared in the magazine) concerning aspects of its political line." Cahiers' earlier, Althusser-influenced attitude was that the PCF was reformable, that its cultural line was "relatively autonomous" from its political perspectives, and that it was riven by internal struggles between "a faction favorable to the avant-garde and concerned about dialectical materialism, and a conservative, eclectic and reactionary wing." Such a position was henceforth deemed to be a form of "political opportunism"

32 Interview with Jean Narboni, March 18, 2014. He elaborated on this comment by saying: "The leftists were cinematically backwards. Either they had a myopic vision which said: 'No, why are you speaking about Straub and Godard? We have to film the struggles.' [...] Or they were politically active during the day, and in the evening they went to see a Sergio Leone film." 33 It was at this time, too, that Cahiers followed the French Maoist practice of writing the party's abbreviation with quotation marks around the "C" (i.e. "P.'C.'F.") in order to convey the ostensible falsity of the PCF's claim to being communist. 
whose effect had been to produce a series of tactical silences and accommodations during Cahiers' rapprochement with the PCF. ${ }^{34}$

This statement was published alongside a correspondence with the editors of La Nouvelle Critique, the tone of which was proof of the new state of political antagonism between the journals. In the area of film theory, however, a state of continuity with the work carried out while Cahiers was in the orbit of the PCF prevailed in the initial moments of its Maoist turn (late 1971-late 1972), and the journal persisted in making advances in this sphere. Installments of Comolli's "Technique et idéologie" appeared up to the September-October 1972 issue, while Bonitzer's series of theoretical texts beginning with "Réalité de la dénotation" also continued unabated. Kané dedicated an article to a "re-reading" of the classical Hollywood film Sylvia Scarlett, while Baudry worked on Intolerance and published the article "Figuratif, matériel, excrémentiel." Daney and Oudart critiqued Visconti's La morte in Venezia, and collective texts on the work of the Groupe Dziga Vertov and the television show $\grave{A}$ armes égales also appeared. All these texts had important repercussions for the field of film studies, and they are discussed more deeply elsewhere in this book. Even the work of figures such as Christian Metz and Jean Louis Schefer, remote from day-to-day political concerns, was published by Cahiers during this time. In none of these texts was Maoist aesthetic theory-as can be found in Mao's Yenan lectures on art ${ }^{35}$ - of particular influence, apart from the occasional use of sloganistic formulae. Theorists such as Althusser (despite his ongoing membership in the "revisionist" PCF), Lacan and Barthes continued to be the journal's presiding maittres à penser. For a time, then, theoretically dense writings co-existed with tracts denouncing the PCF and reprints of Chinese articles on the cinema of the cultural revolution. ${ }^{6}$ Prior to late 1972 , politics may have been "in the command post" of the journal's work, but this was not to the exclusion of film theory.

34 The quotes from this paragraph are from La Rédaction, "Politique et lutte idéologique des classes, Intervention 1," pp. 6-7 [pp. 334-335]. Cahiers also noted its adherence to the party's theses in the article on La vie est à nous and confessed to the "prudent" absence of any mention of the PCF's negative reception of Tristana in the press dossier on Buñuel's film published in issue no. 223 (August 1970, pp. 24-27), despite the divergence in views on the film.

35 See Mao Zedong, Talks at the Yenan Forum on Art and Literature (Peking: Foreign Languages Press, 1956).

36 See, in particular, "Le ballet chinois suit un brillant développement," Cahiers du cinéma no. 236-237 (March-April 1972), pp. 76-81, reprinted from Littérature chinoise no. 1 (1971). Virtually the only PRC film known and appreciated by Cahiers at this time was The Red Detachment of Women (Pan Wenzhan/Fu Jie, 1971), which had been praised by Mao's wife Jiang Qing and graced the cover of issue no. 236-237, but the editors were reticent about issuing their own analysis of this film. 


\section{Changes in Format, Changes in Personnel}

The sweeping turn from a pro-PCF to a Maoist political line ushered in a period of pronounced change for Cahiers. Most visibly, for the SeptemberOctober 1972 issue, the journal altered its format for the first time since the abandonment of the "Cahiers jaunes" in 1964, adopting a far more austere layout in keeping with the far-left publications with which Cahiers was now in dialogue. An editorial noted that this transformation had been desired for several months, in order to "allow us to definitively abandon the 'magazine' format imposed by our ex-publisher," and represented "a non-negligible diminution in the cost of producing Cahiers." ${ }^{37}$ As has often been remarked, the new format was notable for its rarefied use of images, often considered a mark of the Maoist Cahiers' intolerant disdain for the cinema as a whole. Even Comolli has admitted that this policy reflected the journal's "new iconoclasm." ${ }^{8}$ But the "banishment" of photographs and film stills from the pages of Cahiers as an official edict during its Marxist-Leninist period should not be exaggerated. In fact, only two non-consecutive issues (nos. 242-243 and 247) were entirely bereft of images, which when they did appear were utilized for functional/analytic rather than merely decorative purposes. Moreover, doing without images in a film journal is by no means automatically a reflection of hidebound political sectarianism, and the policy of a text-only film journal was notably resurrected by Daney—albeit for very different reasons - when he founded Trafic in 1991.

In addition to the new format, Cahiers moved its offices from the Rue Coquillière to a smaller site on the Rue des Petits-Champs (also in the $1^{\text {st }}$ arrondissement), and its editorial composition was substantially modified. The journal had long been run on de facto collective lines, and changes made in time for the November-December 1972-January 1973 issue reflected this state of affairs: Comolli/Narboni's position as editors-in-chief was done away with, and the virtually defunct comité de rédaction (comprising DoniolValcroze, Kast and Rivette) was abolished, replaced by a collective body including all the active contributors to the journal, with Aumont retaining his administrative duties. More crucial than these logistical transformations, the adoption of a Maoist outlook in 1971-1972 saw a number of changes in personnel at Cahiers, as Pierre and Eisenschitz left the journal, while two activists with Maoist backgrounds, Serge Toubiana and Philippe Pakradouni, joined as editors. 
Pierre's departure in late 1971 was provoked above all by personal reasons: her marriage to Aumont had broken down, and the suicide of her friend Anne Thoraval had also had a traumatic effect on the critic. ${ }^{39}$ But she was also exasperated with the hothouse atmosphere of the post-1968 far left in France, which Pierre has described as "an enormous machine for excommunicating each other in the name of what was supposedly the purest left-wing ideology," and felt that her Cahiers colleagues "were losing contact with reality, including with the cinema itself." ${ }^{\circ 0}$ Pierre's "search for the real" led her to Brazil, where she lived until 1976, and it was from here that she sealed her break from the journal, penning what she now describes as "the notorious letter" to Cahiers on March 8, 1972 protesting against the journal's Maoist line, which led to her removal from the conseil de rédaction. Here, she wrote:

I read with consternation and I formally disapprove in principle of the text "Intervention 1" published last January. It is not for us to give lessons in Marxist-Leninist theory to the universe. [...] We should not abstain from taking sides, but rather, choose an option that above all orients our own practice, that is, the critique and analysis offilm. Two things shocked me about this article. 1) One can feel how much you were driven, on the one hand, by your former missteps (the demand of love from the Party, from $L a$ Nouvelle Critique, etc. which had no real chance of being satisfied); and, on the other hand, by the pressure and initiatives of other journals. I mean, of course, Cinéthique and Tel Quel... 2) The "Chinese wall-poster" style you have suddenly adopted is completely grotesque. Who do you think you are? Totally disengaged from all practical politics, should you really adopt such a tone? ${ }^{41}$

Between Pierre's departure and the arrival of Thérèse Giraud in May 1974, Cahiers was once again a purely masculine affair, and the absence of Pierre's tempering, common-sense disposition perhaps goes some way to explaining the immoderate nature of the journal's Maoist years. She nonetheless remained friendly with her former colleagues upon returning to France in 1976 and wrote scattered articles for the journal in the late 1970s and 1980s before assisting Daney in the founding of Trafic in the early 1990 .

39 Thoraval was a filmmaker who before her death had completed the $16 \mathrm{~mm}$ short film $U n$ troisième, in which Aumont and Pierre acted alongside Michael Lonsdale and Patrice Leconte. 40 Interview with Sylvie Pierre, March 7, 2014.

41 Cited in de Baecque, Histoire d'une revue vol II, p. 252. Pierre has disclosed that the letter was motivated by the brusque response she received from the Cahiers editors when she offered to write on the Brazilian film Os Inconfidentes. Interview with Sylvie Pierre, May 26, 2014. 
Eisenschitz's departure was more rancorous: having joined the PCF in 1970 (after Fieschi, the only one of the journal's editors to do so) and remaining dubious about the merits of the cultural revolution, ${ }^{42}$ his position had become more and more tenuous once Cahiers had embarked on its Maoist turn. While his last article for the journal, an interview with the Taviani brothers, dates to March-April 1971, Eisenschitz remained on the conseil de rédaction until the beginning of 1972, when he and Eduardo de Gregorio (a communist critic from Argentina who had briefly written for Cahiers ${ }^{43}$ ) were purged from the journal following a "show trial" on January 3. Alongside the putsch against Rohmer, this is one of the more contentious episodes in the history of Cahiers. The journal's own public account of the ejection was limited to a succinct footnote: "After the majority of the Cahiers editorial board took up its anti-revisionist position, the only Communist Party member of the board, Bernard Eisenschitz, resigned from the magazine."44 Eisenschitz himself is reticent about the event but is firm that he and de Gregorio were compelled to resign from Cahiers rather than leave of their own volition. ${ }^{45}$ Drawing on archival resources (the "Journal de la rédaction," notably), de Baecque is more expansive about what he dubbed a "shameful moment" in the history of the journal, writing that Narboni had caught Eisenschitz leaving with a text written by Cahiers intended for publication in Le Monde, and, suspecting he was taking it to the PCF, inquired: "Who are you working for?" 46 For his part, Narboni, while regretting the resulting hiatus in his friendship with Eisenschitz, rejects the notion that the January 3 meeting was a "trial" and contends that it merely sought to clarify whether Eisenschitz wanted to stay in the party or continue working for Cahiers, the two having become mutually incompatible. ${ }^{47}$ A page from the meeting's minutes for the "Journal de la rédaction" reproduced by de Baecque nonetheless documents the paranoid and acrimonious tone of the proceedings: Narboni accuses

42 Eisenschitz has said, "For me, it was not the revelations of Simon Leys that convinced me on China (I did have a certain curiosity, all the same). It was the completely pro-Chinese book by Maria-Antonietta Macciocchi, because the 'pro-' argumentation could only reveal the horror of the situation." Interview with Bernard Eisenschitz, April 1, 2014.

43 In addition to several notices in the "Petit Journal" in 1968-1969, de Gregorio had contributed reviews of Model Shop and A Time for Dying, as well as participating in interviews with Marco Ferreri and Carlos Diegues. See Eduardo de Gregorio, "Déplacements (Model Shop)," Cahiers du cinéma no. 222 (July 1970), pp. 56-58; and Eduardo de Gregorio, "A Time for Dying," Cahiers du cinéma no. 233 (November 1971), pp. 57-61.

44 La Rédaction, "Politique et lutte idéologique des classes, Intervention 1," p. 5 [p. 340 ].

6 De Baecque, Histoire d'une revue vol. II, p. 251.

Interview with Jean Narboni, March 18, 2014. 
Eisenschitz of "denigrating us in all of Paris," while Bonitzer argues that "this practice (the theft of the article) is hardly that of someone who is in the journal." The minute-taker even felt the need to note, at one point, that "the tone becomes heated. ${ }^{18}$ In any case, as a result of these proceedings, Eisenschitz's departure from the journal was definitive, and from this point on he would devote his critical energies to La Nouvelle Critique and other publications.

The gap left by Pierre and Eisenschitz was soon filled by Serge Toubiana and Philippe Pakradouni, two militant students who came into contact through Cahiers thanks to the journal's activities teaching film on university campuses. Toubiana, born into a family of communist Sephardic Jews in Tunisia on August 15, 1949, had arrived in Paris from Grenoble in the summer of 1971, wishing to study cinema at Paris-III's Censier-Daubenton campus. In his hometown, he had been a member of the PCF in the years 1966-1968 while also helping to run the city's ciné-club. ${ }^{49}$ Following disagreements on Prague and May '68, he was excluded from the party and became active with the Maoist group Vive la révolution!. Ironically, his move to the capital was inspired by a wish to leave behind the world of political activism. In Toubiana's words, "I went to Paris in 1971 to break with this militant blindness. The only exit, the only possible horizon in my eyes, was the cinema." ${ }^{\circ}$ His contacts with Daney, Kané and Bonitzer at Censier led to Toubiana's integration in the journal, which initially took the form of his participation in the "Groupe Lou Sin d'intervention idéologique," a group consisting of Cahiers editors and students at Paris-III which, in addition to serving as a nom de plume for several texts published in Cahiers, also agitated against the university's department chair, who had initially refused to extend the contract of the Cahiers editors teaching in the cinema program. After participating in his first editorial meeting on September 29, 1972, Toubiana's background as a Maoist activist enabled him to quickly become a central figure in the journal. Indeed, this marked the beginning of a 30 -year association with Cahiers, a large portion of which was spent as editor-in-chief. ${ }^{5^{1}}$

48 See De Baecque, Histoire d'une revue vol. II, plate XXIII.

49 Interview with Serge Toubiana, April 29, 2014. See also Serge Toubiana, Les Fantômes du souvenir (Paris: Bernard Grasset, 2016), pp. 29-49. Toubiana recalls that, while at the lycée (where, incidentally, Jean-Louis Leutrat was one of his teachers), his taste in cinema was closer to Positif than it was to Cahiers.

$5^{0}$ Serge Toubiana, interviewed by Nicole Vulser, "Serge Toubiana, l'homme cinémathèque," Le Monde, May 10, 2003.

$5^{1}$ Toubiana was initially co-editor-in-chief with Daney from 1974 to 1981 , then held the position alone until 1992. From 1992 to 2000, he was the head of Cahiers' publishing arm, leaving when 
Unlike his colleagues, however, Toubiana never felt himself to be a natural writer. Ill at ease with film theory, he preferred to attend to the journal's administrative tasks, and this experience proved valuable for his later stint as director of the Cinémathèque française in the years 2003-2015..$^{2}$

In contrast with Toubiana's enduring tenure at Cahiers, Philippe Pakradouni's involvement with the journal was brief: a rapid rise in the journal's ranks in 1972 was soon followed by his marginalization before the year 1973 was out. Pakradouni was in fact the pseudonym adopted by Philippe Zarifian (born 1947), the younger brother of Cahiers fellow traveler Christian Zarifian. He attended Narboni's courses at Vincennes before being introduced by the Cahiers critic to the journal. Like Toubiana, Pakradouni brought with him experience as a Maoist activist—otherwise sorely lacking among the journal's editors - and his confidence with the language and organizational methods of the Marxist-Leninist tradition ensured his ascendency within an editorial team that had been battered by several years of political vacillations and internal disputes. While Pakradouni was a key figure in the "Front culturel révolutionnaire" project that dominated Cahiers in the months leading up to August 1973 and was involved in the drafting of lengthy but often supercilious political platforms such as "Quelles sont nos tâches sur le front culturel?," his near-total lack of cinematic culture was also crushingly evident: in his time at the journal, he did not publish a single line that directly concerned the critical response to a film. Retrospective blame for the dogmatic excesses of the Maoist period is often solely laid at Pakradouni's feet by his former colleagues. In this sense, he serves as a convenient proxy for the other critics' denial of their own perceived misdeeds-a spectral status that is illustrated in the film $\grave{A}$ voir (absolument) si possible when Bonitzer refers to him as "Philippe Pakradouni, to not say his name." Aumont, who refers to Pakradouni as a "Stalinist dictator," has even gone on record as claiming that he was "an undercover agent from the CGT [who] arrived at Cahiers and almost killed it," adding: "we were truly manipulated."53 After

the journal was bought out by Le Monde. He now states that he regrets having stayed on so long at the journal, preventing a younger generation of critics from truly establishing themselves in the journal. See Interview with Serge Toubiana, April 29, 2014.

52 Toubiana was thus the only figure associated with Cahiers during its Marxist period who later became a "functionary" within the film industry.

53 Aumont, "Le gai savoir," p. 37. Asked about this claim, Aumont stands by it, although he admits he has no proof to back this accusation. His main piece of evidence is that Zarifian later re-surfaced as a CGT functionary, a move that was virtually impossible for a former Maoist. Interview with Jacques Aumont, March 11, 2014. The hypothesis is nonetheless dismissed by Comolli, Narboni and Eisenschitz. 
leaving Cahiers, Pakradouni had no further contact with the journal or its editors, and, dropping his pseudonym, later became a sociologist specializing in labor issues at the Université Paris-Est Marne-la-Vallée, his past at Cahiers expunged from his personal biography. ${ }^{54}$

\section{The Front Culturel Révolutionnaire}

Despite this infusion of new blood into the editorial team, Cahiers was experiencing, in late 1972, another moment of crisis. At this stage it was still capable of producing theoretical texts of high quality, even if they were increasingly weighed down by the political langue de bois of the Maoist movement. ${ }^{55}$ But the journal was perennially beset with financial issues, and the threat of total collapse loomed. Its issues became more and more sporadic: six numbers were published in 1972, four in 1973, and five in 1974, and the idea of officially reverting to a bimonthly or quarterly publication frequency began to be discussed. ${ }^{6}$ Cahiers was also widely considered illegible by those uninitiated in the finer points of its gauchiste discourse and was precipitously losing its readership. A low point was reached with its February 1973 issue, which sold only 3403 copies (compared to 11,561 in April 1971), 2069 of which were overseas subscriptions, including a large number of North American universities. ${ }^{57}$ As Daney later disclosed: "If we had not been Cahiers but, let's say, Cinéthique, a journal without an aura, without a past, without international subscriptions, I believe we would have gone under. Without even realizing it. We were saved by the title and by the people who were still attached to this title. ${ }^{8}{ }^{8}$ Going by remarks in the "Journal de la rédaction," the mood within the offices became increasingly gloomy. A September 29, 1972 entry plaintively asked: "Cahiers is not going well. Why? Tired? Not only. Personal problems? Not only. What, then?”

54 See philippe.zarifian.pagesperso-orange.fr (accessed January 1, 2021). Of the former editors contacted for this research project, Pakradouni/Zarifian was the only one who did not respond to enquiries.

55 As early as July 1971, however, the "Journal de la rédaction" lamented that "Oudart is currently the only one of us capable of producing applied theoretical texts, quickly, and without perturbing the rest of his work for the journal." Cited in de Baecque, Histoire d'une revue vol. II, p. 230.

56 See Comolli, "Yes, we were utopians (Part 1)."

57 This information is provided by de Baecque in Histoire d'une revue vol. II, p. 225.

$5^{8}$ Serge Daney, interviewed by Michel Crépu, Gilles Delavaud, Michel Mesnil and Olivier Mongin, "Passion de l'image: Des Cahiers du cinéma à Libération: Entretien avec Serge Daney," Esprit vol. 83 no. 11 (November 1983) pp. 111-133. Repr. in Daney, La Maison cinéma et le monde vol. II, pp. 7-31, here p. 17 . 
Narboni, who along with Bonitzer was the driving force behind the Maoist turn, attempted an answer: "Non-functioning due to the egoism of each of us, due to the lack of work. Why aren't we working? [...] We no longer know what a journal called Cahiers du cinéma ought to do."59

It was in this void that the idea for a "Front culturel révolutionnaire" (nicknamed "Front Q" in the "Journal de la rédaction") first aired by Pakradouni, took hold of Cahiers. The use of the term "cultural front" had a double meaning: it was both the sphere of social activity in which the journal was to intervene and the organizational form such an intervention was planned to take. Cahiers had already made an attempt at reaching out to broader political/cultural forces when it held a stage (workshop) entitled "Cinéma et luttes de classe" at the Avignon festival in July 20-27, 1972, which attracted around 6o participants and was considered by the journal to be "an important phase in the transformation of our practice of diffusion and of our conception of the ideological struggle on the cultural front." ${ }^{60}$ Public debates at Avignon centered on the French militant film Soyons tout, the Chinese pedagogic film En renvoyant le dieu de la peste and the Groupe Dziga Vertov's Vent d'Est. ${ }^{61}$ The journal's compte-rendu of the event provided it with an opportunity to give a critical overview of its prior public interventions, stretching back to the "Montage" debate in Aix-en-provence in February 1969. For the Cahiers of late 1972, the period in which a "Marxist-Leninist" orientation was reclaimed can be divided into three phases. The first, "bourgeois-progressist" phase (1969) was dominated by an Althusser-influenced structuralism, which actually left the journal's critical practice relatively unchanged: the same directors were defended as in Cahiers' "idealist era," and the "bourgeoisie-proletariat antagonism" was remote from the journal's concerns. The second phase (1970-1971), promoting "materialist cinema," saw the accent placed on the formal work of avant-garde

59 Cited in de Baecque, Histoire d'une revue vol. II, p. 257. Narboni himself, however, states: "I don't know if things were sadder than usual. The links between us were still friendly." Interview with Jean Narboni, March 18, 2014.

60 “Intervention à Avignon: 'Cinéma et luttes de classes': Premier bilan critique," Cahiers du cinéma no. 241 (September-October 1972), pp. 7-18, here p. 7.

61 Debates on the first two films were published in the following issue, along with an interview with Serge Le Péron, a Maoist militant and member of the Vincennes-based collective responsible for Soyons tout, who would later become a regular critic for Cahiers. The Vent d'Est discussion, potentially the most interesting of the three, was never published due to an error with the tape recording. See “Cinema et luttes de classes, Intervention à Avignon, 2," Cahiers du cinéma no. 242-243 (November-December 1972-January 1973), pp. 70-94. The Avignon workshop was attended byJump Cut editors Chuck Kleinhans and Julia Lesage, who were curious about but skeptical of the Maoist line promulgated by Cahiers. See Chuck Kleinhans, private communication, March 22, 2016. 
filmmakers (Straub, Oshima, the Tavianis) and re-readings of Hollywood cinema but was judged to be erroneous for its understanding of "the ideological struggle in non-pertinent terms of opposition" (such as latent/manifest, visible/non-visible, full/empty) and its misplaced confidence that bourgeois ideology would crumble like a vampire once exposed to the light of critical theory. The third phase (1972), dominated by "anti-revisionism," was viewed more favorably for recognizing that "politics also commands all cultural production and work." Still, even this phase was said to have suffered from an "eclecticism" in the selection of films to be screened at Avignon and an empirical, untheorized approach to the debates surrounding these films. ${ }^{62}$

Although they recognized that Avignon was used as a tool by the PCF to co-opt its "contestatory 'outside," Cahiers viewed the proposal from festival head Jacques Robert to organize an eight-day workshop within the festival, with paid attendance, as a valuable opportunity to "work more seriously and systematically [...] and above all to have a closer and more militant contact with the participants." ${ }^{\prime 3}$ Gathering a collection of students, MarxistLeninist activists and a handful of PCF members, the concrete results of the workshop were fragmentary, but the overall experience was deemed a positive one and paved the way for the planned establishment of the "Front culturel révolutionnaire" at the following Avignon festival, in 1973. The platform paper “Quelles sont nos tâches sur le front culturel?” was drawn up by Narboni and Pakradouni on November 22, 1972 and published in issue no. 242-243. A bracing critique of Cahiers' critical practice up to that point, the platform argued for "a radical transformation of our conception of the relationship between theory and practice," which would consist of "placing the journal in the service of all those comrades who intervene, in a direct relationship with the masses, on the cultural front." Cultivating "the art of film criticism" had to be "definitively liquidat[ed]," and work such as the re-readings of Sylvia Scarlett and Intolerance was to be ceased immediately. ${ }^{64}$ Instead, the journal was to be transformed into an "instrument of the class struggle in the cultural domain" and would operate in the service of the Marxist-Leninist movement.

62 “Intervention à Avignon, 1" pp. 9-11.

63 Ibid., p. 12.

64 "Quelles sont nos tâches sur le front culturel?," pp. 6, 12. A footnote savaged the articles appearing in the previous issue: part 6 of "Technique et idéologie" was judged "a purely theoretical reflection" that had lost its "force of intervention," Kané's review of two Italian films was attacked for remaining within "the framework of 'film criticism," and Baudry's analysis of Intolerance was derided for being "academic," "structuralo-Freudian" and "not susceptible to any productive effect today." Needless to say, these strictures do an injustice to the texts in question. 
The sweeping demolition of Cahiers' past activity was undertaken with a rare violence, and yet - officially at least - the entire editorial board swung behind the Front culturel project. Five working groups were set up to build ties with "relay-elements" (that is, militants active in the cultural sphere), while the editorial team followed the Leninist precepts of conceiving of itself as a "collective organizer." 65 The issues leading up to the 1973 Avignon festival were filled with position papers and reports on this work, to the near total exclusion of any discussion of cinema. These efforts were not entirely worthless, with the journal entering into discussions with Maoist groups such as the UCFM-L and the Prolétaire Ligne Rouge, ${ }^{66}$ as well as activists such as Serge Le Péron and Alain Bergala, both of whom would later become critics for Cahiers. ${ }^{67}$ Discussions were even held with Cinéthique on a prospective merger of the two publications, and Cahiers joined its erstwhile rival in denouncing the Tel Quel-aligned Mouvement de Juin 71, thereby breaking the influence that Sollers and his colleagues exerted over both film journals. ${ }^{68}$ Behind the scenes, however, the Cahiers editors were divided by the Front culturel even before its "founding congress" took place: Pakradouni, Narboni, Toubiana and Bonitzer were the main driving force behind the project, but even here the latter two editors harbored private reservations. ${ }^{69}$ Aumont, Kané, Oudart and Daney assented to the initiative but mainly played a

65 This is a reference to the Lenin quote that "A newspaper is not only a collective propagandist and a collective agitator, it is also a collective organizer." V.I. Lenin, "Where to begin?," in The Collected Works of V.I. Lenin vol. V(Moscow: Progress, 1961), pp. 13-24, here p. 22.

66 According to the Cahiers editors, the contact with the UCFM-L was the most theoretically fruitful, but the only texts that evinced this collaboration was a later article by member Bernard Sichère, "La bête et le militant," Cahiers du cinéma no. 251-252 (July-August 1974), pp. 19-30. The PLR was responsible for the manifesto "Vive le cinéma, arme de propagande communiste," Cahiers du cinéma no. 245-246 (April-May-June 1973), pp. 31-42. This text ended with the bombastic peroration, "Down with bourgeois cinema! Down with the myth of counter-information! Long live the cinema, arm of political education! Long live the cinema, arm of communist propaganda!" (p. 42) and spoke of "China and Albania, red bases of world revolution" (p. 32). The empty sloganeering of this manifesto is often treated by historians as the nadir of Cahiers' Marxist-Leninist turn, but it should be noted that in the editors' introductory remarks, the text was already criticized on this basis. See Ibid., p. 31.

67 Bergala's first article for Cahiers was written under the pseudonym "Alain Belbo." See Alain Belbo, "Problèmes d'une stratégie de l'animation," Cahiers du cinéma no. 245-246 (April-May-June 1973), pp. 15-18. He did not resume writing for the journal until 1976, from that point on under his real name. 68 See "Critique des positions du 'Mouvement de Juin 71," Cahiers du cinéma no. 245-246 (April-May-June 1973), pp. 68-87.

69 Bonitzer now maintains that “Simply put, I didn't believe in it. I didn't believe that Cahiers could have any kind of political action or influence. I think I wanted to believe, like many others at the time, but deep down I absolutely didn't believe in it." Interview with Pascal Bonitzer, April 30, 2014. 
secondary role in its implementation and were not at ease in the world of political activism. Baudry and Comolli were more alienated from Cahiers during the "Front culturel" period and were politically closer to the earlier perspective of reforming the PCF from within. Baudry formally resigned in February 1973, arguing for a critique of "the revisionism of the Party" rather than "the revisionist Party" and concerned at the journal's apparent abandonment of theoretical work..$^{0}$ Comolli's position was more ambiguous: consumed with preparatory work on his film La Cecilia from 1971 onwards, he had become a somewhat aloof figure in the journal by this time. While today Comolli assumes unmitigated responsibility for Cahiers' Maoist period, he never attacked "revisionism" with the vigor that his fellow editors did, and his colleagues are today convinced that he remained attached to the earlier political line of reforming the PCF. ${ }^{1}$

Preceded by nine months of frenetic cultural animation by the Cahiers editors, the five-day stage at the 1973 Avignon festival was intended to inaugurate the Front culturel révolutionnaire as an ongoing organizational body coalescing the totality of Marxist-Leninist aligned cultural militants in France. Despite drawing 150 attendees (a creditable number), the Avignon conference was nonetheless perceived as a failure by the majority of the Cahiers team. Even the official, necessarily upbeat report on the event admitted that its meetings were "too frequent, too long and poorly prepared" and gave rise to "authoritarian and bureaucratic tendencies." ${ }^{2}$ Indeed, apart from productive discussions on the culture of national minorities and immigrant workers, the conference descended into internecine sectarian disputes between the different Maoist tendencies represented, and even the Cahiers editors found themselves subject to barbed insults. In hindsight, Narboni, who still argues that the concept of a cultural front was an "idea that was not absurd per se," admits that its realization was "beyond our means" and that its failure was primarily determined by the fact that "it took place at a moment that was the end of gauchisme."73 Indeed, by 1973, the Maoist movement, and the far left more generally, had reached a point

70 Pierre Baudry, "À propos de la démission de Pierre Baudry," Cahiers du cinéma no. 245-246 (April-May-June 1973), pp. 88-89.

71 Aumont, Pierre and Bonitzer all insist that Comolli was never involved in the journal's Maoist turn and remained broadly aligned with the PCF. While he remained officially on the editorial board, his participation in meetings became more sporadic in 1972 and 1973, and outside of the "Technique et idéologie" series, he rarely wrote for the journal during this period.

72 "Pour un front culturel révolutionnaire (Avignon 73)," Cahiers du cinéma no. 248 (c. late 1973), pp. 5-12, here p. 10.

73 Interview with Jean Narboni, March 18, 2014. 
of decline. Five years of feverish activity after May '68 had taken a steep personal toll on the movement's activists, one that was exacerbated by the harsh repression of militants by the Gaullist state. The promulgation of the "anti-casseurs law" in April 1970 led to the imprisonment of more than 1000 left-wing activists for "crimes" such as selling newspapers or attending demonstrations. ${ }^{74}$ In the early 1970s, the political impetus in France reverted to the conservative right, while the reality of the Chinese cultural revolution became more and more apparent. When the Maoist activist Pierre Overney was killed in March 1972, the resulting obsequies brought 200,000 people onto the streets in one of the period's largest assemblies of the French far left, but the funereal atmosphere of the march was palpable, and Althusser would later claim that it was gauchisme itself that was being buried that day. ${ }^{75}$ If this symbolic end point of the wave of left-wing militancy could be momentarily disregarded by the Cahiers editors, the concrete experience of Avignon directly confronted them with the exhaustion of the far left and the breakdown of their own project. Comolli relates the aftermath of Avignon in the following terms: "We emerged from the failure of the Revolutionary Cultural Front bruised and bloodied. Afterwards, we met in a bar one evening, we looked at each other, and without needing to say much at all, we all profoundly understood that our will to continue this project had been broken. ${ }^{76}$ Feeling "morally and politically responsible for the situation," Comolli and Narboni resigned from the journal, which after Avignon was on the verge of collapse.

\section{Film Criticism During the Front Culturel}

The period of the Front culturel is often presented as one in which reflection on the cinema was almost entirely abandoned in favor of political agitation within an amorphously defined cultural sphere. Certainly, the task of film criticism during this time was explicitly subordinated to political exigencies, and the issues of Cahiers published in late 1972-1973 reveal a journal that appeared to be barely concerned with the cinema. The "Journal de la rédaction" had, as early as February 1971, noted "We don't go to the cinema anymore, which is radically true,"77 and Reynaud declares with

76 Comolli, "Yes, we were utopians (Part 1)."

77 Quoted in De Baecque, Histoire d'une revue vol II, p. 228. 
some justification that the activity of Cahiers, at this point, "can be read as two parallel lines: what it did, and what it missed. And the part of the 'reality' it missed was enormous. It stopped paying attention to the films released in the cinemas." ${ }^{78}$ But the wholesale nature of this renunciation of film criticism can be exaggerated; in fact, even if they formed a small part of the journal's activity, critical texts continued to be written and published throughout this time. In some key ways, however, the critical method adopted in the three issues in which the Front culturel policy prevailed (nos. 244-247) departed markedly from the approach that was dominant both before and after this period. If one of my chief hypotheses is the existence of a Cahiers "line" that runs from the journal's origins under Bazin, right through its Marxist period and up to the departure of Daney in 1981, then the critical texts of its dogmatic Maoist moment fundamentally represent an aberration in the history of the journal. Most palpably, films were now to be judged along strictly instrumentalist political lines-that is, their ability to mobilize the proletariat in its revolutionary struggle against the twin enemies of bourgeois reaction and PCF revisionism. Furthermore, in a volte-face from the journal's prior practice of emphasizing a film's form (its écriture) when evaluating it, cinematic works were now to be assessed primarily on the basis of their content. Concomitantly, the journal's legendary illegibility was subject to an autocritique: "Quelles sont nos tâches sur le front culturel?" explicitly decried a "fatalistic' conception of the journal's relationship with its addressees," asking "What is the benefit, for example, of a correct critique of a television program, if $99.99 \%$ of workers who see it are not reached by this critique?"79 A later article would similarly rail against the adoption of "an ornate style which, under the pretext of signifying drift or the care for 'writing,' generally only served to blur the comprehension of texts. ${ }^{" 80}$ Cahiers hence endeavored to write in a more straightforward, accessible fashion - although these efforts were hampered by the Maoist langue de bois which now dominated the journal and which was just as alienating for outsiders as its earlier "theoreticist" style had been. Hand in hand with this stance was the abandonment of the theoretical influences that had impregnated Cahiers since the late 1960 s. A balance sheet from a working group set up on this question determined

78 Reynaud, “Introduction,” pp. 10-11.

79 "Quelles sont nos tâches sur le front culturel?," p. 10. The text in question was evidently the Groupe Lou Sin's analysis of $\grave{A}$ armes égales, which is further discussed in Chapter 26.

80 Jacques Aumont, "Groupe 3: Les acquis théoriques: Premier bilan du groupe," Cahiers du cinéma no. 244 (February-March 1973), pp. 40-43, here p. 41. 
that its earlier interest in the contemporary theory of Lacan, Althusser and Barthes reflected a "complaisant, egocentric attitude" of "cultivating theory for the sake of theory." ${ }^{81}$ Apart from a politically narrow utilization of Althusser's notion of the Ideological State Apparatus, these thinkers were essentially abandoned as reference points during this period. The film criticism written under the Front culturel policy was thus, on several levels, atypical of the Cahiers writers, and few of the resulting reviews have stood the test of time. ${ }^{82}$

Discussions of the Front culturel have generally avoided addressing the reviews written by Cahiers during this period, but they nonetheless warrant analysis - even if only as testimonies to the political pressures the journal had subjected itself to and the surprising critical evaluations that resulted. The first two reviews under the new perspective were also notable for deriving from discussions with radical students from the cinema department at the Université de Paris-III (where several Cahiers editors lectured), thus attesting to a politicized, collectivist approach to film criticism as well as an intersection between the worlds of cinephilia and academia that would only grow more preponderant in the years to come. ${ }^{83}$ Aumont censured Bernard Paul's depiction of trade union struggle in Beau Masque for conveying the revisionist line of the PCF in the lead-up to the March 1973 legislative elections (where the union de la gauche, an alliance with the Parti socialiste, had a genuine prospect of attaining a parliamentary majority) and saw the film as an "antidote" for communist militants to the recent gauchiste films on the same topic (Coup pour coup and Tout va bien). Daney and Oudart, meanwhile, penned a review of Loach's Family Life, which viewed the film from an Althusserian standpoint as the articulation of two ISAs (the family and the psychiatric institution) that was nonetheless bereft of any understanding of their "global function" and treating them from the "petty-bourgeois" viewpoint of the struggle between the individual and society rather than the struggle between classes. $^{84}$

The concept of the ISA was also the theoretical framework for Daney's review in issue no. 245-246 of Nel nome del padre and Sbatti il mostro in prima pagina (both by Marco Bellochio), which were judged to support the

\footnotetext{
81 Ibid.

82 Kané even admits that he essentially "parroted" the "stereotyped phraseology" of MarxistLeninist discourse in his writings during this time. Interview with Pascal Kané, March 12, 2014. 83 See Aumont, "Groupe 3: Les acquis théoriques," p. 43.

84 Serge Daney and Jean-Pierre Oudart, "Sur Family Life (de Kenneth Loach)," Cahiers du cinéma no. 244 (February-March 1973), pp. 44-48.
} 
PCI thesis that "the gauchistes are the objective harbingers of fascism." 85 For Daney, the "radicality of Bellochio's 'despair" is further denoted by the absence of a "positive hero" in the film: this concept, drawn directly from Mao's theories on art, had already been developed in an article written by Daney in the previous issue, based on one of the "working groups" that Cahiers had set up. Rejecting Cahiers' earlier advocacy of critically deconstructing "the very idea of representation," Daney argued that the presence of a "positive hero" condensing the contradiction between the avant-garde and the masses represented the "line of demarcation between the bourgeois cinema and the revolutionary cinema." ${ }^{\prime 86}$ Despite the quasi-Zhdanovian socialist-realism of its line of argumentation, the notion of a "positive hero" would persist in Daney's criticism well beyond the demise of the journal's Maoist orientation, and it would notably function as a conceptual counterpoint to the cynicism of the "retro mode" in mid-1970s French cinema. Still more surprising was the guardedly positive reception given by Bonitzer and Toubiana to Costa-Gavras' État de siège, which repudiated the "unilateral" critique of $Z$ made by Cahiers in 1969 for ignoring the "positive fact that constituted the diffusion among the working-class and popular masses of a film whose content [...] had the merit of being anti-fascist and anti-militarist." ${ }^{87}$ The goal of État de siège-to make a film denouncing American imperialism - was thus given Cahiers' approval, although demurral was registered to the film's "sentimental moralism" and its pacifist opposition to the Tupamaros' policy of revolutionary violence. In any case, the political value of État de siège was evaluated purely in terms of the film's content-its form was now a non-issue for Cahiers.

Issue no. 247 saw a subtle departure from this critical line, even though the journal was still under the sway of the Front culturel project. Bonitzer's triple review of Ultimo tango a Parigi, La Grande Bouffe and La Maman et la putain was dubious about the hedonistic egoism of all three films, seeing them as "crepuscular reflections of the bourgeois conception of the world." Although he conceded that Eustache's film was more avant-gardist and "infinitely more talented" than the other two works, it was considered to be "more or less enclosed in the scandal" that they had provoked. ${ }^{88}$ Assimilating

85 Serge Daney, “Au nom du Père, Viol en première page," Cahiers du cinéma no. 245-146 (AprilMay-June 1973), pp. 43-49, here p. 49.

86 Serge Daney, “Groupe 4: Le héros positif," Cahiers du cinéma no. 244 (February-March 1973), pp. 54-58, here p. 54 .

87 Pascal Bonitzer and Serge Toubiana, "État de siège," Cahiers du cinéma no. 245-246 (AprilMay-June 1973), pp. 49-54, here p. 49.

88 Pascal Bonitzer, "L'expérience en intérieur (Dernier Tango à Paris, La Grande Bouffe, La Maman et la Putain)," Cahiers du cinéma no. 247 (July-August 1973), pp. 33-36, here p. 33. 
the three works in this manner was later hotly contested by Eustache, himself a former Cahiers critic, who found Bonitzer's review to be "in bad faith" and contended that he "did not feel at all in solidarity" with Ferreri and Bertolucci's films." ${ }^{89}$ The lukewarm attitude to Eustache did not last long: Bonitzer himself would heap praise on Une sale histoire in $19788^{90}$ and by the end of the decade, Cahiers considered La Maman et la Putain to be one of the totemic films of the 1970s. ${ }^{91}$ Furthermore, it is worth noting that the article in question represented a chink of openness from within the political dogmatism enveloping Cahiers, as references to Bonitzer's long-standing theoretical figures de proue (Lacan, Barthes and Bataille) saw the return of their names to the pages of Cahiers after a significant period of purgatory and presaged the rejection of a hardcore Maoist line that would come after the failure of the Avignon conference.

\section{Works Cited}

Louis Althusser, "Idéologie et les Appareils idéologiques d'état (Notes pour une recherche)," La Pensée no. 151 (June 1970), pp. 3-38. Translated as "Ideology and Ideological State Apparatuses: Notes towards an Investigation," in idem., Lenin and Philosophy and Other Texts, trans. Ben Brewster (New York: Monthly Review Press, 1971), pp. 85-132.

—, L'avenir dure longtemps (Paris: Stock/IMEC, 1992).

[Anon.], "Le ballet chinois suit un brillant développement," Cahiers du cinéma no. 236-237 (March-April 1972), pp. 76-81.

Antoine de Baecque, Les Cahiers du cinéma: histoire d'une revue vol. II: Cinéma, tours détours 1959-1981 (Paris: Cahiers du cinéma, 1991).

Jacques Aumont, "Groupe 3: Les acquis théoriques: Premier bilan du groupe," Cahiers du cinéma no. 244 (February-March 1973), pp. 40-43.

—, interviewed by Patrice Blouin and Jean-Marc Lalanne, "Le gai savoir," Les Inrockuptibles, April 27, 2005, pp. 36-38.

Alain Belbo, "Problèmes d'une stratégie de l'animation," Cahiers du cinéma no. 245246 (April-May-June 1973), pp. 15-18.

89 Jean Eustache, interviewed by Serge Toubiana, "Entretien avec Jean Eustache," Cahiers du cinéma no. 284 (January 1978), pp. 16-27, here p. 25.

90 Pascal Bonitzer, "Le silence de l'œil (Une sale histoire)," Cahiers du cinéma no. 285 (February 1978), pp. 39-41.

91 Bonitzer also notably published a touching obituary to Eustache after the latter's suicide in 1981. Pascal Bonitzer, "Jean Eustache a franchi la porte," Cahiers du cinéma no. 330 (December 1981), pp. 16-17. 
Pascal Bonitzer, "Fétichisme de la technique: la notion de plan," Cahiers du cinéma no. 233 (November 1971), pp. 4-10.

—, "L'expérience en intérieur (Dernier Tango à Paris, La Grande Bouffe, La Maman et la Putain)," Cahiers du cinéma no. 247 (July-August 1973), pp. 33-36.

—_, "Le silence de l'œil (Une sale histoire)," Cahiers du cinéma no. 285 (February 1978), pp. 39-41.

—_, "Tel Quel," in “Dictionnaire sans foi ni loi," Cahiers du cinéma no. 325 (June 1981), p. 120.

—, "Jean Eustache a franchi la porte," Cahiers du cinéma no. 330 (December 1981), pp. 16-17.

—, interviewed by Stéphane Bouquet, Emmanuel Burdeau and François Ramone, "Nos années non-légendaires: Entretien avec Pascal Bonitzer," in Emmanuel Burdeau (ed.), Cinéma 68 (Paris: Cahiers du Cinéma, 2008 [1998]).

—, Jean-Louis Comolli and Jean Narboni, "Cinéma/idéologie/politique: Porretta Terme, 2," Cahiers du cinéma no. 233 (November 1971), pp. 46-47.

Christophe Bourseiller, Les Maoïstes: La folle histoire des gardes rouges français (Paris: Plon, 1996).

C.d.C., "Cinéma, idéologie, politique (pour Porretta-Terme)," Cahiers du cinéma no. 232 (October 1971), pp. 54-55. Translated as "Cinema, Ideology, Politics (for Porretta Terme)," trans. Alan Williams, in Nick Browne (ed.), Cahiers du Cinéma vol. III: 1969-1972 The Politics of Representation (London: Routledge, 1990), pp. 287-290.

[Cahiers du cinéma], "Lu dans la presse," Cahiers du cinéma no. 231 (September 1971), p. 53 .

— , "Éditorial," Cahiers du cinéma no. 241 (September-October 1972), p. 5.

—_, "Intervention à Avignon: 'Cinéma et luttes de classes': Premier bilan critique," Cahiers du cinéma no. 241 (September-October 1972), pp. 7-18.

—, "Quelles sont nos tâches sur le front culturel?" published in the following issue of Cahiers (no. 242-243, November-December 1972-January 1973), pp. 5-25.

—, "Cinema et luttes de classes, Intervention à Avignon, 2," Cahiers du cinéma no. 242-243 (November-December 1972-January 1973), pp. 70-94.

—, "Critique des positions du 'Mouvement de Juin 71," Cahiers du cinéma no. 245246 (April-May-June 1973), pp. 68-87.

—, "Pour un front culturel révolutionnaire (Avignon 73)," Cahiers du cinéma no. 248 (c. late 1973), pp. 5-12.

Albert Cervoni, “Avignon, le cinéma et les sandwiches," L'Humanité, August 26, 1970, p. 6.

Jean-Louis Comolli, interviewed by Daniel Fairfax, "Yes, we were utopians; in a way, I still am...': An Interview with Jean-Louis Comolli (Part 1)," Senses of Cinema no. 62 (April 2012), sensesofcinema.com/2012/feature-articles/ 
yes-we-were-utopians-in-a-way-i-still-am-an-interview-with-jean-louis-comollipart-1/ (accessed January 1, 2021).

-, Cinéma contre spectacle (Lagrasse: Verdier, 2009). Translated as Cinema against Spectacle: Technique and Ideology Revisited, trans. and ed. Daniel Fairfax (Amsterdam: Amsterdam University Press, 2015).

- Jean-Paul Fargier, Gérard Leblanc, Jean Narboni, Marcelin Pleynet and Philippe Sollers, “Cinéma, littérature, politique," Cahiers du cinéma no. 226-227 (JanuaryFebruary 1971), p. 115 .

Serge Daney, "Au nom du Père, Viol en première page," Cahiers du cinéma no. 245-146 (April-May-June 1973), pp. 43-49.

—, "Groupe 4: Le héros positif," Cahiers du cinéma no. 244 (February-March 1973), pp. 54-58.

—, interviewed by Michel Crépu, Gilles Delavaud, Michel Mesnil and Olivier Mongin, "Passion de l'image: Des Cahiers du cinéma à Libération: Entretien avec Serge Daney," Esprit vol. 83 no. 11 (November 1983) pp. 111-133. Repr. in Daney, La Maison cinéma et le monde vol. II: Les Années Libé 1981-1985 (Paris: P.O.L., 2005), pp. 7-31.

—, Persévérance (Paris: P.O.L., 1993). Translated as Postcards from the Cinema, trans. Paul Douglas Grant (Oxford: Berg, 2007).

— and Jean-Pierre Oudart, "Sur Family Life (de Kenneth Loach)," Cahiers du cinéma no. 244 (February-March 1973), pp. 44-48.

Jean Eustache, interviewed by Serge Toubiana, “Entretien avec Jean Eustache," Cahiers du cinéma no. 284 (January 1978), pp. 16-27.

Eduardo de Gregorio, "Déplacements (Model Shop)," Cahiers du cinéma no. 222 (July 1970), pp. 56-58.

—, "A Time for Dying," Cahiers du cinéma no. 233 (November 1971), pp. 57-61.

Jacques Henric, "Une déclaration de J. Henric," Cahiers du cinéma no. 236-237 (March-April 1972), p. 98.

François Hourmant, Les Années Mao en France: Avant, pendant et après Mai 68 (Paris: Odile Jacob, 2018).

A.L., "Un amalgame tendencieux," La Nouvelle Critique no. 37 (October 1970), p. 59. V.I. Lenin, "Where to begin?," in The Collected Works of V.I. Lenin vol. V(Moscow: Progress, 1961), pp. 13-24.

Simon Leys, Les Habits neuf du président: Chronique de la "révolution culturelle" (Paris: Édtions Champ Libre, 1971). Translated as The Chairman's New Clothes: Mao and the Cultural Revolution, trans. Carol Appleyard and Patrick Goode (New York: St. Martin's Press, 1977).

Robert Linhart, L'Établi (Paris: Minuit, 1978). Translated as The Assembly Line, trans. Margaret Crosland (Amherst: University of Massachusetts Press, 1981). Maria-Antonietta Macciocchi, De la Chine, translated into French by Louis Bonalumi (Paris: Seuil, 1971). 
Mao Zedong. "On Contradiction” (1937), in idem., Mao: On Practice and Contradiction, ed. Slavoj Žižek (London: Verso, 2007), pp. 67-102.

—, Talks at the Yenan Forum on Art and Literature (Peking: Foreign Languages Press, 1956).

Jean-Claude Milner, L'Arrogance du présent: Regards sur une décennie 1965-1975 (Paris: Bernard Grasset, 2009).

La Rédaction, "Les Cahiers à Avignon," Cahiers du cinéma no. 224 (October 1970), pp. $57-58$.

—, "Réponses à Politique-Hebdo," Cahiers du cinéma no. 229 (May 1971), pp. 61-64.

Bérénice Reynaud, "Introduction: Cahiers du Cinéma 1973-1978," in David Wilson (ed.), Cahiers du Cinéma vol. IV: 1973-1978 History, Ideology, Cultural Struggle (London: Routledge, 2000), pp 1-44.

Kristin Ross, May '68 and its Afterlives (Chicago: University of Chicago Press, 2002). Philippe Sollers, "De la contradiction," Tel Quel no. 45 (Spring 1971), pp. 3-23.

[Tel Quel], "Déclaration sur l'hégémonie idéologique bourgeoisie/révisionnisme," Tel Quel no. 47 (Autumn 1971), pp. 133-141.

—, "Mouvement de juin 1971," "Le dogmatisme à la rescousse du révisionnisme," Tel Quel no. 48-49 (Spring 1972), pp. 175-19o.

—, “À propos du 'Maoïsme,” Tel Quel no. 68 (Winter 1976), p. 104.

Serge Toubiana, interviewed by Nicole Vulser, "Serge Toubiana, l'homme cinémathèque," Le Monde, May 10, 2003.

—, Les Fantômes du souvenir (Paris: Bernard Grasset, 2016).

Richard Wolin, Wind from the East: French Intellectuals, the Cultural Revolution, and the Legacy of the 196os (Princeton: Princeton University Press, 2010). 


\title{
10. Cahiers du cinéma and Jean-Luc Godard
}

\begin{abstract}
This chapter focuses on the relationship between Cahiers du cinéma in the post-1968 period and the nouvelle vague filmmaker Jean-Luc Godard. The links between the two ran deep: Godard had been a critic for the journal in the 1950s, while in the 1960s and 1970s he stood alongside Straub/Huillet as the quintessential representative of political cinema for Cahiers, with the increasingly radical content of his films mirrored by a restless experimentation with film form. Indeed, it was Godard's initial turn to Maoism in 1969 (and his formation of the "Groupe Dziga Vertov" with Jean-Pierre Gorin) that was a major influence on Cahiers' own political trajectory, and one of the landmarks of the journal's long-standing interest in the director was the series of texts on the films of the Groupe Dziga Vertov published in 1972, which are analyzed here.
\end{abstract}

Keywords: Cahiers du cinéma, Jean-Luc Godard, Groupe Dziga Vertov, Marxism-Leninism, political cinema, Tout va bien

\section{Fellow Travelers: Cahiers du cinéma and Godard in the 196os}

Along with Straub/Huillet, Godard forms the other half of what Daney termed le strobgodar, a two-headed monster which, in the critic's view, "is presiding over the end of modern cinema"1 but which also safeguarded the journal's continued interest in the cinema, even at the height of its Maoist period. As Bonitzer has stated, "In all these years, in the most heightened, most dogmatic, closed off militant period, as well as in more open times, the fact that we did not let go of the red thread of Godard's work allowed us to

Fairfax, D., The Red Years of Cahiers du Cinéma (1968-1973). Volume I: Ideology and Politics. Amsterdam: Amsterdam University Press, 2021 DOI 10.5117/9789463728508_CH1O 
remain connected to the cinema." The journal's defense of Godard, along with Straub/Huillet, was a tenacious one and was perhaps the key point of distinction between Cahiers and other left-wing cinephilic currents. Daney, for instance, vividly recalls his experience lecturing on the two filmmakers to gauchiste students: "For our first course at Censier, Pascal Bonitzer and myself, mortified at the front of the lecture hall—with radical students itching to start a fight, whose cinematic tastes oscillated between Sam Peckinpah and Francesco Rosi-howled in blanching voices that materialist cinema was Godard and Gorin's Vent d'Est and the Straubs' Nicht versöhnt, and that on this point there was to be no compromising."3 Indeed, Godard was an ever-present point of reference for the journal and has remained so for the Cahiers writers up to the present day. Moreover, his own political evolution was closely aligned with that of the journal, as, like Cahiers, the director became steadily radicalized throughout the 1960s, culminating in a turn to Maoism in the early 1970s, and then critically re-evaluated his prior conceptions of political cinema in the latter part of the decade. This parallel development can at least partly be ascribed to the intellectual influence Godard had on the young critics, as the increasingly radical nature of his work prompted them to further push their own theoretical and political viewpoints. As a former writer for Cahiers, Godard maintained close links to the journal, and it was due to the initiative of Narboni in 1968 that his early film criticism was anthologized for the first time. ${ }^{4}$ It was only for a brief period in 1969-1971 that relations between the journal and filmmaker were distant, due primarily to Godard's disdain for his former employer's PCF-aligned "revisionism." Outside of this interlude, Cahiers devoted a large number of articles responding to the release of Godard's films and accorded him interviews on several occasions.

Godard's early films were a touchstone for the cinephilic awakening of many of the younger Cahiers' critics, even before they joined the journal. At the same time, both Comolli and Narboni published reviews of Godard films (Le Petit Soldat and Le Mépris respectively) shortly after joining the journal. This engagement with the filmmaker continued later in the 1960 s and initially emphasized the groundbreaking formal techniques of Godard's work. In 1965, Comolli's review of Alphaville insisted on its political relevance,

2 Bonitzer, “Nos années non légendaires," p. 152.

3 Daney, Persévérance, p. 92 [p. 76].

4 See Jean Narboni (ed.), Godard par Godard (Paris: Pierre Belfond, 1968). This edition appeared in English in 1972 (translated and edited by Tom Milne), and an expanded version edited by Bergala was published by Cahiers in 1984, with a second volume following in 1998. 
arguing that "the immediate future spoken of by the film is indeed our contemporary era: here, we are the voyeurs of ourselves." Godard's filmmaking was "creation against the grain," and his films were "never truly finished, the puzzle is never complete; new pieces can always be integrated into it." In January 1967, Narboni focused on the formal structure of Deux ou trois choses que je sais d'elle, seeing its collage-like structure as an "atomic" movement in which "the random jumps of the electrons from one orbit to another integrate themselves into a vaster gravitation." ${ }^{6}$ The journal's response later that year to La Chinoise - whose depiction of a Parisian cell of Maoist students uncannily presages the later political development of Cahiers - combined these two perspectives. Bontemps labeled the film a "political act" due to its "radical interrogation of the cinema and profound engagement in this art," while Comolli perceived it to be "all told, the most plastic and the most political film" in Godard's œuvre. ${ }^{7}$ Comolli's review foreshadowed the semiological mode of film analysis that would impregnate much of Cahiers' later writings by arguing that "what every film timidly suggests to its spectator, that its images should be read, La Chinoise demands more expressly: the image should be read, and nothing in it should not be read, since anything that cannot be read in it is not there." ${ }^{3}$

In the same issue (October 1967), Cahiers published a long interview with Godard which served as a clarion call for the intensification of the journal's political radicalism - even the title, "Lutter sur deux fronts," is indicative of this perspective. Godard had already granted two interviews to Cahiers (in 1962 and 1965), both of which discussed the relationship of cinema to film criticism. In the first, he famously declared: "Today I still consider myself a critic, and, in a sense, I am one more than ever. Instead of writing criticism, I make films, and try to introduce a critical dimension to them."9 Insisting that if the cinema disappeared, he would continue to make film

5 Jean-Louis Comolli, “À rebours? (Alphaville)," Cahiers du cinéma no. 168 (July 1965), pp. 86-87, here p. 87 .

6 Jean Narboni, "Notes sur 2 ou 3 choses que je sais d'elle," Cahiers du cinéma no. 186 (January 1967), pp. 32-33, here p. 33. Translated as "Notes on Two or Three Things...," Cahiers du Cinéma in English no. 10 (May 1967), p. 31.

7 Jacques Bontemps, "Une libre variation imaginative de certains faits (La Chinoise)," Cahiers du cinéma no. 194 (October 1967), pp. 30-34, here p. 34; and Jean-Louis Comolli, "Le point sur l'image (La Chinoise)," Cahiers du cinéma no. 194 (October 1967), pp. 29-30, here p. 29.

8 Ibid.

9 Jean-Luc Godard, interviewed by Jean Collet, Michel Delahaye, Jean-André Fieschi, André S. Labarthe and Bertrand Tavernier, "Jean-Luc Godard," Cahiers du cinéma no. 138 (December 1962), pp. 21-39, here p. 21. Translated as "Interview with Jean-Luc Godard," in idem., Godard on Godard, pp. 171-196, here p. 171. Godard's last critical piece for Cahiers was published a little more than 
with "a pencil and paper," Godard nonetheless lamented the loss, by 1962, of the polemical spirit of the 1950s, which would be revived a fortiori in the post-1968 years: "The thing that made Cahiers was its position in the front line of battle. [...] The Cahiers critics were commandos. Today, they are an army at peace, going out on maneuvers from time to time."”o By 1965 , he claimed that film criticism had attained its "age of reason" and was "almost at the point reached by art and music critics: giving information is not enough, there is nothing to explain, less need to defend and attack. ${ }^{{ }^{111}}$ At the same time, Godard argued that the literary style of the earlier period of criticism had to make way for a "pedagogical criticism" that would educate the reader on the work of figures such as Straub, Bertolucci and Skolimowski.

The ${ }^{196} 67$ interview "Lutter sur deux fronts," ostensibly focused on $L a$ Chinoise, in fact broached a wide range of topics relating to the nexus between cinema and politics, attesting to the more radical outlook shared by Godard and Cahiers at this time. The fruit of Godard's contact with members of the UJCM-L and the radical students at Nanterre University, La Chinoise nonetheless, as the director admitted, intensely displeased those Maoist students who served as its inspiration: "I've made a movie I call La Chinoise, in which I adopt, against the point of view of the French Communist Party, the point of view of the writings of Mao Zedong or the Cahiers marxistes-léninistes. I repeat, it is film that's imposed the direction I take, which explains why the Cahiers marxistes-léninistes can accuse it of being 'leftist' and why L'Humanité nouvelle can even attack it for being a 'fascist provocation."'12 But Godard felt that this was primarily due to the fact that he "didn't make it clear enough that the characters aren't members of a real Marxist-Leninist cell. They ought to have been Red Guards. I'd have avoided certain ambiguities. The real activists [...] wouldn't have been as annoyed by it as they were." ${ }^{\prime 3}$ The conversation with Cahiers subsequently moved into more theoretical terrain.

two years earlier, in April 196o. See Jean-Luc Godard, "Frère Jacques," Cahiers du cinéma no. 106 (April 1960), p. 4. Translated as "Frère Jacques," in idem., Godard on Godard, pp. 163-164.

10 Godard, in Collet et al., "Jean-Luc Godard," pp. 20, 38 [pp. 171, 195].

11 Jean-Luc Godard, interviewed by Jean-Louis Comolli, Michel Delahaye, Jean-André Fieschi and Gérard Guégan, "Parlons de Pierrot: nouvel entretien avec Jean-Luc Godard," Cahiers du cinéma no. 171 (October 1965), pp. 18-34, here p. 33. Translated as "Let's Talk about Pierrot," in idem., Godard on Godard, pp. 215-234, here pp. 229-230.

12 Jean-Luc Godard, interviewed by Jacques Bontemps, Jean-Louis Comolli, Michel Delahaye, Jean Narboni, "Lutter sur deux fronts: conversation avec Jean-Luc Godard," Cahiers du cinéma no. 194 (October 1967), pp. 12-26, 66-7o, here p. 16. Translated as "Struggle on Two Fronts: A Conversation with Jean-Luc Godard," trans. D.C.D., Film Quarterly, vol. 22 no. 2 (Winter 1968-1969), pp. 20-35, here p. 23 .

13 Ibid., p. 15 [p. 21]. 
Here, after critiquing the film semiology of Metz and Pasolini, Godard in effect anticipates the line of thought developed by Comolli in "Technique et idéologie": having recently purchased an editing table, the filmmaker notes that the very design of the apparatus enforces a Hollywood mode of continuity editing that inhibits any radical experimentation with montage in the vein of Eisenstein and Resnais, and he concludes from his experience that "it comes down to a simple economic gimmick that all by itself bears out a whole ideology. [...] If you're trying to make revolutionary movies on a reactionary editing table, you're going to run into trouble." He even, albeit semi-seriously, hints at the idea of writing a text for Cahiers:

The only thing I'd want to write for Cahiers now-it would take time to do it; I'm always running into something else to say on the subject-would be something about the ways to get film off to a complete new start. I'd discuss it in terms of the problems a young African would have to face. I'd tell him, "All right, your nation has just won its freedom. Now that you're free to have a film of your own, you and your comrades have been asked to get it started."14

This passage not only portends Godard's participation in the founding of Mozambican television after the country's independence in the late 1970s, it also heralds the prolonged concern for Third World, anti-imperialist cinema that will appear on the pages of Cahiers in the ensuing decade.

\section{8-1972: Alienation and Reconciliation}

If La Chinoise prophesied the rise of the Maoist movement of the early 1970s, which would engulf both Godard and Cahiers, the filmmaker's next work, Week-End, was the culmination of a cinematic crisis that had besieged Godard since at least his 1965 statement "Pierrot mon ami" (published in Cahiers), where he hauntingly called out: "the only great problem with cinema seems to me more and more with each film, to be when and why to start a shot and when and why to end it?"'5 Week-End, therefore, not only consisted of a rebarbative attack on contemporary bourgeois civilization and a definitive rupture with the commercial film industry (signaled by

14 Ibid., p. 25 [p. 29].

15 Jean-Luc Godard, "Pierrot mon ami," Cahiers du cinéma no. 171 (October 1965), pp. 17-18, here p. 17. Translated as "Pierrot My Friend," in idem., Godard on Godard, pp. 213-215, here p. 214. 
the "Fin de cinéma" title-card in the film's closing credits), it also consisted of a zero-point of cinematic montage, a tabula rasa on the basis of which Godard, in his ensuing Marxist-Leninist period, could experiment with new methods of "building" film images. ${ }^{16}$ This is recognized by Aumont in his review of the film, as the critic speaks of Week-End as a collection of "floating splinters, whose assemblage in a film evokes a submersed continent from which emerge only a few islands" whilst recognizing that "all these disjointed fragments are nonetheless crisscrossed underground by the same dialectical movement, one between softness and violence, tenderness and cruelty." The film's status as a "site for the encounter of two antagonistic formal categories, whose jolting coexistence defines the film's dynamic" - namely, the "cry" and the "murmur" - even leads Aumont to question the very status of film criticism, and he thus concludes his article by citing Blanchot's claim that "the critic is by nature on the side of silence."

Oudart conveyed similar ideas in his response to Godard's One Plus One, albeit expressed in that critic's favored semio-psychoanalytic terminology: while conceding that the problem posed by the film was "always the same: the relationship between political discourse and the political gesture, between erotic discourse and the erotic act, between creative practice and the work," he argued that One Plus One's "revolutionary action" consisted of "perceiving the poverty of the signified while discovering the play of the signifier, in the gaps of which can be traced out the promise of all possible meanings. ${ }^{18}$ Three months later, in September 1969, Aumont's report on the Berlin film festival was effusive in its enthusiasm for Le Gai Savoir (which screened for the first time after having been censored by the ORTF ${ }^{19}$ ), calling it the "first entirely theoretical film in the history of the cinema" while acknowledging that its conceptual density required "a more elaborate approach" than that allowed for by "the rapidity of a festival notice."20

A more detailed discussion of Godard's films had to wait for another three years-a period in which the director, either alone or as part of the "Groupe Dziga Vertov," completed no less than seven films and worked

16 For more on the role of montage in the work of Jean-Luc Godard, see Daniel Fairfax, "The Dialectics of Montage in Jean-Luc Godard (1965-1998)," MPhil thesis, University of Sydney, 2010. 17 Jacques Aumont, "Létang moderne (Week-End)," Cahiers du cinéma no. 199 (March 1968), pp. 59-6o.

18 Jean-Pierre Oudart, "Dans le texte (One Plus One)," Cahiers du cinéma no. 213 (June 1969), pp. 59-6o.

19 In a snub to the French censors, Cahiers published extracts from the soundtrack in issue no. 200-201, pp. 53-55.

20 Jacques Aumont, "Berlin 69," Cahiers du cinéma no. 215 (September 1969), pp. 41-46, here p. 46 
on several other unfinished projects. While the work of Straub, Jancsó, Buñuel, Kramer, Oshima and Rocha was discussed at length during this time, Godard's output was rarely mentioned in anything more than a cursory fashion. On the surface, it seems anomalous that Cahiers - at the height of its Marxist period, in which its stated mission of defending films that yielded a "critical de-construction of the system of representation" - should be so taciturn about a filmmaker whose work, more than that of any of his contemporaries, embodied precisely this goal. In fact, this situation was determined by Godard's political opposition to Cahiers' strategy of aligning itself with the PCF. By late 1968, the filmmaker identified closely with the Maoist movement in France, and his chosen collaborators in the years 1969-1972, including Jean-Henri Roger and Jean-Pierre Gorin, were drawn from the ranks of the pro-Chinese student left. In October 1968, shortly after the publication of Godard par Godard under Narboni's auspices, Godard took the step of removing his name from Cahiers' comité de rédaction (although his active participation in the committee was very limited in the first place). In a further embarrassment for the Cahiers editors, the inaugural issue of Cinéthique featured an interview with Godard in which the filmmaker vocally censured Cahiers for being subservient to its owner Filipacchi, presciently stating: "The problem for Cahiers du cinéma: nothing's changed. They are completely imprisoned — even if they knew what to write-unless they intend to stop the journal and write what they need to write. But then Filipacchi will stop them, because Filipacchi cannot publish the Cahiers marxistes-léninistes. ${ }^{21}$ Cinéthique continued to be the recipient of Godard's favor, screening his films at public events and publishing a statement on British Sounds at his behest. ${ }^{22}$ Elsewhere, the filmmaker criticized Comolli and Labarthe's documentary on the 1968 legislative elections, Les deux Marseillaises, for its ostensibly even-handed approach towards the major political parties, claiming that "this type of cinema represents the position of Le Monde, the position we call objective, an 'objectivity' that is the myth of liberal countries like England. Objectivity consists of showing both Jews and Hitler, for example: ten minutes of Hitler and then ten minutes of Jews. It does indeed seem objective, because they both have ten minutes, but it is meaningless." ${ }^{23} \mathrm{~A}$ further slight to Cahiers, which was in the midst of its

21 Godard, "Un cinéaste comme les autres," p. 12.

22 Jean-Luc Godard, "Premiers ‘sons anglais," Cinéthique no. 5 (September-October 1969), p. 14.

23 Jean-Luc Godard, interviewed by Alain Jouffroy, "Entretien," Le Fait public no. 2 (January 1969), repr. in Jean Collet (ed.), Jean-Luc Godard, $4^{\text {th }}$ ed. (Paris: Éditions Seghers, 1974), pp. 145-157, here p. 149. 
mammoth Eisenstein translation project, can even be perceived in the name of the "Groupe Dziga Vertov" (GDV). On the soundtrack to Vent d'Est and in numerous interviews given at the time, the work of the "revolutionary" Vertov was directly opposed to that of the "revisionist" Eisenstein. ${ }^{24}$

Cahiers nonetheless remained diplomatic when it came to Godard's work: prompted by queries made by numerous readers as to their relationship with the filmmaker, Comolli (in the same issue as Aumont's discussion of Le Gai Savoir) noted that the "beginning of a response" was already underway. It would have taken the form, he relates, of:

a long interview (or rather discussion) with Godard, on the subject of his departure from Cahiers, his reasons for doing so, and the declarations that he has made in various places about Cahiers and politics. This discussion (in which Delahaye, Narboni and myself participated) was recorded, transcribed and given back to Godard so that he could re-read it and correct his interventions (as we usually do). After long delays, Godard ended up telling us that he preferred for the interview not to be published. More's the pity. ${ }^{25}$

Comolli promised "something else, which is in the pipeline and which should appear in a coming issue," and advised readers to watch Un film comme les autres and British Sounds in the meantime. Advertisements in subsequent issues would list a special issue on Godard among the texts that "Cahiers will publish," but political considerations during the journal's rapprochement with the PCF prevented this dossier from being realized. The "Journal de la rédaction" for February 26, 1971 noted the need to include an "introductory text in order to clarify that we are not in agreement with the slandering of the party," and the dossier came to be jokingly known within the Cahiers team as "Luttes en litanie." ${ }^{26}$ Thus, despite his prolific output, throughout 1970 and much of 1971 public discussion of Godard's latest work was largely

24 See, for instance, Jean-Luc Godard and Jean-Pierre Gorin, interviewed by Marcel Martin, “Le Groupe ‘Dziga Vertov,” Cinéma 70 no. 151 (December 1970), repr. in Jean-Luc Godard, Godard par Godard vol. I: 1950-1984, ed. Alain Bergala (Paris: Cahiers du cinéma, 1998), pp. 342-350, p. 343.The distinction made between Vertov and Eisenstein is defended chiefly through their contrasting attitudes towards "bourgeois" fiction. On a strictly political level, there was no clear distinction between the two: both were enthusiastic supporters of the Bolsheviks in the early years of Soviet rule, and both would fall foul of the Stalinist censorship regime in the 1930 and 1940 s.

25 Jean-Louis Comolli, "Le cahier des lecteurs," Cahiers du cinéma no. 215 (September 1969), pp. 4-9, here p. 9 .

26 See de Baecque, Histoire d'une revue vol. II, p. 248. 
avoided by the journal, whose editors were hesitant about entering into the potential political minefield posed by the contradiction between Godard's Maoism and their own proximity to the PCF.

This impasse was broken in May 1971 by Bonitzer, who concluded his article "Réalité de la dénotation" with the claim that Groupe Dziga Vertov films such as Vent d'Est and Pravda provided the possibility for "overthrowing" the ideology overdetermining the preeminence of figuration in the cinema by offering a "political reading" that was "diagonal to the surface of representation" and was capable of opening the film up to "another scene" - that of political economy. ${ }^{27}$ The same issue published an interview the editors gave to Politique-Hebdo in which they argued that the recent work of the Groupe Dziga Vertov, and above all Luttes en Italie, represents "one of the rare attempts - referring explicitly to historical and dialectical materialism - to strive, with difficulty, to develop its specific (cinematic) practice on this basis. ${ }^{28}$ In a subtle shift away from its previous focus on Eisenstein, Cahiers also began to place more emphasis on publishing the theoretical writings of Dziga Vertov. Taken together, these gestures represented a significant attempt to orient the journal towards Godard's latest work. Its allegiance to the filmmaker was sealed in the October 1971 issue, when Cahiers' conversion to Maoism removed the final barrier to co-operation with the GDV. The journal heralded the shift by emblazoning its front cover with a still from Vladimir et Rosa, the most recent film made by Godard/Gorin at the time.

\section{On the Films of the Groupe Dziga Vertov}

In mid-1972, the long-promised dossier on the films of Godard's Marxist-Leninist period was finally published. Both the May-June and July-August 1972 issues engaged deeply with his work, treating, in parallel articles, the films made under the rubric of the "Groupe Dziga Vertov" (British Sounds, Pravda, Vent d'Est, Luttes en Italie and Vladimir et Rosa) and Godard/Gorin's higherprofile release Tout va bien. This endeavor was signed by the "Groupe Lou Sin d'intervention idéologique," whose very name (drawn from the early twentieth-century Chinese poet Lu Xun, a close confidante of Mao's in the

27 Pascal Bonitzer, “Réalité’ de la dénotation,” Cahiers du cinéma no. 229 (May 1971), pp. 39-41, here p. 41. Translated as “'Reality' of Denotation,” trans. Lindley Hanlon, in Browne (ed.), Cahiers du Cinéma vol. III, pp. 248-253. This article will be further discussed in Chapter 25 .

28 “Réponses à Politique Hebdo," Cahiers du cinéma no. 229 (May 1971), pp. 61-64, here p. 62. 
pre-revolutionary era) was obviously modeled on the moniker adopted by Godard/Gorin. The division of their corpus from the years 1969-1972 into two separate articles reflected Cahiers' recognition of the fundamental difference between Tout va bien and the preceding films: whereas the GDV films were seen as works of Marxist-Leninist theoretical practice, Tout va bien, with its larger budget, a more recognizable narrative and big-name stars (Yves Montand and Jane Fonda) was understood, in a Gramscian vein, as a "national-democratic" art work involving a conscious use of Brechtian dramatic devices and a strategy aimed at appealing to a wide audience. Indeed, the extent to which Tout va bien can even be included in JeanLuc Godard's filmography is open to debate: having been incapacitated in a motorcycle accident in 1971, the filmmaker later estimated his own contribution to the film to be roughly $5^{-6 \%}$, with Gorin largely responsible for writing and directing duties. ${ }^{29}$ Although Tout va bien pastiches earlier Godard films, the comparatively taut storyline and the tendentiousness of certain scenes is an anomalous departure from the rest of Godard's œuvre, and Cahiers is therefore justified in treating the GDV films separately to Tout va bien. Moreover, despite occupying similar political ground to Godard/ Gorin, differences in line remained between the journal and the filmmakers. Whereas Cahiers remained skeptical of the existing Maoist groupuscules, Godard and Gorin gravitated towards the "Mao-Spontex" current: close relations with Vive la révolution! (Vladimir et Rosa), and the ex-Gauche prolétarienne (Tout va bien) are discernible in their films, and Godard even wrote articles for the latter organization's newspaper J'accuse..$^{0}$ The Cahiers texts on Godard/Gorin's films also served a secondary purpose, to differentiate Cahiers' perspective on this attempt at Marxist filmmaking from the analysis already carried out by their peers at Cinéthique, who had written at length on the GDV's work both in their own journal and in other outlets such as the radical art journal $\mathrm{VH} 101 .^{31}$

The Groupe Lou Sin's two-part article “Le 'Groupe Dziga-Vertov': Sur les films du 'groupe'” offered a critical analysis of this corpus, charting Godard's passage from an "anarchistic" ideologico-political orientation in La Chinoise,

29 See Jean-Luc Godard, "Warum ich hier spreche...," translated into German by Gerhard Theuring, Filmkritik vol. 19 no. 9 (September 1975), pp. 420-429, here p. 421.

30 These articles were later reprinted in Nicole Brenez and Michael Witt (eds.), Jean-Luc Godard: Documents, pp. 174-177. The supermarket scene in Tout va bien was inspired by similar actions carried out by Gauche prolétarienne militants in the early 1970s.

$31 \quad$ See Gérard Leblanc, "Quelle avant-garde?," Cinéthique no. 7-8 (c. late 1970), pp. 72-92; Gérard Leblanc, "Sur trois films du Groupe Dziga Vertov," VH 101 no. 6 (1972), pp. 21-36; and Gérard Leblanc, "Lutte idéologique et Luttes en Italie," VH 101 no. 9 (Autumn 1972), pp. 73-99. 
Week-End and One Plus One to a "practice more rigorously determined by politics" in subsequent films. In the Groupe Lou Sin's view, the initial films of this post-1968 period nonetheless still bore traces of Godard's auteurist past. Un film comme les autres is criticized for its "'musical' conception of montage," which merely mimes the "anarchism and spontaneism of the movement," while the "empirical filming" of British Sounds and the unfinished One A.M. are also mostly disdained. These films do represent the beginning of the "principle of an ideological intervention of the voice-over on the image-track," but it is Pravda that is "the first systematic attempt to struggle on two heterogeneous fronts, which all the other films of the group will inscribe: the political struggle (against the bourgeoisie and revisionism) and the struggle on the front of the "philosophy of images and sounds." Pravda, Vent d'Est and Luttes en Italie thus constitute a veritable MarxistLeninist triptych: all three films adopt a tripartite structure that strives to mime the "practice-theory-transformed practice" dialectic posed by Mao. ${ }^{32}$ To a certain extent, however, this theoretical approach is symptomatic of the absence of any concrete political effect that the GDV films might have: unlike the Soviet cinema of the 1920s, France in the 1970s lacked a mass revolutionary party towards which Marxist filmmakers could orient their work. While Cahiers argue that the fact that the films forcefully pose the question "For whom? Against whom?" points to an overturning of "the concept of art that has reigned in Western metaphysics," they acknowledge that because these films operate outside of any "social or libidinal demand" (there is little public desire for such films, even amongst left-wing militants), they are instead more profitably situated within the sphere of theoretical research: "they explore a fallow ideological terrain, the relationship of representation to its political 'outside,' the inscription of this outside in the scene of representation, the material scene of images and sounds." ${ }^{33}$

Pravda, which treats the political situation of Czechoslovakia after the Soviet invasion, represents "the first time that a film has posed the necessity of philosophical work for transforming the practice of images and sounds" due to the fact that its own production of images is subject to critique on the

32 The Cahiers dossier included transcriptions of the bandes-sonores of all three films, documents that now constitute valuable pedagogical aids to a deeper understanding of these complex cinematic objects. See "Bande paroles de Luttes en Italie," Cahiers du cinéma no. 238-239 (MayJune 1972), pp. 40-57; "Bande paroles de Pravda," Cahiers du cinéma no. 240 (July-August 1972), pp. 19-30; and "Bande paroles de Vent d'est," Cahiers du cinéma no. 240 (July-August 1972), pp. 31-50. 33 The quotes from this paragraph are from the Groupe Lou Sin d'intervention idéologique, "Le 'Groupe Dziga-Vertov': Sur les films du 'groupe' [Part 1]," Cahiers du cinéma no. 238-239 (May-June 1972), pp. 34-39, here pp. 34-35. 
soundtrack. And yet it is deemed to be a "mechanistic, dogmatic film" whose "broad, reciprocally overdetermined political and philosophical contours are erroneous." The chief source of Pravda's theoretical deficiency derives from the "dogmatic error" of transposing Mao's distinction between "perceptual knowledge" and "conceptual knowledge" into a "metaphysics of the true and the false," one that derives from the film's chosen method of placing "just sounds" (Marxist texts) over "false images" (the "empirical" footage of Czechoslovakia shown in the film). The provenance of this philosophical solecism is understood to reside in "Althusser's thesis of the ideology/science cleavage, a thesis, revisionist in nature and drawn from bourgeois origins (Bachelard), that tends to occlude the class struggle within ideology," and it is accompanied by the film's chief political error, which consists of a "unilateral condemnation of the petty-bourgeois character of the revolt of the Czech people against Soviet social-imperialism" and an insufficient analysis of the nature of revisionism. ${ }^{34}$

Derived from a project to film a "Marxist Western" in Italy with the participation of Daniel Cohn-Bendit and Gian-Maria Volonte, Vent d'est is a critique of the errors of Pravda. Its key slogan- "Not a just image, just an image"35_ is an unmistakable retort to the earlier film's sterile dichotomy between "just sounds" and "false images." For Cahiers, the fact that the "weight of 'objective reality' of the referent" is no longer operative (the film is based on a fictional premise rather than documentary footage) means that the GDV is free to "interrogate the role of images and sounds in the material production of the ideological effects of all those films collected under the rubric of the Western." The result of a "takeover" at the editing stage by the crew's "Marxist-Leninist minority" (Gorin, essentially), Vent d'est's ambitious nature stems from its goal of producing "an overview of both the history of the cinema and the political history in which it is inscribed." It is marred, however, by "ideological errors of an ultra-left variety" - exemplified, in particular, by the penultimate sequence justifying acts of terrorist violence in the name of a "civil war between capital and labor." 36

While the "undeniably productive effects of irrationality" in Vent d'est led the Groupe Lou Sin to dub it the "richest and most accomplished" of

34 Ibid., pp. 36-37. The term "social-imperialism" referred to the Maoist notion that the USSR, in spite of its socialist economy, had become an imperialist power akin to those of the capitalist West.

35 Although this phrase is primarily associated with Godard, it was actually devised by Gorin. Godard admitted to this in a radio interview in 1989. See Jean-Luc Godard, interviewed by Noël Simsolo, À voix nues, France Culture, November 21, 1989.

36 Groupe Lou Sin, “Le 'Groupe Dziga-Vertov' [Part 1]," pp. 37-38. 
Godard-Gorin's films, Luttes en Italie was seen as the theoretical culmination of the Marxist-Leninist triptych. An overt attempt to "adapt" Althusser's theoretical text "Idéologie et les appareils idéologiques d'état" to the screen, the film is the most structured, systematic attempt made by the GDV to produce a "political/philosophical critique of the 'innocence of vision,' the myths of obvious truth [évidence] and immediate knowledge [connaissance], of direct access to the real, which are ideologically defined by empiricism and spontaneism (in the broader and narrower sense of this word)." Its mission of grappling with the ideological mechanisms that overdetermine "the sacrosanctity of film technique" is, it goes without saying, one that is shared by Cahiers. But it also represented the end point of this project: after Luttes en Italie, the GDV attempted to "connect with the masses in struggle" by working under the political direction of the Palestinian liberation movement in the unfinished Jusqu'à la victoire and realized a burlesque political sature in Vladimir et Rosa before the failed effort at a commercially oriented film with revolutionary politics in Tout va bien. The impasse reached by the GDV led the Cahiers writers to ponder whether it is even possible for audiences to receive in anything other than a hostile manner a political cinema divorced from the prevailing critical realism of bourgeois ideology: "If realism is suppressed," they speculate, then "(active, frank and trenchant) critique becomes intolerable." 37

This more general question is addressed in the second installment of the Groupe Lou Sin's text. The difficulty so often attested in comprehending the GDV's films is not, they claim, incidental. Nor does it arise from any ambiguity in the films, which are in fact stridently unambivalent and openly avow their own mechanisms of signification. Rather, it derives from the "apparent complexity of a model overriding the apparent simplicity of its referent." This gives rise to a double reproach: whereas the signified in the GDV films is frequently derided for being "too simplistic, rough, insultingly flat," their construction (the signifier) is equally faulted for being "too difficult, hermetic and elitist because complex." ${ }^{88}$ The injunction frequently issued by the GDV - to make films politically, rather than political films - thus results in a radical, conscious interrogation of the relationship between the filmic image and its referent. As the Groupe Lou Sin puts it, the question that the GDV films pose to the viewer is, in essence: "Is presentification equivalent to an assertion? Is a shot of a revolver (to use Christian Metz's famous example) 'groupe' (2)," Cahiers du cinéma no. 240 (July-August 1972), pp. 4-9, here p. 6. 
equivalent to the phrase 'Here is a revolver'?"39 Whereas conventional film practice answers resoundingly in the affirmative, even when the subjectmatter is overtly political in nature, the GDV's chief theoretical advance was their recognition of the constitutive heterogeneity of their films-in particular, the disjunction between image and soundtrack. Although initially understood dogmatically (i.e. Pravda's opposition between false images and just sounds), this factor is productively developed to the point that the tacit goal of the GDV's work is the production of a "just discourse on just some images [juste des images]."40

These two terms are, however, interrogated by Cahiers: a sound/text can never simply be the illustration of an image or vice versa. This would suppose the possibility of a direct translation between the two media, an equivalence between a shot of a revolver and the phrase "Here is a revolver." Rather, "what takes place is more complex and more perverse than what a simplistic theory of communication is able to grasp." Whenever a sound (discourse) is used to designate an image, a "supplementary sheath" is intercalated between "the utopian immediacy of the real and its transcription," which ends up avowing the fact that an image is not merely visual in nature but is the "exorbitant place-holder of the real" of which "this limitation of its power deprives us." The mere avowal of the notion that an image is "just an image" on the soundtrack, however, is insufficient for materialist film practice. So a further step is taken by the GDV, whose films "keep the spectator at a distance by exercising, in their stead, a knowledge of that which the images remain silent about" and not a knowledge in the monolithic form of "that's how it is." In Luttes en Italie, this passage is metaphorically relayed by the replacement of the black images of the first part of the film (whose presence is questioned by the voice-over in the second part) by "images of relations of production"-specifically, a proletarian operating a machine in a factory. But it is only by means of the voice-over that the viewer is to know that this image is to be read as an "image of relations of production." As Cahiers point out, it would in fact be more apt to denote such an image as one of "productive forces" rather than "relations of production" (two distinctly different concepts in Marxist political economy). More importantly, merely showing such an image gives little theoretical insight into the social functioning of the referent. Luttes en Italie thus remains on the level of a simulacrum of the "just" position of the spectator and is incapable of ascending to the level of Marxist theory as its authors intended. In spite of this limitation, Cahiers 
place great value on the works of the GDV: "It is because these films simulate the production of the knowledge that they exercise with the aid of the concepts of Marxism-Leninism that their object (their referent) is produced instead of being given, and problematic instead of being ambiguous. ${ }^{241}$

\section{Coup pour coup vs Tout va bien: Pathways to a Brechtian cinema}

Cahiers also devoted a lengthy and influential article to a comparison of Tout va bien and Coup pour coup by Marin Karmitz. ${ }^{42}$ The need to contrast the pair of films was self-evident. Coup pour coup and Tout va bien were released within two months of each other (February and April 1972 respectively), and they treat similar subject matter. Inspired by real-life "sequestrations" led by the Gauche prolétarienne, they both depict factory workers taking their boss hostage. Moreover, both films were directed by self-identified Maoists, and they provoked a significant amount of discussion in the French press, a critical corpus that Baudry symptomatically analyzed for Cahiers. ${ }^{43}$ The fact that Godard/Gorin's film was released soon after Karmitz's led to accusations of plagiarism, to which Gorin responded by saying "The phenomena unleashed by the class struggle are nobody's private property. A discussion will inevitably result, which will be extremely beneficial. People can see two types of cinema that amount to two different political positions with respect to the present context." ${ }^{44}$ He went on to critique Karmitz, arguing that "Coup pour coup is not a contemporary film for us. [...] It's The Salt of the Earth in 1972, and it is in this sense that we are led to attack it." ${ }^{\text {5 }}$

Cahiers followed the signal to attack Karmitz's film. Central to the distinction the journal made between the two films was the question of performance, and, with it, film aesthetics more broadly. To play the role

41 The quotes from this paragrpah are all from ibid., p. 9.

42 Despite not appearing in English translation, this article was one of the most influential Cahiers texts for "political modernist" film theory in 1970s Anglo-American academia. See, for instance, Julia Lesage, "Visual Distancing in Godard," Wide Angle vol. 1 no. 3 (March 1976), pp. 4-13; and Kristin Thompson, "Sawing through the Bough: Tout va bien as a Brechtian film," Wide Angle vol. 1 no. 3 (March 1976), pp. 38-51.

43 Pierre Baudry, "La critique et Tout va bien," Cahiers du cinéma no. 240 (July-August 1972), pp. 10-18.

44 Jean-Luc Godard and Jean-Pierre Gorin, interviewed by Marlène Belilos, Michel Boujut, Jean-Claude Deschamps and Pierre-Henri Zoller, "Pourquoi Tout va bien?: Entretien avec Jean-Luc Godard and Jean-Pierre Gorin," Politique-Hebdo no. 26, April 27 1972. Repr. in Godard, Godard par Godard vol. I, pp. 367-375, here p. 370.

45 Ibid., p. 371. 
of the striking factory workers, Karmitz utilized non-professional actors from working-class backgrounds, prompting a naturalistic acting style with its roots in the "kitchen-sink" realism of British filmmakers such as Tony Richardson and Karel Reisz, an aesthetic further accentuated by the use of on-location shooting and handheld camerawork. Godard/Gorin, by contrast, not only used stars as the leads (Yves Montand and Jane Fonda) but gave the proletarian roles to unemployed actors ${ }^{46}$ and adopted an aesthetic method borrowed liberally from Brecht's practice of the Verfremdungseffekt. Gorin defended this approach as an "attempt at producing materialist fictions," but he also cautioned against an overly schematic application of Brechtian theatrical techniques: "We cannot avoid starting over from a certain number of things Brecht highlighted. This said, we are doing something else entirely, we are making cinema. [...] In any case, the conception that Brecht had of ideology is historically dated."47

The reference to Brecht was indisputably of major importance for $\mathrm{Ca}$ hiers, but the journal's debt to the dramatist should not be overstated. ${ }^{8}$ In November 1970, Narboni asserted, on the occasion of the publication of a collection of Brecht's film-related texts titled Sur le cinéma, that "We will return more broadly to these fundamental texts, whose reinscription and reactivation in the contemporary political and theoretical context must be thought through. ${ }^{199}$ For the most part, however, Brecht's writings were less prominent as an influence than were the theories of Lacan, Althusser and Derrida in the years 1969-1971. 1972, by contrast, saw a flowering of interest in Brecht on the part of Cahiers, as the political efficacy of films gained in importance for the journal. In short, distanciation took the place of deconstruction. In addition to its pertinence to the GDV, Brecht's work was also discussed in relation to René Allio's Les Camisards, and Cahiers reprinted a French translation of his seminal article "Anmerkungen zur Oper Aufstieg und Fall der Stadt Mahagonny" as an appendix to the Groupe Lou Sin's discussion of Coup pour coup and Toutva bien..$^{50}$ Seen as the "ideological

46 In an interview with Le Nouvel Observateur, Godard complained that working-class non-actors had a tendency to "spontaneously" act like Jean Gabin. Cited in Groupe Lou Sin d'intervention idéologique, "Deux Films: Coup pour coup et Tout va bien," Cahiers du cinéma no. 238-239 (MayJune 1972), pp. 5-24, here p. 18.

47 Ibid., p. 373 .

48 This tendency is most flagrant in Lellis' Bertolt Brecht, Cahiers du cinéma and Contemporary Film Theory.

49 Jean Narboni, "Brecht et le cinéma," Cahiers du cinéma no. 225 (November-December 1970), p. 56 .

50 See Jacques Aumont, "Comment on écrit l'histoire," Cahiers du cinéma no. 238-239 (MayJune 1972), pp. 64-70; François Regnault, "Les Camisards et le film d'histoire," Cahiers du cinéma 
'key"' to Godard/Gorin's film, the Mahagonny text differentiates between the dramatic ("culinary") theater and Brecht's own epic ("didactic") approach to mise en scène, which Cahiers understood as mirroring the distinction between the "immutability of being" in idealist metaphysics and the notions of "change, rupture, the becoming of contradictions" inherent to dialectical materialism. The GDV was therefore commended for reviving the relevance of Brecht's theories in the present context, which "today have a decisive importance, ideologically and politically, in the field of cinema." $5^{1}$

Cahiers held the reverse attitude towards Coup pour coup: given its long-held antipathy towards cinematic naturalism and the hostility the journal had already shown to Camarades, a negative reaction to Karmitz's new film was to be expected; all the same, the immoderate harshness with which the Groupe Lou Sin denounced Coup pour coup is striking. The film had already been the subject of polemic among Maoist film critics on the pages of Écran 72: for Guy Hennebelle (who held a more utilitarian position on political cinema and detested the formal experimentation of Godard and Straub), Karmitz was "one of the most important French filmmakers of the day," and his work was "remarkable in its power and accuracy." ${ }^{22} \mathrm{By}$ contrast, Cinéthique's Gérard Leblanc condemned the film's spontaneism and opportunism (originating in the "erroneous line" of La Cause du peuple) and judged it to be a "resolutely passive, tail-endist" reflection of the class struggle in France. Cahiers, at this stage rather close to Cinéthique's political outlook (both journals adhered to Maoism but remained distant from the Mao-Spontex tendency), sided with Leblanc against Hennebelle but pushed his critique of Karmitz further. By remaining at the level of "bourgeois reportage," Coup pour coup is not only impregnated with a "spontaneist ideology" rooted in "the empiricist conception of knowledge," it is also "in the tailwinds of revisionism." 53 This is at once a far more serious charge to make against a self-identified Maoist filmmaker and one that seems counter-intuitive: much of Coup pour coup, after all, centers on the opposition between the revolutionary impetus of the textile workers and the class-collaborationist approach of the Party-aligned trade union leaders and would thus seem to constitute a political critique of the PCF. Cahiers argues, however, that the film's "anarcho-syndicalist" economism (excessively focusing on demands

no. 238-239 (May-June 1972), pp. 71-74; and Bertolt Brecht, "Notes sur l'opéra Grandeur et décadence de la ville de Mahagonny," Cahiers du cinéma no. 238-239 (May-June 1972), pp. 28-32.

51 Groupe Lou Sin, "Le 'Groupe Dziga Vertov' (2)," p. 5.

52 Guy Hennebelle and Gérard Lebanc, "Polémique à propos de Coup pour coup de Marin Karmitz," Écran 72 no. 4 (April 1972), pp. 41-44, here pp. 41, 43.

53 Groupe Lou Sin, "Deux films: Coup pour coup, Tout va bien," p. 9. 
for higher wages to the exclusion of other political issues) in fact represents a strain of revisionism that, dormant under the electoralist strategy initiated by Maurice Thorez, has recently resurfaced due to the resurgence of class struggle in France after 1968.

This political defect is accompanied by an "ultra-democratic" naïveté in the filmmaking process (its goal of "giving a voice to the workers") and a blind faith in the virtues of naturalist "authenticity" in the depiction of proletarian characters. The idea, for instance, that professional actors were capable of playing bosses and union leaders but not working-class characters was judged to be a "workerist" fantasy that was contemptuous of both the workers and the actors. By contrast, it is precisely because Yves Montand could perfectly well incarnate a worker that Godard/Gorin refused to give the actor such a role. More broadly, their work entailed not reducing or effacing the "contradictions between the economy of the film and the politics of its authors" but rather "exasperating them to make them productive," and it is this that allows the film to denote the contradictory position of bourgeois intellectuals in the class struggle and to carry out a "correct analysis" of revisionism, which is, at bottom, the "penetration of bourgeois ideology in the working-class." Moreover, in opposition to Karmitz's naturalism, which has the goal of a "restitution' of lived experience," Godard-Gorin's depiction of a factory strike is a "crystallization" or "condensed reflection" of the state of political struggle in France, and it is therefore able to confront the question of revisionism and class conflict in a way that Coup pour coup avoids. Whereas in Coup pour coup, "the accent is placed on affectivity," Tout va bien centers on questions of "process and logic." Hence, while the two films share a common referent (factory sequestrations in contemporary France), there is nonetheless for Cahiers "an antagonism as far as the formal line adopted in each film is concerned. ${ }^{54}$ Although the journal had made a marked political shift since the "Cinéma/idéologie/critique" editorial, its emphasis on formal criteria as the decisive factor in judging a film's ideological status remained, at least in mid-1972, intact.

In spite of a valuable formal analysis of both films, which rightly promoted Tout va bien as the more revolutionary work, Cahiers' lengthy comparison is marred by the excessive vigor with which Coup pour coup is attacked. If its conservative approach to performance, narrative, mise en scène and other formal questions is justifiably critiqued, the inference that the film shares in the political "revisionism" of the PCF is much more difficult to sustain, and the logic of Cahiers' argument in attempting to defend this stance becomes 
patently convoluted. Indeed, in November 1973, while still under the sway of its "Front culturel" period and thus more open to the instrumentalist notion of political art espoused by Karmitz, the journal retracted its claims about his film. Responding to a letter from Hennebelle-who maintained his strident opposition to Cahiers' earlier "intellectualist, aesthetic ultraleftism" but applauded its recent evolution-Bonitzer broadly defends the journal's positions but says of the Groupe Lou Sin article that "it was false and sectarian to write that Coup pour coup was a film 'in the tailwinds of revisionism'-in the tailwinds of reality, yes, but the reality which it reflected was not revisionist, since it was a question of a revolt against the bosses and the revisionists." The critic goes on to admit that Cahiers' response to the film should have considered its origins as a critique of Camarades and a reflection on The Salt of the Earth (which is itself, in Bonitzer's view, "a profound film that we ought to analyze").55

\section{The "Therrorized": Cahiers du cinéma and the later Godard}

This rectification notwithstanding, Godard's work retained its primacy for the journal. ${ }^{6}$ As with his shift to Maoism at the turn of the decade, Godard's turn away from revolutionary politics preceded and was an influence on Cahiers' own political evolution over the course of the 1970s. As Bonitzer would later observe, Godard's films were a "barometer of the atmosphere of the time," 57 and the Cahiers writers could not help but be swayed by his change in views. As early as Godard/Gorin's late 1972 trip to North America to tour Tout va bien and Letter to Jane on the college circuit, their Marxism-Leninism had already been adulterated by a reading of Deleuze/ Guatarri's Anti-OEdipe. ${ }^{8}$ By the time Godard completed his next film, Ici et

55 Pascal Bonitzer and Guy Hennebelle, "Pratique artistique et lutte idéologique," Cahiers du cinéma no. 248 (c. late 1973), pp. 53-64, here p. 64.

$5^{6}$ Although it was recanted, the journal's opposition to Karmitz perhaps reflected a reliable intuition: Coup pour coup was the last film Karmitz directed, and he would later go on to become one of the wealthiest moguls in the French film industry, founding the MK2 cinema chain, before acting as an advisor to the Sarkozy government in the 2000 s.

57 Pascal Bonitzer, "Juste une image," Cahiers du cinéma no. 323-324 (April-May 1981), pp. 15-19, here p. 19 .

$5^{8}$ Interviews recorded at this time attest to this blend, with Godard/Gorin referring to capitalism as a "schizophrenic machine" and discussing the role of "flows of desire" in the cinema. See Jean-Luc Godard, interviewed by Ken Mate, Russell Campbell, Louis Alvarez and Maureen Turim, “Let's see where we are: Interview with Jean-Luc Godard and Jean-Pierre Gorin," Velvet Light Trap no. 9 (Summer 1973), pp. 30-36, here p. 33 . 
ailleurs in 1975 (a re-working of the footage shot in Palestine for Jusqu'à la victoire), Anne-Marie Miéville had replaced Gorin as his main collaborator, and he was now interrogating many of the basic tenets of politically engaged cinema that had governed his earlier work - a preoccupation that was shared by Cahiers in the mid-1970s. Godard's trilogy of "post-militant" films, made in the Sonimage studios in Grenoble (with Numéro deux and Comment ça va? following on from Ici et ailleurs), affected the Cahiers critics deeply. Serge Daney recalls vomiting from the emotional impact of a private screening of Ici et ailleurs in Godard's workshop, ${ }^{59}$ and the films incited a flurry of articles in the journal, with newcomers such as Thérèse Giraud, Alain Bergala, Serge Le Péron and Louis Skorecki joining more experienced members of the team in discussing Godard's work. ${ }^{60}$

In parallel with the "ultraviolet" work of Straub-Huillet, Godard's Sonimage films were held up by Bonitzer as occupying an "infrared" position in the spectrum of modern cinema. Whereas Straub "turns back the current of the cinema" by using theater, music and opera as source material, Godard pushes film towards its "infra-cultural avatars" (militant filmmaking, television, video). ${ }^{61}$ Both directors start out with the same principle: "all the cinema is a lie." At the same time, and paradoxically, both are united (and divided) by their "respect for the real." Bonitzer immediately recognizes the potentially counter-intuitive nature of this claim: after all, he concedes, "did we not kill ourselves, at Cahiers, in spreading the word that the 'respect for the real' was the worst form of idealism?" He clarifies, however, that "everything depends on what is understood by 'respect' and 'real"” and asserts: "First of all, the real is not there to be seen. This is what Godard and Straub teach us, working in the opposite direction to that of the mass media." ${ }^{62}$ Rather the real is what is hidden, it is the hors-champ, that which is covered by the black screens of Numéro deux and Ici et ailleurs (described as a "black hole from which the despotic voice of the director can be heard"). Central to the work of Godard and Straub/Huillet is a practice that does not conceive of representation as

59 Daney, L'Exercice a été profitable, Monsieur, p. 252. In the same text he also reveals that "Ici et ailleurs must be the film that I have shown the most often (from New York to Damascus, from Oporto to Brussels)." Ibid., p. 303.

6o See Serge Le Péron, "Numéro Deux: entre le zéro et l'infini, Cahiers du cinéma no. 262-263 (January 1976), pp. 11-13; Serge Toubiana, "Le hasard arbitraire," Cahiers du cinéma no. 262-263 (January 1976), pp. 15-19; Thérèse Giraud, "Retour du même," Cahiers du cinéma no. 262-263 (January 1976), pp. 20-24; and Louis Skorecki, “Questions/Réponses," Cahiers du cinéma no. 262-263 (January 1976), pp. 28-29.

61 Bonitzer, "J.-M.S. et J.-L.G.," p. 5.

62 Ibid.pp. 6-7. 
a "system" or a "metaphysics" but as "nourishment offered to the eye for the real, a representation which, in all senses of the word, cooks [cuisine] the real, sacrifices it by producing it for the eye." ${ }^{\prime 3}$ On the basis of this discussion, Bonitzer sets Godard's technique of déchaînement (unlinking) against the détournement of the situationists: the latter is a "second-degree regime" and, in the end, is nothing but an advertising technique, which only serves to confirm the receivers (the intellectual classes) in the self-estimation of their own intelligence. By contrast, Godard and the Straubs "sovereignly despise all second-degree regimes, all metalanguage," and this is the root cause of the vociferous contempt that their films so often provoke. ${ }^{64}$

Daney's response to Numéro deux and Ici et ailleurs also drew on an implicit alliance between Godard and Straub/Huillet: two issues after the "Straubian pedagogy" of his article on Moses und Aron ("Un tombeau pour l'œil"), he returned with a "Godardian pedagogy." The title of this text, "Le thérrorisé" (the therrorized) plays on the homophony between the words "theorize" and "terrorize" in French, and the article itself centers on Daney's idiosyncratic concept of the discours du manche. ${ }^{65}$ In spite of all the differences between Godard's Sonimage work and the GDV-era films, Daney sees a striking element shared by them: the role of pedagogy. The discours $d u$ manche is an authoritative register of speech whose assertions cannot be argued with, and all of Godard's post-1968 films are dominated by the "positive content" that it conveys. While this content may vary (MarxistLeninist politics in Pravda and Vent d'est, Althusserian theory in Luttes en Italie, Brecht and the role of intellectuals in revolutionary struggle in Tout va bien, radical feminism in Numéro deux), the discours du manche remains unchanged: "it always comes from above and is quick to lay blame." ${ }^{66}$ It is also invariably borne by the voice of a woman, who often speaks in a declamatory or even hectoring tone ("the voice which reprimands, resumes, advises, teaches, explains, theorizes and even $t(h)$ errorizes is always a

63 Ibid., pp. 8-9.

64 Ibid., pp. 9-10.

65 Serge Daney, "Le thérrorisé (pédagogie godardienne)," Cahiers du cinéma no. 262-263 (January 1976), pp. 32-40. Translated as “The T(h)errorized (Godardian Pedagogy)," trans. Bill Krohn and Charles Cameron Ball, https://www.diagonalthoughts.com/?p=1620 (accessed January 1, 2021). In a footnote to their translation, Krohn/Ball note that the term discours du manche (literally, the "discourse of the handle") is "better left untranslated, and explain it by writing, "Implicit in this Daneyism is the idea of 'being on the right side' (the handle by which the tool must be grasped), and, of course, the image of the phallus. It also glances at Lacan's term for the language of the obsessional neurotic: le Discours du Maître (the Discourse of the Master)."

66 Ibid., p. 35 . 
woman's voice"). Such a technique is labeled a "strange feminism," since "it is not clear that feminist demands are satisfied with this 'place' the men no longer want, with this 'power' which they've let drop." ${ }^{\prime 7}$

The uniqueness of Godard's cinema is, however, his undecidable relationship with this "good" discourse: he seems to be speaking from a position of conviction in this discourse's message at the same time as critiquing it, subverting it, or simply mocking it. With the semi-parodic nature of their voice-over commentaries, the GDV films already attested to this undecidabality, but the film that works most with this contradiction is Ici et ailleurs. For Daney: "It is clear that the film's self-interrogation (the kind of disjunction it effects in every direction: between here and elsewhere, images and sounds, 1970 and 1975) is possible and intelligible only because, early on, the syntagma 'Palestinian revolution' already functions as an axiom.. ${ }^{68}$ The key scene of Ici et ailleurs, and one that affected Daney deeply, comes late in the film, when PLO fighters are shown discussing strategy on a riverbank. Godard relates that the translators on the shoot had not rendered their conversation accurately, transmitting their words as blithe revolutionary homilies, when in fact the fedayeen were complaining to their commander about being sent to their certain death on a suicide mission. A few months after the filming, Black September took place, and all the individuals on screen perished at the hands of Jordanian troops. It was several years later that Godard had the idea of freshly translating the resistance fighters' actual words, only to find out that he was watching dead men speak about their own impending demise, a fact he had not originally perceived because, as a formula repeated throughout the film puts it, "the sound was too loud" - that is, the forced optimism of the revolutionary discourse had drowned out any ability to comprehend the reality of the political situation. For Daney, then, the chief task involved in making Ici et ailleurs amounts "quite simply, to translating the soundtrack, making sure one can hear what is said, or better, that one listens to it." ${ }^{\prime 69}$

Ici et ailleurs' interrogation of political engagement in the context of the image-sound relationship made it one of the most important films of the decade for Cahiers, and the journal's editors frequently invoked the maxim that "the sound is too loud" when discussing militant cinema. A more direct collaboration between the journal and the filmmaker arose on the occasion of Cahiers' 3 oo $^{\text {th }}$ issue in May 1979, editorial control of which was given to Godard. The filmmaker used the opportunity to deliver a dense work of 
text/image collage incorporating fragments of an interview given to Cahiers and a 50-page dossier on his aborted project to make a television series in the newly independent country of Mozambique. In a letter to Daney and Toubiana that appears at the beginning of the special issue, Godard writes that "what it is possible to do does not correspond to the real conditions in which a film journal is bought and read, and we must take this into account." He describes what follows as "a few random documents from my drawers which could have been part of the events that we would have chosen to review [passer en revue], on the condition that we would prefer to see things clearly rather than know about them deeply."70

In retrospect, the collages appearing in this special issue strikingly anticipate the montage practices later developed by Godard in Histoire $(s)$ du cinéma and other works of the 1980 s to 2000 s. Indeed, issue no. 300 of Cahiers was published at roughly the same time that Godard was honing his discourse on the history of the cinema in a lecture series in Montreal. ${ }^{71}$ Several Cahiers alumni not only defended this work, they were also closely involved in its creation. Daney, for instance, was interviewed at length for episode $2 \mathrm{~A}$ of Histoire(s), and his ideas on the transformation of visual culture in the late twentieth century exhibit strong parallels with the views expressed by Godard, whose central claim in Histoire $(s)$ is that the cinema effectively "died" after World War II due to its inability to represent the Nazi concentration camps..$^{2}$ Aumont, meanwhile, who was able to view provisional versions of Histoire $(s)$ before it was completed, was the first figure to dedicate a monograph to the work, Amnésies in $1999 .{ }^{73}$ More broadly, the influence that Godard's œuvre has had on the Cahiers writers over the last fifty years is so diffuse that it pervades a wide range of their theoretical, aesthetic and political concerns, and it continues up to the present day. In 2011, for instance, Narboni published a rhapsodic tribute to Godard's Film socialisme in Trafic. Here, the former Cahiers critic notes that the film's title-which unmistakably evokes Godard's Marxist period — is disconcertingly equivocal, since Godard

70 Cahiers du cinéma no. 300 (May 1979, special issue), p. 3.

71 See Jean-Luc Godard, Introduction à une véritable histoire du cinéma, ed. Joël Farges (Paris: Éditions Albatros, 1980).

72 Extracts from the dialogue between Daney and Godard were also printed in Libération and, later, in Cahiers. See Serge Daney and Jean-Luc Godard, "Histoire(s) du cinéma: Godard fait des histoires," Libération, December 26, 1988. Repr. in Jean-Luc Godard, Godard par Godard vol. II: 1984-1998, ed. Alain Bergala (Paris: Cahiers du cinéma, 1998), pp. 161-174; and Serge Daney and Jean-Luc Godard, “Dialogue entre Jean-Luc Godard et Serge Daney," Cahiers du cinéma no. $5^{13}$ (May 1997), pp. 49-55.

73 Jacques Aumont, Amnésies (Paris: P.O.L., 1999). 
chooses to translate socialism as "generosity' or 'hope' or even 'openness"' and refrains from any more precise definition of the term. ${ }^{74}$ But Narboni also points out that the voyage charted by the film around the Mediterranean recalls landmarks of 1960 cinema that were vigorously defended by Cahiers: not only Godard's own Le Mépris but also Sollers/Pollet's Méditérranée, whose fragmentary, symphonic approach to montage anticipated much of Godard's own practice in Film socialisme. Resonances, therefore, of Godardian "political modernism" from the 196os and 1970s can still be felt in the cinema-and, it is worth adding, the film criticism—of the 2010 s.

\section{Works Cited}

Jacques Aumont, "L'étang moderne (Week-End)," Cahiers du cinéma no. 199 (March 1968), pp. 59-60.

—, "Berlin 69," Cahiers du cinéma no. 215 (September 1969), pp. 41-46.

—, "Comment on écrit l'histoire," Cahiers du cinéma no. 238-239 (May-June 1972), pp. 64-70.

—, Amnésies (Paris: POL, 1999).

Pierre Baudry, "La critique et Tout va bien," Cahiers du cinéma no. 240 (JulyAugust 1972), pp. 10-18.

Pascal Bonitzer, "Réalité' de la dénotation," Cahiers du cinéma, no. 229 (May 1971), pp. 39-41. Translated as "Reality' of Denotation," trans. Lindley Hanlon, in Nick Browne (ed.), Cahiers du Cinéma vol. III: 1969-1972 The Politics of Representation (London: BFI, 1990), pp. 248-253.

—, "Juste une image," Cahiers du cinéma no. 323-324 (April-May 1981), pp. 15-19.

—, interviewed by Stéphane Bouquet, Emmanuel Burdeau and François Ramone, "Nos années non-légendaires: Entretien avec Pascal Bonitzer," in Emmanuel Burdeau (ed.), Cinéma 68 (Paris: Cahiers du cinéma, 2008 [1998]).

Jacques Bontemps, "Une libre variation imaginative de certains faits (La Chinoise)," Cahiers du cinéma no. 194 (October 1967), pp. 30-34.

Bertolt Brecht, "Notes sur l'opéra Grandeur et décadence de la ville de Mahagonny," Cahiers du cinéma no. 238-239 (May-June 1972), pp. 28-32.

Jean-Louis Comolli, "À rebours? (Alphaville)," Cahiers du cinéma no. 168 (July 1965), pp. 86-87.

—, "Le point sur l'image (La Chinoise)," Cahiers du cinéma no. 194 (October 1967), pp. 29-30.

—, "Le cahier des lecteurs," Cahiers du cinéma no. 215 (September 1969), pp. 4-9. 
Serge Daney, “Le thérrorisé (pédagogie godardienne)," Cahiers du cinéma no. 262263 (January 1976), pp. 32-40. Translated as "The T(h)errorized (Godardian Pedagogy)," trans. Bill Krohn and Charles Cameron Ball, https://www.diagonalthoughts.com/?p=1620 (accessed January 1, 2021)..

—, La Rampe (Paris: Cahiers du cinéma, 1983).

—, L'Exercice a été profitable, Monsieur (Paris: P.O.L., 1993).

—, Persévérance (Paris: P.O.L., 1993). Translated as Postcards from the Cinema, trans. Paul Douglas Grant (Oxford: Berg, 2007).

— and Jean-Luc Godard, “Histoire(s) du cinéma: Godard fait des histoires," Libération, December 26, 1988. Repr. in idem., Godard par Godardvol. II: 1984-1998, ed. Alain Bergala (Paris: Cahiers du Cinéma, 1998), pp. 161-174.

—, "Dialogue entre Jean-Luc Godard et Serge Daney," Cahiers du cinéma no. 513 (May 1997), pp. 49-55.

Daniel Fairfax, "The Dialectics of Montage in Jean-Luc Godard (1965-1998)," MPhil thesis, University of Sydney, 2010.

Thérèse Giraud, "Retour du même," Cahiers du cinéma no. 262-263 (January 1976), pp. 20-24.

Jean-Luc Godard, "Frère Jacques," Cahiers du cinéma no. 106 (April 196o), p. 4. Translated as "Frère Jacques," in idem., Godard on Godard, trans. and ed. Tom Milne (New York: Da Capo Press, 1972), pp. 163-164.

—, interviewed by Jean Collet, Michel Delahaye, Jean-André Fieschi, André S. Labarthe and Bertrand Tavernier, "Jean-Luc Godard," Cahiers du cinéma no. 138 (December 1962), pp. 21-39. Translated as "Interview with Jean-Luc Godard," in idem., Godard on Godard, trans. and ed. Tom Milne (New York: Da Capo Press, 1972), pp. 171-196.

—, "Pierrot mon ami," Cahiers du cinéma no. 171 (October 1965), pp. 17-18. Translated as "Pierrot My Friend," in idem., Godard on Godard, trans. and ed. Tom Milne (New York: Da Capo Press, 1972), pp. 213-215.

—, interviewed by Jean-Louis Comolli, Michel Delahaye, Jean-André Fieschi and Gérard Guégan, "Parlons de Pierrot: nouvel entretien avec Jean-Luc Godard," Cahiers du cinéma no. 171 (October 1965), pp. 18-34. Translated as "Let's Talk about Pierrot," in idem., Godard on Godard, trans. and ed. Tom Milne (New York: Da Capo Press, 1972), pp. 215-234.

—, interviewed by Jacques Bontemps, Jean-Louis Comolli, Michel Delahaye, Jean Narboni, "Lutter sur deux fronts: conversation avec Jean-Luc Godard," Cahiers du cinéma no. 194 (October 1967), pp. 12-26, 66-70. Translated as "Struggle on Two Fronts: A Conversation with Jean-Luc Godard," trans. D.C.D., Film Quarterly, vol. 22 no. 2 (Winter 1968-1969), pp. 20-35.

—, interviewed by J.-P.C. and G.L., "Un cinéaste comme les autres," Cinéthique no. 1 (c. January 1969), pp. 8-12. 
—, interviewed by Alain Jouffroy, "Entretien," Le Fait public no. 2 (January 1969), repr. in Jean Collet (ed.), Jean-Luc Godard, $4^{\text {th }}$ ed. (Paris: Éditions Seghers, 1974), pp. 145-157.

—, "Premiers ‘sons anglais," Cinéthique no. 5 (September-October 1969), p. 14.

_ , "Warum ich hier spreche...," translated into German by Gerhard Theuring, Filmkritik vol. 19 no. 9 (September 1975), pp. 420-429.

—, Introduction à une véritable histoire du cinéma, ed. Joël Farges (Paris: Éditions Albatros, 1980).

—, interviewed by Noël Simsolo, À voix nues, France Culture, November 21, 1989.

— and Jean-Pierre Gorin, interviewed by Marcel Martin, "Le Groupe 'Dziga Vertov," Cinéma 70 no. 151 (December 1970), repr. in Jean-Luc Godrd, Godard par Godard vol. I: 1950-1984, ed. Alain Bergala (Paris: Cahiers du Cinéma, 1998),, pp. 342-350.

— and Jean-Pierre Gorin, interviewed by Marlène Belilos, Michel Boujut, JeanClaude Deschamps and Pierre-Henri Zoller, "Pourquoi Tout va bien?: Entretien avec Jean-Luc Godard and Jean-Pierre Gorin," Politique-Hebdo no. 26, April 27 1972. Repr. in Jean-Luc Godrd, Godard par Godard vol. I: 1950-1984, ed. Alain Bergala (Paris: Cahiers du Cinéma, 1998), pp. 367-375.

Groupe Dziga Vertov, "Bande paroles de Luttes en Italie," Cahiers du cinéma no. 238239 (May-June 1972), pp. 40-57.

__, "Bande paroles de Pravda," Cahiers du cinéma no. 240 (July-August 1972), pp. 19-30.

—, "Bande paroles de Vent d'est," Cahiers du cinéma no. 240 (July-August 1972), pp. 31-50.

Groupe Lou Sin d'intervention idéologique, "Deux Films: Coup pour coup et Tout va bien," Cahiers du cinéma no. 238-239 (May-June 1972), pp. 5-24.

—, "Le ‘Groupe Dziga-Vertov': Sur les films du 'groupe," Cahiers du cinéma no. 238239 (May-June 1972), pp. 34-39, and Cahiers du cinéma no. 240 (July-August 1972), pp. 4-9.

Guy Hennebelle and Gérard Lebanc, "Polémique à propos de Coup pour coup de Marin Karmitz," Écran 72 no. 4 (April 1972), pp. 41-44.

Serge Le Péron, “Numéro Deux: entre le zéro et l'infini, Cahiers du cinéma no. 262-263 (January 1976), pp. 11-13.

George Lellis, Bertolt Brecht, Cahiers du Cinéma and Contemporary Film Theory (Ann Arbor: UMI Research Press, 1982).

Julia Lesage, “Visual Distancing in Godard,” Wide Angle vol. 1 no. 3 (March 1976), pp. 4-13.

Jean Narboni, "Notes sur 2 ou 3 choses que je sais d'elle," Cahiers du cinéma no. 186 (January 1967), pp. 32-33. Translated as "Notes on Two or Three Things...," Cahiers du Cinéma in English no. 10 (May 1967), p. 31.

— (ed.), Godard par Godard (Paris: Pierre Belfond, 1968). 
—, "Brecht et le cinéma," Cahiers du cinéma no. 225 (November-December 1970), p. 56 .

—, "Film socialisme de Jean-Luc Godard, Trafic no. 8o (Winter 2011), pp. 53-61.

—, "Dans le texte (One Plus One)," Cahiers du cinéma no. 213 (June 1969), pp. 59-6o.

La Rédaction, "Réponses à Politique Hebdo," Cahiers du cinéma no. 229 (MayJune 1971), pp. 61-64.

François Regnault, "Les Camisards et le film d'histoire," Cahiers du cinéma no. 238239 (May-June 1972), pp. 71-74.

Louis Skorecki, “Questions/Réponses," Cahiers du cinéma no. 262-263 (January 1976), pp. 28-29.

Kristin Thompson, "Sawing through the Bough: Tout va bien as a Brechtian film," Wide Angle vol. 1 no. 3 (March 1976), pp. 38-51.

Serge Toubiana, "Le hasard arbitraire," Cahiers du cinéma no. 262-263 (January 1976), pp. 15-19. 



\title{
11. Cahiers du cinéma in the "Post- gauchiste" Era: 1973-1981
}

\begin{abstract}
After the collapse of the Front culturel révolutionnaire and the departure of Jean-Louis Comolli and Jean Narboni as editors in 1973, Cahiers $d u$ cinéma was on the verge of collapse. The journal was rescued by the efforts of Serge Daney and Serge Toubiana, who shifted it away from Maoism and towards a more open political orientation. For much of the 1970s, Cahiers remained firmly on the far left, but it oriented itself toward new political movements (Third World solidarity, feminism, anti-racism) and theoretical trends. Key interviews with Gilles Deleuze, Jacques Rancière, Marc Ferró and, most prominently, Michel Foucault were published, while the Cahiers critics attacked the "retro cinema" trend they saw emerging in this decade. By 1981, however, critical consensus within the journal had frayed again, and Serge Daney's departure marked a conclusive return to the-political and cinematic-mainstream for Cahiers.
\end{abstract}

Keywords: Cahiers du cinéma, Serge Daney, anti-imperialist cinema, retro cinema, Michel Foucault

\section{After Avignon: Resuscitating Cahiers under Daney and Toubiana}

The debacle of the 1973 Avignon conference represented the opportunity for the editors discontented with the situation to overturn the "Pakradouni line." Bonitzer, Toubiana, Kané, Daney and Oudart vacationed together at Avignon after the festival, where, at the initiative of Toubiana, conspiratorial discussions took place about the journal changing direction, which continued in his apartment upon their return to Paris. ${ }^{1}$ On

1 See Toubiana, Les Fantômes du souvenir, p. 61; and De Baecque, Histoire d'une revue vol. II, p. 262. This account has been corroborated in interviews with Toubiana (April 29, 2014) and Bonitzer (April 30, 2014).

Fairfax, D., The Red Years of Cahiers du Cinéma (1968-1973). Volume I: Ideology and Politics. Amsterdam: Amsterdam University Press, 2021 DOI 10.5117/9789463728508_CH11 
October 21, the editorial team met at the journal's offices on the rue des Petits-Champs. Pakradouni remained optimistic about the prospects for the Front culturel and advocated the subordination of cultural work to political struggle-essentially, the voluntary abandonment of Cahiers as a film journal. But he was alone in this perspective. For Bonitzer, the time had come to "shake off the Maoist ideological game that had been the line at Cahiers for motivations that had absolutely nothing to do with the cinema. [...] Simply put, we needed to fire [Pakradouni]." Countering Pakradouni, he and Toubiana proposed that Cahiers return to its "specificity" as a film journal, but a clear decision on the matter was deferred. The second half of 1973 saw Cahiers in limbo: only a single, undated issue was published, and the disparate nature of its contents betrayed the absence of any clear line governing the journal's work at this time: reports on Avignon which continued to speak in Maoist jargon were accompanied by texts that represented a less rigid approach to the cinema. The first of Daney's "Fonction critique" series began a fresh interrogation of the contemporary role of film criticism, ${ }^{3}$ while Pascal Kané furnished a practical example of a film review freed from stifling dogmatism in his take on Billy Wilder's comedy Avanti. Noting that the palpable "anti-Americanism" of Wilder's film profits from remaining within the "limits fixed by the Hollywood system," Kané returned to the Young Mr. Lincoln mode of addressing studio-produced cinema in arguing that "the critical stake of the film is [...] the elucidation, in a narrative system that is still very coherent, of a profound contradiction between the emergence of increasingly insistent and present ideological themes and the manner in which filmic discourse [...] appropriates them." ${ }^{n}$

After months of tension, the dissension within Cahiers was settled at an editorial meeting on February 7, 1974, where Pakradouni was decisively sidelined. Toubiana, in particular, was merciless in his attack, with the "Journal de la rédaction" reporting him as saying "What right do you have to pass from one front to the other, from cinema to politics? [...] In the end, your problem, your pleasure, is political economy. So hasn't it been a total mistake for you to join Cahiers?"5 Pakradouni left the journal shortly

2 Interview with Pascal Bonitzer, April 30, 2014.

3 Serge Daney, "Fonction critique," Cahiers du cinéma no. 248 (c. late 1973), pp. 39-40. Translated as "The Critical Function," trans. Annwyl Williams, in Wilson (ed.), Cahiers du Cinéma vol. IV, pp. 56-72.

4 Pascal Kané, "Sur Avanti," Cahiers du cinéma no. 248 (c. late 1973), pp. 45-48, here p. 48. Translated as "On Avanti," in Wilson (ed.), Cahiers du Cinéma vol. IV, pp. 273-276, here p. 275.

5 Cited in de Baecque, Histoire d'une revue vol. II, pp. 262-263. 
afterwards, "disappearing overnight" in Aumont's words. ${ }^{6}$ Months later, he sent a letter to Cahiers (in the name of himself and other ostensible "members of the ex-Animation Commission of Cahiers"), which accused the journal of succumbing to "petty-bourgeois liberalism" and advocated the "constitution of the authentic Communist Party and the elaboration of a communist program posing the question of proletarian revolution in France." His former colleagues reacted with considerable bemusement to the missive. ${ }^{7}$

This change of course prompted the question of new leadership for Cahiers. Comolli and Narboni both felt they could no longer continue as editors, with Narboni speaking of the period as one of "almost depressive disenchantment," ${ }^{8}$ and both soon turned to filmmaking projects. Aumont's responsibility for the journal's administrative tasks made him the presumed heir to Comolli/Narboni, but he too was increasingly involved in another sphere of film culture: teaching at the cinema studies department at Paris-III. The circumstances of his departure are nonetheless cloudy: Aumont relates that he was excluded in spring 1974 for "rightist tendencies" and that he was "ill-treated" by the other editors, but it seems strange that a purge would have taken place at this point in time, after Pakradouni's departure. He admits "I don't even remember anymore how it concretely happened" but insists that "the memory that I have is that it had become evident that I was going to leave. [...] I no longer understood what was happening, to be frank. I couldn't follow things anymore." ${ }^{\prime 9}$

The three most experienced editors had, in quick succession, left the journal, and a power vacuum resulted. It was to be filled by a new editorial pairing: Daney and Toubiana. In Daney's words, 'I had to answer 'present' when, in late 1973, the journal was given away to whoever was willing to pick it up." ${ }^{\text {"o }}$ Toubiana recalls: "Nobody had asked Serge to play this part. [...] He happened to be available. The only thing I could offer him was that I was there."11 The two had a generally agreed upon division of labor:

6 Interview with Jacques Aumont, March 11, 2014.

7 See Philippe Pakradouni, "Réponse au no. 250," Cahiers du cinéma no. 253 (OctoberNovember 1974), pp. 53-58, here p. 57; and La Rédaction, "Réponse à la réponse," Cahiers du cinéma no. 253 (October-November 1974), pp. 59-65.

8 Interview with Jean Narboni, March 18, 2014.

9 Interview with Jacques Aumont, March 11, 2014. Elsewhere, he has commented, "As for me, I was booted out the door in 1974. I can't remember anymore if it was because I was too left-wing or not left-wing enough." Aumont, "Jacques Aumont, le cinéma né sous X."

10 Daney, L'Exercice a été possible, monsieur, p. 302.

11 Serge Toubiana, "Parce que l'amitié!," Cahiers du cinéma no. 458 (July-August 1992), pp. 6-8, here p. 7 . 
while Daney would provide the critical and theoretical guidance for the journal, drawing Cahiers out of the impasse into which its Maoist orientation had led it, Toubiana would play a more administrative role, gradually re-establishing Cahiers as a commercially viable entity after it had reached the verge of financial abyss, ensuring that issues would again be published on a monthly basis and reconnecting the journal with the readership it had lost. ${ }^{12}$ Charles Tesson, a later writer for Cahiers, has percipiently called the duo the "Moses and Aaron" of the post-gauchiste Cahiers, saying "Serge Daney was an absolute Moses of thought," while Toubiana represented the "pragmatic reality" of the biblical Aaron. ${ }^{13}$

The journal's new orientation was already signaled by Daney in the first installment of "Fonction critique" in which he outlines two potential responses to the question "How to 'intervene' in films?" Firstly, a film's aesthetic criteria could be equated with its political criteria, and secondly, politics could be put in the command post. The two positions, evidently, were those successively defended by Cahiers in 1969-1971 and 1972-1973 respectively. Both perspectives, according to Daney, were "tarnished with a certain dogmatism," and his article sought to establish a new position for film criticism, one that would take account of the fact that the aesthetic criterion does not "flow automatically" from the political criterion. Merely stressing, for instance, that a film is a means for the bourgeoisie to impose its vision of the world is correct from a Marxist standpoint, but it is a knowledge that remains "dead, dogmatic, stereotyped and-as our experience shows - unworkable to the extent that one is incapable of grasping, for each film, how it imposes itself." Similarly, relying on an analysis of the "base apparatus" merely conformed to "ultra-left mysticism" and prevented the journal from making concrete interventions on films. In other words, criticism must focus on "the relationship between two terms: the énoncé (what is said) and the enunciation (when it is said and by whom)." ${ }^{\prime 4}$ From this perspective, a triple critical function is discerned. With films where the énoncé predominates, those that superficially appear to have a neutral, objective, de-subjectified discourse (documentaries, television programs), Cahiers must stress that "there can be no énoncé without enunciation"- that

12 When interviewed, Toubiana placed particular emphasis on the importance of winning back readership during this period, pointing to high sales of issue no. 251-252 (which featured an interview with Michel Foucault) and the special issues edited by Jean-Luc Godard and Marguerite Duras. Interview with Serge Toubiana, April 29, 2014.

13 Charles Tesson, in Le Cinéma des Cahiers: 50 ans d'histoire, d'amour, de cinéma, dir. Edgardo Cozarinsky, 2001.

14 The quotes in this paragraph are from Daney, "Fonction critique," p. 39 [pp. 56-57]. 
is, that a discourse must have a subject that speaks it and an "apparatus" in which it is spoken. For films where the enunciation predominates (auteurist cinema, for instance), the reverse operation is needed: behind the cumbersome subjectivity of the enunciator (the "auteur") it is, in the end, a class with objective interests that speaks - and thus there can be no enunciation without an énoncé. Finally, Daney addresses the mass of films situated between these two poles, particularly those outwardly "progressive" works of "critical realism." In this case, the "line of demarcation between a reactionary, progressive and revolutionary filmmaker" tends to be "mobile, uncertain, blurry." Here, it is the position of the filmmaker with respect to the inevitable "double reading" of the film (that of its énoncés and that of its enunciation) that allows the critic to distinguish between reactionary, progressive and revolutionary works. ${ }^{15}$

Daney's outlook is further developed in "Les Cahiers aujourd'hui," a May 1974 editorial co-signed with Toubiana that, serving as a guide for the journal's new political and critical perspectives, can be seen as something of a sequel to "Cinéma/idéologie/critique." ${ }^{\text {"16 }}$ A detailed overview of the mistakes of the "Front culturel" period dominated this text. Here, Daney/ Toubiana were openly critical of Cahiers' combination of theoreticism (the project itself was presented in overly abstract terms) and empiricism (their practical interventions were piecemeal and lacked any connection with a global strategy). Resulting from the editorial team's blend of "political virginity" and "unbridled politicism," these shortcomings "nourished an entire system of contradictions" that "erupted" at the Avignon conference, the failure of which was exacerbated by the sectarian intransigence of the Marxist-Leninist groups participating in the project. ${ }^{17}$ Locating a "dogmatic current" within Cahiers (in clear reference to Pakradouni), the new editors emphasized the "question of the specificity of the journal" and rejected a vision of Cahiers as the "magazine of a party" (whether existent or in potentia). Instead, they conceived of it as "an apparatus in the service of the struggles of the revolutionary movement, particularly in the area of film." But Cahiers would also be a "critical and theoretical journal," one that would aim to "respond, with its own weapons, to the issues raised by the

15 Ibid., p. 40 [p. 57].

16 Toubiana recalls that his contribution to the text was minimal: "Serge [Daney] had written it in one burst, during the night, asking me the next day to read it and correct. Not a word needed changing." Toubiama, Les Fantômes du souvenir, p. 66.

17 Serge Daney and Serge Toubiana, "Les Cahiers aujourd'hui," Cahiers du cinéma no. $25^{\circ}$ (May 1974), pp. 5-10, here p. 6. Translated as "Editorial: Cahiers Today," trans. Liz Heron, in Wilson (ed.), Cahiers du Cinéma vol. IV, pp. 47-55, here p. 47. 
ideological conjuncture and the struggles flowing out of it."18 Rather than Mao, the main reference points in this project would be Brecht and Gramsci, as well as the Italian leftist dramatist Dario Fo, whose theater company's recent tour of Paris greatly influenced Cahiers at this moment. ${ }^{19}$

While critiquing "dogmatism," Daney/Toubiana were not yet ready to totally abandon the Marxist-Leninist political standpoint that Cahiers had identified with for the last five years, and the journal remained positioned within the milieu of the French far left well into the late 1970s even while adopting a "post-gauchiste" perspective critical of the excesses of the period of heightened political activity in 1968-1972. This era was one of flux and transition for Cahiers, where dogmatic certainty was replaced by a disoriented groping for new directions. Reynaud describes it as a "fractured, turbulent, sometimes exhilarating, sometimes bitter, always engaging" phase in the journal's history, which abounded in "ruptures, contradictory positions, fearless enthusiasms, suspicions, disgusts, stringent self-criticism or amused hindsight." ${ }^{20}$ In this respect, Cahiers was once again in synchronicity with its time: the change in editorial line reflected a broader political cleavage point that took place in the mid-197os. As Daney notes: "It is not difficult to date, between 1973 and 1975, the caesura of the decade: the oil crisis, the beginning of unemployment, the end of the ORTF, the return of consensus." ${ }^{\text {21 }}$ Domestically, the demise of left-wing militancy in France was accompanied by the advent of the union de la gauche (which campaigned for Mitterand as presidential candidate in 1974) and the rise to power of Valéry Giscard d'Estaing, who, while still on the political right, represented a liberal turn away from the authoritarian tendencies of de Gaulle and his successor Georges Pompidou. Under Giscard, film censorship was formally abolished, the media liberalized, and police repression of the left was significantly relaxed, moves that facilitated the reconciliation of former leftists with the political status quo.

These tumultuous changes were reflected in Cahiers by a pronounced changeover of personnel. Bonitzer, Kané and Oudart remained on the editorial committee alongside Daney and Toubiana, while Narboni, having absented himself in 1973, rejoined the journal in 1976. Beyond this core group, however, the pages of Cahiers featured an expansive list of contributors: Alain Bergala, Serge Le Péron, Bernard Sichère and Jean-René Huleu were drawn from militant

Daney, L'exercice a été profitable, Monsieur, p. 303. 
circles; Thérèse Giraud, Dominique Villain, Danièle Dubroux and Nathalie Heinich brought feminist politics into Cahiers; and old friends of Daney such as Jean-Claude Biette and Louis Skorecki returned to writing for the journal. Jean-Paul Fargier made a Damascene conversion in 1976, departing from Cinéthique and joining Cahiers, to which he would contribute until the end of the decade. ${ }^{22}$ Even former Positif critic Louis Seguin submitted occasional articles. Comolli, Baudry and Pierre also published texts on isolated occasions, although none would formally rejoin the team. ${ }^{23}$ Later in the 1970s, a new generation of critics also entered the ranks: chiefly brought in by Toubiana, they included Charles Tesson, Olivier Assayas, Leos Carax, Yann Lardeau, Jean-Jacques Henry and Bernard Boland. Bereft of any participation in the stormy debates of the journal's militant period, their critical perspective would be markedly different from that of their "elders," and they proved to be far more receptive to Hollywood and other popular cinemas such as that of Hong Kong.

The turnover of personnel reflected a fluctuation in the "line" espoused by Cahiers as the 1970 s progressed, shifting from "anti-dogmatic" Marxism to a gradual return to the mainstream of film criticism, an evolution that was reflected by changes in the journal's format in 1976 and 1980, which gave it a glossier, more magazine-like appearance. Despite their personal closeness, this evolution betrayed a division between Daney and Toubiana. Whereas the former sought to anchor Cahiers in its political/theoretical heritage, even at the expense of remaining a marginal publication, the latter was eager for the journal to return to the center of film culture in France, a project that inevitably entailed a more commercially oriented, popular mindset. Simmering throughout the late 1970s, these contradictions eventually came to a head in 1981. Daney's departure from Cahiers that year saw Toubiana's perspective prevail and marked the effective end of Cahiers as a site for the production of film theory derived from the positions it held in the late 196os and early 1970 .

\section{Anti-Imperialist Film Criticism: 1974-1975}

In the initial years of Cahiers' post-Avignon period, the evaporation of the Maoist movement in France led the journal to seek out avenues for politically

\footnotetext{
22 For Fargier's rejection of Cinéthique's approach to militant cinema, see Jean-Paul Fargier, "Pour le dépérissement du cinéma militant," Cinéma d'aujourd'hui no. 5-6 (1976), pp. 163-168. After Fargier's departure, Leblanc would essentially oversee the journal alone, issues of which became more and more sporadic until its demise in 1985 .

23 Comolli was still officially a member of the editorial committee until 1981, but his practical contribution to the journal's editorial line and day-to-day tasks had long ceased.
} 
radical filmmaking in other terrain. In these years, Chile, Palestine and Algeria supplanted China as international sites of interest for revolutionary cinema. Closer to home, the experience of migrants and other minorities in France was given special attention for the first time. In addition to this "anti-imperialist" approach to the cinema, the mid-1970s saw the initial germination of feminist film criticism in France, reflecting the belated birth of a French women's liberation movement, which sprang out of the nascent identity politics of the anarcho-Maoist group Vive la révolution!. For the most part, however, this critical work was the preserve of female critics, particularly Thérèse Giraud and Danièle Dubroux. Reynaud even later regretted that "their witty, often acerbic, texts did not generate larger discussions on issues of feminism or sexual politics per se" and sat uneasily alongside the masculinity of the Cahiers brand of cinephilia. ${ }^{24}$ The chief exception to this state of affairs was Daney's review of Histoires d'A, a film banned for its stance against France's anti-abortion laws. The political context of the film had been discussed by Thérèse Giraud in an earlier issue, and the filmmakers Charles Belmont and Marielle Issartel were interviewed for Cahiers. ${ }^{25}$ Daney, for his part, insisted that the film's claims about the safety of the Karman method were proven above all through its practical demonstration that the technique was filmable - by opening with a long, graphic sequence showing a young woman undergoing the procedure. While the critic noted that this represents a "new relationship" between the woman and her body, it is not feminist issues but questions of film that formed the center of his discussion. Histoires d'A breaks down the dichotomy-shared by both "metaphysical" film theory and "technicist discourse"-between mise en scène (fiction) and direct cinema (documentary). For Daney, the film calls for a "new position — spatial, moral and political—between the filmer and the filmed." The filmed abortion sequence in Histoires d'A allows a glimpse of this new position, and the "collective of enunciation" it thereby creates poses a "question that is essential for thinking through the relations between the political front and the cultural front," namely: "How to restitute to those who struggle - at the same time as the strategic meaning of their struggle — the ardor, inventiveness and pleasure that there is in struggling?"26

24 Reynaud, "Introduction," p. 7.

25 See Thérèse Giraud, "Histoires d'A," Cahiers du cinéma no. 251-252 (July-August 1974), p. 47; and Marielle Issartel and Charles Belmont, interviewed by Serge Daney, Jean-René Huleu and Serge Toubiana, "Histoires d'A: Entretien avec Marielle Issartel et Charles Belmont," Cahiers du cinéma no. 251-252 (July-August 1974), pp. 48-55. The film incited a protest in its defense at Cannes on May 25, 1974 after police intervened to stop it from being projected.

26 Serge Daney, "L'espace politique (Histoires d'Histoires d'A)," Cahiers du cinéma no. 254-255 (December 1974-January 1975), pp. 33-36, here p. 36 . 
A similar framework was used to discuss cinematic representations of the immigrant experience in France, which became distinctly more prevalent in the 1970s. Works such as Bicot-nègres, vos voisins by Med Hondo and Nationalité: immigré by Sidney Sokhona not only addressed the question of "guest-workers" in France but, of supreme importance for Cahiers, they sought to do so from the point of view of the African and Maghrebi migrants themselves. As Daney would later recognize, "the magic word in this short period is 'point of view," a term that can be understood both in the militant political sense (the line of an organization on a given question) and more broadly as "the situation that a filmmaker, his team and his tools de facto occupied during a shoot, the contact he had with the 'actors' who he did not know, and even (above all) if they supported them and their just struggles." ${ }^{27}$ In line with the perspective outlined by Daney, Kanés discussion of Hondo's work linked it to the question of cinematic enunciation - a question that had decidedly become central for Cahiers at this time. Rejecting attempts by militant cinema to "universalize its énoncés" and "detach them from the context in which they operate" (which would only lead to "dogmatic and terroristic propositions"), Kané is in the end ambivalent about the formally heterogeneous sequences that make up Bicots-nègres, vos voisins, concluding that "the film never creates its own proper context of struggle, which would justify it alongside the struggle of its brothers, in the courageous combat that it wishes to carry out." 28 His negative appraisal would be shared by Giraud, who even calls Hondo's film "para-revisionist."29 Nationalité: immigré was more warmly received by Cahiers: Daney found it, for instance, a refreshing alternative to the sterile dogmatism of much militant filmmaking, which had never been able to adequately synthesize "the (necessarily dogmatic) title cards and the (necessarily wretched) 'lived experience'."30 Sokhona's use of title cards within the shot in the film's opening scene, for instance, is comparable to Godard's Ici et ailleurs in its ability to make information "the very matter of his images," and the film's formal maneuvers allowed Daney to perceive that "denotation is also a question of racism." ${ }^{11}$

27 Daney, La Rampe, p. 50.

28 Pascal Kané, "Bicots-nègres, vos voisins de Med Hondo," Cahiers du cinéma no. 251-252 (July-August 1974), pp. 77-78.

29 Thérèse Giraud, "Parler de, parler d'eux... (Bicots-nègres, vois voisins)," Cahiers du cinéma no. 254-255 (December 1974-January 1975), pp. 41-43, here p. 43.

30 Serge Daney, “Sur le papier (Nationalité: immigré)," Cahiers du cinéma no. 265 (MarchApril 1976), pp. 34-37, here p. 37 .

31 Ibid. 
Considerations of international cinema during this period were largely dominated by political concerns, and thus the global flashpoints of the mid-1970s - specifically, China, Chile and Palestine-were given the greatest attention. This turn to Third World cinema can legitimately be criticized for the presence of a certain patronizing paternalism and an Orientalist fascination with non-European cultures: Reynaud notes that the interviews with filmmakers conducted under this rubric "were mostly focused on conditions of production, the filmmakers' struggle with political and cultural powers, the political use of the film etc., and not on issues of mise en scène." ${ }^{2}$ And yet they played a valuable role in breaking the journal free of its previous hermetic isolation within the milieu of the French far left and led to a radical re-casting of many of the questions surrounding politics, ideology and cinema that had formed the center of Cahiers' critical energies in the half-decade after 1968.

Two documentaries by Western filmmakers on China under Mao's rule were the source of ongoing polemics in and around Cahiers: Chung-kuo China by Antonioni and Comment Yukong déplaça les montagnes by Joris Ivens and Marceline Loridan. Antonioni's film — which was loathed by the Chinese media but praised by the still-Maoist Philippe Sollers in Libération -initially received a cool reception by Cahiers, who had rarely warmed to the filmmaker's work. Aumont dubbed Chung-kuo China "a series of ahistorical stereotypes (filmed with art, of course)" which completes "the collection of received ideas on China, its present and its eternity," while Daney, writing for Libération, called it a "sumptuous potluck party" and criticized the film for not giving a voice to the Chinese people themselves. ${ }^{33}$ Ivens/Loridan's Yukong, by contrast, was widely lauded upon its release in 1976, with an interview with the filmmakers and a review by Le Péron, even though Cahiers had long abandoned a strictly Maoist orientation by this time. Soon afterwards, however, Daney would, in his own words, "go to Canossa and end up avowing that he prefers Chung-kuo China by Antonioni over Yukong by Ivens and Loridan." 34 Both films, as Daney argued in his text "La re-mise en scène (Notes)," denoted the relationship between "here" (the West) and "elsewhere" (China under Maoist rule). But whereas Daney criticizes Ivens/ Loridan for making "direct cinema on a coded reality" (which unwittingly

32 Reynaud, "Introduction," pp. 32-33.

33 Jacques Aumont, "Sur La Chine," Cahiers du cinéma no. 248 (c. late 1973), pp. 41-45, here p. 45; and Serge Daney, "Une auberge espagnole singulièrement silencieuse," Libération, October 4, 1973. Repr. in Idem., La Maison du cinéma et le monde vol. I, pp. 145-148, here p. 146.

34 Daney, La Rampe, p. 51. 
attests to a social "pre-mise en scène"), he came to respect Antonioni for the filmmaker's strategy of finding images that strike a balancing act between the requirements of the Chinese authorities and the ethnographic curiosity of Western audiences, a striking example of which is found in the anaestheticfree Caesarian section performed on a Chinese woman that begins the film, since it demonstrates the prowess of the Chinese medical system as well as suggesting that "the relationship that the Chinese have with their bodies is, to say the least, very different from that which exists in a Judeo-Christian, capitalist society such as our own." 35 In pursuing this double operation, Antonioni is, in a metaphor that would be felt across much of Daney's later writings on cinema, akin to a smuggler of contraband: "He could write his position as: (here) (elsewhere). He is between parentheses, at once protected by them and floating between them, without any anchoring, exposed. Exposed to utopia, to the non-place." It is this, then, that ties Antonioni's documentary on the PRC to the rest of his work, which is defined by Daney as "the cinema as non-place, as an affirmation of distance." 36

Soon after this article was published, Mao's death in September 1976 led to the trial of the Gang of Four and the ascension to power of the "capitalist roader" Deng Xiaoping, and cinema relating to the Chinese cultural revolution would cease to be of interest to Cahiers. By this time, the journal's interest in revolutionary film had shifted its focus to other countries. In 1973-1974, Chilean cinema became a significant focus of attention for Cahiers, as the country's Popular Unity government under Salvador Allende radicalized its socialist program before being brutally crushed by Augusto Pinochet's CIA-backed coup on September 11, 1973. During this time, interviews were conducted with Chilean filmmakers-in-exile such as Helvio Soto and Miguel Littin, as well as the Bolivan Jorge Sanjines and the Latin American media theorist Armand Mattelart. For the Cahiers critics, Chile represented a practical demonstration of Althusser's theories of the Ideological State Apparatus. Allende's election meant that the political apparatus was in the hands of a socialist party, but the capitalist class and many wings of the repressive state apparatus (the police, judiciary and, most importantly, the military) remained hostile to his rule. The media - the press, television, radio and the cinema - were thus, to use Althusser's formulation, a "stake in the ideological struggle" in Chile. As Daney/Toubiana recognized, however, the political situation there had induced Cahiers to abandon a "conception

35 Serge Daney, "La remise en scène (Notes)," Cahiers du cinéma no. 268-269 (July-August 1976), pp. 20-26, here pp. 25, 23.

36 Ibid. 
of ideology as the reverse side of Science" and instead led them to speak of ideologies, in the plural, which were in opposition to but also coexisted with each other. Aware of the potential for accusations of "exoticism" (which had already been leveled during the journal's "sinophilic" period), Daney/ Toubiana maintained that the development of communication apparatuses in the South American nation is not merely a question pertaining to foreign nations and argued that "up to a certain point, large swathes of the Chilean experience are transposable to France and Italy."37 Against the dominant ("revisionist") understanding of the failure of the Allende government, the editors outline a cluster of questions centering on issues of ideology, hegemony and knowledge, which were summed up by Rancière in the following terms: "To each circumstance of the class struggle corresponds a certain position of science, of the relationship between its object and those of perception and production, of the division that exists between the visible and the invisible, the phenomenon and the law, etc. ${ }^{38}$ More broadly, in the journal's wish to move beyond the schematic dialectics of Althusserian theory, the philosopher's renegade pupil was an influential figure, and Rancière became one of Cahiers' regular interlocutors throught the 1970s. ${ }^{39}$

With Fatah and other guerrilla organizations intensifying their resistance to Israeli occupation, even after the bloody setback of Black September, Palestine was the other international flashpoint that preoccupied Cahiers in this period. An interest in the Palestinian question was evidently stoked by Godard's Ici et ailleurs (and its unfinished precursor, Jusqu'à la victoire) but was also pertinent to the journal due to its large number of Jewish contributors: Kané, Bonitzer, Narboni and Daney all had a Jewish family background, although none were openly religious at the time. Palestinian militants had also, of course, made global headlines by kidnapping Israeli athletes at the Munich Olympic games in 1972, although the event was not discussed by Cahiers at the time. In 1974-1975, a series of texts focused

37 Serge Daney and Serge Toubiana, "A.I.E. et luttes de classes: Chili 1970-1973," Cahiers du cinéma no. 254-255 (December 1974-January 1975), pp. 6-7.

38 Ibid., p. 7. For the Rancière quote, see Jacques Rancière, "Mode d'emploi à Lire le Capital," Les Temps Modernes no. 328 (November 1973), pp. 788-807, here p. 797.

39 Rancière was interviewed in the "Images de marque" special issue in 1976, participated in the 1978 round table on Man of Iron, and contributed an article attacking La Communion solennelle as a fiction de gauche. See Jacques Rancière, interviewed by Serge Daney and Serge Toubiana, "L'Image fraternelle: Entretien avec Jacques Rancière," Cahiers du cinéma no. 268-269 (JulyAugust 1976), pp. 7-19; and Jacques Rancière, "Fleurs intempestives (La Communion solennelle), Cahiers du cinéma no. 278 (July 1977), pp. 17-20. For Rancière's break with Althusserian doctrine, see Jacques Rancière, La Leçon d'Althusser (Paris: Gallimard, 1974). Translated as Althusser's Lesson, trans. Emiliano Battista (London: Continuum, 2011). 
on the cinema of the Palestinian people: interviews were published with Lebanese filmmakers Heiny Srour and Borhan Alaouié (both of whom were involved with the movement against Israeli occupation), while the Moroccan critic Abdelwahad Meddeb, Serge Le Péron and Jean Narboni all devoted articles to Palestinian films.$^{40}$ Narboni's response to Alaouié's depiction of the 1956 Kafr Kassem massacre was particularly stimulating, affirming that the film offers a corrective to the "false alternative" between the detached distanciation of the "simili-Brechtians" and the affective spectacle defended by the proponents of a "visceral" cinema. In this, he sees Eisenstein as Alaouié's most significant precursor (despite major differences in their respective approaches to filmmaking), since the Soviet director's films were similarly capable of "maintaining the internal tension between blood and sign, of producing a dynamism whereby each would be implied and negated by the other, of setting in motion both the emotional charge and the signifying mechanism." ${ }^{41}$ By far the most important contribution those associated with the journal would make on the issue of the Palestine conflict, however, was a project that preoccupied Narboni at the time he wrote on Kafr Kassem: L'Olivier, a documentary made in 1973-1975 by a collective based in the cinema studies department at Vincennes.

\section{L'Olivier: Filming the Palestinian Struggle}

Since 1970, Narboni had been teaching film regularly at Vincennes (ParisVIII), succeeding Rivette in the post. The project of a film on the Palestine issue arose from contacts the Cahiers critic made with other faculty members and students on campus. Ali Akika, Guy Chapouillié, Danièle Dubroux, Serge Le Péron and Dominique Villain ended up joining Narboni to form the core team responsible for the making of L'Olivier. ${ }^{42}$ The origins of the project came from Akika, an Algerian militant who had traveled to Jordan in 1969 and taken photographic slides for use at activist meetings in France;

40 See Abdelwahab Meddeb, "La leçon sauvage (Kafr Kassem)," Cahiers du cinéma no. 256 (February-March 1975), pp. 47-51; Serge Le Péron, “À propos du cinéma palestinien," Cahiers du cinéma no. 256 (February-March 1975), pp. 35-38; and Jean Narboni, "Le sang changé en signe (Kafr Kassem)," Cahiers du cinéma no. 256 (February-March 1975), pp. 39-46, translated as "Blood into sign," trans. Annwyl Williams, in Wilson (ed.), Cahiers du Cinéma vol. IV, pp. 259-267.

41 Ibid., p. 45 [p. 265-266].

42 Of the five, Le Péron and Dubroux would become regular writers for Cahiers in the 1970s, while Villain (Narboni's partner at the time), wrote and translated texts on an intermittent basis for the journal. 
perceiving the limitations of this method, he met Le Péron at Vincennes to discuss the possibility of making a film on the subject. ${ }^{43}$ Soon a group of six collaborators had coalesced at the Avignon conference in August 1973, which thus makes L'Olivier one of the positive legacies of an event that was otherwise a generally adverse experience for Cahiers. A trip to Lebanon was organized, where contacts were made with Palestinian filmmakers and fedayeen fighters. Two years would pass between this moment and the completion of L'Olivier, as the phases of the filmmaking process were coordinated with the the academic calendar. The 1973-74 school year was dedicated to archival research and establishing contact with European anti-Zionist activists. July and August of 1974 were taken up by further trips to the Middle East, where the bulk of filming took place. Finally, the 1974-75 school year was used for gathering additional footage in Paris and transforming the eight hours of rushes into the final 85-minute edit, which was released in the Cinéma du Temple (now the Luminor Hôtel de Ville cinema) in the Marais district of Paris in March 1976.

In addition to the broader context of Middle Eastern politics in the 1970s, the cinematic context at the time L'Olivier was made was also of central importance to the filmmaking collective, as was made clear in the round table on the film published by Cahiers in February 1976. A negative model for their project was Claude Lanzmann's Pourquoi Israël (1973), a work of political propaganda justifying the existence of the Zionist state. While censuring the film for "completely exclud[ing] the Palestinians," the Vincennes filmmakers were careful to avoid conceiving of their film as a unilateral retort: "We had no wish to remake the Lanzmann in the opposite direction, that is to say, by excluding the Israelis." ${ }^{24}$ Instead, Lanzmann's work was subject to a cinematic critique, as Narboni elucidates:

During the screening of Pourquoi Israël I was haunted the whole time by the insistence of a question absent from the film. [...] This question is quite simply: where am I? [...] What is this place from which I have obtained this frame, and at what price? What power pre-existing my own has permitted it? What new power-effects does the place that I occupy authorize, and on whom? This is a question which [...] in all good conscience, Lanzmann does not even glimpse.

43 Ali Akika, Guy Chapouillié, Danièle Dubroux, Serge Le Péron, Jean Narboni and Dominique Villain, "L'Olivier: Entretien et commentaires," Cahiers du cinéma no. 264 (February 1976), pp 11-40, here p. 12.

44 Ibid., p. 14. 
The most striking example he gives of this problem in Lanzmann's film is a long-shot of the Wailing Wall: "What technical tour de force made it possible? Lanzmann's genius, the skill of his cameraman? No, or not only. Rather, that of the Israeli administration which, since 1967, had cleansed the surrounding Arab neighborhoods, and without which the filmmaker would never have been able to afford himself such a depth of field." 45

A key aim in making L'Olivier was to provide an alternative to many of the received norms of militant cinema in the post-1968 period, which had long been critiqued by Cahiers but which were further subject to interrogation as the journal emerged from its own period of militancy. When pressed on the matter by Daney, Narboni admits that "a certain type of political cinema made since 1968 was no longer possible," specifying that it was the "disdainful insouciance towards formal questions, considered as 'bourgeois,' [...] the catechistic tone, the artificial optimism and the denunciative droning of the voiceovers" that rankled in these films. ${ }^{46}$ He notes in particular that a work such as Revolution Until Victory (1973) by the Newsreel collective, while being a "penetrating, admirably assembled" work, was nonetheless, "suffocating, so rapidly did the information, dates, citations pass by" and that it only led to "stunted, sterilized" discussions after the screenings. ${ }^{47} \mathrm{In}$ contrast, L'Olivier is largely free of voice-over - which, when it does come, is succinct and softly spoken - and relies mostly on interviews with activists and Palestinians. Care was taken to ground these voices in the context of their day-to-day existence: we thus see lengthy sequences where entire families are interviewed together, and other passages show Palestinians returning to their bombed villages or reminiscing about the olive groves of their childhood.

A key influence on this revamped critique of militant cinema came from Godard's Ici et ailleurs, which was seen by the L'Olivier collective before its theatrical release. The transformation of a propaganda film for Fatah into a critical interrogation of the techniques of militant cinema and an exploration of the very nature of the image/sound relationship in the cinema was mirrored by a similar-albeit less historically dramaticshift in the conception of L'Olivier during the film's production process. Le Péron notes that the schematic nature of their initial project, which inscribed the Palestinian struggle into a broader global movement against imperialism (equating the Middle East with events in Chile, Vietnam and 
other post-colonial countries), came to be rejected. Instead, the filmmakers adopted a framework that emphasized the "specific difficulty of the Palestinian problem" and focused as much on the daily life of Palestinian families as it did on more directly political matters. ${ }^{48}$ Far from veering into a "suspect descriptivism, an ethnological approach," Narboni viewed this method as the "struggle between a dynamic, ample conception of politics and a fossilized, bureaucratic point of view on the question." ${ }^{39}$

Notably, too, the filmmakers refused to reduce the issue to that of a racial conflict between Jews and Arabs. Much of the first half of the film comprises interviews with Jewish anti-Zionist activists in both Europe and Israel, ranging from young Maoist militants to elderly Jewish Auschwitz survivors. ${ }^{5^{0}}$ In this sense, one of the totemic moments of L'Olivier shows two members of the far-left group Red Front—one Jewish, the other Arab—-being led from a prison van into a courthouse by the Israeli police, their legs manacled together. Regardless of their nationality, this charged image suggests, the Zionist state is ruthless in its repression of those who resist it. Another more ambiguous expression of Arab-Jewish unity was addressed by Narboni: during the shoot, the group interviewed a young Algerian migrant in Gennevilliers who justifies his belief in the possibility of peaceful coexistence between Palestinians and Israelis by inaccurately claiming that Jews were originally descended from the Arab people. Narboni notes the potential "catastrophe" that arises when an interviewee "gets it wrong,' utters false ideas with respect to the line taken by the mini-apparatus constituted by the filmmaking team." He outlines the two prevailing approaches taken by filmmakers in this situation: either they can take a "sociological, objectivist or neutralist approach" and retain the entire sequence out of respect for the "complexity of the real," or they can adopt a "militant, vigilant" stance that would "censure, redress and rectify" the passage in question, either by cutting it entirely or smothering it with the "correct" authority of a voice-over. Against both of these positions, Narboni advocates a strategy that would subtly highlight the "accent of truth" of such a moment by "inscribing this scene in the economy of the film in such a way that this accent is rendered." ${ }^{51}$

\footnotetext{
48 Ibid., p. 16.

49 Ibid., p. $3^{2}$.

$5^{0}$ These figures include Auschwitz survivor and anti-Zionist campaigner René Raindorf; Piet Nak, a Dutch communist who led a strike of workers in the Netherlands against the deportation of Jews to the concentration camps when the country was under German occupation; and Israel Shahak, a Holocaust survivor and president of the Israeli League for Human and Civil Rights. $5^{1}$ Ibid., p. 27.
} 
Although the Vincennes group were wary of the premature triumphalism of much militant filmmaking, a cautious optimism is nonetheless discernible in the film, one that comes less from a resolute belief in the inevitability of a victorious revolution and more through a portrayal of the ways in which everyday life has already been transformed by the mass mobilization of the Palestinian people. In particular, the role played by Palestinian women within the resistance movement was a major concern for the filmmakers. One sequence in particular shows a group of Palestinian teenaged women from a Lebanese refugee camp sitting in a circle wearing battle fatigues and clutching Kalashnikov rifles. Here, again, the filmmakers of L'Olivier choose to highlight the "accent of truth" of this scene, which comes through in both what the young women say - they speak of their visions of a future, liberated Palestine in paradisiacal terms, despite having never set foot in their homeland - but also how they say it: their words are free of the deadening jargon of many militant groups, and, at first hesitant, they soon gain the confidence to give free reign to their reveries. It is almost as if the process of political awakening is taking place before the spectator's eyes..$^{2}$

Perhaps the most emblematic image of the film, however, is reserved for its conclusion. Here, a guerrilla fighter being treated after suffering injuries from an Israeli attack is lying on a hospital bed, his eyes covered in bandages, a bloodied cloth in his hand, and an intravenous drip attached to his forearm. Haltingly, but with perfect lucidity, he asserts: "We thank the progressive forces and peoples throughout the world for their precious support. Zionism disposes of powerful means of propaganda. We need this solidarity to defeat them, for our cause is just." The contrast with the forced stridency of the perorations preponderant in militant cinema is stark: here we are presented with an image of a bloodied man speaking with immense physical difficulty but unbowed in his political determination. He represents, as Chapouillié notes, "the image of a Palestinian people that is wounded but fighting." ${ }^{3} 3$

Reaction to L'Olivier upon its theatrical release was divided: after bomb threats were made to cinemas screening Ici et ailleurs, there were fears of similar attacks, especially given the fact that the film was being shown in a heavily Jewish neighborhood. ${ }^{54}$ These never eventuated, but the French

\footnotetext{
$5^{2}$ Their mode of speech is noticeably different to that of male teens (known as "lion cubs") in a parallel scene: here one individual seems to speak for the entire group, and his summary history of the Palestinian revolution is recited in mechanical fashion, as if learnt by rote.

53 Chapouillié, in ibid., p. 35.

54 Interview with Jean Narboni, April 2, 2014.
} 
left was far from unanimous in its appraisal of the film. While Hennebelle called it "one of the most successful feature-length films in contemporary French militant cinema," 55 others criticized L'Olivier for offering a "folkloric" and insufficiently political view of the Palestinian struggle. ${ }^{6}$ As could be expected, Cahiers devoted ample coverage to a work that was closely associated with the journal: a round table with the filmmaking team was followed by a review of the film by Comolli, who saw the gap between the Palestinian people and "Palestine as referent" as the film's key stake, and argued that "the force of L'Olivier lies in not eluding the difficulty of a deceptive representation, of bringing deception to the heart of representation, of anchoring deception itself to the offensive force of representation, against satisfying, reassuring, mystifying representations. ${ }^{57}$ The project was evidently close to Comolli's heart: at the same time as Narboni was engaged with L'Olivier, Comolli was working on his own project, La Cecilia. ${ }^{8}$ The two films were released nearly simultaneously and discussed in the same issues of Cahiers. In retrospect, they can be seen as close complements of each other. Made when both editors had left the journal, disheartened at the collapse of a project in which they had each invested a decade of their lives, La Cecilia and L'Olivier both deal with the contradiction between revolutionary utopias and the everyday reality of political struggle, and both relate to questions of collective intellectual labor. But whereas La Cecilia served as the springboard for Comolli's long filmmaking career, L'Olivier remained an isolated experience for Narboni-until 2011 it was the only directorial credit to his name. Since the completion of L'Olivier, Narboni's energies have remained focused on film criticism and teaching. On a political level, meanwhile, the strident anti-Zionism of L'Olivier is distinct from Narboni's later perspectives: not only has he largely been averse to radical political movements in more recent decades, but his views on the Israel/ Palestine question evince a greater degree of sympathy with the Israeli perspective. ${ }^{9}$ When asked about this matter, however, Narboni did not agree that his position had substantially changed since the 1970s. He continues to believe in a right of self-determination for Palestine-while lamenting

56 Narboni discusses these criticisms and ascribes them to the viewpoint of "some bewildered (French and Arab) dogmatists." Narboni, in Ali Akika et al., "L'Olivier," p. 32.

57 Jean-Louis Comolli, "L'image absente (sur L'Olivier)," Cahiers du cinéma no. 265 (MarchApril 1976), pp. 44-47, here p. 47.

$5^{8}$ See Chapter 13 for more on La Cecilia.

59 See, most notably, Narboni's analysis of Chaplin's The Great Dictator in the 2010 monograph Pourquoi les coiffeurs? (Paris: Capricci, 2010). 
the "tragic," seemingly unresolvable nature of the conflict—and he still looks upon his experience making L'Olivier in a broadly favorable light. ${ }^{60}$

\section{Anti-Retro: Cahiers, Foucault and Allio}

Cahiers critics were involved in another film project during this period, with Pascal Bonitzer and Serge Toubiana's participating in the preparatory work for René Allio's 1976 adaption of Moi, Pierre Rivière, ayant égorgé ma mère, ma søur et mon frère... Pierre Rivière's memoire had been exhumed by a research group directed by Michel Foucault, whose own contact with Cahiers was established in a 1974 interview centering on the "retro" trend in mid-1970s European cinema. Exemplified above all by the films Lacombe Lucien by Louis Malle and Portiere di notte by Liliana Cavani, "retro" cinema was marked by a prevailing cynicism and a historical reconsideration of the resistance/collaboration binary during World War II. In France, the retro mode was seen as symptomatic of the rise to power of a "neo-bourgeoisie" (that of "multinational, technocratic big capital") with the narrow victory of Giscard d'Estaing over the union de la gauche in the 1974 presidential election. The "post-gaullist" French state, Cahiers maintained, represented "a chance for the bourgeoisie to rid itself of a certain heroic, nationalist, but also anti-Pétainist and antifascist image, which was still reflected if not by Pompidou, at least by de Gaulle and Gaullism." ${ }^{\text {61 }}$ Cinematically, the ground had been prepared for these films by the demolition of the Gaullist myth of the popular resistance to the German occupation in Marcel Ophuls' 1970 documentary Le Chagrin et la Pitié, a film that was criticized at the time of its release by Pierre Baudry for eliding the discourse of the working class from its overview of the French resistance movement and for the "general blindness" produced by its "series of ambiguities, repressions and things left unsaid." ${ }^{n 2}$

Baudry's review of the Ophuls documentary set the template for Cahiers' later response to the "retro" films of Malle and Cavani. Daney used the concept of the "positive hero" developed during the journal's Maoist period

60 Interview with Jean Narboni, April 2, 2014.

61 Michel Foucault, interviewed by Pascal Bonitzer and Serge Toubiana, "Anti-Retro: Entretien avec Michel Foucault," Cahiers du cinéma no. 251-252 (July-August 1974), pp. 5-15, here p. 5. Translated as "Anti-Retro," trans. Annwyl Williams, in Wilson (ed.), Cahiers du Cinéma vol. IV, pp. 159-172, here p. 159 .

62 Pierre Baudry, "Le Chagrin et la pitié," Cahiers du cinéma no. 231 (August-September 1971), pp. 51-52, here p. $5^{2}$. 
to attack the bourgeois cynicism of the retro mode, bristling against the "generally accepted idea" that " positivity' (the positivity of a message or of a hero) is of interest only to the propagandists, the party men, the big sectarian and Zhdanovian dinosaurs." ${ }^{63}$ In fact, he argues, positivity is not the exception but the rule; the point of distinction comes in the class interests represented by these films: each class "possesses its own style of ideological struggle, its own way of rendering its conception of the world, its own positive ideas," and thus even messages of a negative or indeterminate character can be positive ideas "from the viewpoint of the bourgeoisie and its immediate interests." Moreover, Daney makes the startling concession that, in 1974 in France and Italy, "the initiative belongs to right-wing filmmakers"; rather than repressing domains of human experience such as politics and sexuality (the source of much of Cahiers' earlier criticism of mainstream cinema), the bourgeoisie in these countries is now confident enough to "hold a (bourgeois) discourse on what, only yesterday, it still wanted to hide. [...] It can anchor its fictions in History if it has emptied the word of all content." 64

In "Histoire de sparadrap," Bonitzer continued Daney's line of thinking by reading Lacombe Lucien through the semiotic distinction between denotation and connotation: Lucien's behavior, for instance, may indeed denote fascism, but it "connotes something else entirely, and it is this 'something else entirely,' in principle indefinable (Lucien's psyche), which, in the final instance, carries the meaning." ${ }^{65}$ Bonitzer also attacks the equation made by Malle and Cavani between fascism and sexual perversion, which ends up naturalizing the political ideology of the Nazis, blurring the boundaries between victim and executioner, and masking the true governing structure of fascist ideology: racism. In a later text, Daney similarly focuses on the question of the "eroticization of power" - a question on which, he claims, "the tradition of Marxist economism [...] has nothing to say" — and argues for the construction of a "left perspective" on this issue, drawn not from "some remote dogma, or even the endlessly repeated names of Brecht and Reich" but on the basis of "what, today, in the practice of those who meet these questions in their struggle, already contains this construction." 66

63 Serge Daney, “Fonction critique (2): Qui dit quoi mais où et quand?," Cahiers du cinéma no. 250 (May 1974), pp. 38-42, here p. 38. Translated as “The Critical Function," here p. 58.

64 Ibid., pp. 39-40 [pp. 59-6o].

65 Pascal Bonitzer, "Histoire de sparadrap (Lacombe Lucien)," Cahiers du cinéma no. 250 (May 1974), pp. 42-47, here p. 43.

66 Serge Daney, “Anti-retro (suite): Fonction critique (fin)," Cahiers du cinéma no. 253 (OctoberNovember 1974), pp. 30-36, here p. 35. Translated as “The Critical Function," pp. 56-72, here p. 68. 
The interview with Foucault, appearing in Cahiers' July-August 1974 issue, centered on the same concerns and represented the first time in the journal's post-1968 period that Marxism itself, rather than just its dogmatic distortion, was subject to critique. Foucault here highlights the limitations of the orthodox Marxist definition of fascism and criticizes Marxist intellectuals for their lack of historical knowledge. Not only this, he also excoriates the French far left for lacking a genuine desire to defeat the right "due to a false definition of the masses, a false appreciation of what it means to want to win. To avoid the risk of having victory snatched away it prefers not to run the risk of winning. Defeat, at least, can't be recuperated." ${ }^{\prime 67}$ In terms of the cinema, Cahiers did not always see eye to eye with the philosopher, and in the interview itself Foucault expresses his approval of Le Chagrin et la pitié. ${ }^{6}$ But an opposition to the "retro mode" united the two. In opposition to the "false archeology" displayed by the retro films, Foucault posits the necessity of "popular memory," a need that is particularly acute at a time when "a whole series of apparatuses has been established ('popular literature,' cheap books, but also what is taught in school) to block this development of popular memory." ${ }^{69} \mathrm{He}$ understands the obsessive revisiting of the combats of the 1940 in the retro films as a will to "codify" and "stifle" popular memory in order to impose "a grid for interpreting the present." ${ }^{\text {" }}$ Foucault nonetheless distinguishes between the ways in which sexuality and power are entwined in Lacombe Lucien and Portiere di notte respectively: whereas Malle's film is seen as a "fairly facile antithesis between power and love," Cavani's film, for the philosopher, more probingly explores the erotic charge produced by the exercise of power in fascist regimes..$^{11}$

While finding fault with retro cinema, Foucault admits to the impossibility of making "a positive film about the struggles of the Resistance." ${ }^{2}{ }^{2}$ The interview itself, however, did give rise to a positive counter-model to the work of Malle and Cavani. Foucault's interlocutors at Cahiers, Bonitzer and Toubiana, suggest in the interview that the dossier prepared by Foucault

67 Michel Foucault, "Anti-Retro," p. 15 [p. 171].

68 Ici et ailleurs was also a point of division between the journal and the philosopher. In June 1981, Daney recalled that, "in 1975, Michel Foucault left a screening of Ici et ailleurs at the Quatorze-Juillet Bastille cinema, furious. The man who wrote Discipline and Punish did not want to be disciplined and punished by Jean-Luc Godard." Serge Daney, "Michel Foucault," in "Dictionnaire sans foi ni loi," Cahiers du cinéma no. 325 (June 1981), p. 116.

69 Michel Foucault, "Anti-retro," p. 7.

70 Ibid., p. 13.

71 Ibid., p. 10.

72 Ibid., p. 8. 
and his colleagues on Pierre Rivière (published in 1973) could be fruitfully used to combat the "retro" cinema of Lacombe Lucien. Foucault, seeing the possibilities, turned to René Allio, whose Les Camisards the philosopher recognized as a "beautiful" and "historically impeccable" film. ${ }^{73}$ Drawing on his experience working with Brechtian theatrical troupes, Allio had made films that had been steadfastly defended by Cahiers, which warmly received Une vieille dame indigne and Les Camisards, and published an extensive interview with the filmmaker upon the release of Rude journée pour la reine in $1974 .{ }^{74}$ It was therefore a natural step for Bonitzer and Toubiana, with Foucault's approbation, to approach Allio to adapt Rivière's memoire for the screen. Although they are credited as screenwriters alongside Allio and Jean Jourdheuil, Bonitzer now clarifies that "in truth, Serge and I did not contribute much to the script. [...] Even if we co-signed it, I can't consider myself as one of the film's screenwriters." 75 Their main role, therefore, was that of a passeur (in Daney's sense of the word), transferring sensitive material from one hand to another.

Rivière's memoire was discovered as part of preparatory work on Foucault's major work on the history of judicial punishment, Surveiller et punir, published in 1975. A 20-year-old peasant from Normandy convicted of the murder of his mother and siblings in 1835 , Rivière composed a 100-page treatise outlining his motivations for the crime (to free his father from a loveless marriage with a headstrong wife), despite the fact that he was widely considered to be a barely literate half-wit. Notwithstanding its departures from standard orthography, the text often exhibits a genuine literary flair (Foucault states that "its beauty alone would suffice to protect it today"76) and the Raskolnikovian logic behind Rivière's act confounded the jurists assigned to his case, who were unable to decide whether he was a deluded madman or a lucid criminal: in the end, the death sentence for parricide was commuted to life imprisonment, but Rivière committed suicide soon after his conviction. For Foucault, speaking in a second interview given to

73 Ibid., p. 15 .

74 See Jean-Louis Comolli, "Les miettes de l'existence (La Vieille Dame indigne)," Cahiers du cinéma no. 166-167 (May-June 1967), pp. 126-129; Aumont, “Comment on écrit l'histoire”; and René Allio, "À propos de Rude journée pour la reine," Cahiers du cinéma no. 249 (February-March 1974), pp. 17-25. Rude journée pour la reine, as Toubiana later recognized, "helped [Cahiers] to slowly move beyond our critical torpor." Serge Toubiana, "René Allio et les Cahiers du cinéma," in Sylvie Lindeperg, Myriam Tsikounas and Marguerite Vappereau (eds.), Les Histoires de René Allio (Rennes: Presses universitaires de Rennes, 2013), pp. 265-268, here p. 268.

75 Interview with Pascal Bonitzer, April 30, 2014.

76 Michel Foucault (ed.), Moi, Pierre Rivière, ayant égorgé ma mère, ma sœur et mon frère (Paris: Gallimard/Julliard, 1973), p. 321. 
Cahiers, the case is “a phenomenon for which I can't see any equivalents in the history of crime or of discourse: a crime accompanied by a discourse so powerful and so strange that the crime doesn't in the end exist any more, can't be pinned down, by the very fact of what is said about it by the criminal himself." 77 Allio's film, meanwhile, gives the material a remarkably sober treatment: long recitations of the documents associated with the crime are accompanied by a painstaking recreation of early-nineteenth-century peasant life. Rural inhabitants of the Normandy area in which the events took place were enlisted to play the roles of the Rivière family and their neighbors, such that a confrontation is established between the vernacular diction and gestures of the region (both in the 1830 s and in the present day) and bourgeois modes of speech (the technocratic discourse of the judicial apparatus), which were reproduced by professional actors. Although this procedure could potentially be tarred with the brush of naturalism, Cahiers preferred to see Allio's film as a prise de parole by the peasantry and argued that "the acting of the peasants refers back to the active presence of the dispositif that surrounds them (the camera, the text, the choices made in the mise en scène): it permanently states that all this, everything we see and hear, is written." 78

Cahiers' interview with Foucault ushered in a period of new encounters between the journal and figures on the French intellectual left: between 1975 and 1981, Rancière, Deleuze, historian Marc Ferro and art theorists Jean Louis Schefer and Pierre Legendre were all interviewed by the journal, and they assisted in its shift away from a purely Marxist theoretical framework. At the same time, the Cahiers editors were engaged in grappling with political issues as they presented themselves in contemporary cinema, but they often did so in a groping, tentative manner, with different members of the editorial team reaching different conclusions. Nowhere was this more apparent than in the round tables the journal conducted in the latter half of the 1970s, which often saw Cahiers engaged in internal debates, albeit without the obdurate sectarianism of earlier in the decade. Three of these discussions - on contemporary "naturalist" cinema (held in 1975), Robert Kramer's Milestones (1975) and Chris Marker's Le fond de l'air est rouge

77 Michel Foucault, interviewed by Pascal Kané, "Entretien avec Michel Foucault," Cahiers du cinéma no. 271 (November 1976), pp. 52-53, here p. 52. Translated as "Interview with Michel Foucault," trans. Annwyl Williams, in Wilson (ed.), Cahiers du Cinéma vol. IV, pp. 181-185, here p. 182. The interview was conducted for Kané's short film on the making of Moi, Pierre Rivière, À propos de Pierre Rivière.

78 Kané, in ibid., p. 52; and Serge Le Péron, "L'écrit et le cru," Cahiers du cinéma no. 271 (November 1976), pp. $56-58$, here p. 58 . 
$(1978)^{79}$ - are of particular interest in charting the vicissitudes of the journal's political evolution over the course of this erratic period in its history. But they also evince a certain "retro" nature to Cahiers' own critical practice in the "post-gauchiste" era. All centered on the disenchanted aftermath of the post-1968 period of militancy, and they even, at times, exhibit a nostalgic yearning for a lost past. So much of the discourse produced in this period was written in a kind of preterite tense, referring back to the history of the journal and the radical milieux in which it was situated. Although the editors clearly strove for a new spirit of openness and tolerance, their discussions often seem to be exclusively addressed to fellow anciens combattants, as if only those who were also implicated in the political struggles of the post-1968 militancy could understand the discourse now being developed. The trauma of gauchiste politics continued to leave its marks on the journal well after the movement itself had waned.

\section{The Return to the Mainstream: 1979-1981}

Discord over specific films was nothing new to Cahiers, of course, but in the late 1970s a more fundamental cleavage took place within the journal. Daney and Toubiana had always been something of an odd couple at the head of the journal, but initially the duo's division of labor-between theoretical guidance and administrative knowhow - had been complementary in nature. As the 1970s drew to a close, however, their respective visions for the journal became increasingly divergent, and not even the creation of a comité de direction in 1978 (incorporating Daney, Toubiana, Narboni and film technician Jean-Pierre Beauviala ${ }^{80}$ was able to smooth

79 See Serge Daney, Pascal Kané, Jean-Pierre Oudart and Serge Toubiana, "Une certaine tendance du cinéma français," Cahiers du cinéma no. 257 (May-June 1975), pp.5-21. Translated as "A particular trend in French cinema," trans. Jill Forbes, in Wilson (ed.), in Cahiers du Cinéma vol. IV, pp. 73-91; Pascal Bonitzer, Serge Daney, Thérèse Giraud, Serge Le Péron, Jean Narboni and Dominique Villain, "Milestones et nous (Table-ronde)," Cahiers du cinéma no. 258-259 (July-August 1975), pp. 61-74. Translated in abridged form as "Round Table: Milestones and Us," trans. David Wilson, in Wilson (ed.), Cahiers du Cinéma vol. IV, pp. 142-152; and Serge Daney, Jean-Paul Fargier, Thérèse Giraud, Serge Le Péron and Jean Narboni, "Table ronde sur Le fond de l'air est rouge," Cahiers du cinéma no. 284 (January 1978), pp. 46-51. Translated as "Round Table on Chris Marker's Le Fond de l'air est rouge," trans. Chris Darke, in Wilson (ed.), Cahiers du Cinéma vol. IV, pp. 92-101.

80 Beauviala was the Grenoble-based inventor of the Aäton camera and a collaborator with Godard. His involvement was intended to re-orient the journal towards questions of film and media technology, but this desire was only intermittently realized in subsequent issues of cahiers. 
over the tensions within Cahiers. Certainly, nobody at the journal could cavil at Toubiana's tireless efforts to return the journal to financial stability. The crisis of the Maoist years - in terms of monetary deficits and declining sales - took several years to overcome, and the mid-1970s was punctuated by desperate appeals to the journal's readership in a bid to increase subscription numbers. France's heightened inflation levels and the difficulties for an independent publication to operate within the nation's media monopoly only made matters worse. The July-August 1976 issue was frank about the state of crisis the journal was in: an appeal titled "Cahiers needs 50,00o francs" notified its readers that this sum was rapidly required "so that, once our administration is reorganized with a view to substantial savings, Cahiers can once again become a monthly." ${ }^{11}$ The push met with success, and from September 1976, the journal achieved its aim of appearing regularly at the end of each month. February 1978 saw a change of format to a less austere, more magazine-like style and an augmentation in the number of pages from 68 to 76 per issue. The issue also contained an editorial co-signed by Toubiana and Daney, who acknowledged that "the last text engaging the general orientation of the work at Cahiers, its 'line' as we used to say back then, dates to issue no. 250 (May 1974)." The "almost four years" separating these two editorials was an eternity given the sweeping changes to the political and media landscapes in France in the intervening period, and the new text sought to grasp the contemporary context in which the journal operated, in an attempt "more to sketch out a framework than to erect a line." Distancing themselves from the "indefatigable babble on the "crisis of cinema," the editors nonetheless acknowledge that the cinema has lost its "monopoly over the mass imaginary" to television and that the film spectator has given way to the "cultural consumer." And yet, they reject the notion that Cahiers should "participate in a sort of united front for the defense of the cinema." Instead, it should seek to "carve up [découper] the cinema differently," a tactic that would consist of studying the cinema in its "impurity" (the allusion to Bazin is explicit) and "heterogeneity." 82

What exactly this should consist of, however, remained vague, and the joint signature masked the different directions in which Daney and Toubiana were heading. Daney was backed by the "old guard" of the journal—Narboni, Bonitzer and Kané, with Bonitzer in particular registering his strident

81 Cahiers du cinéma no. 268-269 (July-August 1976), p. 3.

82 Serge Daney and Serge Toubiana, "Éditorial," Cahiers du cinéma no. 285 (February 1978), pp. 4-5. 
opposition to the prospective abandonment of film theory ${ }^{83}$-and de Baecque notes that "violent quarrels frequently broke-out in the "back-office" during this time.$^{84}$ Increasingly, Toubiana's orientation of returning the journal to the center of mainstream film discourse in France gained the upper hand, a change that entailed the dissipation of any engagement with radical politics as well as the marginalization of theoretical discussions. This shift was a gradual one, occurring in fits and starts, and there is no clear date at which the nexus of politics and theory that had marked the Cahiers project for more than a decade came undone. And yet, between 1976 and 1981, the tendency is clear. The "Toubiana line" did, however, represent an opportunity to open the journal up to new developments in cinema that it had disregarded or disdained in earlier years. In particular, the work of the New Hollywood filmmakers was given sustained attention for the first time: Kané, who had always been more susceptible to the charms of contemporary Hollywood cinema, dedicated articles to Taxi Driver and Dog Day Afternoon in 1976 and Brian de Palma in 1977, while Daney followed with an appreciative response to Annie Hall later that year. ${ }^{85}$ By 1979 , blockbusters such as Apocalypse Now and Alien were assuming an increasingly prominent place in the journal; while Daney's and Bonitzer's responses to these films still attested to a wry critical distance, the younger generation of critics brought on by Toubiana were far more adulatory in their attitudes toward Hollywood spectacle. ${ }^{86}$

In addition to the return of Hollywood, the late 197os also saw a reconciliation with Truffaut. The nouvelle vague luminary with whom, even in the 1970s, much of Cahiers' broader fame was still associated, had been close to the journal in the years 1968-1970, despite the fact that he was far from sharing its Marxist outlook. After collaborating with Cahiers on the Henri Langlois campaign in early 1968, Truffaut had provided a sizable amount of capital for the journal's buy-out of Fillipachi two years later. This support was reciprocated in the positive appraisals given to his films during this period-although the increasingly contorted attempts to shoehorn relatively conventional works such as Baisers volés, La Sirène du Mississippi

83 Interview with Pascal Bonitzer, April 30, 2014.

84 De Baecque, Histoire d'une revue vol. II, p. 306.

85 See Serge Daney, "Le cinéphile à la voix forte (Annie Hall)," Cahiers du cinéma no. 282 (November 1977), pp. 38-40. Kané's articles will be discussed in Chapter 20.

86 Serge Daney, "Apocalypse Now (Francis Coppola)," Cahiers du cinéma no. 304 (October 1979), pp. 45-48, here p. 45. See also Pascal Bonitzer, "Apocalypse Now (Francis Coppola)," Cahiers du cinéma no. 304 (October 1979), p. 48; and Pascal Bonitzer, "Alien (Ridley Scott)," Cahiers du cinéma no. 304 (October 1979), pp. 58-59. 
and L'Enfant sauvage into the radical film aesthetics vaunted by Cahiers perhaps indicates that certain opportunistic considerations played a role in these assessments. ${ }^{87} \mathrm{~A}$ freezing in relations came, however in 1971: after Truffaut's withdrawal from the journal's comité de rédaction in August 1970, Cahiers reprinted an interview he gave to La Vie lyonnaise justifying his departure in the following terms: "To be frank, Cahiers today has fallen into politics, they do a Marxist-Leninist analysis of films. Reading the journal is prohibited to anyone who has never gone to university. As for me, I have never read a line of Marx. But they are doing serious work." ${ }^{88}$ Quoting these comments seemed innocuous, but they led to Truffaut sending a message to the Cahiers editors, stating, "At the start of the year you wrote to me to invite me to lunch. I answered: 'Yes, with pleasure.' Since then, I received no. 226-227 and read page 121, which made me lose my appetite. Don't wait for me to start eating, I'm not hungry." ${ }^{\prime 89}$ The rupture was total, and Cahiers' silence on Truffaut's work lasted until Bonitzer's review of La Chambre verte in May 1978, which the critic anointed "the most beautiful, the most profound of François Truffaut's films. ${ }^{\text {"9o }}$ Earlier, in January 1976, Daney and Toubiana had paid a visit to the filmmaker in a bid both for financial support for Cahiers and, tacitly, to receive his approbation for their re-launch of the journal. As Toubiana recalls, Truffaut had harsh words for the journal's Marxist-Leninist period, insisting that it had become so divorced from Bazin's original project that the editors should have abandoned the name Cahiers du cinéma entirely and stated that his position with respect to Daney/ Toubiana's venture would be one of "benevolent neutrality."91 From this point on, the editors assiduously wooed Truffaut: further positive notices greeted L'Amour en fuite in March 1979, Le Dernier Métro in October 1980

87 See Jean-Louis Comolli, "Rêves mouvants (Baisers volés), Cahiers du cinéma no. 205 (1968), p. 57; and Jean-Pierre Oudart, "Rêverie bouclée (La Sirène du Mississippi)." For the texts on L'Enfant sauvage, see Chapter 15 .

88 François Truffaut, interviewed in La Vie lyonnaise, November 1970, repr. as "Le départ de F. Truffaut," Cahiers du cinéma no. 226-227 (January-February 1971), pp. 120-121, here p. 121. A notice in the October 1970 issue observed that Truffaut had already made his decision to withdraw in November 1969, to take effect once Cahiers had recovered its "normal functioning." La Rédaction, "Informations," Cahiers du cinéma no. 224 (October 1970), p. 57.

89 Quoted in de Baecque Histoire d'une revue vol. II, p. 227.

90 Bonitzer even praised the "striking intelligence" of Truffaut's turn as an actor in the film. Pascal Bonitzer, "La Chambre verte (François Truffaut)," Cahiers du cinéma no. 288 (May 1978), pp. 40-42, here p. 40.

91 Serge Toubiana, interviewed by Yann Plougastel, "'Un personnage mystérieux voire romanesque': Entretien avec Serge Toubiana,” Le Monde, hors-série François Truffaut (May-June 2014), pp. $57-63$, here p. 57 . 
and, in the last article Kané would write for Cahiers, La Femme d'à côté in November $1981.9^{22}$ The filmmaker's return to Cahiers was fully consecrated with a two-part interview published in September-October 1980, his first with the journal since $1967 \cdot{ }^{93}$

Truffaut's importance for Toubiana was undeniable, and in 1996, the critic collaborated with Antoine de Baecque on an authoritative biography of the director. ${ }^{94}$ Moreover, his return to grace in Cahiers was emblematic of its new orientation: just as Truffaut represented the "just middle" of the cinema-between mainstream commercialism and avant-garde radicalism-so too did Toubiana seek to re-position the journal in a critical center ground between the lofty rarefaction of film theory and the lower depths of consumer-oriented entertainment guides. ${ }^{95}$ Correspondingly, January 1980 saw the beginning of the "Journal des Cahiers du cinéma," an insert within the magazine that focused on short, journalistic pieces-necessary, the editors stressed, as a response to the "acceleration of cultural consumption." ${ }^{6} \mathrm{~A}$ year later, Cahiers' format was again altered, now containing an additional eight pages and an emphasis on more photographs at the expense of text, with an advertisement for the change proclaiming that "Cahiers du cinéma must become more beautiful." ${ }^{\prime 7}$ The changes were paying dividends: the print run for the monthly was now set at 20,000 copies, and a goal of 8000 subscribers was set for 1981 — qualitatively higher than its entire readership was throughout most of the 1970s.

Despite this boom in sales, the tone in much of Daney's writings during this period was downcast, and by mid-1981, he resolved to end his nearly two decades of involvement with Cahiers, having accepted a long-standing offer from Serge July to become the chief film critic for the left-wing daily Libération. Although an editorial trio involving Bonitzer, Le Péron and Toubiana was initially considered, Bonitzer declined the offer, and instead

92 See Pascal Kané, "Qui y a-t-il sous les jupes des femmes (La Femme d'à côté)," Cahiers du cinéma no. 329 (November 1981), pp. 51-52.

93 See François Truffaut, interviewed by Serge Daney, Jean Narboni and Serge Toubiana, "Entretien avec François Truffaut (1e partie)," Cahiers du cinéma no. 315 (September 1980), pp. 7-17, and "Entretien avec François Truffaut (2e partie)," Cahiers du cinéma no. 316 (October 1980), pp. 21-35.

94 Antoine de Baecque and Serge Toubiana, François Truffaut (Paris: Gallimard, 1996).

95 The term "just middle" (le juste milieu) had already been used to describe Truffaut's work in a 1967 mini-dossier on the filmmaker. See "Francois Truffaut ou le juste milieu," Cahiers du cinéma no. 190 (May 1967), pp. 17-36.

96 Serge Daney and Serge Toubiana, “Un journal dans une revue," Cahiers du cinéma no. 307 (January 1980), p. 59.

97 Cahiers du cinéma no. 317 (November 1980), p. 3. 
Toubiana become sole editor-in-chief, which essentially marked the end of the 1968 generation's involvement with Cahiers. Oudart had already ceased writing for the journal in 1980, and soon after Daney's departure, Narboni and Kané would follow suit. Bonitzer continued to contribute articles until the late 1980 s, but his texts became more intermittent and more divorced from the central project of Cahiers, as his energies were more consumed with screenwriting during this decade. The caesura between the old Cahiers and the new was most clearly symbolized by the pair of issues dedicated to the "Situation of French Cinema" in May and June 1981. The first, overseen by Daney, focused on the journal's canonical nouvelle vague auteurs-Godard, Rivette, Rohmer, Pialat - while texts by Daney himsef ("Le cru et le cuit") and Bonitzer ("Juste une image") sought to discern the continuities in the Cahiers line that ran from its founding under Bazin to the present day - continuities which, it was implied, had now reached their conclusion..$^{8}$ The second, edited by Toubiana, was dedicated to economic questions affecting French cinema from the perspective of producers and audiences and was largely written by a newer generation of critics. From this point on, it was the latter perspective that would prevail in the journal.

Daney was sanguine about what this meant for Cahiers: Toubiana had "watered down the wine," and the journal's current discourse, he noted in 1983 , was "far behind the great theoretical and doctrinaire enthusiasm of yore"; but he accepted that "the times don't lend themselves to this. As far as thinking is concerned, this era is rather weak."99 Indeed, that May 1981 should mark the end point of the political and theoretical project of Cahiers was appropriate: this month also saw the end of 23 years of right-wing rule in the Fifth Republic with the election of Mitterand as president of France. Having gained the support of many of those who, in the 196os and 1970s, had been active in the far left, the Mitterand administration failed to fulfil the promise of the Parti socialiste's electoral program and lurched instead towards a centrist, consensus-based politics-although the boost to film funding under Minister of Culture Jack Lang was a rare bright spot. On a global level, meanwhile, the prospects for a revolutionary overthrow of capitalism had markedly receded. Reagan in the US and Thatcher in the UK ushered in a phase of economic neo-liberalism, while the brutal repression of the Solidarność movement in Poland marked the onset of the Soviet bloc's death spiral. China was now embarking on market reforms under Deng

98 Serge Daney, "Le cru et le cuit," Cahiers du cinéma no 323-324 (May 1981), pp. 11-14; and Bonitzer, "Juste une image."

99 Daney, "Passion de l'image," p. 19. 
Xiaoping, and the anti-imperialist movements in the Third World had lost their impetus. The 1980s, therefore, was a period of global reaction, to which Cahiers was not immune. At the same time, the deaths in the early years of this decade of Lacan, Barthes and Foucault, as well as the detention of Althusser for the murder of his wife, represented a symbolic termination to the wave of French critical theory that had guided the journal since the early 196os. In a cinematic context, the final exhaustion of the modernist period (it too marked by the symbolic deaths of Eustache, Rocha, Truffaut, Fassbinder, Buñuel and Tarkovsky in quick succession in the early 1980s) was recognized by Bergala as early as 1983 and became a major topic for Daney's writings in the 1980 s. $^{100}$ Within this context, little new reflection on the cinema of lasting value could be found on the pages of Cahiers, whether of a political or purely theoretical nature. It is symptomatic then, that de Baecque chooses to end his history of the journal in 1981, while the BFI series of Cahiers articles ends even earlier, at 1978. For a continuation beyond the early 1980s of the project established during Cahiers' Marxist period, we have to turn to other areas and to other ways of thinking and practicing cinema carried out by those who were members of the team in the years 1968-1973.

\section{Works Cited}

Ali Akika, Guy Chapouillié, Danièle Dubroux, Serge Le Péron, Jean Narboni and Dominique Villain, “L'Olivier: Entretien et commentaires," Cahiers du cinéma no. 264 (February 1976), pp 11-40.

René Allio, "À propos de Rude journée pour la reine," Cahiers du cinéma no. 249

(February-March 1974), pp. 17-25.

Jacques Aumont, “Comment on écrit l'histoire," Cahiers du cinéma no. 238-239

(May-June 1972), pp. 64-70.

—, interviewed by Nicole Vulser, "Jacques Aumont, le cinéma né sous X," Le Monde, September 29, 2003 .

Antoine de Baecque, Les Cahiers du cinéma: histoire d'une revue vol. II: Cinéma, tours détours 1959-1981 (Paris: Cahiers du cinéma, 1991).

— and Serge Toubiana, François Truffaut (Paris: Gallimard, 1996).

Pierre Baudry, "Le Chagrin et la pitié," Cahiers du cinéma no. 231 (August-September 1971), pp. 51-52.

100 See Alain Bergala, "Le vrai, le faux, le factice," Cahiers du cinéma no. 351 (September 1983), pp. 5-9. 
Alain Bergala, "Le vrai, le faux, le factice," Cahiers du cinéma no. $35^{1}$ (September 1983), pp. 5-9.

Pascal Bonitzer, "Histoire de sparadrap (Lacombe Lucien)," Cahiers du cinéma no. 250 (May 1974), pp. 42-47.

—, "La Chambre verte (François Truffaut)," Cahiers du cinéma no. 288 (May 1978), pp. 40-42.

—, “Apocalypse Now (Francis Coppola)," Cahiers du cinéma no. 304 (October 1979), p. 48 .

—, "Alien (Ridley Scott)," Cahiers du cinéma no. 304 (October 1979), pp. 58-59.

—, "Juste une image," Cahiers du cinéma no. 323-324 (April-May 1981), pp. 15-19.

— - Serge Daney, Thérèse Giraud, Serge Le Péron, Jean Narboni and Dominique Villain, “Milestones et nous (Table-ronde)," Cahiers du cinéma no. 258-259 (JulyAugust 1975), pp. 61-74. Translated in abridged form as "Round Table: Milestones and Us," trans. David Wilson, in David Wilson (ed.), Cahiers du Cinéma vol. IV: 1973-1978 History, Ideology, Cultural Struggle (London: Routledge, 2000), pp. 142-152. Hereafter CDC IV.

Jean-Louis Comolli, “Les miettes de l'existence (La Vieille Dame indigne)," Cahiers du cinéma no. 166-167 (May/June 1967), pp. 126-129.

—, "Rêves mouvants (Baisers volés), Cahiers du cinéma, no. 205 (October 1968), p. 57 .

—, "L'image absente (sur L'Olivier)," Cahiers du cinéma no. 265 (March-April 1976), pp. 44-47.

Serge Daney, "Une auberge espagnole singulièrement silencieuse," Libération, October 4, 1973. Repr. in idem., La Maison cinéma et le monde vol. I: Les temps des Cahiers 1962-1981 (Paris: P.O.L., 2001), pp. 145-148.

—, "Fonction critique," Cahiers du cinéma no. 248 (c. late 1973), pp. 39-40, Cahiers du cinéma no. 250 (May 1974), pp. 38-42, and Cahiers du cinéma no. 253 (OctoberNovember 1974), pp. 30-36. Translated as "The Critical Function," trans. Annwyl Williams, in CDC IV, pp. 56-72.

—, "L'espace politique (Histoires d'Histoires d'A)," Cahiers du cinéma no. 254-255 (December 1974-January 1975), pp. 33-36.

—, "La remise en scène (Notes)," Cahiers du cinéma no. 268-269 (July-August 1976), pp. 20-26.

—, "Le cinéphile à la voix forte (Annie Hall)," Cahiers du cinéma no. 282 (November 1977), pp. 38-40.

—, "Apocalypse Now (Francis Coppola)," Cahiers du cinéma no. 304 (October 1979), pp. $45-48$.

—, "Le cru et le cuit," Cahiers du cinéma no 323-324 (May 1981), pp. 11-14.

—, "Michel Foucault," in "Dictionnaire sans foi ni loi," Cahiers du cinéma no. 325 (June 1981), p. 116. 
—, interviewed by Michel Crépu, Gilles Delavaud, Michel Mesnil and Olivier Mongin, "Passion de l'image: Des Cahiers du cinéma à Libération: Entretien avec Serge Daney," Esprit vol. 83 no. 11 (November 1983) pp. 111-133. Repr. in Daney, La Maison cinéma et le monde vol. II: Les Années Libé 1981-1985 (Paris: P.O.L., 2005), pp. 7-31.

—, La Rampe (Paris: Cahiers du cinéma, 1983).

—, L'Exercice a été profitable, Monsieur (Paris: P.O.L., 1993).

Serge Daney and Serge Toubiana, "Les Cahiers aujourd'hui," Cahiers du cinéma no. $25^{0}$ (May 1974), pp. 5-10. Translated as "Editorial: Cahiers Today," trans. Liz Heron, in CDC IV, pp. 47-55.

—, "A.I.E. et luttes de classes: Chili 1970-1973," Cahiers du cinéma no. 254-255 (December 1974-January 1975), pp. 6-7.

—, "Éditorial," Cahiers du cinéma no. 285 (February 1978), pp. 4-5.

—, "Un journal dans une revue," Cahiers du cinéma no. 307 (January 1980), p. 59.

—, Pascal Kané, Jean-Pierre Oudart and Serge Toubiana, "Une certaine tendance du cinéma français," Cahiers du cinéma no. 257 (May-June 1975), pp. 5-21. Translated as "A particular trend in French cinema," trans. Jill Forbes, in CDC IV, pp. 73-91.

—, Jean-Paul Fargier, Thérèse Giraud, Serge Le Péron and Jean Narboni, "Table ronde sur Le fond de l'air est rouge," Cahiers du cinéma no. 284 (January 1978), pp. 46-51. Translated as "Round Table on Chris Marker's Le Fond de l'air est rouge," trans. Chris Darke, in CDC IV, pp. 92-101.

Jean-Paul Fargier, "Pour le dépérissement du cinéma militant," Cinéma d'aujourd'hui no. 5-6 (1976), pp. 163-168.

Dario Fo, "Dario Fo à Vincennes," Cahiers du cinéma no. 250 (May 1974), pp. 16-25. Michel Foucault (ed.), Moi, Pierre Rivière, ayant égorgé ma mère, ma sœur et mon frère (Paris: Gallimard/Julliard, 1973).

—, interviewed by Pascal Bonitzer and Serge Toubiana, "Anti-Retro: Entretien avec Michel Foucault," Cahiers du cinéma no. 251-252 (July-August 1974), pp. 5-15. Translated as "Anti-Retro," trans. Annwyl Williams, in CDC IV, pp. 159-172.

—, interviewed by Pascal Kané, "Entretien avec Michel Foucault," Cahiers du cinéma no. 271 (November 1976), pp. 52-53. Translated as "Interview with Michel Foucault," trans. Annwyl Williams, in CDC IV, pp. 181-185.

Marielle Issartel and Charles Belmont, interviewed by Serge Daney, Jean-René Huleu and Serge Toubiana, "Histoires d'A: Entretien avec Marielle Issartel et Charles Belmont," Cahiers du cinéma no. 251-252 (July-August 1974), pp. 48-55.

Pascal Kané, "Qui y a-t-il sous les jupes des femmes (La Femme d'à côté)," Cahiers du cinéma no. 329 (November 1981), pp. 51-52.

Serge Le Péron, “À propos du cinéma palestinien," Cahiers du cinéma no. 256 (February-March 1975), pp. 35-38.

—, "Lécrit et le cru," Cahiers du cinéma no. 271 (November 1976), pp. 56-58. 
Abdelwahab Meddeb, “La leçon sauvage (Kafr Kassem)," Cahiers du cinéma no. 256 (February-March 1975), pp. 47-51.

Jean Narboni, “Le sang changé en signe (Kafr Kassem)," Cahiers du cinéma no. 256 (February-March 1975), pp. 39-46, translated as "Blood into sign," trans. Annwyl Williams, in CDC IV, pp. 259-267.

- , Pourquoi les coiffeurs? (Paris: Capricci, 2010).

Jean-Pierre Oudart, "Rêverie bouclée (La Sirène de Mississippi)," Cahiers du cinéma no. 216 (October 1969), pp. 51-52.

Philippe Pakradouni, "Réponse au no. 250," Cahiers du cinéma no. 253 (OctoberNovember 1974), pp. 53-58.

Jacques Rancière, "Mode d'emploi à Lire le Capital," Les Temps Modernes no. $3^{28}$ (November 1973), pp. 788-807.

—, La Leçon d'Althusser (Paris: Gallimard, 1974). Translated as Althusser's Lesson, trans. Emilian Battista (London: Continuum, 2011).

—, interviewed by Serge Daney and Serge Toubiana, "L'Image fraternelle: Entretien avec Jacques Rancière," Cahiers du cinéma no. 268-269 (July-August 1976), pp. 7-19.

—, "Fleurs intempestives (La Communion solennelle), Cahiers du cinéma no. 278 (July 1977), pp. 17-20.

La Rédaction, "Informations," Cahiers du cinéma no. 224 (October 1970), p. 57.

—, "Réponse à la réponse," Cahiers du cinéma no. 253 (October-November 1974), pp. 59-65.

Bérénice Reynaud, “Introduction: Cahiers du Cinéma 1973-1978," in CDC IV, pp. 1-44. Serge Toubiana, interviewed by Yann Plougastel, "Un personnage mystérieux voire romanesque': Entretien avec Serge Toubiana," Le Monde, hors-série François Truffaut (May-June 2014), pp. 57-63.

—_, "Parce que l'amitié!," Cahiers du cinéma no. 458 (July-August 1992), pp. 6-8.

—, "René Allio et les Cahiers du cinéma," in Sylvie Lindeperg, Myriam Tsikounas and Marguerite Vappereau (eds.), Les Histoires de René Allio (Rennes: Presses universitaires de Rennes, 2013), pp. 265-268.

—, Les Fantômes du souvenir (Paris: Bernard Grasset, 2016).

François Truffaut, interviewed in La Vie lyonnaise, November 1970, repr. as "Le départ de F. Truffaut," Cahiers du cinéma no. 226-227 (January-February 1971), pp. 120-121.

—, interviewed by Serge Daney, Jean Narboni and Serge Toubiana, "Entretien avec François Truffaut," Cahiers du cinéma no. 315 (September 1980), pp. 7-17, and Cahiers du cinéma no. 316 (October 1980), pp. 21-35. 



\title{
12. Bernard Eisenschitz: Cinema, Communism and History
}

\begin{abstract}
This chapter focuses on Bernard Eisenschitz's activities as a film critic and historian after he was expelled from Cahiers du cinéma in 1972. A member of the Parti communiste français throughout the 1970s, he initially wrote for the party's cultural journal La Nouvelle Critique as well as communist publications such as Révolution and L'Humanité, and he exposed the readership of these organs to a wide array of films influenced by Cahiers' own cinematic canon. Later, his lifelong passion for film history manifested itself in a prolific series of books, written with a meticulous care for detail, which included historical surveys of German and Soviet cinema and studies of the filmmakers Nicholas Ray, Fritz Lang and Chris Marker.
\end{abstract}

Keywords: Bernard Eisenschitz, La Nouvelle Critique, Parti communiste français, film history, Soviet cinema

\section{Eisenschitz and the French Communist Party}

After his 1972 exclusion from Cahiers, Bernard Eisenschitz was active throughout the 1970 s as a film critic, programmer and, increasingly, historian, pursuing this work within cultural organizations linked to the PCF. His activity during this period can be seen as a sort of alternative trajectory to that of Cahiers: one in which the strategy of aligning with the Communist Party, with its hundreds of thousands of members and sympathizers, was continued and deepened rather than being abandoned for the tumultuous path of Maoism and its post-gauchiste aftermath. Having joined the PCF in 1970, Eisenschitz remained a member until the late 1970s and wrote for PCF-aligned organs (La Nouvelle Critique, Révolution and L'Humanité) until the mid-1980s. Even up to the present day, however, his work on the cinema has been impregnated by this political orientation, which comes through

Fairfax, D., The Red Years of Cahiers du Cinéma (1968-1973). Volume I: Ideology and Politics. Amsterdam: Amsterdam University Press, 2021 DOI 10.5117/9789463728508_CH12 
above all in the type of cinema with which Eisenschitz has steadfastly engaged: the filmmaking of the Soviet Union and the Eastern bloc, dissident directors within the Hollywood studio system, and German filmmakers who grappled with that country's politically convulsive history. In general, the filmmakers he has focused on have been those who consciously worked within national film production systems - albeit often as subversive or rebellious elements - in order to further their political and aesthetic goals rather than auteurs whose work is divorced from a broader social or filmindustrial context.

Three terms, then, govern Eisenschitz's work from his time at Cahiers up to the present day: cinema, communism and history. These terms were already linked in his early biography. The first screening the young cinephile attended at the cinémathèque was Fritz Lang's Eine Frau im Mond, a viewing inspired by the successful launch of the Sputnik satellite by the Soviet Union. After initially coming to political consciousness as a teen by the Algerian war and the Gaullist coup of 1958, Eisenschitz's interest in politics was soon subsumed by his obsessive cinephilia, until a later moment of radicalization began in $1967 .{ }^{1}$ From this point, his political evolution was linked with that of Cahiers: its initial rejection of the Communist Party during the 1968 protests, followed by the rapprochement with the PCF's cultural milieux beginning in late 1969. Eisenschitz has claimed that his position within the journal was "that of a historian, not that of an ideologue,"2 but he would distinguish himself by being the only member of the post-1968 Cahiers team to take the step of joining the party, doing so in 1970 . He was also the only Cahiers writer to travel to the USSR, attending the Moscow film festival in 1969 and visiting the Soviet film archives in preparation for the "Russie années vingt" special issue. The visit did not instill Eisenschitz with any illusions about the reality of day-to-day life in the Soviet Union, ${ }^{3}$ but it did arouse his interest in Soviet cinema, which thenceforth assumed a central position in Eisenschitz's research, and in addition to his archival work he met contemporary filmmakers such as Otar Iosselliani, Andrei Tarkovsky and Andrei Konchalovsky.

After joining the PCF, Eisenschitz soon found employment, alongside Cahiers alumnus Jean-André Fieschi, in Unicité (the party's audiovisual department), a position he held for the duration of his membership in the

1 Interview with Bernard Eisenschitz, April 1, 2014.

2 Eisenschitz, “A French Roman," p. 21.

3 "We never thought it was a dream, but we saw that it was even less than that," as he would put it. Interview with Bernard Eisenschitz, April 1, 2014. 
party. Fieschi and Eisenschitz, who also collaborated in the film review section of La Nouvelle Critique, maintained a strict division of labor within Unicité. Fieschi oversaw communist-aligned film production, while Eisenschitz concerned himself with distribution. Initially this consisted of disseminating $16 \mathrm{~mm}$ prints of PCF-produced militant films to regional areas for screenings at party meetings. Soon, however, Eisenschitz took the initiative of organizing the theatrical distribution of films from the Eastern bloc. In 1973, for instance, he was involved in the release of East German documentaries by Walter Heynowski and Gerhard Scheumann on the Pinochet coup in Chile as well as the less overtly political Georgian film Pirosmani by Georgi Chengelaia, a biography of the eponymous Caucasian painter. The most ambitious event that Eisenschitz was involved in during this time, however, was a week-long program of films from the USSR at the Avignon festival in July 1975. La Nouvelle Critique had long been involved with Avignon and even offered a program of films and discussions on the topic "Situation and Perspectives of French Cinema" at the 1973 festival, simultaneous with the foundering of Cahiers' project of launching the Front culturel révolutionnaire. ${ }^{4}$ Two years later, the focus on Soviet cinema involved a program of 25 films, accompanied by question-and-answer sessions with directors from the Soviet Union, including a panorama of contemporary films from the Soviet republics. Eisenschitz defended this focus in his summary of the program for La Nouvelle Critique: lamenting that the paucity of Soviet films distributed in France led to an "almost total unawareness of the situation of Soviet cinema," he stressed the diversity of filmmaking cultures that had evolved in the different republics of the USSR, such that he found it more appropriate to speak of "Soviet cinemas" in the plural, with the output of the Ukrainian, Georgian, Uzbek and other nonRussian studios developing independently of Moscow-based production. ${ }^{5}$

Eisenschitz would continue curatorial work such as this long after he severed ties with the PCF, and he has frequently been involved in retrospective programs at the Cinémathèque française as well as festivals such as Bologna and Locarno. When he was still involved with the party, his cultural activity had a dual purpose. Firstly, he participated in the PCF's project of creating a broad-based ideological alternative to Gaullist (and later post-Gaullist) rule in France as it strove to gain a majority of the

4 See [Anon.], “Ciné/N.C. en Avignon," La Nouvelle Critique no. 65 (June-July 1973), p. 77; and [Anon.], "Cinéma: La N.C. en Avignon," La Nouvelle Critique no. 67 (September 1973), p. 85.

5 Bernard Eisenschitz, "Cinéma soviétique: points de continuité," La Nouvelle Critique no. 85 (June-July 1975), pp. 74-76, here pp. 74-75. 
country's support for its union de la gauche program. Secondly, within the communist movement itself, Eisenschitz sought to participate, however modestly, in the transformation of the party towards a more open, pluralist political organization, specifically by deepening its membership's exposure to a diverse range of cinematic practices and by fostering the appropriate discursive framework in which this work could be appreciated, thereby creating a counterpole to the Stalinist, Zhdanovite heritage that still weighed heavily on the party apparatus. His practice therefore mirrored Althusser's political strategy of reforming the party from within, but such parallels are largely coincidental. Eisenschitz professes that he understood little of the polemics among the party's intellectuals upon the publication of Althusser's article on the "Ideological State Apparatuses." ${ }^{n}$

\section{Film Criticism within the PCF: La Nouvelle Critique, L'Humanité, Révolution}

The most important element in this dual counter-hegemonic aspect to Eisenschitz' activity was undoubtedly his film criticism in the 1970s and early 1980s. Beginning with La Nouvelle Critique, this work continued with more sporadic contributions on the cinema to the party's daily newspaper L'Humanité and its weekly cultural magazine Révolution, which was founded in 1979 as a replacement for both La Nouvelle Critique and La France nouvelle. Eisenschitz began writing for the bi-monthly journal in 1970. Initially, this was supplementary to his contributions to Cahiers, thereby continuing the critical polygamy he had practiced in the 196os. Indeed, in the years 19701971, the critic functioned as something of an emissary of Cahiers' critical tastes to the readership of La Nouvelle Critique, which was far larger than that of the film journal. His first article, from November 1970, is indicative of this. Mirroring the discussion of Kramer's Ice in Cahiers and presenting an alternative view to that of other communist critics (including Fieschi), Eisenschitz argued against seeing the film as "an apology for gauchisme," and in the guise of a brief critical notice he presented a synoptic example of the mode of critical analysis practiced by his Cahiers colleagues: only a "totally mechanistic reading" would confuse the ideological content enunciated in

6 "I did not understand why Althusser wrote an article called 'Ideology and Ideological State Apparatuses' for La Pensée, and everyone in the Communist Party was furious. I remember that Jean-André Fieschi was furious about this article. I asked him to explain it to me, but he never did." Interview with Bernard Eisenschitz, April 1, 2014. 
the film with the viewpoint of its filmmaker. Rather, a political reading of any film "must be situated on the level of its application [mise en œuvre]." In the case of Ice, Kramer's film attests to a "decentering of the fiction and its writing," precisely because "formal transposition [mise en forme] can not be defined as the simple transparency or faithful recording of the utterings of the characters," and it is this decentering that allows Kramer to operate "a constant dialectic between gauchiste ideology and futuristic fantasy."7 The next month, however, the kind of nuanced reading given to Ice was not proffered to Camarades, a film with its own stridently gauchiste, anti-PC rhetoric. Here, following Bonitzer's skewering of Karmitz's film for Cahiers, Eisenschitz pillories Camarades as a "workerist, sub-Lelouchian banalization" that is founded on the insoluble contradiction of "making a film transmitting a sectarian [groupsuculaire] ideology and addressing it to the widest possible masses." ${ }^{8}$ In contrast with the great works of cinema focused on the coming to awareness of a subject (Kuhle Wampe, La vie est à nous), Camarades is, for Eisenschitz, a mediocre film filled with "revolutionist logorrhea."

Reviews of historical films given theatrical re-releases formed a focus of Eisenschitz's critical pieces during this time, and his response to the politics of such works no doubt surprised some of his readers. Griffith's Birth of a Nation, for instance, was reviewed in 1971, and although Eisenschitz admits to its racist ideology, he does not dismiss the film for this reason. Introducing the non-specialist readership to Eisenstein's seminal text "Griffith, Dickens and the Film Today," he proceeds to note a key lacuna in the Soviet filmmaker's analysis of the interpenetration of form and ideology in Griffith's work: "What Eisenstein omits is the ideological importance of the imbrication of the sexual theme of white virginity with the political 'message.' Griffith's eroticism (which is itself dated and localized), founded on terror, is more central to his œuvre than his social descriptions, and ends up determining them or simply replacing them in his later works."9 Another American filmmaker widely viewed as a political reactionary, Samuel Fuller, received nuanced consideration via a review of his 1948 film Park Row. Its "erroneous vision" of newspaper journalism as an artisanal trade serves as an allegory for Fuller's own status as an independent filmmaker battling against the Hollywood monopoly. "The

7 Bernard Eisenschitz, "Ice (Robert Kramer)," La Nouvelle Critique no. 38 (November 1970), pp. 96-97.

8 Bernard Eisenschitz, “Camarades (Marin Karmitz)," La Nouvelle Critique no. 39 (December 1970), p. 73 .

9 Bernard Eisenschitz, "The Birth of a Nation (1915) (Naissance d'une nation, D.W. Griffith)," La Nouvelle Critique no. 41 (February 1971), pp. 71-72. 
mode of production of Park Row — near total independence and poverty (and concomitant commercial failure) - is exactly that of the hero's newspaper, which bears the same name as Fuller's production company." ${ }^{10}$ By contrast, Kozintsev/Trauberg's New Babylon is given a lukewarm response, despite the fact that it was politically far closer to the PCF than the work of Griffith or Fuller. In tandem with the sympathetic but firm critique formulated by Cahiers, Eisenschitz sees the film as a "dated vision" of the Paris Commune, remote from the class analysis carried out by Marx, despite the avowed debt the directors had to The Civil War in France. But it also represents "the apogee and conclusion" of a current of enthusiasm that took hold of the Soviet cinema in the late 1920s, and in Eisenschitz's view it is this, rather than any political acuity it may have possessed, that makes the film worthy of interest. ${ }^{11}$ Elsewhere, Eisenschitz's views differed from those of his Cahiers colleagues: the journal, for instance, was scathing towards Il conformista, with Oudart calling it a "simulation of political discourse" attesting to the confusion of its director. ${ }^{12}$ Writing for La Nouvelle Critique, Eisenschitz is more measured in his appraisal of the film. Rejecting the equation between auteur cinema and "poor cinema," he highlights the potential for formal work that a larger budget enabled. For Eisenschitz, Bertolucci's analysis of fascism — a political system that was itself, Brecht notes, "the greatest of formalisms"-results in "an extremely complex, considered play of forms, seeking to exhaust its own possibilities to the point of parody."13

Following Eisenschitz's exclusion from Cahiers, his contributions to $\mathrm{La}$ Nouvelle Critique were no longer dispatches presenting the perspective of another organ and came to more closely conform to the PCF journal's cultural interests. For the most part, however, he would refrain from retaliatory attacks on Cahiers, which when they did come tended to be the work of other Nouvelle Critique writers. Émile Breton, for example, ridiculed the praise heaped on The Red Detachment of Women by Tel Quel (and by implication Cahiers, which also lauded the film) and penned a rebuttal to the film journal's March-April 1972 issue, censuring its editors for a dogmatic understanding of Althusser and

10 Bernard Eisenschitz, "Park Row (Violences à Park Row, 1952, Samuel Fuller)," La Nouvelle Critique no. 44 (May 1971), p. 69.

11 Bernard Eisenschitz, "La Nouvelle Babylone (Grigori Kozintsev, Léonid Trauberg)," La Nouvelle Critique no. 46 (July 1971), p. 48.

12 Jean-Pierre Oudart, "Un discours en défaut," Cahiers du cinéma no. 232 (October 1971), pp. 4-12, here p. 11. Translated as "A Lacking Discourse," trans. Joseph Karmel, in Browne (ed.), Cahiers du Cinéma vol. III, pp. 276-286, here p. 285.

13 Bernard Eisenschitz, "Le conformiste (Bernardo Bertolucci), La Nouvelle Critique no. 44 (May 1971), pp. 68-69. 
taking issue with the "fundamental formalism of their research. ${ }^{14}$ Eisenschitz was more circumspect, unwilling to play the role of political commissar. It is only in a brief review of Dominique Noguez's 1973 anthology Cinéma: théories, lectures that he makes his views about the contemporary state of film theory known: for Eisenschitz, Noguez's volume reflects "a disarray, a refusal to make a theoretical decision, a fear of leaving nothing out, which we should not impute to an individual, but to a rather generalized confusion in the teaching of cinema at the university."15 For the most part, however, Eisenschitz's focus in La Nouvelle Critique remains on films: a program of Vietnamese propaganda shorts, appreciated for the fact that "the formal interest of the films is directly linked to their content, their style commanded by their political project"; Emile de Antonio's Nixon compilation Millhouse: A White Comedy, compared to Brecht's Arturo Ui for its comedic vulgarity; and Edouard Bobrowski's cinéma-direct documentary on the use of "political marketing" during a 1973 municipal election campaign in Arras, Aux urnes citoyens, seen as "testifying massively to the favor of the union de la gauche," despite the filmmaker's own skepticism towards the electoral project. ${ }^{16}$

None of these articles would have ruffled feathers within the party, but when Eisenschitz, along with de Gregorio, Breton and Michel Marie, dedicated a multi-authored analysis to Godard-Gorin's explicitly antiPCF film Tout va bien, discontent was raised among those who were more unequivocally hostile to the film - although Eisenschitz is categorical that while "they were unhappy with what we said in the text, nobody said that it was scandalous for La Nouvelle Critique to publish it." ${ }^{17}$ For the four Nouvelle Critique critics, Tout va bien was "an important film because it marks a stage in the theoretical reflection of Jean-Luc Godard" and even attests to a "rupture with a triumphalist-gauchiste cinema functioning on outdated guidelines. ${ }^{18} \mathrm{All}$ four critics, in their separate interventions, sought to reject the anti-communist énoncés of Tout va bien at the same time as understanding the ways in which the film's formal work often undermined

14 Émile Breton, "Le détachement féminin rouge," La Nouvelle Critique no. 52 (April 1972), pp. 72-73; and Émile Breton, "Sur les Cahiers du Cinéma," La Nouvelle Critique no. 55 (August 1972), pp. 91-92. 15 Bernard Eisenschitz, "Revue d'esthétique: Cinéma: théories, lectures," La Nouvelle Critique no. 69 (December 1973), pp. 85-86.

16 Bernard Eisenschitz, "Vietnam: Cinéma d'un peuple au combat," La Nouvelle Critique no. $5^{2}$ (April 1972), pp. 73-74, here p. 73; Bernard Eisenschitz, "Millhouse: A White Comedy," La Nouvelle Critique no. $5^{2}$ (April 1972), p. 74; and Bernard Eisenschitz, "Aux urnes citoyens," La Nouvelle Critique no. 58 (November 1972), p. 76 .

17 Interview with Bernard Eisenschitz, April 7, 2014.

18 See Bernard Eisenschitz, "Tout va bien: un film 'plein de talent," La Nouvelle Critique no. 56 (September 1972), pp. 64-70. The quote is from an introductory note by Michel Marie on p. 64 . 
its overt content. Eisenschitz, reprising the argument developed two years earlier with respect to Ice, was lucid about the need "to not confuse the film with its explicit discourse, to not reduce it to the ideology that it 'contains.' To judge it thus would amount to seeing works as the immediate reflection of the real, to seek in them a spontaneism of signification that we are better off leaving to bourgeois criticism." 19 While emphasizing the film's comic aspect, Eisenschitz nonetheless sees Toutva bien as a "regression in relation to the films of the Groupe Dziga Vertov," with Godard/Gorin making a calculated concession to the political and economic censorship governing French cinema in 1972. It is, however, precisely the film's "disintegrationdeconstruction" of its status as a spectacle that differentiates it from the comparable undertaking of Coup pour coup, which was more roundly denounced by the Nouvelle Critique writers. While the PCF-aligned journal and Cahiers openly reviled each other at this stage, it is interesting that they both reached similar conclusions about both Karmitz's and Godard-Gorin's films. The cinephilic heritage of Eisenschitz and his schooling in the Cahiers critical tradition doubtless had much to do with this uncanny critical accord.

From 1974 on, Eisenschitz wrote more rarely for La Nouvelle Critique, despite remaining on the editorial board; his last article for the journal was published in 1976, and the end of his political activity dates from soon afterwards. ${ }^{20}$ From that year until the end of the 1970s, however, he became an occasional correspondent for L'Humanité, beginning his association with the newspaper with a short piece on La vie est à nous in January 1976, which was screening as part of the festivities for the PCF's national congress. ${ }^{21} \mathrm{~A}$ couple of dozen articles would follow over the next four years, alerting readers to the screening of films (at festivals or on television) such as Pastorale by Iosselliani and Moses und Aron by Straub/Huillet, as well as, less obviously for a communist audience, the work of Howard Hawks, Vincente Minnelli or the Marx Brothers. ${ }^{22}$ Although writing for L'Humanité allowed Eisenschitz to reach a much vaster readership than either Cahiers or La Nouvelle Critique, his articles were generally limited to short, informational notices, and he was unable to leave his stamp on journalistic film criticism in the same way that Daney would for Libération in the following decade.

19 Ibid., p. 68.

20 Eisenschitz describes his leaving the PCF as a "distancing" rather than a "rupture," and, making metaphorical use of film vocabulary, as "more a fade-out than a straight cut." Interview with Bernard Eisenschitz, April 7, 2014.

21 Bernard Eisenschitz, “La vie est à nous," L'Humanité, January 30, 1976, p. 5.

22 Bernard Eisenschitz, "Pastorale: l'aventure ethnologique," L'Humanité, May 11, 1976, p. 10; and “Moïse et Aaron," L'Humanité, November 2, 1979, p. 2. 
When the weekly magazine Révolution was set up in the 1980s, Eisenschitz willingly migrated to the new platform. Contributing fifteen pieces in the years 1980-1985, he benefited from the more expansive format to write indepth articles, with texts of a historical angle taking on a greater importance over contemporary film criticism. Obituaries were delivered for recently deceased directors such as Louis Daquin and Abel Gance, while retrospectives gave Eisenschitz the opportunity to discuss the work of King Vidor, Boris Barnet and, thanks to a vast program organized by Marco Müller in Turin in 1982, Chinese cinema from the 1930s to the 196os. A screening of a reconstituted version of Intolerance at Cannes allowed Eisenschitz to make a case for understanding the film from a Marxist perspective, observing that the analysis of the "oppression-strike-repression mechanism" in the modern episode of the film is "more concrete and more precise" than that of Eisenstein's Strike. ${ }^{23}$ Book reviews appeared on David Goodis, Howard Hawks and the Lux studio in Italy, while Eisenschitz's response to Victor Navasky's Naming Names provoked a surprising assessment of the Hollywood black list: far from using the McCarthyite witch hunt to politically attack the studio system as a "welcome image of the horrors of capitalist democracy" (as may have been expected in a communist magazine), he criticizes the tendency to equate it with the far more serious repression of filmmakers in Nazi Germany and even declares that there is "a relationship between the will of the [US] Communist Party to superintend artistic creation and that of the studios to prescribe the aesthetics of their products" (described by Max Ophuls as "capitalist realism"). ${ }^{24}$ After the end of his collaboration with Révolution, however, Eisenschitz would largely stop writing for critical outlets - a handful of recent pieces in Le Monde diplomatique being the chief exception - and instead he has focused more squarely on the historical work upon which his contemporary reputation largely rests.

\section{Bernard Eisenschitz: Film Historian}

Eisenschitz tends to describe himself in biographical profiles as a "translator and film historian." In terms of professional status, translation is indeed his primary activity: he has worked on film subtitling since the 1960 s and

23 Bernard Eisenschitz, "Intolérance en 166 minutes," Révolution no. 116, May 21, 1982, pp. 35-36, here p. 35 .

24 Bernard Eisenschitz, "Il y a trente ans le Maccarthysme," Révolution no. 162, January 28, 1983, pp. 33-35, here p. 34 . 
translated a large number of articles and books on the cinema. Doubtless his multilingual family background has enabled him to feel at home in the translation of films and texts from English, German, Italian and Spanish into French, and he has even been one of the few figures directly involved with film subtitles to give serious theoretical attention to the practice. When interviewed, Eisenschitz has argued that "the idea of translation has a lot to do with writing" and that film translation "is a way of understanding the manner in which a film is made more than the manner in which the dialogue is made; it allows one to understand the respiration of a film, its editing, speech rhythms, the nature of speech." ${ }^{25}$ In 2013, he even dedicated the text "Sous-titrage mon beau souci" to the intricacies of subtitling, which included a prolonged discussion of the different English renderings of the poetic voice-over to Nuit et brouillard, before concluding with a Marxist analysis of the state of subtitling in the digital era: far from improving the quality of subtitling work, technological advances have only served to imperil the survival of translators by putting downwards pressure on their wages. But Eisenschitz warns against Ludditism. "It is not," he contends, "the instrument that threatens to destroy this activity, but the social conditions in which it is exercised." He even holds out hope for a socially transformative use of the technology: "This technical mutation may, however (and this is already the case, sometimes), help to invent new creative relations between the translators of films and their authors." ${ }^{26}$

It is Eisenschitz's work as a film historian, however, that is both his true passion and the activity for which he is best known. In his self-effacing words, "I am above all a film historian. It is my primary activity, but it is often the last in terms of time and means." ${ }^{27}$ Being a historian of the cinema has entailed, for Eisenschitz, a diverse range of practices, including historiography, archival work, curatorial programming, public lectures, restoration and even, at various times, making films. The rigorous nature of this work is all the more impressive given that Eisenschitz received no formal education as a historian and, having abandoned a bachelor's degree in German studies, has never taught at a university or held an academic post. Instead, his "training" as a historian of the cinema came primarily from the hothouse of 1960 s Parisian cinephilia - with its obsessive practices of

25 Bernard Eisenschitz, interviewed by Aline Vannier-Sihvola, "Paroles intemporelles: entretien avec Bernard Eisenschitz" (2015), https://cinefinn.com/2015/o6/27/paroles-intemporellesentretien-avec-bernard-eisenschitz/ (accessed January 1, 2021).

26 Bernard Eisenschitz, "Sous-titrage mon beau souci," Mise au point no. 5 (April 2013), http:// doi.org/10.4000/map.1481 (accessed January 1, 2021).

27 Eisenschitz, "Paroles intemporelles." 
notetaking and list-making — and, more specifically, his interactions with seminal figures of film historiography such as Georges Sadoul and Henri Langlois.

Eisenschitz briefly met Sadoul shortly before the latter's death in 1967, but his contact with the Marxist historian's widow Ruta in Moscow in 1969 led him to oversee the posthumous publications of Sadoul's pharaonic Histoire générale du cinéma, left as a series of scattered manuscripts at the time of his death. Six volumes were published under the tutelage of Henri Langlois between 1972 and 1975, charting the development of the cinema from its "pre-history" to the $1920{ }^{28}{ }^{28}$ Although Eisenschitz's presence in this project is discreet, the work he carried out to bring the manuscripts to a publishable state was considerable, and his prolonged exposure to Sadoul's historiographical method doubtless had a major influence on his later work, as evinced by the Sadoul text that Eisenschitz arranged to be published in La Nouvelle Critique, "Matériaux, méthodes et problèmes de l'histoire du cinéma." ${ }^{29}$ Nonetheless, Eisenschitz now feels that he "did not have the intellectual means" to carry out the requisite work on these volumes and is now "ashamed" of the compromises that were made to bring them into being. At issue was whether Sadoul's text should be respected even when it was flagrantly erroneous: although today the interest of Sadoul's historiography may lie more in the subjective nature of the text (film history as seen by Sadoul) than its objective accuracy, at the time the perceived need for an encyclopedic history of the cinema rendered the situation more ambiguous, and Eisenschitz was commanded by Langlois to make tacit corrections to the text, an imperative that led to a falling out between the two. ${ }^{30}$

If Eisenschitz's contact with Sadoul came through textual materials, with Langlois it came from the films screened at the Cinemathèque française throughout the latter's tenure at the institution. As with virtually the entire generation of Paris-based cinephiles who came of age in the 1950 s and 196os, Eisenschitz's knowledge of film history came principally from Langlois' programming. While Eisenschitz avows his inestimable debt to the man Cocteau nicknamed the "dragon of the cinémathèque," he has also expressed frustration at Langlois' tempestuous personality, the polar opposite to his own methodical disposition: while the cinémathèque

28 See Georges Sadoul, Histoire générale du cinéma vol. I-VI, ed. Bernard Eisenschitz (Paris: Denoël, 1973-1975).

29 See Georges Sadoul, "Matériaux, méthodes et problèmes de l'histoire du cinéma," La Nouvelle Critique no. 47 (October-November 1971), pp. 65-75.

30 Interview with Bernard Eisenschitz, April 7, 2014. 
collection was vastly superior to those of its peer institutions, it was also marked by lacunae stemming from personal feuds instigated by Langlois. Moreover, his refusal to arrange private screenings for researchers such as Eisenschitz meant that the young scholar often had to travel to Brussels to view films, where Jacques Ledoux of the Cinémathèque royale de Belgique was far more obliging. Despite the temperamental differences with Langlois, Eisenschitz was centrally involved in the Cinémathèque's 2014 homage to its founder, Dominique Païni's exhibition “Le Musée imaginaire d'Henri Langlois," which was accompanied by the publication of an anthology of Langlois' writings (Écrits de cinéma) edited by Eisenschitz and Bernard Benoliel. In their preface to the anthology, the editors stress the "liberty of tone" and "fidelity to his tastes" that characterize Langlois' writings. ${ }^{31}$ For Eisenschitz, indeed, the founder of the cinémathèque can most fruitfully be considered as "a historian-essayist" who combined seemingly incompatible qualities: he "refuse[d] to abdicate his subjectivity, and at the same time he refuse[d] to reject anything at all in his role as a programmer." ${ }^{2}$

Eisenschitz's major historical writings will be discussed in the sections below, but these should also be placed within the context of a five-decadelong multifaceted historiographic practice, incorporating activities that are often considered to be peripheral to film history but that are in fact integral to his work. A long-term collaborator with the Cinémathèque française, Eisenschitz has overseen restorations such as that of L'Atalante-conceived as a corrective to a previous effort judged to be "excessive, over-restored"33 and has been involved in a large number of retrospective programs, including career overviews of Frank Tashlin at the Locarno film festival (1994), Fritz Lang at the Valencia filmoteca (1995), Chris Marker at Pesaro (1996), Eisenstein at the Cinémathèque française (1998), and the history of censored Soviet cinema, again for Locarno (2000). He has also turned to filmmaking to pursue historiographic ends: this activity can be traced back to his participation in educational television, yielding the discussion of Une partie de campagne by his Cahiers colleagues and another program on Ivan the Terrible. The fictional short film Printemps 58 (centering on reactions to the May 13 coup that brought de Gaulle to power) followed in 1974,

31 Bernard Eisenschitz and Bernard Benoliel, "Avant-propos," in Henri Langlois, Écrits de cinéma, ed. Bernard Eisenschitz and Bernard Benoliel (Paris: Cinémathèque française/Flammarion, 2014), pp. 23-26, here p. 25 .

32 Bernard Eisenschitz and Bernard Benoliel, interviewed by Nicolas Azalbert, "Le cinéma, art premier: Entretien avec Bernard Benoliel et Bernard Eisenschitz," Cahiers du cinéma no. 699 (April 2014), pp. 78-79, here p. 79 .

33 Eisenschitz, "Paroles intemporelles." 
but more recently Eisenschitz has returned to making pedagogical films, directing short works on L'Atalante (2001), Monsieur Verdoux (2002) and Die Nibelungen (2007) and the more ambitious compilation film on Soviet silent cinema Un sijoli mot: le montage (2003). A unique collaboration with Godard, meanwhile, took place for the book version of the latter's magnum opus Histoire(s) du cinéma. Eisenschitz had made a brief appearance as an actor in Godard's 1992 film Les enfants jouent à la Russie, and the filmmaker tasked him with tracking the source material for the hundreds of films cited in the $4^{1 / 2}$-hour video-essay. ${ }^{34}$ Despite following his ouvre assiduously, Eisenschitz had previously written little on Godard since his Tout va bien piece, but this silence was broken with an article on Godard's 2006 exhibition at the Centre Pompidou, in which he counter-intuitively criticizes the need "to understand everything, to have everything explained, to seek to underline the links. Why interpret? 'What is shown can not be said." Instead, Eisenschitz urges the visitor to delight in the unexpected: "that sudden revelations and encounters can happen, this is what an exhibition can do (hanging [accrochage] my fine care). Whereas the film imposes its discourse, the gallery-stroller imposes their own rhythm, their tastes and distastes. JLG knows this and does it with us." ${ }^{35}$

This article appeared in Cinéma, the second of two film journals with which Eisenschitz was involved as an editor in the 1990s to 200os. Having been on the editorial board of Cinémathèque under Dominique Païni's direction, Eisenschitz left in 1999 as part of a mass exodus when Jean-Charles Tacchella, who had become head of the Cinémathèque française, wanted an organ that focused more purely on historical research. Cinéma was founded in 2001 as a means of continuing the work of Cinémathèque: the previous editorial committee consisting of Eisenschitz, Païni, Aumont, Benoliel, Michèle Lagny and Jean-François Rauger was reconstituted and joined by experimental filmmaker Érik Bullot, and the team now came under the direction of Eisenschitz. Symbolically, Cinéma began with issue no. 02, to signal continuity with the eighteen issues of the journal Cinémathèque, which collectively represented issue no. 1 of the new journal. Eisenschitz described the new journal's goal in a way that also describes much of his own practice in film culture: as being to "connect two approaches, which, separately, are well represented in film studies: the subjective approach drawn from the French critical tradition and the academic approach drawn from the

34 Bernard Eisenschitz, interviewed by Charles Tesson, "Une machine à montrer l'invisible: Entretien avec Bernard Eisenschitz," Cahiers du cinéma no. 529 (November 1998), pp. 52-57. 
study of the cinema by university researchers, especially historians. ${ }^{n 6}$ Work by French writers including Narboni, Émile Breton and Jacques Rancière was accompanied by that of scholars from abroad such as Tag Gallagher, Adriano Aprà, Peter von Bagh and Janet Bergrstrom. The presiding tastes of the journal, however, were impregnated by Eisenschitz's own outlook, and the quality of the writing published attests to his exigencies as an editor. Of most interest, each issue of the journal included a DVD featuring previously inaccessible films (by Mizoguchi, Stroheim, Straub/Huillet and others), a pioneering strategy that was considered an integral part of the journal's editorial work. In 2007, however, publisher Léo Scheer withdrew his support for the project, and Cinéma ceased publication after issue no. 14. While regretting the collapse of the ambitious project, Eisenschitz is also self-critical with respect to his role as an editor: "It was a journal that was dominated by my cinephilic taste, which possibly stifled things that did not interest me: theory, experimental cinema, etc. Maybe I did not reach out enough for them to have the place they deserved. I strove to go in my own direction, a cinephilic and historical direction." ${ }^{37}$

\section{Two National Cinemas: Germany and the USSR}

In the blend of history and cinephilia that constitutes the core of Eisenschitz's work as a film historian, two national cinemas and three auteurs stand out: firstly, the cinemas of Germany and the USSR, and secondly, the work of Nicholas Ray, Fritz Lang and Chris Marker-all highly politicized filmmakers who, in different ways, rebelled against and subverted the institutional structures in which they worked. Perhaps more than any other national cinema, the respective histories of German and Soviet film production have been marked by the tumultuous historical vicissitudes that striated the two states over the course of the twentieth century. Both countries were marked by revolutions (successful and abortive), the rise of totalitarian regimes, Cold War paranoia, and periods of thaw and relative openness. But both nations also saw the rise of successive generations of filmmakers who aspired to make great cinema even under the most adverse

36 Bernard Eisenschitz, interviewed by Jean-Michel Frodon, "Bernard Eisenschitz, approches croisées," Le Monde, October 24, 2001.

37 Interview with Bernard Eisenschitz, April 7, 2014. In the same interview, Eisenschitz revealed that a fifteenth issue of Cinéma had been prepared for publication but never saw the light of day. 
conditions. Indeed, it is this often tragic tension between the will to artistic creation and larger historical forces that has fueled Eisenschitz's interest in the cinematic output of Germany and the Soviet Union. In both cases, moreover, he nuances the idea of a single "national" cinema: his emphasis on the various national cinemas produced by the fifteen Soviet republics in the 1975 program of the films of the USSR was already an indication of this perspective, which has continued throughout his work on the cinema of the world's first socialist state. Germany, too, is marked by a multiplicity of cinemas, this time more diachronic in nature and determined by the country's political transformations: from the Wilhelmine Empire to the Weimar republic, the Nazi regime, and the period of post-war division followed by reunification in 1989 .

The notion that German film is marked above all by plurality is the guiding thread of Eisenschitz's 1998 overview of the nation's cinema. Le cinéma allemand is avowedly a history written from the standpoint of "someone who discovered the great pre-1933 German cinema at the Cinémathèque française of the rue d'Ulm and Chaillot, then thanks to the archives at Brussels, the GDR and West Berlin." ${ }^{38}$ Published as part of François Vanoye's "Cinéma 128 " collection, the enforced concision of a text dealing with such a vast topic resulted in a pithy style, with bracing passages such as this description of the end of the silent period in German cinema: "The haunted screen [écran démoniaque] is no longer on the agenda. In 1929-1930, Arnold Schönberg composes his Begleitmusik zu einer Lichtspielszene, whose three parts bear the sub-headings, 'Threatening danger, fear, catastrophe.' The real cinema ceased to say anything about these emotions." 39

Beyond the idea of a multiplicity of cinemas that bear the appellation "German" - a category that includes, for Eisenschitz, films made by Germans in exile as well as those made by non-Germans working inside the country (Griffith, Dreyer, Rossellini, Straub, Kramer) — the guiding hypothesis of the study is that "the history of German cinema is joined with that of the century. The cinema became Germany's history, it had a stake in it and shaped it, it was an opinion on it and a vision of it. Its ruptures are more visible there than they are elsewhere. ${ }^{m 0}$ Moreover, the historian abides by the dictum that "Every film, every œuvre, says more than and something

38 Bernard Eisenschitz, Le cinéma allemand (Paris: Nathan, 1999), p. 6. This work builds on an earlier study Eisenschitz undertook, Le cinéma allemand d'aujourd'hui (Paris: Documents, 1976).

39 Eisenschitz, Le cinéma allemand, p. 35.

40 Ibid., p. 5 . 
other than what was in the conscious intentions of its author. ${ }^{\text {"11 }}$ Eisenschitz barely tempers his enthusiasm for German cinema's halcyon periods, those moments when "the cinema comes to be the best expression of the state of the nation and its imaginary. ${ }^{142}$ Of perhaps greater interest, however, are the passages on production during Nazi rule and the even more obscure work of East German filmmakers. Eisenschitz categorically affirms that 1933 represents the point at which "one of the greatest cinemas of the world ceases to exist, and the industry of images becomes an instrument for the 'aestheticization of politics' that Nazism represents."43 But he also recognizes that Goebbels was "one of the first practitioners of mass communication" and that the propagandistic methods promoted by the minister of culture were often explicitly modeled on Soviet practices. While from the standpoint of film art, the films made in the period 1933-1945 are judged to be "of zero interest," 44 Eisenschitz nonetheless trenchantly probes the work of Sirk, Riefenstahl, Harlan and others during this era. His book also rescues GDR cinema from the scholarly purgatory in which it had been mired, one where "forty years of films [had become] forgotten, never discussed, even in the German language, almost invisible and inaccessible. ${ }^{45}$ Eisenschitz's access to East German film archives placed him in an optimal position to overturn this critical neglect. In the historian's view, "if the GDR was a 'satellite' of the USSR, it was also something else: a country and a culture where intellectuals and artists who participated in the struggle against Hitler recognized themselves. ${ }^{{ }^{26}} \mathrm{He}$ does not shrink, however, from charting the passage towards political repression and audience indifference leading up to the fall of the Berlin Wall, against which forces the likes of Konrad Wolf, Heiner Carow and Jürgen Böttcher intrepidly battled. Eisenschitz is palpably terser when it comes to the reunified nation's cinema of the 199os, but it is perhaps symptomatic of his intuitive sense for the aesthetic and historical forces animating the German cinema that he closes the book by discussing Kurz und schmerzlos, the debut of the then little-known Turkish-German filmmaker Fatih Akin, whose depiction of the "violent history of friendship between a Greek, a Turk and a Serb" takes place in "a Hamburg from which Germans have almost completely disappeared." ${ }^{27}$

$$
\begin{aligned}
& \text { Ibid., p. } 24 . \\
& \text { Ibid., p. } 15 . \\
& \text { Ibid., p. } 5 . \\
& \text { Ibid., p. } 58 . \\
& \text { Ibid., p. } 87 . \\
& \text { Ibid., p. } 90 . \\
& \text { Ibid., p. } 123 .
\end{aligned}
$$


If Eisenschitz's interest in German cinema dates to his time as an assiduous patron of Langlois' cinémathèque programs, his fascination for its Soviet counterpart is just as long-lasting. The "Russie années vingt" special issue of Cahiers was not only organized by Eisenschitz but also contains some of the most important articles he wrote for the journal. Three texts published as part of the special issue place Soviet montage cinema within the broader context of the Russian cultural and artistic avant-gardes of the 1920s. In "Maïakovski, Vertov," Eisenschitz traces the situation of mutual influence prevailing between the filmmaker and the poet: both tend to be linked with the constructivist movement, but the Cahiers writer rejects the idea of a "falsely obvious connection of linear filiation" between them, in favor of a relationship marked by numerous "detours and ramifications." ${ }^{\text {"4 }}$ "Le Proletkult, Eisenstein" carries out a similar operation for the role played by the director of Battleship Potemkin within the artistic institution led by Anatoli Lunacharsky, whose "ultra-left" promulgation of "proletarian culture" faced the hostility of Lenin and Trotsky. ${ }^{49}$ Finally, Eisenschitz's "Note sur Meyerhold et le cinéma" charts the theater director's numerous ties with filmmaking: although the two films he directed are no longer extant, there remain a large number of texts by Meyerhold on the cinema, ranging from unrealized scripts to critical notices, and his influence on his students —including Yutkevich, Ekk and Eisenstein — remains the one area in which "we can successfully seek a definition of Meyerhold's relationship with the cinema." ${ }^{50}$ In the case of Eisenstein, the nexus was a particularly close one, and Eisenschitz quotes Soviet film historian Leonid Kozlov's hypothesis that the style of Ivan the Terrible - and even the character of Ivan-referred to Meyerhold, who had been something of a substitute father-figure for the filmmaker.

Eisenschitz's more recent writings on Soviet cinema tend to shift the focus away from the titans of the 1920s to figures whose critical stock has been more mitigated. The work of Boris Barnet formed one center of Eisenschitz's later research. A planned monograph on the director was never realized, but for an early issue of Trafic Eisenschitz did publish a diary of his time in Moscow spent researching Barnet's œuvre. His September 1992 visit represented the first time he set foot in the former Soviet Union after its

48 Bernard Eisenschitz, “Maïakovski, Vertov," Cahiers du cinéma no. 220-221 (May-June 1970), pp. 27-28.

49 Bernard Eisenschitz, "Le Proletkult, Eisenstein," Cahiers du cinéma no. 220-221 (MayJune 1970), pp. 39-44.

$5^{0}$ Bernard Eisenschitz, "Note sur Meyerhold et le cinéma," Cahiers du cinéma no. 220-221 (May-June 1970), pp. 87-89, here p. 87. 
dissolution and coincided with a retrospective on Barnet organized by Naum Kleiman, another kindred spirit in the film history milieu. Eisenschitz's travel notes alternate between accounts of his exposure to previously unseen Barnet films and his experiences of a newly post-communist Russia, whose residents struggle to survive against the forces of hyperinflation and gangster capitalism. The latter is observed with bemused detachment and even moments of humor, such as when his visit to the Eisenstein house, kept intact by Kleiman, is described as a "return to the USSR." Eisenschitz, meanwhile, does not overly romanticize Barnet's œuvre: his viewing of the high-Stalinist work A Night in September (1939) is described as a "harsh blow, even if I always knew that it was an act of survival, no more nor less. ${ }^{n 5^{1}}$ But Bountiful Summer (1950), equally a work of "socialist-realist" propaganda, is lauded for showing a "harmony between the characters and nature that can otherwise only be seen, occasionally, in the work of Griffith and Henry King," and Eisenschitz concludes that "Barnet did not put forth the idea that communism has realized a harmony with nature, he incarnated it." For this reason, the historian assents to the sentiment articulated by Rivette-in a 1953 review of Bountiful Summer, his first article for Cahiers - that "if we except Eisenstein, Boris Barnet must be considered the best Soviet filmmaker." $5^{2}$

The work on Barnet served as a prelude to Eisenschitz's major achievement in resuscitating lesser-known specimens of Soviet cinema: the ambitious retrospective Lignes d'ombre: une autre histoire du cinéma soviétique (19261968) for the Locarno film festival in 2000, which was accompanied by a book of the same title. Highlighting the output of censored Soviet filmmakers between the years 1926 (the year Battleship Potemkin was released) and 1968 (the invasion of Czechoslovakia), 53 the book brings together historical documents, portraits of the filmmakers affected, an interview with Kleiman and an introductory text by Eisenschitz himself. Soviet censorship was particularly perverse: unlike its Nazi counterpart, which did not even countenance the realization of films that did not unambiguously conform to its ideological diktats, the Soviet studio system not only produced films that later met the ire of the censor, it often poured significant state funds into these projects. As Eisenschitz, notes, a particularity of Soviet cinema was

$5^{1}$ Bernard Eisenschitz, "Boris Barnet: journal de Moscou," Trafic no. 5 (Winter 1992), pp. 117-135, here p. 118 .

$5^{2}$ Ibid., pp. 129-130. For the Rivette quote, see Jacques Rivette, "Un nouveau visage de la pudeur (Un été généreux)," Cahiers du cinéma no. 20 (February 1953), pp. 49-50.

53 See Bernard Eisenschitz, interviewed by Sophie Grassin, "Les interdits du cinéma soviétique," L'Express, July 27, 2000, p. 36. 
that "the function of the producer [did] not exist. [...] The director is master of his film: it is possible to harrass him, humilitate him [...] but not to take his work from him." ${ }^{44}$ Banned films were, for the most part, not destroyed, simply "shelved" for a later date, meaning that the body of work available for screening in the post-Soviet era was considerably rich. The gambit of the retrospective was to present a potential alternative vision of Soviet cinema to that of the accepted canon, and part of its mission was to "relativize the identification, which used to appear obligatory, between political art and the avant-gardes." ${ }^{5}$ All Soviet films were profoundly marked by politics. The resource-intensive nature of film production meant that the kind of schizophrenia that pervaded other artistic practices-Shostakovich, for instance, alternating between pompous official music and personal, avantgarde compositions - existed, in the cinema, within the films themselves: "[Filmmakers] worked for the most part with a high idea of themselves and the enterprise in which the country was engaged in, and the little game of 'critical or uncritical?' can only be resolved by answering: [...] both at the same time." ${ }^{6}$

\section{Three Rebels: Nicholas Ray, Fritz Lang, Chris Marker}

Alongside his output on national cinemas, Eisenschitz has also dedicated significant historical research to his elected "rebel" filmmakers, an effort that has resulted in a trio of landmark studies: Roman américain: les vies de Nicholas Ray (1990), Fritz Lang au travail (2011) and Chris Marker (1996). The first of these texts, and the closest one to a standard biography, was the culmination of a project that dated back to 1979, when Eisenschitz participated in the production of Lightning over Water, co-directed by Ray and Wim Wenders shortly before the former's death. A collaborator on this film, Terry Fox, compared Ray to Captain Ahab for having "rebelled against all restrictions and [having] lived in an absolute manner, according to the code he had formulated," and Ray's widow relayed to Eisenschitz that, on his hospital bed, the director quoted at length from Moby Dick. ${ }^{57}$ It was upon

54 Bernard Eisenschitz, "Introduction," in idem. (ed.), Lignes d'ombre: une autre histoire du cinéma soviétique (1926-1968) (Milan: Mazzotta, 2000), p. 15.

55 Ibid., p. 12.

56 Ibid., p. 15 .

57 Bernard Eisenschitz, Roman américain: les vies de Nicholas Ray (Paris: Cristian Bourgois, 1990), p. 554. Translated as American Journey: The Lives of Nicholas Ray, trans. Tom Milne (London: Faber and Faber, 1993), p. 492. 
hearing about this recitation that Eisenschitz struck upon the idea of writing a biography on the filmmaker. His research for the project coincided with the moment when the Hollywood studios began depositing their archives to American universities, which allowed Eisenschitz to establish the production history of Ray's films with unprecedented precision. This archival work was buttressed with oral testimony from Ray's collaborators. "Lived cinema," for Eisenschitz, "is something that must complement archived cinema." 58

The resulting book is a pioneering study, elevating the genre of the Hollywood biography to the status of scholarly research. After charting Ray's Wisconsin childhood, Eisenschitz follows his career from his agit-prop theater days in the 1930s through his time working within the Hollywood studio system and up to his experimental work in upstate New York in the 1970s. Of these three periods in the filmmaker's career, the first is the most eye-opening aspect of Eisenschitz's study. Together with Elia Kazan, Ray participated in political theater troupes such as the Theater of Action and the Federal Theater Project (the latter subsidized by the New Deal-era Works Progress Administration), which sought to agitate for political change and bring culture to the working masses. Ray never joined the Communist Party and subsequently did not feel the full brunt of the Hollywood witch hunt, but his theater activities brought him into close contact with communist militants. Cahiers du cinéma, of course, had always idolized Ray: a young Godard even famously claimed that "if the cinema ceased to exist, only Nicholas Ray gives the impression of being able to reinvent it." ${ }^{59}$ It is in Eisenschitz's biography, however, that the full extent of Ray's subversion of the Hollywood studio system is revealed and that his status as a lifelong rebel is highlighted. As Eisenschitz recalls, "he dreamt of another cinema that could concentrate everything in an image and could say everything via the image." The historian draws satisfaction from Rivette's observation that "what was interesting about the book is that they couldn't have imagined that Ray was a crazy visionary like Abel Gance." ${ }^{\prime 0}$

If anything, Eisenschitz's work on Lang, which reached its culmination with Fritz Lang au travail in 2011, had a longer gestation than the Ray biography. He reports having carried out archival work on Lang as early as 1970, interviewing surviving collaborators for Sadoul's Histoire générale,

$5^{8}$ Interview with Bernard Eisenschitz, April 7, 2014.

59 Jean-Luc Godard, "Rien que le cinéma (L’Ardente gitane)," Cahiers du cinéma no. 68 (February 1957), pp. 42-44, here p. 42. Translated as "Hot Blood," in idem., Godard on Godard, trans and ed. Tom Milne, pp. 43-45, here p. 43 .

60 Eisenschitz, “A French Roman," p. 25. 
and he has recalled that Lang's opposition to fascism made him a hero for Eisenschitz's family of exiles from Austria and Germany. ${ }^{61}$ Studying Lang had a twin advantage to the comparable work on Ray. Firstly, thanks to Lang's friendship with Eisner, the director had donated his meticulously compiled personal archives to the Cinémathèque française, giving Eisenschitz ready access to the material. Secondly, his status as a major filmmaker was widely recognized as early as the 1920 , resulting in a much greater amount of pre-existing historical work. The first fruit of Eisenschitz's research work was a 1992 monograph on one of Lang's most politically engaged films, the 1941 work of anti-Nazi propaganda Man Hunt. Here, a 70-page discussion of the film is accompanied by a portfolio of film stills and preparatory sketches drawn from the Cinémathèque's Fritz Lang archive. Eisenschitz judges that, out of all Lang's films, Man Hunt is "one of those that most clearly affirms the total imbrication between 'documentary' and fantasy." ${ }^{\prime 2}$ The film also exemplifies a trait that the historian sees as a general feature of Lang's work: it allows us to see "the extent to which there is not a Fritz Lang 'method,' on the one hand, and his films on the other hand, with his themes, obsessions and styles, but to what degree the movement that goes from what he likes to call the 'idea' to the screen is indissolubly linked to his method." ${ }^{\prime 63}$

This notion will also be the guiding principle of Eisenschitz's major work on Lang, Fritz Lang au travail, which combines a biographical overview of the filmmaker's life with detailed documentation on the preparation of his films. For a filmmaker who had built up a substantial mythology around himself-but who, in depositing his personal archives, provided the tools for this mythology to be dismantled - the project also entailed carefully separating fact from fiction while avoiding the temptation to salacious revelation that marked earlier efforts such as Patrick McGilligan's biography of Lang. ${ }^{64}$ As with Ray, Lang's work is dominated by his intractable fidelity to his own artistic vision; for Eisenschitz, his steadfast position is that of "the rejection of compromise and the path of least resistance" and "the struggle against producers, not because they represent money, but because they are more easily satisfied than him." ${ }^{\prime 65}$ In this sense, the book is propelled by Lang's own awakening political consciousness: from the unengaged dandy

61 Bernard Eisenschitz, interviewed by Jacques Mandelbaum, "Bernard Eisenschitz, 'Fritz Lang a toujours refusé les compromis," Le Monde, October 19, 2011.

62 Bernard Eisenschitz, Man Hunt de Fritz Lang (Crisnée: Yellow Now, 1992), p. 75.

63 Ibid., p. 39 .

64 Patrick McGilligan, Fritz Lang: The Nature of the Beast (New York: St. Martin's Griffin Press, 1997).

65 Bernard Eisenschitz, Fritz Lang au travail (Paris: Cahiers du cinéma, 2011), p. 6. 
of the 1910 and early 1920s, who was frustrated at the outbreak of revolution during the shoot of his first film, we see a filmmaker progressively pushed into political action through his disgust at fascism. Although Eisenschitz tempers Lang's own claims that Das Testament des Dr. Mabuse was specifically conceived as a riposte to Hitler, he charts the remarkable twin chronologies of the film's completion and the rise to power of the Nazis. Shooting finished on the film in mid-January 1933, and by the end of the month Hitler had become Reichskanzler. On February 27, the Reichstag fire gave the pretext for the suppression of constitutional rights, and the March 5 elections gave a sweeping majority to the NSDAP, while communist and social-democratic deputies were forced into exile. On March 20, Mabuse was ready for projection, and the next day its premiere was announced for March 24. On March 23, its run was canceled; the same day, the Reichstag voted in the Ermächtigungsgesetz, giving dictatorial powers to Hitler. On March 28, Goebbels addressed members of the film industry, including Lang, at the Hotel Kaiserhof; the following day, he personally viewed Mabuse. It was banned on March 30. As Eisenschitz summarizes, "Between the conception and the completion of the Testament, the state had passed without resistance into the hands of a gang of criminals, but it is only after the fact that we can put it like that." ${ }^{\text {} 6}$

Paradoxically, it is during his exile in Hollywood that Lang's filmmaking is the most politicized: Man Hunt, Hangmen Also Die! and Ministry of Fear were works specifically conceived to bolster anti-fascist sentiment; at the same time, however, his portraits of the liberal-democratic American society in which he had found refuge, including Fury, You Only Live Once, The Woman in the Window and Beyond a Reasonable Doubt, offered a dark, pessimistic vision of the country. Eisenschitz's focus on the production history of these films - featuring Lang's famously stormy relationship with the studio bosses - attests to the filmmaker's "obsessive relationship with this supplementary, mechanical eye that is the cinema." ${ }^{67}$ But Fritz Lang au travail is also a story of redemption, one in which Cahiers plays a central role. By the 196os, Lang was an exile from the cinema, unable to find backers for his films, and, as Eisenschitz notes, he was generally considered a "great creator from the silent period, whose 'American' period marked his decline. ${ }^{68}$ But the dogged defense of his work by Langlois and the Cahiers critics of the 1950s and 196os, leading to his appearance in Godard's Le Mépris, initiated his consecration in France and, subsequently, the rest of the world. 
Chris Marker, Eisenschitz's third rebel, never worked in the commercial film industry. And yet his long relationship with the PCF and the communist movement on a global level represents a similar institutional dynamic to the relationship Ray and Lang had with the studios, one that involved both working with power when appropriate and establishing a firm autonomy from it when necessary. Eisenschitz recalls meeting the filmmaker at the Leipzig documentary film festival in 1971, where Marker received a prize for his essay on Aleksandr Medvedkin Le Train en marche, and a close collaboration developed between the two in the mid-1980s, when Eisenschitz worked on the subtitles for Marker's television series L'Héritage de la chouette. Given the proliferation of scholarship on Marker today, it is perhaps astonishing that the Italian anthology Eisenschitz assembled to accompany a retrospective on Marker's work in Pesaro in 1996 is the first book dedicated to the filmmaker. Eisenschitz has compared it to his earlier publication on Bogart: a "compilation book" gathering a wealth of documents on the subject, in this case articles by Edgardo Cozarinsky, Jean-Louis Leutrat, Louis Seguin and Jean-André Fieschi, the "script" for Sans Soleil and the 1993 epilogue to Le Fond de l'air est rouge, and an annotated filmography collating extracts from a vast number of critical responses to Marker's films. Eisenschitz's own contribution is relatively short but no less decisive. Here the historian opposes Marker to Godard, in spite of their obvious affinities. Unlike his comrade-in-arms, Marker "has always been happy to tell stories, and has never abdicated this right, one that is difficult to exercise." Moreover, Marker's films would not have come into existence if, for each one, "the only possible technical—and thus narrative — solution to tell the story had not been found. ${ }^{\prime 69}$ In defending Marker's work, Eisenschitz was, of course, in conflict with the Cahiers "line" on the filmmaker: far from sidestepping this fact, he confronts it head-on, acknowledging Delahaye's denunciation of Le Joli Mai and noting the continuities between that text and the later critiques of Le Fond de l'air est rouge. In this polemic, Eisenschitz sees "the incompatibility between two lefts, the left which issued from the resistance and the anti-colonial struggles, and the left which appeared with the $1960 \mathrm{~s}$ divorce within the communist movement"-but he insists that the value of Marker's work is in its recognition that these two lefts were nonetheless united "like the scorpion and the frog in Mr. Arkadin." ${ }^{70}$

69 Bernard Eisenschitz, "Chris Marker, quelquefois les images," Trafic no. 19 (Summer 1996), pp. 46-57, here pp. 47-48. This text was originally published in Italian in Bernard Eisenschitz (ed.), Chris Marker (Rome: Dino Audini, 1996).

70 Ibid., p. 5 o. 
For Eisenschitz, in spite of the absence of Marker's face and voice from the films he realized, they are "the most autobiographical films in existence." Whereas Rouch needed to use his own voice in order to circulate "his unsettling objects" and Godard ended up "launching his body into his films in order to close them off to the outside world," in Marker's case "the absence of C.M. evidently only serves to underline his presence - the commentary does not say 'I,' but the style does."71 As a summation of Eisenschitz's own work as a historian and scholar, these lines could hardly be improved upon. All his texts are written in a self-effacing style, where an objective, neutral tone prevails and where the emphasis is placed on historical fact over individual critical opinion. And yet there is a strong personal side to his major books on the cinema, which Eisenschitz himself has stressed: his decision to dedicate studies on these cinematic rebels represents "profoundly subjective choices, which I try to justify, perhaps, by the great objectivity of the tone, because I prepare argumentations that are as irreproachable as they can be, but my sentiment is that these books are very much linked to my own subjectivity." ${ }^{2}$

\section{Works Cited}

[Anon.], "Ciné/N.C. en Avignon," La Nouvelle Critique no. 65 (June-July 1973), p. 77. —, "Cinéma: La N.C. en Avignon," La Nouvelle Critique no. 67 (September 1973), p. 85. Émile Breton, "Le détachement féminin rouge," La Nouvelle Critique no. $5^{2}$ (April 1972), pp. $72-73$.

—, "Sur les Cahiers du Cinéma," La Nouvelle Critique no. 55 (August 1972), pp. 91-92. Bernard Eisenschitz, "Maïakovski, Vertov," Cahiers du cinéma no. 220-221 (MayJune 1970), pp. 27-28.

—, "Le Proletkult, Eisenstein," Cahiers du cinéma no. 220-221 (May-June 1970), pp. 39-44.

—, "Note sur Meyerhold et le cinéma," Cahiers du cinéma no. 220-221 (MayJune 1970), pp. 87-89.

—, "Ice (Robert Kramer)," La Nouvelle Critique no. 38 (November 1970), pp. 96-97.

—, "Camarades (Marin Karmitz)," La Nouvelle Critique no. 39 (December 1970), p. 73.

—, "The Birth of a Nation (1915) (Naissance d'une nation, D.W. Griffith)," La Nouvelle Critique no. 41 (February 1971), pp. 71-72.

_-, "Le conformiste (Bernardo Bertolucci), La Nouvelle Critique no. 44 (May 1971), pp. 68-69.

71 Ibid., pp. 52-53.

72 Interview with Bernard Eisenschitz, April 7, 2014. 
—, "Park Row (Violences à Park Row, 1952, Samuel Fuller)," La Nouvelle Critique no. 44 (May 1971), p. 69.

—, "La Nouvelle Babylone (Grigori Kozintsev, Léonid Trauberg)," La Nouvelle Critique no. 46 (July 1971), p. 48.

—, "Vietnam: Cinéma d'un peuple au combat," La Nouvelle Critique no. $5^{2}$ (April 1972), pp. 73-74.

_, "Millhouse: A White Comedy," La Nouvelle Critique no. 52 (April 1972), p. 74.

_ , "Tout va bien: un film 'plein de talent," La Nouvelle Critique no. 56 (September 1972), pp. 64-70.

—, "Aux urnes citoyens," La Nouvelle Critique no. 58 (November 1972), p. 76.

—, "Revue d'esthétique: Cinéma: théories, lectures," La Nouvelle Critique no. 69 (December 1973), pp. 85-86.

—, "Cinéma soviétique: points de continuité," La Nouvelle Critique no. 85 (JuneJuly 1975), pp. 74-76.

—, Le cinéma allemand d'aujourd'hui (Paris: Documents, 1976).

—, "La vie est à nous," L'Humanité, January 30, 1976, p. 5 .

—, "Pastorale: l'aventure ethnologique," L'Humanité, May 11, 1976, p. 10.

—_, "Moïse et Aaron," L'Humanité, November 2, 1979, p. 2.

—, "Intolérance en 166 minutes," Révolution no. 116, May 21, 1982, pp. 35-36.

—, "Il y a trente ans le Maccarthysme," Révolution no. 162, January 28, 1983, pp. 33-35.

_-, Roman américain: les vies de Nicholas Ray (Paris: Cristian Bourgois, 199o). Translated as American Journey: The Lives of Nicholas Ray, trans. Tom Milne (London: Faber and Faber, 1993).

-, Man Hunt de Fritz Lang (Crisnée: Yellow Now, 1992).

—, "Boris Barnet: journal de Moscou," Trafic no. 5 (Winter 1992), pp. 117-135.

—, "Chris Marker, quelquefois les images," Trafic no. 19 (Summer 1996), pp. 46-57. Originally published in Italian in Bernard Eisenschitz (ed.), Chris Marker (Rome: Dino Audini, 1996).

—, interviewed by Charles Tesson, "Une machine à montrer l'invisible: Entretien avec Bernard Eisenschitz," Cahiers du cinéma no. 529 (November 1998), pp. $5^{2-57}$.

-, Le cinéma allemand (Paris: Nathan, 1999).

—, Lignes d'ombre: une autre histoire du cinéma soviétique (1926-1968) (Milan: Mazzotta, 2000).

—, interviewed by Sophie Grassin, "Les interdits du cinéma soviétique," L'Express, July 27, 2000, p. 36 .

—, interviewed by Jean-Michel Frodon, "Bernard Eisenschitz, approches croisées," Le Monde, October 24, 2001.

—, "La réponse de Godard," Cinéma 012 (2006), pp. 90-101.

—, Fritz Lang au travail (Paris: Cahiers du cinéma, 2011). 
—, interviewed by Jacques Mandelbaum, "Bernard Eisenschitz, 'Fritz Lang a toujours refusé les compromis," Le Monde, October 19, 2011.

- , interviewed by Fernando Ganzo, "A French Roman. A Story about the Influence of Soviet Avant-Garde on Cahiers du Cinéma and the Later Rediscovery of Nicholas Ray: An Interview with Bernard Eisenschitz," Cinema Comparat/ive Cinema no. 2 (Spring 2013), pp. 18-28.

—, "Sous-titrage mon beau souci," Mise au point no. 5 (April 2013), https://doi. org/10.4000/map.1481 (accessed January 1, 2021).

— and Bernard Benoliel, "Avant-propos," in Henri Langlois, Écrits de cinéma, ed. Bernard Eisenschitz and Bernard Benoliel (Paris: Cinémathèque française/ Flammarion, 2014), pp. 23-26.

— and Bernard Benoliel, interviewed by Nicolas Azalbert, "Le cinéma, art premier: Entretien avec Bernard Benoliel et Bernard Eisenschitz," Cahiers du cinéma no. 699 (April 2014), pp. 78-79.

—, interviewed by Aline Vannier-Sihvola, "Paroles intemporelles: entretien avec Bernard Eisenschitz” (2015), https://cinefinn.com/2015/06/27/parolesintemporelles-entretien-avec-bernard-eisenschitzl (accessed January 1, 2021). Jean-Luc Godard, "Rien que le cinéma (L’Ardente gitane)," Cahiers du cinéma no. 68 (February 1957), pp. 42-44.

Patrick McGilligan, Fritz Lang: The Nature of the Beast (New York: St. Martin's Griffin Press, 1997).

Jean-Pierre Oudart, "Un discours en défaut," Cahiers du cinéma no. 232 (October 1971), pp. 4-12. Translated as "A Lacking Discourse," trans. Joseph Karmel, in Nick Browne (ed.), Cahiers du Cinéma vol. III: 1969-1972 The Politics of Representation (London: Routledge, 1990), pp. 276-286.

Jacques Rivette, “Un nouveau visage de la pudeur (Un été généreux)," Cahiers du cinéma no. 20 (February 1953), pp. 49-50.

Georges Sadoul, "Matériaux, méthodes et problèmes de l'histoire du cinéma," La Nouvelle Critique no. 47 (October-November 1971), pp. 65-75.

—, Histoire générale du cinéma vol. I-VI, ed. Bernard Eisenschitz (Paris: Denoël, 1973-1975). 


\title{
13. Jean-Louis Comolli: A Theoretical Practice of Political Cinema
}

\begin{abstract}
In this chapter, Jean-Louis Comolli's shift from editor of Cahiers du cinéma to director of fiction and, predominantly, documentary films is followed. After early forays in filmmaking in the late 1960s, his first significant project was La Cecilia in 1976, a fictionalized account of an anarchist commune in Brazil. But the bulk of his cinematic output since the 1980 s has been in documentary cinema, the highlight of which has been the multi-part series focusing on electoral politics in the southern French city of Marseilles from the 1980 s to the present day, dubbed Marseille contre Marseille. As well as practicing documentary filmmaking, Comolli has also continued to develop his theoretical views on the cinema, resulting in a combination of film theory and practice that has few equivalents in the contemporary era.
\end{abstract}

Keywords: Jean-Louis Comolli, La Cecilia, anarchism, documentary cinema, political filmmaking, elections in Marseilles

\section{From Film Criticism to Filmmaking: La Cecilia}

Alongside Eisenschitz's work as a film-historian, Comolli's experience as a filmmaker and theorist of film practice from the 1960 s to the present day is the other key site of political engagement exercised by the Cahiers writers. Indeed, in 2006 Comolli would boldy state, "I believe I practice an engaged cinema." In doing so, he has amassed a corpus of more than forty works of fiction and, more preponderantly, documentary, made for both cinema and television. Released in 1976, La Cecilia was his first post-Cahiers work, and many of the political and technical problematics

1 Jean-Louis Comolli, "Notes sur cinéma et politique," in idem., Corps et cadre, pp. 297-299, here p. 298.

Fairfax, D., The Red Years of Cahiers du Cinéma (1968-1973). Volume I: Ideology and Politics. Amsterdam: Amsterdam University Press, 2021 DOI 10.5117/9789463728508_CH13 
that will course throughout Comolli's later œuvre are already introduced in this film. Comolli often depicts his decision to tackle the historical experience of the Cecilia colony - a colony conceived and piloted by the prominent Italian anarchist Giovanni Rossi-as a direct result of the foundering of the Cahiers project, but the film's genesis dates to well before this moment: an initial screenplay for La Cecilia was completed in collaboration with Eduardo de Gregorio in late $1971 .{ }^{2}$ Moreover, although he now considers La Cecilia to be his "first real film,"3 Comolli actually already had a degree of experience in filmmaking, taking on directorial duties for television programs on Pierre Perrault and Miklós Jancsó, the documentary Les Deux Marseillaises on the June 1968 French legislative elections (co-directed with André S. Labarthe) and two unreleased short fiction films. ${ }^{4}$ Nonetheless, La Cecilia was to be Comolli's first fiction feature and represented-in both aesthetic and logistical terms-a breakthrough for the budding filmmaker.

One of a large number of socialist communes founded in the Americas by European émigrés in the nineteenth century, La Cecilia was initiated by Rossi and ten other settlers in Brazil in April 1890 and lasted four years, growing to a population of 150 before its collapse and the colonists' return to Italy. Trained in agricultural science, Rossi considered the commune to have been a successful preliminary "experiment." Despite the material hardship involved in building a sustainable social unit from scratch, La Cecilia's inhabitants "led an existence that overflowed with vitality, that trembled with excitement." ${ }^{\prime 5}$ And yet the initial version of Comolli's project was guided by a critique of, in his words: "what we called at the time (1971), in a rather condescending fashion, [...] the 'anarchizing tendencies of the

2 An early, undated version of Comolli/de Gregorio's script, noticeably different to the completed film, is presently available for consultation in the Cinémathèque française archives in Paris under the reference code SCEN492-B145.

3 Jean-Louis Comolli, interviewed by Rosa Lleó, "How to Film History: An Interview with Jean-Louis-Comolli about La Cecilia," Afterall (2009), afterall.org/article/how.to.film.history. an.interview.with.jean-louis. comolli.about.la.cecilia (accessed January 1, 2021).

4 Of these works, Comolli now only mentions Les Deux Marseillaises in his filmography. The two television programs, part of Labarthe's “Cinéastes de notre temps" series, can be viewed in the Bibliothèque nationale de France, Paris. The two short films, Un coup pour rien and Commeje te veux (both 1970), which were made under amateur conditions and never released commercially, are not presently available for viewing. A screenplay for the former film, however, is housed in the archives of the Cinémathèque française (reference code BERAUD2-B1) and reveals a Gidean narrative concerning two would-be left-wing terrorists who plan to assassinate a provincial industrialist.

5 Jean-Louis Comolli, La Cecilia: Une commune anarchiste au Brésil en 1890 (Dossier d'un film) (Paris: Daniel et cie, 1976), p. 39. 
intellectual petty-bourgeoisie."”6 As Comolli's project progressed, however, its critical target changed in nature: henceforth, the film would interrogate the broader question of the revolutionary intellectual's role in the class struggle. Or as the critic-turned-filmmaker put it: "The negative character changed: it is no longer Rossi the anarchist (and through him the negative nature of anarchism), but Rossi the theorist, the master of the experiment who arranges matters so as not to be at risk. It is not only politics $[. .$.$] that$ Rossi represses, but also the discourse and the body of the other, the desire of the other, about which he wants to know nothing."7

It is possible that Comolli had always been attracted to this material due to its resonance with his own experience in the theoretical and political cauldron that was the Cahiers team in the late 1960 s and early 1970s-cut off, to a large degree, from broader political struggles and obsessively focused on internal disputes and the clarification of its "line." But once he had detached himself from the journal, $\mathrm{La}$ Cecilia much more tangibly acquired the status of an allegory for the critic's period at Cahiers. Looking at the work retrospectively, Comolli acknowledges that "in truth, the subject, or the theme, of the film was concealed, since it was really a film which spoke about what had happened in the Cahiers group in the months beforehand," and it is evident that the figure of Giovanni Rossi can function as a cipher for Comolli and Narboni's position within Cahiers, having voluntarily dissolved their privileged status as editors-in-chief into a broader collective grouping at the time of the journal's radicalization. Indeed, the question of leadership within far-left movements is of fundamental importance in the film: as instigator of the commune and its theoretical driving force, Giovanni Rossi cannot help but play a role as leader, but he remains a character who refuses this function through an "admirable excess of historical awareness." ${ }^{8}$ At crucial junctures, however, La Cecilia is found to be in need of leadership, and it is here that Rossi will abrogate his responsibilities to the group he had established, preferring to play the role of external observer in a manner befitting his scientific background.

More broadly, the dynamic of the film is generated by the intersection between external historical forces and contradictions internal to the

6 Jean-Louis Comolli, “La Cecilia: Présentation,” Cahiers du cinéma no. 262-263 (January 1976), pp. $69-78$, here p. 76 .

7 Ibid.

8 The quotes in this paragraph are from Jean-Louis Comolli, interviewed by Daniel Fairfax, "Yes, we were utopians; in a way, I still am...: An Interview with Jean-Louis Comolli (part 2)," Senses of Cinema 64 (September 2012), sensesofcinema.com/2012/feature-articles/yes-we-wereutopians-in-a-way-i-still-am-interview-with-jean-louis-comolli-part-2/ (accessed January 1, 2021). 
commune. In La Cecilia, history functions not as an "absolute outside, a master-reference" but as a "causal outside, an outside within the inside, which acts on it, determines it and transforms it in the very process of being repressed by it." 9 Thus, the film is punctuated by incursions of outside history into the enclosed world of the Cecilia commune, frequently depicted through the use of framing and scenographic composition. For example, when Rossi and a fellow communard, Rocco, venture to a general store to buy supplies, they are met with hostility and aloofness from the storeowner and local customers, who see Italian migrants as an unwelcome threat to their standard of living. This economic contradiction is depicted in the spatial construction of the scene. As a caption in Cahiers notes: "The two universes are hermetically sealed from one another, there is no communication apart from the exchange or purchase of domestic products; hence, there are no common visual codes. Nobody is worthy of a look, nobody is seen by anybody else."1o

Similarly, when the group pays a collective visit to the governor's house to discuss the revocation of their title deed to La Cecilia, the contrast between the communards and the functionary they address is multiply connoted: their working-class dress and impassioned diction contrast with the stiff formality of the bureaucrat who receives them, while their ebullient gestures and movements perpetually spill out over the boundaries of a scenic space that can barely contain them. It is at this point, however, that the internal contradictions within the group burst out into the open. While Rossi is on a lecture tour of Italy, a mass meeting is called to discuss the situation facing the commune. A sharp division arises between those who insist that a vote be taken on sending the group's proletarian members to a government road-building unit in order to pay off La Cecilia's debt to the new republic, and those-led by Luigi, the embodiment of an unwavering, purist attachment to the ideals of libertarian anarchism - who see this as the onset of an insidious form of "parliamentarism." No political common ground exists between the two groups; they are shown facing off against each other from either side of a visual chasm.

The most overt use of screen space to depict the pressures to which the group is subject, however, comes at the end of La Cecilia. In high spirits, the group stages a reading of Dantons Tod by Georg Büchner. ${ }^{11}$ Significantly, Luigi

9 Comolli, “La Cecilia: Présentation,” p. 74.

10 The caption appears in Cahiers du cinéma no. 264, p. 47.

11 There is some irony to the use of the play in La Cecilia: Dantons Tod is far from being an unambiguous celebration of the revolutionary zeal of the Jacobin wing of the revolutionary movement, which is the spirit in which the Cecilia group performs the text. 
plays the character of Robespierre, while Rossi has no role per se, instead whispering lines from the text for all the characters - a function that is symbolic of his relationship to the commune. The intellectual Lorenzini, meanwhile, is given the role of a sans-culotte, who declaims, at one point, the revolutionary catch-cry "in the name of the law, there is no law." ${ }^{\text {"2 }}$ The others applaud the uncompromising sentiment of the phrase, but Rossi stops and looks off-screen. A slow lateral pan reveals - by means of an "irruption of the hors-champ"13_-an officer from the republican army standing in the doorway. He informs the inhabitants of La Cecilia that they have been conscripted to quash a nearby rebellion and will be escorted to military headquarters in one hour's time. The group is crestfallen, their dream of an anarchist utopia has been snuffed out by the repressive state apparatus, but it is Luigi—not, pointedly, Rossi—who has the last word: "Italy? Why not? Brazil? Why not? Anywhere is fine... But not here. Not like this. Our place is no longer here. There are other things to do."

That La Cecilia should end with a theatrical scene was a deliberate move by Comolli and formally rhymes with the film's opening moments in which Rossi meets Dom Pedro during a performance of Nabucco in Milan. The film is thus bookended by allusions to the theater, which, Comolli claims, should be viewed as the "toppling over of fiction, as the superposition, dislocation [décalage] or unhinging of two representations (the filmic scene and the theatrical scene), one on top of the other, one against the other." ${ }^{\prime 14}$ A similar bifurcation of the scene is produced within the shot itself through the use of depth of field. The deep-focus lenses used by Comolli on the film yielded images whose multiple layers possessed equal visual clarity. Building on the theoretical discussion already adumbrated in "Technique et idéologie" in 1971, Comolli rejects the Bazinian notion that this technique reinforces the "realism" of the cinematic image. Instead, it "theatricalizes the shot," thereby denouncing the cinematic image as an artificial construction, most notably through the production of a "lateral-vertical decentering of the 'subjects." More than a mere "montage within the shot," such an image offers a "re-inscription of theatrical space and duration, [...] where the performance $[j e u]$ of the actors involves an interplay with the other actors and the elements of the decor, and where the bodies are always captured

12 Comolli notes that this sentence possesses an "extraordinary violence" and that the chosen conclusion to the film gestured towards "turning the end of the Colonia Cecilia into a larger version of all stories of failed utopias." Comolli, "How to Film History."

13 The quote comes from another caption in Cahiers du cinéma no. 264 , this one on p. 49.

14 Comolli, La Cecilia, p. 104. 
within a given space and time."15 Certainly, La Cecilia is replete with striking depth of field compositions, and these are frequently combined with roaming, Jancsóesque long-takes, including one majestic shot early in the film that lasts nearly seven minutes. Formal inventiveness is also evident on the level of sound, where frequent bursts of anarchist song contrapuntally punctuate the film's diegesis, as well as in La Cecilia's lacunary, decentered narrative structure. ${ }^{16}$ Whether these innovations represented a significant challenge to the formal conventions of mainstream filmmaking - as had been advocated by Comolli during his time at Cahiers - was nonetheless a disputed question in the reception of the film. Writing for rival film journal Image et son, André Cornand states that "To say that La Cecilia breaks with the habitual working methods, just as it shatters the narrative, to say that it departs from the habitual codes of cinematic representation, amounts to either being ignorant of the cinema or to displaying a certain contempt for everything that has been made in the last few years." ${ }^{17}$ From an English perspective, Alison Smith tentatively agrees with this claim, writing that Comolli's chosen aesthetic strategy is "rather a disappointment, or at least a strange compromise, and unadventurous in comparison with the ideals [...] Comolli praised in his theoretical work. ${ }^{m 8}$ Of further concern for Smith-and in this she echoed earlier reservations aired during an interview with Comolli by the magazine Ciné-Tracts after a poorly received screening of his film during a conference in Milwaukee-is the representation of women in $\mathrm{La}$ Cecilia. For most of the film, the only female inhabitant of the colony is Olimpia, who is presented in an idealized, Milletian manner as a paragon of swarthy beauty. She forms the object of desire for a number of the colonists, including Rossi himself, who embarks on an "experiment in free love" with her that consumes much of the latter half of $L a$ Cecilia. ${ }^{19}$ In contrast to Rossi's

15 Comolli, “La Cecilia: Présentation," p. 78.

16 Comolli felt that the film's music was "the other side of speech, the other sound of the voice, the other voice that is superposed on top of the voice making a speech [discours], the other discourse running underneath that of the logos, of ideology, anticipating it or prolonging it." Comolli, La Cecilia, p. 104.

17 Cornand even avers that Rossi's failure is an unintended metaphor for Comolli's own "failed" passage from film theory to direction. See André Cornand, "La Cecilia," Revue du cinéma/Image et son, no. 304 (March 1976), pp. 73-76, here p. 76 .

18 Alison Smith, "Jean-Louis Comolli and La Cecilia: Theory into Practice," French Cultural Studies no. 4 (February 1991), pp. 13-33, here p. 26. Comolli's film was also reviewed in Jump Cut, with Reynold Humphries and Geneviève Sizzoni offering their own Marxist analysis of the shortcomings of Rossi's commune in "Anarchism vs. reality," Jump Cut no. 12-13 (December 1976), pp. 30-32.

19 The fictional Olimpia is an amalgam of two figures from Rossi's account of the Cecilia commune: an unnamed individual who was the only female member of the initial settlement, 
abstract intellectualism, Olimpia embodies an intuitive instinct for the core principles of anarchism, and the portrayal of her character was viewed by many of those in the Milwaukee audience as sexist and outdated. Comolli, however, contested the notion that his film was sexist, claiming that the audience in question exhibited "a profound lack of understanding of how the image functions" by reading the character on a purely psychological level rather than as a "logical sign."2o

The reception the film garnered on the pages of Cahiers itself was decidedly more enigmatic. While space was given to Comolli to elucidate the principles behind La Cecilia, the film also inspired three reviews-by Toubiana, Daney and Kané - which all seem to be written in a private code: overtly speaking about the film at the same time as covertly discussing their earlier experiences with Comolli at the journal. Toubiana, for instance, writes about the "trauma" provoked by the group's "encounter with the real," ${ }^{21}$ while Daney begins his review with the statement: "There is a phrase that one never hears in La Cecilia. 'I told you so! I said that things would end badly, that it couldn't succeed."'22 Kané, meanwhile, stresses the importance of play (le jeu) in Comolli's film. ${ }^{23}$ When looking back at $L a$ Cecilia, this is also the aspect that the director himself emphasizes: although he used professional actors, the nature of the shoot led to a jubilant spirit of freedom and improvisation reigning on the set, such that, in Comolli's view, "the little troupe of actors and technicians unwittingly became a homologue to the pioneers of this anarchist commune."24 In the process, Comolli's own position as director was transformed. He came to see all the participants as equal collaborators on the project, a transformation that was partly an unforeseen consequence of his own inexperience on set: "I was the young rookie [...] in a film where I did not comprehend what was going on, with actors who I could not understand (in reality, they directed me, rather than vice versa)." ${ }^{25}$

and a later arrival called Elèda with whom Rossi undertook his "experiment." The presence of a single woman in the film has clear parallels with the situation at Cahiers, where Sylvie Pierre found herself in an otherwise entirely male group.

20 Jean-Louis Comolli, interviewed by Ron Burnett and Phil Vitone, "Jean-Louis Comolli: On the Practice of Political Film: An Interview," Ciné-tracts no. 4 (Spring-Summer 1978), pp. 44-47, here p. 46.

21 Serge Toubiana, "Les arpenteurs," Cahiers du cinéma no. 264 (February 1976), pp. 41-43, here p. 43 .

22 Serge Daney, “Chantez le code," Cahiers du cinéma no. 264 (February 1976), pp. 52-54, here p. 52.

23 Pascal Kané, "Le détour par l'enfance," Cahiers du cinéma no. 265 (March 1976), pp. 21-24.

24 Jean-Louis Comolli, "La Cecilia ou l'enfance," in idem., Corps et cadre, pp. 351-357, here p. 353.

Comolli, "Yes, we were utopians (Part 2)." 


\section{Fiction and Non-Fiction: From L'Ombre rouge to Tous pour un!}

La Cecilia was a moderate critical and commercial success, but Comolli's entry into the world of auteur filmmaking would be far from straightforward. His next project, based on an ambitious script (which would have yielded a 265-minute film), focused on the Paris commune, but although shooting was announced for late $1978,{ }^{26}$ the film was never realized. In spite of the commitment of an impressive list of actors (Gérard Depardieu, Claudia Cardinale, Brigitte Fossey and Andréa Ferréol), backing from the avance sur récettes funding system and an Italian co-producer, Comolli was unable, "through a lack of force in the conception and the initiative of the production, to go beyond these initial steps." ${ }^{27}$ When this project fell through, his energies were turned to another undertaking, L'Ombre rouge, a story of political espionage set during the Spanish Civil War, with two Marseilles-based weapons traffickers for the USSR, Anton and Leo, as the protagonists.

As with La Cecilia and La Commune then, L'Ombre rouge was a historical film - a cinematic genre Comolli had written about in guest articles for $\mathrm{Ca}$ hiers in the late 1970s. In "Un corps en trop," for instance, he had specifically treated the problem of actors playing historical characters in period fictions: turning to Renoir's La Marseillaise, he remarks on the existence of a "bodily rivalry" between Pierre Renoir playing Louis XVI and the real-life monarch, which Jean Renoir solves by representing the difficulty of performing the role within the very performance of his brother. ${ }^{28}$ The affinities between Comolli's three projects go deeper than this, however: all three focused on the complications of commitment, with its concomitant defeats and compromises, interrogating what it means to live with a political idealwhich, for Daney, is “Comolli's eternal question." ${ }^{29}$ Furthermore, as Comolli outlines, all three relate "the same type of story: the difficult, dialectical relations between subjects and the group to which they belong." ${ }^{\circ}$ As with La Cecilia, the conclusion of L'Ombre rouge is a pessimistic one. Despite his dedication to the Comintern, Anton faces being recalled to Moscow, where he will inevitably face a show trial, and instead commits suicide. Leo, in

26 According to a notice in the March 20, 1978 edition of Le Figaro, which gave the film's working title as La Commune.

27 Jean-Louis Comolli, interviewed by Alain Bergala and Alain Philippon, "Entretien avec Jean-Louis Comolli," Cahiers du cinéma no. 333 (March 1982), pp. 23-31, here p. 23.

28 Comolli, "Un corps en trop," p. 8.

29 Serge Daney, “Deux paumés du Komintern," Libération, July 18-19, 1981, repr. in idem., La Maison cinéma et le monde vol. II, pp. 349-352, here p. 351.

30 Comolli, “Entretien avec Jean-Louis Comolli," p. 23. 
despair and fleeing his Soviet pursuers, utters what Daney called a "famous line of dialogue" lamenting the futility of his revolutionary activities: "A whole life for nothing!"31 It was on this apparent fatalism that reviewers of the film were most divided: writing for Révolution, PCF critic Émile Breton denounced the film as a "spit in the face" to the communist movement and upbraided his colleagues for their more laudatory response to the film. ${ }^{32}$ The conventional, even glossy style of L'Ombre rouge also raised eyebrows in certain quarters. Comolli himself noted his attraction to "a certain image of classical cinema" and felt there were similarities between L'Ombre rouge and the serial films of Feuillade. He even came out in favor of "transparent" filmmaking, claiming, "I am still a partisan of a certain transparency, which means that the active part of writing must not be detected immediately, but act on a pre-conscious level." ${ }^{\prime 3}$ Michel Mardore compared its style with that of the anti-communist comic Tintin au pays des Soviets - a trait bolstered by the fact that a graphic novel adaptation of the film drawn in Hergé's ligne claire style by Ted Benoit was published in tandem with the film's release. Similarly, Daney, although broadly supportive of the endeavour, nonetheless expressed reservations about its "retro glazing effects." 34

In spite of the thematic similarity with La Cecilia, the production of L'Ombre rouge was of a very different nature to that of the earlier film: with a budget of 6 million francs, a script co-written with historian Gérard Guicheteau, and the involvement of star actors (Claude Brasseur, Jacques Dutronc and Nathalie Baye), Comolli's second feature-length fiction much more closely conformed to the norms of French commercial cinema. For the director, however, this episode in his filmmaking career was a mixed one: while he found working within an industrial structure of filmmaking" to have a "pedagogical, didactic" value, the more rigidly organized nature of the shoot was "not a joyful experience" and did not sit easily with Comolli's preference for improvisation and spontaneity. His following film, Balles perdues (a comedy thriller from 1983) returned to this looser filmmaking spirit, but its box-office failure seemed to block the way for Comolli to make any further progress in fiction filmmaking. The only fictional works since completed by Comolli are Le Bal d'Irène, a

31 Serge Daney, "Jean-Louis Comolli, L’Ombre rouge," Libération, October 28, 1981, repr. in idem., La Maison cinéma et le monde vol. II, pp. 59-62, here p. 6 o.

32 Émile Breton, “L’Ombre rouge," Révolution no. 91, November 27, 1981.

33 Comolli, "Entretien avec Jean-Louis Comolli," pp. 26, 29-30.

34 See Michel Mardore, “Comolli, Hergé: même combat," Le Nouvel Observateur, October 31, 1981; Jean-Louis Comolli and Ted Benoît, Dans les griffes de l'Ombre rouge (Paris: Éditions de l'Étoile, 1981); and Daney, “L'Ombre rouge," p. 62. 
1986 television film, and Pétition, an adaptation of the Václav Havel play made the same year. From this point on, his energies would be focused on documentary filmmaking, for the most part conceived for television broadcast. Two projects made in the years 1987-1988 were decisive in Comolli's transition to the documentary mode and brought an end to the "blurred zone" that the period 1982-1987 represented in Comolli's own eyes. ${ }^{35}$ Both were made for public television, and in the period since the 1980 s this would be the filmmaker's preferred distribution platform. As Comolli explains, his decision to work in television rather than cinema was a consciously political choice to "maintain the principle of a political and artistic public sphere." Not only was he able "to show on the small screen (as much as possible) formal systems which diverge from the dominant ones" but, through the sheer mass of television spectators (many times more than even a successful art-house release could achieve), his work could also "reach viewers who have not already been strictly classified within the cultural segments of the markets. ${ }^{36}$ Although Comolli continues to see television as a "majoritarian ideological apparatus, a system of control of behavior and thought, a shop-window for commodified society," he insists that it is possible to "fight against the adversary within the boundaries of its own activity."37 In the case of Comolli's electoral films, their television broadcast was of particular importance: it enabled these works to be present in the very space where, to a large degree, election campaigns in the contemporary era are played out and provided the possibility for "a different political experience from that of the 'spectacle' to which television tries to habituate us." ${ }^{38}$

Tabarka 42-87 (1987) was of obvious personal relevance for Comolli: the film charts the return to the Tunisian town of Tabarka of the settlercommunities who had lived there until the end of the colonial era. Despite mainly being of Spanish and Italian origin, these residents were classified as French by the colonial authorities, and they mostly left for Europe in the wake of Tunisian independence. Upon visiting Tabarka in 1987, they are warmly welcomed by the local inhabitants, eager to reunite with former neighbors and friends, and the two communities enjoy a feast together in commemoration of the bombing of the area by the German Luftwaffe in 1942. A low-key work, the film nonetheless conveys a humanist perspective in 
its depiction of solidarity across racial and religious divisions and presents an optimistic political vision of the potential for the scars of colonialism to be healed through tolerance and hospitality. It was the production of Tabarka 42-87 that led to Comolli's discovery of "the great emotion involved in filming my contemporaries in a documentary-that is, in their fiction and not just in my fiction,"39 and it was the first film in which he developed a filmmaking dispositif that has governed his documentary work since then. This approach consists essentially of three "rules of the game," which have the goal of "trying to receive the aleatory soul of polymorphous events": firstly, to "organize as little as possible, and in moments of grace to not organize at all," secondly, "to efface (or blur) the boundary between life and the scene" and, finally, "to reduce the distance between the camera and the people it films.". ${ }^{20}$

First established for Tabarka 42-87, these principles were also followed during the filming of Tous pour un! (1988), which focused on the two rounds of the 1988 French presidential election, and which is the main pivoting point of Comolli's work as a filmmaker. With its focus on grassroots activity during an election campaign, Tous pour un! returned to the subject matter of Les deux Marseillaises, which had treated the legislative elections in the same north-western district of the Parisian banlieue (Asnières) twenty years earlier. The 1968 election saw the right convincingly retain power on the national stage in a wave of conservative reaction to the events of May. ${ }^{4}$ On the local level, Gaullist candidate Albin Chalandon (a minister under de Gaulle) saw off both the PCF and the socialists, who had nominated actor Roger Hanin as a candidate. In the 1980s, it was President François Mitterand whose power was confirmed at the ballot box, shattering the hopes of the right that rival candidate Jacques Chirac would be able to topple him. As with the earlier film, Comolli retains a degree of even-handedness in his treatment of the different political parties, and his interviews with militants also dismantle the tribalist myth of parliamentary politics, as many confess to backgrounds in rival groupings. The main shock, however, of the 1988 election-both to the French political system and the cross-party ecumenism Comolli had cultivated - was the rise of Jean-Marie Le Pen's Front national (FN). Absent in the previous presidential election, the far-right candidate

39 Ibid., p. 27.

40 Ibid., pp. 33-34.

41 The election was called for during a radio broadcast by de Gaulle, in which he refused to resign the presidency and called for the defense of parliament democracy against "totalitarian" forces. This address can be heard on the soundtrack in the opening sequence of Les deux Marseillaises. 
won nearly $15 \%$ of the vote in the first round, effectively scuppering Chirac's chances of unifying the right to defeat Mitterand. The spectacular entry of a xenophobic extremist fringe into French politics represented a profound metamorphosis of the electoral landscape, whose effects are still being felt today. With his adamant opposition to the far right, it also tested Comolli's approach to documenting the political process, a challenge that centered around the question of whether FN members should be filmed in the same manner as their counterparts from other political parties. This dilemma would preoccupy the filmmaker for much of the following decade.

\section{Marseille contre Marseille (I): Filming the Political}

More particularly, this ethical problem would haunt Comolli's most significant work on electoral politics, the ten-part series retrospectively titled Marseille contre Marseille extending from the late 1980 s to the present: eight "episodes" were filmed in quick succession in the period 1989-2001, while two "epilogues" dating from 2008 and 2014 have subsequently been completed. In total, the released films come to approximately $13^{1 / 2}$ hours of running time. The succession of glimpses into political life in Marseilles combines to produce a grand fresco of the city during a period of significant social transition in France. Initially conceived for television broadcast, the episodes of Marseille contre Marseille have more recently been projected in cinémathèques, cultural centers and museums across France. ${ }^{42}$ While Comolli admits to affinities between his series and other documentaries on electoral campaigns (such as Primary by D.A. Pennebaker and $50.81 \%$ by Raymond Depardon), the vast temporal scope of the series sets it apart from these works and brings it closer to the ethnographic studies of Rouch. Comolli, indeed, has been explicit that "Our approach is closer to anthropology than it is to journalism." 43 While the city itself and its political machinery

42 At the same time, the possibility of broadcasting the episodes on television has significantly dwindled: whereas Marseille de père en fils was shown on both France 3 and Arte, Rêves de France à Marseille could not find a television partner and instead was released in theaters in 2003 . The two epilogues, meanwhile, were produced for a much smaller budget by the INA (Institut national de l'audiovisuel) and are primarily available for viewing on its website.

43 Jean-Louis Comolli, interviewed by Catherine Humblot, "La chronique marseillaise de JeanLouis Comolli," Le Monde, February 15-16, 1998, p. 5. For the debt to Pennebaker and Depardon, see Comolli, Voir et pouvoir, pp. 287-288. Comolli's admiration for Rouch can be seen in numerous texts, including "Ici et maintenant, d'un cinéma sans maître," in Comolli et al., Les années pop: $1956-1968$, pp. 33-58. 
are explored at length in the series, individual participants in Marseilles politics have also become recurring characters, aging, growing in stature, or disappearing in disgrace or ignominy, while new figures enter the stage. Some even make improbable comebacks. In the first installment of the series, for instance, conservative politician Jean-Claude Gaudin resigns himself to the fact that he will not become the mayor of Marseille. Six years later he was elected to the post, which he held until 2020.

Comolli's turn to documentary filmmaking in the late 1980 os was also accompanied by a return to film theory after a hiatus of more than a decade in which he wrote very little on the cinema. Since this time, he has amassed a theoretical output totalling nearly 2000 pages, a wide selection of which is contained in the two critical anthologies Voir et pouvoir and Corps et cadre. While Comolli's broader theoretical outlook on the position of cinema in the contemporary era will be discussed more deeply in the epilogue, much of this material directly addresses his own documentary filmmaking, and this theoretical reflection immeasurably enriches the value of the films he has made in this period. Comolli, therefore, merits a status as one of the great theorist-practitioners of the cinema in the lineage of Eisenstein, Epstein, Pasolini and Godard, and the proceeding analysis of the Marseille contre Marseille series will seek to intertwine his filmmaking with his film theory as two complementary, dialectically interacting aspects of an integral cinematic praxis.

The genesis of the Marseille contre Marseille series owed much to circumstance. Comolli had biographical ties to the city (the port of entry for many of those migrating from Algeria to France), and shooting L'Ombre rouge in Marseilles renewed his affection for it. His original project in the late 1980 , however, was a documentary on the diverse religious communities of Marseilles, a city whose status as a migrant hub has turned it into a melting pot of different denominations. It was in the middle of filming this project that the Marseilles political scene exploded: Gaston Defferre, the politically impregnable socialist mayor of the city who had been in office since 1953, was challenged for control of the party apparatus by younger rival Michel Pezet. The latter won in a bruising political battle, and on the night of Pezet's designation as secretary-general of the regional branch of the Parti socialiste (PS) in May 1986, Defferre died of a brain hemorrhage after falling in his home. The spectacular death of Defferre, around whose individual figure so much power in the city had been accummulated, was a traumatic moment for political life in Marseilles, and in the absence of an annointed dauphin a fratricidal war of succession between Defferre loyalists and Pezet's supporters broke out, with Pezet accused by Defferre's widow, 
the writer Edmonde Charles-Roux, of having contributed to the mayor's death. Comolli was inexorably drawn to this topic, and he sees it as "one of the strengths of documentary filmmaking" that he was quickly able to "change course and begin a new film." ${ }^{\text {44 }}$ He saw the internal battle within the PS as a "tragic combat, which, with its intrigues, conspiracies and family feuds, was practically Shakespearian," and the mythological nature of the dispute forms a key part of the tapestry woven into the two-part overture to the series completed in 1989, Marseille de père en fils, whose three hours of screen time were drawn from 100 hours of raw footage edited over the course of seven months. ${ }^{45}$

In charting the internal battle between Pezet and the pro-Defferre forces, led by Robert Vigouroux, who would eventually prevail and be elected mayor of Marseille, Comolli gained a premonitory glimpse into a process of political degeneration wherein, by 1999, he could attest that "the PS in Marseilles ha[s] almost entirely self-destructed (if not as a 'system,' then at least as a political force and direction) and only recompos[ed] itself from within as a simulacrum. ${ }^{26}$ This process presaged the decomposition of the PS on a national level: the Marseille battle preceded the split in the party that took place at its 1990 congress in Rennes, as the Mitterand administration was riven by corruption scandals and personal rivalries. Weakened in strongholds such as Marseille, the party would go on to a disastrous result in the legislative elections of 1993. It won only 53 seats out of 577 (down from 260), and soon after the election result, outgoing prime minister Pierre Bérégovoy committed suicide. Moreover, local-level politics in Marseilles echoed the political shockwave represented by the fall of the Berlin Wall in 1989, an event whose global repercussions would have a notable effect on both the left and the right in France. By the time of Marseille en mars, filmed in 1993, the dramatic changes in the world political order had been consciously registered by all sides of politics. While it was predictable that the collapse of communism and the erection of a global neoliberal hegemony would lead to a crisis of identity for the left, Comolli also reveals anxiety among the traditional forces of the right. Jean-François Mattei, a candidate for the center-right Union pour la démocratie française, admits that in the "brutal confrontation" between

44 Comolli, "Yes, we were utopians (Part 2)."

45 Ibid. See also Anne Baudry, cited in Jacques Gerstenkorn and Martin Goutte (eds.), Cinémas en campagne: De la chronique électorale à la fiction politique (Lyons: Fage, 2012), p. 61.

46 Jean-Louis Comolli, "La ville de l'impossible oubli," L'Image, le monde no. 1 (1999). Repr. in Comolli, Voir et pouvoir, pp. 480-488, here p. 481. 
collectivism and capitalism in the twentieth century, neither side proved satisfactory: while the Soviet Union "was incapable of constructing a society fit for humans," free-market capitalism in the US has led to 37 million Americans living in poverty. In a downcast mood, the politician concludes that "without political references or values, we are doomed." His despair is accentuated by Comolli's montage: immediately before the interview with Mattei, a local voter being handed a leaflet by an environmentalist candidate can be heard exclaiming, "Le Pen's the only one who's making things happen."

In order for the series to adequately take stock of politics in the southern city, however, an extra element was felt to be necessary for the project. As Comolli explains:

I immediately realized that, in order to make this new film on the political battle being waged in Marseilles, I needed the support of someone who was intimately familiar with the city's politics. I had read Michel Samson's articles in Libération, and I found him a very interesting journalist, so I went to Paris and asked to meet him. When we met, I knew I would work with him right away. I said that I was interested in working with a journalist, because he has the requisite knowledge and contacts, an entire network that I don't have access to, but only on the condition that he truly become a character in the film, because I had no desire to simply have an expert lurking in the shadows. ${ }^{47}$

Samson has centrally participated in all the Marseilles films and is credited as co-author of the Marseille contre Marseille series. His on-screen presence as an investigator into the back corridors of political power, probing and pursuing his interlocutors with mild-mannered persistence, instills the series with an unmistakably cinematic quality, giving it resonances above all with the detective genre. Samson's drives through the city recall Lemmy Caution in Alphaville (a film that was already cited in Les deux Marseillaises), while Patrick Leboutte has compared him to Peter Falk in the Colombo TV series..$^{48}$ Comolli, meanwhile, stresses the importance of Samson's physical body to the aesthetic needs of his approach to documentary: "I explained to him that I needed his body to be filmed. The body of the journalist had to become the body of a character, it had to be exposed, and its fragility, its

47 Comolli, "Yes, we were utopians (Part 2)."

48 Patrick Leboutte, "Portrait d'un journaliste en détective," in Marseille contre Marseille, DVD booklet (Doriane Films, 2005), pp. 2-3. 
weakness had to be shown. ${ }^{149}$ Comolli has theorized the human body in the cinema as a repository of "filmed speech" (la parole filmée), arguing that since Chronique d'un été (the first documentary to use synch sound on location), the documentary has been able to "push the inscription of the body to its furthest extent. Further, even, than the theater." ${ }^{\circ 0}$ For Comolli, Marseille contre Marseille has highlighted "the subtle, ill-defined link between erotics and politics," and the goal of his series is to "film bodies, to film political men and women in Marseilles as bodies, speaking, mobile bodies, in space and time, playing between light and shadow, off-screen and on-screen, in short, cinematic bodies." ${ }^{11}$ Noting that Samson is often filmed partially blocking the spectator's view of his interlocutors, Comolli argues that his body "re-frames the frame somewhat, inscribes itself in the frame as a screen or a mask [cache]: a surface on which words and looks rebound." ${ }^{2}$

The question of on-screen corporeal presence in the Marseilles films is closely linked to Comolli's use of duration, which is present in the series in two major ways. Firstly, the aesthetic technique adopted for the series relies heavily on lengthy, uninterrupted takes focusing on the "speaking bodies" of local political figures. Secondly, the extension of the series over the course, now, of a quarter of a century introduces an additional element of duration to the project, one linked to the Braudelian notion of the longue durée, registering subtler, long-term processes at work beyond the more immediately recognizable electoral peripeteia that monopolize media coverage of the political scene. As Comolli has recognized, the fact that the series preserves moments of political life that would otherwise be washed away by cultural amnesia has significantly altered the interaction between the filmmakers and their interviewees: the politicians shown in Marseille contre Marseille now know "that we are constructing an archive of the future, and that part of their public action will pass to posterity in this filmed form. They tell themselves that here, perhaps, there is a date with something like history."53 As Marseille contre Marseille stretched first into the 199os and then into the 200os, these two modes in which time and cinema intersect have come to the forefront of the project.

Comolli, "Yes, we were utopians (Part 2)."

50

$5^{1}$ Jean-Louis Comolli, “Marseille avec et sans retours," Trafic no. 93 (spring 2015), pp. 46-55, here p. 46.

$5^{2}$ Jean-Louis Comolli, "Destin cinématographique du journaliste," in Giorgio Gosetti and Jean-Michel Frodon (eds.), Print the legend - Cinéma et journalisme (Paris: Cahiers du cinéma, 2004). Repr. in Comolli, Corps et cadre, pp. 48-62, here p. 6 o.

53 Comolli, Voir et pouvoir, p. 377. 


\section{Marseille contre Marseille (II): Filming the Enemy}

A predilection for the long-take aesthetic has been a perennial feature of Comolli's filmmaking since La Cecilia and has come to feature heavily in the Marseilles films. Comolli has expressly drawn on the theory of Bazin to link this procedure to an understanding of the cinema's ability to produce a "true inscription" - understood here as the "specificity of the cinema to bring together, in the same space-time (the scene) one or more bodies (actors or not) and a mechanical dispositif, camera, sound, lights, technicians." For Comolli, however, the "ontological realism" of the cinema lies "less on the side of the photograph as imprint of the visible world, and more on the side of time, of a common time, of an elapsing of time common to the action and its recording, of a synchronism. ${ }^{54}$ Experimenting with this form of duration in the Marseille contre Marseille series, meanwhile, intensifies the political nature of the long-take technique and derives not only from the material used in the final edit of the film but also in the nature of the filming process. Filming an interview with a politician that endures for up to two hours creates a markedly different dynamic between the individual and their on-screen image than that which currently prevails in media coverage of election campaigns. Instead of reducing discourse to a brief, stage-managed soundbite, it allows for freedom and improvisation and fosters a certain loss of control. Comolli notes the importance of allowing tiredness to settle in - on the part of Samson, his interviewees and the filmmakers - and argues that this process opens up "a certain charging of time: suddenly, speech is no longer organized in the same way. When you speak for a duration of two hours, for example, even if we only use two minutes of it in the film, these two minutes taken from two hours will be different from two minutes taken from twenty minutes, or two minutes taken from two minutes. The form of speech changes." ${ }^{55}$

Retaining these conversations in uninterrupted long takes has become a formal hallmark of the series. Indeed, the fact that the editing rhythm of the films departs so markedly from the frenetic pace of most televisual image production is a large part of its subversive effect and brings it closer to the work of contemporary "slow cinema" filmmakers, whose work has been defended by Comolli in his recent writings on cinema. A notable early

54 Jean-Louis Comolli, “Du réalisme comme utopie," in Gérald Collas (ed.), Cinéma européen, le Défi de la réalité (Coordination européenne des Festivals, 1997), repr. in Comolli, Voir et pouvoir, pp. $380-386$, here p. 382 .

55 Comolli, "Yes, we were utopians (Part 2)." 
instance of this procedure was visible in Marseille de père en fils: a five-minute take shows Samson walking along the La Joliette wharf in the Marseille docklands with Defferre supporter Charles-Émile Loo (nicknamed Milou) as he delivers a "Jesuitical monologue on the art and the manner of killing the father without doing anyone harm. ${ }^{\prime 56}$ Editor Anne Baudry had difficulties with cutting the sequence and so eventually took the radical option of retaining it in its entirety. ${ }^{57}$ For Comolli, it is only by showing the scene in continuity that he can adequately represent the progressive divergence between the bodies of Samson and Milou-reflecting the sense of unease that Samson feels towards the rhetorical dissemblances of the PS apparatchik. This "co-presence of elements," then, serves principally to highlight a political divide: "it is no longer possible to see Milou without seeing the gap opened up by the growing absence of Samson, who is absent by the very fact of his presence. Like the scene, the gaze of the spectator is split into two."58

This aesthetic approach became more politically trenchant in later episodes of Marseille contre Marseille, which, throughout the 199os, were dominated by the entry onto the politial stage of two larger-than-life, populist figures. On the left, flamboyant businessman Bernard Tapieowner of the Olympique de Marseille football club and briefly a minister under Mitterand-sought control over the city's politics, pursuing a glitzy, personality-based campaign that local poet and independent candidate Christian Poitevin lambasted as the "Americanization" of French politics. Tapie's star shone brightly but briefly: by the late 1990s he was mired in debt and corruption scandals and banned from seeking public office. Of more enduring influence was the Front national's strategic offensive to "take" the Provence-Alpes-Côte d'Azur region, which involved campaigns by Jean-Marie Le Pen and Bruno Mégret. Growing support for the FN amongst the non-immigrant working class in Marseilles was bolstered by its dominance in surrounding rural areas. In filming the 1992 regional elections for La campagne de provence, Comolli's focus rested on the relationship between the FN's growing political support and the victories it made on the semiotic level. The language it used, speaking of an "invasion" of France by immigrants and of threats to the country's "identity," had seeped into the political mainstream, even when the FN was unable to win electoral power. Indeed, this "ideological victory" was consciously understood by

56 Gérard Althabe and Jean-Louis Comolli, Regards sur la ville (Paris: Éditions du Centre Pompidou, 1994), p. 47.

57 Gerstenkorn/Goutte, Cinéma en campagne, p. 61.

$5^{8}$ Althabe/Comolli, Regards sur la ville, p. 48. 
Mégret—unwittingly espousing a Gramscian strategy — as preparing the ground for the "political victory" to come. 59

Filming the Front national re-framed the question of Comolli's own political engagement. He and Samson could remain detached observers to the infighting within the PS. They were also able to retain a "republican" respect for figures of the center-right such as Gaudin, who "even if we do not share his political ideas, moves us in his contradictions." When it came to the Le Penists, by contrast, Comolli was moved to affirm that "our position is that of the engaged, and thus actively anti-fascist filmmaker. I fight the Front National, including when I film them." ${ }^{\text {oo }}$ How exactly to do this in the most effective manner possible was a constant concern and has given rise to several articles by Comolli on the question of "filming the enemy." FN militants had already been recorded on camera for Tous pour un! and Marseille de père en fils. Despite witnessing some revelatory moments (activists singing racist songs, for instance), Comolli discarded the footage as too distant from the central projects of these films. These experiences were nonetheless seen as a valuable first stage in encountering the FN, one which entailed "filming in order to know them better, but not yet filming in order to combat them better." ${ }^{61}$

As Le Pen rose in political prominence, this question was again posed, but the two films that focus most on the FN in the 199os-La Campagne de Provence from 1992 and La Question des alliances five years later-offer different strategies for filming one's political adversary. As Comolli explains:

For La Campagne de Provence, which shows how the themes of the Front national became the themes of the campaign, we chose to film all individuals and parties in the same manner, in a sort of equilibrated distance, so as to avoid any privileged relationship. The same distance for everybody, no private interviews, but rather, always in public circumstances. $L a$ Question des alliances led us to change our dispositif. The Front national had become a major political force, distance could not work a second time, and we decided to carry out very long, very precise, very well-prepared interviews on the strategies that the parties-above all those on the right-had towards the $\mathrm{FN}^{62}$

59 Mègret himself left the FN in 1999 and ran for president in 2002 as a candidate for the Mouvement national républicain.

6 o Comolli, “La chronique Marseillaise," p. 5.

61 Jean-Louis Comolli, “Comment filmer l'ennemi?,” Trafic no. 24 (Winter 1997), repr. in idem., Voir et pouvoir, pp. 387-40o, p. 390.

62 Comolli, "La chronique Marseillaise," p. 5. 
In both examples, duration once again comes to the fore. For Comolli, Le Pen's political success is at least partly derived from "the manner in which politics is dealt with on television." Le Pen is "a champion of the soundbite, he is a champion of the slogan," and the FN has contributed towards shifting politics to a level of discourse that resembles advertising or PR. ${ }^{63}$ Hence, the long takes of the film not only combat the forms of contemporary media coverage, they also have a deeply political purpose, allowing Front national figures like Le Pen and Mégret to effectively reveal their own mendacity: "By filming Bruno Mégret for an hour or more, his cunning and ambitiousness appear. His strategy becomes visible on a psychological level." ${ }^{64}$ As such, Comolli became critical of his earlier attempts, in La campagne de Provence, to accentuate the "monstrousness" of the FN's ideological discourse by mannerist filmic touches - distorted frames, green-tinged lighting, an ironically discordant jazz score by Louis Sclavis — describing it as a "rather desperate effort" to "push the spectator towards a logical sentiment of horror and revolt when faced with the ordinary monstrosities of the FN." ${ }^{65}$ Later films in the series treating the FN-Marseille en mars and La question des alliances - are thus filmed in a soberer, less politically slanted manner, but this "defeat of propaganda" is now understood as a more effective means of waging political struggle. The $\mathrm{FN}$ is henceforth filmed in such a way as to "give body and presence to the enemy, so that it appears in its strength, such as it is today on the political scene - a threat to be taken seriously. Here, horror is not a caricature. It lies within logical thinking, reasoning, calculation, negotation." ${ }^{\prime 66}$

Two moments in the series stand out for their incisive illustration of the underlying political dynamic of the $\mathrm{FN}$, and, tellingly, neither required the kind of mannerist embellishments of which Comolli was self-critical. Instead, they resembled Brecht's notion of the Gestus - a technique that seeks to capture the reality of broader social relations through performance and staging - but for the fact that, here, they are achieved by the alteatory means of the documentary rather than the calculated techniques of the theater. Three decades earlier, Comolli had already detected such an effect when writing on La Reprise du travail aux usines Wonder in "Le détour par le direct." Here, the capture by a documentary film crew of the "absolutely raw event" of a female worker resisting entreaties to return to her job after

63 Comolli, "Yes, we were utopians (Part 2)."

64 Comolli, "La chronique Marseillaise."

65 Comolli, “Comment filmer l'ennemi?," p. 396.

66 Ibid., p. 400. 
the end of a strike is seen as a "crystallization and symbolization of the entire situation of worker-boss-union relations in the months of May and June." Each character, "as if by miracle," in Comolli's account of the scene:

plays the role that is their own, says the words that are the key phrases of this strike, to such a degree that an irresistible impression of unease is installed. It could not be clearer that nothing has been "tampered" with; and yet everything is so exemplary, "truer than the truth," that we can only make reference to the most Brechtian of scenarios, the document seemingly produced by the most masterful of fictions. ${ }^{67}$

Towards the end of Marseille en mars, we see Le Pen walking through a street market in the small Mediterranean town of Gardannes. Encircled by a throng of admirers and reporters, he seems in high spirits as he makes his way through the market. An inaudible off-screen heckle draws an ironic remark from the self-assured FN leader, but at this moment a staffer innocuously brushes his body in an attempt to protect the politician from the surrounding crush of humanity. Le Pen seizes up, his face wrenched in momentary horror, and, with unexpected violence, unleashes a volley of abuse at the culprit: "Don't touch me like that, damn it! I told you not to touch me! I don't like it when you touch me like that." Although Le Pen immediately recomposes himself, acting as if nothing has happened, it is in this punctual moment — captured, "as if by miracle," on camera- that the entire façade of the FN's drive towards political legitimacy falls away, and the fear and psychosis that subtends its anti-immigrant politics is revealed. For Comolli, the moment is a "return of the real." "Filmed, this phobic gesture and speech suddenly open onto another scene that lurks behind the smiles and bonhomie. Something of the relationship between the political idea and the political body is inscribed here, a relationship that only the cinema can aver and unfold. As soon as it is incarnated and represented, power becomes its own caricature. There is no need to force the point, it is forced all by itself." ${ }^{n}$

A second, related moment of punctual Gestus appears in the series, but this one has remained undiscussed by Comolli. In La question des alliances, Comolli includes, for the first time in the series, an interview with a grassroots FN member. Uniquely, it is Comolli himself, rather than

67 Comolli, "Le détour par le direct (1)," p. 49. This article is discussed in greater depth in Chapter 2.

68 Comolli, “Comment filmer l'ennemi," p. 391. 
Samson, who interviews the activist. Although he remains off-screen throughout, this is the only time in the entire series in which Comolli himself interacts with an on-screen "character." Marie-Odile Rayé, however, is anything but the sterotypical image of the FN supporter as oafish bullyboy. Middle-class, well-dressed and soft-spoken, she comes across as reasonable and articulate, even as she fulminates against a political order that has finally managed to erect a cordon sanitaire against her party, stating ominously: "They insult us, but we will win alone, without the media. We have time." If any moment in the series presages Marine Le Pen's more recent project to "de-demonize" the FN (now re-named the Rassemblement national) in order for it to achieve a viable electoral majority, it is this. But the framing of this sequence, held in a steady, immobile shot for several minutes of uninterrupted screen time, further accentuates the internal contradictions of the FN's drive towards respectability, away from the provocations of Le Pen père. To Marie-Odile's left, a laser-printed poster tacked to the wall urges party members to "respect the person who is speaking by not interrupting. In politics, we must know how to listen." Not only is this an unexpected attitude to find in a far-right campaign office, it is also, ironically, an apt description of Comolli's own filmmaking method in the Marseilles series. Behind Marie-Odile, however, plunged in shadow and half-obscured by a door frame, there is another poster whose slogan precisely spells out the racism that, irrespective of attempts at "de-demonization," remains at the core of the FN's political project: "Immigrants enter, jobs leave: protect our borders!" This composition was chanced upon by Comolli, and he may not even have been aware of it while filming, but the prolonged, static nature of the shot emphasizes its status as a Brechtian Gestus, elucidating, through the juxtaposition of scenic elements, the ideological contradictions seething within the filmmaker's declared enemy.

\section{Marseille contre Marseille (III): Filming the city}

As Marseille contre Marseille continued into the 2000s, the series shifted its gaze away from the $\mathrm{FN}$, which despite gaining greater national prominence during this period (especially when Le Pen reached the second round of the 2002 presidential election) had been effectively shut out of political power on the south coast. The later episodes of the series-Nos deux Marseillaises and Rêves de France à Marseille in 2001, and the two epilogues Les clés de Marseille (2008) and Marseille entre deux tours (2016) — moved the focus 
towards a less spectacular but more sociologically fundamental transition in the political culture of Marseilles: the emergence of second-generation Maghrebi migrants as political actors, notably in the PS. France has been especially slow in integrating its migrant communities into the country's political system, but it would be natural that Marseille would spearhead this process. The city's long tradition of welcoming migrants and refugees from diverse backgrounds, and the earlier efforts made by Italian, Armenian and Jewish communities to wield political influence, placed it in a unique situation within the French political context. As the later installments in Marseille contre Marseille show, however, this process was far from a smooth one.

These installments also delineate the evolution that has taken place in the political culture of Marseilles since the start of the series, one that reflects, albeit with delays and décalages, the demographic changes experienced by the city. In 1989, politics in Marseilles was still exclusively the domain of white French men, a monopoly that was at odds with the cultural diversity of the city's population. Comolli devotes a significant proportion of Marseille de père en fils to migrant communities from the Arab world and sub-Saharan Africa, including a touching sequence where Zohra Maaskri, an Algerian migrant whose son was shot dead by the Marseilles police, ascends the stairway of the Notre-Dame-de-la-Garde cathedral. But at this stage they were still unrepresented within the prevailing municipal power structures. Since they were effectively cut off from the political scene, the presence of these communities in the 1989 films functions in a contrapuntal fashion - they are the outside of the world of electoral politics, representing a different scene to that of the elections shown. The new films, by contrast, are governed by the inverse hypothesis: here, Comolli wagers, "the two scenes would tend to overlap." 69

Nos deux Marseillaises is structured around two parallel biographical paths: Samia Ghali and Nadia Brya are both young Islamic women descended from north African migrants, and both are attempting to establish themselves as elected officials on PS tickets. But it is here that their narratives diverge: Ghali, the politically savvier of the two, opts to take a safe spot on the party's slate for the municipal elections, while Brya is handed a far more challenging position: winning a departmental district that has long been a bastion of the communists. With Ghali's victory assured, the film concentrates on Brya's efforts to mobilize her community in support of her bid to defeat the PCF, but she falls agonizingly short of doing so. In this 
"modern fable at the foot of the vast estates of the northern districts, ${ }^{70}$ Brya was the sacrificial victim, and she failed to establish herself in Marseilles politics. Ghali, meanwhile, has become a significant figure in the city's political scene, and her fierce battle with Patrick Mennucci (who has recurrently featured in Marseille contre Marseille since 1989) to be the PS's candidate for mayor in the 2014 municipal elections formed the backdrop for the series' latest installment.

In addition to depicting the demographic evolution of Marseilles and the effects this has had on its electoral machinery, the series is also a portrait of Marseilles tout court, and Comolli has stressed this aspect of the films in a number of texts. From the very first episode, the political dialogues were regularly interspersed with languid panoramic shots of the city. Taking in its dramatic shoreline, picturesque harbour, the housing estates of the north and the hills beyond its perimeter, the camera frequently lingers on residents, pedestrians, shoppers or café dwellers. Comolli's initial supposition was that the program of "filming the city" provided by the very title of the first installment (Marseille de père en fils) was impossible: "This city, I tell myself, is invisible to me, I can not see anything of it, it is not promised to me, it only reaches me in one or another of its fragments, which, I hope, will be able to stand in for the whole. ${ }^{71}$ But with the progressive accretion of these fragments, over the course, now, of 25 years of filming, a portrait of the city has taken shape, one that constitutes "a corpus of bodies and a network of signs," or, alternatively, "an inexhaustible reserve of fictions. A story-city. A labyrinth where the dice of encounters, good or bad, is cast." ${ }^{2}$

Deploying the ideas of the historian Fernand Braudel, Sylvie Lindeperg has given a perceptive account of the multiple temporalities, stratified but intersecting with each other, that are at work in Marseille contre Marseille: beyond the "evental history" of short-term historical incidents (electoral defeats and victories, the rise and fall of individual politicians), there is an "intermediate time" that stretches across decades and takes in economic cycles, demographic changes and more fundamental political shifts, such as the decomposition of traditional political structures from the 1980 s to the present day. Additionally, however, Braudel's longue durée, a temporality inscribed by the history of "geographical and material structures," is also

70 Jean-Louis Comolli and Michel Samson, "Nos deux marseillaises," Marseille contre Marseille DVD booklet (Doriane Films, 2005), p. 9.

71 Althabe/Comolli, Regards sur la ville, p. 27

72 Jean-Louis Comolli, "Marseille, ville ouverte," in Thierry Paquot and Thierry Jousse (eds.), La Ville au cinéma (Paris: Cahiers du cinéma, 2005), repr. in Comolli, Corps et cadre, pp. 177-186, here p. 182 . 
present in the series, which takes the shape of the hills that squeeze Marseilles onto the coastline; the mistral winds whose brute force PS functionary Philippe Sanmarco, in Marseille de père en fils, insists has filtered into the local political climate; the sea that has linked the city, historically, culturally and even temperamentally with its fellow Mediterranean metropolises. ${ }^{73}$ For Comolli himself, Marseilles is above all a "city of the impossibility of forgetting," an urban palimpsest where 2600 years of continuous human settlement finds itself cohabiting with the present. It is "history made into a city," and, in particular, a site where France's colonial past is made manifest: both a launchpad for wars of conquest and a refuge for those fleeing the disastrous legacy of European imperialism. ${ }^{74}$ Paradoxically, however, the history of war, oppression and genocide that has left indelible traces on Marseilles also provides the condition for the city to be "one of the possible figures of utopia," and it is a continued belief in utopia, even after the great political defeats of the late twentieth centry, that is at the core of Comolli's political outlook.

Two decades into Gaudin's mayoralty, which came to rival Defferre's in its longevity, the once proudly proletarian city has been significantly reshaped in the neoliberal image of his political ideals. Investment in the city center has boomed and was further catalyzed by Marseilles' status as the European capital of culture in 2013. New museums and modern tramways have opened, while the Massalia festival created by Gaudin appropriates the city's ethnic diversity for marketing and tourism purposes. But its migrant areas remain mired in structural poverty, and Ghali laments, in Les clés de Marseille, that "two Marseilles" have arisen from the city's widening economic polarization, a statement verified by her and Samson's visit to a refugee campsite on the margins of the city, whose residents, bereft of electricity and running water, are aptly described by the politician as living in "fourth world" conditions. Filmed in 2014, Marseille entre deux tours focuses only intermittently on Ghali's joust with Mennucci, the ostensible pretext of the film: an opening scene showing a campaign rally attended almost entirely by journalists suggests that electoral politics has become an empty charade played out almost entirely for the purposes of media spectacle. Instead, the film's main focus lies on the hors-champ of the electoral campaign, and most of its screen time is absorbed by discussions with historians of the city, poets, playwrights and ecologists, who are variously engaged in forging counter-narratives of Marseilles that diverge from those provided by broadcast media and the

73 Sylvie Lindeperg, “À suivre...: Marseille et les trois ordres du temps," Trafic no. 48 (Winter 2003), pp. 29-37.

74 Comolli, “La ville de l'impossible oubli," p. 485. 
press. Julie de Muer, a young activist and "urban narrator" who founded the "Hôtel du Nord" co-operative, is the last of these figures and perhaps the one whose utopianism is most in tune with Comolli's own sentiments: from a rocky hilltop overlooking the city, she dreamily muses about the Celtic villages that ringed the original Roman settlement and praises Marseilles for the spirit of inexhaustible curiosity it instills in its residents.

Comolli's documentary work of the 1990 s to 2010 s has extended far beyond the Marseilles series. Jeux de rôles à Carpentras (1998) and Le Monde dans l'arène (2008) looked at the intersections between politics and the media, and both films also featured Michel Samson as their "guide." Rêve d'un jour (1995) and Jours de grève à Paris Nord (2003) centered on the 1995 general strikes, which revived trade union militancy in France and briefly summoned the specter of May'68. Outside of France, Comolli has looked at the trial of former Maoist activist Adriano Sofri in Italy (L'Affaire Sofri, 2001), the biography of 1930s Catalan anarchist Buenaventura Durruti (Buenaventura Durruti, anarchiste, 1999) and New Caledonia's independence movement, the last violent struggle against French colonialism (Belep danse autour de la terre, 1990 and Les Esprits de Koniambo (en terre kanak), 2004). Beyond the realm of politics, his documentaries have also looked at the mundanity of white-collar office work in the public sector (La Vraie Vie (dans les bureaux), 1993) as well as the artistic work involved in the fields of architecture (Naissance d'un hôpital, 1991), music (Le Concerto de Mozart, 1996) and poetry (Le peintre, le poète et l'historien, 2005). Homages to filmmakers have included those to Youssef Chahine (Chahine \& Co, 1993), Alain Resnais (Face aux fantômes, 2009), Roberto Rossellini (La Dernière Utopie (la télévision selon Rossellini), 2006) and Federico Fellini (À Fellini d'un spectateur amoureux, 2013). And in 2011, together with Narboni, Comolli interrogated his own past at Cahiers in $\grave{A}$ voir absolument (si possible). But the ten films that comprise the Marseille contre Marseille series will inevitably be regarded as his true magnum opus. Comolli's exploration of a city and its politics for nearly three decades is a unique endeavor in the history of film, and it is one that is further enriched by its multiple intersections with the filmmaker's copious theoretical reflections on the cinema in general and politically engaged documentary filmmaking in particular.

\section{Works Cited}

Émile Breton, "L’Ombre rouge," Révolution no. 91, November 27, 1981.

Jean-Louis Comolli, "Le détour par le direct (1)," Cahiers du cinéma no. 209 (February 1969), pp. 48-54. Translated as "The Detour through the Direct," trans. 
Christopher Williams, in idem. (ed.), Realism and the Cinema: A Reader (London: BFI, 1980), pp. 224-244.

—, La Cecilia: Une commune anarchiste au Brésil en 1890 (Dossier d'un film) (Paris: Daniel et cie, 1976).

—, "La Cecilia: Présentation," Cahiers du cinéma no. 262-263 (January 1976), pp. 69-78.

—, "Un corps en trop," Cahiers du cinéma, no. 278, July 1977, pp. 5-16. Translated as "Historical Fiction: A Body Too Much," trans. Ben Brewster, Screen vol. 19 no. 2 (Summer 1978), pp. 41-53.

—, interviewed in Ron Burnett and Phil Vitone, "Jean-Louis Comolli: On the Practice of Political Film: An Interview," Ciné-tracts no. 4 (Spring-Summer 1978), pp. 44-47.

—, interviewed by Alain Bergala and Alain Philippon, "Entretien avec Jean-Louis Comolli," Cahiers du cinéma no. 333 (March 1982), pp. 23-31.

—, Voir et pouvoir: L'innocence perdue: cinéma, télévision, fiction, documentaire (Lagrasse: Verdier, 2004). Hereafter VP.

—, "Du réalisme comme utopie," in Gérald Collas (ed.), Cinéma européen, le Défi de la réalité (Coordination européenne des Festivals, 1997). Repr. in VP, pp. 380-386.

—, "Comment filmer l'ennemi?," Trafic no. 24 (Winter 1997). Repr. in VP, pp. 387-400.

- interviewed by Catherine Humblot, "La chronique marseillaise de Jean-Louis Comolli," Le Monde, February 15-16, 1998, p. 5 .

_ - "La ville de l'impossible oubli," L'Image, le monde no. 1 (1999). Repr. in VP, pp. 480-488.

-, Corps et cadre: Cinéma, éthique, politique (Lagrasse: Verdier, 2012). Hereafter CC.

—, "Destin cinématographique du journaliste," in Giorgio Gosetti and Jean-Michel Frodon (eds.), Print the legend - Cinéma et journalisme (Paris: Cahiers du cinéma, 2004). Repr. in CC, pp. 48-62.

_ , "Marseille, ville ouverte," in Thierry Paquot and Thierry Jousse (eds.), La Ville au cinéma (Paris: Cahiers du cinéma, 2005). Repr. in CC, pp. 177-186.

-, Cinéma contre spectacle (Lagrasse: Verdier, 2009). Translated as Cinema against Spectacle: Technique and Ideology Revisited, trans. and ed. Daniel Fairfax (Amsterdam: Amsterdam University Press, 2015).

—, interviewed by Rosa Lleó, "How to Film History: An Interview with Jean-LouisComolli about La Cecilia," Afterall (2009), afterall.org/article/how.to.film.history. an.interview.with.jean-louis. comolli.about.la.cecilia (accessed January 1, 2021).

—, "Notes sur cinéma et politique," in CC, pp. 297-299.

—, "La Cecilia ou l'enfance," in CC, pp. 351-357.

—, interviewed by Daniel Fairfax, "Yes, we were utopians; in a way, I still am...: An Interview with Jean-Louis Comolli (part 2)," Senses of Cinema 64 (September 2012), sensesofcinema.com/2012/feature-articles/ 
yes-we-were-utopians-in-a-way-i-still-am-interview-with-jean-louis-comollipart-2/ (accessed January 1, 2021).

—, "Marseille avec et sans retours," Trafic no. 93 (Spring 2015), pp. 46-55.

— and Gérard Althabe, Regards sur la ville (Paris: Éditions du Centre Pompidou, 1994).

— and Ted Benoît, Dans les griffes de l'Ombre rouge (Paris: Éditions de l'Étoile, 1981).

— and Michel Samson, "Nos deux marseillaises," Marseille contre Marseille DVD booklet (Doriane Films, 2005), p. 9.

André Cornand, "La Cecilia," Revue du cinéma/Image et son, no. 304 (March 1976), pp. 73-76.

Serge Daney, “Chantez le code," Cahiers du cinéma no. 264 (February 1976), pp. 52-54.

—, "Deux paumés du Komintern," Libération, July 18-19, 1981, repr. in idem., La Maison cinéma et le monde vol. II: Les Années Libé 1981-1985 (Paris: POL, 2005), pp. 349-352. Hereafter MCM II.

—, "Jean-Louis Comolli, L'Ombre rouge," Libération, October 28, 1981, repr. in MCM II, pp. 59-62.

Jacques Gerstenkorn and Martin Goutte (eds.), Cinémas en campagne: De la chronique électorale à la fiction politique (Lyon: Fage, 2012).

Reynold Humphries and Geneviève Sizzoni, "Anarchism vs. reality," Jump Cut no. 12-13 (December 1976), pp. 30-32.

Pascal Kané, "Le détour par l'enfance," Cahiers du cinéma no. 265 (March 1976), pp. 21-24.

Patrick Leboutte, "Portrait d'un journaliste en détective," in Marseille contre Marseille, DVD booklet (Doriane Films, 2005), pp. 2-3.

Sylvie Lindeperg, "À suivre...: Marseille et les trois ordres du temps," Trafic no. 48 (Winter 2003), pp. 29-37.

Michel Mardore, “Comolli, Hergé: même combat," Le Nouvel Observateur, October 31, 1981.

Alison Smith, "Jean-Louis Comolli and La Cecilia: Theory into Practice," French Cultural Studies no. 4 (February 1991), pp. 13-33.

Serge Toubiana, "Les arpenteurs," Cahiers du cinéma no. 264 (February 1976), pp. 41-43. 
The uprising which shook France in May 1968 also had a revolutionary effect on the country's most prominent film journal. Under editors Jean-Louis Comolli and Jean Narboni, Cahiers du cinéma embarked on a militant turn that would govern the journal's work over the next five years. Inspired by Marxist and psychoanalytic theory, the "red years" of Cahiers du cinéma produced a theoretical outpouring that was seminal for the formation

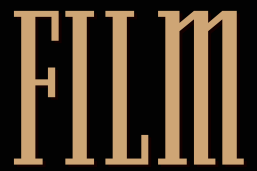

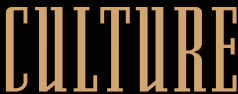

IN TRANGITIDN of film studies and is still of vital relevance for the contemporary audiovisual landscape.

The Red Years of Cahiers du Cinéma (1968-1973) gives an overview of this period in the journal's history and its aftermath, combining biographical accounts of the critics who wrote for Cahiers in the post-1968 period with theoretical explorations of their key texts.

Daniel Fairfax is Assistant Professor of Film Studies at the Goethe-Universität Frankfurt and an editor of the online film journal Senses of Cinema.

“Daniel Fairfax's book is an impressive work that casts new light on the history of Cahiers du cinéma. Thanks to exhaustive archival research, Fairfax re-establishes the coherent yet complex trajectory of the journal. It is an exemplary study: the outcome of true dedication, astute critical sensibility and a great passion for film."

FRANCESCO CASETTI, YALE UNIVERSITY

“During its 'red years,' the core contributors to Cahiers du cinéma rethought cinema in ways that have had lasting influence for contemporary film studies. This is an extraordinarily comprehensive work that not only yields a tremendous amount of information and theoretical nuance, but also offers new ways of understanding Cahiers in its Marxist phase."

PHILIP ROSEN, BROWN UNIVERSITY

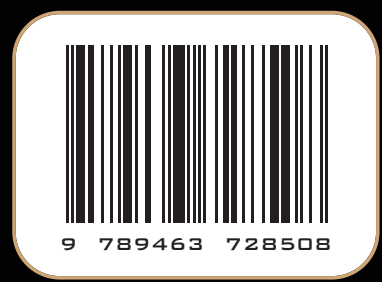

